\title{
SISTEMAS DEPOSICIONAIS NO QUATERNÁRIO COSTEIRO ENTRE JAGUARUNA E IMBITUBA, SC.
}

\author{
Paulo César Fonseca Giannini
}

\author{
Orientador: Prof. Dr. Kenitiro Suguio
}

TESE DE DOUTORAMENTO

Programa de Pós-Graduação em Geologia Sedimentar

VOLUME 1

SÃO PAULO

1993 
UNIVERSIDADE DE SÃO PAULO

INSTITUTO DE GEOCIÊNCIAS

\title{
SISTEMAS DEPOSICIONAIS NO QUATERNÁRIO COSTEIRO ENTRE JAGUARUNA E IMBITUBA, SC.
}

\author{
Paulo César Fonseca Giannini
}

Orientador: Prof. Dr. Kenitiro Suguio

TESE DE DOUTORAMENTO

Programa de Pós-Graduação em Geologia Sedimentar

VOLUME 1

São Paulo

1993
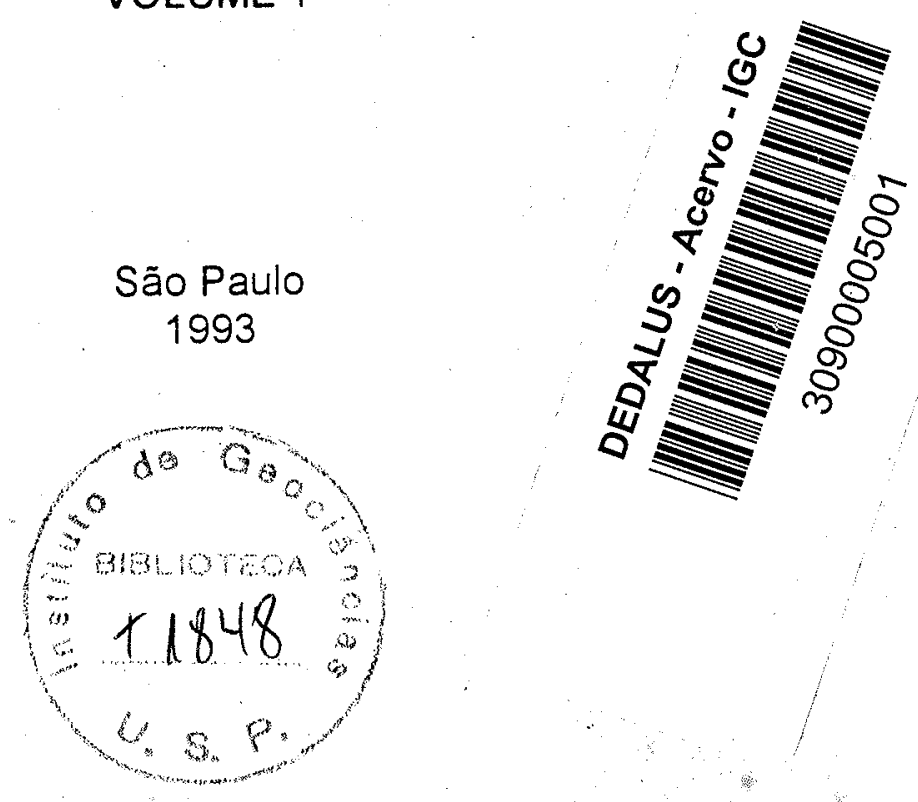
Nossa visão de mundo é só uma "perspectiva".

L.V.Bertalanffy

("Modelos Teóricos em Biologia", 1965)

Todo ponto de visão é um ápice de uma pirâmide invertida, cuja base é indeterminável.

Se conhecêssemos a verdade, vê-la-iamos; tudo mais é sistema e arredores.

As viagens são os viajantes. O que vemos não é o que vemos, senão o que somos.

...do vale ao céu ou do monte ao céu, a distância que é diferença não faz diferença.

Bernardo Soares

("O Livro do Desassossego", 1930)

Eu sou do tamanho do que vejo E não do tamanho da minha altura.

Alberto Caeiro

("O Guardador de Rebanhos", 1911-12) 
A Betti, Paula, Rodrigo e Guilherme 


\section{AGRADECIMENTOS}

Quem acredita que as "interações sistêmicas" permeiam tudo deve admitir que não há trabalho de um único autor. Nesse sentido, esta Tese possui co-autores inumeráveis, um sistema complexo de forças de trabalho. $\mathrm{Na}$ impossibilidade de citar todos, tentarei pelo menos destacar a contribuição deixada por alguns.

O Prof.Dr. Kenitiro Suguio (IG-USP) sugeriu-me e apresentoume à área de trabalho, uma escolha acertada. Cumpriu seu papel de orientador com a seriedade profissional e a dignidade humana que são sua marca registrada. Conseguiu aliar as funções de crítico e de incentivador em um clima de mais franca amizade.

Elizabete do Rocio Santos (acadêmica de geologia, UFPR) é minha candidata à sucessão de Anita Garibaldi no título de "heroína de Laguna". Dos pneus desencalhados às peneiras remendadas, sua participação essencial em atividades de campo e laboratório resume-se a iniciativa e coragem, sem jamais perder a ternura com este decepcionante Giuseppe (... O amor, que move as dunas e as outras areias...)

O Prof.Dr. Rodolfo José Angulo (Dpto.Geologia, UFPR) ofereceu-me as discussões geológicas mais calorosas. Teve a paciência de ler, e até me convenceu de que sem pular pedaços, todos os meus intermináveis manuscritos, fazendo criticas da maior importância. Amparou-me nos meus momentos de dificuldades com a fotointerpretação. Como se não bastasse, teve a ousadia de me corrigir alguns erros de português.

Importantes foram também as discussões e comentários feitos pelo Prof.Dr. Armando Márcio Coimbra (IG-USP), com sua paixão contagiante por assuntos sedimentológicos, e pelo Prof. Mário Luis Assine (Dpto.Geologia, UFPR), com seu conhecimento de estratigrafia genética. No campo da filosofia da ciência, os geólogos Hilton Garcia Fernandes (Engenharia Elétrica, USP), Prof.Dr. Paulo César Soares (Dpto.Geologia, UFPR) e Tadeu Cava (Mineropar) transmitiram-me a emoção intelectual necessária para não desistir da idéia de aplicar "teoria de sistemas". Ainda no plano das discussões proveitosas, não posso me esquecer também da participação do Prof.Dr. Valdir Lopes Ponçano (IPT-SP) em meu Exame de Qualificação.

Em laboratório, tive o apoio inestimável de meus alunos do curso de geologia da UFPR (bolsistas-trabalho e voluntários): de Edilson Sawasato e Nilza Nakahara, a concentração oriental e o bom humor; de Ronald Zimermann, a raça e "rock'n roll"; de Simone Biscaia, a "preciosa presença". Agradeço também a Jaqueline Kogut (Iniciação Científica-CNPq) e Maria Cristina de Souza (PET), pela eficiência e generosidade com que se empenharam na dramática reta final deste trabalho.

Na última jornada de campo, fomos transportados por Marcelo Mendonça, motorista da Prefeitura de Laguna, que se tornou alegre companhia e amizade inesquecivel.

Os desenhos foram feitos como música pelo sr. Luis Mello e pela geóloga Leila Perdoncini (pós-graduanda, UFPR). Oto. Laurentino Rosa foi o maestro, um verdadeiro arte-finalista $e$, muitas vezes, um artista. 
A digitação do texto ficou em família. Rogerio, Idani e Tónio tiveram muito trabalho e muita paciência: no fundo, um gesto de carinho. Tónio deu-me também a assistência necessária em "software". Ainda em familia, agradeço à mãe Ida pela revisão do "abstract", pela força e pela memorável "visita de campo".

Este trabalho teve ainda apoio financeiro de instituições: do CNPq (Auxílio à Pesquisa código 407748/87-GL/FV/PQ), do convênio FINEP/PADCTUFPR (Projeto no 65.91.03.03.00) e do convênio UFPR/FUNPAR (Projeto 120/92). A FATMA (Fundação de Amparo a Tecnologia e Meio Ambiente do Estado de Santa Catarina, sede de Florianópolis) fez o empréstimo de fotografias aéreas. A Prefeitura Municipal de Laguna (gestão 1989-92), através do Dr. Marco Aurélio Bazan e do Eng. Alberto Guisi Silvestre, deu condições logísticas para a realização de atividades de campo. As datações carbono 14 puderam ser conseguidas no prazo de conclusão da Tese graças à voluntariedade da equipe do Laboratório de Radionuclídeos do CENAUSP, em Piracicaba (SP), e , em especial, do Prof. Luís Carlos Pessenda.

Quero agradecer ainda a todos alunos, funcionários $e$ professores do Dpto. de Geologia da UFPR e do curso de pós-graduacão do IG-USP, pela prestatividade e companheirismo. 
SISTEMAS DEPOSICIONAIS NO QUATERNÁRIO COSTEIRO ENTRE JAGUARUNA E IMBITUBA, SC.

\section{SUMÁRIO}

\section{VOLUME 1}

AGRADECIMENTOS

p.III

SUMÁRIO

p.V

ÍNDICE DE TABELAS

p.IX

ÍNDICE DE FIGURAS

p.XIII

ABSTRACT

p.XXIV

RESUMO

p.XXV

1. INTRODUÇÃO

p.1

1.1. ÁREA DE ESTUDO

p.1

1.2. METAS E OBJETIVOS

p. 2

1.2.1. METAS

p. 2

1.2.2. OBJETIVOS

p.3

1.3. COBERTURA QUATERNÁRIA : EVOLUÇÃO DO CONHECIMENTO

p. 4

2. MÉTODOS

p.9

2.1. PESQUISA BIBLIOGRÁFICA

p.9

2.2. ABORDAGEM SISTEMICA

p.9

p.9

2.2.1. "TEORIA DE SISTEMAS": HISTÓRICO E FUNDAMENTOS

2.2.2. "TEORIA DE SISTEMAS" EM GEOCIÊNCIAS E EM GEOLOGIA SEDIMENTAR p. 10

2.2.3. PROPOSTA DE MÉTODO DE ANÁLISE DE SISTEMAS VOLTADA À GEOLOGIA SEDIMENTAR

2.2.3.1. Introdução

2.2.3.2. Exame prévio de sistemas

p. 12

p. 12

2.2.3.3. Descrição externa

p. 13

2.2.3.4. Descrição interna

2.2.3.4.1. Concepção de modelos e dinâmica

p. 15

p. 17

p. 17

2.2.3.4.2. Estudo de estabilidade de sistemas

p. 20

p. 21

2.2.3.4.3. Estruturas dissipativas

2.2.4. INTEGRAÇÃO SISTÊMICA DE PRINCÍPIOS DE EROSÃO E SEDIMENTAÇÃO COSTEIRAS

2.2.4.1. Introdução

2.2.4.2. Apresentação de princípios

p. 24

p. 24

p. 24

2.2.4.3. Leis sistêmicas : integração de princípios

p. 27

2.2.5. UMA PROPOSTA DE ANÁLISE DE FÁCIES

p. 30 
2.3. ATIVIDADES DE CAMPO

2.3.1. BASE CARTOGRÁFICA E AEROFOTOGEOLÓGICA - MODELO PRELIMINAR

2.3.2. AMOSTRAGEM

2.3.3. MEDIDAS DE CAMPO

2.4. ATIVIDADES DE LABORATORIO

2.4.1. ANÁLISES GRANULOMÉTRICAS

2.4.2. ANÁLISES DENSIMÉTRICAS

2.4.3. ANÁLISES DE DESMAGNETIZAÇÃO E MAGNETOMETRIA

2.4.4. ANÁLISES MINERALÓGICAS VIA ÓPTICA

2.4.5. DOSAGEM DE MATÉRIA ORGÂNICA

2.4.6. DATAÇÃO POR RADIOCARBONO

2.5. TRATAMENTO E FORMA DE APRESENTAÇÃO DE RESULTADOS

2.5.1. INTRODUÇÃO

2.5.2. PERFIS GEOLÓGICOS E MAPAS

2.5.3. DERIVA EÓLICA POTENCIAL

p. 31

p.33

p. 36

p.37

p.37

p.38

p.39

p. 41

p. 41

p. 41

p. 42

p. 42

p. 42

p.43

2.5.4. PARÂMETROS MORFOMÉTRICOS E TAXAS DE MIGRAÇÃO DE DEPÓSITOS EÓLICOS

2.5.5. CLASSIFICAÇÃO DE ESTRATIFICAÇÕES CRUZADAS

2.5.6. DIAGRAMAS DE ROSA-DOS-VENTOS

2.5.7. PARÂMETROS ESTATISTICOS DE GRANULOMETRIA

2.5.8. ANÁLISE DE REGRESSÄO LINEAR

p. 44

p. 45

p. 45

p. 46

p. 47

2.5.9. CLASSIFICAÇÃO NOMINAL PARA FREQÜENCIAS DE MINERAIS

2.5.10. INDICES E RAZÕES DE MATURIDADE MINERALÓGICA

PESADOS

p. 48

p. 48

2.5.11. COMPARAÇÃO ENTRE ASSEMBLÉIAS MINERALÓGICAS QUADRADO

POR QUI-

p. 49

3.EXAME PRÉVIO E INTEGRADO DE SISTEMAS DEPOSICIONAIS

3.1. MACROAMBIENTE

3.1.1. CLIMA

3.1.1.1. Fatores de controle climático

3.1.1.2. Classificação do clima atual

p.51

p.51

p.51

p.54

3.1.1.3. Influência de perturbações climáticas na sedimentação costeira p.54

3.1.2. TECTÔNICA

3.1.2.1. Arcabouço tectono-estrutural

3.1.2.2. Neotectônica

3.1.3. NIVEL RELATIVO DO MAR

3.1.3.1. Curvas de variação no Holoceno

3.1.3.2. Nivel relativo do mar e evolução da sedimentação quaternária

3.2. SUPRIMENTOS DE MATÉRIA E ENERGIA

p. 55

p. 55

p. 57

p. 58

p. 58

p.61

p.63

3.2.1. ROCHAS-FONTES: ESTRATIGRAFIA E PETROLOGIA p.63

3.2.1.1. Embasamento pré-cenozóico

3.2.1.2. Cobertura cenozóica pré-quaternária

p.63

p.67

3.2.1.3. Cobertura quaternária da plataforma continental

3.2.2. PADRÕES HIDRO E AERODINÂMICOS ATUAIS

3.2.2.1. Hidrografia

3.2.2.1.1. Lagoas

p.69

p.69

p.69

p.69 
3.2.2.2. Regime de ventos e de ondas

p.72

3.2.2.2.1. Introdução: conceitos básicos p.72

3.2.2.2.2. Potenciais de deriva eólica p.73

3.2.2.3. Potenciais de deriva litorânea p.77

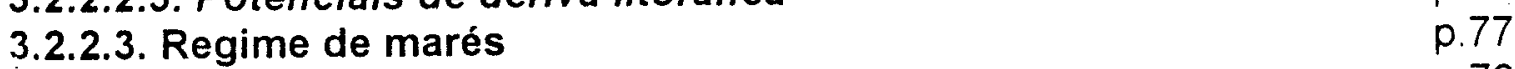

3.2.2.4. Padrão de correntes p.78

3.3. DELIMITAÇÃO DE SISTEMAS DEPOSICIONAIS p.81

3.3.1. INTRODUÇÃOO p.81

3.3.2. SISTEMA BARRA-BARREIRA (REGRESSIVO) p.82

3.3.3. SISTEMA PLANÍCIE COSTEIRA p.83

3.3.4. SISTEMA LAGUNAR p.83

3.3.5. SISTEMA EÓLICO ·p. 85

3.4. SAMBAQUIS, SISTEMAS DEPOSICIONAIS E NIVEL DO MAR p.86

4. DESCRIÇÃO EXTERNA p.88

4.1. PROVENIENCIA SEDIMENTAR p.88

4.1.1. FONTES PRIMÁRIAS (PRÉ-QUATERNÁRIAS) - p.88

4.1.2. FONTES SECUNDÁRIAS p.93

4.2. ENTRADAS, SAIDASE SALDOS p.99

4.2.1. INTRODUÇĀOO p.99

4.2.2. SISTEMA PLANICIE COSTEIRA p.101

4.2.3. SISTEMA BARRA-BARREIRA p.102

4.2.4. SISTEMA LAGUNAR p.103

4.2.4.1. Considerações gerais p. p.103

4.2.4.2. Dinâmica do canal Camacho p. 103

4.2.4.3. Dinâmica do canal Entrada da Barra p. 106

$\begin{array}{ll}\text { 4.2.5. SISTEMA EÓLICO } & \text { p.107 }\end{array}$

5. DESCRIÇÃO INTERNA DOS SISTEMAS p.109

5.1. SISTEMA BARRA-BARREIRA p.109

5.1.1. IDADE RELATIVA p.109

5.1.2. PADRÃO FISIOGRÁFICO p.110

$\begin{array}{ll}\text { 5.1.2.1. Leques de sobrelavagem } & \text { p. } 110\end{array}$

5.1.2.2. Desembocadura lagunar p.113

5.1.2.3. Praia de mar aberto p.113

5.1.3. PADRÃO SEDIMENTOLÓGICO p.114

$\begin{array}{ll}\text { 5.1.3.1. Granulometria } & \text { p.115 }\end{array}$

5.1.3.2. Mineralogia $\quad$ p.116

5.2. SISTEMA PLANICIE COSTEIRA p. 123

5.2.1. IDADE RELATIVA p.123

$\begin{array}{ll}\text { 5.2.2. PADRÃO FISIOGRÁFICO p.124 } & \text { p.125 }\end{array}$

$\begin{array}{ll}\text { 5.2.2.1. Planície com cordões litorâneos } & \text { p. } 125\end{array}$

$\begin{array}{ll}\text { 5.2.2.2. Tômbolos e pontões } & \text { p. } 126\end{array}$

$\begin{array}{ll}\text { 5.2.2.3. Praias de mar aberto } & \text { p.127 }\end{array}$

5.2.3. PADRÃO SEDIMENTOLÓGICO p.130

5.2.3.1. Granulometria $\quad$ p.130

$\begin{array}{ll}\text { 5.2.3.2. Mineralogia } & \text { p.133 }\end{array}$ 
5.2.3.2.1. Minerais pesados

p. 133

5.2.3.2.2. Minerais leves

p. 139

5.3. SISTEMA LAGUNAR

p. 140

5.3.1. IDADE RELATIVA

p. 140

5.3.2. PADRÃO FISIOGRÁFICO

p. 144

5.3.2.1. Associações de facies

p. 144

5.3.2.2. Subfácies principais

p. 146

5.3.2.1. Várzeas de inundação e altas planícies

p.146

5.3.2.2.2. Lagos residuais

5.3.2.2.3. Praias lagunares

5.3.2.2.4. Fundo lagunar raso marginal

p. 146

p. 147

5.3.2.2.5. Desembocadura lagunar

p. 148

p.149

5.3.2.2.6. Delta lagunar

p. 152

5.3.2.7. Planicie aluvial de canais interlagunares

p. 154

5.3.2.2.8. Planície com cordões lagunares

p. 154

5.3.2.2.9. Dunas eólicas lagunares

p.156

5.3.3. PADRÃO SEDIMENTOLÓGICO

p. 156

5.3.3.1. Estruturas sedimentares

5.3.3.2. Granulometria

5.3.3.3. Mineralogia

5.3.3.3.1. Minerais pesados

5.3.3.3.2. Minerais leves

p.156

p.161

p. 164

p. 164

5.3.3.4. Matéria orgânica

p. 167

5.4. SISTEMA EOLICO

p. 168

p.169

5.4.1. IDADE RELATIVA

p. 169

5.4.1.1. Unidades de empilhamento

p. 169

5.4.1.2. Variedades geomorfológicas

p. 176

5.4.1.3. Gerações eólicas

5.4.2. PADRÄO FISIOGRÁFICO

5.4.2.1. A questão da escala

5.4.2.2. Cavalgamento de depósitos eólicos

p.182

p.182

p. 182

p.183

5.4.2.3. Taxas de migração de depósitos eólicos

p. 185

5.4.2.4. Critérios para nomenclatura de depósitos eólicos p.186

5.4.2.5. Associações de fácies

p.188

5.4.2.6. Fácies e subfácies principais

p.193

p.193

5.4.2.6.1. Depósitos com obstáculo fixo

p. 197

5.4.2.6.2. Cordões de dunas frontais

p.202

5.4.2.6.3. Dunas lineares transversais

5.4.2.6.4. Dunas barcanas e cadeias barcanóides

p.205

5.4.2.6.5. Frentes e dunas parabólicas

p. 208

5.4.2.6.6. Depósitos residuais de deflação versus interdunas p. 212

5.4.2.6.7. Depósitos lacustres

p. 213

p. 214

5.4.3. PADRÃO SEDIMENTOLÓICO

p. 214

5.4.3.1. Estruturas sedimentares

p. 214

5.4.3.1.1. Hierarquias de superficies eólicas

p. 226

5.4.3.1.2. Estratificações em dunas frontais

p. 228

5.4.3.1.3. Estruturas em rampas de areia e dunas de topo de encosta

p.235

5.4.3.2. Granulometria 
5.4.3.2.1. Associação de fácies depósitos mantiformes p.235

5.4.3.2.2. Associação de fácies dunas e lençóis parabólicos p.237

5.4.3.2.3. Associação de fácies eólica indiferenciada p.238

5.4.3.3. Mineralogia

p. 240

5.4.3.3.1. Minerais pesados

p. 240

5.4.3.3.1.1. Associação de fácies depósitos mantiformes

p. 240

5.4.3.3.1.2. Associação de fácies dunas e lençóis parabólicos

p. 233

5.4.3.3.1.3. Associação de fácies eólica indiferenciada

p. 245

5.4.3.3.2. Impregnação em minerais leves e a cor nos sedimentos eólicos

5.4.3.3.3. Matéria orgânica

6. DISCUSSÃO FINAL

p.253

6.1. SINTESE DA EVOLUÇÃO PALEOGEOGRÁFICA

p. 253

6.2. EVENTOS DE DEPOSIÇÃO EOLICA NO QUATERNÁRIO SUPERIOR: UMA TENTATIVA DE CORRELAÇÃO ENTRE CONTINENTES p.254

REFERÊNCIAS BIBLIOGRÁFICAS

p.261

\section{VOLUME 2}

ANEXOS : TABELAS A1 A A56, FIGURAS A1 A A19, PRANCHAS A1 E A2

\section{INDICE DE TABELAS E FIGURAS}

\section{ÍNDICE DE TABELAS - VOLUME 1}

Tabela 2.1. Exemplos de uso do termo "ambiente" em geologia sedimentar

Tabela 2.2. Tipos de problemas no estudo de sistemas, segundo Dooge (1968)

Tabela 2.3. Convenções para codificação de amostras adotada neste trabalho p.34

Tabela 2.4. Escala de classificação nominal para freqüências percentuais de minerais pesados

Tabela 3.1. Localização, faciologia e extensão de lagoas na planície litorânea entre Jaguaruna e Imbituba

Tabela 3.2. Bacias hidrográficas na parte centro-sul da vertente atlântica catarinense

Tabelas 3.3 e 3.4. Resultados em "unidades vetoriais" de deriva potencial eólica média mensal e anual segundo a fórmula de Lettau \& Lettau (1975 apud Fryberger 1979) - Período 1975-1983

3.3. Estação meteorológica (Inemet) de Laguna

3.4. Estação meteorológica (Inemet) de Araranguá

p.75

3.5. Estação meteorológica (Inemet) de Urussanga

p. 75

3.6. Estação meteorológica (Inemet) de Florianópolis 
Tabela 4.1. Resultados de ajuste estatístico entre assembléias médias de minerais pesados (transparentes não micáceos) pelo método dos quiquadrados - Assembléias de regolitos de rochas pré-quaternárias como populações esperadas $\quad$ p.89 Tabela 4.2. Resultados de ensaios de análise densimétrica ao líquido denso (bromofórmio - $\mathrm{CHBr}_{3}$ - densidade $\mathrm{a}=2,83 \mathrm{~g} / \mathrm{cm}^{3}$ ) e de separação magnética ao imã manual - Fração areia fina - Amostras de regolito de rochas e sedimentos préquaternários

Tabela 4.3. Resultados de análise mineralógica quantitativa ao microscópio petrográfico - Amostras de regolito de rochas e sedimentos pré-quaternários - Fração areia fina ou muito fina, pesada

p.90

Tabela 4.4. Assembléias mineralógicas médias por lote de amostras e respectivas razões mineralógicas - Fração areia fina ou muito fina, pesada não magnética

Tabela 4.5. Resultados de ajuste estatístico entre assembléias médias de minerais pesados (transparentes não micáceos) pelo método dos quiquadrados - Assembléias de sedimentos quaternários como populações esperadas p.95 Tabela 5.1. Distribuição de fácies em superficie no sistema barra-barreira p.110 Tabela 5.2. Distribuição de fácies em superficie no sistema planície costeira p.124 Tabela 5.3. Resultados de ensaio de análise magnetométrica ao Separador Isodinâmico Frantz e de estudo de impregnação superficial de grãos à lupa binocular Sistemas marinhos - Fração areia muito fina, leve

p. 142

Tabela 5.4. Distribuição de fácies em superfície no sistema lagunar - Associação de fácies baía-laguna

p.143

Tabela 5.5. Distribuição de fácies em superfície no sistema lagunar - Associação de fácies baixio-laguna

p.144

Tabela 5.6. Resultados de ensaio de análise magnetométrica ao Separador Isodinâmico Frantz e de estudo de impregnação superficial de grãos à lupa binocular - Sistema lagunar - Fração areia muito fina, leve

p.168

Tabela 5.7. Resultados de ensaio de dosagem de matéria orgânica total - Sistema lagunar, amostras de sedimentos turfosos

p. 168

Tabela 5.8. Quantificação do deslocamento recente de dunas eólicas da geração 4 com base em comparação de aerofotografias verticais de datas diferentes (1952 $x$ 1977-1979)

Tabelas 5.9 a 5.11. Distribuição de fácies em superfície no sistema eólico

5.9. Associação de fácies depósitos mantiformes

p. 186

p.189

5.10.Associação de fácies dunas e lençóis parabólicos

p. 189

p. 190

5.11.Associação de fácies indiferenciada

p.190

Tabela 5.12. Parâmetros morfométricos de depósitos eólicos da geração 4 , determinados com base em exame de aerofotografias $1: 25.000$ (1977-1979)

Tabela 5.13. Resultados de ensaio de análise magnetométrica ao Separador Isodinâmico Frantz e de estudo de impregnação superficial de grãos à lupa binocular Sistema eólico - Fração areia muito fina, leve

p. 249

Tabela 5.14. Resultados de ensaio de dosagem de matéria orgânica total Sistema eólico, fração pelítica

p. 251 


\section{ÍNDICE DE TABELAS EM ANEXO (A) - VOLUME 2}

Tabela A1. Resultados brutos de ensaios de análise granulométrica-Sistema barra-barreira

Tabela A2. Percentis e parâmetros estatísticos de distribuição granulométrica em massa - Sistema barra-barreira

p.4

Tabela A3. Resultados de análise estatística de correlação e regressão lineares simples e múltipla entre atributos granulométricos e a coordenada geográfica $\mathrm{S}-\mathrm{N}$ Sistema barra-barreira

Tabela A4. Resultados de ensaios de análise densimétrica ao líquido denso e de separação magnética ao imã manual - Fração areia fina ou muito fina - Sistema barrabarreira

p.9

Tabela A5. Resultados de análise mineralógica quantitativa ao microscópio petrográfico - Fração areia fina ou muito fina, pesada - Sistema barra-barreira. p.11

Tabela A6. Resultados de análise estatística de correlação e regressão lineares entre teores de minerais pesados e a coordenada geográfica $\mathrm{S}-\mathrm{N}$ - Fração areia muito fina Sistema barra-barreira

p. 14

Tabela A7. Resultados de análise estatística de correlação e regressão lineares simples entre atributos mineralógicos e a coordenada geográfica S-N - Fração areia muito fina, pesada, não magnética - Sistema barra-barreira p.15

Tabela A8. Resultados brutos de ensaios de análise granulométrica - Sistema planície costeira

p. 16

Tabela A9.Percentis e parâmetros estatísticos de distribuição granulométrica em massa - Sistema planície costeira

Tabela A10. Resultados de análise estatística de correlação e regressão lineares simples e múltipla entre atributos granulométricos e a coordenada geográfica $\mathrm{S}-\mathrm{N}$ Sistema planicie costeira

p.26

Tabela A11. Resultados de ensaios de análise densimétrica ao líquido denso e de separação magnética ao imã manual - Fração areia muito fina - Sistema planície costeira

Tabela A12. Resultados de análise mineralógica quantitativa ao microscópio petrográfico - Fração areia muito fina, pesada - Sistema planície costeira p.32

Tabela A13. Resultados de análise estatística de correlação e regressão lineares entre teores de minerais pesados e a coordenada geográfica $\mathrm{S}-\mathrm{N}$ - Fração areia muito fina - Sistema planície costeira

Tabela A14. Resultados de análise estatística de correlação e regressão lineares simples entre atributos mineralógicos e a coordenada geográfica S-N - Fração areia muito fina, pesada, não magnética - Sistema planície costeira p.37

Tabela A15. Resultados brutos de ensaios de análise granulométrica - Sistema lagunar

Tabela A16. Percentis e parâmetros estatísticos de distribuição granulométrica em massa - Sistema lagunar

p. 41

Tabela A17. Resultados de análise estatística de correlação e regressão lineares simples e múltipla entre atributos granulométricos e a coordenada geográfica S-N Sistema lagunar

p. 44 
Tabela A18. Resultados de ensaios de análise densimétrica ao líquido denso e de separação magnética ao imã manual - Fração areia fina ou muito fina - Sistema lagunar

Tabela A19. Resultados de análise mineralógica quantitativa ao microscópio petrográfico - Fração areia fina ou muito fina, pesada - Sistema lagunar

p. 47

Tabela A20. Resultados de análise estatística de correlação e regressão lineares entre teores de minerais pesados e a coordenada geográfica $\mathrm{S}-\mathrm{N}$ - Fração areia fina ou muito fina - Sistema lagunar

p. 49

Tabela A21. Resultados de análise estatistica de correlação e regressão lineares simples entre atributos mineralógicos e a coordenada geográfica S-N - Fração areia fina ou muito fina, pesada, não magnética - Sistema lagunar p.50

Tabela A22. Resultados brutos de ensaios de análise granulométrica - Sistema eólico - Associação de fácies depósitos mantiformes

p. 51

Tabela A23. Percentis e parâmetros estatisticos de distribuição granulométrica em massa - Sistema eólico - Associação de fácies depósitos mantiformes

p. 57

Tabela A24. Resultados de análise estatistica de correlação e regressão lineares simples e múitipla entre atributos granulométricos e a coordenada geográfica $\mathrm{S}-\mathrm{N}$ Sistema eólico - Associação de fácies depósitos mantiformes

p.63

Tabela A25. Resultados de ensaios de análise densimétrica ao líquido denso e de separação magnética ao imã manual - Fração areia muito fina - Sistema eólico Associação de fácies depósitos mantiformes

p.67

Tabela A26. Resultados de análise mineralógica quantitativa ao microscópio petrográfico - Fração areia muito fina, pesada - Sistema eólico - Associação de fácies depósitos mantiformes

p. 70

Tabela A27. Resultados de análise estatistica de correlação e regressão lineares entre teores de minerais pesados e a coordenada geográfica S-N - Fração areia muito fina - Sistema eólico - Associação de fácies depósitos mantiformes

p.73

Tabela A28. Resultados de análise estatística de correlação e regressão lineares simples entre atributos mineralógicos e a coordenada geográfica S-N - Fração areia muito fina, pesada, não magnética - Sistema eólico- Associação de fácies depósitos mantiformes

p.74

Tabela A29. Resultados brutos de ensaios de análise granulométrica - Sistema eólico - Associação de fácies dunas e lençóis parabólicos

p. 75

Tabela A30. Percentis e parâmetros estatísticos de distribuição granulométrica em massa - Sistema eólico - Associação de fácies dunas e lençóis parabólicos p.79

Tabela A31. Resultados de análise estatística de correlação e regressão lineares simples e múltipla entre atributos granulométricos e a coordenada geográfica $\mathrm{S}-\mathrm{N}$ Sistema eólico - Associação de fácies dunas e lençóis parbólicos

p.83

Tabela A32. Resultados de ensaios de análise densimétrica ao líquido denso e de separação magnética ao imã manual - Fração areia muito fina - Sistema eólico Associação de fácies dunas e lençóis parabólicos $\quad$ p.85 Tabela A33. Resultados de análise mineralógica quantitativa ao microscópio petrográfico-Fração areia muito fina, pesada - Sistema eólico - Associação de fácies dunas e lençóis parabólicos

p. 86

Tabela A34. Resultados de análise estatística de correlação e regressão lineares entre teores de minerais pesados e a coordenada geográfica S-N - Fração areia muito fina - Sistema eólico - Associação de fácies dunas e lençóis parabólicos

p. 88 
Tabela A35. Resultados de análise estatística de correlação e regressão linear simples entre atributos mineralógicos e a coordenada geográfica S-N - Fração areia muito fina, pesada, não magnética - Sistema eólico - Associação de fácies dunas e lençóis parabólicos

Tabela A36. Resultados brutos de ensaios de análise granulométrica - Sistema eólico - Associação de fácies indiferenciada

Tabela A37. Percentis e parâmetros estatísticos de distribuição granulométrica em massa - Sistema eólico - Associação de fácies indiferenciada p.96

Tabela A38. Resultados de ensaios de análise densimétrica ao líquido denso e de separação magnética ao imã manual - Fração areia muito fina - Sistema eólico Associação de fácies indiferenciada

p.99

Tabela A39. Resultados de análise mineralógica quantitativa ao microscópio petrográfico - Fração areia muito fina, pesada - Sistema eólico - Associação de fácies indiferenciada

p.101

\section{ÍNDICE DE FIGURAS - VOLUME 1}

Figura 1.1. Localização da área estudada em relação a América do Sul, Brasil e Santa Catarina.

Figuras 1.2 e 1.3. Mapas prévios da área em estudo

p.1

p.5

Figura 1.2 (esquerda). Mapa da área entre Laguna e Imbituba estudada por Guerra (1950b).

Figura 1.3 (direita). Mapa geológico da região entre Jaguaruna e Imbituba, segundo Pimienta (1958)

Figura 2.1. Mapa de sistemas deposicionais recentes na costa noroeste do golfo do México, apresentado em trabalho pioneiro sobre sistemas deposicionais, de Fischer \& McGowen (1967).

p. 11

Figura 2.2. Hierarquia espacial de sistemas geomorfológicos, crescente ao longo da escala temporal (vertical ascendente). Modificado de Chorley \& Kennedy (1971) por Gregory (1985).

p. 18

Figura 2.3. Representação dos tipos de estabilidade de sistemas, por analogia com a mecânica clássica. Segundo Huggett (1985).

p. 20

Figura 2.4. Analogia entre dois sistemas metaestáveis em sedimentologia. p.22

Figura 2.5. Representação "cúspide-catástrofe" da combinação não linear entre as variáveis energia de onda e nivel freático na produção de erosão versus acreção praial. Segundo Chappell (1978 apud Huggett 1985).

p. 23

Figura 2.6. Os seis estágios ou tipos morfodinâmicos de praias e costas segundo Wright et al.(1979).

p. 24

Figura 2.7. Esquema integrado dos princípios de Bruun (1962) e Dean (1987) sobre erosão e sedimentação costeiras induzidas por elevação de nível do mar. p.27 Figura 2.8. Representação "cúspide-catástrofe" tentativa da combinação das variáveis granulometria e energia de onda ou elevação de NRM na produção de morfodinâmicas praiais erosivas ou acrecionares.

p. 29

Figura 2.9. Articulação de folhas topográficas $1: 50.000$ abrangendo a área em estudo e vizinhanças.

p. 32

Figura 2.10. Esquema genérico para parâmetros morfométricos de depósitos eólicos da geração 4 em dois tipos de associações de fácies: mantiforme e lençol parabólico. 
Figura 2.11. Quadro de confiabilidade de resultados, em função da quantidade e significado geológico de medidas de estratificações cruzadas, proposto por Fernandes (1992).

p. 46

Figura 3.1. Trajetória de massas de ar na América do Sul sob clima normal (quadro inferior, incluindo também correntes oceânicas) e sob efeito El Niño (quadro superior).

p.53

Figura 3.2. Mapa fisiográfico da margem continental de Santa Catarina compilado por Zembruscki (1979).

p.56

Figura 3.3. Arquitetura de uma margem passiva do tipo atlântico segundo Lister et al. (1986).

p.57

Figura 3.4. Curvas de variação do NRM durante os últimos 7 mil anos em diferentes setores da costa sudeste do Brasil, segundo Suguio et al. (1985 apud Suguio \& Martin 1987).

p.59

Figura 3.5. Esboço de curva de variação do NRM durante os últimos 7 mil anos na costa do Rio Grande do Sul, segundo Tomazelli \& Villwock (1989).

p.59

Figura 3.6. Perfil esquemático idealizado da costa do Rio Grande do Sul, apresentando justaposição de quatro sistemas laguna-barreira. Modificado de Villwock et al.(1986) por Martin et al. 1988a.

Figura 3.7. Esquema da evolução paleogeográfica costeira das regiōes Sudeste e Sul do Brasil, modificado de Suguio et al.(1985) e Villwock et al.(1986) por Suguio \& Martin (1987).

p.62

Figura 3.8. Estruturação brasiliana do Sul do Brasil segundo Fragoso Cesar (1991).

p.64

Figura 3.9. Esquema da relação espacial entre "superfícies de agradação $e$ degradação" continentais do Brasil, segundo Bigarella et al.(1965). p.68

Figura 3.10. Bacias hidrográficas da costa centro-sul catarinense, segundo Radambrasil-IBGE (1986c).

p.71

Figura 3.11. Maregrama baseado em tábua de marés previstas (DHN 1989) para 0 porto de Imbituba.

p.78

Figura 3.12. Evolução de morfologia planimétrica lagunar através da formação de esporões arenosos, segundo modelo de Zenkovitch (1967).

p. 80

Figura 3.13. Quatro tipos de trajetórias de correntes em lagunas sob ação predominante de diferentes tipos de forças hidráulicas: diferenças de densidade ( $\mathrm{A}$ e $B$ ), efeito Coriolis (C) e efeito residual de correntes de maré (D). Compilado de Dyer $(1979,1986)$.

p. 81

Figura 3.14. Esquema evolutivo, durante os últimos 120 mil anos, para desembocaduras de grandes rios em costas brasileiras dominadas por ondas. Segundo Dominguez et al.1987 (apud Dominguez 1990).

p. 85

Figuras 4.1 e 4.2. Comparação entre sistemas deposicionais e associações de fácies pertencentes ao Holoceno atual ou a geração 4 p.96 4.1 (superior). Histograma de freqüências percentuais médias de minerais pesados. 4.2 (inferior). Histograma de razões mineralógicas médias.

Figuras 4.3 e 4.4. Comparação entre sistemas deposicionais e associações de fácies pertencentes ao Holoceno antigo, geração 3 ou unidade 3 .

4.3 (superior). Histograma de freqüências percentuais médias de minerais pesados.

4.4 (inferior). Histograma de razōes mineralógicas médias. 
Figuras 4.5 e 4.6. Comparação entre sistemas deposicionais e associações de fácies pertencentes ao Pleistoceno ou geraçōes 1, 2 e $2 \mathrm{~A}$. p.98

4.5 (superior). Histograma de freqüências percentuais médias de minerais pesados.

4.6 (inferior). Histograma de razões mineralógicas médias.

Figura 4.7. Esboço gráfico para a interação entre sistemas deposicionais ativos na área em estudo, utilizando a representação sistêmica clássica. Terminologia e simbologia baseada em Chorley \& Kennedy (1971), Bertallanffy (1972) e Gregory (1985).

Figura 4.8. Carpete de tração na praia de Santa Marta Pequeno.

p. 100

p.101

Figura 4.9. Canal Camacho bloqueado por dunas lineares e barcanóides. Praia da Cigana ao fundo.

p. 104

Figura 4.10. Vista aérea (obliqua) do canal Entrada da Barra, em sua secção oceânica.

Figura 5.1. Vista parcial do sistema barra-barreira a partir do flanco norte do morro Santa Marta Grande.

p. 109

Figura 5.2. Blocos-diagrama para sistemas de barreiras regressivas, com ênfase a fácies de sobrelavagem.

p. 111

Figura 5.3. Seções longitudinais em leques de sobrelavagem segundo Schwartz (1975): em AA', delta tipo Gilbert progradante em pond; em BB', estratificações subhorizontais formadas por fluxo em lençol.

p. 112

Figura 5.4. Ponds digitiformes na frente de leques de sobrelavagem entre a laguna Garopaba do Sul (esquerda) e a Praia Grande do Sul. p.112

Figura 5.5. Praia do Cardoso vista a partir de sua ponta norte. p.114

Figuras 5.6 e 5.7. Comparação entre sedimentos de diferentes idades no sistema barra-barreira.

p. 118

5.6 (superior). Histograma de freqüências percentuais médias de minerais pesados.

5.7 (inferior). Histograma de razões mineralógicas médias.

Figuras 5.8 e 5.9. Variação ao longo da costa da porcentagem setorial (medias, máximos e minimos) de contagem de minerais pesados transparentes - Sistema barrabarreira.

p. 120

5.8 (superior). Subfácies pós-praia.

5.9 (inferior). Subfácies antepraia.

Figuras 5.10 e 5.11. Variação ao longo da costa de percentagens médias setoriais de contagem de espécimes de minerais pesados - Sistema barra-barreira

p. 121

5.10 (superior). Subfácies pós-praia.

5.11 (inferior). Subfácies antepraia.

Figuras 5.12 e 5.13. Variação ao longo da costa do indice mineralógico ZTR setorial (médias, máximos e mínimos) - Sistema barra-barreira:

p. 122

5.12 (superior). Subfácies pós-praia.

5.13 (inferior). Subfácies antepraia.

Figura 5.14. Degrau entre o sistema planicie costeira pleistocênico e o lagunar a oeste da vila de Mirim.

Figura 5.15. "Piçarras", atribuidas ao sistema planície costeira pleistocênico, aflorando sob lençol parabólico ativo.

p. 124

Figura 5.16. Praia de cascalho junto a ponta do Catalão, extremidade sul da praia de Muita Água.

p. 127 
Figuras 5.17 e 5.18. Praias no sistema planície costeira.

p. 128

Figura 5.17 (superior). Praia do Sol vista a partir de sua extremidade norte (ponta de Itapirubá).

Figura 5.18 (inferior). Praia de Muita Água, com paleodunas em erosão marinha em sua extremidade norte (ponta da Careca do Velho).

Figura 5.19. Concentração de minerais pesados escuros em sulcos de ravinamento na praia de Muita Água.

p. 129

Figuras 5.20 e 5.21. Comparação entre sedimentos de diferentes idades no sistema planicie costeira.

$\mathbf{5 . 2 0}$ (superior). Histograma de freqüências percentuais médias de minerais pesados.

5.21 (inferior). Histograma de razões mineralógicas médias.

Figuras 5.22 e 5.23. Variação ao longo da costa da porcentagem setorial (médias, máximos e minimos) de contagem de minerais pesados transparentes - Sistema planície costeira.

p. 136

5.22 (superior). Subfácies pós-praia.

5.23 (inferior). Subfácies antepraia.

Figuras 5.24 e 5.25. Variação ao longo da costa de porcentagens médias setoriais de contagem de espécimes de minerais pesados - Sistema planicie costeira.

p. 137

5.24 (superior). Subfácies pós-praia.

5.25 (inferior). Subfácies antepraia.

Figuras 5.26 e 5.27. Variação ao longo da costa do índice mineralógico ZTR setorial (médias, máximos e mínimos) - Sistema planicie costeira.

p. 138

5.26 (superior). Subfácies pós-praia.

5.27 (inferior). Subfácies antepraia.

Figuras 5.28. Modelo de delta de maré enchente em costa de mesomarés segundo Hayes \& Kana 1976 (apud Angulo 1992).

p. 150

Figura 5.29. Modelo de delta de maré vazante em costa de mesomarés segundo Hayes \& Kana 1976 (apud Angulo 1992).

p. 151

Figura 5.30. Frente nordeste do delta lagunar do rio Tubarão, vista a partir do morro da Glória.

p. 153

Figuras 5.31 e 5.32. Camada conchifera com deformação induzida por lutocinese, em escavação de lavra de calcáreo em Jaboticabeira.

p. 157

5.31 (superior). Aspecto geral do afloramento.

5.32 (inferior). Detalhe destacando antiforme e marcas de raizes.

Figura 5.33. Afloramento de areias bioclásticas em Perrixil.

Figura 5.34 e 5.35. Estruturas superficiais de praias lagunares arenosas.

5.34 (superior). Barras de espraiamento lagunar.

5.35 (inferior). Microondulações de crista sinuosa e topo chato.

Figuras 5.36 e 5.37. Comparação entre associações de fácies no sistema lagunar.

5.36 (superior). Histograma de freqüências percentuais médias de minerais pesados.

5.37 (inferior). Histograma de razões mineralógicas médias.

Figuras 5.38 a 5.40. Unidades de empilhamento eólicas.

5.38 (superior). Unidades 1,2 e 3 em ravina pluvial cortando duna de topo de encosta no flanco sudeste do morro Santa Marta.

5.39 (inferior esquerda). Unidades 1, 2 e 3 em paleoescarpa de abrasão marinha a sul de Vila Nova. 
5.40 (inferior direita). Detalhe de mesmo afloramento, destacando nivel de marcas de raizes sob a camada preta.

Figuras 5.41 e 5.42. Bioturbações no topo da unidade 1 na região de Vila Nova.

5.41 (superior). Na camada preta (aspecto de raízes).

5.42 (inferior). Abaixo da camada preta.

Figura 5.43. Seção geológica de "campo de dunas fóssil situado $3 \mathrm{Km}$ a sul de Imbituba" (Vila Nova) segundo Bigarella (1975c).

p. 172

Figura 5.44. Escarpa esculpida sobre granitos e sedimentos eólicos da geração 1 , cavalgada por rampas Je areia da geração 2 , na ponta do Ji.

p. 173

Figuras 5.45 e 5.46. Morfoestratigrafia da unidade 1 em dunas de topo de encosta entre ponta do Catalão e praia de Muita Água.

p. 174

5.45 (superior). Escarpa de abrasão marinha e conglomerado praial, ao sopé de patamar de relevo.

5.46 (inferior). O mesmo patamar, coberto por areias mais claras atribuídas a unidade 2.

Figura 5.47. Biecha intraformacional no contato basal da unidade $2 \mathrm{com}$ a unidade 1. Dunas de topo de encosta da ponta de llhota.

p. 175

Figura 5.48. Perfis topográfico-geológicos transversais à costa.

p. 178-179.

Figura 5.49. Frentes do lençol parabólico ativo de Vila Nova-Roça Grande cobrindo dunas parabólicas geração 2 .

p. 180

Figura 5.50. Morfologia da associação de fácies depósitos mantiformes de gerações 2 (primeiro plano) e 4 próximo a Arroio Corrente, Jaguaruna.

p. 180

Figura 5.51. Aspecto parcial do lençol parabólico geração 3 de Ribanceira, Imbituba, recobrindo dunas geração 2 (cor alaranjada, ao fundo).

p. 181

Figuras 5.52 e 5.53. Diagramas sobre dimensão e morfologia das formas deposicionais produzidas pelo vento.

p. 183

Figura 5.52 (esquerda). Diagrama binário de dispersão granulometria (percentil $20 \%$ mais grosso) versus comprimento de onda, para formas de leito eólicas transversais, segundo Wilson (1972).

Figura 5.53 (direita). Diagrama idealizado de formas de leito eólicas em função de tamanho de grão, seleção granulométrica e velocidade do vento, segundo Fritz \& Moore (1988).

Figura 5.54. Seções esquemáticas em perfil de dunas cavalgantes transversais sobre draas barcanóides com (A) e sem faces de deslizamento (B).

p. 184

Figura 5.55. Feições geométricas das formas de relevo mais comuns produzidas por deposição ou deflação eólica em zonas costeiras, segundo Semeniuk et al. (1989).

Figura 5.56. Tipologia e gerações de dunas eólicas na costa sul da Austrália associadas a diferentes morfodinâmicas praiais, segundo Short (1988).

p.191

Figura 5.57. Morfologia de feições eólicas longitudinais na costa gaúcha segundo Tomazelli (1990).

Figuras 5.58 e 5.59. Aspecto geral de dunas com obstáculo fixo.

p. 191

5.58 (superior). Geração 4 no flanco norte do morro Santa Marta Grande.

p.194

5.59 (inferior). Gerações 3 e 4 (areias claras) sobre 1 e 2 na ponta da llhota.

Figura 5.60. Lençol parabólico ativo cavalgando depósitos de topo de encosta geração 2 no morro Entrada de Barra.

p. 195 
Figura 5.61. Lâminas deformadas em padrão estilolitico em rampa eólica geração 4 no lado noroeste do morro Santa Marta Grande.

Figura 5.62. Ocorrência local de dunas frontais incipientes associada a calhas interdunares inundadas. Campo de dunas lineares transversais na Praia Grande do Sul, após chuvas "El Niño"de maio-junho de 1992.

p.199

Figuras 5.63 a 5.65. Variação na morfologia de dunas frontais e lineares transversais na praia do Ji, de sul para norte.

5.63 (superior). Dunas frontais dômicas bem desenvolvidas.

5.64 (meio). Restos de erosão de dunas lineares (primeiro plano) associados a dunas frontais baixas.

5.65 (inferior). Destruição quase total de dunas frontais, associada a maior desenvolvimento de dunas lineares.

Figura 5.66. Dunas lineares transversais com falésias de abrasão marinha de altura métrica.

p.202

Figura 5.67. Seção transversal à praia em uma duna frontal na parte sul da praia do Sol. A superfície de separação maior é um pavimento artificial.

p.202

Figura 5.68. Cercas de contenção de areia na margem interna do lençol parabólico ativo de Vila Nova - Roça Grande.

p.203

Figura 5.69 e 5.70. Aspecto geral de dunas lineares transversais na Praia Grande do Sul.

5.69 (superior). Em condições meteorológicas normais.

5.70 (inferior). Em condiçōes "El Niño", com formação de corredores inundados.

Figuras 5.71. Seção paralela à direção da costa produzida por abrasão marinha em uma duna linear transversal.

p. 205

Figura 5.72. Cadeias barcanóides superpostas ao lençol parabólico ativo de Vila Nova

- Roça Grande, vistas de sudoeste (sotavento).

p.206

Figura 5.73. Dunas lineares transversais similares a barcanas na Praia Grande do Sul, próximo a Garopaba do Sul. p.206

Figuras 5.74 e 5.75. Feições de reversão eólica.

p.207

5.74 (superior). Exposição erosiva de estratificações cruzadas frontais em cadeias barcanóides.

5.75 (inferior). Pequenas faces de avalancha no lado barlavento (nordeste) de lençol parabólico.

Figuras 5.76 e 5.77. Feições de reversão eólica em cadeias barcanóides. p.208

5.76 (superior). Segunda linha de crista, formada a nordeste (direita) da crista "normal".

5.77 (inferior). Formação de brechas de areia úmida na crista "normal".

Figura 5.78. Frentes parabólicas da associação mantiforme na região de Dunas do Sul, a sudoeste da lagoa Laranjal. p.210

Figura 5.79. Pequeno lençol parabólico a sudoeste da ponta do Ji (direita, ao fundo), visto a partir da face de avanço.

p. 210

Figura 5.80. Vista lateral das frentes do lençol parabólico ativo de Ibiraqüera-Arroio, cavalgando lençóis parabólicos, geração 3 (elevações vegetadas), e depósitos eólicos indiferenciados, geração 2 (terreno vegetado plano).

p. 211

Figura 5.81. Montes residuais de deflação de lençóis parabólicos, geração 3 , exercendo efeito de sombra sobre lençóis geração 4. Próximo a praia do Sol. p.211

Figura 5.82. Microcones de sombra: estrutura superficial erosiva de planícies interdunares.

p. 213 
Figura 5.83. Modelo para formação de superficies de primeira ordem através da migração de dunas simples (A), segundo Kocurek (1988).

Figura 5.84. Estratificações cruzadas de grande extensão e baixo mergulho no flanco sudeste de rampa de areia eólica geração 2 , na ponta do Ji.

p. 216

Figura 5.85. Superficie de segunda ordem em rampa eólica de barlavento, no flanco norte do morro Santa Marta Grande.

Figura 5.86. Sucessão de seqüências de lâminas iniciadas por 218 ordem no flanco sotavento de cadeia barcanóide.

Figuras 5.88 a 5.90. Morfologias de depósina superfície de duna barcanóide. p.219

Figuras 5.88 a 5.90. Morfologias de depósitos de avalancha em cadeias barcanóides.

5.88 (superior). Leque composto por coalescência de pequenos linguas de p.220 areia, em vista lateral.

5.89 (meio). Mesmo leque em vista frontal.

5.90 (inferior). Morfologia "em tobogan", produzida por junção de avalanchas em cadeias transversais entre si.

Figuras 5.91 a 5.93. Estruturas em frentes de dunas parabólicas truncadas na horizontal por pavimentos interdunares.

p. 222

5.91 (superior). Aspecto geral de lentes de fluxo granular coalescidas ou individuais em meio a laminação fina e regular característica de queda de grãos.

5.92 (inferior esquerda). Detalhe de mesmo tipo de estrutura.

5.93 (inferior direita). Lâminas lenticulares de fluxo granular alternadas com laminação fina regular de queda de grãos e dobras convolutas.

Figuras 5.94 e 5.95. Laminação risca de agulha em depósitos eólicos geração 2. Rampas de areia na ponta do Ji.

p. 223

5.94 (superior). Em provável estratificação cavalgante subcrítica, com desenvolvimento incipiente de crostas planares.

5.95 (inferior). Em corte semi-frontal a lâminas lenticulares de fluxo de grãos, alternadas com làminas finas de queda de grãos.

Figuras 5.96 e 5.97. Laminação risca de agulha em depósitos eólicos geração 1. Dunas de topo de encosta no morro Santa Marta Grande.

5.96 (superior). Aspecto geral, notando-se recobrimento por areias inconsolidadas da unidade 4.

5.97 (inferior). Aspecto de detalhe.

Figura 5.98. Distribuição em mapas e perfil dos principais tipos de estratificação laminar em dunas eólicas barcanas e transversais ou barcanóides. Segundo Hunter (1977) e Kocurek \& Dott (1981).

Figura 5.99. Laminações eólicas com convoluções geradas por liquefação. Pavimento interdunar em barcanóide próximo ao Canal Camacho.

Figura 5.100. Diagramas circulares para azimutes de mergulho em estratificações cruzadas de depósitos eólicos.

Figuras 5.101 e 5.102. Dois tipos de paraconglomerados intraformacionais p.227 com obstáculo fixo geração 2 , na ponta da llhota.

5.101 (superior). Brecha "amalgamada" (sentido de Mutti \& gradação inversa-normal; formada por fluxo granular subaquoso.

$\mathbf{5 . 1 0 2}$ (inferior). Brecha sobre superfície erosiva nítida, ressaltada por crosta de infiltração, contendo estratificação plano-paralela incipiente; formada por tração em regime de fluxo superior. 
Figura 5.103. Camada lenticular de brecha rica em feldspato e fragmentos líticos, em meio a areias com crosta de infiltração. Rampa eólica geração 2, face nordeste da ponta de Santa Marta Grande.

p. 230

Figura 5.104. Plano de deslizamento rúptil em depósito eólico com lentes de fluxo de areia. Rampa de areia de sotavento, geração 2 , na ponta do Ji.

p. 230

Figura 5.105 a 5.106. Bandas de infiltração em dunas de tipo de encosta, geração 2 .

p. 231

5.105 (superior). Bandas planares na ponta do Ji.

5.106 (inferior). Bandas contorcidas na ponta do Cravo.

Figura 5.107. Bandas de infiltração contorcidas acompanhando a superfície topográfica e com mergulho maior que o ângulo de repouso de areia.

p. 232

Figuras 5.108 e 5.109. Comparação entre sedimentos de diferentes gerações eólicas na associação de fácies depósitos mantiformes.

p.241

5.108 (superior). Histograma de freqüências percentuais médias de minerais pesados.

5.109 (inferior). Histograma de razões mineralógicas médias.

Figura 5.110. Concentrações superficiais de minerais pesados na face de barlavento temporária (reversa) de cadeia barcanóide.

p. 242

Figuras 5.111 e 5.112. Comparação entre sedimentos de diferentes gerações eólicas da associação de fácies dunas e lençóis parabólicos

p. 244

5.111 (superior). Histograma de freqüências percentuais médias de minerais pesados.

5.112 (inferior). Histograma de razões mineralógicas médias.

Figuras 5.113 e 5.114. Comparação entre sedimentos de diferentes gerações eólicas da associação de fácies indifereciada.

p.246

5.113 (superior). Histograma de freqüências percentuais médias de minerais pesados.

5.114 (inferior). Histograma de razões mineralógicas médias.

Figuras 5.115 e 5.116. Comparação entre unidades faciológicas eólicas pertencentes

a geração 3 ou unidade 3 .

5.115 (superior). Histograma de freqüências percentuais médias de minerais pesados.

5.116 (inferior). Histograma de razões mineralógicas médias.

Figura 5.117. Contraste de cor entre duas gerações eólicas em margens opostas do arroio Paes Leme, Imbituba. A sul (direita), dunas avermelhadas da geração 2; a norte, dunas esbranquiçadas da geração 3 .

p. 248

Figura 5.118. Histograma de comparação entre unidades ou gerações na associação de fácies indiferenciada, quanto a teor de matéria orgânica na fração pelítica

Figura 6.1. Relações morfoestatigráficas em "dunas de captação" do morro da Joaquina, na ilha de Santa Catarina, segundo Bigarella (197.5c). p.255

Figura 6.2. Modos e tempos de formação de dunas em barreiras regressivas $(a, b)$ e transgressivas ( $b, c, d)$. Modelo baseado no caso do Sul da Austrália, simplificado de Short (1988).

p. 257

Figura 6.3. Escarpas irregulares de arenito pardacento com aspecto maciço, geração 1 , colmatadas e "abraçadas" por areias estratificadas de geraçōes mais novas (2 a 4).

Flanco oeste do morro Santa Marta Grande.

p. 259 
INDICE DE FIGURAS EM ANEXO (A) - VOLUME 2

Figuras A1 a A19: Mapas de detalhamento faciológico baseado em aerofotointerpretação.

p. 106-124

Figura A1. Sistemas eólico e barra-barreira na região do lago Arroio Corrente.

p. 106

Figura A2. Sistemas eólico e lagunar na região entre Morretes, Riachinho e Retiro. p. 107

Figura A3. Sistemas eólico e lagunar na região entre Retiro, Riachinho e Jaguaruna. p.108

Figura A 4. Sistemas eólico e lagunar na região dos lagos Figueirinha e Gregório Bento.

p. 109

Figura A 5. Sistemas eólico, lagunar, barra-barreira e planície costeira na região de lago Laranjal e Garopaba do Sul.

p. 110

Figura A 6. Sistemas eólico e lagunar na região de Jaboticabeira e lago Delfino.

Figura A 7. Sistemas eólico, lagunar e barra-barreira na região de Garopaba do Sul, Camacho e Cigana.

p. 112

Figura A 8. Sistemas eólico, lagunar e barra-barreira na região do rio do Meio.

Figura A 9. Sistemas eólico, lagunar e barra-barreira na região de Campo Verde.

F.114

Figura A10. Sistemas eólico, lagunar e planície costeira na região entre Passagem da Barra e morro Mar Grosso.

p. 115

Figura A11. Sistemas eólico, lagunar e planície costeira na região entre morro Mar Grosso, Cabeçuda e Barbacena.

p.116

Figura A12. Sistemas eólico, lagunar e planície costeira na região entre Barranceira, Praia do Ji e Caputera.

p.117

Figura A13. Sistemas eólico, lagunar e planície costeira na região entre Bentos, praia do Sol, Perrixil e Estreito.

p.118

Figura A14. Sistemas eólico, lagunar e planície costeira na região de Itapirubá, Ponta Rasa e Roça Grande.

p.119

Figura A15. Sistemas eólico, lagunar e planície costeira na região de Guaiuba, Vila Nova e Porto da Vila.

p. 120

Figura A16. Sistemas eólico, lagunar e planície costeira na região de lagoa da Bomba e Imbituba.

p. 121

Figura A17. Sistemas eólico e lagunar na região entre Imbituba e ponta do Catalão.

p.122

Figura A18. Sistemas eólico, lagunar e planicie costeira na região de foz do rio d'Una, Balsinha, Nova Brasilia e Areal.

p.123

Figura A19. Sistema eólico na região entre Nova Brasília, ponta da Ribanceira, lago Doce do Arroio e Ibiqüera.

p.124

Figuras A20 a A56. Gráficos de variação sul-norte de resultados granulométricos e mineralógicos.

p. 125-161

Figura A20. Variação sul-norte de medidas granulométricas - Sistema barra-barreira Fácies planície indiferenciada (holocênica antiga)

p.125 
Figura A21. Variação sul-norte de medidas granulométricas - Sistema barra-barreira Fácies praia de mar aberto - Subfácies pós-praia - Setor Praia Grande do Sul. p. 126

Figura A22. Variação sul-norte de medidas granulométricas - Sistema barra-barreira Fácies praia de mar aberto - Subfácies antepraia - Setor Praia Grande do Sul.

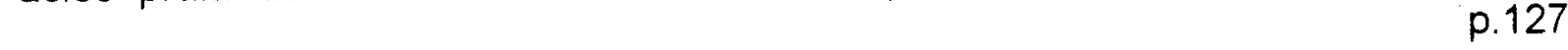

Figura A23. Variação sul-norte de medidas granulométricas - Sistema barra-barreira - Fácies praia de mar aberto - Subfácies antepraia - Setor Praia Grande do Sul. p. 128

Figura A24. Variação sul-norte de medidas granulométricas - Sistema barra-barreira Fácies praia de mar aberto - Setor Praia Grande do Norte.

p.129

Figura A25. Variação sul-norte de atributos mineralógicos - Sistema barra-barreira Fácies praia de mar aberto - Setor Praia Grande do Sul.

p.130

Figura A26. Variação sul-norte de atributos mineralógicos - Sistema barra-barreira Fácies praia de mar aberto - Setor Praia Grande do Norte.

p.131

Figura A27. Variação sul-norte de atributos mineralógicos - Sistema barra-barreira Fácies praila de mar aberto - Setor Santa Marta Pequeno.

p. 132

Figura A28. Variação sul-norte de medidas granulométricas - Sistema planície costeira - Fácies praia de mar aberto - Subfácies antepraia - Setor Mar Grosso. p.133

Figura A29. Variação sul-norte de medidas granulométricas - Sistema planície costeira - Fácies praia de mar aberto - Subfácies pós-praia - Setor Sol.

p.134

Figura A30. Variação sul-norte de medidas granulométricas - Sistema planície costeira - Fácies praia de mar aberto - Subfácies antepraia - Setor Itapirubá.

p.135

Figura A31. Variação sul-norte de medidas granulométricas - Sistema planície costeira - Fácies praia de mar aberto - Subfácies pós-praia - Setor Vila Nova.

p. 136

Figura A32. Variação sul-norte de medidas granulométricas - Sistema planície costeira - Fácies praia de mar aberto - Subfácies antepraia - Setor Vila Nova. p.137 Figura A33. Variação sul-norte de medidas granulométricas - Sistema planicie costeira - Fácies praia de mar aberto - Subfácies pós-praia - Setor Imbituba. p.138

Figura A34. Variação sul-norte de medidas granulométricas - Sistema planície costeira - Fácies praia de mar aberto - Subfácies antepraia - Setor Imbituba. p.139

Figura A35. Variação sul-norte de medidas granulométricas - Sistema planície costeira - Fácies praia de mar aberto - Subfácies antepraia - Setor Imbituba.

p. 140

Figura A36. Variação sul-norte de atributos mineralógicos - Sistema planicie costeira Fácies praia de mar aberto - Subfácies pós-praia - Setor Ji.

p. 141

Figura A37. Variação sul-norte de atributos mineralógicos - Sistema planície costeira Fácies praia de mar aberto - Subfácies antepraia - Setor Ji.

p. 142

Figura A38. Variação sul-norte de atributos mineralógicos - Sistema planície costeira Fácies praia de mar aberto - Setor Sol.

p. 143

Figura A39. Variação sul-norte de atributos mineralógicos - Sistema planície costeira Fácies praia de mar aberto - Setor Itapirubá.

p. 144

Figura A40. Variação sul-norte de atributos mineralógicos - Sistema lagunar Associação de fácies baía-laguna - Fácies antebarreira.

p. 145

Figura A41. Variação sul-norte de atributos mineralógicos - Sistema lagunar Associação de fácies baixio-laguna.

p. 146

Figura A42. Variação sul-norte de medidas granulométricas - Sistema eólico Associação de fácies depósitos mantiformes - Geração 4 - Fácies dunas frontais Barlavento e crista. 
Figura A43. Variação sul-norte de medidas granulométricas - Sistema eólico Associação de fácies depósitos mantiformes - Geração 4 - Fácies dunas frontais Sotavento.

Figura A44. Variação sul-norte de medidas granulométricas - Sistema eólico Associação de fácies depósitos mantiformes - Geração 4 - Fácies manto de areia.

Figura A45. Variação sul-norte de atributos mineralógicos - Sistema eólico Associação de fácies depósitos mantiformes - Geração 2 - Fácies manto de areia.

p. 150

Figura A46. Variação sul-norte de atributos mineralógicos - Sistema eólico Associação de fácies depósitos mantiformes - Geração 4 - Fácies dunas frontais Crista.

Figura A47. Variação sul-norte de atributos mineralógicos - Sistema eólico Associação de fácies depósitos mantiformes - Geração 4 - Fácies manto de areia Subfácies dunas transversais - Barlavento.

p. 152

Figura A48. Variação sul-norte de atributos mineralógicos - Sistema eólico Associação de fácies depósitos mantiformes - Geração 4 - Fácies manto de areia Subfácies dunas transversais - Crista e sotavento.

p. 153

Figura A49. Variação sul-norte de atributos mineralógicos - Sistema eólico Associação de fácies depósitos mantiformes - Geração 4 - Fácies manto de areia Subfácies cadeias barcanóides - Crista.

p. 154

Figura A50. Variação sul-norte de atributos mineralógicos - Sistema eólico Associação de fácies depósitos mantiformes - Geração 4 - Fácies manto de areia Subfácies frentes parabólicas.

p. 155

Figura A51. Variação sul-norte de medidas granulométricas - Sistema eólico Associação de fácies dunas e lençóis parabólicos - Geração 2 - Fácies formas parabólicas - Subfácies dunas e frentes de lençóis parabólicos - Barlavento. p.156

Figura A52. Variação sul-norte de medidas granulométricas - Sistema eólico Associação de fácies dunas e lençóis parabólicos-Geração 3 . p.157

Figura A53. Variação sul-norte de medidas granulométricas - Sistema eólico Associação de fácies dunas e lençóis parabólicos - Geração 4 - Fácies formas parabólicas - Subfácies dunas e frentes de lençóis parabólicos. Figura A54. Variação sul-norte de atributos mineralógicos - Sistema eólico Associação de fácies dunas e lençóis parabólicos-Geração 2.

p.159

Figura A55. Variação sul-norte de medidas granulométricas - Sistema eólico Associação de fácies indiferenciada - Unidade 3.

Figura A56. Variação sul-norte de atributos mineralógicos - Sistema eólico Associação de fácies indiferenciada - Geração 2 - Crostas e intercrostas de infiltração.

\section{ÍNDICE DE PRANCHAS EM ANEXO (A) - VOLUME 2}

Prancha A1. Mapa de localização de pontos de amostragem (1:100.000)

Prancha A2. Mapa de sistemas deposicionais (1:100.000). 


\section{ABSTRACT}

An attempt of conceptual analysis of the language used in theory of systems, applied to Quaternary coastal sedimentation, allowed the recognition and description, on surface, of four types of depositional systems in the area of the big lagoonal complex of southern-central Santa Catarina coast (Garopaba do Sul, Camacho, Santa Marta, Santo António, Imaruí and Mirim lagoons). Depositional system is defined as a set of facies formed by processes in connected and organized operation, having thus typical pattern of spatial arrangement of facies. Two of the recognized systems spread from Pleistocene to Holocene: the aeolian and strandplain systems. The other two systems, lagoon and barrier-bar, are considered as Holocene.

Each depositional system is submitted to an external and internal description. The external description concerns to exchanges of sediments and energy between systems; these exchanges occur through two different ways, alternated in the time: the feedback (maintenance of the equilibrium steady state) and the events of spontaneous evolution (searching for a new steady state). Examples of alternance between mechanisms of exchange are the cycles of closing and opening of the Camacho lagoonal inlet (transfer channel between lagoon and barrier-bar systems) or the phases of activation and interruption of primary aeolian dunes (exchange relationship between the beach facies of barrier-bar and strandplain systems and the aeolian system). The internal description departs from the conception of spatialtemporal hierarchies of facies, for each depositional system, and bases itself on the physiographic and sedimentological characterization (sedimentary structures, grainsize and heavy minerals) of systems in different levels of this hierarchy. It is outstanding the subdivision of the lagoon system into two associations of facies, the low-lagoon, generated by the partial transgressive drowning of other pre-existing systems, and the bay-lagoon, formed by deposition of a barrier during the transgression started at the end of Pleistocene. In the aeolian system, besides the two associations of facies related to contrasting rates of sedimentary supply, at least four deposit generations are recognized. It is supposed that there are laws of dependence between three factors: the types of associations of facies, the morphostratigraphy of aeolian generations and the way of dynamic interaction (feedback versus spontaneous evolution) between aeolian system and oceanic beach facies. The last factor is controlled by the behaviour of the relative sea level (RSL). In that basis, general correlation between aeolian generations in the study area and of coasts of similar RSL pattern in other continents has been proposed. 


\section{RESUMO}

Uma tentativa de análise conceitual da linguagem usada em teoria de sistemas, aplicada à sedimentação costeira quaternária, permitiu o reconhecimento e a descrição, em superfície, de quatro tipos de sistemas deposicionais na área do grande complexo lagunar centro-sul catarinense (lagoas Garopaba do Sul, Camacho, Santa Marta, Santo António, Imaruí e Mirim). Sistema deposicional é definido como conjunto de fácies formadas por processos em operação conexa e organizada, possuindo assim padrão típico de arranjo espacial de fácies. Dos sistemas reconhecidos, dois estendem-se do Pleistoceno ao Holoceno: os sistemas eólico e planície costeira. Os outros dois sistemas, lagunar e barra-barreira, são considerados holocênicos.

Cada sistema deposicional é submetido a uma descrição externa e interna. A descrição externa trata das trocas de sedimentos e energia entre sistemas; estas trocas ocorrem sob dois modos diferentes, alternados no tempo: a retroalimentação (manutenção do estado estacionário de equilibrio) e os eventos de evolução espontânea (busca de novo estado estacionário). Exemplos de alternância entre mecanismos de troca são os ciclos de fechamento e abertura da desembocadura lagunar do Camacho (canal de transferência entre os sistemas lagunar e barrabarreira) ou as fases de ativação e cessamento de dunas eólicas primárias (relação de troca entre a fácies praial dos sistemas barra-barreira ou planicie costeira e o sistema eólico). A descrição interna parte da concepção de hierarquias espaço-temporais de fácies, para cada sistema deposicional, e baseia-se na caracterização fisiográfica e sedimentológica (estruturas sedimentares, granulometria e minerais pesados) do sistema em diferentes niveis desta hierarquia. Destaca-se a subdivisão do sistema lagunar em duas associaçōes de fácies, a baixio-laguna, gerada pelo afogamento transgressivo parcial de outros sistemas preexistentes, e a baia-laguna, formada por deposição de uma barreira durante a transgressão iniciada no final do Pleistoceno. No sistema eólico, além de duas associações de fácies relacionadas a taxas de aporte sedimentar contrastantes, são reconhecidas pelo menos quatro gerações deposicionais. Supõem-se leis de dependência entre três fatores: os tipos de associações de fácies, a morfoestratigrafia de gerações eólicas e o modo de interação dinâmica (retroalimentação versus evolução espontânea) entre sistema eólico e fácies praial. O último fator é controlado pelo comportamento do nivel relativo do mar (NRM). Com base ñisso, correlações gerais entre gerações eólicas da área em estudo e de costas de padrão de NRM similar em outros continentes são propostas. 


\section{CAPITULO 1. INTRODUÇÃO}

\section{1. ÁREA DE ESTUDO}

O Quaternário costeiro entre Jaguaruna e Imbituba (figura 1.1) abrange as grandes lagunas do litoral centro-sul catarinense (Garopaba do Sul Camacho e Santo António - Imaruí - Mirim). Dois aspectos tornam esta área propícia à experiência acadêmica de uma abordagem sedimentológica que aproxime conceitos e métodos da "análise de fácies" (Walker 1976; Anderton 1985) e da "teoria" de sistemas deposicionais (Fisher \& McGowen 1967) à "teoria geral de sistemas" (Bertalanffy 1968). O primeiro aspecto é sua diversidade faciológica, sua complexidade de processos lagunares, eólicos e marinhos interdependentes; cabe lembrar, a este respeito, que a teoria de sistemas nasceu da necessidade de resolver um problema de complexidade. O segundo aspecto é a singularidade da área enquanto sede, no Holoceno, de uma "bacia" de afogamento lagunar extensiva e contínua; atende assim a um requisito de "naturalidade" de fronteiras, conveniente ao seu tratamento como sistema geomorfológico maior (Galloway 1979), ainda que estas fronteiras holocênicas não coincidam obrigatoriamente com os limites de sistemas deposicionais preexistentes pleistocênicos.

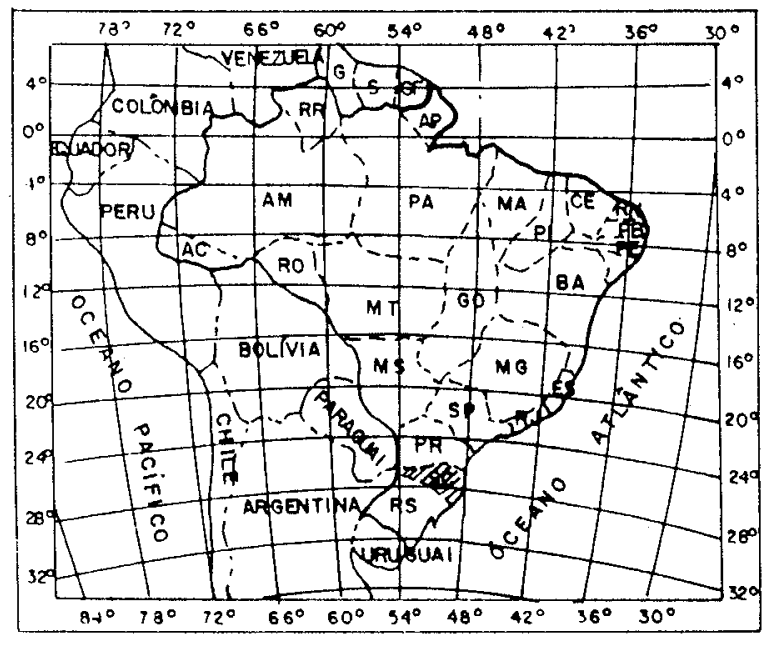

LOCALIZACÃO DA ÁREA NO ESTADO

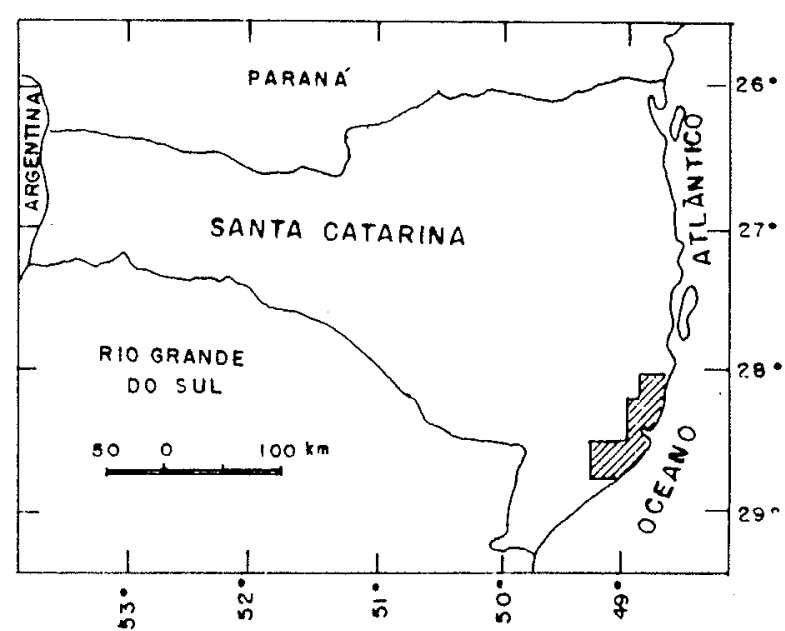

Figura 1.1. Localização da área estudada em relação a América do Sul, Brasil e Santa Catarina.

A área de Jaguaruna-Imbituba apresenta também singularidades de âmbito geográfico, ambiental e arqueológico, com possiveis implicações sedimentológicas. Sua particularidade geográfica diz respeito à localização em zona de transição de características fisiográficas. Seu extremo norte, na região de Garopaba-Imbituba, tem-se reconhecido como início da zona fisiográfica das lagunas do Sul do Brasil (Martin et al.1988b), que se estende até as lagunas Patos e Mirim (RS), enquanto a região de Laguna, em sua parte sul, tem sido considerada 
como fronteira geográfica natural entre o litoral sul e o litoral sudeste do pais (Silveira 1964; Villwock 1987). Este caráter limitrofe deve-se em essência à mudança de orientação da linha de costa, passando de ENE, a sul do Cabo de Santa Marta Grande, para NNE, a norte da cidade de Laguna. Além disso, as planícies largas e contínuas prevalecentes a sul de mesmo cabo dão lugar rumo norte a paisagem dominada por lagunas, baias, ilhas e praias recortadas pelo embasamento proterozóico. Esta transição reveste-se de interesse geológico, seja por sua origem ligada a condicionamentos tectônico-estruturais de ordem regional (item 3.1.2.1) seja por sua influência na distribuição de fácies e nos padrões hidrodinâmicos locais de correntes de deriva litorânea.

No aspecto ambiental, a área enfocada tem como problema central a poluição química e detrítica da bacia hidrográfica do rio Tubarão, incluindo o seu complexo lagunar receptor, pela indústria de extração, beneficiamento e derivação química do carvão da Formação Rio Bonito (Paleozóico da Bacia do Paraná) explorado na regiāo de Siderópolis, Urussanga e Criciúma (Kux \& Valeriano 1982; Garcia 1986; Tommasi 1987). A questão ambiental de maior relevância na sedimentação da área emersa, à qual se restringe este trabalho, são as enchentes em mesma bacia hidrográfica, acompanhadas por mecanismos episódicos de fluxos de massa em encostas (Bigarella \& Becker 1975b) e de rompimento 'temporário de barreiras lagunares (itens 5.1.2.1. e 4.2.4).

Do ponto de vista arqueológico, a área de Jaguaruna-Imbituba é singular pela concentração e dimensões relativamente grandes de sambaquis. Em levantamento de "jazigos conchíferos" (bancos de moluscos e sambaquis) na quadricula de Laguna, Castro \& Castro (1969a,b) identificaram mais de 80 ocorrências; destas, 40 referiam-se a sambaquis então existentes na área costeira entre Imbituba e Laguna. Os maiores deles, como os sambaquis de Garopaba do Sul, Carniça e Cabeçuda apresentavam volumes superiores a $200 \mathrm{mil} \mathrm{m} \mathrm{m}^{3}$ (Bocchi \& Liberatore 1968c). Os sambaquis são duplamente importantes no estudo da sedimentação na área. Primeiro, como fornecedores potenciais de informações sobre variações do NRM (nivel relativo do mar) holocênico (Guerra 1950a; Pimienta 1958; Martin et al. 1986, 1988b). Segundo, como possivel indicio de elevada produtividade biológica local durante pelo menos parte do Holoceno, favorecida por regime climático elou hidrodinâmico (item 3.2.2.4).

\subsection{METAS E OBJETIVOS}

Uma série de objetivos imediatos de estudo foi estabelecida tendo-se em vista o cumprimento de metas ou objetivos mediatos pré-fixados.

\subsubsection{METAS}

Para efeito de apresentação, dividem-se as metas de trabalho em cinco. Duas delas são de cunho metodológico; referem-se a uma proposta de 
modo de abordar os objetivos. As outras três são de conteúdo; definem o que será buscado como informação científica na tentativa de uso destes meios de abordagem.

A primeira meta de caráter metodológico consiste em aplicar a "teoria geral de sistemas" de Bertalanffy (1968) ao conceito geológico de "sistemas deposicionais", a partir da conotação atribuida ao termo em sua proposição original por Fisher \& Mc Gowen (1967). A segunda meta, extensão operacional da anterior, constitui-se na divisão da área estudada em sistemas deposicionais de fácies e na caracterização paragenética das fácies previamente reconhecidas em cada um dos sistemas.

As metas de conteúdo circunscrevem-se em: primeiro, explicar os padrões observados de distribuição espaço-tempo das fácies dentro dos sistemas deposicionais e dos sistemas dentro da área em estudo, com ênfase às fácies eólicas e lagunares e suas feições associadas tais como variedades morfológicas de dunas, bancos de conchas, sambaquis e depósitos turfosos; segundo, esboçar a evolução sedimentar da área no decorrer do Quaternário, através da caracterização dos sistemas deposicionais antigos e modernos e de suas relações de erosão e sedimentação; e terceiro, determinar focos possiveis de problemas ambientais e potenciais econômicos da cobertura sedimentar.

\subsubsection{OBJETIVOS}

Procurou-se atingir as metas apresentadas através da realização dos objetivos enumerados em seguida:

1) Estabelecer e aplicar critérios sistêmicos para a subdivisão hierárquica ergódica de sistemas deposicionais em associações faciológicas, fácies e subfácies, baseada em informações de superfície.

2) Reconhecer e reformular em linguagem sistêmica leis ou principios reguladores dos balanços de sedimentação entre os vários sistemas deposicionais identificados.

3) Fazer a descrição geomorfológica e sedimentológica das fácies contidas em cada sistema deposicional, com ênfase a aspectos aerofotogeológicos e ao estudo de estruturas sedimentares, granulometria e minerais pesados, incluindo a variação espaço-temporal destes atributos através da hierarquia ergódica ( Os cinco objetivos seguintes são prioridades de investigação das variações espacial e temporal).

4) Avaliar a importância relativa da deriva litorânea longitudinal e do aporte transversal de sedimentos à costa no transcorrer da evolução quaternária da área.

5) Mapear a distribuição geográfica e vetorial da influência do agente eólico na dispersão dos sedimentos superficiais.

6) Estabelecer possiveis correlações entre os sistemas deposicionais identificados e os "sistemas laguna-barreira I, II, III e IV" de Villwock et al. (1986), assim como com as unidades cronoestratigráficas (informais) holocênica e pleistocênica de Martin et al. (1988b).

7) Verificar o comportamento do nivel relativo do mar (NRM) nos últimos 2 mil anos na área em estudo, visando explicar a discrepância entre as curvas de variação de NRM neste período propostas por Martin et al. (1988b), para Santa Catarina, e por Tomazelli \& Villwock (1989), para o Rio Grande do Sul. 
8) Reconhecer e caracterizar as várias geraçōes provavelmente existentes de depósitos eólicos na região, correlacionando-as, quando possivel, a gerações identificadas em outros paises.

9) Classificar as feições deposicionais e erosivas geradas pelo vento, em especial quanto a tipos de dunas.

10) Caracterizar, de modo qualitativo, o regime morfodinâmico dos vários setores praiais, avaliando sua eventual influência na disponibilidade de areia para retrabalhamento eólico e nas dimensões e tipologia de dunas assim derivadas.

11) Rediscutir gênese e significado geológico das denominadas "estruturas de dissipação de dunas" (Bigarella 1975 a,b), muito freqüentes em dunas que cavalgam pontões cristalinos na região.

12) Situar, no contexto de interrelação entre fácies ou sistemas, as ocorrências de concentraçōes sedimentares minerais e orgânicas de valor econômico, como minerais pesados, concheiros e turfas, e os fenômenos de implicações ambientais como movimentos de massa, rompimento de barreiras litorâneas e migração de dunas eólicas.

\subsection{COBERTURA QUATERNÁRIA: EVOLUÇÃO DO CONHECIMENTO}

Um dos primeiros estudos específicos sobre depósitos sedimentares quaternários na área enfocada foi empreendido por Guerra (1950b). Nesse trabalho, é apresentada em mapa uma distribuição faciológica muito simplificada, na qual 0 autor se limita a distinguir entre "planície litorânea" e "banhados" (figura 1.2). A planicie litorânea é descrita como formada por terraços de "restingas", de altura não superior a $6 \mathrm{~m}$, terraços lagunares, incluindo bancos de conchas, e dunas eólicas alongadas, subparalelas à costa, influenciadas pelos ventos de NNE e SSW. É mencionada a existência de "dunas fósseis e vivas" na região de Imbituba assim como de "invasão dos afloramentos de granito pelas dunas" na ponta da Entrada da Barra, em Laguna. Os "banhados" ou "brejos" a oeste do morro de Passagem da Barra são atribuídos à incorporação, por assoreamento gradual, de ilhas de "mangue" à "restinga" de areia adjacente. Faz-se assim, de modo indireto, a primeira referência à relação genética dos banhados desta localidade com barras de maré.

Um mapa mais detalhado da mesma área foi apresentado por Pimienta 1958 (figura 1.3) no âmbito de projeto de implantação de um porto carbonifero. Este autor atribuiu a formação da planície litorânea à regressão que sucedeu a "Transgressão Flandriana" e supôs sua inteira cobertura por sedimentos de idade holocênica. Tomando por base medidas de campo de descarga sólida do rio Araranguá, situado a sul de Jaguaruna, estimou uma taxa anual de aporte fluvial à costa no setor entre Torres (RS) e Laguna de apenas $25 \mathrm{~m}^{3}$ de areia por $\mathrm{km}^{2}$ de bacia de drenagem, valor que ele reconheceu como insuficiente para explicar a deposição durante o Holoceno do grande volume de areia existente na área. Admitiu deste modo que uma parte significativa da areia holocênica deve ter provindo do retrabalhamento de sedimentos pleistocênicos preexistentes na plataforma continental ou na própria planície. Resultados granulométricos referentes a zona costeira submersa defronte à desembocadura do rio Araranguá foram apresentados; 0 autor interpretou tendência 

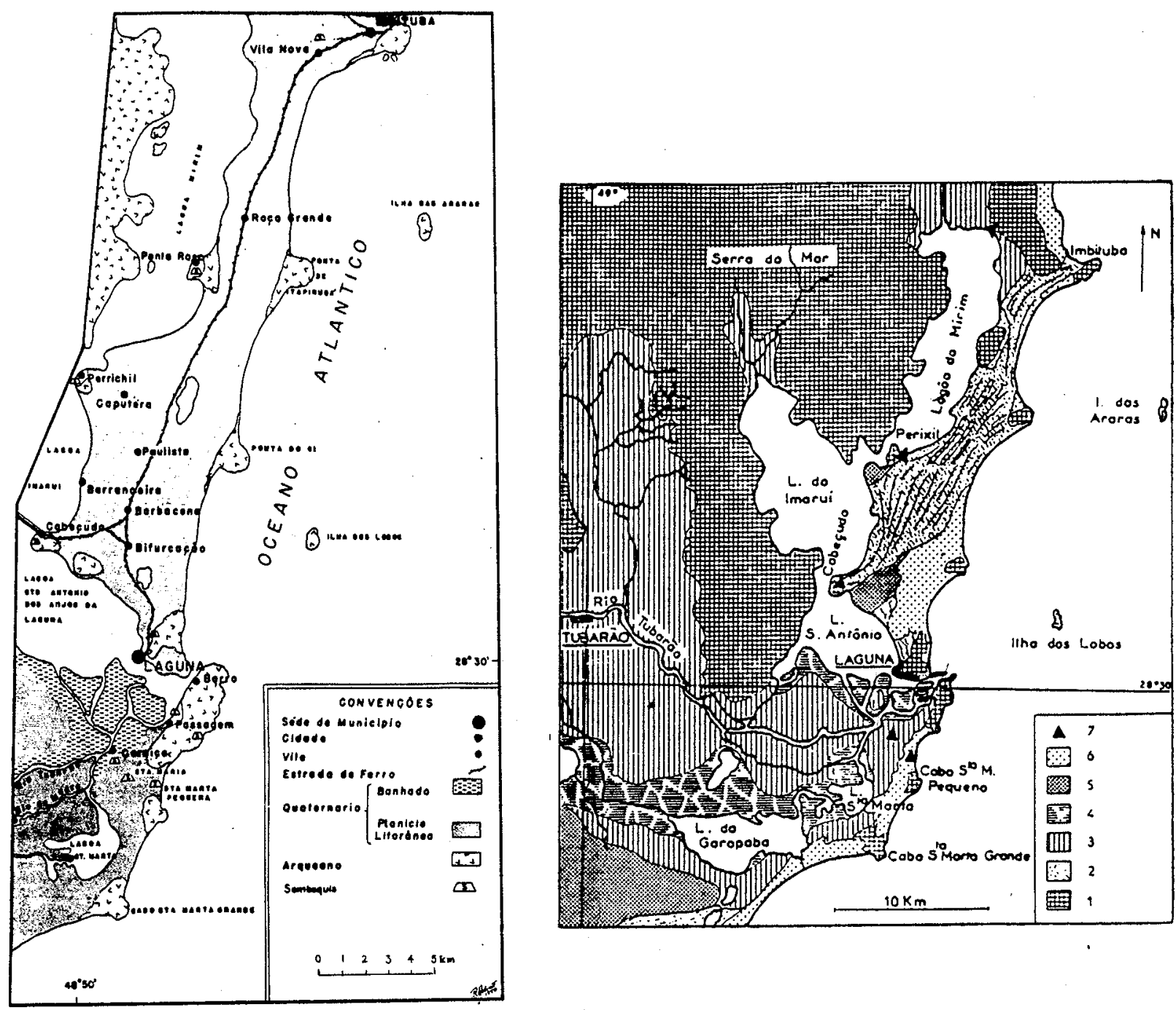

Figuras 1.2 e 1.3. Mapas prévios da área investigada.

1.2 (esquerda). Mapa da área entre Laguna e Imbituba estudada por Guerra (1950b).

1.3 (direita). Mapa geológico da regiăo entre Jaguaruna e Imbituba, segundo Pimienta (1958). 1. Cristalino; 2. Restingas; 3. Planície deltaica; 4. Lodo; 5. Dunas fixadas; 6. Dunas livres; 7: Principais sambaquis.

para diminuição de granulometria média da isóbata $-5 \mathrm{~m}$ até a isóbata $-30 \mathrm{~m}$, com "isometria máxima" (maior similaridade entre amostras) na zona de barra de arrebentação externa, e concluiu que as "vasas de origem fluvial" formam um cinturão margeando a costa a partir das profundidades superiores a $30 \mathrm{~m}$. Supôs com isto, a estabilização das barras de arrebentação, indicando uma fase atual de relativa constância na posição da linha de costa. Diagnosticou o papel dos ventos alternados de $S$ e de NE, os primeiros mais violentos e os últimos mais freqüentes, na determinação dos rumos resultantes de deriva litorânea longitudinal e deriva eólica, respectivamente. Sugeriu a existência de relações diretas entre a fase atual de ativação de dunas eólicas e suposta tendência para estabilização da linha de costa. Apresentou, também, considerações sobre a dinâmica sub-recente do "delta intralagunar do rio Tubarão", reconhecendo a existência de uma frente abandonada 
em sua parte sul, hoje ocupada pelas lagunas Garopaba do Sul e Camacho. Segundo o autor, o canal Camacho, aberto ciclicamente, seria um remanescente do antigo acesso a mar aberto desta frente deltaica desativada.

Para um resumo final da concepção de Pimienta (1958) sobre a história sedimentar da área em estudo, vale citar as quatro fases evolutivas por ele enumeradas, uma primeira de transgressão marinha e três de "aluvionamento". $\mathrm{Na}$ fase inicial, a "Transgressão Flandriana" teria provocado a abrasão e inundação da planicie até a base atual das zonas serranas de rochas pré-cambrianas. Em seqüência, o primeiro estágio de aluvionamento formou uma planície de "restingas" (cordões) isolando lagunas; na etapa seguinte, o delta do rio Tubarão progradou, entulhando parte dos corpos lagunares; e, no último estágio, dunas eólicas avançaram através das planícies "deltaica" (antebarreira) e de "restingas", criando a paisagem atual. Este quadro evolutivo, assim como as demais conclusões obtidas por Pimienta (1958) permanecem em sua essência aceitas até hoje, à exceção da atribuição exclusiva da cobertura da planicie litorânea ao Holoceno. Algumas de suas idéias, como a da relação entre a dinâmica do canal Camacho e a atividade do delta, são retomadas e reformuladas neste trabalho.

Entre o final da década de 1960 e o início da década de 70 , a região costeira de Imbituba a Jaguaruna e arredores foi objeto de trabalhos sistemáticos de cartografia geológica executados pelo Departamento Nacional de Produção Mineral (DNPM), com a apresentação de uma série de artigos e relatórios internos (Castro \& Castro 1969a,b; Ferreira 1969; Shulz et al.1970; Teixeira 1969; Albuquerque \& Horbach 1972). Adicionados os trabalhos realizados anteriormente pelo DNPM na área de Tubarão (Putzer 1955), esta bibliografia resumia o conhecimento cartográfico existente à época sobre a área em estudo e que se encontra compilado em publicações referentes a Carta Geológica do Brasil ao Milionésimo (Mônaco et al. 1974a; Willig et al. 1974). Devido à escala reduzida de mapeamento, pouca ênfase é dada nestas obras à separação de unidades faciológicas da cobertura sedimentar. Sua maior contribuição encontra-se no levantamento das potencialidades econômicas da planície litorânea, como em relação a vasas silicosas lacustres em Imbituba (Castro \& Castro 1969a; Willig et al.1974) e a bancos de conchas lagunares enquanto fonte de calcário (Bocchi \& Liberatore 1968 a,b,c,d).

Entre 1970 e 80, foram publicados os primeiros e possivelmente únicos estudos sobre os aspectos granulométrico, paleontológico e hidrogeológico da cobertura sedimentar quaternária na área de Jaguaruna-Imbituba. Martins et al. (1970) e Martins \& Martins (1974) obtiveram parâmetros granulométricos de Folk \& Ward (1957) para amostras interespaçadas de $2 \mathrm{~km}$, coletadas na praia e em dunas ativas adjacentes, ao longo de costa compreendida entre Araranguá e Imbituba. Encontraram o predominio de areias bem selecionadas e consideraram a assimetria, tipicamente positiva para os depósitos eólicos e negativa para os praiais, como discriminador ambiental mais eficiente. Não foi abordada a questão do significado sedimentológico da variação vetorial de parâmetros granulométricos ao longo do setor costeiro amostrado.

No aspecto paleontológico, a única referência encontrada é o artigo de Macedo \& Ferreira (1976), a respeito da tafocenose biodetrítica de sedimentos subsuperficiais (profundidade maior que $9,0 \mathrm{~m}$ ) do vale do baixo rio Tubarão. Três características são atribuidas pelos autores a esta assembléia fossilifera: o registro de espécimes marinhos de foraminiferos, ostracodes, espinhos de 
equinóides e espículas de esponjas associados a moluscos e diatomáceas cêntricas de ambiente misto; a presença de fragmentos de vegetais lenhosos; e o predomínio de formas faunísticas bentônicas jovens pouco ou nada desgastadas. Esses três aspectos levaram os autores a concluir por um paleoambiente de deposição parálicomarinho sob condições hidrodinâmicas de baixa energia. A falta de dados mais precisos sobre localização de pontos de amostragem e datação dificulta o aproveitamento destes resultados para interpretações paleogeográficas. Características hidrogeológicas da cobertura quaternária foram discutidas por Brito Neves et al. (1979), para todo o litoral catarinense, e por Santos (1978), para a área de Imbituba-Imaruí. De acordo com este último autor, os sedimentos arenosos finos e homogêneos da planície litorânea compõem um aqüifero livre com espessura média de $60 \mathrm{~m}$.

O conjunto de obras publicadas nas décadas de 1960 e 70 detalhou mas não modificou o quadro evolutivo da área concebido por Pimienta (1958). Este quadro tornou-se questionável, porém, face às conclusões do estudo sistemático sobre o comportamento cronológico e altimétrico do NRM quaternário na costa brasileira, iniciado com a publicação de Martin \& Suguio (1976) sobre o litoral paulista, e que atentava para a possibilidade de existência de terraços marinhos pleistocênicos. Mesmo antes disto, Bigarella (1975d) já supunha a présença de dunas de idade pleistocênica na região de Vila Nova, a sul da cidade de Imbituba. Com a extensão daquele estudo sistemático à costa de Santa Catarina (Suguio et al.1986; Martin et al.1986), um novo esquema evolutivo (sintetizado no item 3.1.3.2) foi proposto, assim como mapas da cobertura sedimentar em escalas 1:150.000 (Martin \& Suguio 1986) e 1:200.000 (Martin et al.1988b). Neste último, as unidades quaternárias foram separadas quanto a sua idade (holocênica, pleistocênica ou indiferenciada) e caracterização litológica. Apesar de o mapa possuir, segundo os próprios autores, caráter "descritivo", atribuem-se interpretações ambientais às unidades reconhecidas. Identificam-se desse modo, quatro unidades na área entre Jaguaruna e Imbituba. A primeira é formada por "areias marinhas litorâneas", correspondente às praias atuais e a terraços holocênicos e pleistocênicos; os terraços pleistocênicos são mapeados sob a forma de uma faixa subparalela à costa, interrompida apenas na região do delta do rio Tubarão. A superposição de dunas ativas e estabilizadas é indicada em algumas partes dos terraços marinhos. A segunda unidade consiste em "sedimentos argilosos e arenosos de lagunas e baías", melhor representados na área pelo delta do rio Tubarão, de idade holocênica. A terceira unidade, dos "sedimentos argilo-arenosos flúvio-lagunares", é identificada na parte alta do delta (planície deltaica) e nos vales dos rios Linha Anta e Sangão, escavados ao interior dos terraços pleistocênicos da região de Jaguaruna. A idade atribuida é também holocênica. A quarta unidade litológica, dos "sedimentos continentais mal selecionados", ocorre em parte das encostas perisserranas, com idade quaternária não diferenciada, e é relacionada pelos autores a alúvios fluviais e colúvios.

A separação feita por Martin et al. (1988b) entre terraços arenosos holocênicos e pleistocênicos é baseada na menor altitude dos primeiros, no seu menor grau de impregnação epigenética dos grãos e na maior nitidez dos "alinhamentos superficiais de cristas praiais", como os identificados a norte da cidade de Laguna. Devido ao recobrimento extensivo dos terraços por dunas eólicas, os critérios mencionados de altimetria e nitidez de alinhamentos podem ter seu uso dificultado na área, fazendo-se convenientes estudos que determinem e mapeiem 
diferentes gerações de depósitos eólicos. Martin \& Suguio (1986) e Martin et al. (1988 b) introduziram a abordagem desta questão ao supor a existência de três gerações eólicas. A mais velha, exemplificada pelas dunas da praia de Muita Água, em Imbituba, é formada por areias avermelhadas pedogenizadas e densamente vegetadas. Os autores consideram sua idade mais antiga que 7 mil anos e mais nova que 120 mil anos. A segunda geração é composta, segundo eles, por dunas inativas holocênicas de areias claras, vegetadas. $E$ a mais recente constitui-se de dunas ativas de areias brancas, na faixa mais externa da planície litorânea. 


\section{CAPITULO 2. MÉTODOS}

\subsection{PESQUISA BIBLIOGRÁFICA}

A pesquisa bibliográfica foi realizada em duas fases. Na fase preliminar, ainda durante elaboração do plano inicial de trabalho, deu-se ênfase a publicações sobre a geologia regional, classificadas segundo quatro assuntos principais: aspectos petrológicos e tectono-estruturais do embasamento préQuaternário, sedimentologia e estratigrafia da cobertura quaternária costeira, aspectos econômico-ambientais e arqueologia de sambaquis. A literatura sobre geologia regional foi localizada com auxílio da Bibliografia Analítica da Geologia do Brasil (1640-1983), publicada pelo Departamento Nacional de Produção Mineral (DNPM). Parte significativa das obras selecionadas, encontrando-se em relatórios inéditos do DNPM, foi consultada na biblioteca da sede do 10 Distrito desta empresa em Florianópolis (SC).

A segunda fase de levantamento bibliográfico abrangeu quatro temas preferenciais: teoria de sistemas em geociências, análise e modelos de fácies, sedimentação costeira marinha e eólica e discussões metodológicas sobre obtenção e tratamento de resultados granulométricos. Obras sobre estes temas foram selecionadas inicialmente de publicações recentes (últimos 5 a 10 anos) de uma série de periódicos (Journal of Geological Education, Journal of Sedimentary Petrology, Marine Geology, Revista Brasileira de Geociências, Sedimentary Geology, Sedimentology, Shore and Beach), extraindo-se delas referências de outras publicações e/ou anos anteriores para leitura adicional.

As informaçōes de maior parte da bibliografia consultada foram sintetizadas e integradas em trabalho de revisão crítica dos temas mencionados (Giannini 1991).

\subsection{ABORDAGEM SISTEMMICA}

\subsection{1. "TEORIA DE SISTEMAS": HISTÓRICO E FUNDAMENTOS}

A "teoria geral de sistemas" tem suas origens nas ciências biológicas, através do surgimento, durante a década de 1920, da idéia de "reação sistêmica" de Weiss e da "teoria organísmica" de Bertalanffy. Ambas representavam o organismo vivo como um sistema de componentes em interação mútua e dinâmica. $O$ comportamento do organismo seria assim descrito por "leis gerais do sistema orgânico" (Bertalanffy 1937), diferentes das leis da física clássica no fato de se referirem a sistemas abertos, isto é, sistemas capazes de se manter em um estado estacionário (com constância do todo e de suas partes) de produção mínima de entropia, através do fluxo contínuo de energia e matéria com seu meio (Bertalanffy 1932 apud Bertalanffy 1950; Prigogine 1947 apud Huggett 1985). Percebeu-se, quase de imediato, que esta "lei de mínima produção de entropia" para sistemas biológicos 
abertos tinha validade para outros sistemas organizados, nos mais diversos campos da ciência, de tal modo que pareceu possivel a formulação de uma "teoria geral de sistemas", capaz de obter a unificação sintética do conhecimento científico.

Apesar disto, o que hoje se conhece como "teoria de sistemas" apresenta-se antes como programa de objetivos metodológicos que como resultado adquirido (Delattre 1981). Alguns aspectos fundamentais da "teoria de sistemas", relacionados por Bertalanffy (1972), devem ser encarados, portanto, apenas como princípios de abordagem. O primeiro deles é o uso e a descoberta de "leis sistêmicas", isto é, analogias lógicas entre relações que, embora pertencendo a fenômenos distintos, são formalmente idênticas entre si. A "teoria dos sistemas abertos" é indicada pelo autor como exemplo mais geral de lei sistêmica, uma vez demonstrado que até mesmo os paradigmas que a antecederam, como a dinâmica newtoniana e a teoria dos sistemas irreversiveis fechados ou de máxima entropia de Clausius, podem ser tratados como seus casos particulares (para fluxo de entropia igual a zero). O segundo principio da abordagem sistêmica é o uso de modelos, construções analógicas de objetos observados, que constituem a única forma pela qual sistemas podem ser expressos. Os modelos são versáteis, adaptáveis a qualquer tipo de explicação ou sistema a ser explicado, por causa de seus enunciados analógicos. Seu caráter de "explicações em princípio" confere-lhes poder preditivo e capacidade de teste e auto-falseamento (Delattre 1981; Fichter 1988).

Bertalanffy (1950, 1965) considera menos relevante o modo como um modelo é inicialmente abstraído (modelo conceitual) que a maneira pelo qual ele é finalmente descrito. A descrição do modelo constitui o terceiro aspecto fundamental da abordagem sistêmica. Este aspecto será melhor discutido adiante (item 2.2.3), onde se apresentará uma proposta de descrição de sistemas deposicionais baseada na "teoria de sistemas".

\subsection{2. "TEORIA DE SISTEMAS" EM GEOCIÊNCIAS E EM GEOLOGIA SEDIMENTAR}

$\mathrm{Na}$ tipologia clássica de sistemas, os objetos de estudo das geociências são invariavelmente sistemas abertos (Huggett 1985). Revelou-se, com isto, a conveniência de se utilizarem novas tipologias. Duas delas, surgidas na geografia física, têm sido de uso comum. A primeira deve-se aos trabalhos de Chorley \& Kennedy (1971), Terjung (1976) e Strahler (1980), que classificaram sistemas quanto ao nível de descrição. Segundo este critério, um sistema pode ser definido sob três modos diferentes: em termos de formas externas, em termos de processos (fluxos de energia e matéria) e em termos de relações entre processos e formas resultantes. O primeiro tipo, o "sistema forma", pode ser exemplificado, no contexto da geologia sedimentar, por uma duna eólica representada por variáveis pertinentes à sua geometria, como crista, face de avalancha ("slipface") e flanco de barlavento, e à sua constituição, como granulometria e cobertura vegetal. O segundo tipo, denominado "sistema cascata" ou "sistema fluxo", consiste de uma série de linhas de fluxo de matéria e/ou energia unindo diferentes estoques. Os mecanismos de avalancha e de queda de grãos na frente de uma duna podem ser vistos como duas linhas de fluxo que transferem diferentes quantidades e granulometrias de areia e que dissipam diferentes niveis de energia dos estoques de crista para os estoques de sotavento. $O$ 
terceiro tipo de sistema recebe o nome de "processo-resposta" ou "processo-forma". Trata-se de sistemas de fluxos de energia considerados em mútua interação com sistemas morfológicos, de tal modo que mudanças no primeiro alteram o segundo e vice-versa

O segundo critério de classificação de sistemas, atribuído a Weaver (1958 apud Huggett 1985) também permite reconhecer três tipos. O primeiro tipo é o sistema simples, por exemplo, seixos dispersos sobre uma praia arenosa: cada elemento, se solicitado por forças conhecidas, poderá reagir de modo previsivel e independente. O segundo tipo é o sistema complexo mas desorganizado, como as moléculas protominerálicas de um magma dentro de uma câmara fechada. O último tipo é o sistema complexo e organizado, onde os elementos são muitos e suas relações muito fortes para que possam ser estudados isoladamente, mas estas relações possuem uma natureza organizada. É o caso do mesmo magma durante um derrame; ou de grãos de areia num fluxo granular, onde a organização das intensas interações de pressão dispersiva intergranular pode até materializar-se, no registro deposicional, na forma de uma estrutura gradacional inversa (Bagnold 1941; Sallenger 1979; Collinson \& Thompson 1982). Pode-se observar, através destes exemplos, que os modelos complexos desorganizados são, a rigor, modelos de sistemas fechados, sendo inadequados à descrição da maioria dos sistemas naturais de certa complexidade.

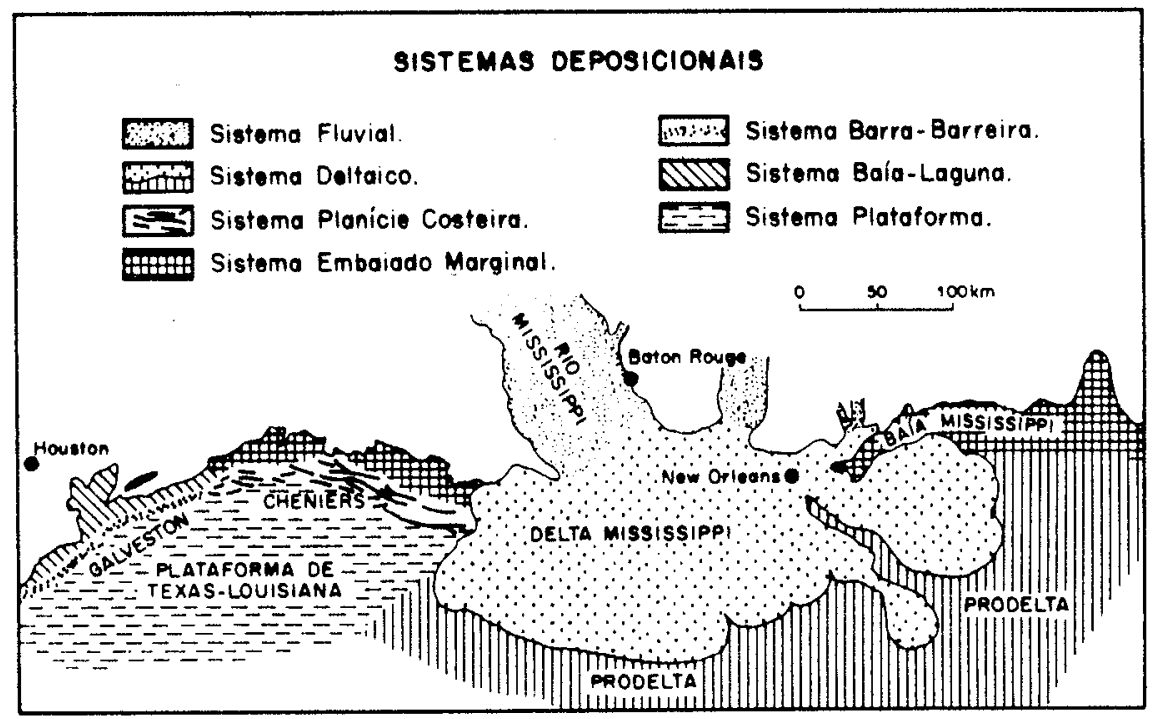

Figura 2.1. Mapa de sistemas deposicionais recentes na costa noroeste do golfo do México, apresentado em trabalho pioneiro sobre sistemas deposicionais, de autoria de Fisher \& McGowen (1967).

Em geologia sedimentar, um dos potenciais mais evidentes do enfoque sistêmico são os complexos arranjos tridimensionais de fácies denominados "sistemas deposicionais" (Fisher \& McGowen 1967; figura 2.1). O tratamento destes sistemas através de modelos processo-resposta organizados tem sido sugerido ou adotado por diversos autores (Krumbein \& Sloss 1963; Galloway 1979; Galloway \& Hobday 1983; Fritz \& Moore 1988), além de ter influenciado Walker (1976) em sua proposta de análise de fáceis. Devem ter-se sempre ressalvados porém dois aspectos. O primeiro é que não se pode atribuir às relações processo-resposta o caráter de causa-efeito, e portanto de norma ou paradigma (Anderton 1985; Fichter 
1988). O segundo é que um modelo processo-resposta complexo, em escala ou nível de tratamento maiores, pode implicar o emprego de modelos-processo ou modelosforma simples, em escalas mais básicas (Anderton 1985). Esta consideração tem conseqüências importantes quanto ao modo de abordagem, pois enquanto sistemas simples podem ser satisfatoriamente descritos pela física newtoniana clássica, sistemas complexos requerem o uso da segunda lei da termodinâmica, quando desorganizados, ou da lei de mínima produção de entropia de Prigogine, quando organizados (Gregory 1985; Huggett 1985). Como aplicar esta última lei na descrição de sistemas deposicionais é uma das questões que será abordada em seguida.

\subsubsection{PROPOSTA DE MÉTOdO DE ANÁlise DE SISTEMAS VOLTADA À GEOLOGIA SEDIMENTAR}

\subsubsection{Introdução}

A "teoria de sistemas" surge na história da ciência como uma tentativa de reação ao que Ortega y Gasset (1930) denominou de "barbárie da especialização". O propósito de integrar conhecimentos aparece como sua meta mais geral, a ser perseguida dos niveis mais particulares para os niveis mais abrangentes (Delattre 1981). No nivel particular da geologia sedimentar, um dos casos de segregação de especialidades encontra-se entre a geologia do Quaternário acadêmica e a geologia do Quaternário desenvolvida como ferramenta da geologia do petróleo (Giannini 1991). Um sintoma desta segregação é que o conceito original de sistemas ou complexos deposicionais (Boyd \& Dyer 1964; Hayes \& Scott 1964; Fisher \& McGowen 1967), surgido no estudo do Quaternário costeiro voltado a geologia do petróleo, e consagrado dentro desta, tem permanecido sob quase esquecimento na geologia do Quaternário acadêmica. Constata-se assim um paradoxo; o de um conceito, nascido de estudos do Quaternário costeiro, que não evolui a não ser em rochas de idade não quaternária. Este fato, entre outros parcialmente já abordados por Giannini (1991), torna justificável uma retomada do enfoque sistêmico a áreas de sedimentação costeira quaternária.

O primeiro passo para uma unificação de conhecimentos, segundo Delattre (1981), é a formulação de uma linguagem comum. Uma linguagem, segundo o autor, é feita de conceitos, que se podem decompor em dois níveis, um semântico, do formalismo que o expressa, e um sintático, do seu significado. A unificação de linguagens requer a integração de conceitos sintaticamente análogos, contidos em contextos diferentes, sob um conceito semântico único. Em geologia sedimentar, a falta de uma integração deste gênero é freqüentemente motivo da falência cientifica de conceitos importantes. Já são clássicos hoje os exemplos dos termos "fácies", no âmbito da estratigrafia tradicional (Weller 1958), "graywacke" (Dott 1964) e "ambiente sedimentar" (tabela 2.1); este último, apesar disto, tem sido inadequadamente utilizado por alguns autores como sinônimo de sistemas deposicionais. 


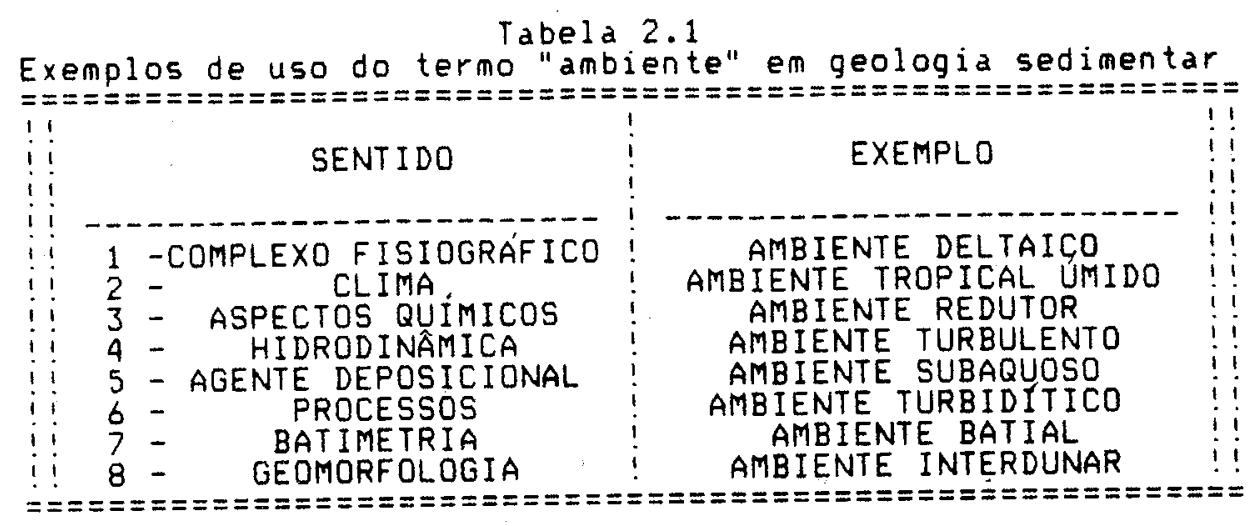

A existência de uma linguagem bem estruturada é a base necessária para a descrição de sistemas, isto é, para a criação de modelos (Delattre 1981). Há vários tipos de modelos quanto a sua forma de descrição tais como os modelos-escala e os modelos matemáticos estatísticos ou determinísticos, mas todos eles partem de uma descrição preliminar do sistema que constitui o chamado modelo conceitual (Bertalanffy 1965; Huggett 1985). Um modelo conceitual pressupõe estabelecimento inequívoco de conceitos e portanto de uma linguagem. Deste modo, a primeira etapa de descrição conceitual de um ou mais sistemas, em determinado compartimento da ciência, é a padronização de uma linguagem compatível. A nível semântico, já se dispõe hoje de uma linguagem sistêmica potencialmente aplicável a todas as modalidades da ciência, a qual deve ser submetida a análise conceitual (sintática) cada vez em que for transferida a qualquer uma destas modalidades (Delattre 1981). É dentro desta análise conceitual, aplicada à geologia sedimentar do Quaternário, que se inserem este e os próximos três itens desta Tese. O método de estudo de sistemas aqui proposto possui alcance modesto, em razão de seu caráter exclusivamente conceitual, mas é requisito preliminar obrigatório na construção de modelos mais refinados. Seu uso justifica-se, além disto, pelo "valor de um quadro sistêmico como poderoso instrumento de explicação" (Sugden \& John 1976 apud Gregory 1985). Divide-se o método em três etapas: exame prévio, descrição externa e descrição interna. Para facilitar a compreensão do texto, os termos pertencentes à semântica sistêmica aparecerão diferenciados em negrito.

\subsubsection{Exame prévio de sistemas}

O exame prévio visa situar o sistema (ou um conjunto de sistemas) no seu meio ou macroambiente, isto é, no sistema ou espaço de hierarquia superior que o envolva. Ele abrange três tarefas: estudo do macroambiente, estudo das interações de matéria e energia entre sistemas e meio e delimitação de fronteiras dos sistemas ou subsistemas maiores. Nesta etapa, procede-se do todo em direção às partes, procedimento em essência analitico. Para que se possa executar tais tarefas, duas questões prévias devem estar respondidas: qual definição de sistema deposicional adotar e qual o critério para subdividir a área de estudo em sistemas deposicionais. Em resposta a primeira questão, é adotada aqui a acepção original do termo; como nos três trabalhos pioneiros (Boyd \& Dyer 1964; Hayes \& Scott 1964; Fisher \& Mc Gowen 1967) não há definição formal, mas apenas operacional, assumese a definição de Galloway (1979) inferida de Fisher \& Mc Gowen (1967): "uma 
unidade estratigráfica física tridimensional geneticamente definida, consistindo de um conjunto contiguo de fácies sedimentares relacionadas por processos". Galloway (1979) deriva ainda da aplicação original do conceito três corolários: (1) sistemas deposicionais são os equivalentes estratigráficos de unidades fisiogeográficas maiores; (2) sistemas deposicionais formam os tijolos de construção essenciais no preenchimento de uma bacia sedimentar; (3) o conceito aplica-se com maior eficiência onde os limites entre sistemas estejam preservados e possam ser mapeados. De acordo com Chorley \& Kennedy (1971), todo sistema geocientífico caracteriza-se pela "operação conjunta de componentes como um todo complexo, de acordo com algum padrão observado". Na definição operacional de Fisher \& Mc Gowen (1967), este "padrão observado" corresponde a uma distribuição espacial de fácies e/ou associações de fácies. Isto implica em terem-se estabelecidas também definições rigorosas para estes dois últimos termos que sejam compatíveis com a abordagem sistêmica e onde as fácies e suas associações possam até ser tratadas como subsistemas. A concepção de fácies de Walker (1976) representa-as como materializações de processos sedimentares, tornando-as adequadas ao tratamento processo-resposta. Esta definição é adotada aqui com as modificações propostas por Anderton (1985), que enfatiza a independência entre a fácies descritiva, modelo real, e a fácies interpretativa, modelo abstrato, destituindo da associação processo-resposta qualquer caráter de norma geral. Isto permite ao método de modelagem de fácies.ser compativel com o princípio da falseabilidade de Popper (1934). Quanto à definição de associação de fácies, considera-se não haver diferença entre um sistema deposicional e suas associações de fácies, a não ser com relação a hierarquia de subdivisão na área de estudo e ao grau de conexão interna, problemas que pertencem à questão seguinte.

A solução para a segunda questão, como dividir uma área em sistemas, pode ser obtida em dois passos. Se os sistemas deposicionais, tais como na proposta de Fisher \& McGowen (1967), são vistos como tijolos de construção no preenchimento sedimentar da bacia, o primeiro passo consiste em se definir os limites da bacia a ser subdividida em sistemas. Conforme Galloway (1979), este conceito de "bacia" da definição original não deve ser entendido com conotação fixa de natureza ou escala, podendo referir-se tanto a uma imensa sinéclise, como a um pequeno graben ou a uma baía moderna. A "bacia" deve ser vista assim como um sistema natural maior, cuja escolha preestabelece a escala, imediatamente mais baixa, dos sistemas deposicionais a se distinguir. Esta distinção de sistemas constitui o segundo passo; ela é feita.examinando-se a geometria bidimensional interna da "bacia", por meio de imagens de satélites, fotografias aéreas e mapas prévios, e reconhecendo-se unidades de preenchimento sedimentar e seus respectivos padrões característicos de distribuição de fácies. Uma "bacia" pode ser dividida por exemplo em dez unidades de preenchimento, as quais possam ser agrupadas em três unidades maiores. Haverá dúvida sobre quais unidades chamar de sistemas deposicionais e quais unidades considerar como meras associações de fácies. $O$ primeiro critério de decisão é 0 critério estético (Dooge 1968), ou de máxima simplificação na descrição de relações sistema-meio ("bacia"), cuja condição mais importante é a de que a ação do sistema sobre o meio pode depender das variáveis do sistema e das variáveis do meio, mas o sistema não é capaz de modificar os fatores do meio aos quais ele é sensivel (Delattre 1981). Comumente, unidades de diferentes escalas de subdivisão da bacia satisfazem esta condição, mas apenas as maiores relacionam-se diretamente com a "bacia" como 
seu meio, isto é, estão em hierarquia de escala imediatamente inferior a da "bacia"; estas serão então as mais compativeis com a denominação de sistema deposicional. O segundo critério, corolário do primeiro, é o critério de máxima conexidade de Thom (1972), que afirma ser o sistema individualizado como domínio conexo do espaço ("bacia"). Deste modo, o sistemas deposicionais são as associaçōes de fácies de mais intensa conexidade a uma mesma hierarquia de escala imediatamente inferior a da "bacia". Um exemplo modelar de associações de fácies em conexidade fraca e que não podem ser consideradas sistemas deposicionais são as associações de fácies do modelo de leque submarino de Mutti \& Ricci-Lucchi (1972).

\subsubsection{Descrição externa}

O princípio essencial da "teoria de sistemas" nas palavras de Bertalanffy (1952 apud Bertalanffy 1972) afirma que "as propriedades e modos de ação dos níveis superiores não se podem explicar pela soma das propriedades e modos de ação que correspondem a seus componentes isoladamente; apesar disto, é possivel chezar aos niveis mais elevados partindo dos componentes menores, quando se conhece o conjunto de componentes e suas interrelações". Com respeito à descrição de sistemas, este principio implica duas condições necessárias. A primeira consiste em que os componentes menores já devam estar reconhecidos; enquanto o exame prévio (item anterior), por seu caráter analitico, requer um conhecimento geral da "bacia" e de seu meio, a descrição é uma etapa de síntese e pressupõe o conhecimento tão minucioso quanto possivel das fácies. A segunda condição é a de que o estudo sistêmico do conjunto de interaçōes entre componentes deva anteceder o estudo sistêmico dos componentes; deste modo, é ideal que a descrição interna de cada sistema deposicional seja precedida pela descrição externa do sistema deposicional em mútua relação com seus sistemas vizinhos na "bacia".

O objetivo principal da descrição externa é determinar o padrão de operação do sistema e sua função em relação à operação geral de seu meio (Bertalanffy 1972). Segundo Dooge (1968), há dois modos distintos de se abordar a operação de um sistema. O primeiro é através do exame de suas relações com leis físicas e com as características inerentes à sua própria natureza. Em sistemas deposicionais, estas relações são consideradas apenas nos níveis mais básicos de descrição de fácies, como na interpretação de estruturas sedimentares em termos de regime de fluxo. O segundo modo é através das relações entre entradas ("inputs") e saídas ("outputs") de matéria, energia ou informação (ganho de ordem), denominadas canais ou funções de transferência. Corresponde ao modo mais sintético e clássico de descrição externa de sistemas, cujo modelo gráfico usual é um diagrama de blocos e linhas de fluxo interblocos, simbolizando os sistemas e os canais de transferência, respectivamente. O estudo de um canal de transferência pode objetivar a solução de um problema de detecção, quando a entrada é o elemento desconhecido da relação, identificação ou sintese, quando o sistema é o elemento desconhecido, ou de predição, quando a saída é o elemento desconhecido (tabela 2.2). Estes são os quatro tipos principais de "problemas de análise sistêmica", segundo Dooge (1968). Em sistemas deposicionais costeiros atuais, não existem "problemas de análise sistêmica", pois os três componentes de funções de transferência são geralmente bem conhecidos por observação direta. Se predições rio campo da engenharia costeira têm-se demostrado falhas, isto se deve a exclusão ou 
avaliação errônea do efeito de fenômenos "extremos" (White 1974 apud Gregory 1985) ou "episódicos" (Hsu 1983; Dott 1983), como tormentas, dentre os fatores de saída de sedimentos da praia (Pilkey 1989, 1991). O estudo de sistemas deposicionais quaternários inativos constitui um problema de sintese: a entrada do sistema é conhecida de modo aproximado através de informações relativas ao volume, à textura e à mineralogia dos sedimentos e a saida é dada por informações análogas coletadas em sistemas vizinhos, mas a operação do sistema, exceto por informações indiretas via feiçōes geomorfológicas e estruturas sedimentares, é incógnita. Sua inferência deve ser feita então através de simulação, em nível conceitual (Dooge 1968), de processos; e do exame de compatibilidade dos processos supostos com as feições observadas, empregando-se o método processo-resposta (Fichter 1988).

Tabela 2.2

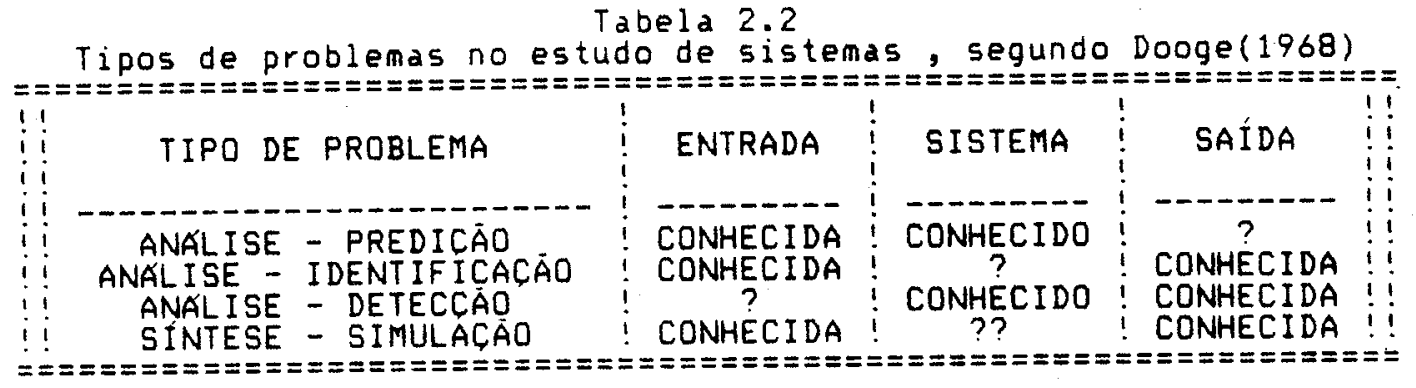

Dois conceitos fundamentais na descrição externa de um sistema são a comunicação e a retroalimentação. A comunicação pode ser definida como o intercâmbio de informação (entropia negativa) entre um sistema e o meio (Bertalanffy 1972). A formação ou organização de arranjos de componentes sistêmicos, tais como padrões de configuração faciológica em um sistema deposicional, requer ganho de informação pelo sistema (Bertalanffy 1950). Este efeito só é possivel através de aumento de entropia no meio e da comunicação entre sistema e meio que caracteriza um equilibrio de fluxo ou estado estacionário ("steady state", também traduzido como "estado estável", alternativa descartada aqui para evitar confusōes com sistema estável; ver item 2.2.3.4.2). A retroalimentação é o mecanismo de troca controlada de entropia pelo qual o sistema se mantém em constante equilíbrio de fluxo, mesmo que sua entropia diminua. A analogia clássica do principio de funcionamento deste mecanismo é a do termostato (Bertalanffy 1950, 1965). Trata-se portanto de um controle de função do sistema em relação a seu meio (Bertalanffy 1972).

As definições clássicas de comunicação e retroalimentação envolvem, como se pode ver, um terceiro conceito fundamental da "teoria de sistemas", que é o de entropia. Cabe traduzir o significado deste termo, originado na termodinâmica, ao enfoque sistêmico aplicado a ciências naturais (Lauffer 1975). Alguns aspectos regem o uso sistêmico adequado do conceito. O mais geral deles, demonstrado por Tonnelat (1978), é o da inexistência de associação obrigatória entre entropia e desordem. A entropia é originalmente uma concepção de energia termodinâmica, e assim relacionada com a desordem de movimento de partículas microscópicas. Fora deste contexto, a correspondência entre entropia e desordem deixa de ser geral. É o que acontece quando se transfere do contexto da concepção microscópica para a observação macroscópica (Lazlo 1972 e Huggett 1976 apud Gregory 1985); ou ainda quando se passa do contexto de niveis energéticos para o 
contexto de arranjos espaciais. Na prática do estudo de sistemas deposicionais, realizada aqui no contexto da observação macroscópica de arranjos espaciais, a conclusão que se pode extrair deste exame conceitual da entropia, é que não convém utilizar-se o termo, a não ser como uma analogia puramente formal do conceito de desordem, o qual deve pois ser também examinado.

Da avaliação conceitual das idéias de ordem e desordem, realizada por Tonnelat (1978) e por Delattre (1981), algumas considerações devem servir como diretrizes para a descrição de sistemas deposicionais. A primeira delas é que a ordem não possui equivalência universal com a complexidade. A segunda é que a ordem implica o aparecimento e/ou a estabilização de singularidades, entendidas como "situações privilegiadas de pelo menos certos elementos no espaço de descrição". As singularidades podem representar-se, entre ou dentro de sistemas deposicionais, como posições relativas preferenciais de um sistema em relação a outro ou de uma fácies em relação a outra, respectivamente. A terceira consideração referese à necessidade de distinguir se os processos de gênese de ordem ou desordem devem-se a interações entre sistemas ou se são resultado de uma evolução espontânea do sistema, não correspondida por mudanças recíprocas de grau de ordenação em seu meio. Neste último caso, deixa de ser válido o "princípio da mínima produção de entropia", onde se situa o conceito de retroalimentação, e a descrição externa clássica não será suficiente para abordar o fenômeno. É um caso que, por isto mesmo, será deixado para análise no item referente a descrição interna (item 2.2.3:4).

Nos casos de sistemas abertos com validade do princípio da retroalimentação, parece possivel falar-se em fenômenos movidos por causas finais, isto é, pelo objetivo de alcançar o estado estável de equilibrio de fluxo, numa espécie de generalização sistêmica do princípio químico de Le Chatelier. Esta idéia de causalidade final ou equifinalidade pode ser útil na descrição de eventos encadeados no tempo, enquanto for possivel abordá-los como reversiveis (Delattre 1981). Bertalanffy (1960) destaca até a possibilidade de descoberta de leis de construção-destruição ou de morfologia dinâmica, baseadas na premissa da equifinalidade. Leis utilizadas no estudo de perfis de equilibrio costeiro, como a "regra de Bruun", por exemplo, podem em primeira instância ser incluídas. Falta verificar se são leis válidas para casos de reversibilidade eqüifinal, referidos por Bartalanffy (1960), ou para situações de evolução espontânea irreversível. Polèmicas sobre a funcionalidade prática da "regra de Bruun" (Dean 1987) situam-se exatamente nesta questão, que será discutida adiante (item 2.2.4).

\subsubsection{Descrição interna}

\subsection{Concepção de modelos: estruturas e dinâmica}

O objetivo principal da descrição interna é a determinação dos padrões organizados de arranjo espacial de fácies e subfácies que caracterizam cada sistema deposicional e que na semântica sistêmica correspondem a estruturas ou padrões (Bertalanffy 1950, 1972; Delattre 1981; Gregory 1985). Este caráter estrutural da descrição interna torna-a, em primeira instância, uma produção de modelos de formas. Como já visto (item 2.2.2), os modelos de formas podem tanto referir-se à geometria do sistema, representada por exemplo por um mapa geológicogeomorfológico, como à sua constituição, representada pela variação espacial de 
atributos mineralógicos, texturais ou de estruturas sedimentares. $\mathrm{Na}$ prática, é inevitável a inclusão de aspectos genéticos, através de conjecturas sobre a evolução do sistema no tempo (Gregory 1975), de tal modo que se torna conveniente a sua abordagem como modelo processo-resposta (Fritz \& Moore 1988; Fichter 1988). Assim, a descrição interna é não somente estrutural, como também dinâmica, no sentido de que abrange a variação do sistema (Bertalanffy 1972).

Há vários problemas potenciais na confecção de modelos processo-resposta em geologia (Anderton 1985; Fritz \& Moore 1988; Fichter 1988). Estes problemas residem, em sua maior parte, no uso implícito de duas premissas: uma atualista e outra causalista (Fichter 1978). A premissa atualista admite que as estruturas são, em essência, invariantes no tempo, isto é, as relações processoresposta de um sistema são as mesmas e com o mesmo padrão de configuração espacial, em qualquer época. A premissa causalista postula que os sistemas são lineares, isto é, certas entradas ou processos internos produzem sempre as mesmas saidas ou respostas, independentemente da ocorrência ou não de outras entradas ou processos, de tal modo que a soma de causas produza a soma de seus efeitos isolados (Dooge 1968; Huggett 1985). Sabe-se porém que os sistemas naturais com freqüência possuem uma parcela de variância e são não lineares, o que constitui dois problemas no tratamento de sua dinâmica. Na prática, estes dois problemas traduzemse como a dificuldade de manusear a variável tempo. Como observado por Schumm \& Lichty (1965), as distinções entre causa e efeito "dependem do lapso de tempo envolvido e da magnitude do sistema geomórfico considerado". Deste modo, para cada escala espacial e temporal de abordagem, certas relações de processo-resposta se destacam enquanto outras se obscurecem. Em um sistema deposicional quaternário com atividade continuada até dias atuais, a totalidade espacial do sistema corresponde a um registro de fenômenos ocorridos durante toda sua evolução, enquanto a sedimentação contemporânea restringe-se a uma parcela de sua área total. À medida que se amplia em direção ao passado o intervalo de tempo investigado, amplia-se também a abrangência espacial (Schumm \& Lichty 1965; Chorley \& Kennedy 1971); compõe-se assim uma hierarquia de escalas de tempo e de espaço, as quais mantêm entre si uma correspondência ergódica (figura 2.2).

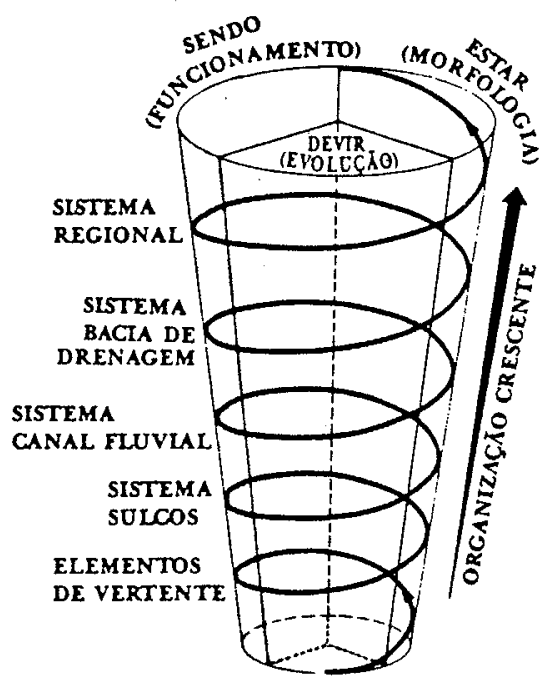

Figura 2.2. Hierarquia espacial de sistemas geomorfológicos, crescente ao longo da escala temporal (vertical ascendente). Modificado de Chorley \& Kennedy (1971) por Gregory (1985). 
A integração progressiva ("zoom") do sistema através destas sucessivas hierarquias conduz a seqüências evolutivas (Gregory 1985), de grande interesse em estudos do Quaternário. $\dot{E}$, além disto, compativel com o método epistemológico proposto por Delattre (1981) para os problemas da variância e da não linearidade em estudos sistêmicos: a "superação das considerações causais" através de um enfoque que dê ênfase à "evolução e à invariância de propriedades estruturais". A estatística adquire ai papel auxiliar importante (Delattre 1981; Gregory 1985), uma vez que funções e correlações entre entradas e saidas do sistema devidamente situadas no tempo, podem ser consideradas como referências de invariância (Delattre 1981). No caso específico de sistemas deposicionais em escala de tempo geológica, a coleta de dados não se refere usualmente a entradas e saídas de sedimentos, mas sim a saldos, representados por estoques sedimentares nas diferentes partes do sistema (Shuisky \& Schwartz 1983; Huggett 1985). As estatísticas referem-se assim a estruturas de configuração espacial e devem, sempre que possivel, ser estabelecidas em relação a coordenadas geográficas. As estruturas espaciais por elas descritas revestem-se de significado temporal ou dinâmico, seja por se referirem a gerações de sistema deposicional de idades distintas, seja por resultarem, no caso de uma geração isócrona, de processos de transporte com um efeito resultante no tempo. Nesta segunda situação, cada estrutura possui, inerente, uma correspondência com a geografia ou paleogeografia da época. Num estudo tridimensional, a estrutura do sistema deposicional estaria representada pelas variaçōes vertical e horizontal de fácies, relacionadas entre si através da lei de Walther, exemplo mais abrangente de "lei sistêmica" em geologia sedimentar.

Com base nessas considerações, estabeleceu-se um procedimento padrão para descrição interna dos sistemas deposicionais na área de estudo. Os sistemas são subdivididos de forma canônica em associações de fácies, fácies e várias hierarquias de subfácies, em ordem crescente de restrição no tempo e no espaço. As subfácies de menor hierarquia em cada sistema são depósitos atuais. Os sistemas encontram-se estudados em suas variáveis fisiográficas, relacionadas com a forma e as dimensões dos estoques, e sedimentológicas, relacionadas com a dinâmica. Énfase é dada à variação geográfica de variáveis granulométricas e mineralógicas, visando relacionar-se as estruturas dos modelos sedimentológicos à estrutura do modelo fisiográfico de mesma idade. Análise estatística de regressão linear é empregada como ferramenta auxiliar na avaliação de estruturas nos modelos sedimentológicos. Modelos processo-resposta associando propriedades estruturais de granulometria a rumos preferenciais de transporte sedimentar por ventos $e$ correntes litorâneas são apresentados com base no "método de Mc Laren". Este método consiste em um modelo empírico geral de padrão de variação geológica unidimensional de parâmetros granulométricos como resposta a processos de transporte com uma direção resultante (Mc Laren 1981, 1982; Mc Laren \& Bowles $1985,1991)$. Modelos gerais análogos, para variação geográfica de minerais pesados, são mais ou menos inferidos através de grande volume de trabalhos (Friese 1931 apud Pettijohn 1957; Russell 1937; Smithson 1941; Hubert 1962; Dietz 1973; Giannini 1987; Morton \& Smale 1990).

A variação de estado dos sistemas no tempo geológico é investigada aqui através da comparação de estruturas de modelos fisiográficos e sedimentológicos entre o Pleistoceno, o Holoceno antigo e o Holoceno atual. Dentro das estruturas de modelos sedimentológicos, meréce destaque a influência da 
dissolução pós-deposicional (Pettijohn 1941; Suguio et al.1974; Morton 1984, 1987; Morad \& Aldahan 1986; Giannini 1987; Milliken 1988; Milliken \& Mack 1990), com seu efeito de "destruição de invariâncias", diretamente correlacionável à idade dos
sedimentos.

\subsection{Estudo da estabilidade de sistemas}

A estabilidade de um sistema é dada por seu comportamento diante de flutuações nas variáveis de estado. Se se imagina um espaço cujas dimensões sejam as variáveis ativas na flutuação, a estabilidade é determinada pela trajetória que o ponto de representação do sistema descreve neste espaço de estado (Huggett 1985). A analogia clássica é a do um corpo esférico, o sistema, colocado sobre uma superfície de formato qualquer, representando seu espaço de estado (figura 2.3). De acordo com as características das variáveis de estado, o sistema pode então ser classificado em estável, instável, metaestável ou neutro. Um sistema estável é aquele que tende a manter suas variáveis restritas a um intervalo de valores médios. É exemplificado, em geologia sedimentar costeira, por uma planície litorânea cujo espaçamento entre alinhamentos de cristas praiais oscile ligeiramente em torno de um valor modal (Huggett 1985). O sistema instável mantém-se enquanto não houver perturbações; quando isto acontece, suas variáveis assumem valores distintos ao extremo. É um caso raro, representado por sistemas autofágicos como certos tipos de leques aluviais (Thornes 1983 apud Huggett 1985). O sistema metaestável mantém-se enquanto as pertubações ocorrerem dentro de certos limites; quando tais limites são ultrapassados, ele passa a dissipar energia espontaneamente, rumo a estados de ordem maior. Os exemplos do derrame magmático e da avalancha eólica, citados anteriormente (item 2.2.2), encaixam-se neste tipo de sistema, também chamado dissipativo. O sistema neutro é aquele em que a perturbação altera apenas a posição do sistema em relação a um referencial externo, mas não sua estrutura (forma $e$ dimensões), como talvez exemplificado pela migração lateral de meandros fluviais (Thornes 1983 apud Huggett 1985).

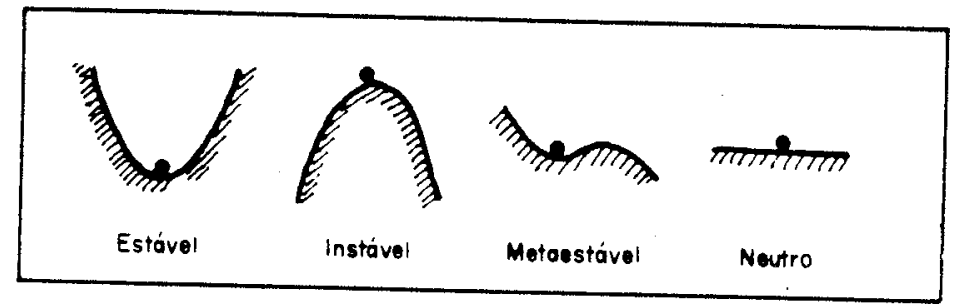

Figura 2.3. Representação dos tipos de estabilidade de sistemas, por analogia com a mecánica clássica. Segundo Huggett (1985).

Quanto mais complexo for o sistema, menor a possibilidade de se descrever um estado para o sistema como todo. O enfoque deve então ser restrito a partes do espaço físico ou do espaço de estado do sistema.

Um conceito sistêmico relacionado com a estabilidade é o de sensitividade. Expressa o grau de influência de mudanças nas variáveis de uma fácies em fácies vizinhas e a taxa de recuperação do sistema após perturbaçc̃es (Huggett 1985; Gregory 1985). Dois conceitos relacionados são o tempo de residência, que designa o periodo de manutenção do estoque ou fácies sedimentar 
em determinado estado de equilibrio de fluxo, e o atraso ou defasagem ("lag": Huggett 1985), que indica o tempo que o sistema ou fácies leva para reencontrar um estado de equilíbrio após ter sido perturbado. Brunsden \& Thornes (1979 apud Gregory 1985) propõem a quantificação da sensitividade através do quociente entre tempo médio de defasagem e tempo médio de recorrência do evento perturbador.

\subsubsection{Estruturas dissipativas}

A lei de sistemas abertos ou lei da minima produção de entropia de Bertalanffy-Prigogine (item 2.2.1) perde validade quando os sistemas são afastados, para além de certos limites, de seu estado estacionário. Fala-se então em desequilíbrios muito distantes do equilibrio. Os sistemas em tal situação são levados a dissipar entropia, de modo irreversivel, sem reposição de entropia vinda do meio: adquirem, como efeito, novos estados estacionários caracterizados por organização interna notável. As estruturas de alta organização, por serem produzidas através de dissipação de energia, foram chamadas por Prigogine (1980) de estruturas dissipativas. Os exemplos do derrame ou sil magmático e da avalancha de areia eólica, citados anteriormente (item 2.2.2), ilustram a produção de tais estruturas em geologia. No caso do sil, o magma recém-colocado em contato com rochas de temperatura muito mais baixa que a de seu estado estacionário de fusão, submete-se a processos de dissipação de entropia através do desenvolvimento de uma célula de convecção de calor, a qual gera o seu resfriamento e transformação em rocha. A estrutura dissipativa pode preservar-se na rocha tanto em nível megascópico, representada por superficies de disjunção remanescentes das linhas de fluxo e isotermas de convecção, como em nível microscópico, na forma de texturas e de arranjos cristalinos. No outro exemplo, da avalancha eólica, grãos de areia concentrados na porção íngreme superior da face de sotavento, ao serem sujeitos a ação de ventos muito mais fortes que os ventos de sua deposição por saltação, tornam-se instáveis e passam a alimentar um fluxo gravitacional ao longo da face de avalancha. Durante o fluxo, o efeito de pressão dispersiva cria um empacotamento aberto e possibilita a produção de gradação inversa, materializando assim um aumento de organização em nivel microscópico (Hunter 1976, 1977; Sallenger 1979; Collinson \& Thompsom 1982; Fryberger \& Schenk 1988).

Existem exemplos de sistemas que podem ser submetidos a sucessivas mudanças de configuração e a sucessivos estados estacionários de estrutura dissipativa. Cada um dos sucessivos estados estacionários destes sistemas corresponde a condições relativamente estreitas de variáveis de estado, de modo que eles resultam facilmente instabilizáveis. Tais exemplos são especialmente comuns entre os fenômenos relacionados com fluxo de fluidos e com processos de erosão, transporte e deposição (Huggett 1985). Podem-se citar, entre os primeiros, as séries de formas de leito originadas sob fluxo unidirecional em função de variações no número de Froude e na granulometria (diagrama-modelo de regime de fluxo) e, entre os últimos, a sucessão de padrões morfodinâmicos de praias arenosas segundo Wright et al. (1979). Uma analogia entre estes dois exemplos é ilustrada pela figura 2.4 .

A possibilidade de formação de estruturas dissipativas caracteriza o comportamento dinâmico de sistemas metaestáveis (item 2.2.3.4.2). Neste tipo de sistema, o fenômeno da retroalimentação (item 2.2.3.3) só é possivel 
dentro de certos limites de oscilação das variáveis de estado. Tais limites ou limiares ("thresholds") são representados, por exemplo, pelas linhas que separam diferentes formas de leito em um diagrama-modelo de regime de fluxo. Eles denotam descontinuidades no espaço de estado. Uma vez rompido o limiar, através de oscilação de variáveis, e decorrido certo tempo de atraso, o sistema adquire novo estado estacionário dentro do qual a retroalimentação será novamente possivel. Em alguns sistemas, porém, o estado e a estrutura anteriores podem continuar coexistindo indefinidamente com seus sucessores, caracterizando assim a superação de um limiar intransitivo. De acordo com Chappell (1983 apud Huggett 1985), limiares intransitivos relacionam-se com oscilações em variáveis internas do sistema enquanto limiares transitivos associam-se a perturbações em suas condições de contorno. Deste modo, correspondem respectivamente aos limiares intrinsecos e extrínsecos de Schumm (1979 apud Gregory 1985).

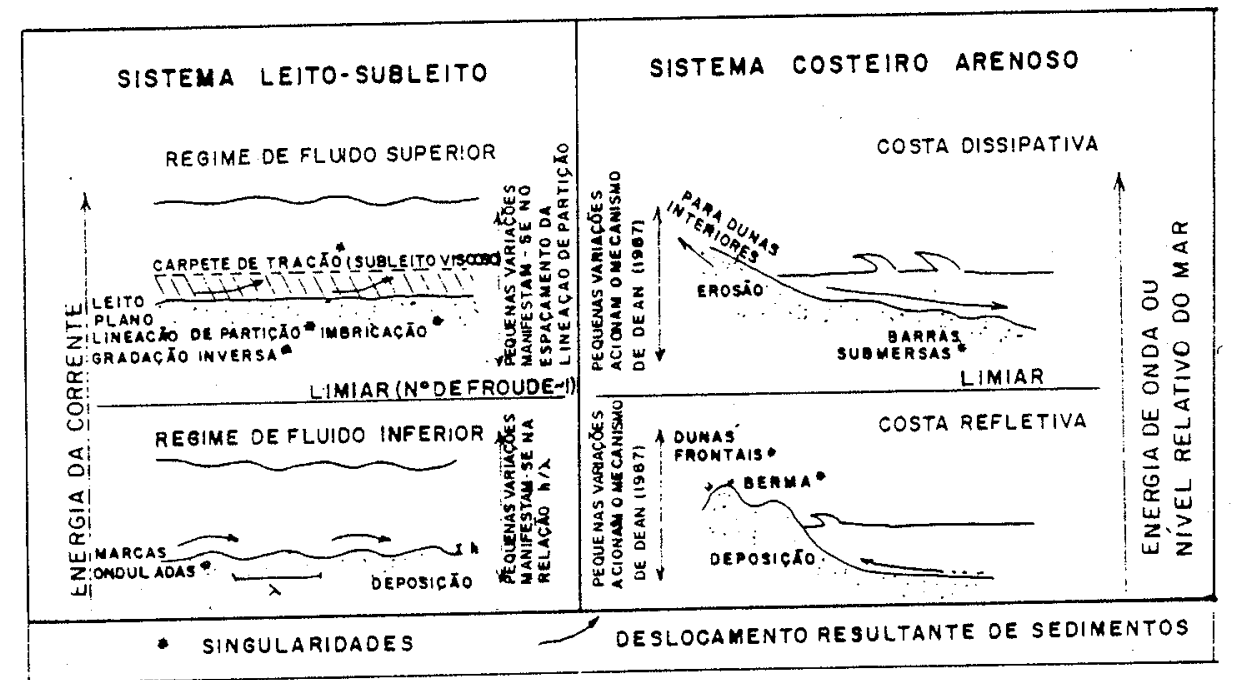

Figura 2.4. Analogia entre dois sistemas metaestáveis em sedimentologia. Para simplificaçăo, é desprezada em ambos os casos a influéncia da granulometria. $O$ aumento, além de certos limites, de energia fornecida aos sistemas, provoca a destruiçăo (erosão) da estrutura preexistente e surgimento de novo estado estacionário caracterizado por maior status de ordem e de dissipaçăo de energia. A destruição da estrutura preexistente implica erosão dentro do sistema, com deslocamento de sedimentos de um subsistema para outro (leito para subleito ou praia para face litorânea). Com aumento de energia, o deslocamento de sedimentos e o surgimento de singularidades favorece o subsistema mais envolvido pelo meio aquoso; e vice-versa.

Aumentos bruscos de energia em curto espaço de tempo, que são a característica principal dos chamados eventos episódicos, conduzem na maior parte das vezes à superação de limiares e à produção de estruturas dissipativas. Se eventos episódicos, como defende Della Favera (1984), possuem participação essencial no registro sedimentar, o mesmo pode ser estendido às estruturas dissipativas. No que tange à produção destas estruturas, alguns eventos episódicos possuem, no entanto, uma caracteristica peculiar: o estado estacionário a ser atingido através da dissipação não é único, e o sistema deve optar, no limiar, por um dentre dois ou mais novos regimes de equilibrio. Esta característica é o que se chama de bifurcação, e seus princípios teóricos encontram-se na teoria das catástrofes de 
Thom (1972). A bifurcação ocorre quando uma ou mais variáveis no espaço de estado do sistema são não lineares. Num espaço de estado tridimensional por exemplo, a superfície representativa do limiar aparecerá como a parte do meio de uma folha dobrada (figura 2.5), cada superfície contínua de dobra acima ou abaixo do limiar constituindo um tipo de alternativa. A maioria das bifurcações estudadas em geologia, como o exemplo de Chapell (1978 apud Huggett 1985), aqui reproduzido, ocorre entre erosão e deposição, com duas variáveis de estado quaisquer combinando-se não linearmente para gerar ou intervir numa terceira variável. No exemplo da figura 2.5 , energia de onda e nivel freático combinam-se para criar efeitos episódicos de fluidificação de areia (opção erosiva) ou acreção de barras litorâneas (opção deposicional).

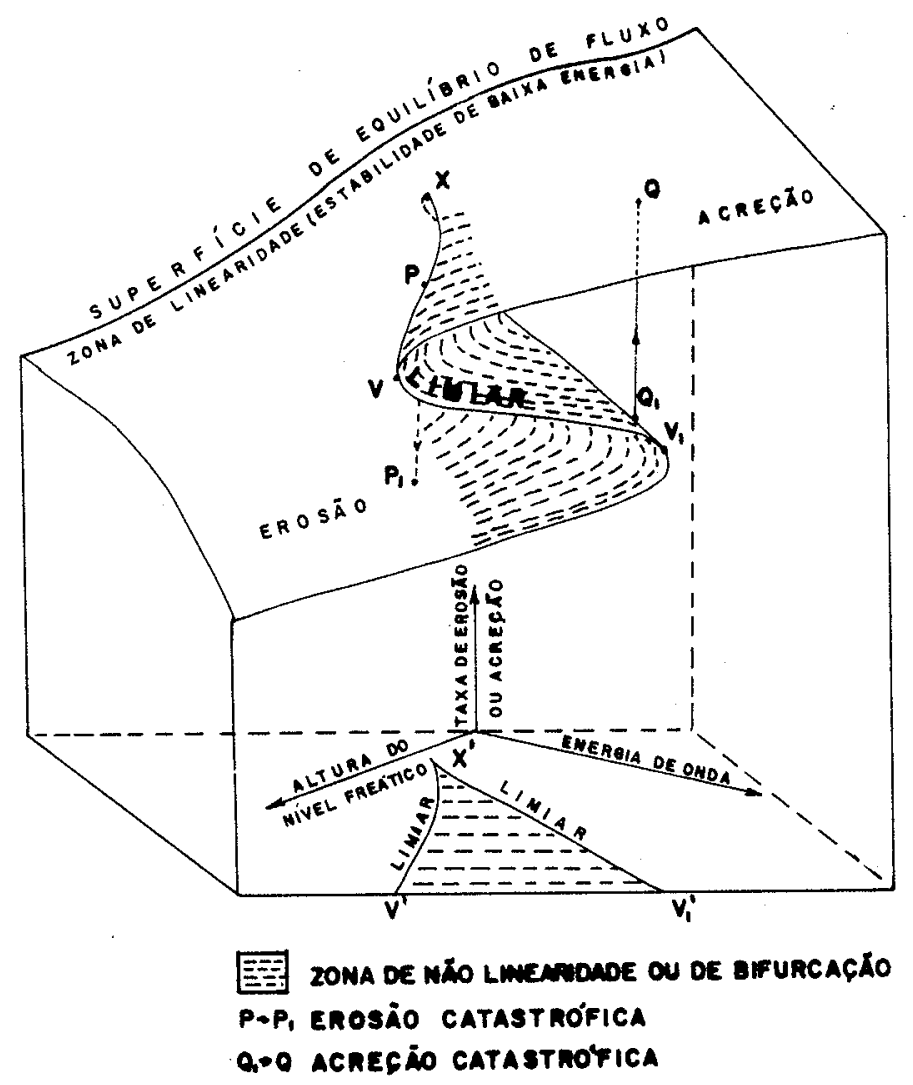

Figura 2.5. Representação "cúspide-catástrofe" da combinaçăo năo linear entre as variáveis energia de onda e nivel freático nà produção de erosăo versus acreçăo praial. Segundo Chappell (1978 apud Huggett 1985).

Bifurcações diferentes podem suceder-se na evolução de um sistema tanto quanto estados estacionários diferentes, o que introduz uma dimensão histórica em seu desenvolvimento (Prigogine 1980). 


\subsubsection{INTEGRAÇÃO SISTÊMICA DE PRINCÍPIOS DE EROSÃO E SEDIMENTAÇÃO COSTEIRAS}

\subsubsection{Introdução}

A transcrição integrada, em linguagem sistêmica, de diferentes princípios teóricos encontrados na literatura sobre sedimentação costeira quaternária, alguns deles aparentemente antagônicos, permite a descoberta de leis sistêmicas estabelecendo correspondências entre eles. Tais leis facilitam a compreensão de modelos dinâmicos de sistemas deposicionais costeiros, como os que serão apresentados neste trabalho, devendo por isto serem previamente reconhecidos.

\subsubsection{Apresentação dos princípios}

Cinco princípios ou fundamentos são considerados. 0 primeiro deles é o "princípio de Bruun", o qual estabelece um mecanismo de reajuste do perfil de equilibrio costeiro compreendido entre a praia e a face litorânea ("inshore" ou "nearshore zone"), em resposta a elevações do nível relativo do mar (NRM). Segundo Bruun (1962), este ajuste seria representado por uma acreção do fundo marinho na face litorânea (incluindo parte rasa da costa afora) até a recuperação da espessura de lâmina de água existente no mesmo local antes da subida de NRM. Esta sedimentação na face litorânea ocorreria através do aporte de sedimentos erodidos na praia (figura 2.6 )

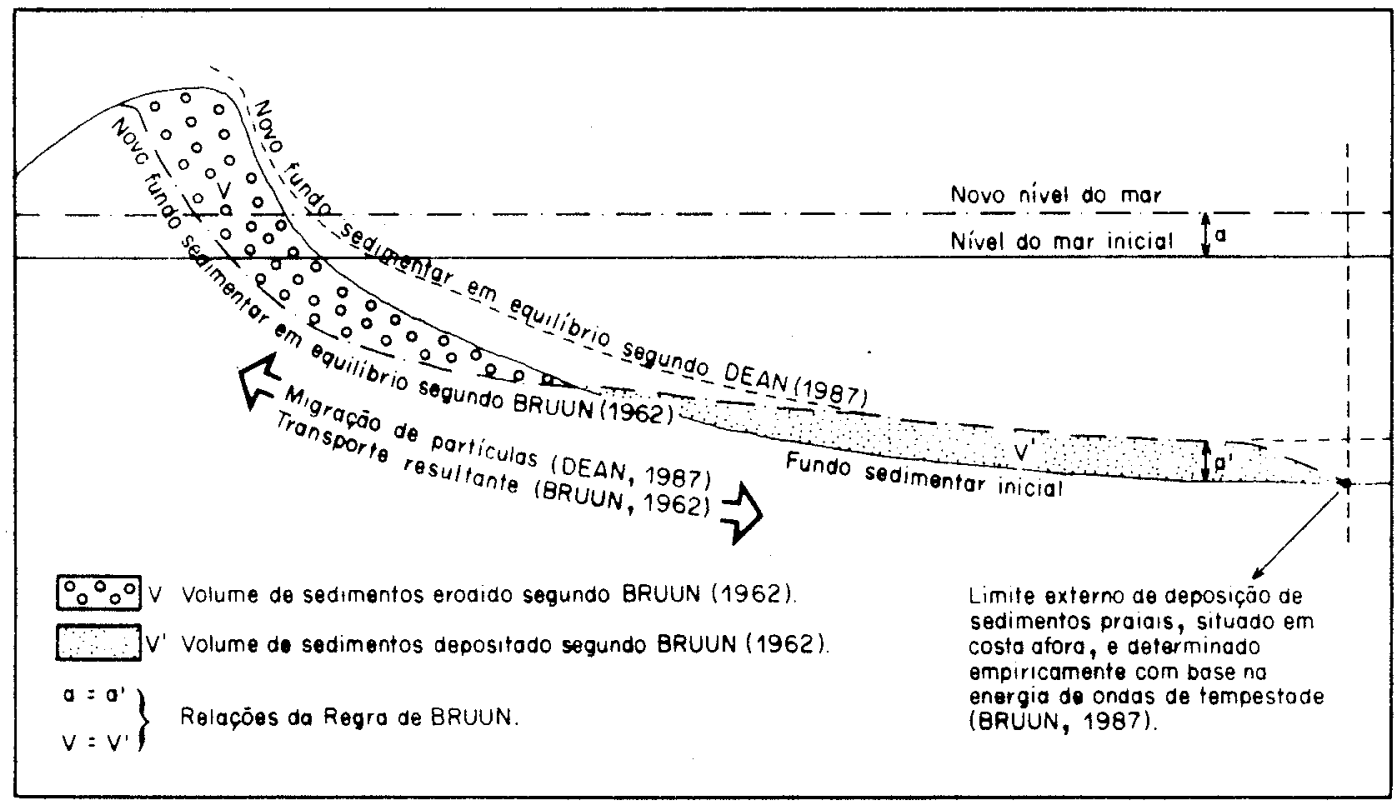

Figura 2.6. Esquema integrado dos principios de Bruun (1962) e Dean (1987) sobre erosão e sedimentaçăo costeiras induzidas por elevaçào de nivel do mar.

Bruun (1962) postulou também que a sensitividade da costa à elevação de NRM depende de seu declive e da escala de tempo de observação. Declives acentuados seriam mais sensiveis a elevações de NRM de curta duração, 
dando-Ihes respostas erosivo-deposicionais rápidas, enquanto declives suaves responderiam apenas a elevações de longo prazo, apresentando respostas defasadas no tempo. Comprovações do "princípio de Bruun" ou de sua formulação matemática, denominada "regra de Bruun", foram obtidas em laboratório, através de modelosescala (Schwartz 1965, 1967) e no campo, através de observações de efeitos sazonais de marés (Schwartz 1967; Dubois 1975, 1976, 1977; Pickrill 1985). A extensão reciproca do princípio ao caso regressivo foi sugerida em medidas de campo realizadas nos Grandes Lagos durante um período de quatro anos (Weishar \& Wood 1983). Não se conhecem evidências diretas do modo de manisfestação do princípio em escalas de tempn mais prolongado, mas acredita-se que a resposta erosiva a uma mudança de NRM não seja automática, dependendo da ocorrência de sucessivas flutuações rápidas (Bird 1973 apud Bird \& Paskoff 1979) ou tempestades costeiras (Dubois 1982). Outra condição necessária, segundo o último autor, é que a granulometria do sedimento a ser transferido seja inferior à variação de NRM acumulada no tempo. Esta condição implicaria a seletividade granulométrica do processo erosivo, tendendo a concentrar sedimentos mais finos e negativamente assimétricos na praia, no caso regressivo, ou na face litorânea, no caso transgressivo; esta implicação permanece, porém, pouco documentada.

O uso do modelo matemático da "regra "de Bruun" para resolver problemas de predição de recuo erosivo de linhas de costa sob regime de NRM ascendente tem experimentado insucessos; em razão disso, Dean (1987) propõe um modelo alternativo para o "princípio de Bruun" que leve em consideração a heterogeneidade granulométrica ao longo do perfil transversal à costa (figura 2.6). Segundo este modelo, tal perfil, para costa em equilíbrio, é caracterizado por uma distribuição geográfica (estrutura) de granulometrias ajustada à distribuição de energia, altura e dinâmica média das ondas ao longo de sua extensão. Ocorrida uma elevação de NRM, a reposta natural do perfil é recuperar sua estrutura inicial, através de migração de sedimentos no sentido da costa ("onshore"). O transporte de sedimentos ocorreria deste modo em rumo oposto ao previsto pelo "principio de Bruun", implicando a manutenção do equilibrio erosivo-deposicional. Pequenas taxas de acreção ou degradação praial recentes, encontradas pelo autor em âmbito local ao longo da costa transgressiva da Flórida, são por ele atribuídas a variações normais de aporte externo. Em escala de tempo maior, Dean (1987) atribui o declive ingreme da parte mais rasa da plataforma interna em áreas transgressivas ao acúmulo de areias na costa, por migração "onshore" durante a fase de ascensão suave de NRM iniciada por volta de 6 mil anos A.P.. Antes disto (20 mil a 6 mil A.P.), a elevação de NRM teria sido muito mais rápida que a transferência de sedimentos para a costa, o que favoreceu a manutenção do declive suave atualmente observado nas partes mais profundas ( $>8$ a $25 \mathrm{~m}$ ) das mesmas plataformas.

Um terceiro principio fundamental sobre erosão e sedimentação costeiras é o que pode ser chamado de "princípio de Leatherman", a respeito do mecanismo de recuo erosivo de ilhas ou barras-barreiras. Este principio opõe-se à idéia anteriormente aceita de que as ilhas-barreiras em costas transgressivas migram para o interior sem perda de massa. Leatherman $(1983,1987)$ demonstrou que ocorre erosão na face de mar aberto da barreira, sem reposição de sedimentos na face lagunar, até que a barreira atinja uma largura mínima. Alcançada esta largura limitrofe, a passagem de grandes volumes de sedimentos litorâneos fara a zona lagunar torna-se possivel, através de canais ("inlets") e de seus "deltas de 
maré enchente" ("ebb tide deltas") associados e através de fenômenos episódicos de sobrelavagem ("washover"). Só então tem-se migração, sem saldo erosivo, da barreira. O processo de recuo erosivo da barreira resulta, a longo prazo, descontínuo, alternando períodos de erosão líquida com periodos de migração de sedimentos rumo a zona lagunar. Os fenômenos de sobrelavagem e de erosão e deposição de "deltas de maré", assim como efeitos associados de abertura e fechamento de canais, são cíclicos e episódicos (Lankford 1977; Bruun 1978; Webb et al.1989). Segundo Lankford (1977), o escoamento hidrológico superficial ("run off") que alimenta o corpo lagunar é uma das variáveis mais ativas na ocorrência episódica de ciclos de abertura e fechamento de canais. Um aumento continuo de escoamento superficial, acompanhado de elevação do lençol freático, pode aumentar a pressão na barreira e facilitar a liquefação das areias e sua erosão tixotrópica através do embate sucessivo de ondas de alta energia (figura 2.5; Lankford 1977; Bruun 1978). Uma vez rompida a barreira numa zona de fraqueza, a fase de abertura pode durar de dias a anos, na dependência da competência deposicional de correntes de deriva litorânea em comparação com correntes de maré (Emery \& Stevenson 1957). De modo geral, grandes lagunas recebendo escoamento superficial regular apresentam um ciclo anual enquanto lagunas pequenas e/ou sem entrada regular de escoamento superficial apresentam ciclos esporádicos (Lankford 1977).

O quarto fundamento de sedimentação costeira é não um só principio, mas um conjunto deles que associa a morfodinâmica da costa a variáveis diversas como granulometria, energia das ondas e aporte de areia. Variações isoladas ou combinadas destes fatores levam a mudanças de padrão morfodinâmico (estrutura) desde um extremo reflexivo até um extremo dissipativo, de acordo com a classificação de Wright et al. 1979 (figura 2.7). Segundo esta classificação, costas de padrão reflexivo são caracterizadas por face praial ("beach face") de perfil transversal ingreme e linear, com bermas e cúspides bem desenvolvidos; a zona de translação de ondas ("surf") é ausente, e a deriva transversal ocorre através das próprias ondas incidentes, e não por efeitos induzidos como correntes sagitais ("rip currents"). Costas dissipativas caracterizam-se por faces litorâneas ("nearshore") de perfil transversal côncavo para cima e por zona de translação larga e aplainada; a topografia é complexa, com a presença de uma ou mais barras longitudinais, truncadas por células de correntes sagitais. Segundo Wright et al. (1979), o grau de dissipatividade aumenta com a altura (energia) da onda e diminui com o declive do perfil costeiro. Este reflete o arcabouço geológico, o suprimento sedimentar e a granulometria. Mantidas fixas outras variáveis, 0 aumento de suprimento rumo à praia (em detrimento de zonas mais profundas) e o aumento da granulometria favorecem 0 incremento do declive e a refletividade. 0 padrão refletivo representa deste modo o estágio de máxima acreção praial e forma-se somente após períodos prolongados de ondas baixas, enquanto o padrão dissipativo resulta de abundância de sedimentos na face litorânea, formando-se durante ou imediatamente após tormentas severas. Costas reflexivas e dissipativas representam repectivamente os membros extremos deposicional e erosivo de um ciclo de sedimentação praial (Wright et al.1979).

O quinto fundamento teórico aqui considerado refere-se à dinâmica de equilibrio entre ventos, ondas e areias na formação de dunas eólicas costeiras. Pode-se enunciá-lo na forma de dois princípios: (1) o volume de areia disponivel na costa é diretamente relacionado à energia das ondas (Short 1988); (2) a morfodinâmica controla as taxas e as formas de erosão praial subaérea (Wright et al. 
1979; Short \& Hesp 1982). A tradução prática destes dois principios, segundo Short (1988), é a ocorrência preferencial de dunas eólicas em praias de padrão morfodinâmico dissipativo, em contexto transgressivo, especialmente quando o declive da plataforma interna é ingreme.

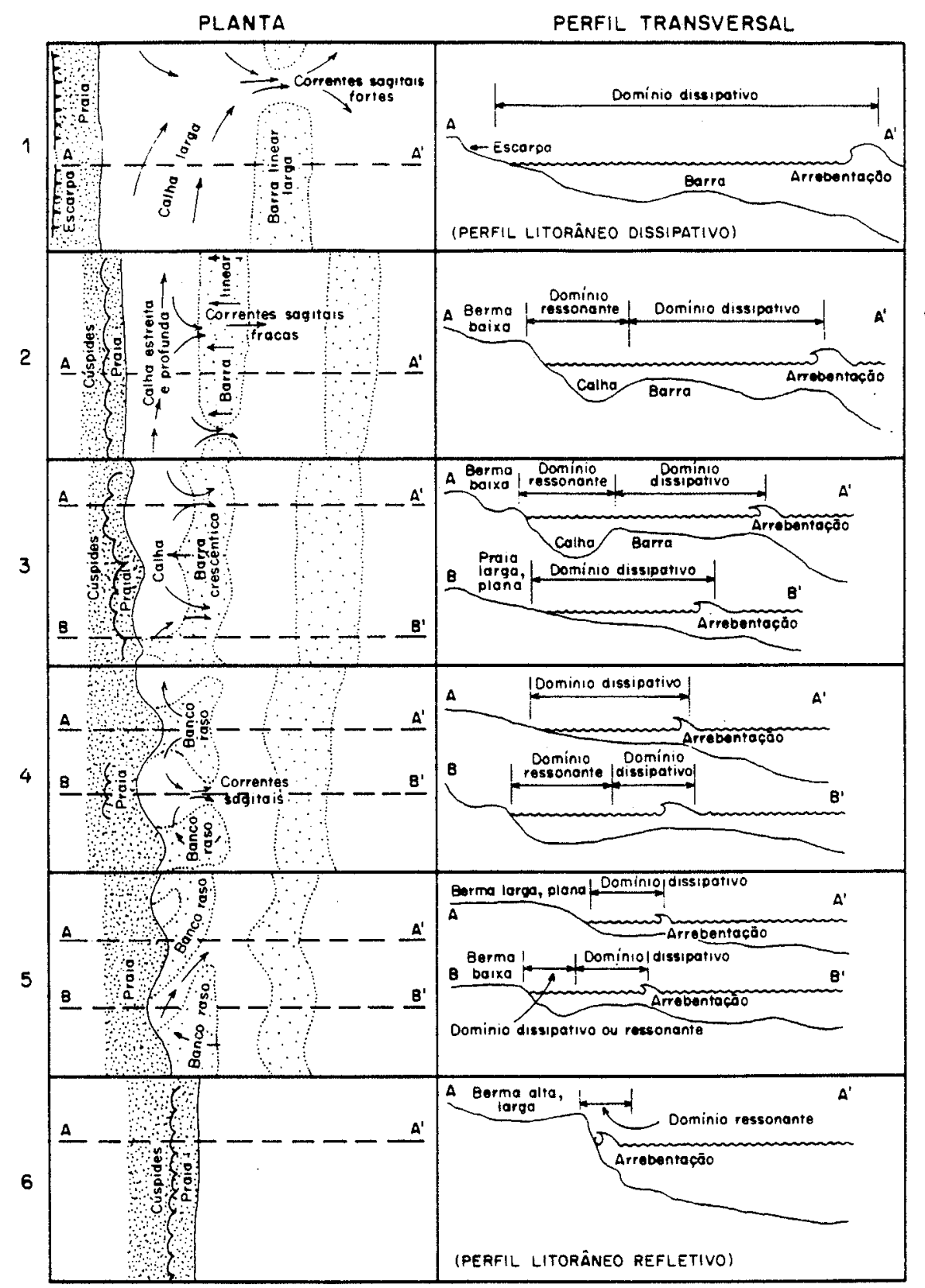

Figura 2.7. Os seis estágios ou tipos morfodinámicos de praias e costas segundo Wright et al.(1979). Tem-se, de 1 a 6, um ciclo de acreção praial completo

\subsubsection{Leis sistêmicas: integração de princípios}

Os princípios de Bruun e de Dean podem ser encarados como descrições da operação de um sistema costeiro maior, que engloba entradas e saídas de sedimentos entre vários subsistemas: a pós-praia, a praia, a face litorânea e a costa afora ("offshore"). O aparente antagonismo entre os dois princípios desaparece 
quando se observa que eles se referem a duas situações de troca de "entropia" diferentes, dentro de um mesmo sistema metaestável (cf. item 2.2.3.3). O mecanismo descrito por Dean (1987) é um exemplo de retroalimentação: em condições ideais de aporte externo nulo, não há saldo líquido de areia nos subsistemas envolvidos, pois a mesma quantidade que deixa um subsistema " $x$ ", em direção ao seu subsistema vizinho mais próximo da costa, entra no subsistema " $x$ ", proveniente de seu subsistema vizinho mais distante da costa. Pelo "princípio de Bruun", o saldo de transporte (comunicação) entre subsistemas é diferente de zero, uma vez que areia da praia é carreada para a face litorânea, sem perdas para a zona de costa afora abaixo de certa batimetria limitrofe (Bruun 1962: p.129, (6); 1987; Dubois 1992). Não se trata, neste caso, de mecanismo de retroalimentação, e sim de evolução espontânea, visando a produção de uma estrutura dissipativa. Em nivel morfológico, o aumento de ordem reflete-se em maior grau de dissipatividade na costa, no sentido de Wright et al. (1979): costas dissipativas possuem maior número de singularidades no subsistema face litorânea, representadas por arranjos espaciais de calhas e barras longitudinais e de canais de correntes sagitais. Em nivel sedimentológico microscópico, é possivel que o aumento de ordem reflita-se no transporte seletivo de granulometrias preconizado por Dubois (1982), criando singularidades na estrutura das propriedades granulométricas ao longo do perfil costeiro.

No caso inverso, variação de NRM negativa, o saldo de transporte sedimentar ocorre no sentido do subsistema praial e a tendência morfodinâmica teórica é para a produção de perfis mais refletivos. Apesar de o status de ordem e dissipação de energia cair no sistema como todo, singularidades morfológicas de menor energia deposicional, como bermas e cúspides praiais e cordões de dunas frontais, podem desenvolver-se no subsistema favorecido pela deposição (figuras 2.4 e 2.7 ).

Como mecanismo de retroalimentação, o "princípio de Dean" é válido somente dentro de certos limites de flutuação de variáveis, especialmente do nivel do mar. Nessas condiçōes, o saldo de transporte sedimentar em cada subsistema é nulo. Eles encontram-se portanto em estado estacionário de equilíbrio de fluxo entre erosão e deposição. Rompidos os limites de variação de NRM, a operação do sistema passa a ser regida pelo "principio de Bruun"; criam-se mudanças no regime erosivo-deposicional e um saldo no transporte de sedimentos; a "entropia" diminuiu espontaneamente no subsistema favorecido pela deposição, caracterizando assim a formação de uma estrutura dissipativa e o alcance de novo estado estacionário, quando então o "princípio de Dean" readquire sua validade. Sabe-se serem as estruturas dissipativas resultantes de fenômenos episódicos, os quais parecem representar uma energia de ativação. Esta função seria desempenhada aqui pelas tempestades costeiras. Deve-se frisar também que, se a opinião de Dubois (1982) estiver correta, a manifestação do "princípio de Bruun" depende ainda de um outro fator, a granulometria, a qual possui provavelmente combinação não linear com as demais variáveis. O limiar entre a validade dos principios de Dean e de Bruun em um sistema praial pode ser concebido portanto, em primeira aproximação, através de uma superfície dobrada em um espaço de estado tridimensional, cujas variáveis são o NRM, a energia das ondas e a granulometria (figura 2.8). Dentre estas variáveis, o NRM é a variável primária, mediata, enquanto as demais são imediatas. Uma vez que o NRM é uma variável externa ao sistema, o limiar deve possuir caráter transitivo (cf. 
item 2.2.3.4.3), o que significa, como já esperado, que os mecanismos de Bruun e de Dean não podem ocorrer simultaneamente.

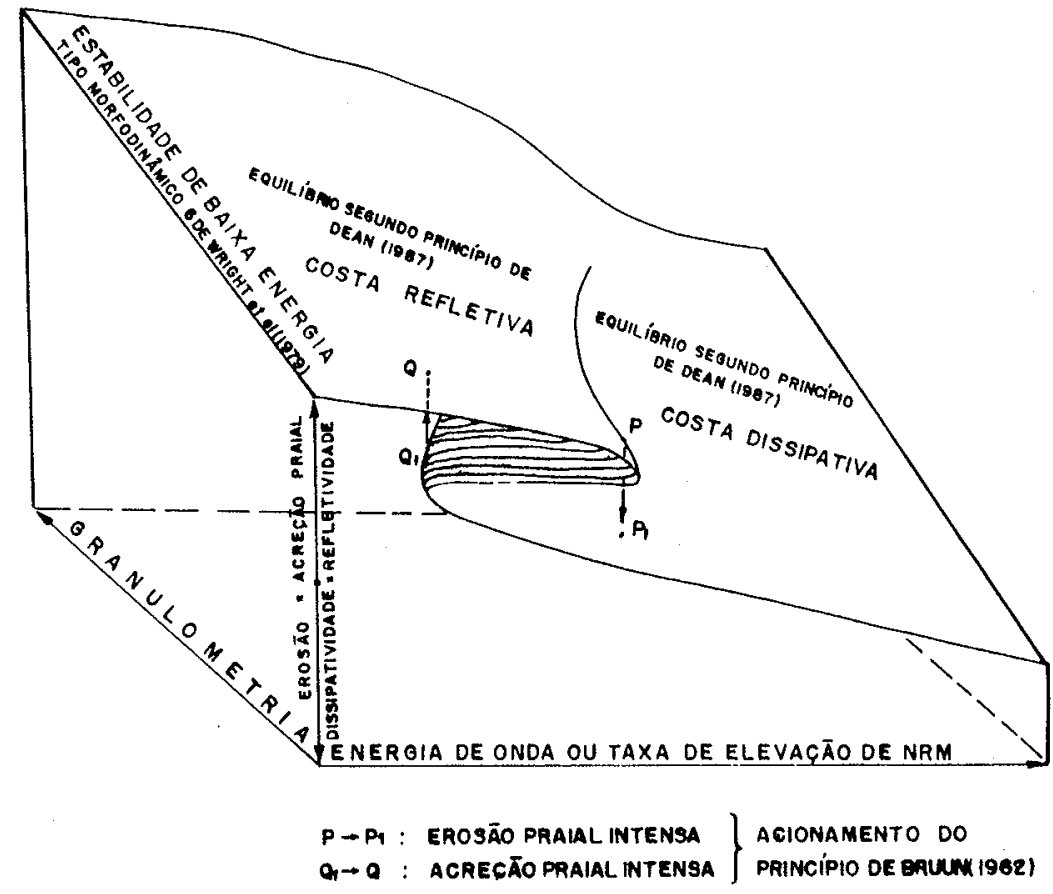

Figura 2.8. Representaçăo "cúspide-catástrofe" tentativa da combinaçăo das variáveis granulometria e energia de onda ou elevaçăo de NRM na produçăo de morfodinámicas praiais erosivas ou acrecionares. Erosăo ou acreçăo suave no "equilibrio de Dean" pressupరe condiçăo de manutençăo do aporte externo (continental) de sedimentos.

Um conceito sistêmico de importância essencial nos mecanismos descritos por Dean (1987) e por Bruun (1962) é o atraso, isto é, o tempo que o sistema leva para readquirir o equilíbrio de fluxo após uma oscilação de NRM. No caso específico do "princípio de Bruun", o atraso depende da freqüência $e$ intensidade com que tempestades costeiras se sucedem (Dubois 1982). Em ambos os casos, o atraso tem relação direta com a amplitude da oscilação em função do tempo , representada pela velocidade de queda ou ascensão de NRM. A influência do declive da plataforma interna (até a costa afora rasa), notada por Bruun (1962), explica-se por analogia e relação genética com os tipos morfodinâmicos de Wright et al. (1979). Plataformas de inclinação abrupta, assim como costas refletivas, representam um estado morfodinâmico de acreção costeira; são portanto, mais sensíveis à erosão praial e subaérea. Plataformas de declive suave, assim como costas dissipativas, representam um estado erosivo e são mais susceptiveis à acreção praial e subaérea. Deste modo, as primeiras dão respostas erosivas mais rápidas a oscilações positivas de NRM, enquanto as últimas dão respostas deposicionais mais rápidas a oscilações negativas. Devido ao efeito do atraso, velocidades relativamente elevadas de ascensão de NRM, como a de $0,8 \mathrm{~m} /$ século, inferida para o periodo entre 20 mil e 6 mil anos A.P. (Dean 1987), podem manter o "princípio de Bruun" constantemente acionado, sem que haja tempo hábil para que os sedimentos de fundo se rearranjem segundo o "princípio de Dean", para adaptar-se a novas condições de energia e profundidade. Como efeito, a cobertura da plataforma continental a cotas 
batimétricas atuais superiores a cerca de $50 \mathrm{~m}$ apresentaria caráter palimpséstico. 0 fato de o "princípio de Bruun" prevalecer durante ascensões rápidas de NRM sugere que estados estacionários de equilibrio costeiro sejam raramente ou nunca atingidos nestes períodos. Isto significa a existência constante de um excesso de areia na praia, instável segundo o "princípio de Bruun", porém impossibilitado, devida à taxa de ascensão ser maior que a de erosão praial por tempestades, de se transferir para a face litorânea. Nos termos de Wright et al. (1979), a transgressão, por seu efeito erosivo praial, favorece um aumento crescente no grau de dissipatividade da costa; as costas dissipativas assim formadas mantêm, devido à rapidez da ascensão do NRM, um excesso de areir. na zona de praia, instável com sua condição morfodinâmica, e que tende por este motivo a ser consumido por processos subaéreos. Isto explica porque costas dissipativas durante ou após eventos transgressivos representam condição ideal para a formação de grandes campos de dunas eólicas costeiras, como observado por Short (1988).

Outras feiçōes geomorfológicas de costas atuais relacionadas com o atraso na resposta a elevação do NRM são as ilhas e barras-barreiras. Com a redução abrupta na velocidade de ascensão de NRM ocorrida mundialmente por volta de 6 mil anos A.P., parte do excesso de areia remanescente na praia, passa a migrar para a face litorânea de acordo com o "princípio de Bruun", constituindo ali depósitos volumosos que em algumas regiōes chegam à emersão. $\mathrm{Na}$ continuidade da transgressão posterior à redução brusca da taxa de elevação de NRM, estes depósitos podem ser parcialmente afogados, constituindo ilhas-barreiras (Dean 1987). Em costas que permanecem transgressivas até dias atuais, como a do leste norteamericano, as barreiras experimentam sucessivas alternâncias de fases erosivas e fases de migração, conforme o modelo de Leatherman (1983, 1987) desde que não ocorra estabilização ou progradação local por efeito de deriva litorânea longitudinal (Rampino \& Sanders 1983). As fases erosivas guardam correlação com o "princípio de Bruun" e representam assim evoluções espontâneas, enquanto as migrações associam-se ao "principio de Dean" e envolvem mecanismos de retroalimentação. 0 limiar torna-se mais complexo, pois passa a envolver uma nova variável, a largura da barreira.

A erosão de uma barreira, através de transporte resultante de sedimentos costeiros, via desembocadura lagunar ou sobrelavagem, no rumo do sistema lagunar adjacente, é um mecanismo de consumo de excessos sedimentares praiais não eliminados pelo mecanismo de Bruun (1962), a exemplo da remobilização eólica. Isto é válido tanto para barreiras transgressivas quanto regressivas. Os processos de controle de saldos sedimentares descritos por Bruun (1962), Short \& Hesp (1982) e Leatherman $(1983,1987)$ são, portanto, interdependentes (figura 4.1).

\subsubsection{UMA PROPOSTA DE ANÁLISE DE FÁCIES}

A descrição de sistemas deposicionais pressupõe o conhecimento prévio das fácies (item 2.2.3.3); por seu caráter de sintese conceitual, ela deve ser antecedida por uma análise tão minuciosa quanto possivel dos sistemas. Esta análise, que inclui as observações de campo, não é feita habitualmente em linguagem sistêmica, nem se pretende que seja: não se pode adaptar o objeto de 
estudo à linguagem sistêmica, antes que sua constituição e os problemas a se resolver estejam devidamente colocados, em sua linguagem específica (Delattre 1981). Apesar disto, cabe que esta análise de fácies seja feita de modo compatível com os objetivos sistêmicos, o que pode ser subdividido em dois requisitos. Em primeiro lugar a análise de fácies deve permitir a produção de modelos, falsificáveis através de raciocínios processo-resposta, conforme idealizado por Fichter (1988). A característica principal destes modelos (de fácies) é sua capacidade permanente de fazer predições, cuja verificação no campo ou via testes laboratoriais e estatísticos estimula novas observações (e possíveis novos modelos). Em segundo lugar, esta análise deve enfatizar as interrelações entre as fácies, de acordo com o princípio essencial da "teoria de sistemas" (item 2.2.3.3).

As concepções de análise e modelo de fácies de Walker (1976) são um marco histórico e a experiência mais difundida da penetração do enfoque sistêmico na descrição de fácies sedimentares. Apesar disto, apresentam inconsistências notadas por Anderton (1985), que propôs um método alternativo de análise de fácies para seqüências verticais. O método adotado neste trabalho é basicamente uma versão da proposta de Anderton (1985), adaptada ao estudo de associações de fácies horizontais no Quaternário. Ele inicia-se por uma fase preliminar de levantamento cartográfico e aerofotogeológico da área, com estabelecimento de associações de fácies e sistemas deposicionais hipotéticos. As fases posteriores podem ser assim enumeradas: (1) descrição detalhada do afloramento ou feição geomorfológica; (2) subdivisão em fácies descritivas; (3) compilação das características de cada fácies (modelos descritivos); (4) dedução dos processos deposicionais de cada fácies (modelos genéticos); (5) exame das relações espaciais entre fácies e reconhecimento de associações faciológicas (modelo descritivo integrado); (6) interpretação do ambiente da associação (modelo genético integrado); (7) modelagem final das fácies individuais; (8) teste de consistência via predição: retorno à fase (1) ou à fase (5), e assim sucessivamente. O conceito de modelo de fácies de Anderton (1985) é versátil, e este método pode ser utilizado tanto em nivel de afloramento como em nível de bacia. O exercício de "zoom", alternando pequenas e grandes escalas de modelagem em sucessivos testes de consistência é recomendável (Coimbra \& Giannini 1990; Della Favera 1990).

Anderton (1985) enfatiza que uma inversão na ordem das etapas conduz a riscos de erros. Deste modo, a interpretação genética de uma fácies isolada, antes da descrição de fácies vizinhas de mesmo contexto sedimentar, tende a ser muito mais ambigua que a interpretação das várias fácies já descritas como um conjunto coerente. Este aspecto, de outro modo já destacado por Walker (1976), implica a importância do reconhecimento de associações laterais de fácies.

\subsection{ATIVIDADES DE CAMPO}

\subsubsection{BASE CARTOGRÁFICA E AEROFOTOGEOLÓGICA - MODELO PRELIMINAR}

As atividades de campo foram voltadas a identificação, mapeamento e caracterização de fácies sedimentares empregando-se o método de 
análise de fácies exposto (item anterior). Como este método requer maior número possivel de revisōes de modelos, foram realizadas quatro jornadas de campo, sendo a primeira destinada ao reconhecimento prévio da área. Através desta primeira jornada e de levantamento cartográfico e aerofotogeológico, elaborou-se o modelo de fácies genérico preliminar. A base de dados cartográficos foram os mapas geológicos em escala 1:150.000 de Martin \& Suguio (1986) e 1:200.000 de Martin et al. (1988b), além de sete folhas topográficas 1:50.000 (figura 2.9) abrangendo a área de estudo (IBGE 1976; quadrícula SH-22-X-B; folhas 1-4, de Tubarão; II-1, de São Martinho; II-2, de Imbituba; II-3, de Laguna; II-4, de Vila Nova; IV-2, de Jaguaruna; e V-1, de Garopaba do Sul). A base de dados aerofotogeológicos consistiu de fotografias em escala 1:25.000 obtidas em duas datas diferentes (Cruzeiro do Sul, vôos de 1952 e de 19771979).

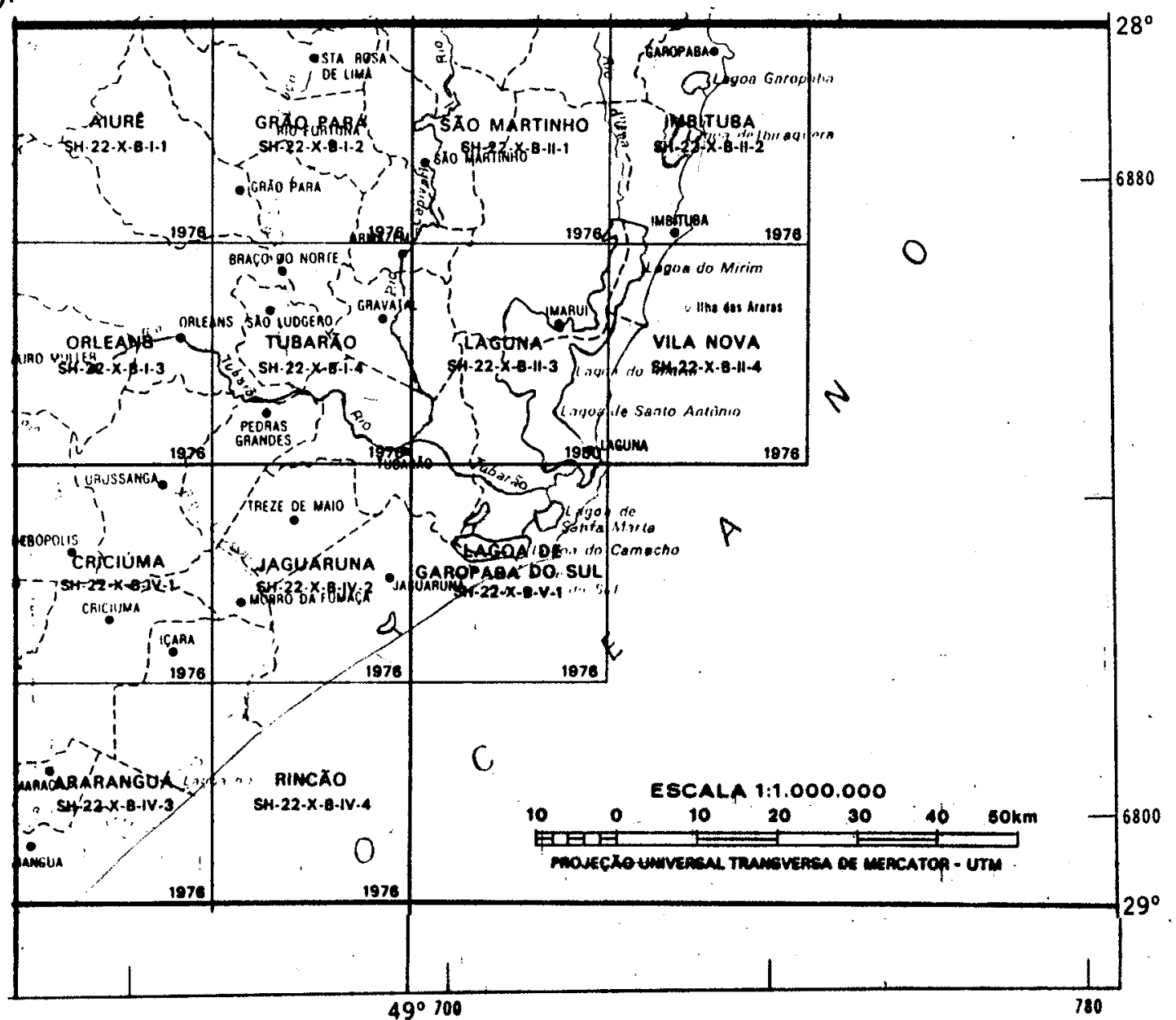

Figura 2.9. Articulaçăo de folhas topograficas 1:50.000 abrangendo a área em estudo e vizinhanças.

O modelo de fácies provisório obtido através dos dados cartográficos e aerofotogeológicos disponiveis foi sucessivamente detalhado e modificado nas jornadas de campo subseqüentes, as quais incluiram observações de detalhe, medidas de campo e coleta de amostras. 


\subsubsection{AMOSTRAGEM}

Coleta de amostras de material inconsolidado a semiconsolidado foi procedida em quatro casos: (1) sedimentos superficiais ou subsuperficiais arenosos da cobertura pleistocênica e holocênica de zonas emersas ao largo de toda planicie; (2) sedimentos superficiais pelíticos a pelítico-psamíticos de zonas de sedimentação lagunar e flúvio-lagunar holocênica turfosa; (3) mantos de intemperismo ou sedimentos coluvionares associados a depósitos pré-quaternários ou a rochas cristalinas incluindo sedimentos de leques continentais terciários, sedimentitos da Bacia do Paraná e granitóides, aflorantes na zona perisserana adjacente à planicie litorânea ou em seus pontōes costeiros; (4) sambaquis encontrados sobre diferentes tipos de substrato, sedimentar ou não (item 3.4).

As amostras do caso (1) destinaram-se a análises granulométicas e mineralógicas, visando detalhar a caracterização sedimentológica de suas respectivas fácies. As areias coletadas foram identificadas com códigos de campo, segundo sistemas deposicionais e fácies informais preestabelecidas na etapa de reconhecimento preliminar (item anterior). Para efeito de apresentação final neste trabalho, os códigos de campo encontram-se substituídos por códigos "definitivos", os quais resumem informações sobre o sistema deposicional e a localização da amostra de acordo com as convenções apresentadas na tabela 2.3.

Procurou-se distribuir os pontos de amostragem de areias segundo espaçamentos tão regulares quanto possíveis, com objetivo de facilitar o mapeamento de atributos sedimentológicos. A distância interamostral média adotada variou conforme a faciologia, oscilando entre $0,5 \mathrm{~km}$ para as areias de subfácies antepraia e pós-praia de sistemas marinhos atuais e $2 \mathrm{~km}$ para areias lagunares e de dunas de orla praial. As amostras de antepraia foram coletadas na parte superior da zona de espraiamento média, estimada com base na posição relativa da maré; e as de pós-praia, a meia distância entre a amostra de antepraia e as dunas eólicas de orla praial. De modo geral, a coleta foi feita no intervalo de profundidade aproximado de 30 a $60 \mathrm{~cm}$, em quantitade suficiente para perfazer uma massa entre 1 e $2 \mathrm{~kg}$. Areias em maiores profundidades foram amostradas nas situações excepcionais em que se suspeitou de contaminação superficial do terreno ou em que exposições verticais revelaram variaçōes litológicas de origem a ser investigada. Este último foi o caso de valas de drenagem em dunas de topo de encosta (definição no item 5.4.2.2) de vários pontōes ao longo da costa, nas quais puderam ser reconhecidas e correlacionadas até quatro unidades estratigráficas informais, denominadas 1 a 4 , da inferior para a superior. Dentre estas, a unidade 2 caracteriza-se pela presença de nódulos decimétricos ou estruturas de bandamento planar ou contorcido, do tipo "dissipação" de Bigarella (1975a,b), formadas por cimentação organo-ferruginosa diferencial. No caso específico destas estruturas bandadas, obtiveram-se amostras das crostas de cimentação e das areias inconsolidadas intercrustais, com o intuito de caracterizar-se a natureza do bandamento.

A maioria das dunas eólicas, em especial as de morfologia pouco dissipada, foi amostrada em três posiçōes diferentes, com o objetivo de se obter controle sobre variações internas em suas propriedades granulométricas e mineralógicas. Os três pontos de coleta foram locados na crista, no barlavento e no sotavento de cada duna, quando estes elementos morfológicos apresentaram-se 
Tabela 2.3

Convencoes para codificacao de anostras adotada neste trabalho

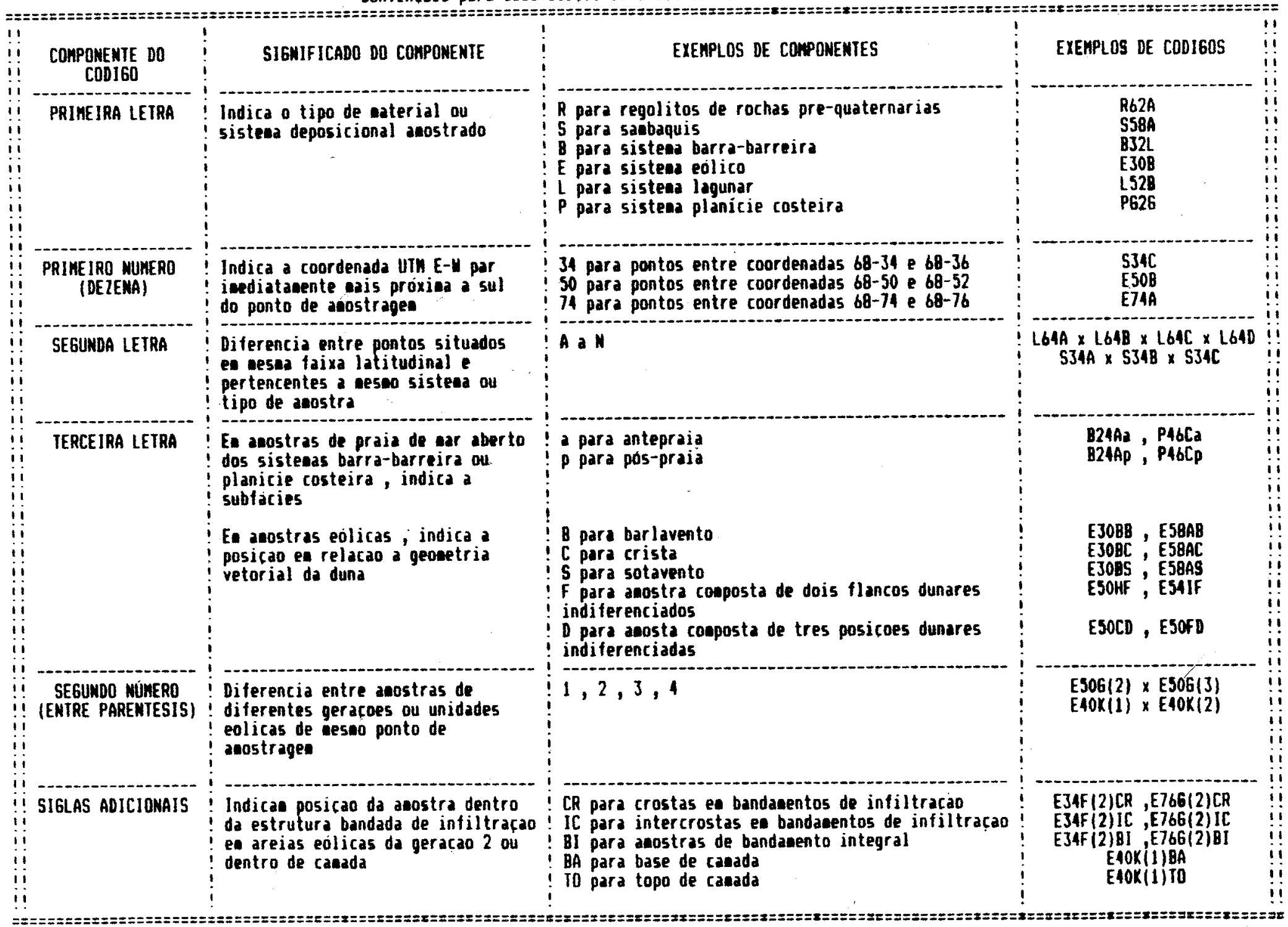


visiveis por critérios de campo elou aerofotogeologia. Entre as dunas inativas, houve porém diversos casos em que amostras de flancos opostos não puderam ser seguramente diferenciadas entre si (código $E n^{\circ}$ letra $F$ ) ou em que nem mesmo a crista pode ser identificada (código E no letra D). Nestes casos, considerou-se, para efeito de apresentação de resultados granulométricos, a média obtida entre as amostras referentes a posições distintas porém indeterminadas de mesma duna.

As amostras coletadas no caso (2) destinam-se a ensaios de dosagem de matéria orgânica, tendo em vista a avaliação preliminar da turfa na região como recurso energético potencial. A coleta foi feita em pontos interespaçados de aproximadamente $2 \mathrm{~km}$, compondo perfis ao longo de diferentes zonas de sedimentação flúvio-lagunar com cobertura de sedimentos turfosos. Amostraram-se os $30 \mathrm{~cm}$ superficiais, em massas de ordem de 0,5 a $1 \mathrm{~kg}\left(\sim 100 \mathrm{~cm}^{3}\right)$, acondicionadas em sacos plásticos. Estas amostras incluem-se no sistema deposicional lagunar (código L...).

As amostras de regolitos e colúvios (caso (3), código R...) foram destinadas a análise de minerais pesados, com objetivo de estabelecerem-se assembléias médias diagnósticas de possiveis rochas-fontes. Buscou-se obter uma amostragem que representasse as principais variedades de rochas existentes na área serrana circunjacente à planície costeira, ou em seus pontōes 'e testemunhos rochosos. A coleta foi feita preferencialmente no horizonte $C$ de perfis de solo, em massas de 2 a $3 \mathrm{~kg}$.

As amostras de sambaquis (caso (4), código $S \ldots$ ) foram coletadas visando-se constituir um arquivo para eventuais dataçōes, seis delas apresentadas neste trabalho (item 2.4.6). Todos os sambaquis visitados, quando acessiveis e em razoável estado de preservação, foram amostrados. Coletaram-se amostras integrais (sem eliminação do sedimento associado), em massas de 1 a $2 \mathrm{~kg}$, acondicionadas em sacos plásticos. Na maioria dos casos, foram feitas três coletas distintas, na base, no topo e na parte média da acumulação atual. A coleta nas porções basal e média dos sambaquis foi executada através de mini-galerias de 20 a $40 \mathrm{~cm}$ de penetração horizontal, descartando-se os $10 \mathrm{~cm}$ mais superficiais, enquanto que no topo outra amostra foi obtida analogamente, por escavação vertical. A amostragem diferenciada visou fornecer base de dados para a datação do período completo de construção de cada sambaqui. Não se tem segurança, contudo, da correlação entre as três amostras coletadas no sambaqui e o início, o meio e o fim de sua construção, exceto nos casos em que a estratigrafia interna é visível através de cortes artificiais.

A locação dos pontos de amostragem foi íeita diretamente sobre fotografias aéreas e mapas topográficos, baseando-se em alguns casos em medidas de distância a pontos de referência conhecidos, feitas através de odômetro de automóvel com precisão de leitura de $\pm 0,05 \mathrm{~km}$.

No total, foram coletadas 858 amostras, localizadas em 586 diferentes pontos de amostragem, com a seguinte distribuição: 410 amostras em 177 pontos do sistema eólico; 171 amostras no sistema planicie costeira; 129 amostras no sistema barra-barreira; 73 amostras no sistema lagunar, sendo 11 de turfas; 61 amostras em 26 sambaquis; e 18 amostras de colúvios e regolitos. 


\subsubsection{MEDIDAS DE CAMPO}

Dois tipos de medidas de campo foram executados: altimetria, com emprego de altímetro portátil Paulin, e atitudes de estratificações cruzadas, com uso de bússola Brunton.

As medidas altimétricas tiveram como objetivo a confirmação e complementação da rede de altitudes prováveis fornecida nos mapas topográficos. Estas altitudes são passiveis de erros, pois correspondem muitas vezes ao topo da cobertura vegetal (Rodolfo J. Angulo, UFPR, comunicação pessoal). Além disso, em algumas regiões, as altitudes indicadas suscitaram dúvidas sobre a atribuição de terraços marinhos ao Holoceno (menores que aproximadamente $5 \mathrm{~m}$ ) ou ao Pleistoceno, ou até mesmo sobre a natureza eólica ou marinha dos sedimentos. Tal era o caso das regiōes entre Jaguaruna e a margem sul da laguna Garopaba do Sul, com altitudes inferidas entre 9 e $34 \mathrm{~m}$, e entre as lagunas Mirim e Ibiraqüera, com altitudes entre 11 e $30 \mathrm{~m}$, ambas atribuidas, no mapa sedimentar de Martin et al. (1988b), ao Pleistoceno (indiferenciado) marinho. Medidas altimétricas in loco permitiram confirmar a ordem de grandeza dos dados disponiveis nas folhas topográficas bem como detectar uma geomorfologia de ondulações alongadas suaves com comprimento de onda decamétrico, característica de depósitos eólicos mantiformes (item 5.4.2.4).

As leituras no altímetro foram convertidas a valores reais através de curvas de correção diárias, com duas ou mais medidas de controle em pontos de altitude conhecida $(0 \mathrm{~m}$, à beira mar). As temperaturas ambientes no instante de cada leitura foram também anotadas, mas as correções referentes resultaram inferiores ao erro teórico de $\pm 1 \mathrm{~m}$ na precisão das medidas. Quanto a este erro, na prática, revelou-se ocasionalmente maior, o que ficou evidenciado pela obtenção de altitudes corrigidas com valores abaixo de $0 \mathrm{~m}$ em terraços marinhos e lagunares holocênicos. Erros de imprecisão deste tipo foram mais comuns nos dias de trabalho em que se realizaram apenas duas medidas de controle. Quando detectados erros desta natureza maiores que $\pm 2 \mathrm{~m}$ ou $\pm 20 \%$ do máximo ou minimo valor esperado, todas as medidas de mesmo dia de trabalho foram desprezadas. As medidas remanescentes revelaram-se compatíveis em ordem de grandeza com as altitudes prováveis fornecidas nas cartas topográficas, como se pode avaliar através do mapa de pontos em anexo (prancha A1). Este fato é sugestivo de que não há, nas folhas topográficas da área estudada, problemas de altimetria do tipo mencionado por Angulo.

Medidas com bússola de altitudes em depósitos eólicos foram tomadas em dois tipos de estruturas: planos de laminação "risca de agulha" ("pinstripe" sensu Fryberger \& Schenk 1988) em areias semi-consolidadas de dunas frontais incipientes, ao longo da praia de Itapirubá, e crostas de cimentação em bandamentos planares da unidade 2 de paleodunas de topo de encosta, nas pontas do $\mathrm{Ji}$ e da llhota. Ambas as estruturas não foram contempladas no trabalho clássico de Bigarella (1975) sobre a geometria interna das dunas costeiras de Santa Catarina.

Estruturas primárias em dunas frontais foram reconstituidas e medidas em outras regiōes de regimes eólicos algo distintos ao da área aqui abordada destacando-se os trabalhos de Bigarella et al. (1970/71, 1972), no Paraná, e de Hesp (1988), na Austrália. A principal caracteristica de regime eólico capaz de produzir 
alguma peculiaridade nas dunas frontais da área de Laguna-Imbituba é o subparalelismo dos ventos prevalecente e predominante em relação à linha de costa (item 3.2.2.2). As medidas visando avaliar esta possibilidade foram feitas com bússola e prancheta em arestas de intersecção de seções subverticais de erosão natural das dunas frontais; por serem os planos predominantemente sub-horizontais, determinaram-se as direções através da técnica de nivelamento do clinômetro.

Estruturas de bandas irregulares de cimentação diferencial em areias eólicas do litoral catarinense foram descritas por Bigarella (1975a,b), dentre as que ele denominou "estruturas de dissipação". Na região de Laguna, além das crostas irregulares, ocorrem também crostas subplanares, cuja constância de atitude geral faz supor relações com estruturas primárias preexistentes (item 5.4.3.1.3). Para verificação desta última hipótese, foram tomadas cerca de 40 atitudes de crostas planares em paleodunas na Ponta do Ji e mais 15 na Ponta da llhota. As medidas foram facilitadas pela existência de secções naturais ao longo de ravinas de erosão pluvial, dentro das quais as bandas crustificadas são preferencialmente preservadas e expostas (figuras 5.83 e 5.104 ).

\subsection{ATIVIDADES DE LABORATÓRIO}

As atividades de laboratório voltaram-se à caracterização textural, química e mineralógica das fácies e suas associações, bem como de gerações de sedimentos marinhos regressivos, de unidades estratigráficas e gerações de dunas eólicas, e de estruturas sedimentares de origem duvidosa do tipo das "estruturas de dissipação" de Bigarella (1975a,b).

Atendendo a esses objetivos, foram realizados seis tipos principais de ensaios quantitativos: granulométrico, densimétrico, magnetométrico, mineralógico, de dosagem de matéria orgânica e de datação pelo método radiocarbono.

\subsubsection{ANÁLISES GRANULOMÉTRICAS}

Das amostras de campo, foram subamostradas massas iniciais secas de cerca de $50 \mathrm{~g}$, no caso de sedimentos, seguindo indicações de Mizutani (1963 apud Socci \& Tanner 1980), ou de $100 \mathrm{~g}$, no caso de regolitos e colúvios. Evitou-se o uso do método da quarteação, tendo-se em vista conclusões experimentais de Emmerling \& Tanner (1974), que questionam a validade de duas ou mais quarteações sucessivas como processo estatístico de redução de massa. As amostras foram em seguida dispersas com pirofosfato de sódio trihidratado $\left(\mathrm{Na}_{3} \mathrm{P}_{2} \mathrm{O}_{7} \cdot 3 \mathrm{H}_{2} \mathrm{O}\right)$ sob agitação mecânica de duração padronizada, submetidas a um ensaio único de pipetagem conforme Galehouse (1971b) para dosagem de silte-argila total, e elutriadas através de fluxo de água ascendente em funil liso, para eliminação do sobrenadante pelítico. Pipetagem completa, em todos os intervalos de 1,0 phi entre silte grosso e argila foi executada somente nos casos de amostras sedimentares com teor visivelmente elevado (da ordem de $10 \%$ ou mais) de pelíticos e nas amostras de 
unidades 1 a 4 (ver item 5.4.1.1) de dunas de topo de encosta, incluindo materiais de crosta e intercrostas em bandas de cimentação da unidade 2.

O resíduo de elutriação de todas as amostras foi na seqüência submetido a peneiramento. Críticas ao emprego do método do peneiramento de areias são de há muito conhecidas, especialmente no que se refere a sua incompatibilidade de natureza física com o método da pipetagem aplicado às frações mais finas de mesma amostra (Sengupta \& Veenstra 1968; Gibbs 1972; Winkelmolen 1982). A preferência pelo uso do peneiramento neste trabalho pode-se justificar sob vários aspectos: (1) o problema da combinação de dois métodos fisicamente distintos, a pipetagem e o peneiramento, deve neste caso ser considerado nulo, pois a quase totalidade das amostras é de areias puras ou contendo finos pedogênicos, os quais não serão, por este motivo, computados no cálculo de parâmetros texturais; (2) estudos comparativos realizados por Coleman \& Entsminger (1977 apud Socci \& Tanner 1980) sugerem que o peneiramento é mais acurado que os tubos de decantação, pelo menos enquanto medida de tamanho de grão; (3) mesmo que exista uma eventual maior precisão dos ensaios de decantação no aspecto hidrodinâmico, a interpretação física de resultados é tão improvável quanto a interpretação física de resultados de peneiramento, como foi demonstrado por Winkelmolen (1982); (4) se o objetivo do uso de resultados granulométricos é, como nesta Tese, interpretar sua variação espacial através da comparação entre amostras, sem correlação çom parâmetros físicos de ambiente, torna-se pouco relevante a escolha do método a ser empregado, desde que adotado o mesmo para todas as amostras; (5) maior parte do acervo de resultados de granulometria para areias costeiras acumulado na literatura geológica até hoje è referente a ensaios de peneiramento.

$O$ peneiramento foi realizado em todos os intervalos de 0,5 phi compreendidos entre $0,062 \mathrm{~mm}$ (limite silte $x$ areia) e $4 \mathrm{~mm}$ (limite grânulo $x$ seixo), através de vibração mecânica "rot-up" por tempo padronizado de 12 minutos. O intervalo de 0,5 phi pode ser considerado mais que suficiente para a precisão de parâmetros de Folk \& Ward (1957) e razoável, ainda que maior que o ideal, para o cálculo de parâmetros analíticos pela técnica dos momentos (Swan et al.1978, 1979).

\subsubsection{ANÁLISES DENSIMÉTRICAS}

Uma parte das amostras processadas no ensaio de granulometria foi submetida a análise densimétrica por flutuação-afundamento em líquido denso (bromofórmio, $\mathrm{CHBr}_{3}, \mathrm{~d} \sim 2,85 \mathrm{~g} / \mathrm{cm}^{3}$ ), seguindo em linhas gerais procedimentos descritos por Parfenoff et al. (1970) e Carver (1971). Em sedimentos, Carver (1971) recomenda a execução deste tipo de análise em duas frações granulométricas distintas do intervalo areia fina - muito fina. Este intervalo apresenta a granulometria adequada para observação e identificação diretas (sem necessitar de moagem prévia) ao microscópio petrográfico; sua divisão em duas amostras teria por objetivo apenas fornecer um controle sobre a influência da razão hidráulica na distribuição mineralógica, uma vez que diferentes minerais (com diferentes razões hidráulicas) apresentam seus teores modais a diferentes granulometrias. Por outro lado; deve-se considerar que a totalidade dos minerais pesados freqüentes em sedimentos exibe teores modais deslocados para granulometrias mais finas, de 1 a 
menos que 1 phi, em relação ao teor modal de minerais leves na amostra (Rittenhouse 1943); este fato permite que se quantifiquem, de modo representativo, os minerais pesados de um só intervalo granulométrico de 1 phi, desde que situado imediatamente acima (mais fino) do intervalo modal do sedimento (Armando M.Coimbra, IGUSP, comunicação pessoal). A adoção deste critério no presente caso fez com que o intervalo submetido a análise densimétrica fosse como regra o de areia muito fina $(0,062$ - 0,125 mm), salvo por algumas exceções (areia fina) dentre amostras lagunares e coluvionares.

A escolha das amostras submetidas a densimetria seguiu a critérios de distribuição geográfica por sistema deposicional. Nos sistemas marinhos (planície costeira e barra-barreira), foram estudadas amostras da fácies praial (subfácies antepraia e pós-praia) do Holoceno atual e de subfácies indiferenciadas do Holoceno antigo e do Pleistoceno. Nos doze diferentes compartimentos praiais amostrados, analisou-se um número de amostras de praia proporcional à extensão do compartimento, entre um mínimo de dois para praias de bolso (Teresa e Muita Àgua) e um máximo de dez para praias extensas (Praia Grande do Sul). Nas áreas com depósitos marinhos antigos, procurou-se completar perfis transversais e longitudinais à costa com distanciamento médio de $2 \mathrm{~km}$ entre pontos adjacentes. No cômputo final, analisaram-se 48 amostras no sistema barra-barreira, sendo 44 na fácies praia e quatro no Holoceno antigo indiferenciado, e 74 amostras no sistema planície costeira, sendo 58 na fácies praia, duas no Holoceno indiferenciado e 14 no Pleistoceno.

No sistema eólico, a seleção das amostras para densimetria foi feita em dois grupos: dunas de orla praial (frontais e transversais ativas) e depósitos interiores (incluindo quatro gerações e três associações de fácies: item 5.4). Dentre as amostras de dunas praiais, submeteram-se a densimetria todas as provenientes de crista dunar, distanciadas entre si de $2 \mathrm{~km}$; a estas adicionaram-se amostras de barla e sotavento localizadas ao longo da Praia Grande do Sul. Amostras de crista de dunas interiores foram escolhidas de modo a perfazer perfis, dois longitudinais e três transversais à costa com espaçamento interamostral médio de 2 $\mathrm{km}$. Amostras provenientes de diferentes unidades de dunas de topo de encosta também foram estudadas. No cômputo geral, analisaram-se 108 amostras eólicas, sendo 57 de orla praial e 51 de depósitos interiores.

Outras 22 amostras foram selecionadas para densimetria representando as principais fácies ao longo do sistema lagunar. Dentre as amostras de regolito e colúvio, foram escolhidas dez.

A exemplo da análise granulométrica, o ensaio de densimetria teve seus resultados expressos em massa, através de pesagem em balança analítica de seus produtos flutuado e afundado em bromofórmio. Parte dos produtos flutuados e todos os afundados foram em seguida submetidos a ensaios de separação magnética.

\subsubsection{ANÁLISES DE DESMAGNETIZAÇÃO E MAGNETOMETRIA}

Dois tipos de ensaio envolveram propriedades magnéticas de frações anteriormente obtidas: a desmagnetização dos concentrados de minerais pesados, com uso de imã de bolso, e a análise magnetométrica da fração de minerais leves, através de aparelho Separador Isodinâmico Frantz, modelo L-1. 
A desmagnetização foi efetuada atritando-se de modo suave um imã manual envolvido em saco plástico sobre a fração de minerais pesados previamente espalhados em superficie lisa. Como regra um certo número de grãos não magnéticos aderidos ao plástico ou mecanicamente arrastados pelos magnéticos, teve que ser posteriormente removido com uso de pincel fino. Em seguida, o imã foi retirado do interior do saco plástico, liberando-se os minerais magnéticos para pesagem em balança analítica. Este processo foi aplicado para as fraçōes de minerais pesados de todas as amostras analisadas, como forma de determinação quantitativa indireta de mineralogia de pesados opacos.

O Separador Frantz consiste de um eletroimã envolvendo uma canaleta alongada e inclinada de dois compartimentos longitudinais, por onde a amostra em granulação menor que grânulo deve fluir por gravidade sob vibração mecânica. O campo eletromagnético criado no meio do dipolo apresenta lal geometria que permite separar, de cada lado da canaleta, minerais suscetiveis e não suscetíveis à atração exercida por ele. A intensidade do campo a cada ensaio de separação é regulável através de um correntômetro variável entre 0,0 e 2,0 A (amperes), o que permite que o eletroimã possa ser utilizado como um medidor de suscetibilidade magnética de minerais em grãos. Outras variáveis operacionais tais como as inclinações frontal e lateral da canaleta e a vazão de entrada de amostra completam o funcionamento do aparelho, cujos detalhes podem ser encontrados em Hess (1956) e Martins (1964).

No presente caso, o Separador Frantz foi empregado para analisar 29 amostras de minerais leves, representativas dos principais sistemas deposicionais e de suas respectivas gerações, quanto ao grau de impregnação superficial dos grãos por material limonítico. Como a presença de ferro no mineral, seja qual for sua forma de ocorrência, tende a aumentar sua suscetibilidade magnética, grãos mais impregnados podem ser separados de grãos mais límpidos, e posteriormente quantificados em massa. Os objetivos desta separação são: (1) verificar se existe correlação entre a intensidade de cor e de consolidação das areias e - grau de impregnação dos minerais leves por peliculas ferruginosas; e (2) procurar critérios analíticos magnetométricos de distinção entre tipos e idades de sistemas deposicionais.

Após testes com diferentes parâmetros operacionais, foram selecionadas para uso sistemático as amperagens de 1,0 e $1,8 \mathrm{~A}$, sob inclinação frontal de 15 graus e vazão menor que $0,2 \mathrm{~g}$ por minuto. Obtiveram-se assim três frações magnetométricas por amostra analisada: +1,0 A, $-1,0+1,8 \mathrm{~A}$ e -1,8 A.

Outra utilização do Separador Frantz, esta de caráter eventual, foi como auxiliar na determinação de minerais pesados em casos de incerteza durante a identificação ao microscópio petrográfico. A medida da suscetibilidade magnética atuou então como propriedade diagnóstica adicional, tomando-se como referência a tabela de atraibilidade de minerais ao Separador Frantz segundo Parfenoff et al. (1970). 


\subsubsection{ANÁLISES MINERALÓGICAS VIA ÓPTICA}

A análise mineralógica via óptica foi executada de dois modos diferentes: determinação semiquantitativa expedita à lupa binocular (aumento de 20 a 80 vezes), para frações de minerais leves atraídos ao Separador Frantz (frações magnetométricas $+1,0 \mathrm{~A}$ e $-1,0+1,8 \mathrm{~A}$ ), e determinação quantitativa ao microscópio petrográfico (aumento de 100 a 800 vezes), para frações de minerais pesados desmagnetizados.

A análise à lupa objetivou quantificar em partes por dez classes de minerais estabelecidas quanto ao grau de impregnação superficial. Os resultados desta estimativa em volume foram posteriormente ponderados em massa por fração magnetométrica e por fração densimétrica.

$\mathrm{Na}$ análise ao microscópio petrográfico, as espécimes de minerais pesados, incluindo opacos e micáceos, foram quantificadas por contagem, utilizando-se o "método da faixa" ("ribbon method" de Galehouse 1971a) até a totalização de no mínimo cem grãos. Em seguida prosseguiu-se a contagem exclusiva de minerais transparentes não micáceos até totalizarem-se novamente cem grãos, desta vez dentro do subgrupo. A contagem foi realizada em lâminas de montagem provisória, empregando-se alfabromonaftaleno em óleo nujol, a $40 \%$ em volume, cọmo meio liquido de imersão. Este recurso permite economia de tempo e material, além de possibilitar o manuseio direto de grãos de identificação problemática (Giannini 1987).

\subsubsection{DOSAGEM DE MATÉRIA ORGÂNICA}

A determinação de matéria orgânica foi realizada através de ataque por água oxigenada $\left(\mathrm{H}_{2} \mathrm{O}_{2}\right) 30$ volumes a quente $\left(60^{\circ} \mathrm{C}\right)$ segundo método de Grant-Gross (1971). A análise foi aplicada a amostra total, no caso de sedimentos flúvio-lagunares turfosos e à fração pelitica previamente dispersa com pirofosfato de sódio quando em sedimentos arenosos de dunas de topo de encosta (termo definido no item 5.4.2.2). Neste último caso o ensaio teve por objetivo verificar se há diferenciação de teor de matéria orgânica nas várias unidades reconhecidas, visando identificar deste modo a influência de processos pedogenéticos e a eventual existência de paleossolos em meio às mesmas unidades.

No total, foram submetidas a este ensaio 41 amostras, sendo 11 de sedimentos turfosos e 30 do sistema eólico.

\subsubsection{DATAÇÃO POR RADIOCARBONO}

Seis amostras de conchas de moluscos (predominio de Anomalocardia brasiliana), coletadas em sambaquis, foram datadas pelo método de análise de $\mathrm{C}^{14}$ natural. As datações foram executadas pelo Laboratório da Seção de Radionuclídeos Naturais do Centro de Energia Nuclear na Agricultura da Universidade de São Paulo (CENA-USP, Piracicaba, SP). Os resultados encontram-se 
apresentados, segundo a convenção internacional, em anos A.P., sendo presente o ano de 1950 e o erro de $\pm \sigma$ (desvio-padrão) ou $68 \%$ de probabilidade.

\subsection{TRATAMENTO E FORMA DE APRESENTAÇÃO DE RESULTADOS}

\subsubsection{INTRODUÇÃO}

Os resultados apresentados neste trabalho podem ser subdivididos em dois grupos. No primeiro, incluem-se informações e medidas obtidas através de descrições de campo e aerofotogeologia. Podem-se citar, como exemplos, mapas, perfis geológicos, diagramas circulares de rosa dos ventos para estratificações cruzadas, tabelas de deriva potencial eólica por quadrante em estações meteorológicas e tabelas de parâmetros morfométricos e de taxa de locomoção de depósitos eólicos. No segundo grupo, inserem-se os resultados analíticos de ensaios laboratoriais diversos, expressos em tabelas e gráficos. Entre eles, destacam-se: resultados brutos de análise granulométrica, parâmetros estatísticos de distribuição granulométrica, resultados de separação densimétrica, resultados de magnetomętria ao Frantz, freqüências percentuais de contagem de minerais pesados, ajustes estatísticos entre assembléias médias de minerais pesados por faciologia ou idade e resultados de análise de regressão linear entre coordenadas geográficas e variáveis granulométricas e mineralógicas diversas. Tabelas e gráficos foram, em maioria, programados e impressos em microcomputador através da planilha de cálculo Lotus123, versão 2.3, da Lotus Development Corporation. Dois padrões internos aqui estabelecidos para a apresentação das tabelas analíticas foram o agrupamento de resultados segundo sistemas deposicionais e associações de fácies e o cálculo de média, desvio-padrão, máximo e mínimo para fácies e subfácies com mais que três amostras analisadas.

Tabelas, mapas e gráficos foram confeccionados de modo que se tornem auto-explicativos. Apesar disto, alguns comentários prévios devem ser feitos acerca de métodos elou premissas de tratamento gráfico e estatistico neles utilizados.

\subsubsection{PERFIS GEOLÓGICOS E MAPAS}

Sete perfis topográfico-geológicos seccionando regiões dominadas pelo sistema eólico são apresentados, visando empregar-se a comparação visual de geomorfologias como critério de distinção entre associações de fácies elou gerações eólicas (figura 5.48). Este método já foi utilizado cnm objetivos similares por Wasson (1983) na classificação de dunas na costa australiana.

Os mapas apresentados são de três tipos. O primeiro é um mapa-base de localização de pontos de amostragem em escala 1:100.000 (prancha A1), altitudes compiladas ou medidas em campo, principais vias de locomoção, nomes de acidentes geográficos, cidades e vilas e o cadastro dos sítios arqueológicos. No 
segundo mapa, em mesma escala, são destacados as associações de fácies e sistemas deposicionais reconhecidos, com distinção de idade relativa (prancha A2). 0 terceiro tipo de mapa visa o detalhamento local de fácies e subfácies e baseia-se na reconstituição aerofotogeológica interpretativa em escala 1:25.000. 19 mapas deste tipo são apresentados, cobrindo as feições de arranjo faciológico de maior interesse ilustrativo (figuras A1 e A19).

\subsubsection{DERIVA EÓLICA POTENCIAL}

Tabelas de potenciais médios mensais e anuais de deriva sedimentar eólica, por quadrante geográfico, foram obtidas através da aplicação da fórmula de Lettau \& Lettau (1975 apud Fryberger 1979) a dados colhidos em quatro estações meteorológicas da região (tabelas 3.3 a 3.6). Esta fórmula pode ser expressa como

$$
Q \sim V^{2}(V-V t) \cdot t
$$

onde $Q$ representa a taxa de areia transportada, $V$ é a velocidade média a $10 \mathrm{~m}$ de altura, medida na estação meteorológica, Vt é a velocidade mínima de impacto para transporte de areia e $\mathrm{t}$ é a proporção de tempo em que o vento atuou na direção considerada. Adotou-se como valor limítrofe $\mathrm{Vt}$ a velocidade de $5 \mathrm{~m} / \mathrm{s}$, a qual tem sido assumida, com base em curvas empíricas de Bagnold (1941), como velocidade mínima de transporte eólico de areia fina (Hunter \& Richmond 1988; Fritz \& Moore 1988; Tomazelli 1990). Todas as grandezas foram consideradas no sistema CGS, o mesmo adotado por Fryberger (1979) em sua classificação nominal de regime eólico quanto ao valor da deriva potencial $Q$. Uma análise dimensional em sistema CGS da fórmula (1) permite verificar que a grandeza vetorial $Q$ expressa-se em $\mathrm{cm}^{3} / \mathrm{s}^{2}$, o que Fryberger (1979) denominou "unidades vetoriais" (UV). Não se trata, deste modo, de uma grandeza física convencional, motivo pelo qual se presta apenas a avaliações qualitativas ou comparativas da construtividade sedimentar do vento. Cabe enfatizar também que estas avaliações referem-se sempre a energia potencial e não à construção efetiva, pois o valor de $Q$ não leva em consideração a influência de fatores de dificil quantificação como a topografia, a umidade, a vegetação, a distribuição granulométrica e a disponibilidade de areia (item 3.2.2.2.2).

As tabelas de deriva potencial eólica apresentadas baseiamse em medidas diárias de velocidade máxima de vento para cada intervalo de oito horas coletadas ao longo de um periodo total de nove anos de medição compreendidos entre 1975 e 1984. Os dados referem-se às estações de Araranguá, Laguna, Florianópolis e Urussanga e foram obtidos na sede em Porto Alegre (RS) do $8^{\circ}$ Distrito do Instituto Nacional de Meteorologia (Inmet). 


\subsubsection{PARÂMETROS MORFOMÉTRICOS E TAXAS DE MIGRAÇÃO DE DEPÓSITOS EÓLICOS}

Parâmetros morfométricos de dunas eólicas, determinados por medições em aerofotografias verticais, foram apresentados por Tomazelli (1990) para a região costeira de Tramandaí, no Rio Grande do Sul. O método foi aqui adaptado ao objetivo de descrição morfológica de fácies e de associações de fácies. Distinguiramse assim dois tipos de parâmetros, os parâmetros de associação e os parâmetros de fácies, os quais se encontram ilustrados na figura 2.10. Os parâmetros de associação são representados por comprimento e largura de depósitos mantiformes e lençóis parabólicos (termos comentados no item 5.4.2.4), enquanto os parâmetros de fácies são dados por dois dos parâmetros previamente definidos por Tomazelli (1990), ou seja, o espaçamento e a curvatura de dunas. Estes parâmetros de fácies foram determinados em dunas barcanas, barcanóides e lineares transversais (tabela 5.11).

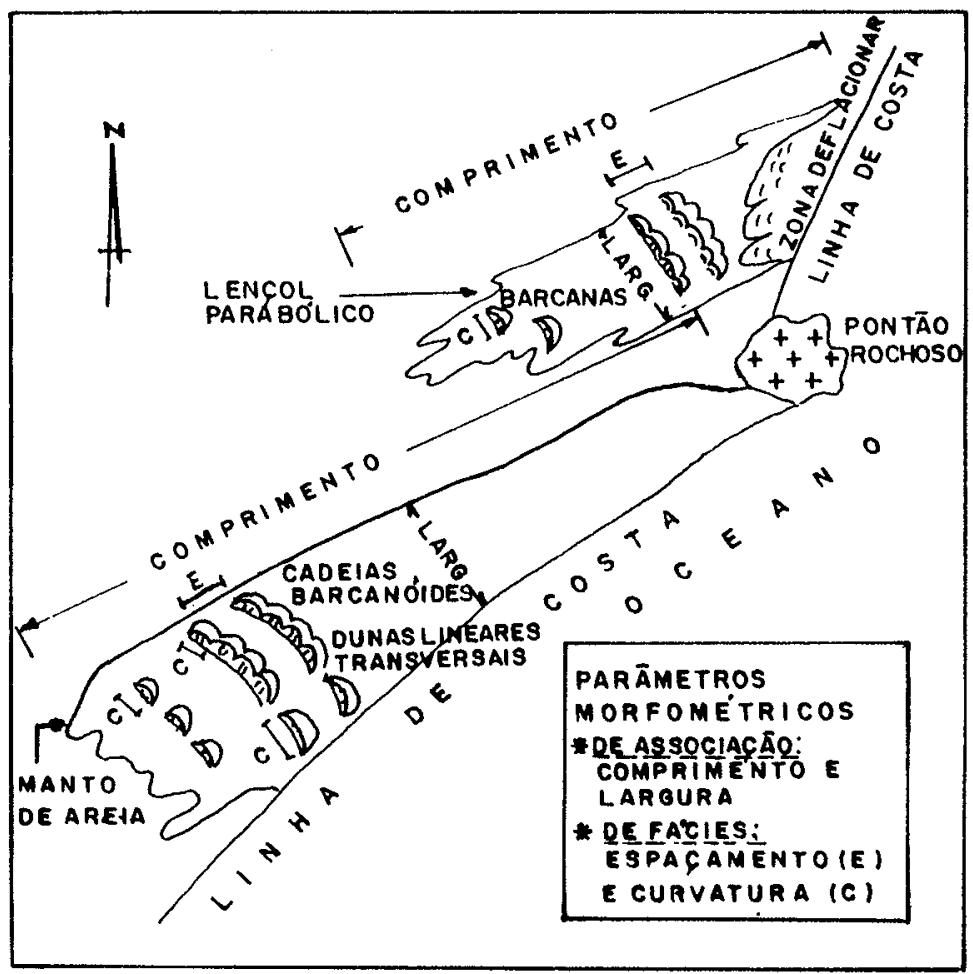

Figura 2.10. Esquema genérico para parametros morfométricos de depósitos élicos da geraçăo 4 em dois tipos de associaçóes de fácies : mantiforme e lençol parabólico. Parámetros de fácies baseados em Tomazelli (1990).

A medição indireta da taxa de deslocamento de dunas eólicas pela comparação de fotos aéreas de épocas diferentes foi utilizada por diversos autores (Finkel 1959; Mc Kee \& Douglas 1971; Tomazelli 1990). Os requisitos principais são a localização da feição comparada em posição central das fotografias e a compatibilização de escalas. Neste trabalho, o método foi aplicado a doze feições escolhidas em diferentes partes da área estudada (tabela 5.7). 


\subsubsection{CLASSIFICAÇÃO DE ESTRATIFICAÇÕES QUANTO A ESCALA}

Referências descritivas a estratificações sedimentares são feitas com base nos critérios de Campbell (1967). Este autor divide os estratos componentes de um corpo sedimentar em quatro tipos, em ordem crescente de extensão areal e intervalo de tempo de formação: lâminas, seqüências de lâminas ("laminasets"), camadas ("beds") e seqüências de camadas ("bedsets"). Todos os tipos de estrato são delimitados por superficies síncronas. No caso das camadas, consideradas unidades principais de construção, as superficies delimitantes podem ser superficies de acamamento ou inconformidades. As camadas são a única hierarquia que pode ser reconhecida em qualquer seqüência estratificada.

Segundo a classificação de Campbell (1967), uma lâmina é o menor estrato megascópico em uma seqüência sedimentar. Difere da camada por ser relativamente uniforme em composição e textura, por não exibir estratificação interna visivel e por possuir menor extensão areal. De acordo com este critério, não há limite teórico para a espessura máxima de uma lâmina.

Seqüências de lâminas são conjuntos de lâminas concordantes. Campbell (1967) admite correspondência entre estâ definição e o conceito de "seqüências" ("sets") segundo Mc Kee \& Weir (1953). Consistem em geral de estruturas geradas pela migração de uma mesma forma de leito simples. Em sedimentos eólicos, incluem seqüências alternando sedimentos mais grossos e mais finos (Stokes 1964 apud Campbell 1967), delimitadas por superfícies de $2^{a}$ ou $3^{a}$ ordem na nomenclatura de Brookfield (1977). Seqüências de lâminas menores, separadas por superfícies de $3^{a}$ ordem, dentro de seqüências de lâminas maiores delimitadas por superficies de $2^{a}$ ordem, são aqui denominadas "intra-seqüências".

As seqüências de camadas, segundo Campbell (1967) correspondem às "co-seqüências" ("cosets") de Mc Kee \& Weir (1953), porém em sentido mais restrito de escala, uma vez que camadas constituídas por seqüencias de lâminas podem ser também consideradas co-seqüências.

\subsubsection{DIAGRAMAS DE ROSA DE FREQÜÊNCIAS}

Diagramas circulares de rosa de freqüências foram utilizados para representar medidas de rumo de mergulho de planos de estratificação cruzada no sistema eólico (figura 5.99). O vetor de azimute médio e seu respectivo fator de consistência ("vector strength") foram calculados através das fórmulas de senos e cossenos apresentadas por Collinson \& Thomson (1982, p.181). O fator de consistência não possui significado absoluto em termos de confiabilidade estatística do resultado: um fator de consistência elevado, indicativo de alta dispersão de medidas, pode resultar de polimodalidade relacionada à geometria da duna. Além disso, seu cálculo não leva em consideração o significado geológico de cada superfície medida, isto é, sua hierarquia na construção geométrica do depósito. Em vista deste tipo de problemas, Fernandes (1992) propôs um método de avaliação da confiabilidade de padrões de rosa de freqüências, o qual alia critérios de estatística clássica ao significado geológico da medida (figura 2.11). Atribui assim um número mínimo ideal 
de medidas para cada ordem de grandeza espacial da estratificação. A classificação empregada para estas ordens de grandeza, baseadas em Mc Kee (1963 apud Fernandes 1992), associa dimensões absolutas de altura das seqüências ("sets") a cada uma delas: $1^{a}$ ordem, com mais de $3 \mathrm{~m}$ de altura, $2^{a}$ ordem, com 0,3 a $3 \mathrm{~m}$, e $3^{a}$ ordem, com menos de $0,3 \mathrm{~m}$. No caso de dunas costeiras quaternárias, o uso da classificação de Mc Kee não é funcional devido a pelo menos dois inconvenientes. $O$ primeiro refere-se à existência de cruzadas de baixo ângulo, nas quais a espessura da seqüência não é um critério adequado para avaliar a ordem de grandeza da estratificação. O segundo problema é a altura pequena de algumas dunas costeiras, que impossibilita a formação de seqüências de $1^{a}$ ordem no sentido de Mc Kee. Desse modo, uma classificação genética relativa das estratificações, como a de Campbell (1967), é mais representativa de seu significado geológico na construção do depósito. Por esta razão, o método de Fernandes (1992) é aqui utilizado em versão modificada, com a seguinte hierarquia de seqüências de estratificações cruzadas: $1^{a}$ ordem, para camadas; $2^{a}$ ordem, para seqüências de lâminas; $3^{a}$ ordem, para intraseqüèncias de lâminas.

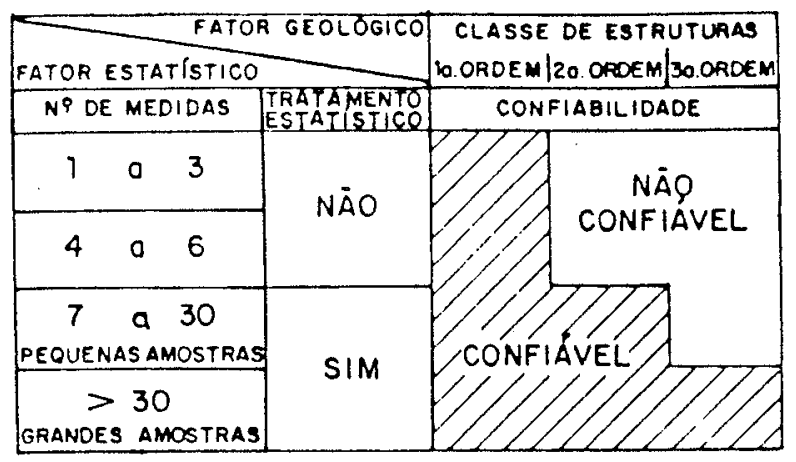

Figura 2.11. Quadro de confiabilidade de resultados, em função da quantidade e significado geológico de medidas de estratificaçס̃es cruzadas, proposto por Fernandes (1992).

\subsubsection{PARÂMETROS ESTATÍSTICOS DE GRANULOMETRIA}

Revisões bibliográficas críticas do uso de parâmetros estatísticos de granulometria no estudo de sedimentos costeiros foram apresentadas recentemente por Ponçano (1986) e Giannini (1989, 1991). Uma das conclusões destes trabalhos é que os parâmetros gráficos de Folk \& Ward (1957) não devem ser considerados como objetos de interpretação geológica confiável, o que tem sido demonstrado sob diferentes pontos de vista (Chappell 1967; Koldyjk 1968; Davis \& Ehrlich 1970; Isphording 1972; Swan et al. 1978; Tucker \& Vacher 1980; Jordan et al. 1981; Winkelmolen 1982). O cálculo de parâmetros de Folk \& Ward só se justifica hoje por se tratar de um padrão de referência clássico e universal de expressão de resultados granulométricos; sua interpretação não se pode fazer sem o uso simultâneo de técnicas mais simples e seguras, como resultados brutos de distribuição percentual, percentis da curva acumulativa e diagramas triangulares (Doeglas 1968; Asseez 1972; Tucker \& Vacher 1980), ou de parâmetros alternativos mais sensíveis, como os obtidos pela técnica dos momentos analíticos (Swan et al. 1978, 1979; El Ella 
\& Coleman 1985). Além disso, muitas das limitações dos parâmetros de Folk \& Ward e de outros indices granulométricos não são suficientes para impedir seu emprego, com relativo sucesso, como propriedade vetorial (Krumbein 1938; Evans 1939; Russel 1939; Miller 1956; Shideler 1973; Self 1977; Mc Cave 1978; Greenwood 1978; Mc Laren 1981, 1982; Jacobsen \& Schwartz 1981; Bryant 1982; Mc Laren \& Bowles 1985, 1991; Giannini 1987, 1989; Livingstone 1989).

Com base nestas considerações, parâmetros de Folk \& Ward são utilizados neste trabalho em conjunto com parâmetros estatísticos analíticos e percentis da curva acumulativa (tabelas A2, A9, A16, A23, A30 e A37), assim como de resultados de distribuição percentual bruta (tabelas A1, A8, A15, A22, A29 e A36), dando-se ênfase, em sua interpretação, a aspectos de variação geográfica (item 2.2.3.4.1). Parâmetros de Folk \& Ward e percentis foram obtidos através do programa de computação LABSE.COM, de Jorge K. Yamamoto (Laboratório de SedimentologiaIGUSP 1991), enquanto parâmetros analíticos foram calculados pelo programa MOMENTOS.WK1, criado em sistema Lotus-123, e que utiliza as fórmulas estatísticas de Pearson. Frações pelíticas não foram computadas no cálculo dos parâmetros.

\subsubsection{ANÁLISE DE REGRESSÃO LINEAR}

Dois métodos principais foram empregados para avaliar-se a variação geográfica de caracteristicas granulométricas e mineralógicas dos sedimentos estudados: gráficos de dispersão binária em função de coordenadas geográficas (figuras $A 20$ e A56) e análise de correlação e regressão lineares com mesmas coordenadas (tabelas A3, A6, A7, A10, A13, A14, A17, A20, A21, A24, A27, A28, A31, A34, A35). O uso combinado destes dois métodos é justificado pela regra de Reichmann (1961 apud Huggett 1985) segundo a qual uma reta de regressão jamais deve ser aceita ou interpretada sem o exame criterioso do diagrama de dispersão de pontos correspondente; a recíproca é válida (Huggett 1985).

Informações sobre as técnicas de correlação e regressão lineares e sobre seu uso em geologia podem ser encontradas em trabalhos diversos (Harbaugh \& Merrian 1968; Landim 1983; Huggett 1985; Giannini 1987). De fundamental deve-se guardar que: (1) o sinal da correlação, positivo quando direta e negativo quando inversa, é dado pelo sinal oposto ao de b na equação de regressão y $=\mathrm{a}+\mathrm{bx} ;(2)$ o coeficiente de determinação $\mathrm{R}^{2}$ denota o quanto a variação de uma variável $(y)$ é explicada pela variação da outra $(x)$ segundo a equação da regressão linear; (3) o valor de $\mathrm{R}^{2}$ pode ser favorecido pelo acaso se o número de pontos amostrais for pequeno, de modo que o nivel de confiança na correlação deve ser avaliado por um teste estatistico que associe a correlação r ao número de amostras $\mathrm{N}$, tal como o teste $T$ de Student.

Resultados de regressão linear foram aqui obtidos através de comandos estatísticos do sistema Lotus-123 (Williams 1986). Em geral, aplicou-se a regressão múltipla a teores de distribuição na fração areia, e regressão simples a parâmetros e percentis granulométricos e a teores de minerais pesados. O nível de confiança na correlação foi obtido através da comparação de valores calculados pelo teste T de Student com seus valores tabelados por Fisher \& Yates (1938). 
Do ponto de vista sistêmico, as regressões e correlações lineares obtidas constituem uma forma de avaliarem-se estruturas sedimentológicas lineares dentro de associações de fácies e sistemas deposicionais. Apesar da falta de linearidade dos sistemas naturais (Thornes \& Ferguson 1981 apud Huggett 1985), relações monotônicas lineares entre variáveis granulométricas e variáveis espaciais têm sido admitidas, com relativo sucesso como premissa fundamental no "método de Mc Laren" de interpretação vetorial de granulometria (Mc Laren \& Bowles 1991). Isto não significa que tendências lineares não se possam combinar segundo padrões não lineares de variação no espaço.

\subsubsection{ESCALA NOMINAL PARA FREQÜÊNCIAS DE MINERAIS PESADOS}

Várias escalas de classificação nominal de freqüências

de minerais pesados são encontradas na literatura. Algumas, como a utilizada por Wu $(1981,1989)$ listam um número excessivo de classes, tornando-se pouco práticas. Outras mais simples, como a de Coutinho \& Coimbra (1974) empregam para algumas das classes intervalos muito amplos, tornando-se pouco precisas. Em vista disso, utiliza-se neste trabalho uma escala alternativa, que expresse melhor as variaçōes significativas de mineralogia ao largo da área estudada (tabela 2.4).

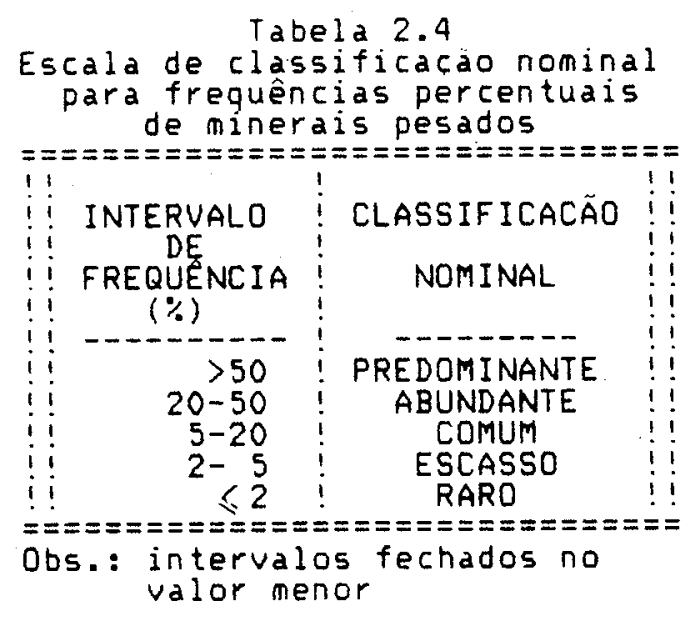

\subsubsection{0. ÍNDICES E RAZÕES DE MATURIDADE MINERALÓGICA}

O conceito de maturidade mineralógica, concebido por Folk (1951), refere-se às mudanças quantitativas de mineralogia sofridas por um sedimento ao longo de processos que o levaram a sua composição atual, seja durante o transporte e a deposição, seja no transcorrer de fenômenos diagenéticos. Há duas dificuldades na interpretação da maturidade mineralógica; a primeira é a de distinguir entre causas primárias e causas diagenéticas de maturidade, o que depende da observação de aspectos texturais dos minerais utilizados como indicadores de maturidade; a segunda dificuldade reside em saber até que ponto um índice de maturidade resulta de atuação de processos sedimentares e não da composição da 
rocha-fonte primária, o que requer comparações com os indices mineralógicos de rochas-fontes potenciais e/ou, mais uma vez, a investigação de traços texturais. Mantém-se portanto a idéia original de Folk (1951) segundo a qual a maturidade é um conceito dual, de tal modo que a maturidade mineralógica ou química não possa ser separada totalmente da maturidade textural ou física, para fins de interpretação genética. Como corolário desta idéia pode-se postular que a maturidade mineralógica, estabelecida independentemente de descrições texturais, é em princípio uma característica apenas descritiva do sedimento.

Com base nas considerações acima, sete tipos de indices diretos ou inversos de maturidade mineralógica foram calculados por amostras individuais ou agrupadas. Todos os indices utilizados referem-se a assembléias de minerais pesados transparentes não micáceos, sendo três deles somatórios simples e os outros quatro razões entre somatórios. O primeiro índice somatório ou índice ZTR (iZTR), seguindo a definição de Hubert (1962), é dado pela soma das porcentagens de zircão mais turmalina mais rutilo, minerais considerados ultraestáveis. Índices calculados de modo análogo para minerais metaestáveis (iMET) e instáveis (iINS), de acordo com a classificação de Pettijohn et al. (1972), foram também obtidos. As quatro razões mineralógicas apresentadas, todas indicadores diretos de maturidade mineralógica são: $r 1=i Z T R / i I N S, r 2=i Z T R /$ iMET, $r 3=i M E T / i I N S$ e $r 4=$ zircão + rutilo / turmalina + epidoto + hornblenda (figuras 4.2, 4.4, 4.6, 5.7, 5.21, 5.37, 5. 1.09, 5.112, 5.114 e tabela 4.4).

O cálculo de $r 4$, colocando turmalina como denominador de índice direto de maturidade, deveu-se a observação freqüente, nas amostras estudadas, de turmalinas com alteração intensa, assim como de correlação direta entre o teor deste mineral e os teores de minerais tidos como menos estáveis, especialmente pistachita e hornblenda. Não se trata portanto de um índice direto convencional ou universal de maturidade, mas que, neste estudo específico, merece ser melhor investigado enquanto possivel indicador de proveniência ou maturidade genética.

\subsubsection{COMPARAÇÃO ENTRE ASSEMBLÉIAS MINERALÓGICAS POR QUIQUADRADO}

O teste do quiquadrado é um dos recursos estatísticos para verificação de hipóteses de ajuste entre distribuições de freqüências. Utilizações da técnica na comparação entre assembléias quantitativas de minerais pesados em sedimentos podem ser encontradas em Landim (1983) e Giannini (1987).

$O$ valor quiquadrado $\left(X^{2}\right)$ é uma função somatória das diferenças quadráticas entre freqüências de cada componente (mineral pesado) nas duas distribuições comparadas (assembléias). Ele pode ser expresso, dentre outros modos, pela fórmula utilizada neste trabalho:

$$
X^{2}=\sum_{i=1}^{n}\left(\left(O_{i}-P_{i}\right) / P_{i}\right)^{2}
$$


onde Oi corresponde ao teor observado do mineral i numa assembléia e Pi ao teor do mesmo mineral em assembléia padrão ou de referência, que seja anterior ou contemporânea à primeira. Um baixo valor $X^{2}$ indica que as distribuições possuem ajuste estatístico seja por possuírem rocha-fonte comum seja por ter a primeira (O) relação direta de proveniência sedimentar com a segunda $(P)$. A diferença de idade entre os sedimentos também pode ser um fator importante na determinação do $X^{2}$ uma vez que a dissolução intraestratal atua, proporcionalmente ao tempo na modificação da mineralogia original (Pettijohn 1941).

O critério estatístico para decidir se a somatória $X^{2}$ é ou não suficientemente baixe para que se possa confirmar a hipótese nula de correlação de idade e proveniência entre as assembléias é a comparação com os valores tabelados de $X^{2}$ para diferentes niveis de confiança (Fisher \& Yates 1938). A fórmula (2) fornece um teste de hipótese de alto rigor, de tal modo que ajustes a $99 \%$ de confiança devam ser esperados apenas no caso de amostras de mesma população, isto é, de íntima correlação crono e litoestratigráfica.

Duas tabelas de resultados de $X^{2}$ são apresentadas. A primeira estabelece ajustes estatísticos entre assembléias médias de minerais pesados por sistema deposicional ou associação de fácies e por idade relativa (tabela 4.5). A segunda estabelece ajustes entre as mesmas assembléiaś e assembléias médias de regolitos das possiveis rochas fontes pré-quaternárias (tabela 4.1). O rigor da segunda tabela é menor que o da primeira, principalmente pela falta de controle na amostragem de influências pedogênicas na composição mineralógica do regolito. Permite, ainda assim, uma avaliação grosseira das principais rochas-fontes primárias da planície quaternária. 


\section{CAPITULO 3. EXAME PRÉVIO INTEGRADO DE SISTEMAS DEPOSICIONAIS}

\subsection{MACROAMBIENTE}

\subsubsection{CLIMA}

\subsubsection{Fatores de controle climático}

Segue-se aqui a classificação utilizada por Tomazelli (1990), que distingue entre fatores estáticos e dinâmicos de controle climático. Entre os fatores estáticos, incluem-se a posição geográfica da área enfocada e o relevo, enquanto os fatores dinâmicos relacionam-se ao movimento relativo de massas atmosféricas de alta e baixa pressão (anticiclones e ciclones respectivamente). Em escala de tempo geológico restrita (Quaternário), estes últimos fatores podem ser considerados como as variáveis de estado ativas do clima enquanto sistema metaestável. De acordo com Lorenz (1968 apud Huggett 1985), o sistema climático global não possui uma estrutura macroscópica única no tempo, mas alterna estados estacionários distintos, os quais cambiam-se entre si atravessando limiares intransitivos, de modo abrupto ou mesmo catastrófico. Um exemplo de mudança climática deste tipo é o fenômeno "El Niño".

A posição geográfica da área estudada dentro da Zona Subtropical Sul (Strahler 1977) favorece a influência de massas atmosféricas marítimas, de origem tropical e polar. O controle climático exercido pelo relevo tornase importante quando massas úmidas de ar vindas do oceano são barradas por encostas abruptas; sofrem então o efeito de condensação, dando origem a precipitações orográficas. Escarpas com esta função no litoral catarinense são representadas pela serra Geral, na região sul de Laguna, com cotas de até $1100 \mathrm{~m}$ e pelas serras de Itajaí e do Taboleiro, entre Laguna e Joinville, com cotas de até 1200 $\mathrm{m}$. De acordo com Orselli (1986), o fato de estas encostas serem mais distantes da costa no litoral sul catarinense que no litoral norte é um dos fatores determinantes da pluviosidade relativamente baixa a sul. Na cidade de Araranguá, situada numa depressão de dissecação remontante da serra Geral nas bacias hidrográficas dos rios Mampituba e Araranguá, registra-se a menor média anual de precipitação pluviométrica no Estado (1219 mm, conforme Orselli 1986).

Em seu aspecto dinâmico, o clima da região costeira catarinense é controlado por duas massas de ar anticiclônicas (com circulação interna divergente anti-horária): a Massa Tropical Atlântica e a Massa Polar Atlântica (Orselli 1986). A primeira é uma massa de ar quente, de circulação essencialmente marítima, úmida devido à intensa evaporação de água do mar, e de posição semipermanente entre as latitudes 18 e $35^{\circ} \mathrm{S}$ (Orselli 1986; Horn 1988; Tomazelli 1990). A segunda é uma massa de ar frio de origem antártica sob tendência de deslocamento para norte, com trajetória predominantemente marítima no verão e continental no inverno (Orselli 1986; Martin et al. 1988b). A permanência do Anticiclone Tropical sobre determinada região favorece o tempo estável e ensolarado, enquanto o avanço pulsátil do Anticiclone Polar associa-se a ocorrência de chuvas. Nas estações quentes do ano, a 
chegada da Massa Polar, aquecida e carregada da umidade absorvida em sua rota oceânica, propicia chuvas pesadas ("de verão"), de forte controle orográfico (Martin et al. 1988b). Nas estaçōes frias, a Massa Polar vem de encontro à Massa Atlântica em trajetória continental SW-NE, causando formação de típica frente fria, com seus ventos ciclônicos associados (Tomazelli 1990) e condensação da umidade de ar quente na forma de chuvas frontais. Os dois anticiclones alternam-se em ritmo sazonal sobre a área costeira. O avanço da Massa Polar rumo nordeste, intensificado no outonoinverno, associa-se a ventos preferenciais ciclônicos no mesmo rumo, devido à formação de uma zona deprimida de pressão entre os dois centros de pressão alta, enquanto seu recuo na primavera-verão favorece ventos anti-horários com componentes predominantes na costa para sul.

No sistema climático global, essa alternância de posição geográfica entre os dois anticiclones atlânticos representa uma troca constante de energia dos anticiclones entre si e com seu meio, caracterizando um estado estacionário de equilíbrio de fluxo. Um dos mecanismos de ruptura natural deste equilibrio é o bloqueio das trocas internas de energias, aumentando seu status de ordenação macroscópica. Tal efeito é representado episodicamente pelo fenômeno "El Niño" na costa pacifica da América so Sul (figura 3.1), o qual acarreta, como conseqüência, uma corrente quente de jato subtropical dirigida da costa do Peru ao Sul-Sudeste do Brasil (Martin et al. 1988b, 1991; Arantes 1992). Esta corrente gera o bloqueio da migração rumo norte da Massa Polar, subdividindo a costa brasileira em duas zonas climaticamente opostas. Segundo Martin et al. (1988b, 1991), o fenômeno de inundações catastróficas registrado no litoral catarinense em 1983 estaria associado a retenção prolongada da Massa Polar no sul do país por efeito da ocorrência do "El Niño". 


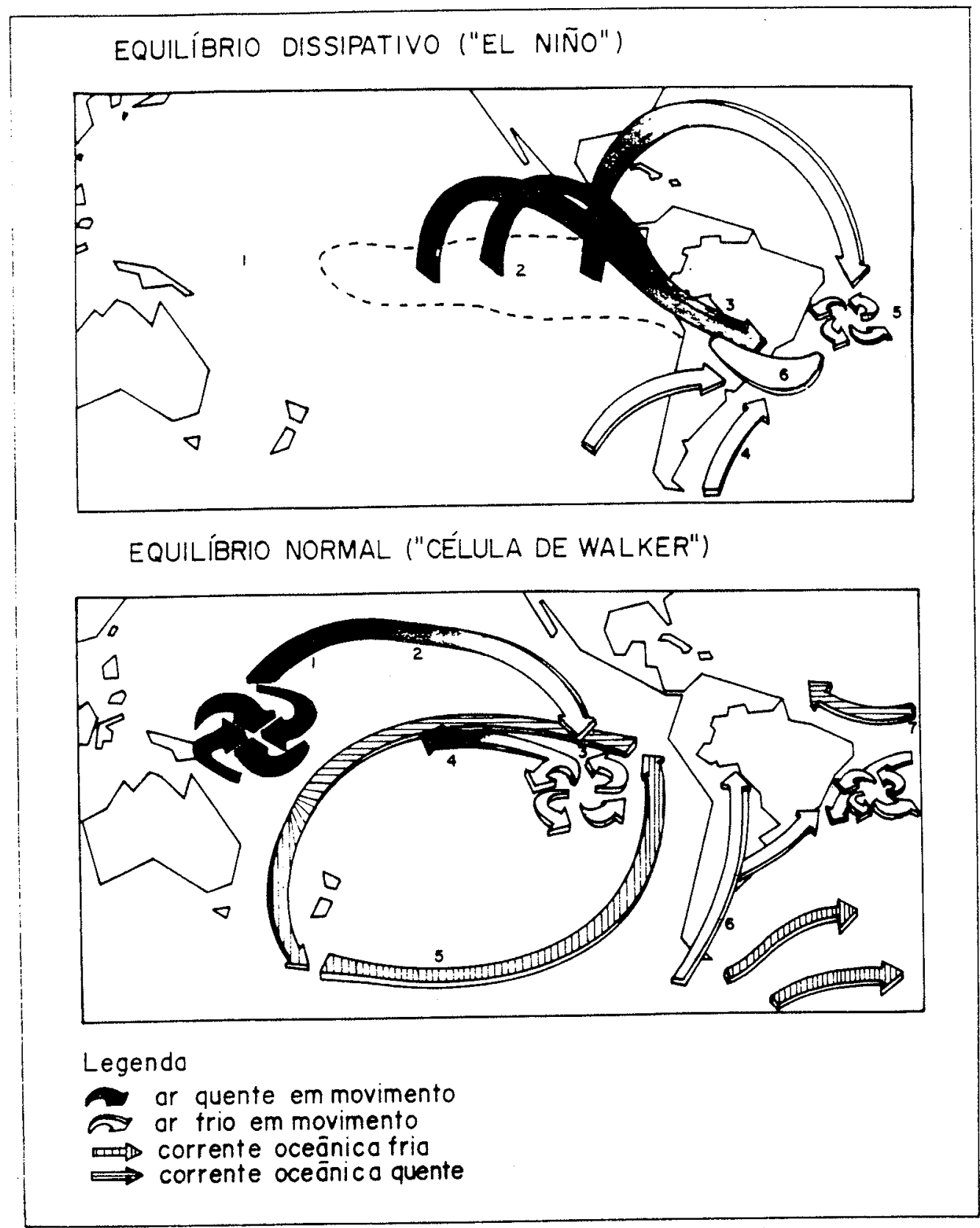

Figura 3.1. Trajetoria de massas de ar na América do Sul sob clima normal (quadro inferior, incluindo também correntes oceánicas) e sob efeito "El Niño" (quadro superior). Em condiçð̃es normais, o ar quente no Norte da Oceania ascende, criando zona de baixa pressåo (1) e desloca-se rumo leste (2); neste trajeto, esfria-se por influência de massas polares, desce e forma um anticiclone (3), o qual em seu desvio para oeste, por ventos alísios (4), fecha o circulo da corrente de Humboldt (5). Em condiçסes "El Niño", fatores desconhecidos fazem a pressăo subir no Norte da Oceania (1); os ventos alísios e a corrente de Humboldt enfraquecem-se, elevando a temperatura do mar e da atmosfera no Pacifico Equatorial (2); uma parte do ar quente tende a deslocar-se para os pólos, mas é desviada para sudeste ou nordeste pela força de Coriolis; o ramal sudeste (3) gera um jato quente sobre o Sul do Brasil, o qual bloqueia a massa de ar polar (4); outra parte ascende e volta a descer no Nordeste do Brasil, reforçando o anticiclone do Atlântico (5); uma zona de pluviosidade (6) forma-se na convergência entre 3, 4 e 5. Compilado de Martin et al.(1991) e Arantes (1992). 


\subsubsection{Classificação do clima atual}

O clima na região de Laguna é do tipo $\mathrm{Cfa}$, na classificação de Köppen (1948 apud Monteiro 1958), ou $\mathrm{B}_{2} \mathrm{~B}^{\prime}{ }_{3}$ ra' na classificação de Thornthwaite (1948 apud Orselli 1986). Estas classificações permitem descrevê-lo como clima subtropical úmido mesotérmico, sem estação seca, com verão quente, pouco ou nenhum déficit de água e baixa concentração de verão na evapotranspiração potencial.

As seguintes médias meteorológicas anuais são inferidas por Orselli (1986) para a região estudada: temperatura de $190 \mathrm{C}$, sendo de $230 \mathrm{C}$ em janeiro e $14^{\circ} \mathrm{C}$ em julho; umidade relativa de pouco mais que $85 \%$ na área de Gravatal-Imarui-Imbituba e de pouco menos nas áreas de Jaguaruna-Laguna e de Garopaba; número de dias de chuva entre 110 (Imbituba) e 120 (Laguna); taxa de precipitação entre $1250 \mathrm{~mm}$ (Imbituba) e $1400 \mathrm{~mm}$ (Laguna). Uma avaliação expedita de boletins de registro diários da estação meteorológica Inemet de Laguna evidencia que os dias de chuva associam-se de modo preferencial à atuação de ventos fortes (> $5 \mathrm{~m} / \mathrm{s}$ ) de quadrantes entre SW e SE. Esta observação atesta a correlação entre dias de chuva e o avanço da Massa de Ar Polar para norte (ver também item 3.2.2.2.2).

\subsubsection{Influência de perturbações climáticas na sedimentação costeira}

Além de determinar $o$ regime de ventos e de ondas, controlando a intensidade e a orientação das derivas eólica e litorânea, o clima influi na sedimentação costeira regional por meio de perturbações episódicas, geradoras de aumento temporário anómalo de pluviosidade. No registro histórico recente, o litoral sul catarinense foi palco de pelo menos três eventos deste tipo: em março de 1974 (Bigarella \& Becker 1975b), em julho de 1983 (Orselli 1986; Martin et al. 1988b) e em maio de 1992 (Arantes 1992). Os dois últimos coincidem com manifestações globais do fenômeno "El Niño". De acordo com Bigarella \& Becker (1975b), as conseqüências geológicas mais evidentes do primeiro evento, na área entre Mampituba e Laguna, foram: formação de cicatrizes de escorregamento ("slump scars") nas secções mais ingremes de escarpas da serra do Taboleiro; redeposição do material escorregado na forma de leques ou como sedimento incorporado na carga fluvial; aumento temporário da vazão sólida do rio Tubarão, com aquisição local de caráter de sistema entrelaçado ("braided"); e intensa agradação pelítica na planície de inundação do Tubarão, atingindo espessuras de até $0,6 \mathrm{~m}$ no flanco de diques naturais e $1,5 \mathrm{~m}$ nos leques de crevassa. Além destes, outros efeitos virtuais das inundações periódicas na área são a reativação temporária ou mudança de curso de canais distributários no delta do Tubarão, a progradação rápida deste delta nas margens sul da lagoa Santo António e noroeste da lagoa Garopaba do Sul e a ocorrência de fenômenos de sobrelavagem ("washover") no sistema barra-barreira, incluindo abertura e fechamento de desembocaduras ("inlets") lagunares (item 4.2.4).

Segundo Bigarella \& Becker (1975b), os movimentos de massa desencadeados durante perturbações climáticas tendem a recorrer nas mesmas localidades desde o Pleistoceno superior, devido a interação entre morfologia de escarpas e geometria de juntas. Deste modo, muitos dos fenômenos gravitacionais recentes retrabalham antigos "mantos coluvionares" de mais de $2 \mathrm{~m}$ de espessura. Durante os escorregamentos, blocos, seixos e grânulos de zonas de manto de 
intemperismo delgado do topo das vertentes podem misturar-se à lama de zonas de manto espesso de porções inferiores (Bigarella \& Becker 1975b). A presença de lama como agente lubrificante reduz a intensidade de desintegração durante o transporte, permitindo a preservação de grãos de quartzo e feldspato pouco arredondados em granulação milimétrica.

\subsubsection{TECTÔNICA}

\subsubsection{Arcabouço tectono-estrutural}

A caracterização macroambiental da área em estudo, em relação ao aspecto tectono-estrutural, depende do reconhecimento da associação entre a compartimentação fisiográfica da costa sul-brasileira e a distribuição de elementos estruturais no embasamento cristalino e bacias marginais adjacentes. Algumas m'גjanças geomorfológicas podem ser enumeradas como possiveis expressões dessa compartimentação: (1) a serra do Mar acompanha a zona de ocorrência da Bacia de Santos, deixando de aparecer a sul de Joinvillé (Almeida 1953; Brito Neves et al. 1979), próximo ao limite norte da chamada Plataforma. de Florianópolis, um paleoalto estrutural do Terciário inferior; (2) o domínio aflorante da Bacia do Paraná aproxima-se bruscamente da costa na região de Balneário Rincão, flanco norte do Sinclinal de Torres, pouco a sul da borda meridional da Plataforma de Florianópolis; (3) no cabo de Santa Marta, em Laguna, observa-se uma mudança brusca de direção da linha de costa, de NNE, a norte, para ENE, a sul; (4) a região costeira que se estende de Imbituba a Itajaí é mais escarpada e recortada que os setores vizinhos a norte, e, principalmente, a sul; (5) a plataforma continental interna torna-se mais estreita e íngreme no setor compreendido entre cabo de Santa Marta e Itajaí (figura 3.2).

As mudanças enumeradas permitem representar a latitude de Laguna, de modo aproximado, como fronteira entre compartimentos costeiros. A sul deste paralelo, vale a correlação traçada por alguns autores no Rio Grande do Sul (Villwock 1984; Tomazelli 1990), considerando a planície costeira quaternária como extensão aflorante e mais ocidental da Bacia de Pelotas, em solução de continuidade com os sedimentos submersos da plataforma continental. A norte do mesmo paralelo, até a região de Itajaí, a costa passa a avizinhar-se a leste pela Plataforma de Florianópolis. Esse paleeoalto separa as bacias marginais de Santos e Pelotas sob a forma de faixa alongada EW. Asmus $(1978,1981)$ incluiu a Plataforma de Florianópolis dentro de um dos vários alinhamentos oceânico-continentais subperpendiculares à costa por ele admitidos na margem oriental da América do Sul, o Alinhamento Florianópolis - Rio Uruguai. A idéia de existência de grandes alinhamentos deste tipo na costa sul brasileira já fora adotada em trabalhos clássicos, merecendo menção o "eixo de compartimentação tectônica passando por Lages e Anitápolis", de Paiva (1933), e a "linha tectônica Torres-Posadas", de Leinz (1949). 


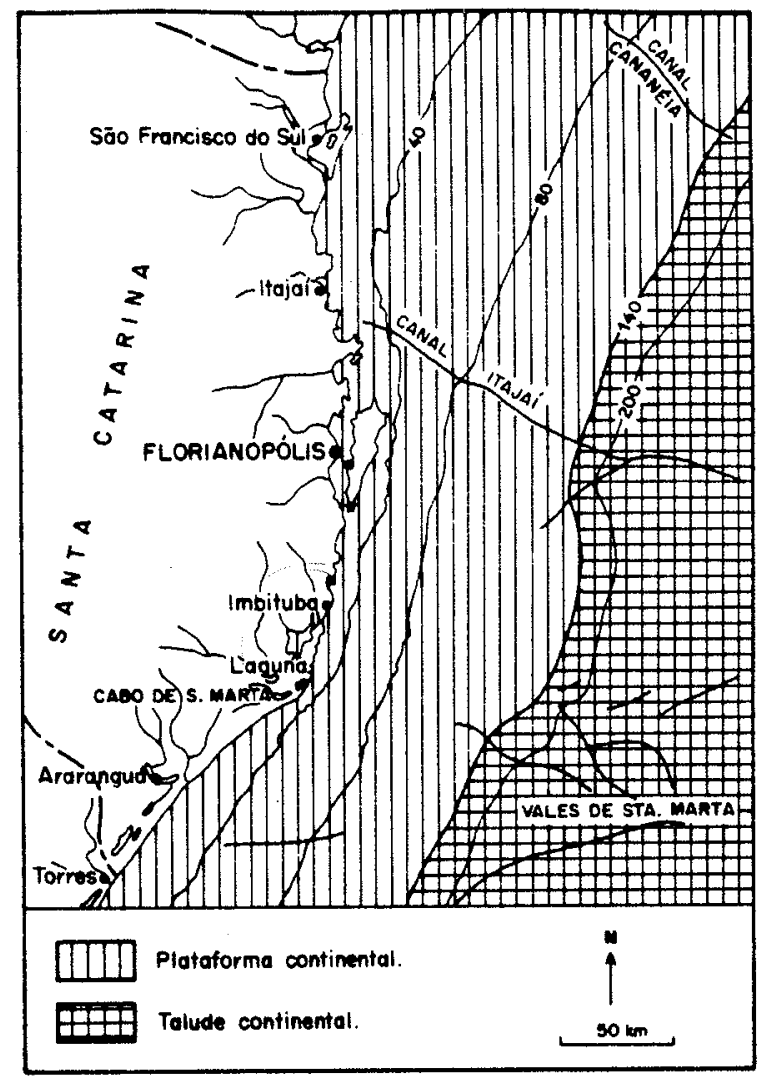

Figura 3.2. Mapa fisiografico da margem continental de Santa Catarina compilado por Zembruscki (1979).

Macedo (1987) admite a presença, ao longo da Plataforma de Florianópolis, de uma zona de cisalhamento que separa e desloca em rejeito dextrogiro o bloco de crosta continental estirada do Platô de São Paulo, a norte, em relação ao bloco de crosta oceânica adjacente a Elevação do Rio Grande, a sul. Isto permite caracterizá-la como zona de falhas de transferência, ligada a acomodação relativa de segmentos crustais vizinhos com diferentes taxas de estiramento (Pereira \& Macedo 1990); esta zona de transferência teria prolongamento continente adentro, guardando sob este aspecto correspondência com o Alinhamento Florianópolis - Rio Uruguai de Asmus (1978, 1981). A expressão estrutural em superfície de tal feição continental-oceânica é antes inferida que observada. Se for possivel generalizar a conclusão que Almeida (1991) obteve em relação ao Alinhamento de Cabo Frio, a característica que melhor expressa este tipo de feição é a de alinhamento magmático, cuja disposição não seria a de linhas EW, e sim, na forma de arcos, relacionados aos círculos mínimos de rotação das placas continentais ao decorrer de seu afastamento. Durante o esforço distensional na separação das placas, o manto sofreria fusão parcial e o magma resultante seria alojado preferencialmente ao longo de falhas subcrustais associadas a zonas de transferência (Almeida 1991). Com isto, torna-se possivel supor que intrusões magmáticas alinhem-se ao longo de um só arco de círculo de expressão regional, conforme Almeida (1991), e ao mesmo tempo, ao longo de diferentes falhas de transferência EW, tais como as inferidas por Macedo et al. (1991). 
De acordo com o modelo de Lister et al. (1986), zonas de transferência podem separar segmentos de placas litosféricas de diferentes posições em relação a falhas de descolamento ("detachment faults") e com arquiteturas estruturais contrastantes: de um lado, "margens de placa inferior", com intenso falhamento "rift" subparalelo à costa, de mergulho variável; de outro, "margens de placa superior", com estruturação mais simples à base de falhas normais pouco rotacionais, relacionadas a reativação por abaulamento crustal de direções preexistentes (figura 3.3). Se este modelo é admitido, a superposição de zonas de transferência nos limites norte e sul da Plataforma de Florianópolis explica as diferenças estruturais entre este paleoalto e as bacias marginais de Santos e Pelotas. A extensão destas diferenças às zonas continental e costeira adjacentes, até agora não demonstrada, explicaria também a compartimentação geomorfológica abservada na costa catarinense.

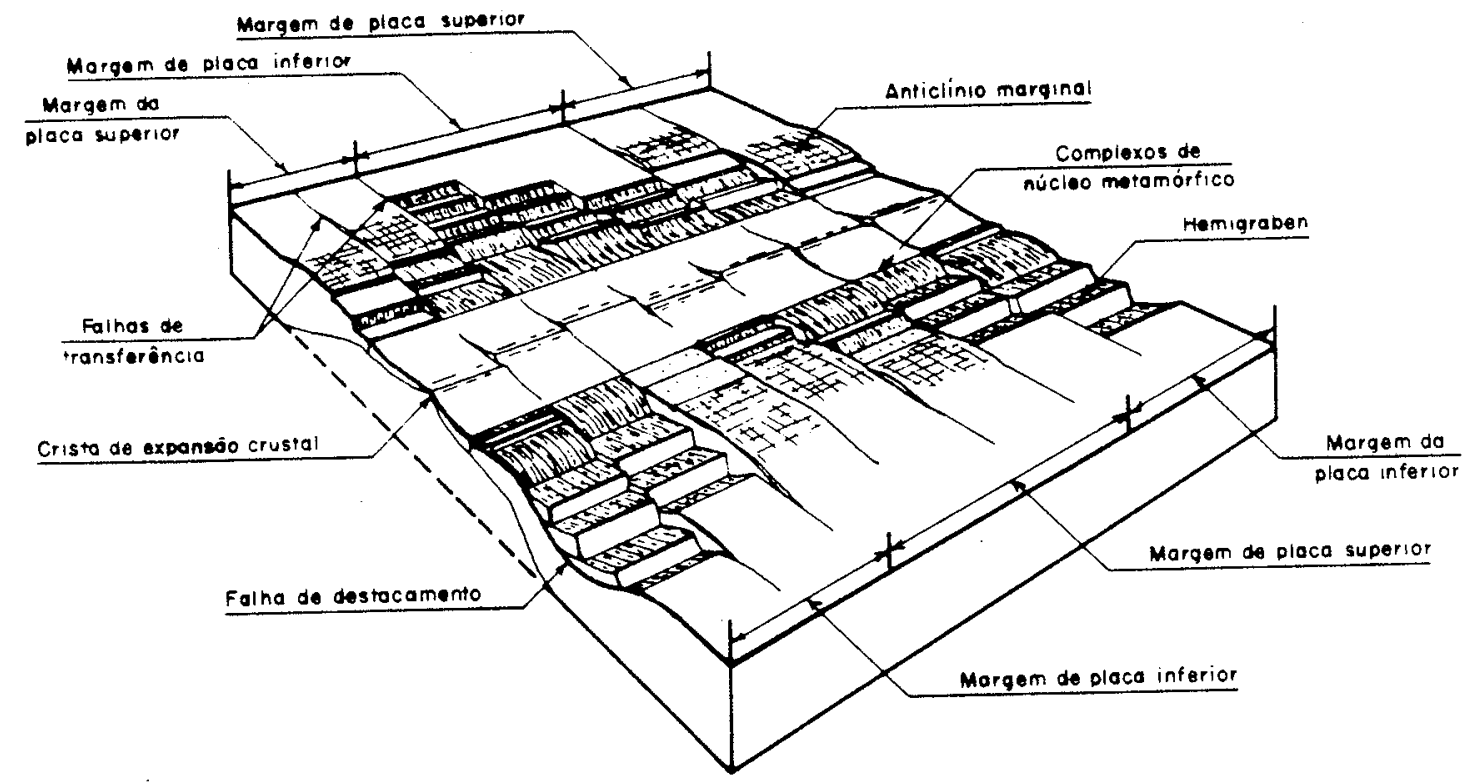

Figura 3.3. Arquitetura de uma margem passiva do tipo atlantico segundo Lister et al.(1986). Ocorre alternáncia entre placas superior e inferior separadas por falhas de transferéncia, o que explica mudanças de padrão morfoestrutural ao longo da costa.

A tectônica rúptil continental é marcada pelo predomínio dos sistemas direcionais N30E e N60E, denominados respectivamente Sistema Riograndense e Sistema Catarinense (Putzer 1953, 1955). Estas direções são possivelmente associadas a falhas primitivas da costa (Trainini et al. 1978) e sofreram várias fases de reativação entre o Eopaleozóico e o Terciário (Horbach \& Marimon 1980). Não existe zoneamento aparente em sua distribuição espacial, exceto quanto ao domínio do sistema N3OE nas rochas que afloram próximo à costa.

\subsubsection{Neotectônica}

Suspeitas e indicios de atividade tectônica neocenozóica no sudeste catarinense, com virtual influência no contexto da sedimentação costeilia quaternária, permanecem sem comprovação suficiente. Entre eles, podem ser 
destacados os seguintes: (1) Asmus (1981) sugeriu que o caráter mais escarpado e recortado das costas atravessadas por alinhamentos, como o Florianópolis - Rio Uruguai, possa indicar uma atividade tectônica destes "até épocas mais recentes"; (2) Horbach \& Marimon (1980) acreditam que uma fase de reativação rotacional dos sistemas de falhas N3OE e N6OE esteja em andamento, por efeito de uma distensão E$W$ de reajuste isostático; (3) Dias Neto (1986) relata que o maior sismo já registrado no Estado de Santa Catarina, com magnitude de $5,6 \mathrm{mb}$, teve seu epicentro localizado na plataforma continental entre as latitudes de Florianópolis e Araranguá; (4) na mesma área, a presença de um conjunto de vales submarinos de plataforma externa e talude (vales de Santa Marta: figura 3.3) associa-se à ausência anômala de depósitos superficiais de lamas terrigenas, substituidas por fácies arenosas (Zembruscki 1979; Martins \& Martins 1985).

\subsubsection{NIVEL RELATIVO DO MAR}

\subsubsection{Curvas de variação no Holoceno}

Compilação de datações por método radiocarbono no litọral catarinense (Martin et al. 1988b) reporta a existência de 56 resultados disponíveis, dentre conchas de sambaquis (33) ou de depósitos sedimentares marinhos ou lagunares $(20)$ e fragmentos vegetais $(3) ; 26$ destas datações referem-se a área compreendida entre Jaguaruna e Imbituba e 15 foram utilizadas como indicadores de paleonivel para a confecção da curva de variação do nivel relativo do mar (NRM) durante os últimos 7 mil anos no Estado de Santa Catarina (Martin \& Suguio 1986; Martin et al. 1988b). Esta curva apresenta algumas lacunas na base de dados, sendo a maior delas no trecho correspondente aos últimos 2 mil anos. Para esses casos, seus autores adotaram uma configuração análoga à deduzida para outros setores da costa brasileira (figura 3.4). A curva representa a sucessão de três máximos, ocorridos em 5100, 3600 e 2500 anos antes do presente (A.P.). As cotas atingidas pelo mar durante estes máximos teriam sido respectivamente de $4,0 \mathrm{~m}, 2,5 \mathrm{~m}$ e 2,0 m acima do nivel atual (erro de $\pm 0,5 \mathrm{~m}$ ).

O esboço de curva proposto por Tomazelli \& Villwock (1989) para a costa do Rio Grande do Sul (figura 3.5) baseia-se essencialmente em evidências geomorfológicas e sedimentares não datadas. Ele acompanha em linhas gerais o padrão inferido por Martin et al. (1988b) para o setor vizinho a norte, exceto em relação ao trecho final da curva, no qual é representada uma queda de NRM abaixo do nivel atual entre 2300 e 1000 anos A.P. seguida de elevação ainda em andamento. Entre as "evidências de uma tendência contemporânea de elevação do NRM na costa do Rio Grande do Sul" enumeradas por Tomazelli \& Villwock (1989) e Tomazelli (1990), pode-se destacar: (1) erosão recente da linha de costa oceânica sugerida pelo exame de fotografias aéreas de datas sucessivas e por aspectos de campo, incluindo o freqüente afloramento de turfa na pós-praia atual, datada em 1975 \pm 150 anos A.P.; (2) processos erosivos similares nas margens de corpos lagunares; (3) existência de terraços lagunares submersos (cota - $1 \mathrm{~m}$ ) às margens das lagoas dos Patos e de Tramandaí; e (4) deslocamento transgressivo de dunas eólicas (10 a 38 
m/ano) de idade estimada inferior a 1000 anos como possível reflexo de uma elevação de NRM.
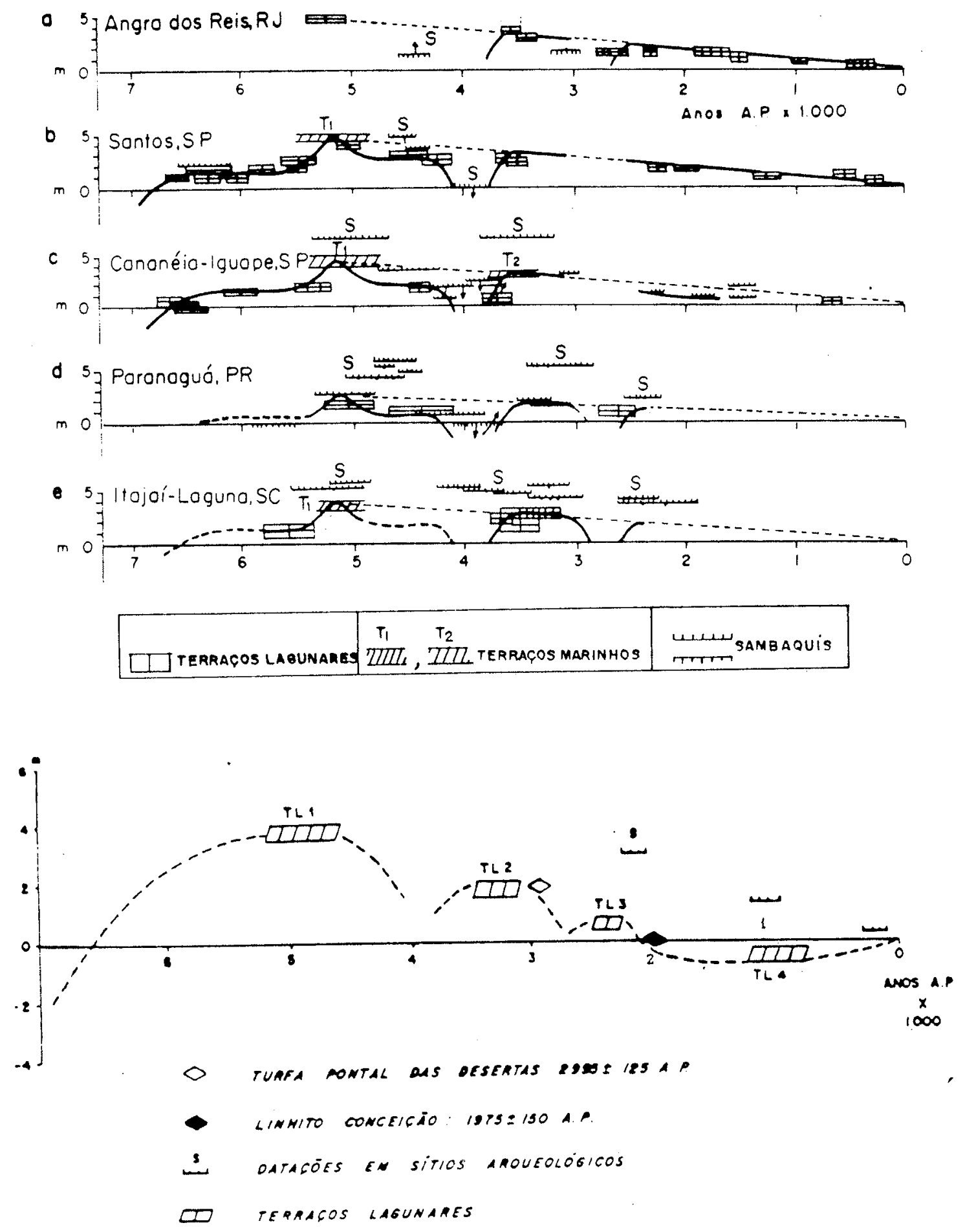

Figuras 3.4 e 3.5. Curvas de variação do NRM durante os últimos 7 mil anos.

3.4. Em diferentes setores da costa sudeste do Brasil, segundo Suguio et al.(1985 apud Suguio \& Martin 1987). A curva de Itajai-Laguna é estendida por Martin et al.(1988b) a todo litoral catarinense.

3.5. Na costa do Rio Grande do Sul, segundo Tomazelli \& Villwock (1989). 
Cabe reiterar que nem a curva inferida por Martin et al. (1988b) para Santa Catarina nem o esboço de Tomazelli \& Villwock (1989) para o Rio Grande do Sul baseam-se em dados de paleoniveis seguros, comprovados por datação de amostras de suas respectivas regiōes, no que se refere aos últimos 2 mil anos. Os dados disponiveis mais próximos são duas dataçōes realizadas por Angulo (1992) no sul do Paraná e norte de Santa Catarina (praia de Armação), as quais são mais compativeis com o declinio suave de NRM extrapolado por Martin et al. (1998b) para o setor catarinense. Avaliar qual padrão de variação de NRM melhor se adapta à área entre Jaguaruna e Imbituba requer um exame de consistência e de extensão para norte de cada uma das quatro evidências citadas de ascensão recente de NRM no Rio Grande do Sul, conforme segue: (1) não se encontraram, na área aqui estudada, sinais conclusivos de tendência para recuo ou avanço da linha de costa marinha, seja no campo seja em aerofotografias; em relação à turfa em erosão na praia, datada por Tomazelli \& Villwock (1989), cabe ressalvar que sedimentos turfosos não são indicadores altimétricos confiáveis de paleonivel marinho, pois depósitos deste tipo podem formar-se tanto abaixo como acima do nivel do mar; além disto, por sua grande porosidade, são sujeitos a rápida compactação e decréscimo na altitude original (Greensmith \& Tucker 1986); o fato destes depósitos, de origem continental, encontrarem-se em erosão nas praias marinhas atuais näo representa necessariamente uma evidência de elevação de NRM, pois pode resultar de mudanças na hidrodinâmica costeira; mesmo que se admita que esta erosão resulte de uma tendência recente de elevação de NRM, não há dados que permitam interpretá-la como uma elevação em escala de tempo milenar; (2) o mesmo pode ser estendido a virtual erosão ao longo de margens lagunares; (3) não se dispōe de informações detalhadas sobre a morfobatimetria lagunar na região de Jaguaruna-Imbituba; bancos submersos marginais observados em fotografias aéreas não apresentam qualquer feição que indique seu caráter virtual de antigos terraços abrasivos; mesmo que isto pudesse ser admitido a exemplo do Rio Grande do Sul segundo Tomazelli \& Villwock (1989), tais terraços de abrasão poderiam pertencer a outros NRM mais baixos que o atual previamente reconhecidos na costa brasileira, como o de 2800 A.P., por exemplo, ou terem origem subatual (i.e. últimas décadas a poucos séculos); (4) dunas em transgressão atual, com taxas de migração próximas às medidas por Tomazelli (1990) no litoral gaúcho, são documentadas neste trabalho; mesmo tipo de comportamento é observado em outras áreas costeiras cujo NRM nos últimos milênios supõe-se em declínio, como o Nordeste do Brasil, o Japão (Endo 1986) e as costas sudoeste e sudeste da Austrália (Pye 1983b; Belperio et al. 1984; Short 1988; Semeniuk \& Semeniuk 1991); o fenômeno da transgressão dunar não pode ser utilizado, portanto, como um indício de transgressão marinha em escala milenar.

Deste modo, a curva proposta por Villwock \& Tomazelli (1989) não possui evidências conclusivas, fato já reconhecido pelos próprios autores. Os indicios de ascensão recente de NRM por eles apresentados podem em parte ser consistentes, porém não são suficientes para se atribuir a esta ascensão escala de tempo milenar. Apesar de não se dispor de contra-evidências que permitam descartar esta última hipótese em definitivo, considera-se mais coerente adotar para a região em estudo o padrão de variação de NRM, inferidora partir de dados mais seguros, para os estados de São Paulo (Suguio \& Martin 1978) e Paraná (Angulo 1992). 


\subsubsection{Nivel relativo do mar e evolução da sedimentação quaternária}

Esquemas evolutivos para planicies costeiras quaternárias no litoral sul do Brasil foram apresentados por Villwock (1984) e Villwock et al. (1986), referindo-se especificamente à costa gaúcha, e por Suguio \& Martin (1987) e Martin et al. (1988a), propondo um modelo genérico para toda costa sul-sudeste brasileira baseado em trabalhos anteriores, incluídos os dois primeiros.

Villwock et al. (1986) postularam a progradação da planície costeira gaúcha através da justaposição lateral de quatro "sistemas laguna-barreira" vinculados a flutuações de NRM (figura 3.6). O sistema laguna-barreira 1 é representado por areias eólicas muito pedogeneizadas, ancoradas em encostas cristalinas, preservadas em faixa SW-NE à retaguarda das lagunas Guaíba e Gravataí. O sistema laguna-barreira II corresponde a areias eólicas e marinhas, preservadas localmente na parte interna da barreira geográfica que isola hoje as planicies lagunares de Patos e Mirim. O sistema III consiste em areias marinhas e eólicas em seqüência vertical progradacional, associadas à regressão que sucedeu o máximo de NRM de cerca de $8 \mathrm{~m}$ acima do atual, ocorrido em 120 mil A.P.. A laguna-barreira IV é formada por cordões praiais e campos de dunas depositados durante e após a transgressão no Holoceno, que isolou uma série de pequenas lagunas existentes ainda hoje.

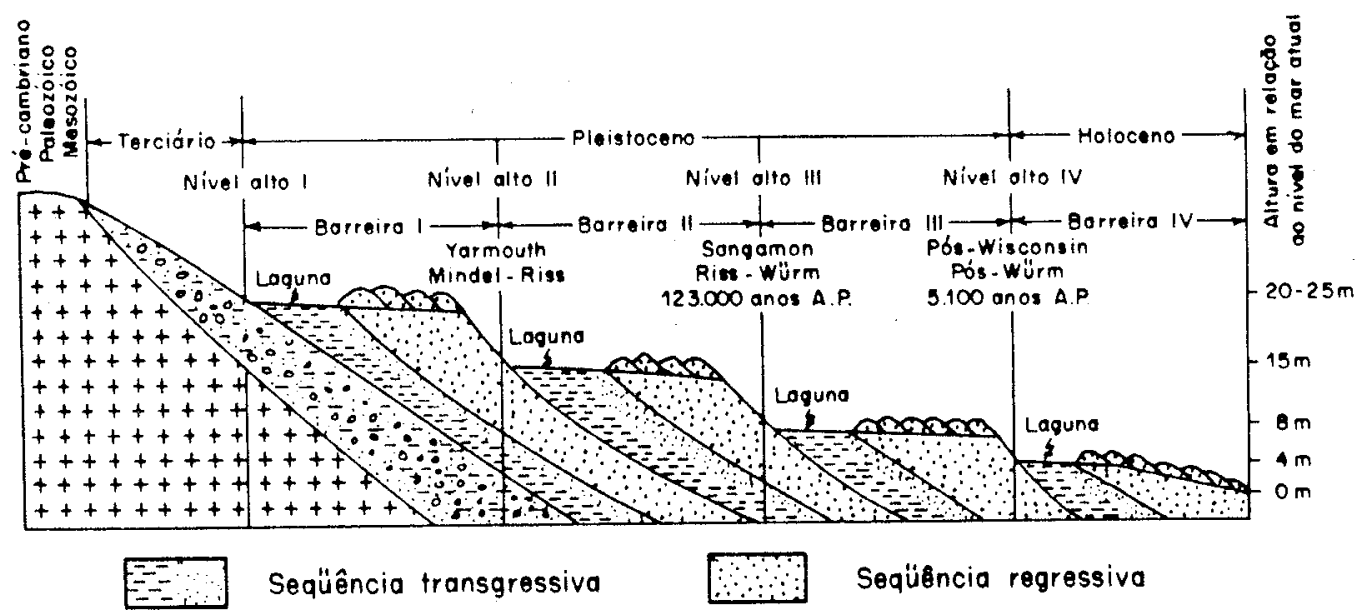

Figura 3.6. Perfil esquemático idealizado da costa do Rio Grande do Sul, apresentando justaposiçăo de quatro sistemas laguna-barreira. Modificado de Villwock et al.(1986) por Martin et al.(1988a).

No modelo evolutivo de Martin et al. (1988a) para o SulSudeste brasileiro, sete estágios são reconhecidos (figura 3.7). No estágio I, "máximo da regressão pliocênica", o baixo nivel de base e o clima semi-árido favorecem a deposição de leques aluviais e deltaicos. O estágio II, "transgressão e regressão do Pleistoceno inferior", estaria representado por sedimentos eólicos da barreira I de Villwock et al. (1986). O estágio III, no Pleistoceno médio, corresponderia à formação dos terraços de cerca de $13 \mathrm{~m}$ de altitude, correlacionáveis à barreira II. No estágio 
IV, "transgressão e regressão do Pleistoceno superior", teriam-se formado os terraços de até $10 \mathrm{~m}$ de altitude, bem preservados ao longo de todo o litoral brasileiro; esses depósitos correlacionam-se a Formação Cananéia (Petri \& Suguio 1973; Suguio \& Martin 1978) e à barreira III. Os estágios V a VII, no Holoceno, são documentados por indicadores de paleoniveis do mar datados por carbono 14 (item anterior). No máximo NRM holocênico $(V)$, baixos cursos fluviais foram afogados e em seguida isolados do mar aberto por barreiras. A formação de barreiras e lagunas pode ter-se iniciado por volta de 7 mil anos A.P., antes mesmo do máximo transgressivo, como sugerem algumas datações. A formação de deltas lagunares teria-se iniciado após este máximo, na fase VI, podendo continuar até dias atuais, como no caso do rio Tubarão. No estágio VII, os autores descrevem a "construção de terraços marinhos a partir da ilha-barreira original, resultando na progradação da linha costeira".

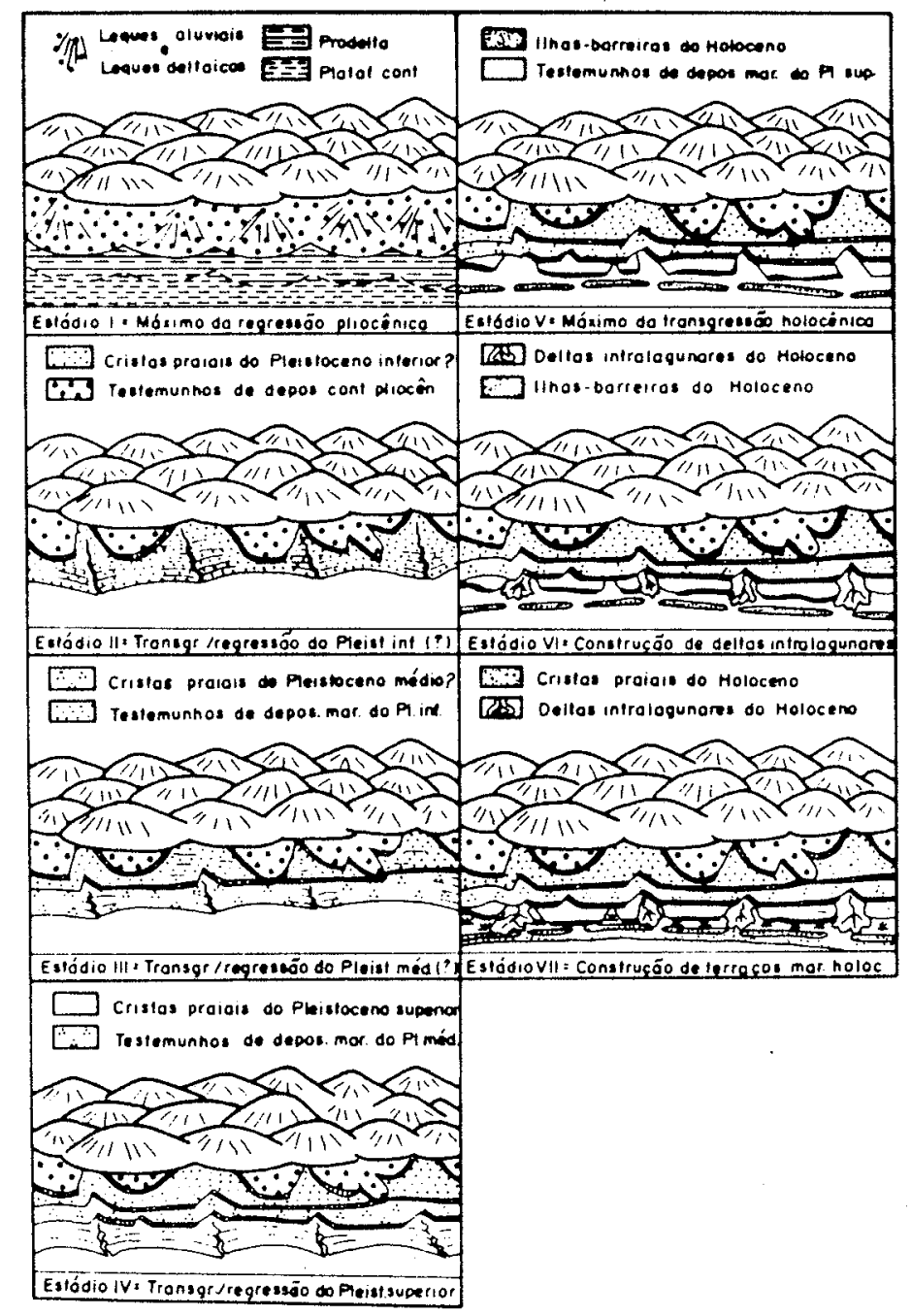

Figura 3.7. Esquema de evolução paleogeografica costeira das regiōes Sudeste e Sul do Brasil, modificado de Suguio et al.(1985) e Villwock et al.(1986) por Suguio \& Martin (1987).

Sedimentos correlativos aos estágios IV a VI (barreiras III é IV) são amplamente reconhecidos e mapeados no litoral catarinense (Martin et al. 1988b). 
O estágio III (barreira II) tem seu registro limitado até agora aos terraços altos de Itapema (Martin et al. 1988a), $120 \mathrm{~km}$ a norte de Imbituba, já associados originalmente por Bigarella \& Becker (1975d) ao penúltimo evento interglacial (Yarmouth ou RissMindel). A dificuldade de reconhecimento de terraços altos correlativos a barreira II torna-se acentuada em áreas costeiras com retrabalhamento eólico generalizado, como o setor que vai de Garopaba (SC) a Tramandaí (RS), onde as altitudes originais de deposição marinha encontram-se modificadas pela ação superimposta do vento. Autores que descreveram a detalhe a cobertura sedimentar de áreas compreendidas por este setor (Horn 1988; Tomazelli 1990) não identificaram a presença da barreira II. A barreira I também não foi registrada até agora, nem neste setor, nem em qualquer outra região da costa sul-sudeste brasileira. É provável que sua única ocorrência conhecida, restrita a área de Lombas (RS), resulte de um conjunto muito específico de condições favoráveis de deposição e preservação.

\subsection{SUPRIMENTOS DE MATERIA E ENERGIA}

\subsubsection{ROCHAS-FONTES: ESTRATIGRAFIA E PETROLOGIA}

\subsubsection{Embasamento pré-cenozóico}

O embasamento pré-cenozóico aflorante no Estado de Santa Catarina abrange o Escudo Atlântico e a Bacia do Paraná (Radambrasil-IBGE 1986a). De acordo com o modelo geotectônico regional de Fragoso Cesar (1991), o Escudo Atlântico é representado em todo o litoral centro-sul do Estado pelo Cinturäo Dom Feliciano (Fragoso Cesar 1980), um cinturão móvel brasiliano relacionado com oceano marginal a leste do Continente Rio de la Plata (figura 3.8). Este cinturão apresenta compartimentação interna, através de zonas de cisalhamento sinistrais direcionadas entre NE e N, em duas unidades principais: o Batólito Pelotas (Fragoso Cesar et al. 1986 apud Fragoso Cesar 1991), a sul do Lineamento Major Gercino (próximo a Florianópolis), e a Faixa de Dobramentos Tijucas (Hasui et al. 1975), a norte.

O Batólito Pelotas é também conhecido como Cráton Dom Feliciano (Picada 1971; Issler 1982, 1983; Radambrasil-IBGE 1986a ) ou Maciço Mediano de Pelotas (Hasui et al. 1975). Trata-se, segundo Fragoso Cesar (1991), de cinturão multi-intrusivo cambriano ( 550 M.a., milhões de anos), relacionado a injecção de centenas de plútons subalcalinos sin a tardi-cinemáticos ao cisalhamento NE. O batólito inclui ainda tetos pendentes do substrato petrotectônico proterozóico e rochas vulcânicas ácidas, os quais ocorrem em intima associação com as intrusões (Radambrasil-IBGE 1986a; Fragoso Cesar 1991). O substrato denominado Grupo Taboleiro (Albuquerque \& Horbach 1972; Silva 1987), Complexo Metamórfico Migmatilico (Trainini et al. 1978), Grupo Canguçu (Radambrasil-IBGE 1986a) ou Complexo Granítico-Gnáissico Pinheiro Machado (Fragoso Cesar 1991), constitui-se de rochas migmatizadas e deformadas de fácies anfibolito (Orlandi Filho \& Silva 1979). Predominam os metatexitos de paleossoma metaigneo. No Estado do Rio Grande do Sul, Fragoso Cesar (1991) registrou a presença de quatro litotipos predominantes: granitóides porfiríticos, ortognaisses, migmatitos e enclaves máficos, todos contendo 
hornblenda e/ou biotita como minerais escuros principais; outros acessórios transparentes, registrados em menores quantidades (sempre inferiores a $5 \%$ ), foram : titanita, apatita, alanita, zircão e diopsídio. Mineralogia semelhante, mais a presença eventual de rutilo e epídoto, foram registrados por Silva \& Dias 1981 (apud Silva 1987) no Complexo Taboleiro, de Santa Catarina. Ocorrem ainda, no substrato proterozóico, xenólitos de paragnaisses e lentes deformadas de leucogranitos, estes ricos em muscovita, biotita e turmalina, e tendo apatita, zircão e granada como acessórios mais importantes (Fragoso Cesar 1991).

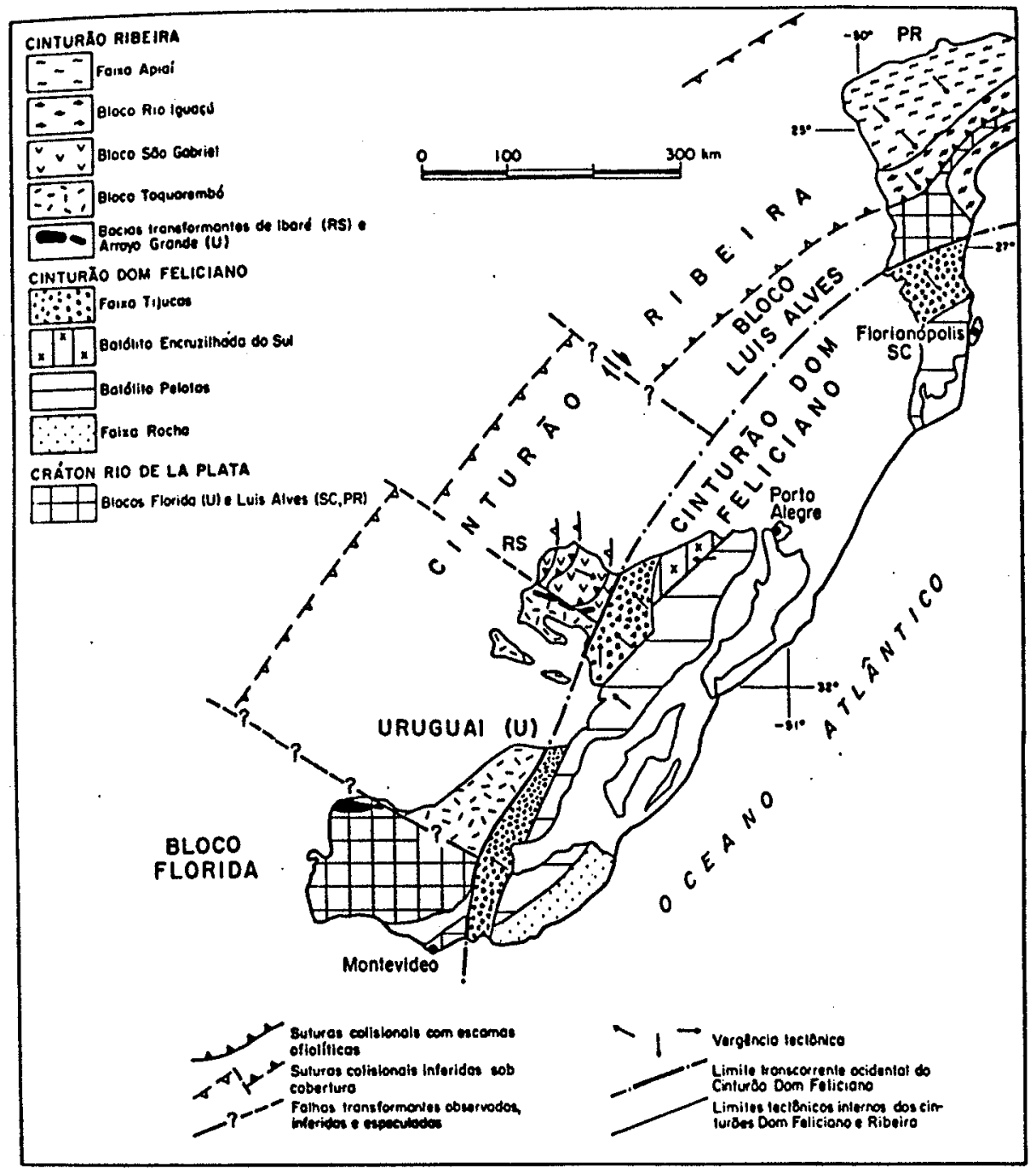

Figura 3.8. Estruturaçăo brasiliana do Sul do Brasil segundo Fragoso Cesar (1991).

As rochas filoneanas e extrusivas ácidas correspondem à Formação Cambirella e compreendem aplitos, riólitos e microgranitos, os quais cortam ou recobrem o substrato proterozóico ou as próprias intrusōes graníticas (Basei 1985; Radambrasil-IBGE 1986a). A mineralogia inclui biotita, hornblenda, titanita e apatita (Basei 1985). Nas proximidades da área em estudo, a principal ocorrência da Formação Cambirella encontra-se na região de Paulo Lopes, drenada pelas bacias hidrográficas dos rios da Madre e d'Una. Diques de riólito foram identificados também 
na folha de Laguna por Castro \& Castro (1969a), especialmente no flanco oeste do morro Ribeirão Pequeno, à margem sudoeste da laguna Santo António (bacia do rio Tubarão).

A unidade plutônica do Batólito Pelotas é denominada por Fragoso Cesar (1991) Suite Granítica Dom Feliciano, referida em trabalhos anteriores como Complexo Granítico Pedras Grandes (Castro \& Castro 1969b; Teixeira 1969; Brito Neves et al. 1979), Complexo Granítico Dom Feliciano (Picada 1971), Grupo Pedras Grandes (Albuquerque \& Horbach 1972; Mônaco et al. 1974a, b), Suite Intrusiva Pedras Grandes (Trainini et al. 1978; Silva 1982, 1987) e Suite Intrusiva Taboleiro (Radambras!l-IBGE 1986a). Consiste em plútons rasos de biotita granitos, quartzo monzonitos e quartzo dioritos, localmente milonitizados (Radambrasil-IBGE 1986a; Fragoso Cesar 1991). No Rio Grande do Sul, Fragoso Cesar (1991) registrou a presença de biotita, titanita, apatita e zircão dentre seus principais minerais acessórios transparentes; em Santa Catarina, Silva (1987) encontrou, além desses minerais, rutilo, fluorita, epidoto e granada. Com exceção de biotita, todos os minerais citados ocorrem em quantidade traço. Menciona-se ainda a existência de corpos gábricos microgranulares, em geometria estratiforme ou lenticular, preenchendo fraturas da encaixante nos arredores dos plútons graníticos e por estes afetados na forma de mega-enclaves. Essas rochas contêm titano-augita, anfibóliós, olivina, micas e epidoto (Fragoso Cesar 1991).

Estruturas de fluxo igneo e de milonitização conferem aos granitos da Suite Dom Feliciano aspectos similares aos migmatitos e gnaisses do Complexo Pinheiro Machado. De acordo com Fragoso Cesar (1991), a proporção dos granitos intrusivos dentro do Batólito Pelotas encontra-se, por esta razão, subestimada em alguns dos mapas regionais anteriores. Em relação à costa centro-sul de Santa Catarina, esta afirmativa aplica-se possivelmente aos mapas de Horbach \& Marimon (1980) e Radambrasil-IBGE (1986a), onde maior parte da área drenada pela bacia hidrográfica do rio Tubarão é atribuida ao substrato proterozóico correlacionável ao Complexo Pinheiro Machado. Mesma região é mapeada por outros autores (Mônaco et al. 1974a,b; Morgental \& Kirchner 1983) como granitos intrusivos correspondentes à Suite Dom Feliciano. Deste modo, o Complexo Pinheiro Machado ocorre por consenso apenas a norte e a oeste de Águas Mornas, área drenada predominantemente pela bacia do rio Itajaí. A suite intrusiva tem sido mapeada por extensões muito discrepantes, desde toda a serra do Taboleiro (Mônaco et al. $1974 a, b)$ até áreas restritas a pontōes costeiros e aos "stocks" de Morro da Fumaça, Jaguaruna, Imaruí, Rio Chicão e Palmeira do Meio (Radambrasil-IBGE 1986a). No "stock" de Imaruí, em seus afloramentos da região de Imbituba, descrevem-se granitos com xenólitos metassedimentares ("Metarcósio Pedreiras" de Ferreira 1968) e de rochas granitóides. Segundo Castro \& Castro (1969a,b) o granito que constituiu os xenólitos é o mesmo que ocorre a noroeste da laguna Mirim ("Granito Balsinha"), onde se supõe portanto a presença de substrato proterozóico, como admitido nos mapas de Horbach \& Marimon (1980) e Radambrasil-IBGE (1986 a). Xenólitos em grande abundância puderam ser observados ainda nos granitos do Costão do llhote, a sul de Laguna.

A Faixa Tijucas é também referida na literatura como Faixa do Xisto Central (Jost 1981 apud Issler 1983) ou Faixa Arco-Fossa Tijucas (Issler 1982, 1983; Radambrasil-IBGE 1986a). Issler (1983), utilizando três terminologias petrotectônicas diferentes, classifica-a como "faixa metamórfica de baixa pressão", 
"faixa orogênica do tipo herciniana" e "faixa de colisão". Considera esta última classificação mais apropriada e atribui a faixa ao encontro, no Evento Brasiliano, entre as "placas continentais Rio de La Plata e Dom Feliciano". Para Fragoso Cesar (1991), que admite o modelo de dois cinturōes móveis justapostos de cada lado do Cráton Rio de La Plata, a Faixa Tijucas é a componente litoestrutural mais interior (ocidental) de um grande cinturão móvel a leste do cráton, o Cinturão Dom Feliciano (figura 3.8). Ela compreende, segundo mesmo autor, napes vertentes para NW, escamas de embasamento pré-brasiliano e uma antefossa preenchida por "fliysches" e molassas posteriores ao napismo, a qual inclui o Grupo Brusque da Bacia do Itajaí. O plutonismo associado abrange intrusões graniticas sin a tardi-cinemáticas em relação ao avanço das napes, compondo, segundo o Radambrasil-IBGE (1986a), as suítes Guabiruba, Valsungana e Catinga. As suites Guabiruba e Valsungana são as unidades litotectônicas dominantes na parte sul da faixa. Geotectônica e petrologicamente correlatas, diferem em essência apenas quanto a idade pouco mais antiga e ao caráter mais calco-alcalino da segunda (Wernick \& Penalva 1978; Basei 1985; Radambrasil-IBGE 1986a). São considerados plútons circunscritos tardi a póstectônicos do Proterozóico superior (Wernick \& Penalva 1978; Morgental \& Kirchner 1983). Petrograficamente, descrevem-se ortoclásio granitóides leucocráticos, com destaque para a presença de granitos a duas micas, monzonitos, dioritos e granodioritos (Trainini et al. 1978); Wernick \& Penalva 1978; Basei 1985). De acordo com análises apresentadas por Silva (1987), a mineralogia de acessórios é muito similar a da Suite Pedras Grandes. Não há consenso sobre a diferenciação entre as suites Guabiruba e Valsungana em mapa. A maioria dos autores, porém, admite a ocorrência de pelo menos uma delas na região entre Anitapólis, a oeste, Paulo Lopes, a leste, Santa Rosa de Lima, a sul, e Águas Mornas, a norte (Horbach \& Marimon 1980; Morgental \& Kirchner 1983; Radambrasil-IBGE 1986a). Esta região abrange o extremo norte da bacia hidrográfica do rio Tubarão, e o extremo sul da bacia do rio Tijucas, além das porções significativas das pequenas bacias dos rios Cubatão e da Madre (figura 3.10).

A Bacia do Paraná, na região sudeste de Santa Catarina, está representada por unidades litoestratigráficas que vão do Permo-Carbonífero ao JuroCretáceo (Itararé, Rio Bonito, Palermo, Irati, Serra Alta, Teresina, Botucatu e Serra Geral). Sua borda leste de afloramentos, no trecho entre Urussanga e Rancho Queimado, constituída em essência por sedimentos das unidades Itararé e Palermo, é drenada pela captação superior ocidental da bacia hidrográfica do rio Tubarão. A sul de Urussanga, as rochas de diversas unidades da bacia do Paraná passam a ser drenadas pelas cabeceiras da bacia do rio Araranguá (Mônaco et al. 1974a). Sedimentos do Grupo Itararé, Formação Rio do Sul, ocorrem ainda em área restrita ao longo do vale superior do rio Aratingaúba, a noroeste da laguna Mirim (Horbach \& Marimon 1980; Radambrasil-IBGE 1986a).

Intrusões de rocha básica e intermediária, vinculados à Formação Serra Geral, ocorrem de modo marcante entre Laguna e Florianópolis, formando enxames de diques orientados segundo N2OE e N3OE (Castro \& Castro 1969a; Morgental \& Kirchner 1983). Diques de orientação predominante subparalela à costa podem ser vistos no flanco norte do cabo de Santa Marta Grande, na ponta de Ji e na orla rochosa de Imbituba entre as pontas do Cravo e da Careca do Velho. Em Santa Marta Grande e no Ji, os diques sofrem erosão preferencial e controlam os 
cursos de água locais. Este fato é um exemplo de seu potencial como rocha-fonte para os sedimentos costeiros, apesar de sua pequena expressão em área.

\subsubsection{Cobertura cenozóica pré-quaternária}

Depósitos continentais cenozóicos no limite interior das planicies costeiras brasileiras permanecem relativamente pouco estudados. A falta de horizontes-guia tem levado à proposição de vários nomes locais para unidades litoestratigráficas cuja correlação mútua é estabelecida muitas vezes com base de dados precária. Outro problema freqüente no estudo destes depósitos é a interpretação de um ambiente deposicional semi-árido argumentada por feições que podem possuir, a rigor, origem nos gradientes de relevo e portanto no contexto tectônico, e não na condição paleoclimática. Entre estas feições podem-se mencionar a presença marcante de depósitos de fluxos gravitacionais e enxurradas e a baixa maturidade textural e mineralógica. Tal é o caso, por exemplo, da interpretação paleoclimática clássica para a Formação Alexandra, no Paraná (Bigarella et al. 1956; Bigarella \& Salamuni 1961). Análises mineralógicas em sedimentos da região de Matinhos (PR), aflorantes no local em que foi definida a Formação Alexandra, indicaram quantidades substanciais de feldspato euedral de dimensões milimétricas; na mesma seção, ocorrem horizontes de turfa cuja análise palinológica (Lima \& Angulo 1990) permitiu reconhecer um clima mais úmido e uma idade mais antiga (Mioceno inferior) do que se supunha na literatura clássica. Conclusão paleoclimática semelhante obteve Mello (1990) em relação à Formação Pariqüera-Açu por ele redefinida, no baixo vale do rio Ribeira de Iguape (SP), o que permite supor uma provável relação com a Formação Alexandra (Mello 1990; Angulo 1992). Estes dois autores demonstraram ainda que parte dos sedimentos atribuídos anteriormente às formações Pariqüera-Açu e Alexandra pertence a unidades ora mais antigas ora mais novas.

No Estado de Santa Catarina, ainda não se dispõe de uma revisão da estratigrafia dos depósitos continentais cenozóicos nos moldes das apresentadas por Mello (1990) em São Paulo e por Angulo (1992) no Paraná. Não é objetivo deste trabalho realizá-la. Cabe porém uma análise crítica da bibliografia disponivel, embasada pela experiência daqueles dois autores nos estados vizinhos. Três unidades continentais cenozóicas foram definidas no Leste catarinense: a Formação lquererim (Bigarella et al. 1961), a Seqüência Canhanduva (Bigarella \& Salamuni 1961) e as Camadas Cachoeira (Bigarella et al. 1965). Bigarella \& Becker (1975c) propuseram ainda o termo Formação Itaipava para designar o conjunto indiferenciado dos sedimentos continentais terciários e pleistocênicos do rio ltajaíMirim. A Formação lquererim ocorre sob a forma de depósitos rudáceos polimíticos com "matriz de natureza coluvionar", aflorantes na região de Garuva, próxima à fronteira com o Paraná. A Seqüência Canhanduva consiste basicamente em depósitos rudáceos polimíticos com clastos angulosos e estratificação incipiente, atribuídos a fluxo denso em clima árido, repousando sobre paraconglomerados de "matriz coluvionar", considerados de clima úmido. Esta seqüência aflora em corte da rodovia BR-101 localizado entre Camboriú e Itajaí. As Camadas Cachoeira são descritas como uma alternância irregular de argilas e areias arcoseanas, que ocorre preenchendo depressão alongada N-S do embasamento cristalino, possivelmente de origem tectônica, situada a sul de Tijucas. Foram interpretadas originalmente como 
sedimentos de "bajada" desenvolvida sob condições de clima semi-árido (Bigarella et al. 1965).

Martin et al. (1986b) mapeiam as áreas de afloramento das unidades lquererim, Canhanduva e Cachoeira como pliocênicas. De acordo com os autores, as três unidades possuem provável correlação com o Grupo Barreiras, no Nordeste, e com as formaçōes Pariqüera-Açu (SP), Alexandra (PR) e Graxaim (RS) no Sul-Sudeste do pais. Entretanto, a análise geomorfológica de pediplanos e pedimentos aplicada por Bigarella (1975 b) a unidades continentais do Sul do Brasil (figura 3.9) não sustenta essa hipótese. Segundo esta análise, a Formação lquererim correlaciona-se ao desenvolvimento dos pedimentos pleistocênicos $P_{2}$ e $P_{1}$ (mais antigo e mais novo, respectivamente), enquanto a Seqüencia Canhanduva associa-se a $P_{2}$. As Camadas Cachoeira, interpretadas em sua proposição original como contemporâneas a $P_{1}$, foram consideradas por Bigarella \& Becker (1975c) como mais antigas, correlacionadas com o pediplano $\mathrm{Pd}_{1}$ (Plioceno superior - Pleistoceno inferior). Este último estaria ligado também à deposição da Formação Alexandra.

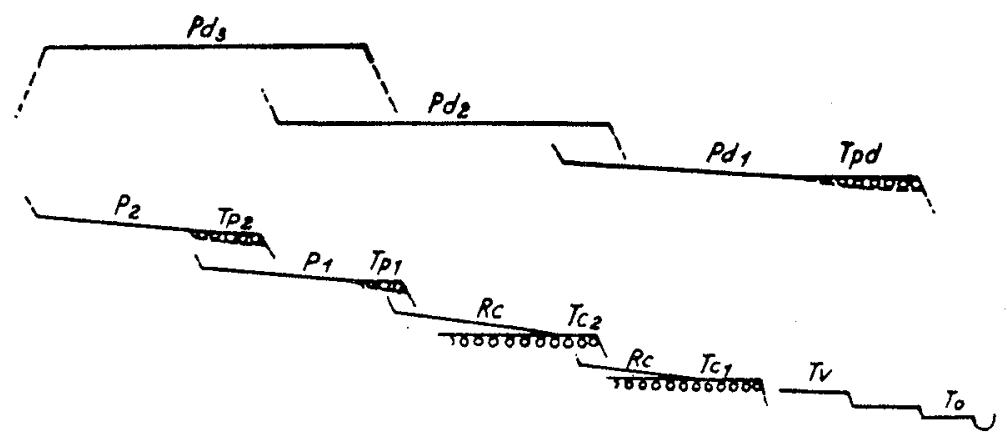

Figura 3.9. Esquema da relaçăo espacial entre "supenficies de agradaçăo e degradaçào" continentais do Brasil, segundo Bigarella et al.(1965). $P d=$ pediplano; $P=$ pedimento; $T p=$ terraço correspondente a pedimento; $R c=$ rampa de colúvio; $T C=$ baixo terraço com cascalho; $T V=$ terraço de inundaçào fluvial; $T_{0}=$ planície de inundaçåo fluvial atual.

Embora as idades atribuidas por Bigarella \& Becker (1975c) às superfícies aplainadas seja tentativa e sujeita a erros, como demonstrado por avaliações polinológicas na Formação Alexandra (Lima \& Angulo 1990), não há evidência de inconsistências nas correlações por ele traçadas. Deste modo, as unidades lquererim e Canhanduva seriam mais novas que as Camadas Cachoeira e que a Formação Alexandra, ou seja, posteriores ao Mioceno inferior. Angulo (1992) considera a boa preservação da morfologia deposicional original dos depósitos da Formação lquererim, sob a forma de leques aluviais coalescentes, como evidência de sua modernidade em relação à Formação Alexandra. Atribui-lhe deste modo, em caráter tentativo, idade plio-pleistocênica.

$\mathrm{Na}$ região entre Jaguaruna e Imbituba, Martin et al. (1988b) mapeiam depósitos continentais por eles atribuidos ao Plioceno em cinco áreas restritas (1 a $8 \mathrm{Km}^{2}$ ) de afloramentos: junto ao morro Grande, a sudoeste de Jaguaruna; em dois testemunhos a oeste de morro Congonhas; em Vila Capivari, cidade de Tubarão; e em São Tiago, próximo a margem sudoeste da laguna Imaruí. Observações expeditas em alguns afloramentos nestas áreas indicaram o predominio de areias granulosas mal selecionadas a teores variáveis de argila, com aspecto maciço, e elevado grau de consolidação. Não há sinais de preservação da morfologia 
deposicional no campo ou em aerofotografias. Com base nestas carcterísticas, considerou-se possivel a correlação destes depósitos com as Camadas Cachoeira e a Formação Alexandra, o que inviabiliza as interpretações de idade e paleoclima (semiárido) admitidas por Martin et al. (1988b). Na falta de estudos mais detalhados, a idade destes depósitos no mapa geológico deste trabalho foi referida de modo genérico e tentativo como terciária.

\subsubsection{Cobertura quaternária da plataforma continental}

Não se dispôe de informações precisas sobre a sedimentologia de depósitos quaternários na plataforma continental adjacente à costa centro-sul de Santa Catarina. Estudos de reconhecimento no âmbito do Projeto Remac indicam que a maior particularidade deste setor da plataforma brasileira é a ausência anômala dos depósitos de lama de plataforma externa, os quais se estendem a sul além do paralelo de Chuí, RS, e a norte até a coordenada de Iguape, SP (Kowsmann et al. 1977; Zembruscki 1979). De acordo com Kowsmann \& Costa (1979), os sedimentos da plataforma interna na região que abrange a costa centro-sul catarinense são areias subarcosianas a subortoquartziticas, bem arredondadas e bem selecionadas. A assembléia de minerais pesados é caracterizada pela presença principal de cianita, estaurolita e andaluzita, atribuidas pelos autores a rochas metamórficas da Faixa de Dobramentos Ribeira, e augita, relacionada a rochas précambrianas de filiação ignea básica e a intrusões de diabásio mesozóicas. A influência destas últimas aumenta a sul do cabo de Santa Marta Grande, denunciada por uma elevação nos teores de augita que atinge seu máximo na plataforma adjacente a Torres (RS).

\subsubsection{PADRÕES HIDRO E AERODINÂMICOS ATUAIS}

\subsubsection{Hidrografia}

\subsubsection{Lagoas}

O termo "lagoas" é aqui empregado em sua acepção genérica, independente de dimensões e de grau de afastamento ou conexão com o mar, como adotado por Radambrasil-IBGE (1986c), Tomazelli (1990) e mapas topográficos da região. Dentre as lagoas, adota-se uma diferencição entre lagunas e lagos. Lagunas são definidas conforme Fisher (1983) como corpos aquosos alongados paralelamente á costa, apresentando comunicação com mar aberto através de uma entrada ou desembocadura ("inlet"); incluem-se nesta última definição as lagunas interligadas com padrão "em oito" (figura 3.12), como o complexo Santo António - Imaruí - Mirim. São considerados lagos os corpos aquosos sem ligação direta com o mar via "inlet". Alguns dos lagos da região integraram complexos de lagunas interligadas durante niveis do mar mais altos que o atual; tais são os casos dos lagos Laranjal, Figueirinha e Gregório Bento, na parte sul da área estudada, os quais podem assim ser classificados como lagos paleolagunares. Em nivel de análise faciológica, eles representam fácies lacustres atuais dentro de um sistema lagunar holocênico (item 
5.3.2.2.2). A salinidade provavelmente não é um critério adequado para distinguir-se entre lagos e lagunas, pois alguns corpos lacustres podem ter sua salinidade aumentada por influência de canais intermitentes de conexão com lagunas, pequenos canais de maré ou mesmo, possivelmente, do lençol freático.

Pelo menos 25 lagoas são reconhecidas na área compreendida entre Jaguaruna e Imbituba (tabela 3.1). O complexo lagunar Santo António-Imaruí-Mirim, com $185 \mathrm{~km}^{2}$, é o maior de Santa Catarina e corresponde a mais de $50 \%$ de toda área coberta por lagoas costeiras no Estado.

Tabela 3.1

Localizacao taciologia e extensao de lagoas na planicje litoranea entre jaguaruna e lobituba

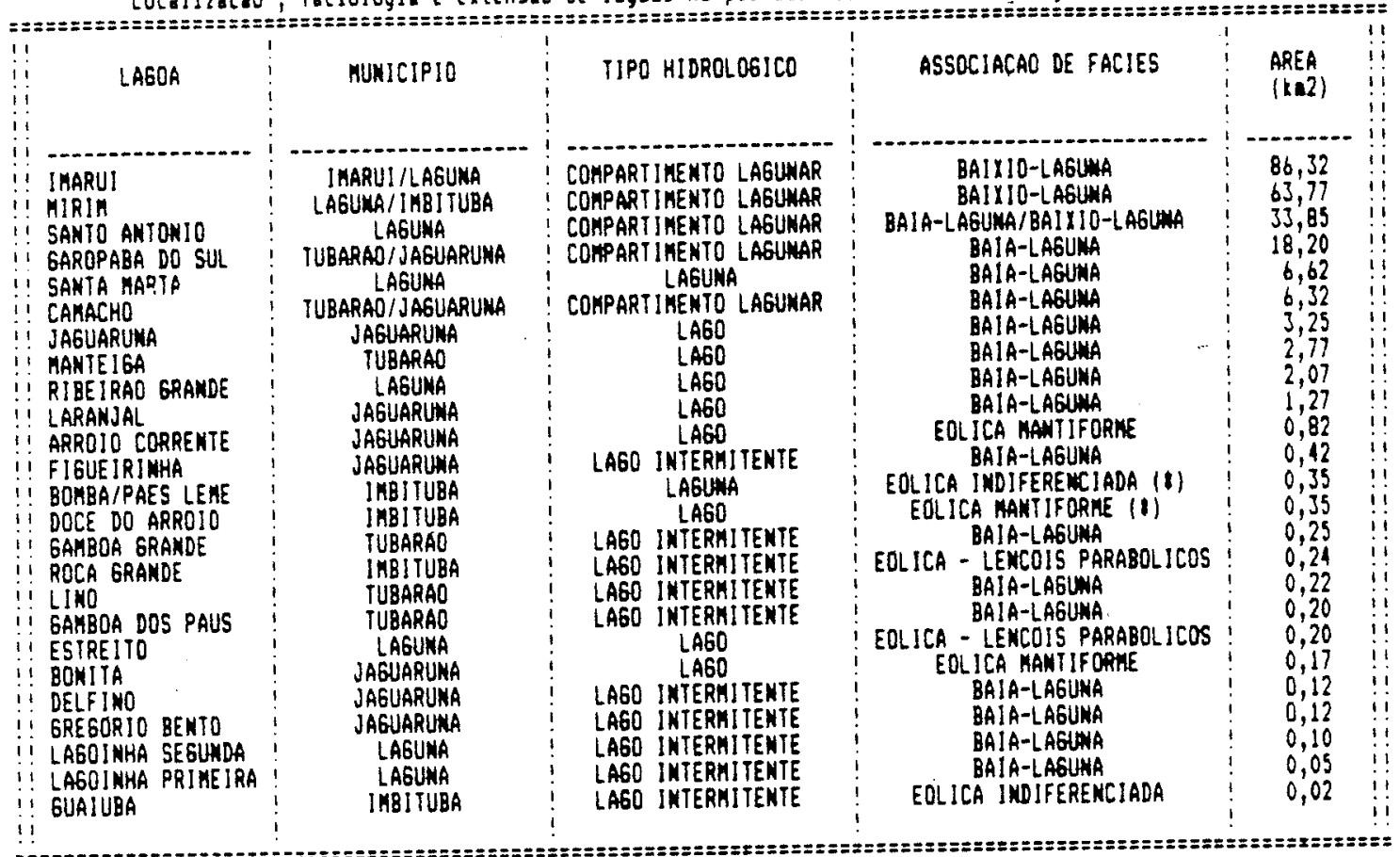

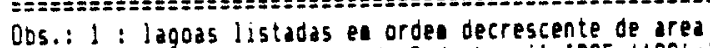

2 : dados codificados de Radabrasil-186E (1986c)

$3(1)$ : carater baixio-laguna ee escala de facies

\subsection{Rios}

A região costeira entre Jaguaruna e Imbituba recebe aporte fluvial direto através de duas bacias hidrográficas, a do rio Tubarão e a dos rios d'UnaAratingaúba. Considerando-se a possibilidade de aporte sedimentar indireto por correntes de deriva litorânea, a sedimentação costeira nesta área pode sofrer ainda influências das bacias hidrográficas vizinhas de Urussanga e da Madre (figura 3.10) Medidas hidrográficas dessas bacias apresentam-se resumidas na tabela 3.2.

A bacia do Tubarão é a segunda maior bacia fluvial da vertente atlântica de Santa Catarina. Estende-se entre Jaguaruna, Lauro Müller, São Bonifácio e Anitápolis e alimenta as lagunas de Garopaba do Sul, Camacho, Santa Marta e Santo António. Drena, em sua maior parte, a unidade geomorfológica serra do Taboleiro (Radambrasil-IBGE 1986b), caracterizada por vales fluviais ingremes e profundos com significativo controle estrutural, o qual se reflete na orientação geral NNE dos rios Capivari e Braço do Norte, afluentes da margem norte do rio Tubarão. A 
bacia do Tubarão avizinha-se a sul, pela bacia do Urussanga, coincidente com a depressão geomorfológica da zona carbonífera catarinense.

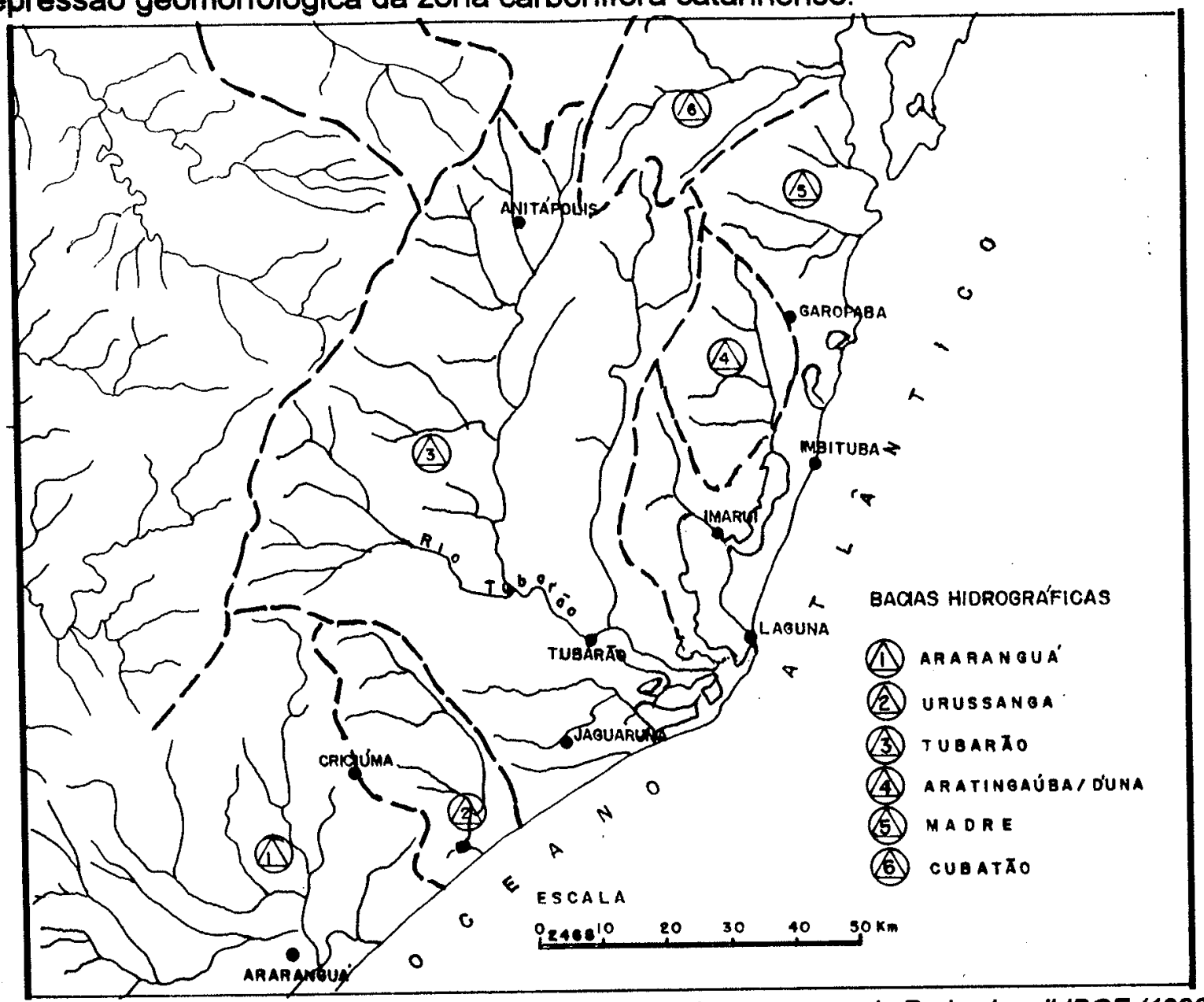

Figura 3.10. Bacias hidrográficas da costa centro-sul catarinense, segundo Radambrasil-IBGE (1986C).

Tabela 3.2

Bacias hidrograficas

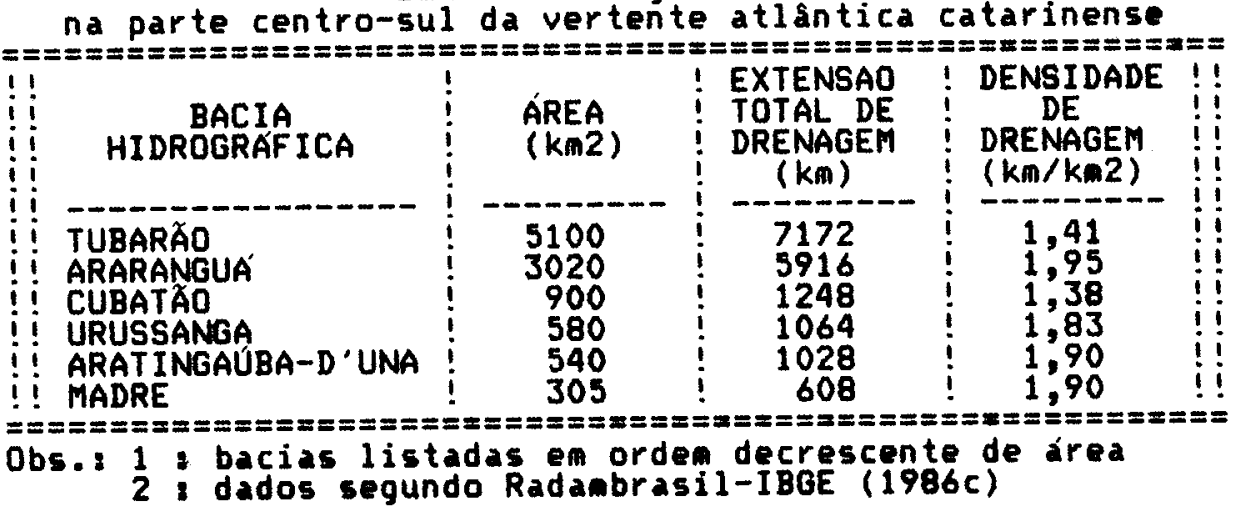

A bacia de Aratingaúba-d'Una alimenta as lagunas interligadas de Imaruí e Mirim respectivamente. Atravessa, a norte e a oeste destas lagunas, a porção mais externa da serra do Taboleiro entre as coordenadas de Laguna e Garopaba. Avizinha-se, a norte, pela pequena bacia hidrográfica do rio da Madre, que drena a região de Paulo Lopes. 


\subsubsection{Regime de ventos e de ondas}

\subsection{Introdução: conceitos básicos}

O regime de ventos pode ser definido como conjunto de características dinâmicas regionais, referentes a distribuição de energia eólica no tempo e no espaço, tais como direções de atuação e suas respectivas freqüências e velocidades (Goldsmith 1978; Fryberger 1979). O regime eólico em áreas costeiras determina o regime de ondas do mar e suas correntes induzidas de deriva litorânea, as quais controlam o aporte e a distribuição de sedimentos na costa. Possui portanto dupla função no desenvolvimento de dunas eólicas costeiras: age diretamente no transporte da areia seca incoesa disponivel e atua indiretamente no fornecimento desta mesma areia.

Em vista das relações entre ventos e ondas do mar, uma classificação comum para os dois agentes pode ser obtida da reunião da classificação usual de regimes eólicos (Goldsmith 1978; Fryberger 1979; Villwock 1987) com a classificação usual de regimes de ondas e deriva litorânea longitudinal (Jacobsen \& Schwartz 1981). O primeiro aspecto desta classificação comum é o que faz distinção entre o conceito de "prevalecência", referente às direções mais freqüentes de ondas ou ventos, e o de "predominância", para direções de maior intensidade. O segundo aspecto é o que diferencia entre o efeito sedimentar temporário ou sazonal, de curto prazo, e o efeito resultante ou residual, duradouro no tempo geológico, do regime eólico ou de ondas. O terceiro aspecto consiste no reconhecimento das escalas de atuação de ventos e ondas, distinguindo-se entre efeitos de energia alta e abrangência regional, ligados a tempestades, efeitos de energia normal e abrangência regional, com focos de geração distantes da costa, e efeitos de energia normal e abrangência local, originados na própria área costeira de atuação. O quarto aspecto da classificação comum para regimes eólicos e de ondas é a determinação vetorial do "fetch" ou distância de ação das ondas ou ventos, que indica a extensão de água ou sedimentos sobre a qual estes agentes podem teoricamente atuar, livres de obstáculos (definição modificada de Jacobsen \& Schwartz 1981).

O efeito sedimentar resultante, no caso das ondas, é na maioria das vezes relacionado ao rumo predominante de deriva litorânea longitudinal. Em contraste, no caso eólico, este efeito pode estar associado ao azimute prevalecerte, como ocorre no litoral de Rio Grande do Sul e Santa Catarina. Esta inversão de comportamentos entre regimes eólico e de ondas deve-se ao fato de que os ventos predominantes, mais fortes, são preferencialmente acompanhados de chuvas (item 3.1.1.1), o que impede a disponibilidade de areia seca para o transporte eólico (mas não interfere no transporte subaquoso por deriva litorânea).

A distinção entre efeitos de tempestade, efeitos normais regionais e efeitos normais locais equivale, no caso das ondas, à separação entre ondas de tempestade ("storm waves"), ondulaçōes ("swell waves") e vagas ("sea waves"), respectivamente (Lankford 1977; Tomazelli 1990).

As ondulações são ondas de grande permanência, geradas a dezenas ou centenas de quilômetros da costa; caracterizam-se por formato arredondado, baixa esbeltez (relação altura/comprimento) e periodo longo e regular. As vagas são ondas fugazes ligadas a interferência de ventos locais próximos à custa; superimpōem-se às ondulações em padrões complexos e variáveis e apresentam 
cristas agudas e esbeltez elevada. As ondulações, por sua regularidade, são mais importantes na determinação do rumo de deriva longitudinal. A simples observação instantânea da direção de frentes de ondulações, através de fotografias aéreas ou no campo, não é suficiente para predizer o rumo resultante da deriva longitudinal no tempo geológico, pois não leva em conta o efeito de reversões periódicas de duração variável, nem a relação entre direção de ondulação e energia ou a influência das ondas de tempestade. Indicadores sedimentológicos ou geomorfológicos são recursos mais adequados a esta finalidade (Jacobsen \& Schwartz 1.981; Giannini 1987). Como regra pode-se dizer que a direção de ondulação mais comum, prevalecente, não é a mais efetiva no transporte longitudinal a longo prazo. No caso dos ventos, os efeitos locais estão ligados à interferência sofrida por ventos regionais ao atingirem a costa, sob influência de irregularidades topográficas. A deposição eólica, em zonas costeiras mais acidentadas, pode ser comandada pelo padrão de ventos locais e ocorrer numa disposição geométrica oposta a que seria produzida pelo padrão regional (Bigarella 1975a).

A inclinação relativa à linha de costa e a magnitude do vetor "fetch" são fatores determinantes da efetividade de transporte sedimentar pelos agentes ondas ou ventos. No caso das ondas, quanto mais oblíquo o vetor maior é a efetividade da deriva litorânea longitudinal. No caso dos ventos, quanto mais próximo da perpendicularidade estiver o vetor, maior é a efetividade da deriva eólica naquela direção (Goldsmith 1978).

A efetividade de transporte sedimentar de um vetor eólico em dada área e intervalo de tempo depende portanto de sua orientação relativa à linha de costa, de sua freqüência de ocorrência, de sua velocidade, e da freqüência de chuvas associadas, além de aspectos do suprimento sedimentar, como a granulometria. A quantificação teórica desta efetividade faz-se através do cálculo da deriva eólica potencial (DEP), segundo fórmulas como as de Langsberg (1956 apud Goldsmith 1978) e Lettau \& Lettau (1975 apud Fryberger 1979). Tais fórmulas não levam em conta o efeito das chuvas e da direçäo da linha de costa, fatores que devem portanto ser considerados durante a interpretação dos valores de DEP calculados. A efetividade de transporte pelas ondas depende das mesmas variáveis, exceto as chuvas. Deste modo, os resultados ou DEP podem ser usados também como indicadores de deriva litorânea potencial, desde que em costas abertas, livres de interferência significativa de ventos locais.

\subsubsection{Potenciais de deriva eólica}

Foram examinadas as derivas eólicas potenciais (DEP) em quatro estações meteorológicas, uma situada dentro da área em estudo (Laguna) e as demais em suas vizinhanças litorâneas a sul (Araranguá) e a norte (Florianópolis) ou a seu interior (Urussanga). Na classificação nominal de Fryberger (1979) quanto a DEP anual, todas as estações investigadas são de alta energia eólica, mesma classificação encontrada por Tomazelli (1990) em estações do litoral norte do Rio Grande do Sul.

Em Laguna (tabela 3.3), a DEP concentra-se no verão (39\%), seguido do inverno (27\%). Os ventos de S a SW $(53 \%)$ e de N a NE $(41 \%)$ são mais importantes. Os primeiros, mais fortes, atuam preferencialmente no verão, outono e início do inverno, revelando coincidência com dias de chuva da ordem de $70 \%$ enquanto os últimos são mais atuantes no final do inverno e na primavera, épocas 
menos chuvosas. A característica mais singular do regime eólico de Laguna é que a primavera; um dos periodos do ano mais ventosos nas estações vizinhas estudadas tanto aqui como por Tomazelli (1990), apresenta-se como o menos importante, com apenas $14 \%$ da DEP ao ano. As diferenças de distribuição de freqüências, quanto a periodos do ano, entre as localidades estudadas, relacionam-se às diferenças de quadrante modal, estas determinadas por efeitos locais de situação topográfica e direção da linha de costa.

Araranguá (tabela 3.4), situada em meio a ampla planície de dissecação de sedimentos paleozóicos, apresenta-se livre da influência de obstáculos aos ventos predominantes de SW (70 \% da DEP), típicos de frentes frias; a nordeste, patamares residuais da serra Geral na região de Morro da Fumaça dificultam a ação direta de ventos de $\mathrm{N}$ a NE. Como efeito, o inverno é a época do ano de maior DEP (65\%). A primavera comparece em segundo lugar (18\%), com importante participação de ventos de $N$ e NE no mês de setembro. Urussanga (tabela 3.5) localiza-se no interior da depressão geomorfológica da zona carbonifera (RadambrasilIBGE 1986b), tendo as escarpas da serra Geral a sul-sudoeste. Encontra-se assim parcialmente protegida da ação de ventos destes quadrantes. O quadrante NE resulta como o de maior DEP $(40 \%)$, a qual se concentra portanto na primavera (49\%). Florianópolis (tabela 3.6), situada em ilha montanhosa, apresenta-se protegida da ação dos ventos prevalecentes de N a NE (Bigarella 1972; Bigarella 1975a) e de ventos predominantes de SW, o que faz ressaltar a efetividade de ventos diretos ou canalizados de quadrantes S e SE, ativos particularmente durante a primavera (45\%). Os ventos de $N$ e NE, ainda que de importância secundária, possuem DEP três vezes superior a de mesmos quadrantes em Laguna. A coincidência destes ventos com dias sem chuva é suficiente para a produção de faces de avalancha reversas proeminentes em dunas eólicas da Ilha de Santa Catarina (Bigarella 1975a).

Em Laguna, os obstáculos topográficos são limitados a pontões de rocha cristalina. A ausência de bloqueios extensos à ação de ventos de $S$ a SW e $N$ a NE favorece valores de DEP mais baixos e com maior equilibrio de distribuição quanto a quadrantes geográficos e épocas do ano. Ventos predominantes de $S$ a SW atuam também, ainda que mais fracos, no verão e no outono. Podem então coincidir com periodos sem chuva, gerando feiçōes de geometria reversa em dunas barcanóides secas, como o desenvolvimento de faces de avalancha temporárias voltadas para NE, no flanco oposto a face de avalancha permanente (figura 5.74).

A observação em campo e aerofotografias da posição de faces de avalancha permanentes, frentes de dunas parabólicas e rastros residuais de deflação permite confirmar, para a área em estudo, a associação teórica entre ventos prevalecentes (de NE) e a formação de dunas eólicas. Esta observação confirma também uma relação de subparalelismo entre estes ventos e a linha de costa, a qual tende a reduzir a deriva eólica efetiva (Goldsmith 1978). 
Tabela 3.3

Resultados pa "unidades vetoriais" de deriva potencial eolica media nensal e anual segundo a fornula de Lettau Lettau (1975, apud Fryberger, 1979) Estacao Meteorologica (Inenet) de Laguna - Periodo 1975-1984(8)

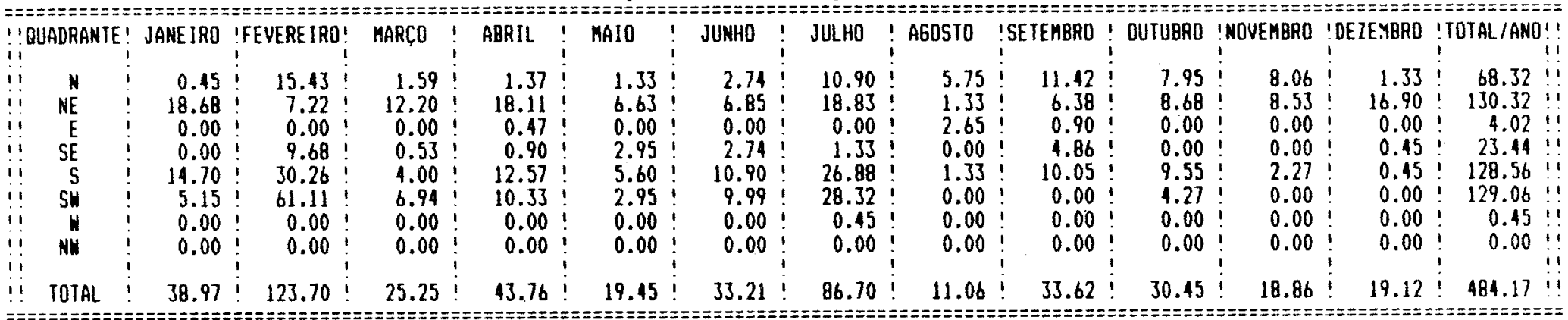

Tabela 3.4

Resultados en "unidades vetoriais" de deriva potencial eolica media mensal e anual segundo a foraula de Lettau 4 Lettau (1975, apud Fryberger, 1979) Estacao Meteorologica (Inemet) de Ararangua - Periodo 1975-1983

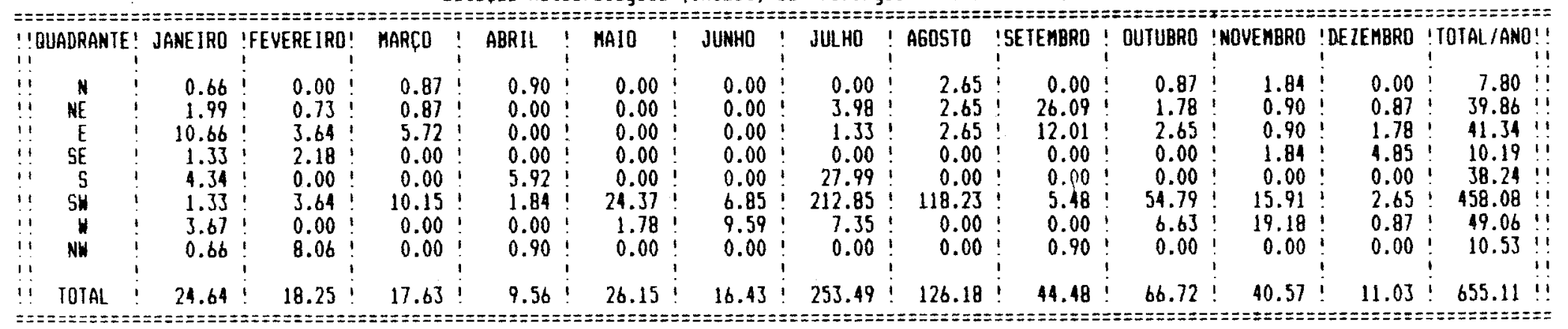


Tabela 3.5

Resultados en "unidades vetoriais" de deriva potencial eolica cedia censal e anual segundo a foroula de Lettau \& Lettau (1975, apud Fryberger, 1979) Estacao Meteorologica (Ineset) de Urussanga - Periodo 1975-1983

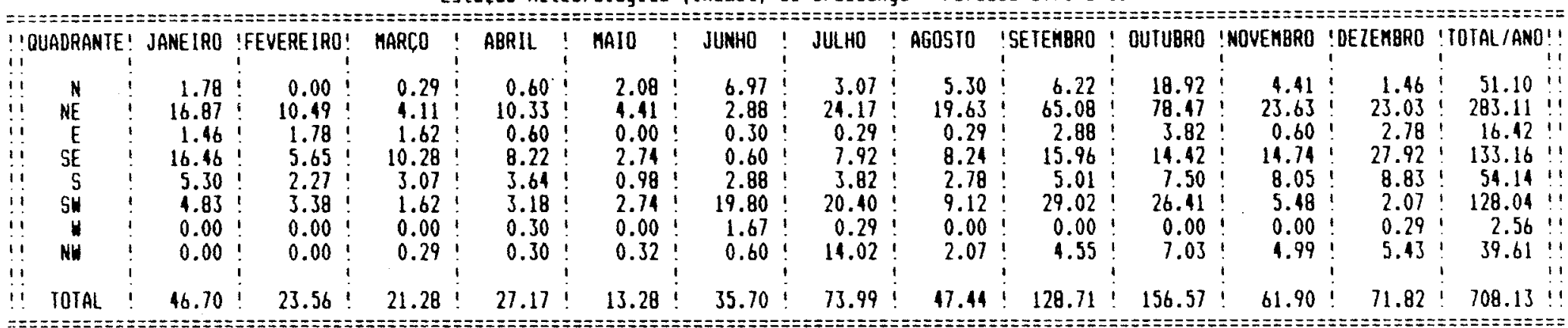

Tabela 3.6

Resultados e "unidades vetoriais" de deriva potencial eolica media mensal e anual segundo a formula de Lettau \& Lettau (1975, apud Fryberger, 1979) Estaça Meteorologica (Inenet) de Florianopolis - Periodo 1975-1983

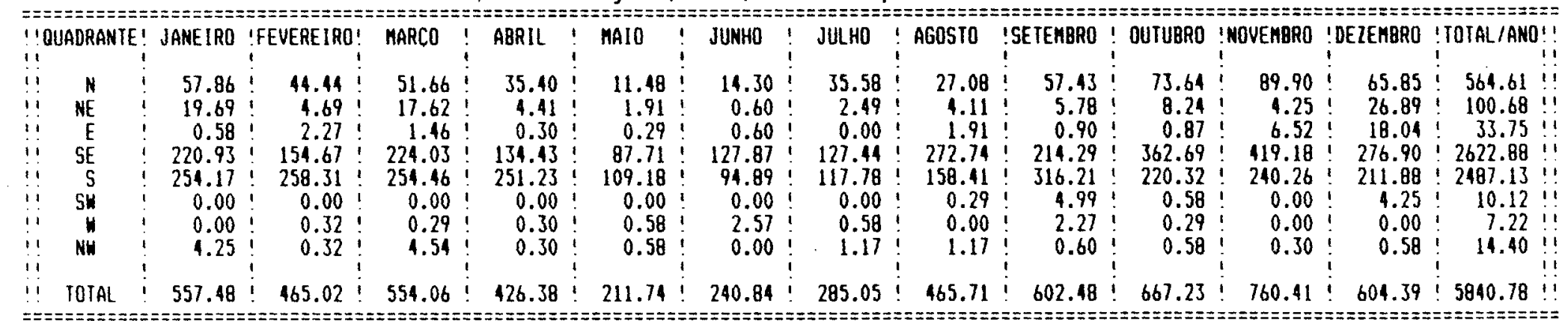




\subsubsection{Potenciais de deriva litorânea}

Com base na interpretação dos resultados de DEP referentes a estação meteorológica de Laguna (tabela 3.3), é possivel sugerir que frentes de ondas de S a SW determinem o rumo resultante de transporte sedimentar litorâneo na área estudada. Esta "predição" sustenta-se no uso implicito de duas premissas: a primeira é a de que o padrão de ventos detectado na estação de Laguna possa ser extrapolado para toda a zona costeira adjacente; a segunda premissa é a de que a deriva litorânea resultante seja determinada pela direção de ondas predominantes.

A predição teórica do rumo de deriva longitudinal é dificultada por depender da orientação relativa entre linha de costa e frentes de ondas predominantes, cuja direção média não se conhece com suficiente precisão. Na prática, o rumo depende também de difrações locais. Ele será verificado através de resultados sedimentológicos (itens 5.1.3 e 5.2.3).

\subsubsection{Regime de marés}

Informações extraidas da Tábua de Marés do porto de Imbituba (DHN 1989) indicam uma amplitude média de maré astronômica de sizígia da ordem de $0,6 \mathrm{~m}$. Se for acrescida a este valor a variação média devida a efeitos meteorológicos, tem-se uma amplitude real estimada com base em observações de campo em pouco mais de $1,0 \mathrm{~m}$, o que permite classificá-la como micromaré $(<2,0 \mathrm{~m})$ segundo Davies (1964) ou como mesomaré (> 1,0 m) segundo Hayes (1975 apud Boothroyd 1978). A última classificação indica que dentre as feiçōes deposicionais ligadas à ação de marés na área de estudo predominam as do modelo de entradas lagunares de mesomaré de Hayes \& Kana 1976 (figuras 5.28 e 5.29).

0 regime de marés de Imbituba é classificado pelo DHN como de irregularidade diurna. Este tipo de regime é caracterizado pela ocorrência de um alto e um baixo principais de maré por dia, sendo as elevações e quedas sucessivas de magnitudes desiguais entre si (Boothroyd 1978). O exame gráfico da Tábua de Marés (figura 3.11) permite verificar ainda a freqüente ocorrência de uma segunda oscilação diária, de menor amplitude, indicando uma tendência para o regime misto. Nos períodos de caráter misto mais acentuado, observa-se que a maré enchente sucede a vazante na variação máxima diária; de acordo com Lankford (1977), este tipo de comportamento favorece o aporte de sedimentos litorâneos rumo ao sistema lagunar. O transporte resultante neste sentido pode ocorrer ao longo do tempo geológico, desde que fortalecido ou não anulado pela incidência de marés meteorológicas. Favorece-se assim o desenvolvimento preferencial de depósitos na porção lagunar da desembocadura, incluindo "deltas de maré enchente" clássicos ("flood tide deltas": Lucke 1934; Emery \& Stevenson 1957; Hayes \& Kana 1976; Davis 1983). Nas entradas lagunares de Camacho e Entrada da Barra, estes deltas são feições proeminentes (item 5.3.2.2.5). 


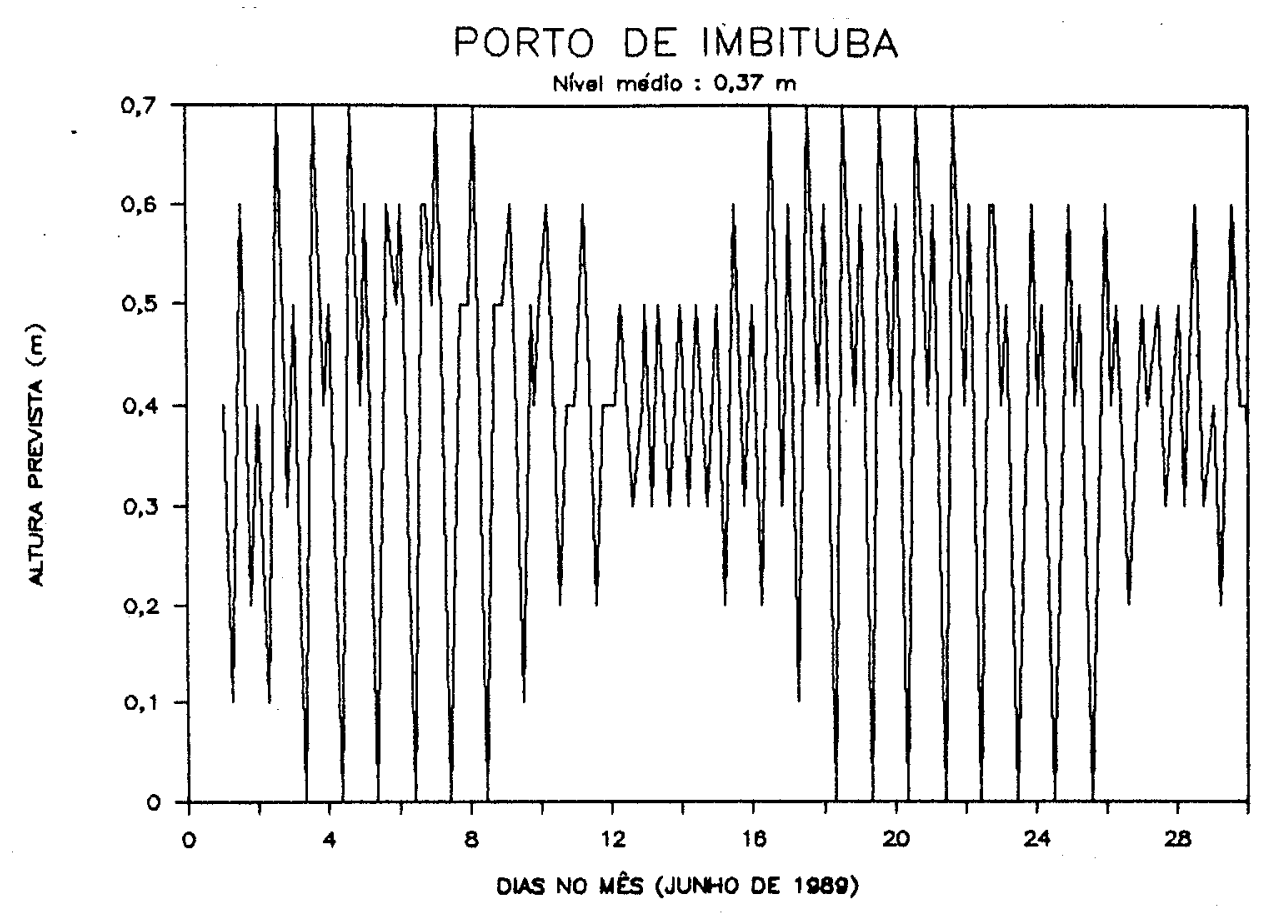

Figura 3.11. Maregrama baseado em tábua de marés previstas (DHN 1989) para o porto de Imbituba.

A influência das condições meteorológicas sobre a maré na região de Laguna é mencionada por Pimienta (1958). De acordo com este autor, ventos de $S$ elevam o nível do mar e desfavorecem as marés baixas, enquanto ventos de NE exercem o efeito inverso. Picos de descarga fluvial no rio Tubarão, quando coincidentes com épocas de ventos $\mathrm{S}$, podem significar o represamento das águas fluviais e a decantação de seus sedimentos nas margens internas da laguna. Pimienta (1958) considera este fenômeno como um dos processos de progradação do delta intralagunar, inicialmente sob a forma de "banhados".

\subsubsection{Padrão de correntes}

O padrão de circulação de águas costeiras que controla a distribuição de sedimentos e de salinidade ao largo de sistemas marinhos e lagunares pode ser atribuído à combinação de quatro tipos de correntes: oceânicas, de água doce, de marés e litorâneas induzidas por ondas (Tomazelli 1990). Em lagunas, alguns tipos de correntes secundárias, como as geradas por forças centrifuga ou de Coriolis, podem superimpor-se (Dyer 1979, 1986).

Duas grandes correntes oceânicas convergentes alternam-se em regime sazonal junto à área em estudo: a Corrente do Brasil, oriunda da deflexão para o quadrante sul das correntes quentes do Atlântico Equatorial que atingem o Nordeste brasileiro, e a Corrente das Malvinas, originária da ramificação rumo norte das correntes polares que se dirigem ao sudoeste da África (figura 3.1). Ambas deslocam-se em trajetórias paralelas e muito afastadas da costa, não afetando diretamente a sedimentação marinha rasa. Entretanto, o aporte indireto virtual de águas frias e ricas em nutrientes orgânicos, trazidas pela Corrente das Malvinas, pode 
ser estimulador potencial da produtividade biológica e da sedimentação bioclástica nos sistemas deposicionais costeiros.

O afluxo de água doce à área costeira em estudo restringe-se a pequenos arroios temporários provenientes de corpos lacustres ou lagunares, córregos de drenagem em pontas e costões cristalinos e canais de desembocadura lagunar. Dentre os primeiros, destacam-se os arroios Corrente, na Praia Grande do Sul, e Paes Leme, na praia de Vila Nova (figuras A1 e A16). No segundo grupo, podem-se mencionar córregos no extremo sul da Praia Grande do Norte, nas praias da Teresa e Gravatá e na Ponta do Ji. O aporte mais significativo de água doce à região costeira em estudo encontra-se nas duas desembocaduras lagunares, a do Camacho e a de Entrada da Barra. Outra desembocadura lagunar, a de Ibiraqüera, ocorre imediatamente a norte da região amostrada neste trabalho. A desembocadura do Camacho é típica de ruptura de barreira sedimentar por ondas de tempestade; sua dinâmica, entretanto, é ainda hoje muito influenciada pela descargá fluvial de distributários do rio Tubarão. Corresponde assim, na classificação genética de desembocaduras lagunares de Bruun (1978) a uma desembocadura de caráter misto entre "de deriva litorânea" e "hidrológico". A desembocadura de Entrada da Barra encaixa-se no estreito formado entre dois morros testemunhos de embasamento cristalino, o morro da Glória, a norte, e o da Entrada da Barra, a sul, podendo ter sua origem primária ligada ao afogamento de ravinas de drenagem preexistentes. Por receber influência direta do rio Tubarão, esta desembocadura também possui caráter misto, na classificação de Bruun (1978), entre "geológico" e "hidrológico". A diferença genética entre as duas desembocaduras da área é um dos fatores determinantes de contrastes em sua dinâmica recente. Enquanto a influência do canal Camacho na circulação costeira é cíclica, devido a alternância de fases de abertura e fechamento, a desembocadura de Entrada da Barra tem permanecido regularmente atuante (item 4.2.4). Durante as fases de atividade da desembocadura lagunar, a circulação de água e sedimentos entre laguna e mar aberto é determinada por um equilibrio de forças entre escoamento fluvial, correntes de maré e correntes de deriva litorânea. Segundo Bruun (1978), o saldo nesse tipo de balanço é representado por deposição de barras submersas nas terminações de cada lado da desembocadura. Se a deriva litorânea supera as correntes de maré mais descarga fluvial no balanço de sedimentação, tais barras tendem a se coalescer e fechar a laguna, como ocorre periodicamente no Camacho.

Desembocaduras lagunares influem também, de modo indireto, na circulação de água no interior das lagunas, pois permitem a entrada e saída de correntes de maré. Muitas outras variáveis combinam-se de forma complexa para determinar o padrão de circulação lagunar. Dentre elas podem-se destacar correntes fluviais, ondas induzidas pela ação direta do vento sobre a superficie da laguna e a somatória vetorial em cada ponto de quatro tipos de forças hidráulicas, a gravidade (densidade), a fricção, a inércia (centrífuga) e a força de Coriolis (Dyer 1986). A influência fluvial pode ser notada através de evidências, em aerofotografias, de jatos hidráulicos na foz dos rios Aratingaúba, à margem noroeste da laguna Imaruí, e d'Una, a noroeste da laguna Mirim (figura A18). No complexo lagunar Garopaba do Sul - Camacho - Santa Marta, os únicos rios com atividade constante na circulação possuem caráter de canais de comunicação interlagunar e funcionam como reguladores de nivel (item 5.3.2.2.7). A influência das ondas lagunares na circulação de águas e sedimentos é essencial na produção de tômbolos e pontais ou esporões 
("spits") marginais, alongados em direção transversal ao eixo maior do sistema lagunar. Uma descrição clássica desse processo é a de Zenkovitch (1967). Ao contrário do que acontece com ondas em mar aberto, a direção principal de migração das frentes de ondas lagunares depende mais da distância de "fetch" que da intensidade do vento. Isto ocorre porque o crescimento das ondas geradas pelos ventos mais fortes é contido pela fricção do fundo raso no mesmo limite das ondas geradas por ventos fracos. Com isto, os ventos paralelos ao alongamento da laguna tornam-se os mais atuantes em sua dinâmica interna, tendendo a produzir pontais transversais que, na situação de equilíbrio, interligam-se e dividem o corpo alongado inicial em várias lagunas eqüidimensionais menores (figura 3.12). Na área em estudo, a direção geral SW-NE de orientação do sistema lagunar coincide com a direção dos ventos predominantes de SW e prevalecentes de NE. Na porção sul do sistema (Garopaba do Sul - Camacho - Santa Marta), a entrada de correntes de maré ou fluviais é apenas sazonal e o desenvolvimento de pontais arenosos encontra-se em estágio mais adiantado; eles ocorrem tanto na margem externa, oriental, das lagunas, quanto na interna, e já atingiram, em relação à laguna Santa Marta, configuração próxima a de equilíbrio. No complexo Santo António - Imaruí - Mirim, a interferência de correntes e a irregularidade de fundo impediram a formação de pontais típicos. Apesar disso, diversos tômbolos concentrados ao longo de sua margem oriental atestam a importância dos ventos de direção SW-NE na tripartição parcial do corpo aquoso.

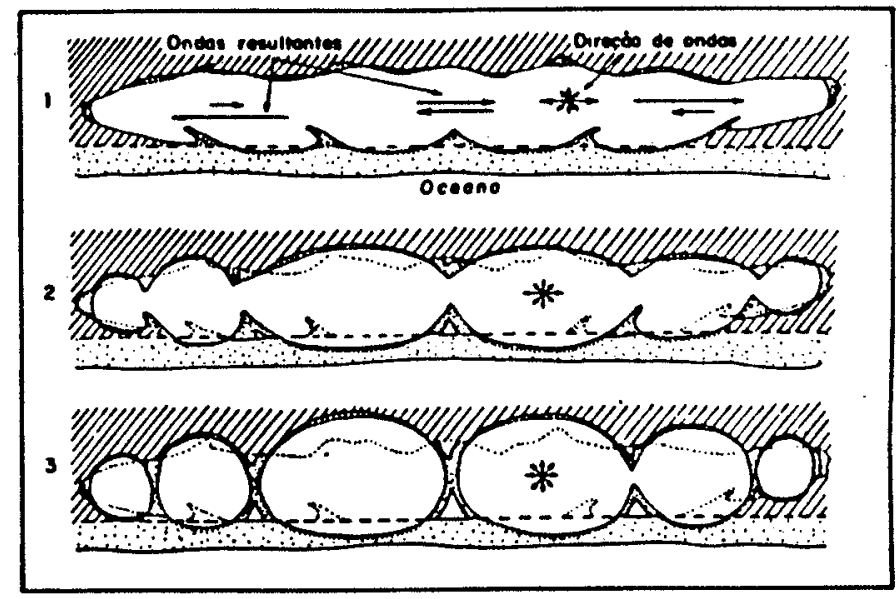

Figura 3.12. Evoluçăo de morfologia planimétrica lagunar através da formaçăo de esporbes arenosos, segundo modelo de Zenkovitch (1967). O estágio 3 representa a configuraçăo de equilíbrio estável.

As demais forças hidráulicas que atuam no padrão de circulação lagunar são de importância subordinada em relação aos ventos. De acordo com Zenkovitch (1967), redemoinhos comandados por estas forças, formados nos arredores de pontais e bancos de areia em geral, são antes conseqüências que causas da deposição local de sedimentos. Deve-se considerar porém que a interação mútua destas forças com correntes fluviais, de maré ou de ondas determina a moldagem final dos mesmos depósitos. A força de Coriolis, ligada à rotação da Terra, manisfesta-se no Hemisfério Sul sob a forma de um desvio do fluxo para sua esquerda (Emery \& Stevenson 1957; Dyer 1979, 1986). Em fluxo de trajetória curva, como ao longo do embaiamento lagunar entre dois pontais ou tômbolos, resulta uma tendência para produção de redemoinho anti-horário (figura $3.13 \mathrm{C}$ ). No entanto, o padrão 
resultante de circulação anti-horário das correntes só prevalece em condições favoráveis ao reforço ou não anulação da força de Coriolis por demais forças hidráulicas; é o que ocorre muitas vezes em baías lagunares amplas (Dyer 1979). Em baias mais fechadas, o balanço de forças hidráulicas pode induzir no fluxo secundário dois tipos principais de circulação: se o fluxo for hiperpicnal (ou hipopicnal em "estuários de mistura parcial"), ele tende a mover-se contornando a margem mais profunda da baía lagunar (oposta aos pontais) e retornando em redemoinho ao atingir a parte mais rasa (figura 3.13A); se for hipopicnal, o fluxo contorna de início a margem mais rasa (adjacente aos pontais) e retorna em redemoinho ao alcançar a margem mais profunda (figura 3.13B). Estes dois padrōes de circulação pressupōem alguma estratificação vertical da massa de água lagunar. Se as águas forem bem misturadas, a circulação ocorre no plano horizontal, independente de gradientes de profundidade. Nesse caso, os fluxos de enchente e vazante ocupam canais separados, e a célula de redemoinho tem caráter residual (figura 3.13D). Discussões adicionais sobre padrões de fluxo secundário em algumas partes do sistema lagunar estudado serão apresentadas adiante (item 5.3.2.2.4), com base na interpretação vetorial de formas de leito no fundo lagunar.

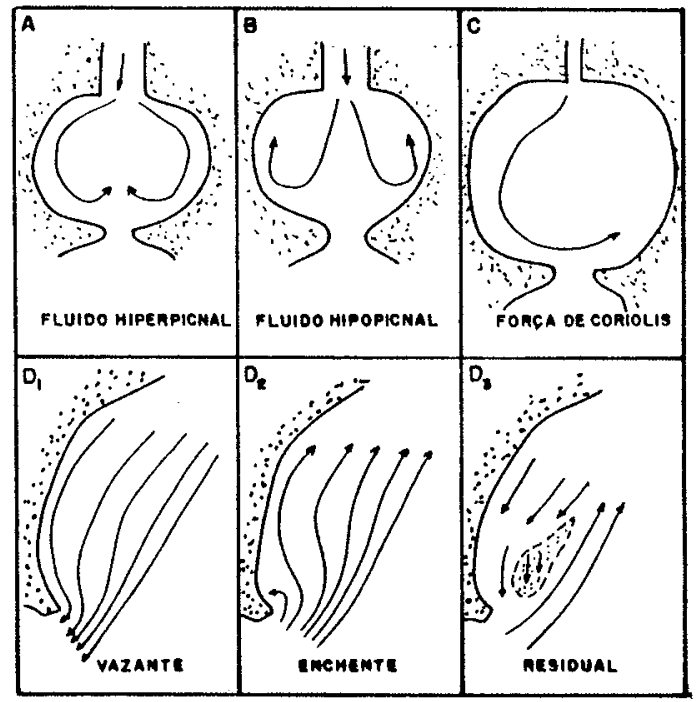

Figura 3.13. Quatro tipos de trajetórias de correntes em lagunas sob ação predominante de diferentes tipos de forças hidráulicas : diferenças de densidade ( $A$ e $B$ ), efeito Coriolis (C) e efeito residual de correntes de marés (D). Compilado de Dyer $(1979,1986)$.

\subsection{DELIMITAÇÃO DE SISTEMAS DEPOSICIONAIS}

\subsubsection{INTRODUÇÃO}

A individualização de sistemas deposicionais, feita segundo métodos previamente discutidos neste trabalho (item 2.2.3.2) é apresentada em seguida. Vale frisar que ela pressupõe a demarcação dos limites da "bacia", 
estabelecidos no capítulo introdutório (item 1.1). A tipologia de sistemas deposicionais encontrada na literatura geológica não é única, e a classificação dos sistemas reconhecidos requer também discussão conceitual dos termos usados para designálos; não se pode classificar um sistema, por exemplo como deltaico, sem antes discutir o que se entende pelo conceito de delta (Dominguez 1990).

\subsubsection{SISTEMA BARRA-BARREIRA (REGRESSIVO)}

O termo composto "barra-barreira" ("barrier-bar"), conforme se subentende de seu uso em análise de sistemas deposicionais por Fisher \& Mc Gowen (1967) e Fisher (1983), descreve sedimentos depositados sob ação de ondas marinhas por "redistribuição e retrabalhamento local ou extensivo ao longo da costa" (caráter de barra), isolando atrás de si um ou mais corpos de água lagunares (caráter de barreira).

De acordo com Fisher (1983), nem todas as barras-barreiras lato sensu (ou simplesmente barreiras) podem ser consideradas sistemas independentes, pois ocorrem também na forma de fácies ativas ou relícticas de "sistemas deltaicos dominados por ondas" (frentes abandonadas ou destrutivas). Esta observação tem como modelo as costas transgressivas norte-americanas. Na costa brasileira, por seu caráter regressivo, barreiras relícticas ou erosivas não ocorrem nos "deltas" modernos (Dominguez 1990), mas são comuns em sistemas planície costeira (item 3.3.3) pleistocênicos dissecados, parcialmente afogados durante os três supostos picos transgressivos do Holoceno. Na área estudada, barreiras residuais de erosão e afogamento são representadas pela faixa de sedimentos pleistocênicos e holocênicos a leste do complexo lagunar Santo António - Imaruí - Mirim. O sistema deposicional barra-barreira ocorre mais a sul, na forma de uma faixa ENE com 0,8 a $2,0 \mathrm{~km}$ de largura e mais de $20 \mathrm{~km}$ de comprimento, formada por sedimentos holocênicos que se estendem desde a margem externa do lago Figueirinha até a orla do morro Entrada da Barra. Encontra-se ai o arranjo faciológico tripartite, diagnóstico deste tipo de sistema deposicional (Reinson 1979; Fisher 1983): a primeira associação de fácies, costeira de mar aberto, resulta de processos de frente de barreira em condições dominadas por ondas; a segunda, de transição com o sistema lagunar vizinho, associa-se a processos em condiçōes de sub a intermarés, no lado protegido da barreira, e a terceira, de margem de desembocadura lagunar ("inlet"), resulta de processos de sub a intermarés na conexão do corpo lagunar com mar aberto.

A interpretação da barreira entre Figueirinha e Entrada da Barra como um sistema deposicional barra-barreira pressupôs a atribuição de idade holocênica (e não pleistocênica) a seus sedimentos. Admitindo-se os modelos para formação de tais sistemas na costa brasileira (Suguio et al. 1982; Dominguez et al. 1987; Dominguez 1990), esta barreira deve ter-se originado antes mesmo do máximo NRM de 5100 anos A.P.. Segundo Dominguez (1990), declinios de NRM, como o que se admite em costas brasileiras entre este máximo e os dias ałuais, impõem condições muito desfavoráveis à sobrevivência de sistemas barra-barreira. Isto decorre da regressão da costa, o que distancia gradualmente as fácies de mar aberto das fácies de borda lagunar, tornando-as independentes entre si. Deixam assim de constituir um sistema tripartite conexo e passam a representar apenas uma barra-barreira fóssil. Apesar disto, no caso em questão, vários aspectos permitem admitir que o caráter 
essencial de atividade conexa do sistema ainda persista: (1) a desembocadura lagunar (canal Camacho) alterna, inclusive em tempos históricos, fases de abertura e de fechamento, mantendo uma comunicação intermitente entre laguna e mar aberto; (2) fenômenos de sobrelavagem ("washover") parcial da barreira ocorrem também em tempos históricos afetando áreas situadas a poucas dezenas de metros da margem lagunar; (3) sambaqui (S3OE) situado sobre a barreira a menos de $350 \mathrm{~m}$ da linha de costa atual foi datado em $4110 \pm 70$ anos A.P. (idade do topo da acumulação), o que indica que a regressão resultante desde essa época não foi maior que aquela distância; (4) alguns processos geológicos que se sucedem atualmente sobre a barreira, como a sobrelavagem por exemplo, não são conhecidos no sistema planície costeira afogado, a norte. Tem-se assim um sistema barra-barreira do tipo regressivo (Moslow 1991).

\subsubsection{SISTEMA PLANICIE COSTEIRA}

O termo "planície costeira" é empregado na literatura geológica brasileira de dois modos: no sentido físio-geográfico (Almeida 1953; Suguio \& Martin 1978), uma espécie de tradução para o "coastal plain" da língua inglesa; e no sentido de "ambiente" ou sistema deposicional (Villwock 1984; Villwock et al. 1986) uma tradução para "strandplain". Na ausência de uma outra versão em português suficientemente precisa e usual para o termo "strandplain", mantém-se neste trabalho o duplo uso de "planície costeira". Para diferenciar os dois sentidos, o termo é antecedido da palavra "sistema", sempre que referido a seu segundo significado.

Fisher (1983) caracterizou o sistema planicie costeira como "uma área progradante devido ao efeito de transporte e deposição de sedimentos por correntes de deriva litorânea longitudinal". A este agente sedimentar devem-se acrescentar ainda pelo menos outros dois: a deriva transversal e as variaçōes de NRM. Segundo mesmo autor, o sistema planície costeira distingue-se do barrabarreira pela ausência de corpo lagunar contiguo (exclua-se deste as lagunas de afogamento de rias erosivas preexistentes mencionadas no item anterior). Isto torna sua faciologia mais monótona, restrita em essência a processos de mar aberto, cuja identificação depende do exame de estruturas sedimentares subsuperficiais.

Reconhecem-se na área pelo menos duas gerações de sistemas planicie costeira, uma pleistocênica e outra holocênica. No norte da área, os dois sistemas estendem-se paralelos desde a margem norte da laguna Santo António até a borda norte da laguna lbiraqüera. A sul, eles prolongam-se ininterruptos da desembocadura do rio Urussanga até a margem sul do lago Figueirinha. O sistema planície costeira pleistocênico norte avizinha-se ao interior com o sistema lagunar; apresenta portanto caráter de sistema afogado em forma de barreira erosiva.

\subsubsection{SISTEMA LAGUNAR}

No trabalho clássico de Fisher \& Mc Gowen (1967), um sistema deposicional da costa do Texas formado pela bacia de afogamento 
transgressivo de vales de drenagem (baia), parcialmente fechada em sua parte externa por um sistema barra-barreira, recebeu o nome de sistema baía-laguna (figura 2.1). Em revisão de suas definições de sistemas deposicionais, Fisher (1983) manteve a referência a baías e lagunas como sistema indiferenciado; destacou, porém, que a faciologia de baias de mar aberto pode ser drasticamente distinta da faciologia de baias fechadas e lagunas. Existiriam, deste modo, dois sistemas diferentes: o sistema baia (aberta) e o sistema baía-laguna. O termo composto para designar o segundo decorreria do fato de que a grande maioria das lagunas norte-americanas, como as do Texas, eram baias abertas, que, durante a fase de semi-estabilização do mar transgressivo, transformaram-se em lagunas bloqueadas por barras-barreiras. No caso da costa brasileira, marcada nos últimos 6 mil anos por oscilações significativas de NRM ausentes no modelo norte-americano, existem não apenas sistemas baía e baia-laguna, como também um outro tipo específico de sistema lagunar, remanescente do afogamento de baixios topográficos atrás de barreiras erosivas durante máximos transgressivos recentes. Deste modo, é possivel distinguir na área entre um sistema baia-laguna, formado pelas lagoas Garopaba do Sul, Camacho e Santa Marta, e um sistema "baixio-laguna", representado pelo complexo Santo António - Imaruí - Mirim. Estes dois sistemas estão genética e espacialmente associados, pois são cronocorrelatos e possuem canais de comunicação regular entre si. Formam assim um sistema deposicional conexo em escala maior, imediatamente inferior a escala. da bacia. Por esta razão, são tratados como duas associações de fácies formadoras do sistema deposicional lagunar.

Uma das características virtuais de baias-lagunas é a formação de deltas de cabeceira de baia (Fisher 1983), também denominados "deltas intralagunares". Esta última designação foi empregada por alguns autores com referência à desembocadura do rio Tubarão (Pimienta 1958; Suguio et al. 1982; Martin et al. 1988b) que constitui a principal particularidade faciológica distintiva da associação baía-laguna com relação à associação baixio-laguna. De acordo com Dominguez (1990), costas de tendência regressiva em zonas de desembocadura de rios com aporte volumoso podem experimentar assoreamento das lagunas de barrasbarreiras através da formação de "deltas intralagunares". Estes constituem um dos estágios comuns à evolução da desembocadura de todos os grandes rios da costa sudeste e nordeste do Brasil (figura 3.14: estágio C). Com a progradação gradual destes deltas interiores, seus distributários erodem a barreira litorânea e a desembocadura atinge seu estágio atual de mar aberto (estágio D). A desembocadura do rio Tubarão, dentro deste modelo, ainda não completou sua evolução, encontrandose no estágio de delta interior $(C)$. 
(A)

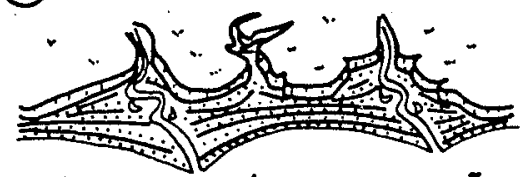

ESTÁGIO I - PLANICE DE CORDÖES LITORANEOS PLEISTOCÉNICOS (DESCIDA DO NIVEL DO MAR)

(C)

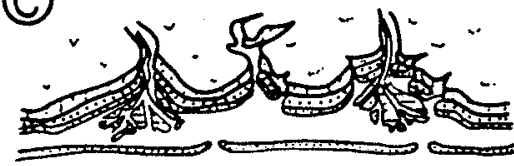

ESTA'GIO III - DELTAS INTRALAGUNARES

¿- PÂNTANO ÁGUA DOCE

$=:$ fluvial
(B)

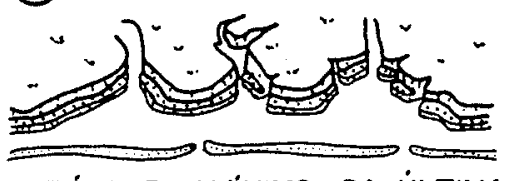

ESTÁGO II - MÁXIMO DA ULLTIMA TRANSGRESSAOO LAGUNAS/ILHAS BARREIRA

(D)

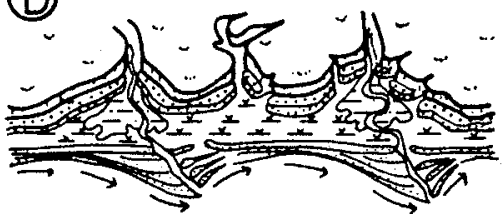

ESTÁGIO IV - PLANICE DE CORDOOES LITORÁNEOS HOLOCÉNICOS (DESCIDA DO NVEL DO MAR) CORDÖES LITORÂNEOS HOLOCÊNM$\cos$

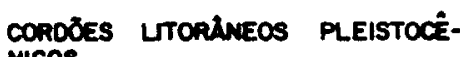
MICOS

Figura 3.14. Esquema evolutivo, durante os últimos 120 mil anos, para desembocaduras de grandes rios em costas brasileiras dominadas por ondas. Segundo Dominguez et al.(1987 apud Dominguez 1990).

\subsubsection{SISTEMA EÓLICO}

O modo integrado pelo qual feiçōes eólicas menores se deslocam sob o efeito do vento efetivo é uma manifestação de seu caráter de sistema dinâmico e conexo. A dificuldade de construção de um modelo de fácies eólicas, comentada por Walker \& Middleton (1977), não implica ausência de caráter sistêmico. Pelo contrário, a conexidade e a homogeneidade de processos, estruturação, texturas e composição, aparentam ser tão grandes, que os depósitos eólicos poderiam ser tratados, em primeira instância, como um sistema simples (Fisher 1983). O problema centra-se portanto na dificuldade de delimitação entre fácies ou associações de fácies eólicas e, por extensão, em que critério se basear para o reconhecimento destas fácies. Embora sem deixar explícita a resposta para esta questão, Fisher (1983) baseia sua caracterização do sistema eólico na descrição de tipos morfológicos de dunas. Uma faciologia fundada em tipos morfológicos parece adequada: observa-se que estes tipos são quase sempre reconheciveis no campo ou por aerofotografias, mantêm entre si relaçōes dinâmicas discerníveis e tendem a distribuir-se geograficamente segundo padrões determinados (McKee 1979; Fisher 1983; Short 1988); em abordagem sistêmica, Soares (1992) considera as fácies eólicas como "registros de entidades morfológicas".

O exame de fácies definidas pelo critério morfológico ao largo da planície em estudo permitiu a distinção entre duas associações de fácies, diferenciadas geneticamente quanto à razão energia eólica / disponibilidade de areia (e/d). A variação faciológica espacial (estrutura), no sentido fonte costeira-interior, em cada uma destas associaçōes, pode ser carcterizada como segue (figura 2.10). Na primeira associação, com baixa razão e/d, dunas frontais incipientes ("incipient foredunes" de Hesp 1988) gradam para dunas transversais lineares e barcanóides, as 
quais terminam em frentes de avanço parabólicas. O excesso de areia disponivel faz com que estas fácies se associem na forma de imensos mantos de areia (vários quilômetros de comprimento e largura: ver tabela 5.11), contínuos e com ondulações superficiais representadas pelas dunas individuais. Na literatura prévia, a feição que melhor se aproxima deste tipo de associação de fácies é a de depósitos eólicos mantiformes (figura 5.57), descritos por Tomazelli (1990) na costa norte do Rio Grande do Sul. Ela pode ser designada portanto como associação de fácies mantiforme. Geneticamente, supõe-se tratar de draas (dunas gigantes) formados pelo espalhamento contínuo de depósitos eólicos, desde as dunas de orla praial até as frentes parabólicas distais.

A segunda associação de fácies consiste em depósitos eólicos menos contínuos, relacionados a razões e/d elevadas. Esta associação inicia-se por fácies residuais de deflação ("blow-outs" e feições do gênero), passa para fácies de dunas transversais barcanas e barcanóides e termina por dunas parabólicas alongadas. Difere da anterior pela ausência de dunas frontais e transversais lineares e pela presença de zona deflacionar, além da extensão menor. Sua forma geral em planta é sempre a de parábola, com virtual individualização de dunas parabólicas na parte frontal, dai a sua designação como associação lençóis e dunas parabólicos.

O sistema eólico tem ocorrência generalizada, superpondo-se sobre os sistemas barra-barreira e planície costeira em maior parte da área. Na região de Campo Verde, pertencente a associação de fácies baía-laguna, pequenas dunas parabólicas formaram-se a partir de areias de cordões lagunares. Elas ocorrem isoladas e restritas em área à zona de afloramento de uma fácies lagunar, não tendo sido por esta razão incluidas no sistema eólico.

Pelo menos quatro gerações de depósitos eólicos puderam ser reconhecidas. A definição das associaçōes de fácies foi baseada nas gerações mais recentes $(3$ e 4 ) e estendida quando possivel às mais antigas. Amostras de depósitos eólicos de características faciológicas pouco diagnósticas foram agrupadas na denominada "associação indiferenciada".

\subsection{SAMBAQUIS, SISTEMAS DEPOSICIONAIS E NIVEL DO MAR}

As primeiras descrições de sambaquis na região de Jaguaruna-Imbituba foram feitas por Abreu $(1928,1944 a, b)$. É evidente neste autor, assim como nos trabalhos pioneiros sobre sambaquis no litoral catarinense (Wiener 1876), a dificuldade de distinção entre bancos de conchas paleolagunares e sambaquis estratiformes ("sambaquis-camadas"). Como exemplo, pode-se citar a parte basal da acumulação conchifera de Ponta Rasa, em Imbituba, interpretada como sambaqui, e cujo caráter de terraço paleolagunar foi mais tarde reconhecido por Guerra (1951). Critérios objetivos para a diferenciação entre sambaquis e terraços foram estabelecidos por este mesmo autor (Guerra 1950a,b; 1951), baseado na observação de 11 depósitos da região, seis dos quais hoje já destruídos em sua totalidade. A exploração de sambaquis para extração de carbonato foi prática comum no passado, principalmente entre as décadas de 1940 e 60, declinando na década seguinte. Dos 33 sambaquis catalogados por Bocchi \& Liberatore (1968a,b,c,d) na área em estudo, dos quais sete intactos e outros sete esgotados na época, a maioria 
permanece hoje em estado de preservação semelhante. Sambaquis desaparecidos depois daquele levantamento, como os de Passagem da Barra, Cabeçuda e Caputera, já se encontravam então em estágio terminal de destruição. Outros sete sambaquis foram descritos na área, em levantamento adicional realizado por Castro \& Castro (1969a). No catálogo de "Sambaquis Conhecidos no Litoral do Estado de Santa Catarina", apresentado por Martin et al. (1988b), contabilizam-se na região entre Jaguaruna e Imbituba um total de 44 sambaquis, entre destruidos, explorados e intactos. Compilação dos sambaquis descritos nesses vários levantamentos mencionados, acrescida de novas ocorrências encontradas durante os trabalhos de campo, permite elevar este total para 72 sambaquis, compondo uma média de mais de um sambaqui a cada $10 \mathrm{~km}^{2}$. Deste total, $45(62 \%)$ concentram-se na área dominada pelo sistema barra-barreira e associação baia-laguna (com sistema eólico associado). $O$ padrão de distribuição geográfica de sambaquis faz supor assim um aumento de produtividade biológica relacionado às características da interação dinâmica entre barra-barreira e baia-laguna.

Do ponto de vista eminentemente arqueológico, o trabalho clássico na região é o de Hurt (1974), que fornece descrições e datações para os sambaquis de Carniça, situados na margem norte da laguna Santa Marta. Estas informaçōes, acrescidas de datações em outros três sambaquis nas localidades de Garopaba do Sul, Congonhas e lagoa Figueirinha, município de Jaguaruna, foram utilizadas por Martin et al. (1988b) na elaboração da curva de variação do NRM para a costa catarinense (figura 3.4), seguindo-se os critérios de Martin et al. (1986) para emprego de sambaquis na reconstituição de paleoniveis marinhos.

Além de seu papel auxiliar na reconstituição de variações na posição de paleolinhas costeiras, os sambaquis da região podem ser úteis na datação da idade máxima de eventos geradores de dunas eólicas. Essa possibilidade já fora ressaltada por Pimienta (1958), ao descrever a existência de sambaquis semisubmersos por mares de dunas eólicas ativas na barreira litorânea a sul do cabo de Santa Marta Grande. O caso inverso, sambaqui repousando sobre paleoduna (geralmente "dunas de topo de encosta", definidas no item 5.4.2.5.1), observado em algumas localidades por Guerra $(1950 a, b)$, pode permitir a determinação de idade minima das dunas fósseis. Dada a ausência de material datável no interior dos depósitos eólicos estudados, a datação aproximada de gerações eólicas através de sambaquis em situaçōes análogas às descritas por Pimienta (1958) e Guerra $(1950 a, b)$ tornou-se conveniente. Seis amostras de sambaquis foram submetidas a datação pelo método radiocarbono neste trabalho. Quatro delas foram coletadas em sambaquis semi-ilhados por depósitos eólicos ativos (geração 4), na barra-barreira entre as vilas de Laranjal e Garopaba do Sul (amostras S28A, S30B, S30D e S30E). As duas amostras restantes foram coletadas em sambaquis embasados sobre paleodunas eólicas, seja da geração 1 no cabo de Santa Marta Pequeno (amostra $\mathrm{S} 38 \mathrm{~A}$ ), seja da geração $2 \mathrm{~A}$, na vila do Estreito (S58A). Os três sambaquis de Garopaba do Sul ( $S 30 B, D$ e E) são vizinhos, mas situam-se a diferentes distâncias da linha de costa. Constituem-se, por isto, em fontes potenciais de informação sobre as oscilações de NRM no sistema barra-barreira. Os resultados de datação nesses seis sambaquis e suas possiveis interpretações são apresentados no decorrer da discussäo dos respectivos sistemas. deposicionais sobre os quais ocorrem (itens 3.3.2, 5.1 .1 e 5.4 .1 .3$)$. 


\section{DESCRIÇÃO EXTERNA}

\subsection{PROVENIENCIA SEDIMENTAR}

\subsubsection{FONTES PRIMÁRIAS (PRÉ-QUATERNÁRIAS)}

Ajustes estatisticos significativos entre assembléias de minerais pesados de regolitos de rochas pré-quaternárias e de sedimentos da planície litorânea são raros (tabela 4.1). Apesar disto, é possivel notar através deles a importância de rochas proterozóicas correlatas ao Complexo Pinheiro Machado (Fragoso Cesar 1991) no aporte sedimentar.

Um exame da ocorrência e freqüência média dos principais minerais pesados nos regolitos e sistemas deposicionais estudados (tabelas 4.3 e 4.4; figuras 4.1 a 4.6) permite algumas conclusões adicionais sobre rochas-fontes primárias. A participação importante de zircão e turmalina em todas as assembléias médias sedimentares decorre de sua presença teoricamente possivel nas rochasfontes regionais de maior representatividade, como granitos intrusivos da Suíte Dom Feliciano, rochas igneas metamorfisadas e migmatizadas, correlatas ao Complexo Pinheiro Machado, e depósitos da Bacia do Paraná. Decorre também de sua elevada estabilidade ao transporte sedimentar. Zircão encontra-se como mineral comum a predominante em todas as amostras de regolito analisadas (tabela 4.3); suas maiores freqüências de contagem dentre componentes transparentes não micáceos, superiores a $80 \%$, ocorreram nos granitos intrusivos cambrianos e nos sedimentos continentais terciários. Nos sedimentos quaternários, sua diversidade de aspectos é indício de fonte igualmente diversificada: ele pode ser róseo ou mais comumente incolor, variando de euedral anguloso a ovóide super-arredondado.

Turmalina é mineral ausente a raro nas amostras de regolito de granito intrusivo, mas pode chegar à abundância no Complexo Pinheiro Machado e na Bacia do Paraná, que devem assim constituir suas fontes continentais mais importantes. Nos sistemas deposicionais quaternários, ocorre com grande diversidade de formas e aspectos, predominando as variedades subeuedrais em tons de pardo. Destas, cerca de 50 \% exibem inclusões em concentração elevada, indício de recristalização metamórfica na rocha-fonte primária (Krinine 1946), o que reafirma a importância de rochas correlatas ao Complexo Pinheiro Machado como fonte sedimentar. Indicolita (variedade azul de turmalina do grupo da elbaíta), mineral tido como indicador de rocha-fonte primária pegmatítica (Pettijohn 1957), ocorre como componente raro a escasso em muitas das amostras estudadas. Pode provir de pequenos filões pegmatiticos associados a Suite Granítica Dom Feliciano, como o observado por Castro \& Castro (1969a) nos arredores da vila de Barreiros, orla de intrusão do "stock" Imaruí. Vale citar ainda a ocorrência de um grão errático de turmalina parda super-arredondada, com crescimento secundário prismático subeuedral e subarredondado, de cor verde clara. Esta feição foi observada em uma única amostra do sistema planície costeira holocênico, em Itapirubá. É indicativa de de rocha-fonte metassedimentar de metamorfismo fraco dentro da fácies xisto-verde 


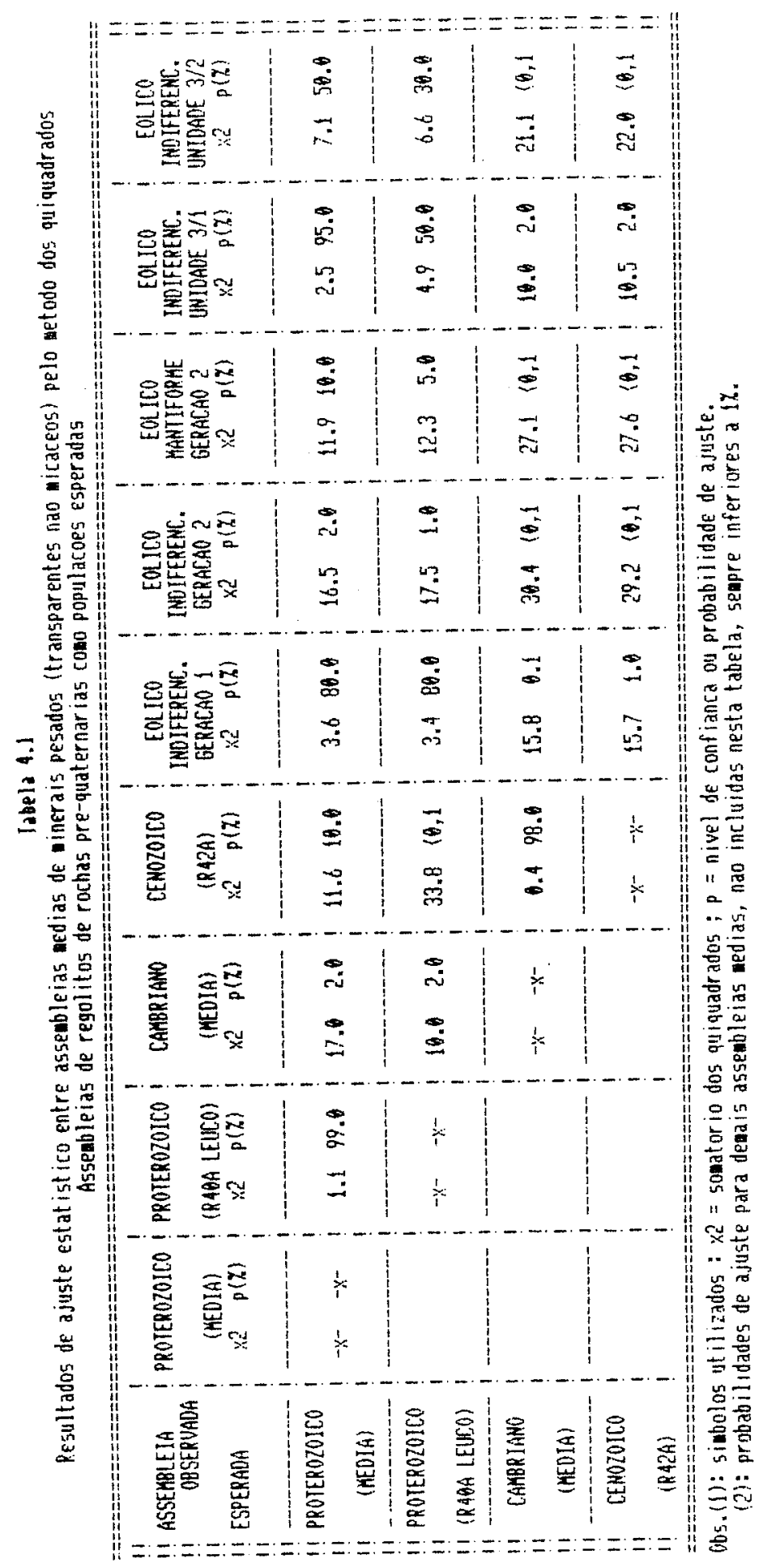


Tabela 4.2

Resultados de ensaios de analise densietrica ao liquido denso (bronotaraio-CHBr3-densidade $d=2.83 \mathrm{~g} / \mathrm{cm}$ ) e de separacao

agnetica ao ina manual - Anostras de regolito de rochas e sediantos pre-quaternarios - Fracoes areia tina (I) ou wito fina

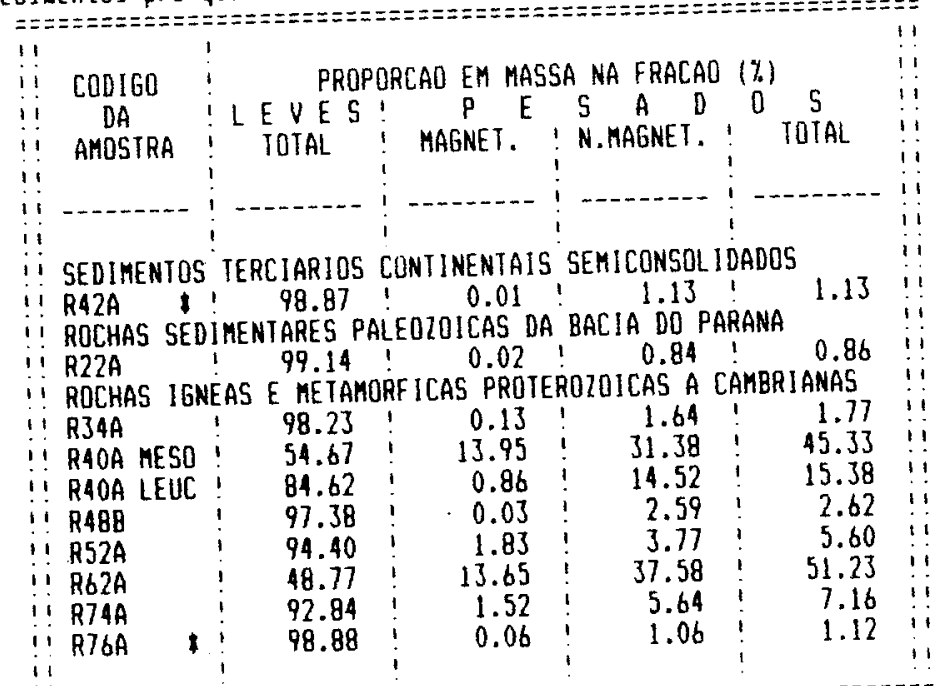

Jabela 4.3

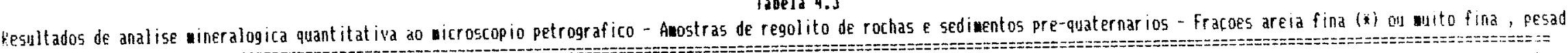

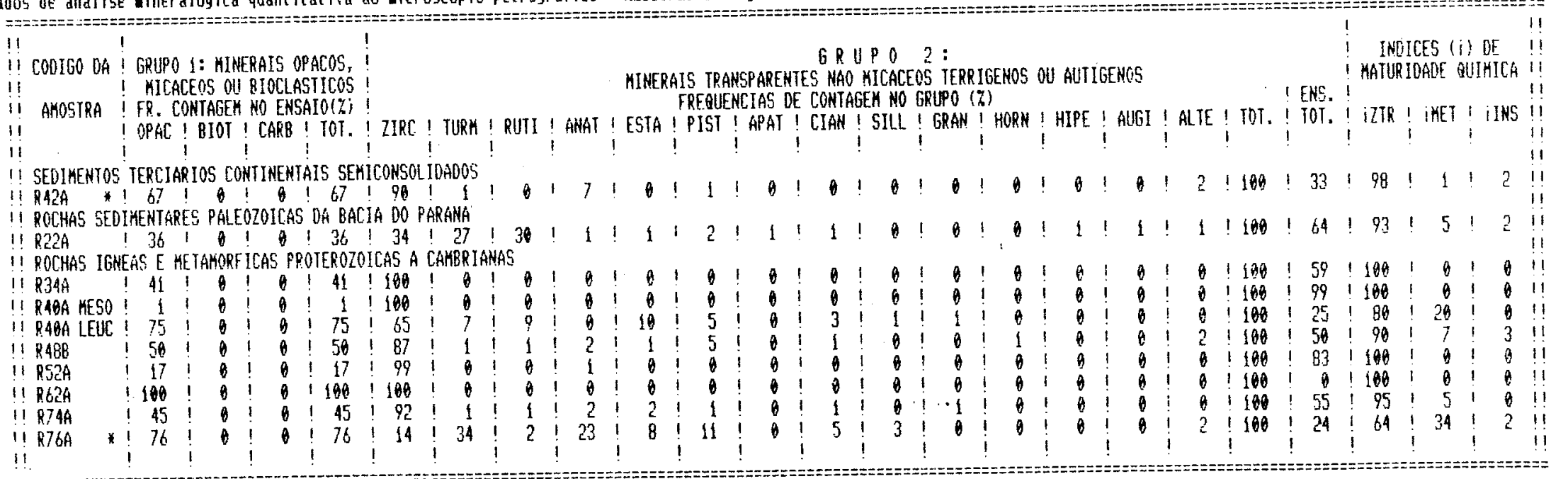


Tabela 4.4

Assembleias eineralogicas édias por lote de anostras e respectivas razoes aineralogicas - Frafào areia fina ou musto fina, pesada näo eagnetica

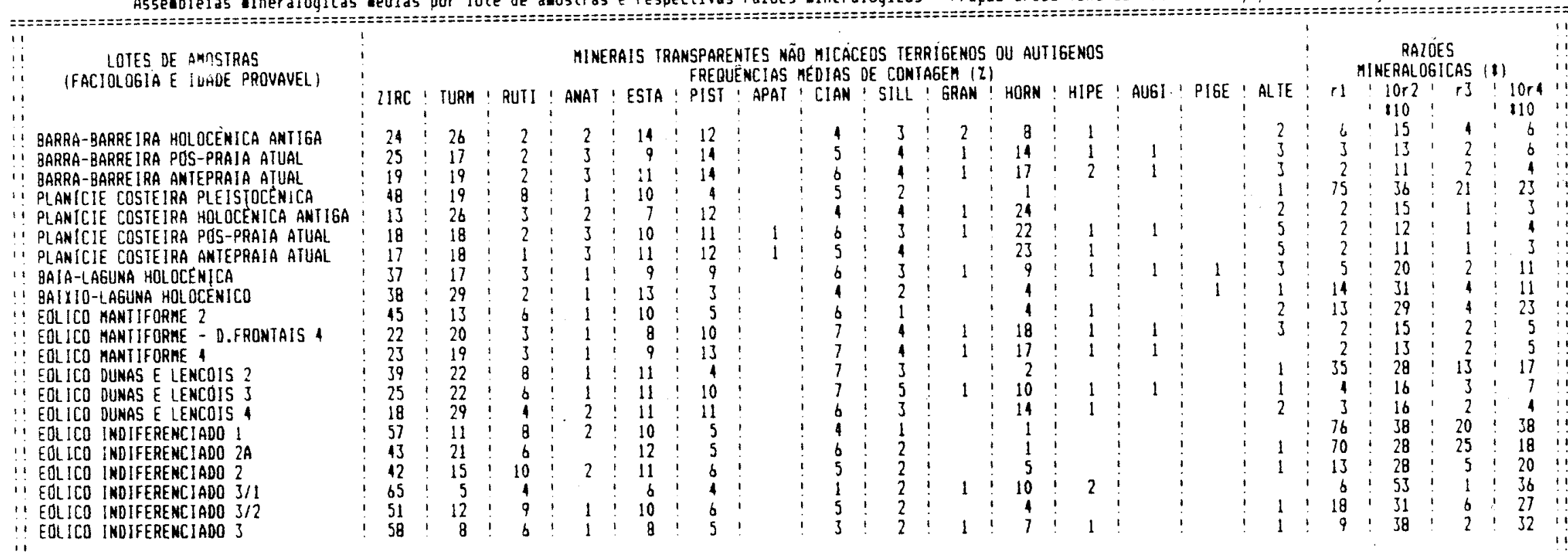

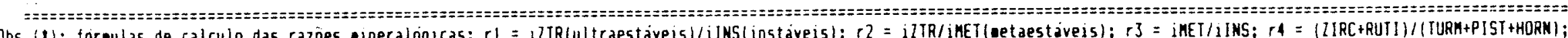
alteritos (ALIE) nao incluidos no calculo. 
(Armando M. Coimbra, IGUSP, comunicação pessoal), de influência remota na área. Os teores mais altos de turmalina nos sedimentos estão associados na maioria das vezes a teores também mais elevados de hornblenda elou pistachita. Como se trata de correlação direta entre um mineral ultraestável e dois metaestáveis e como ocorre tanto entre sistemas holocênicos quanto pleistocênicos, esta relação não pode ser facilmente explicada por fatores pós-deposicionais. O mais provável é que os três minerais possuam entre si uma importante rocha-fonte comum. Esta hipótese é em parte apoiada pelos resultados de mineralogia nas assembléias de regolitos, onde as rochas cristalinas com mais turmalina são também as mais ricas em pistachita. Com zircão, a relação se inverte.

Rutilo, por ser também ultraestável, é outro mineral de ocorrência generalizada nos sistemas deposicionais estudados, porém a concentrações sempre mais baixas que zircão e turmalina. A causa provável é sua baixa disponibilidade inicial nas rochas-fontes. Na análise do regolito, rutilo só foi encontrado nas amostras relacionadas ao Complexo Pinheiro Machado e sempre a freqüências de contagem inferiores a $10 \%$. A exceção foi a rocha sedimentar da Bacia do Paraná, onde o mineral atinge $30 \%$. As rochas paleozóicas devem constituir assim a fonte mais importante de rutilo para os sedimentos quaternários. Nestes, o franco predomínio de grãos de rutilo super-arredondados a arredondados pode ser uma conseqüência da reciclagem de sedimentos paleozóicos ricos no mineral.

Estaurolita é o mineral metaestável de ocorrência mais regular nos sistemas deposicionais estudados. Sua freqüência média de contagem varia em intervalo restrito em torno de $10 \%$. Mineral típico de metamorfismo, deve ter origem principal nas rochas correlatas ao Complexo Pinheiro Machado. Minerais metamórficos associados a estaurolita nos regolitos estudados são cianita e sillimanita. Ambos possuem também ocorrência bastante regular nos sistemas deposicionais quaternários, porém a freqüências menores que estaurolita.

Pistachita e hornblenda ocorrem preferencialmente nos sedimentos holocênicos. A primeira pode possuir rocha-fonte diversificada, incluindo milonitos retrometamorfisados. Com base nas análises de amostras de regolito, podese sugerir que sua fonte principal na área em estudo sejam as rochas correlatas ao Complexo Pinheiro Machado. Quanto à hornblenda, sua raridade no regolito deve-se à facilidade de destruição por processos intempéricos. Análises petrográficas apresentadas por Fragoso Cesar (1991) indicam que se trata de mineral máfico principal na maioria das litologias do Complexo Pinheiro Machado. Estas devem portanto constituir a inferida fonte comum para turmalina, pistachita e hornblenda. Outra rocha-fonte provável para hornblenda são os diabásios associados a Formação Serra Geral: uma pequena parcela dos grãos prismáticos de hornblenda encontrados nos sedimentos quaternários (10 a $20 \%$ em média) apresentam caracteristicas ópticas típicas de "hornblenda basáltica" como cor parda e baixo ângulo de extinção (Parfenoff et al. 1970). Outros minerais possivelmente associados a este tipo de rocha fonte, presentes em pequena quantidade em muitas das amostras estudadas, são augita e pigeonita. 


\subsubsection{FONTES SECUNDÁRIAS}

As relações de fornecimento sedimentar ou área-fonte comum entre os diferente tipos e gerações de sistemas deposicionais ou associaçōes de fácies podem ser preliminarmente avaliadas através do respectivo quadro de ajustes estatísticos entre assembléias médias de minerais pesados (tabela 4.5), complementado graficamente por histogramas (figuras 4.1 a 4.6). Neste quadro, observa-se que os melhores ajustes do sistema deposicional lagunar (nos 18 e 19) ocorrem com sedimentos eólicos atribuidos às gerações 2 e $2 \mathrm{~A}$, de idade anterior ao máximo transgressivo holocênico. Como o sistema lagunar vem-se desenvolvendo desde esta época, o elevado ajuste pode decorrer tanto de contemporaneidade sob área-fonte comum, quanto de retrabalhamento do sistema eólico fóssil pelo sistema lagunar. Observa-se que os ajustes do sistema eólico das geraçōes 2 e $2 \mathrm{~A}$ são menores em relação à associação de fácies baixio-laguna, em cujas margens seus depósitos se encontram bem preservados, que em relação à associação baía-laguna, onde os mesmos depósitos eólicos não são mais encontrados. Uma explicação para este aparente paradoxo é a de que a associação de fácies baia-laguna, em sua porção amostrada (externa), tenha-se formado às custas da erosão e redeposição de sedimentos eólicos das geraçōes 2 e $2 \mathrm{~A}$. Uma evidência disto é o truncamento erosivo das dunas eólicas de geração 2 pelas margens das lagunas Garopaba do Sul, a sudoeste, e Santo António, a nordeste.

As assembléias de minerais pesados de associações de fácies eólicas ativas (nos 16 e 17) apresentam maiores ajustes estatísticos com as assembléias de fácies praiais atuais (figuras 4.1 e 4.2). Esta relação era esperada, uma vez que a praia é a área-fonte principal das dunas costeiras. É significativo o fato de que as probabilidades de ajuste $(p)$ entre sedimentos praiais e associação eólica mantiforme são sempre mais elevadas (> $95 \%$ ) que as probabilidades de ajuste entre os mesmos sedimentos e a associação eólica dunas e lençóis parabólicos (50 a $80 \%$ ). A causa desta diferença é o desenvolvimento de fácies deflacionares, exclusivo da associação dunas e lençóis, o que permite a introdução, nesta associação, de sedimentos erodidos do substrato de deposição eólica. Este corresponde em geral aos sistemas marinhos holocênicos antigos (indiferenciados). Deste modo, enquanto a única fonte imediata da associação mantiforme são os sedimentos praiais, o fornecimento sedimentar, no caso da associação dunas e lençóis parabólicos, divide-se entre praia atual e sedimentos marinhos holocênicos antigos. Evidência disto são as probabilidades de ajuste destes últimos (nos 10 e 11), baixas com relação à associação mantiforme $(20 \%)$ e elevadas com a associação dunas e lençóis (50 a $70 \%)$.

As fácies praial do sistema barra-barreira atual (nos 14 e 15) apresenta probabilidades de ajuste estatístico mais altas com fácies correspondente do sistema planície costeira. Este bom ajuste pode ser atribuido a semelhança e contemporaneidade de processos deposicionais, sob áreas-fontes comuns. A probabilidade máxima ( $99 \%$ ) só é atingida quando se comparam as duas assembléias de antepraia entre si, o que pode ser atribuido a possivel homogeneização dos dois sistemas em direção à plataforma continental submersa. Há também algum ajuste entre a fácies praial do sistema barra-barreira e sua planicie holocênica antiga ( $p$ entre 20 e $50 \%$ ). 
A fácies praial do sistema planicie costeira atual (nos 12 e 13) possui bom ajuste $(p=80 \%$ ) quando confrontada com o sistema planície costeira holocênico antigo. Com base na comparação dos valores de $p$, o fornecimento de sedimentos preexistentes do sistema para a praia atual aparenta ser mais efetivo no sistema planicie costeira que no barra-barreira.

Os sistemas planicie costeira e barra-barreira holocênicos indiferenciados ( $n^{\circ} 10$ e 11) não possuem bons ajustes com nenhum dos sistemas ou associaçōes de idade seguramente anterior (figuras 4.3 e 4.4). Atribui-se este fato à complexidade de fontes primárias e secundárias influindo na formação de ambos. Considerando-se correta a hipótese anteriormente proposta de que a associação baíalaguna foi mais influenciada por aporte de depósitos eólicos das gerações 2 e $2 \mathrm{~A}$ de que a associação baixio-laguna é esperado que esta influência se reflita também no sitema barra-barreira adjacente. Em certo grau, a hipótese é confirmada, pois as únicas probabilidades de ajuste maiores que $10 \%$ entre sistemas marinhos holocênicos antigos e depósitos preexistentes ocorrem exatamente nos confrontos entre barra-barreira e as gerações eólicas 2 e $2 \mathrm{~A}$

O ajuste estatístico entre a assembléia mineralógica do sistema barra-barreira holocênico antigo e a associação de fácies dunas e lençóis parabólicos, geração 3 , atinge $80 \%$ de probabilidade. Há incertezas quanto ao intervalo de tempo de deposição dos sedimentos comparados, o que dificulta a inferência do significado preciso deste ajuste na interpretação de proveniência. As dunas e lençóis da geração 3 apresentam ainda probabilidades de ajuste de mesma ordem de grandeza com as geraçōes 2 e $2 \mathrm{~A}$. Elas ocorrem preferencialmente nas mesmas áreas de afloramento destas duas gerações mais antigas e são vistas recobrindo ou retrabalhando depósitos da geração 2 . O bom ajuste indica portanto, neste último caso, uma relação direta de proveniência, e diferenças sutis de mineralogia devem-se à ação preferencial da dissolução pós-deposicional nas geraçōes mais antigas. A diferença de idade da barra-barreira holocênica com relação a geração eólica 3 é seguramente menor que com a geração 2 e mesmo efeito de dissolução preferencial é supostamente reduzido. É muito provável portanto que o ajuste entre barra-barreira e geração 3 deva-se a contemporaneidade aproximada sob influência de fonte imediata comum (gerações eólicas 2 e $2 A$ ).

As diferentes associações de fácies eólicas das geraçōes $2 \mathrm{Ae}$ 2 (nos. 3 a 6) apresentam entre si, com poucas exceções, probabilidades de ajuste muito altas (figuras 4.5 e 4.6). Sua fonte sedimentar imediata são os sedimentos marinhos pleistocênicos, com os quais estabelecem ajustes estatisticos a mais de 95 $\%$ de confiança. Mais baixa é a probabilidade de ajuste entre estes sedimentos marinhos e a geração eólica $1(80 \%)$, o que pode ser atribuído à grande influência de fontes primárias (granitóides), através de enxurradas e movimentos de massa, na deposição da geração 1 . Cabe destacar que esta geração só ocorre preservada sob a forma de dunas de topo de encosta (item 5.4.2.2), em contato direto com o embasamento cristalino, dai seus ajustes estatísticos elevados com rochas-fontes primárias (tabela 4.1). 


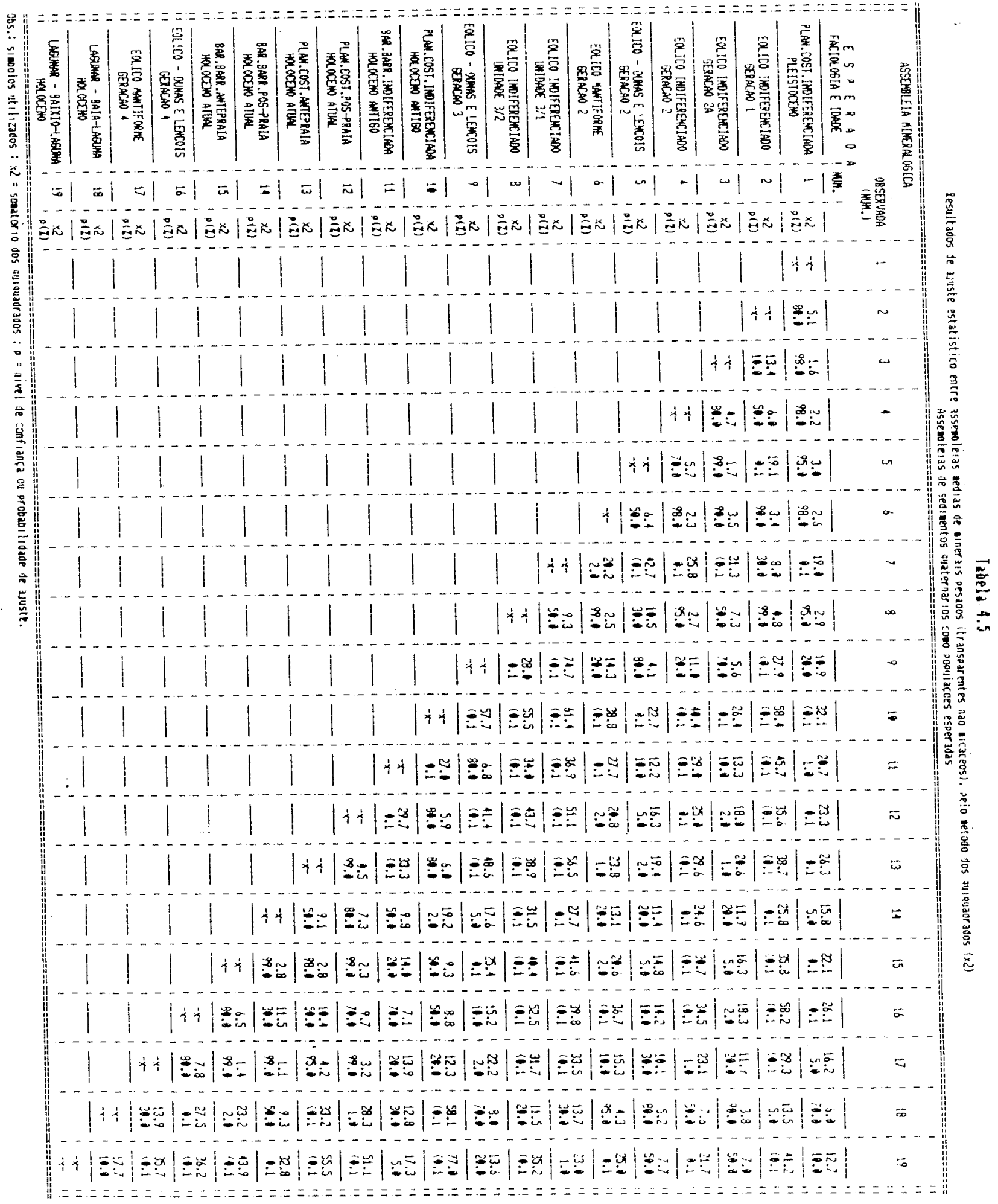




\section{HISTOGRAMA DE MINERAIS PESADOS}

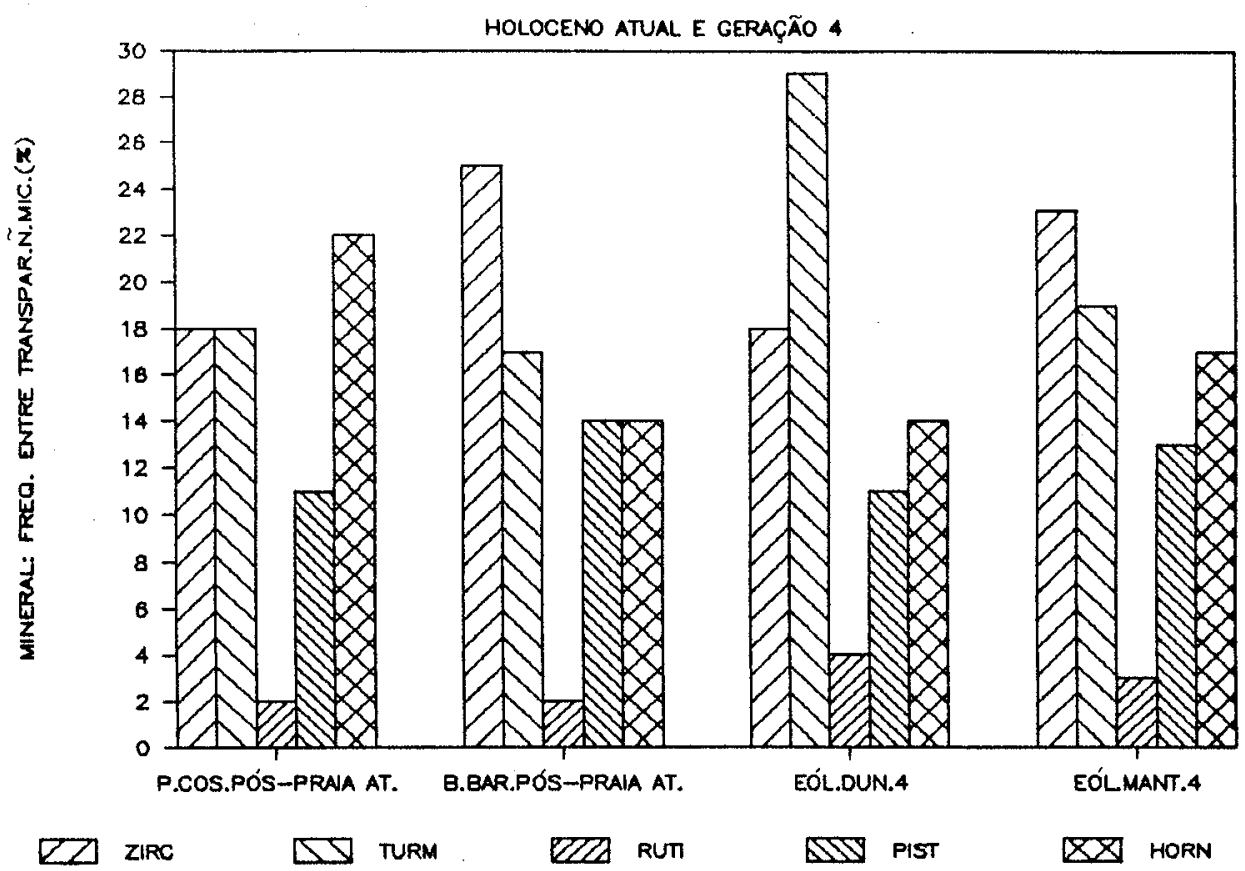

HISTOGRAMA DE RAZÕES MINERALÓGICAS HOLOCENO ATUAL E GERAÇÃO 4

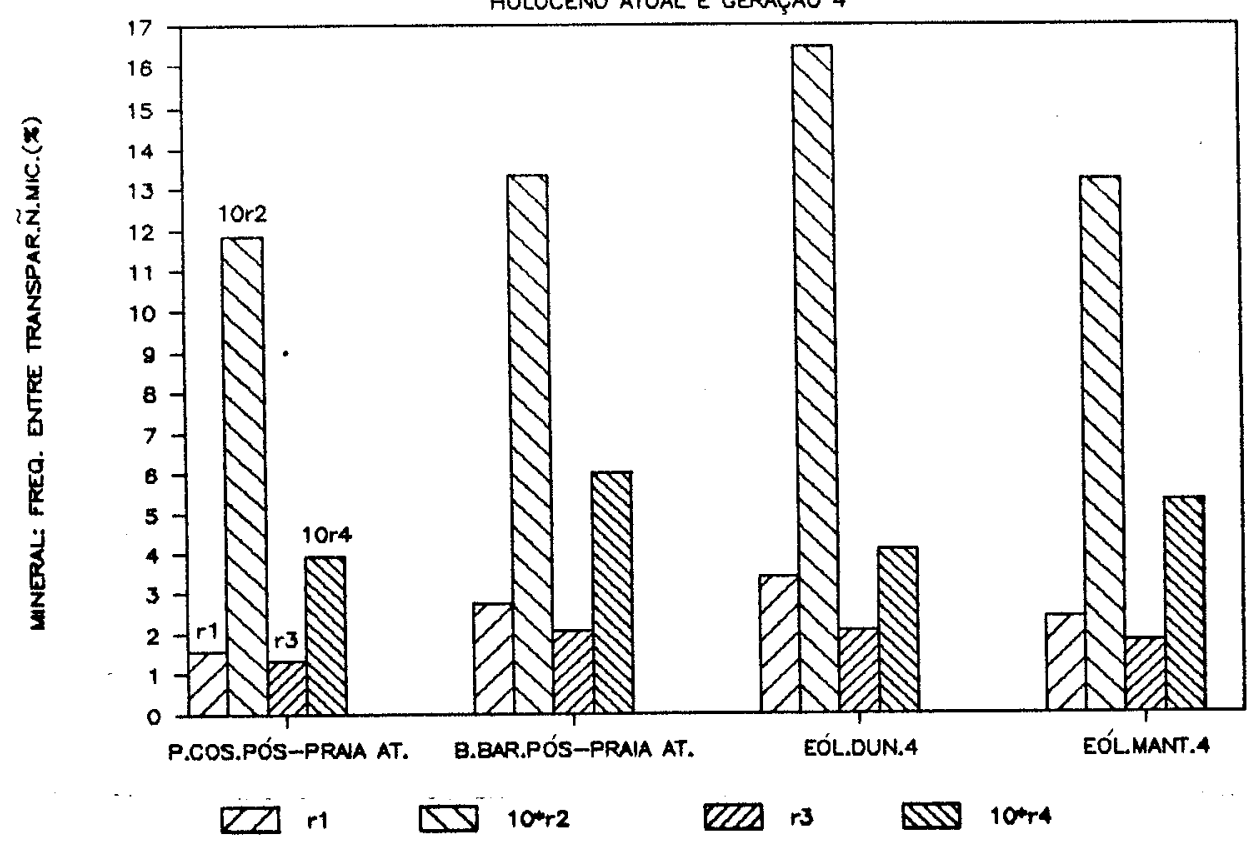

Figuras 4.1 e 4.2. Comparaçăo entre sistemas deposicionais e associaçőes de fácies pertencentes ao Holoceno atual ou a geraçăo 4.

4.1 (superior). Histograma de frequências percentuais médias de minerais pesados.

4.2 (inferior). Histograma.de razóes mineralógicas médias. 
HISTOGRAMA DE MINERAIS PESADOS
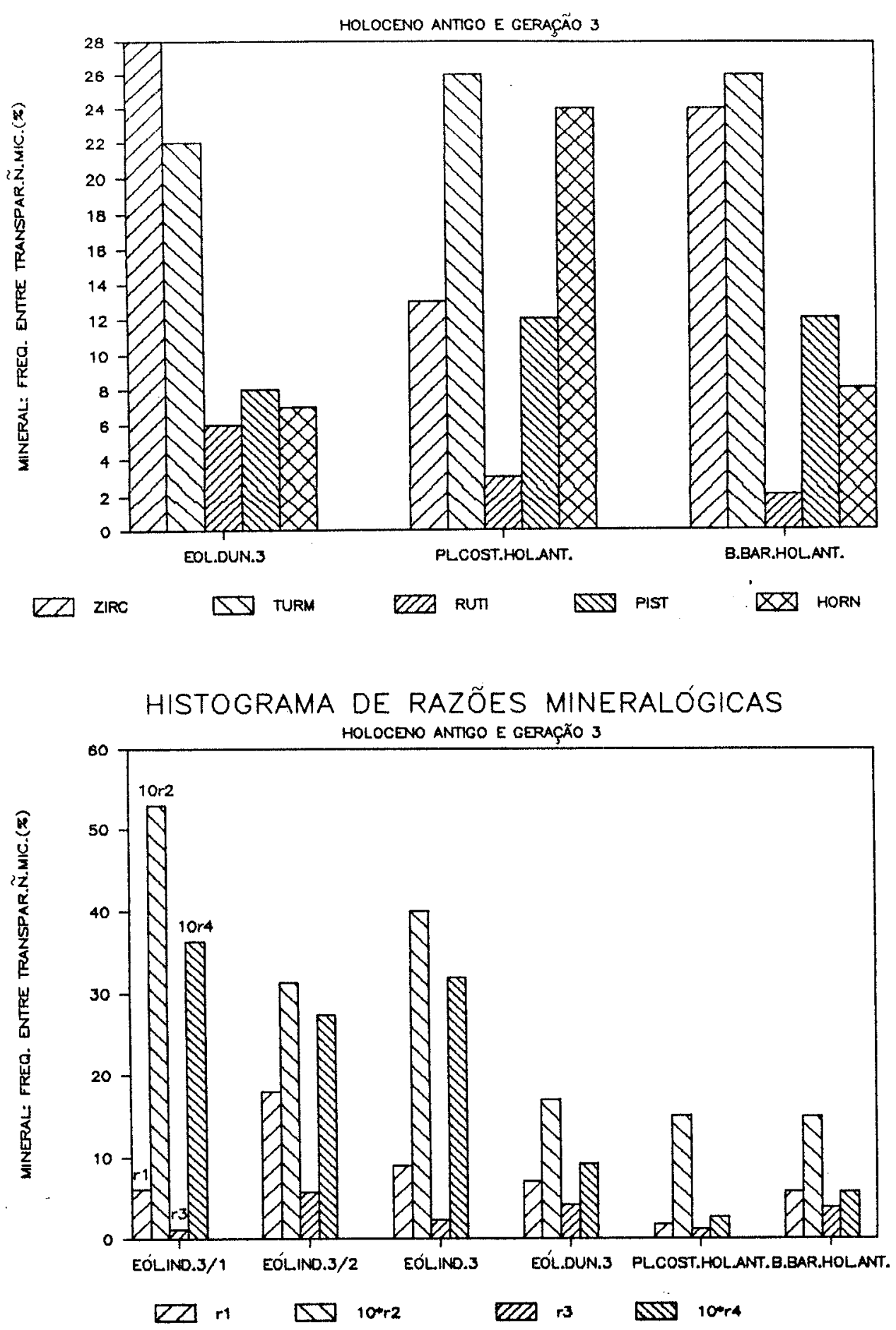

Figuras 4.3 e 4.4. Comparaçăo entre sistemas deposicionais e associaçōes de fácies pertencentes ao Holoceno antigo, geraçăo 3 ou unidade 3.

4.3 (superior). Histograma de frequéncias percentuais médias de minerais pesados.

4.4 (inferior). Histograma de razóes mineralógicas médias. 

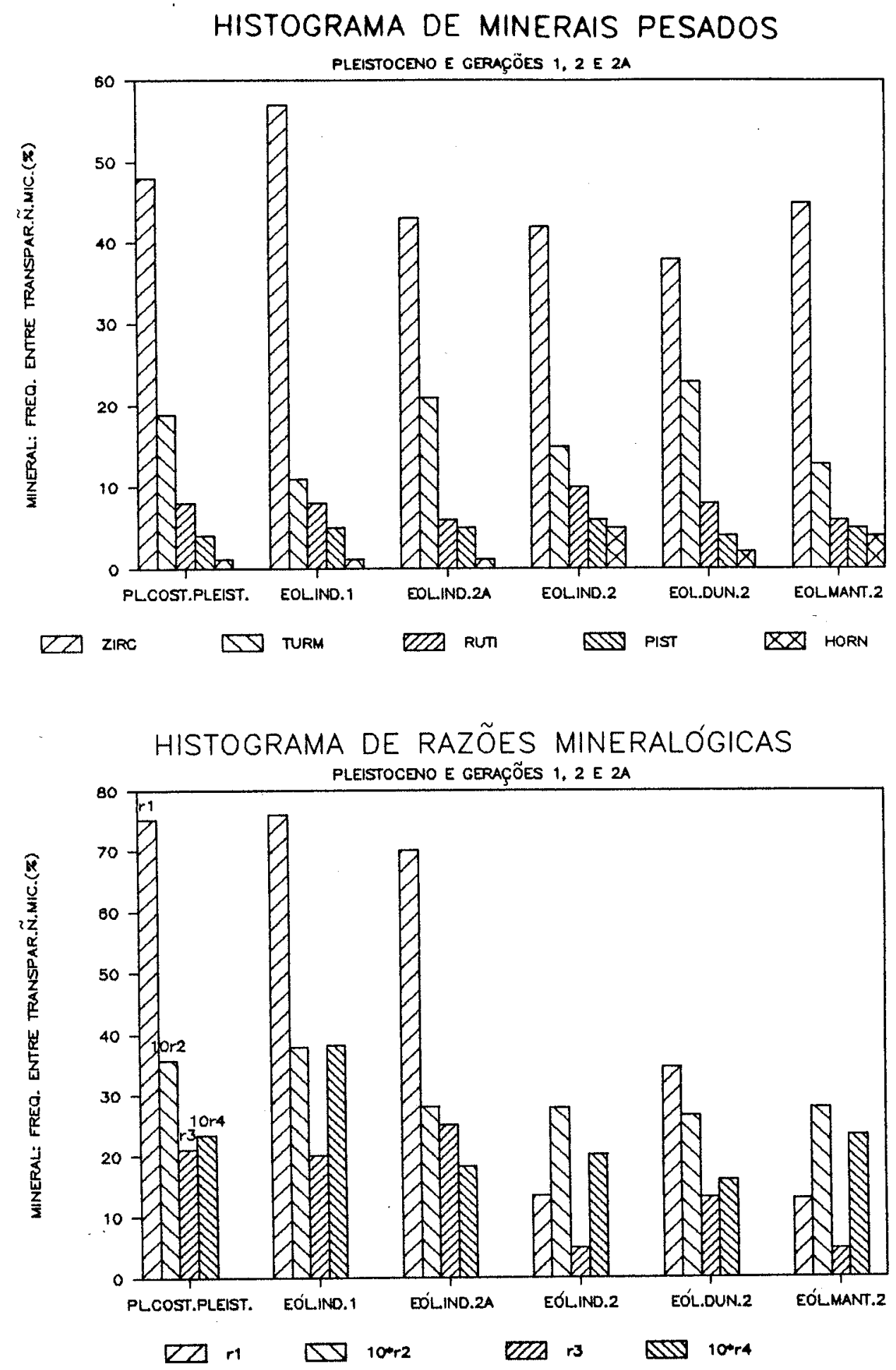

Figuras 4.5 e 4.6. Comparaçăo entre sistemas deposicionais e associaçðes de fácies pertencentes ao Pleistoceno ou geraçðes 1,2 e $2 A$.

4.5 (superior). Histograma de freqüências percentuais médias de minerais pesados. 4.6 (inferior). Histograma de ražes mineralógicas médias. 


\subsubsection{INTRODUÇÃO}

Enquanto sistemas litodinâmicos abertos, os sistemas deposicionais são sujeitos a mútuas entradas e saídas de sedimentos, cujo saldo é controlado por fatores reguladores (Gregory 1985). Estes fatores dizem respeito ao modo de operação de um sistema em relação a seus sistemas vizinhos e a condições macroambientais como clima, NRM e tectônica (figura 4.7). Eles podem ser traduzidos sob a forma de leis de interação sistema-meio, as "leis de construçãodestruição" ou "leis de morfologia dinâmica" de Bertalanffy (1972), das quais são exemplos em sedimentologia costeira o principio de Bruun (1962), os princípios de Short \& Hesp (1982) e vários outros previamente examinados neste texto (item 2.2.4).

Os sedimentos introduzidos num sistema deposicional podem ser submetidos a dois tipos de mecanismos de seleção: um durante sua entrada no sistema, sob influência dos fatores reguladores; outro no interior do sistema, sob efeito de fatores intempéricos e hidrodinâmicos peculiares a suas condições faciológicas (Shuisky \& Schwartz 1983). Isto implica em mudanças nas características dos materiais fornecidos ao sistema, como no volume, na distribuição granulométrica, na distribuição densimétrica e nas proporções entre espécimes de minerais pesados (Shuisky \& Schwartz 1983). As mudanças nestas características refletem as peculiaridades faciológicas do sistema; as características em si são objeto de investigação importante em sua descrição interna, enquanto as mudanças representam o tema de sua descrição externa. Mudanças de volume da entrada de sedimentos, consideradas em balanço com as saidas ocorridas em período equivalente, determinam os saldos, isto é, relaçōes de deposição ou erosão, materializadas no aparecimento ou desaparecimento de singularidades deposicionais. Entradas, saídas e saldos dos quatro sistemas deposicionais são sumariados em seguida, com objetivo de esboçar o modo de operação de cada sistema. Para isto, são tomados como referenciais os sistemas em sua condição ativa, atual. 


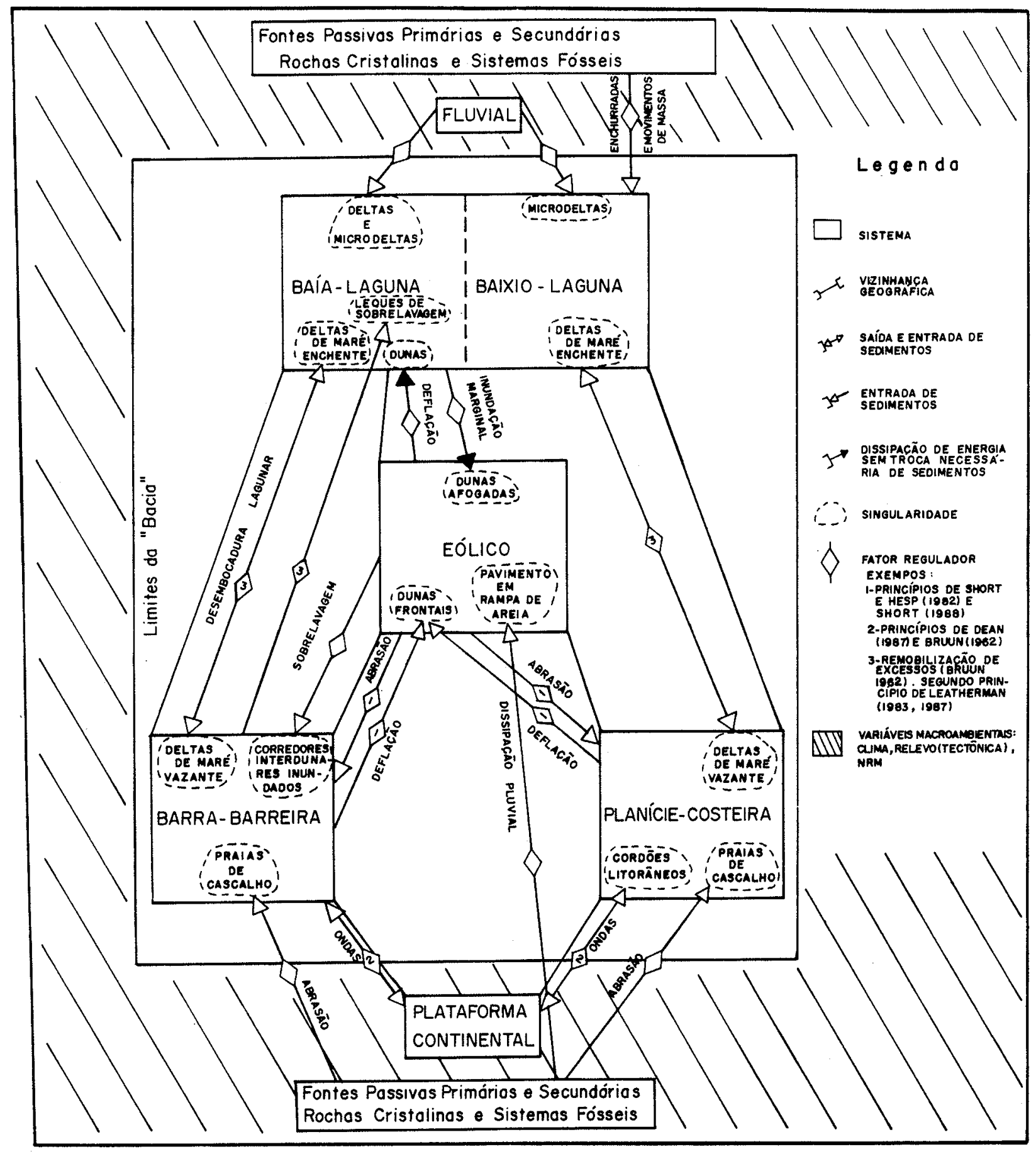

Figura 4.7. Esboço de um modelo gráfico para a interaçăo entre sistemas deposicionais ativos na área em estudo, utilizando a representaçăo sistêmica clássica. Terminologia e simbologia baseada em Chorley \& Kennedy (1971), Bertalanffy (1972) e Gregory (1985). 


\subsubsection{SISTEMA PLANÍCIE COSTEIRA}

As seguintes entradas podem ser enumeradas com referência à operação do sistema planície costeira: (1) sedimentos erodidos de escarpas costeiras por abrasão de ondas, incluindo dunas frontais e lineares transversais, sistemas deposicionais fósseis e rochas cristalinas; (2) sedimentos trazidos de pequenos cursos de água e canais de maré; (3) sedimentos fluviais e lagunares transportados com participação de correntes de maré vazante na desembocadura de Entrada da Barra e no arroio Paes Leme (figuras A10 e A16); (4) grãos trazidos em suspensão e carpetes de tração (figura 4.8) por ventos rumo costa afora; (5) materiais terrígenos e bioclásticos transportados à praia pela saca ("swash") de ondas normais e de tempestade. Entre as várias modalidades de saidas de sedimentos podem ser destacadas: (1) sedimentos conduzidos ao sistema lagunar por meio de correntes de maré enchente atuantes na desembocadura de Entrada da Barra e no arroio Paes Leme; (2) sedimentos de pós-praia seca levados para o sistema eólico por ventos rumo ao interior; (3) materiais em suspensão carreados para o sistema plataforma continental por correntes sagitais ("rip currents") e ressaca ("backwash") de ondas.

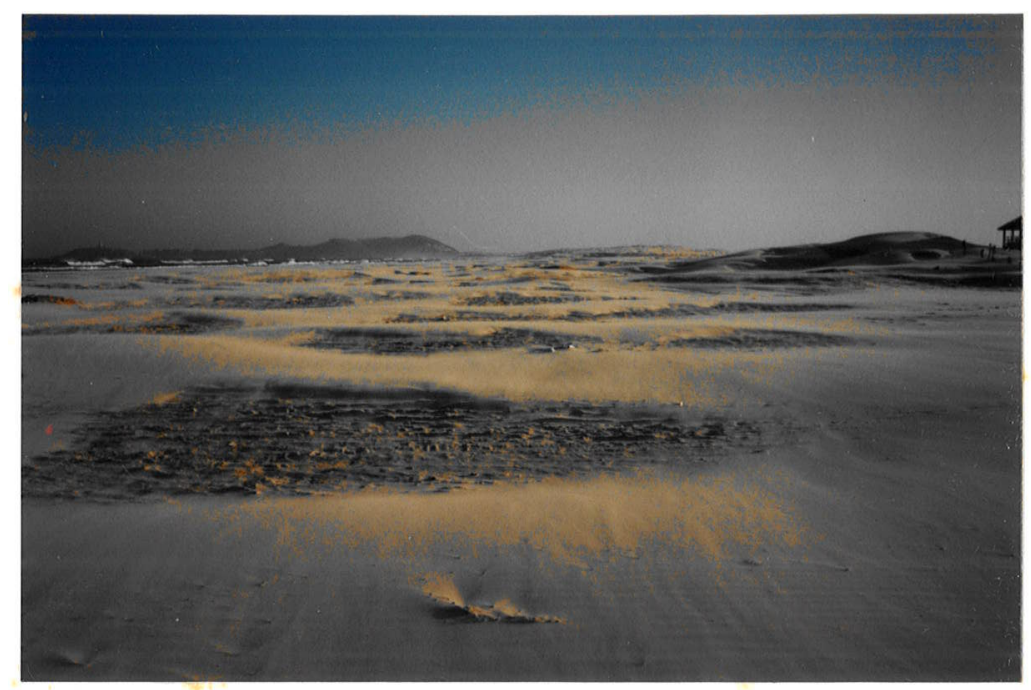

Figura 4.8. Carpete de tração na praia de Santa Marta Pequeno.

Saldos deposicionais no sistema planície costeira podem materializar-se no aparecimento de singularidades como tômbolos, barras submersas e cordões litorâneos. De fundamental importância no desenvolvimento e na configuração destas feições é o balanço de forças entre correntes de deriva longitudinal e transversal (Shuisky \& Schwartz 1983), determinando respectivamente a manutenção ou dispersão de sedimentos no sistema. Este balanço depende da morfodinâmica da praia, do comportamento do NRM e, em última análise, da combinaçäo de fatores reguladores (figura 4.7). A curto prazo, os fatores reguladores em um sistema costeiro de mar aberto são relacionados em essência a um dipolo de energia e matéria, ou seja, a energia de onda e o aporte sedimentar (Wright et al. 1979). Conforme observado por Shuisky \& Schwartz (1983), mudanças no volume de sedimentos da zona costeira promovem mudanças correspondentes na 
energia de onda dissipada. Nas fases em que o suprimento sedimentar à costa submersa cresce, por ação de algum fator regulador qualquer tal como após uma elevação de NRM, mais energia de onda é gasta no transporte de novos sedimentos colocados em circulação e menos em abrasão na praia exposta. Isto cria um saldo favorável à deriva longitudinal (mantendo os sedimentos no sistema costeiro), em comparação com a dispersão transversal para sistemas vizinhos. Processos de acumulação começam a prevalecer, favorecendo a formação de singularidades deposicionais, por exemplo, cordões litorâneos progradantes. A deposição destas singularidades mantém-se enquanto não for reatingido o equilibrio ondas versus aporte ou deriva transversal versus longitudinal, de acordo com o princípio de retroalimentação. Deve-se ressaltar que se o sistema estiver sob regime de uma evolução espontânea em atraso, como o principio de Bruun, no caso, a reaquisição daquele equilíbrio pode ser dificultada, prolongando e/ou intensificando o saldo positivo de sedimentos.

\subsubsection{SISTEMA BARRA-BARREIRA}

A operação do sistema barra-barreira guarda grandes semelhanças com a do sistema planície costeira, apesar de a desembocadura lagunar do Camacho ser de natureza distinta em relação à desembocadura de Entrada da Barra (itens 3.2.2.4 e 4.2.4). Um aspecto particular na dinâmica da barra-barreira é a presença temporária de pequenos canais de sobrelavagem ou ruptura de barreira ("washover channells" ou "breakthroughs"). Estes configuram canais de transferência de sedimentos entre as fácies praiais do sistema barra-barreira e os sistemas eólico e lagunar. Sua ativação suscita o aparecimento de singularidades deposicionais representadas por lagos ("ponds") digitiformes e leques de sobrelavagem (item 5.1.2.1).

Outro canal de transferência essencial na dinâmica da barrabarreira é a própria desembocadura lagunar do Camacho. Em sistemas transgressivos, a desembocadura é um dos meios fundamentais de migração de sedimentos de mar aberto rumo à face lagunar do sistema, o que possibilita o processo de migração da barra-barreira descrito por Leatherman (1983, 1987). Em sistemas regressivos, como se supõe seja o da área em estudo, o efeito de molhe e de suprimento exercido pela desembocadura interfere nas correntes de deriva longitudinal e, por extensão, na progradação da costa. A desembocadura é, além disso, essencial na manutenção da associação de fácies baía-laguna. Por esta razão, outros aspectos da dinâmica do canal Camacho e, em particular, seus ciclos de abertura, fechamento e migração são discutidos dentro do próximo item, referente ao sistema lagunar. 


\subsubsection{SISTEMA LAGUNAR}

\subsubsection{Considerações gerais}

Entradas de sedimentos no sistema lagunar ocorrem através de diversos mecanismos, entre os quais se podem enumerar: (1) enxurradas e movimentos de massa nas encostas cristalinas a oeste do sistema, aportando lamas e detritos areno-cascalhosos, em particular na associação de fácies baixio-laguna; (2) assoreamento de margens lagunares por leques de avalancha seca ou úmida em areias de paleodunas erodidas ou localmente reativadas pela ação antrópica: fenômeno observado na face leste da lagoa Imaruí; (3) aporte de sedimentos fluviais pelos rios d'Una, Aratingaúba e Tubarão; (4) ação transportadora de correntes de maré enchente na parte interior de desembocaduras lagunares; (5) reativação temporária de distributários abandonados do rio Tubarão, tal como o rio da Guarda durante períodos de grande descarga fluvial; (6) rompimento e/ou sobrelavagem do sistema barra-barreira; (7) inundação e erosão dos sistemas barra-barreira (holocênico antigo) e eólico (ativo ou inativo) vizinhos, como na margem sul da laguna Garopaba do Sul.

Dentre os processos de saída de sedimentos, podem: ser destacadas as correntes de maré vazante na porção exterior de desembocaduras lagunares e o fornecimento de areia em suspensão aérea para o sistema eólico. As principais singularidades deposicionais formadas como decorrência de saldo positivo no sistema lagunar são os deltas interiores, as planícies lagunares com resíduos de dunas erodidas por afogamento e os "deltas" ou barras de maré em geral. Mudanças de posição e configuração nos "deltas de maré" do canal Camacho, e possivelmente mesmo sua formação inicial, podem ser atribuidos a efeitos erosivo-deposicionais bruscos, induzidos por episódios em sua maioria associados a ciclos de abertura e fechamento da desembocadura lagunar. A complexidade dos processos que interagem na estabilidade de desembocaduras lagunares originadas por ruptura de barreira, como o canal Camacho, e a dramaticidade de seus efeitos, tornam de especial interesse o seu tratamento sistêmico mais minucioso (Webb et al. 1989), como o que segue.

\subsubsection{Dinâmica do canal Camacho}

Informações históricas sobre a dinâmica do canal Camacho (figura A7) são esparsas e baseiam-se principalmente no relato de moradores. Pimienta (1958) descreve a região de Camacho como "zona de maior fraqueza" da barreira e faz referência a sua abertura temporária, após "tempestade excepcional" em 1927. Esse ano coincide com uma das enchentes históricas no vale do rio Itajaí (Radambrasil-IBGE 1986c), normalmente acompanhadas por efeitos semelhantes no delta do rio Tubarão. Após 1927, o canal permaneceu predominantemente aberto pelo menos até a metade da década de 1930. Uma vez fechado, é provável que não tenha voltado a se abrir, por periodo duradouro, até o início da década de 1970. Neste intervalo de tempo, registram-se no litoral catarinense apenas duas enchentes de vulto, as de 1957 e 1961 (Radambrasil-IBGE 1986c). Nas aerofotografias de 1952, o canal aparece bloqueado por dunas eólicas em toda sua extensão. 
Em 1972, ano "El Niño", com inundações no leste catarinense, - canal não se abriu. Não resistiu, entretanto, ao efeito cumulativo de chuvas e tempestades costeiras associadas no ano seguinte, quando manteve-se ativo por alguns meses. Voltou a abrir-se em março de 1974, período de pluviosidade anômala no vale do rio Tubarão (Bigarella \& Becker 1975b), assim permanecendo por seis anos e oito meses. Sua última fase de abertura teve duração de apenas seis meses; iniciou-se em julho de 1983, durante a mais intensa manifestação do fenômeno "EI Niño" no século (Arantes 1992), o qual modificou ao mesmo tempo a dinâmica de desembocaduras lagunares em outras regiões do globo (Webb et al. 1989). Durante o "El Niño" moderado de 1992, o sistema barra-barreira foi afetado por inundações marinhas e pluviais; observaram-se erosão da cobertura eólica e redução na largura da barreira, a qual, no mês de maio, chegou a atingir menos de $60 \mathrm{~m}$ (figura 4.9). A formação de inúmeros corredores de inundação interdunares (item 5.1.2.1; figura 5.62) distribuiu a pressão ao longo da barreira e contribuiu para evitar a reabertura do canal.

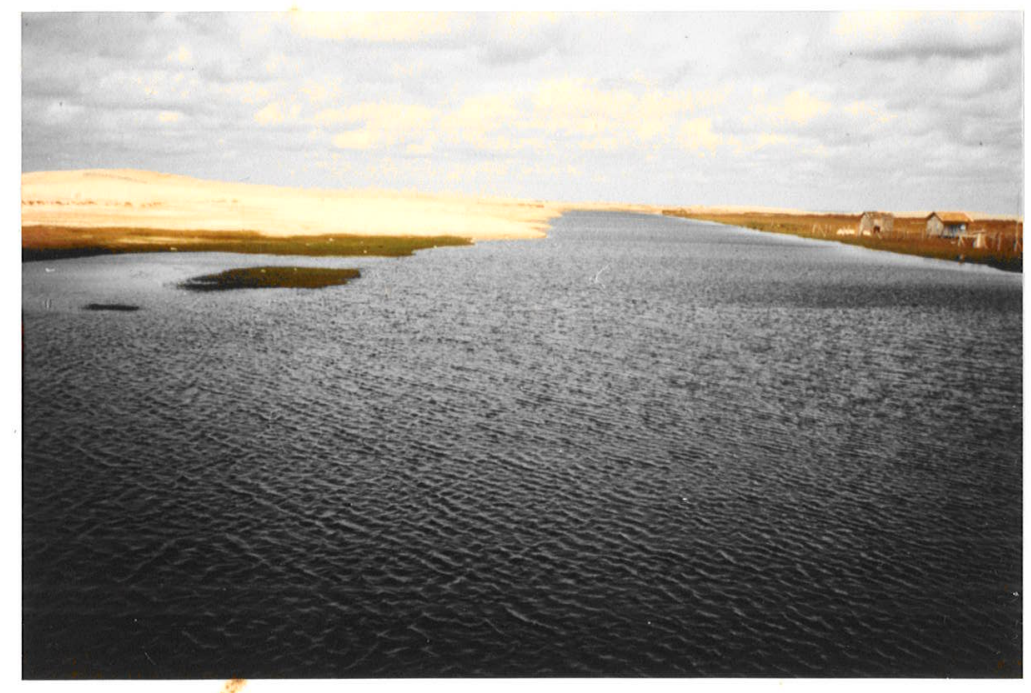

Figura 4.9. Canal Camacho bloqueado por dunas lineares e barcanóides. Praia da Cigana ao fundo.

A desembocadura lagunar do Camacho pode ser encarada como canal de transferência através do qual dois sistemas deposicionais vizinhos, o lagunar e o barra-barreira, realizam intercâmbio de sedimentos e energia. Sob este enfoque, as variáveis de estado que controlam a dinâmica da desembocadura dividemse em três grupos interatuantes, conforme se refiram ao sistema barra-barreira, ao sistema lagunar ou ao próprio canal, com seu caráter de fácies de transição entre sistemas. As principais variáveis do sistema barra-barreira relacionam-se à deriva litorânea induzida por ondas; em seu aspecto potencial, esta deriva refere-se às características físicas das ondas; em seu aspecto efetivo, inclui também a disponibilidade de sedimentos, a morfologia da costa e a irregularidade das ondas, isto é, freqüência e intensidade de tempestades costeiras. Mantidas outras variáveis, quanto mais intensa e irregular a deriva e quanto maior a disponibilidade de sedimentos, maior é a tendência para assoreamento da desembocadura lagunar (Bruun 1978). Nessas condições ocorre transporte de sedimentos costeiros de um lado a outro da desembocadura ("by-passing"), pela ação combinada de deriva litorânea e maré vazante. Os sedimentos em trânsito podem formar bancos arenosos 
às margens e à frente da seção oceânica do canal, e favorecer seu fechamento gradual. Este aspecto é visível no Camacho nas aerofotografias de 1977/79. Os eventos de bloqueio final da desembocadura do Camacho possuem entretanto caráter episódico, dada sua coincidência com marés altas de tempestades. Há dois tipos de efeitos pelos quais as tempestades provocam o fechamento do canal. O primeiro é o deslocamento dos bancos de areia externos à desembocadura ("deltas de maré vazante") em direção às suas seções mais interiores, as quais sofrem constrição. O segundo efeito é a criação de novos canais de ruptura, sob a forma de alagamento de corredores interdunares; a pressão de inundação pela maré enchente torna-se assim melhor distribuida entre os vários canais, de modo que a força erosiva capaz de manter aberto o canal original se enfraquece. Conforme descreve Bruun (1978), o resultado mais comum nessas situações é que nenhum canal, inclusive o principal, permanece aberto

As variáveis da dinâmica da desembocadura referentes ao sistema lagunar são aporte de sedimentos fluviais, volume do reservatório e intensidade das correntes de maré enchente. O volume do reservatório é controlado por uma série de outras variáveis como escoamento superficial ("run-off"), evaporação e precipitação diretas, migração de água pela porosidade da barreira e regime de marés. Aporte sedimentar intenso ao interior da laguna, através de rios ou correntes de maré enchente, diminui a profundidade e área emersa do sistema lagunar e favorece assim o seu fechamento. Aumentos no escoamento superficial $\theta$ na precipitação direta ou diminuição na migração de águas intersticiais elevam o volume de água no sistema lagunar durante marés enchentes e a pressão exercida pelo reservatório sobre a barreira. Esta pressão, acima de certos limites, possibilita o rompimento episódico da barreira através da erosão tixotrópica de areias saturadas em água (abaixo do lençol freático) pelo embate das ondas. De acordo com Lankford (1977), o escoamento superficial é, a curto prazo, a variável mais influente na dinâmica de abertura do canal. Sua importância é evidente no exemplo do canal Camacho, onde os episódios de rompimento da barreira coincidem em geral com grandes enchentes na bacia hidrográfica do rio Tubarão. A instabilidade e sazonalidade irregular da desembocadura do Camacho relaciona-se com as dimensões relativamente reduzidas e com seu escoamento superficial de caráter esporádico. Contribui para sua tendência ao fechamento a localização assimétrica do canal em relação ao reservatório Garopaba do Sul - Camacho. Segundo Bruun (1978), o rompimento original da barreira para formação da desembocadura lagunar tende a ocorrer sempre no "centro hidráulico" do reservatório; no entanto, mesmo sendo esta a posição mais favorável a sua estabilidade, o canal com freqüência migra em seguida no rumo de sotamar. Esta descrição aplica-se possivelmente ao canal Camacho, o qual teria surgido em sua posição ótima, no meio do reservatório (a sudoeste de sua posição atual), deslocando-se em seguida, devido a desativação do rio da Guarda e à deriva longitudinal rumo NE. O caráter composto do pontal lagunar de Aroeira (figura A7), a oeste de Camacho, é uma evidência de que este pontal não se formou apenas por efeito de ondas lagunares propagando-se em direção longitudinal à laguna, conforme o modelo clássico de Zenkovitch (1967), mas que houve também deslocamento de uma fonte externa (marinha) de sedimentos ao longo da margem lagunar antebarreira. Com a restrição do reservatório lagunar de Camacho devida ao crescimento do pontal, a pressão na barreira deve ter caído ainda mais, aumentando assim a irregularidade nos ciclos de abertura do canal. 
O terceiro grupo de variáveis na dinâmica da desembocadura lagunar inclui morfologia e quantidade de canais, comprimento e seção transversal de cada um deles e intensidade das correntes que os atravessam, função da amplitude de maré. Com base nestas variáveis, define-se o prisma de maré ("tidal prism"), quantidade total de água que entra ou deixa a laguna através da desembocadura por unidade de tempo. A redução do prisma de maré favorece o fechamento da desembocadura; ela acontece devido a deposição de bancos arenosos móveis ou fixos no interior da desembocadura, por três tipos de mecanismos naturais: prolongamento do canal; aporte de areias marinhas para o interior durante tormentas severas; e subdivisão do canal principal ou formação de novos canais (Bruun 1978). O prolongamento do canal é uma tendência evolutiva natural em desembocaduras formadas por ruptura de barreira, como a do Camacho, devido a transferência gradual de sedimentos de fundo e margens para os bancos arenosos nas seções lagunar e oceânica do canal.

Somadas todas estas variáveis, fechamento e abertura da desembocadura lagunar do Camacho podem ser entendidos como duas situações de equilíbrio metaestável na interação laguna/barra-barreira. O limiar entre elas é representado por um evento de erosão-deposição abrupto. Tomando como ponto de partida a desembocadura ausente, uma elevação sincrônica de energia nos dois sistemas (enchentes flúvio-lagunar mais ondas de tempestade) acima de certos limites provoca uma erosão episódica no sistema barra-barreira seguida de deposição episódica no sistema lagunar, sob a forma de bancos de areia do tipo "delta de maré enchente". A ordem faciológica no sistema favorecido pela deposição aumenta, em compatibilidade com um estado de maior dissipação de pressão e energia. Se esta energia abaixa de modo substancial, devido a uma queda prolongada no escoamento superficial da laguna e/ou da atividade de ondas e maré enchente, o antigo estado de fechamento tende a ser recuperado. O bloqueio final também é episódico, com o sistema barra-barreira retendo energia e matéria associadas a tempestade costeira sob baixo escoamento continental.

A dinâmica da desembocadura do Camacho não teve até hoje a interferência direta do homem. Algumas tentativas de construção de diques artificiais na margem sul do canal foram iniciadas, a última delas em 1991, mas nunca concluidas. Apesar disto, acredita-se que a influência indireta da atividade agrícola no delta do rio Tubarão, intensificada nas últimas décadas, esteja tornando os episódios de abertura do canal mais raros e efêmeros, como indica a retrospectiva histórica. Isto ocorre devido à distribuição artificial da vazão líquida dos distributários para a irrigação dos campos de cultura do arroz, o que reduz o aporte sazonal direto às lagunas Garopaba do Sul e Camacho.

\subsubsection{Dinâmica do canal Entrada da Barra}

Na desembocadura lagunar de Entrada da Barra (figura A10), nem as mudanças de posição, nem a ciclicidade de abertura e fechamento têm sido observadas. A manutenção do canal aberto é antes decorrência natural de seu caráter de estreito, que efeito da presença de molhes (figura 4.10), cujo início de construção remonta ao século passado. O efeito dos molhes, pelo contrário, aparenta ser de assoreamento gradativo do canal. Eles canalizam as correntes rumo ao mar (maré vazante mais descarga flúvio-lagunar) até profundidades além da zona de 
arrebentação das ondas. Induzem, deste modo, dois efeitos contrários na hidrodinâmica costeira local, um favorável à abertura da desembocadura e outro a seu assoreamento. O primeiro efeito deve-se ao confinamento do canal, tendendo a aumentar o poder erosivo das correntes transversais à costa; deve-se também ao impedimento da integração direta dos sedimentos flúvio-lagunares nas correntes de deriva litorânea longitudinal, o que reduz o aporte ao principal agente de bloqueio da desembocadura (Emery \& Stevenson 1957; Lankford 1977; Dyer 1979). O segundo efeito relaciona-se à interrupção constante das correntes de deriva longitudinal, diminuindo a dispersão ("by-passing") dos sedimentos trazidos pelas correntes vazantes, os quais tendem então a assorear o canal; relaciona-se também ao prolongamento artificial da desembocadura para além de seu "comprimento de equilíbrio" (Bruun 1978). O efeito resultante a longo prazo depende do saldo sedimentar entre esses dois efeitos parciais antagônicos. A maior evidência de que este saldo é favorável ao assoreamento do canal é a perda de navegabilidade para embarcações de grande porte, devido à formação progressiva, no decorrer do século, de bancos de areia submersos. A intensidade das correntes de maré não é suficiente, portanto, paia a dispersão total dos sedimentos flúvio-lagunares não removidos pela deriva litorânea impedida. A pequena amplitude de maré e a reduzida profundidade e volume do corpo de água lagunar são determinantes.

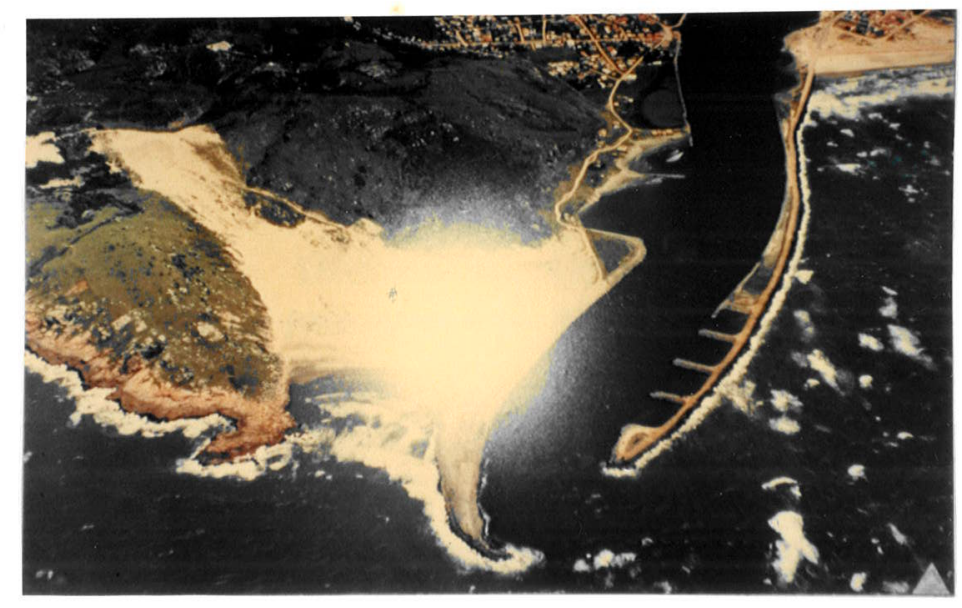

Figura 4.10. Vista aérea (obliqua) do canal Entrada da Barra, em sua seção oceânica. Notar rampa eólica à esquerda. (Foto Bacha, Laguna).

\subsubsection{SISTEMA EÓLICO}

No sistema eólico, a diversidade de entradas sedimentares é pequena quando comparada com demais sistemas deposicionais. Isto ocorre porque o agente que dá nome ao sistema age em mais ampla extensão espacial que os agentes sedimentares essenciais em outros sistemas como ondas e correntes de maré. Enquanto o sistema lagunar ou o barra-barreira estabelecem sede num espaço que é fixo em certa escala de tempo, ali recebendo a influência duradoura de entradas dos 
mais diversos sistemas vizinhos, o sistema eólico mantém-se em constante mobilidade, sem tempo para assimilar influências externas. Sob este aspecto, justificase o caráter de "sistema simples" que the atribui Fisher (1983). A característica de simplicidade nẳo se estende, porém, ao aspecto faciológico, como se verá na descrição interna do sistema (item 5.4.2). O motivo principal é que os saldos entre entradas e saídas determinam uma ampla gama de tipos morfológicos de dunas, os quais podem superpor-se ou deformar-se a diferentes hierarquias de escala. Dada a mobilidade do sistema, o mesmo agente que nele insere maior parte das entradas de matéria promove sua saída. O saldo e portanto o tipo de duna dependem desse equilibrio entre entradas e saídas por um só agente, de onde concluir que a disponibilidade de sedimentos nas áreas-fontes é essencial em sua determinação. $\mathrm{Na}$ prática, esta área-fonte é representada pelas fácies praiais nos sistemas barra-barreira e planicie costeira (item 4.1.2); deste modo, a morfodinâmica praial controla os tipos de fácies eólicas costeiras e suas associações, o que é um corolário dos princípios de Short \& Hesp (1982). O sistema eólico não recebe entradas pela ação de agentes típicos de outros sistemas, mas busca estas entradas através de seu próprio agente principal, nos sistemas vizinhos. O resultado é uma seletividade apurada de aporte sedimentar.

A maior exceção para a regra da entrada única nos sistemas eólicos da área em estudo são as dunas de topo de encosta, depósitos de menor mobilidade retidos por obstáculos rochosos e que, por isto mesmo, ficam mais expostos a entradas não eólicas. Enxurradas e movimentos de massa no regolito de rocha cristalina ou em dunas preexistentes inserem episodicamente quantidades relativamente grandes de lama e materiais grossos na superficie das dunas ativas locais. Uma das conseqüências é a perda de seletividade nesta fácies específica.

Entre as saídas de sedimentos do sistema eólico, pode-se citar, além do próprio vento, a erosão por águas de maré enchente em corredores interdunares, a destruição parcial ou total de dunas frontais pelas ondas (figura 5.66) e a erosão de dunas pelo escoamento superficial. 


\section{CAPITULO 5: DESCRIÇÃO INTERNA DOS SISTEMAS}

\subsection{SISTEMA BARRA-BARREIRA}

\subsubsection{IDADE RELATIVA}

Os sedimentos mapeados aqui como sistema barra-barreira (figura 5.1) foram atribuidos anteriormente ao Holoceno (Pimienta 1958; Suguio et al.1986; Martin et al.1988b). Esta interpretação é mantida neste trabalho face a duas evidências principais: a baixa altitude dos depósitos e o fraco grau de cimentação e dissolução pós-deposicional, manifestado inclusive por aspectos mineralógicos.

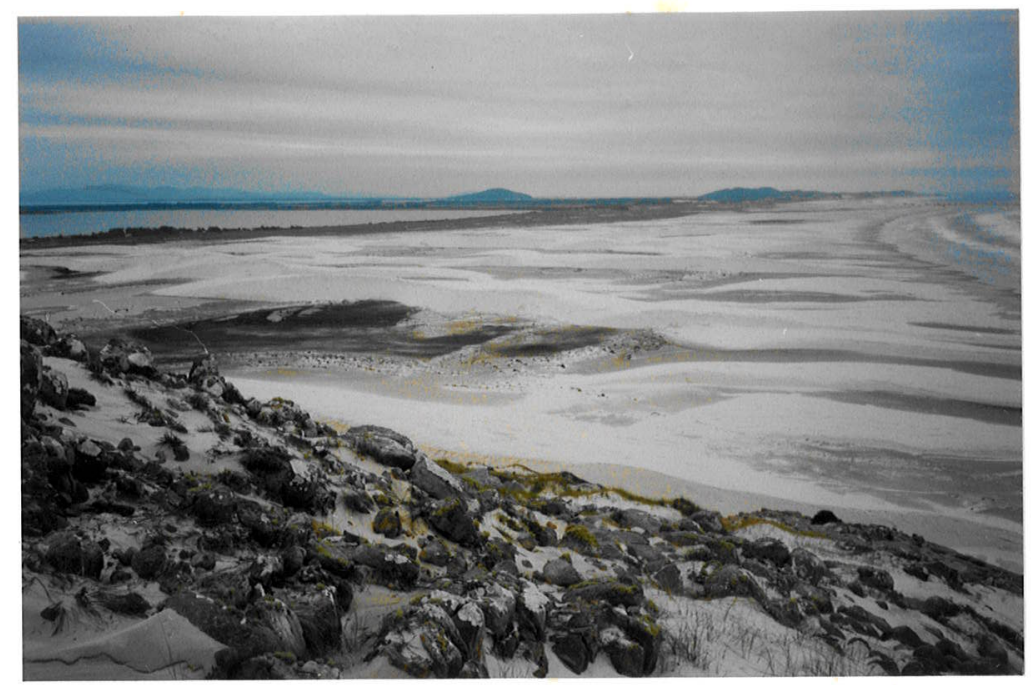

Figura 5.1. Vista panorámica do sistema barra-barreira a partir do flanco norte do cabo de Santa Marta Grande. Destacam-se a Praia Grande do Norte (à direita), a laguna Santa Marta (à esquerda), e dunas transversais lineares e barcanóides (no centro).

As altitudes na parte intermediária (entre as bordas marinha e lagunar) da barreira, indicadas na carta topográfica, variam entre 1 e $2 \mathrm{~m}$. Estes valores parecem corresponder a mínimas altitudes locais em zonas esparsas periodicamente alagadas por águas pluviais ou de maré. De qualquer modo as altitudes do sistema não ultrapassam $5 \mathrm{~m}$, mesmo considerando-se o topo de terrenos ligeiramiente ondulados pela ação eólica.

De acordo com o modelo genético de formação da barrasbarreiras holocênicas (Leatherman 1987; Tomaze!li 1990), pelo menos uma parte do sistema, a mais interna, deve ter sido formada durante fase transgressiva (anterior a 5100 anos A.P.). Não se têm informações suficientes para definir limites em mapa entre as barreiras transgressiva e regressiva. Resultados de datação em conchas coletadas no topo de três sambaquis situados cerca de $2,5 \mathrm{~km}$ a leste da lagoa Laranjal, e distantes da praia atual entre 500 m (S30B) e 300 m (S30E), variaram de 3780 a $4110 \pm 70$ anos A.P., respectivamente. Isto sugere que antes mesmo do 
segundo máximo transgressivo holocênico, pelo menos dois terços da barreira (em largura) já se encontravam depositados.

\subsubsection{PADRÃO FISIOGRÁFICO}

O modelo de hierarquia e distribuição de fácies para o sistema barra-barreira encontra-se esquematizado na tabela 5.1. Detalhes sobre o padrão em mapa de arranjo de fácies são ilustrados nas figuras $A 1, A 4, A 5, A 7, A 8$ e A9. Seguemse alguns comentários sobre as principais unidades faciológicas reconhecidas.

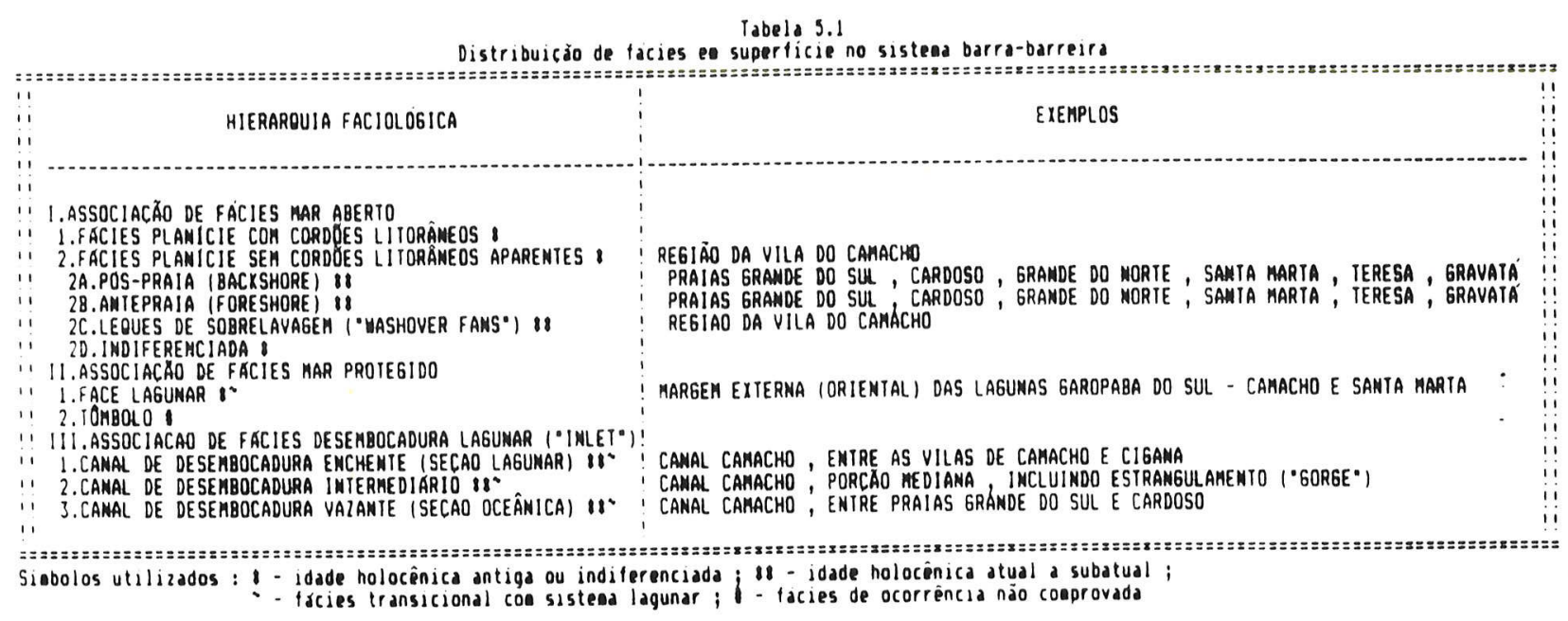

\subsubsection{Leques de sobrelavagem}

Leques de sobrelavagem ou crevassa de barreira ("washover fans") foram inicialmente reconhecidos em fotografias aéreas de 1977-1979, através da presença de vários corpos aquosos digitiformes na região a sudoeste do canal Camacho (subfácies B1 na figura A7). Estes corpos possuem padrão em planta análogo ao da porção de canais de tempestade ("hurricane channels") no modelo de leques de sobrelavagem de Scott et al.(1969 apud Davies 1983) e representam os "ponds" (lagos temporários frontais) do modelo de Schwartz (1975 apud Davis 1983), como se encontra apresentado nas figuras 5.2 e 5.3. Eles apresentam-se fechados no lado do mar por dunas transversais lineares e ramificados ao interior em padrão divergente (figura 5.2B). Semicoalescidos lateralmente, compõem uma faixa inundada paralela à costa de quase $2 \mathrm{~km}$ de extensão, situada no limite entre o sistema eólico mantiforme e o sistema barra-barreira (figura 5.4). Nas aerofotografias de 1952, os mesmos lagos não são aparentes, o que indica terem sido originados ou reativados durante um evento episódico de tempestede ocorrido no intervalo de tempo entre as duas datas de fotografias estudadas. 

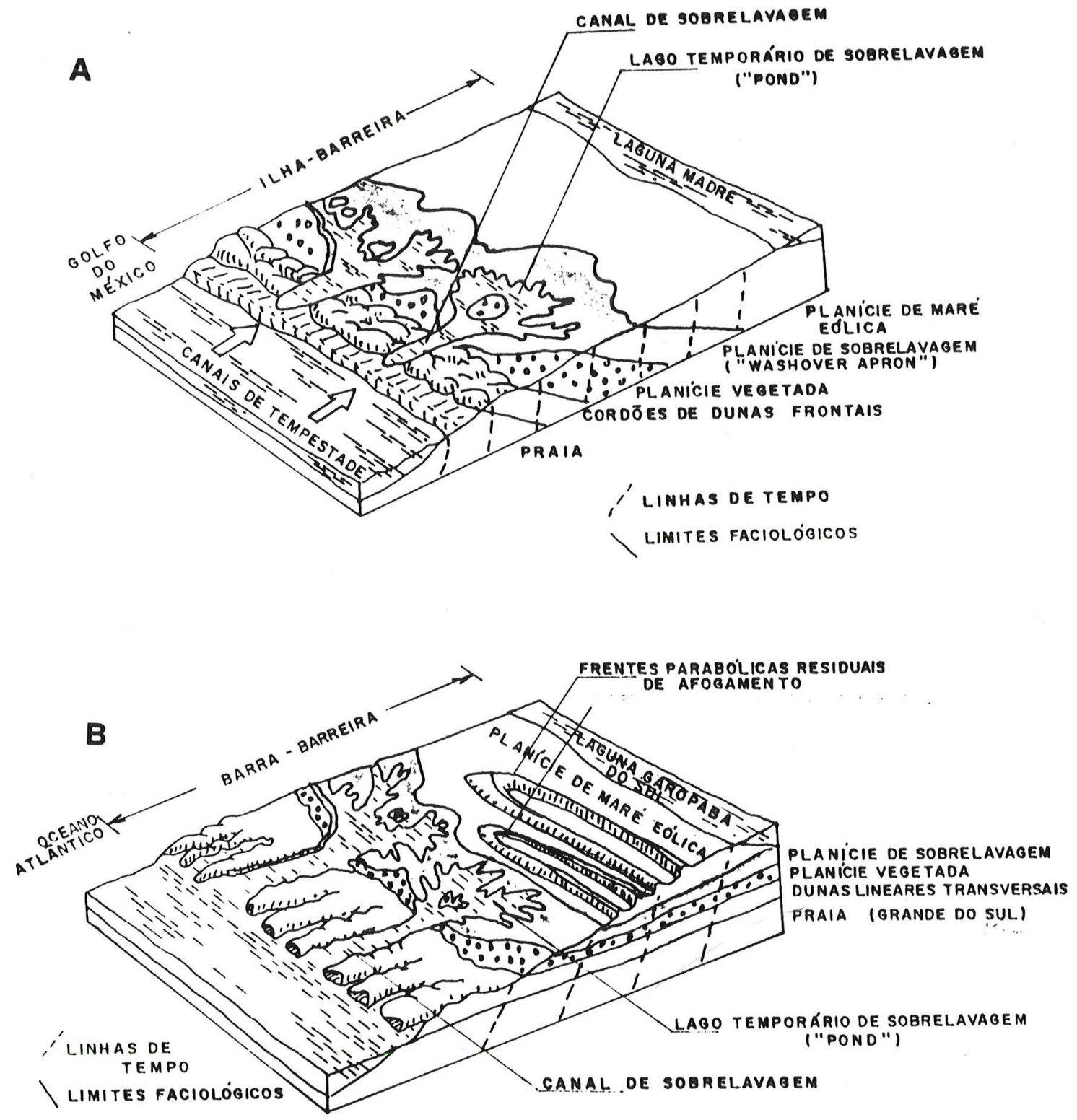

Figura 5.2. Blocos-diagramas para sistemas de barreiras regressivas, com ênfase a fácies de sobrelavagem. (A) Iha-barreira a NRM ascendente na costa do Texas; compilado de Scott et al.(1969 apud Davies 1983) e Bernard et al. (1962 apud Davies 1983). (B) Barra-barreira de Jaguaruna-Laguna (suposto NRM em declínio suave); por analogia com Scott et al.(1969 apud Davies 1983).

Em períodos de inatividade prolongada de episódios de sobrelavagem (escala de poucos anos), os lagos digitiformes dão lugar a brejos ou a baixios secos com vegetação escassa, constituídos por areias enriquecidas em matéria orgânica, em meio a ondulaçōes suaves, cobertas por vegetação rasteira. A diferença de altura entre o topo das ondulaçōes e o fundo brejoso atinge cerca de 0,6 $\mathrm{m}$, o que pode ser considerado como uma espessura mínima aproximada dos sedimentos de leques de ruptura de barreira no local. $\mathrm{O}$ avanço máximo observado do leque em direção ao interior é de $500 \mathrm{~m}$. Além desta distância, as águas e os sedimentos são possivelmente contidos por elevaçōes suaves de topografia relacionadas com resquícios de dunas parabólicas (feição M9 na figura A7). 

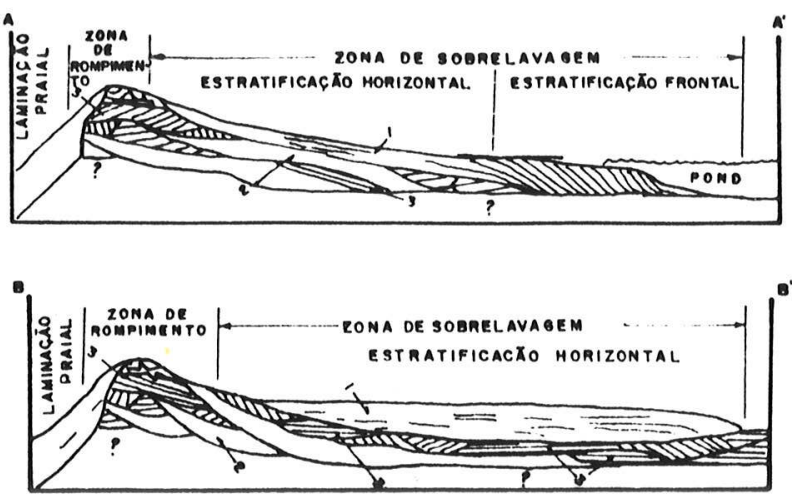

LEGENDA

I LEQUE de soBhelavaeEM RECÉM dePositado

2LEQUES DE SOERELAVAEE M ANTIBOS

3 DEPUSITOS EÓL.LCOS

Figura 5.3. Seçס̃es longitudinais em leques de sobrelavagem segundo Schwartz (1985) : em AA', delta tipo Gilbert, progradante sobre "pond"; em BB', estratificaçס̃es sub-horizontais formadas por fluxo em lençol.

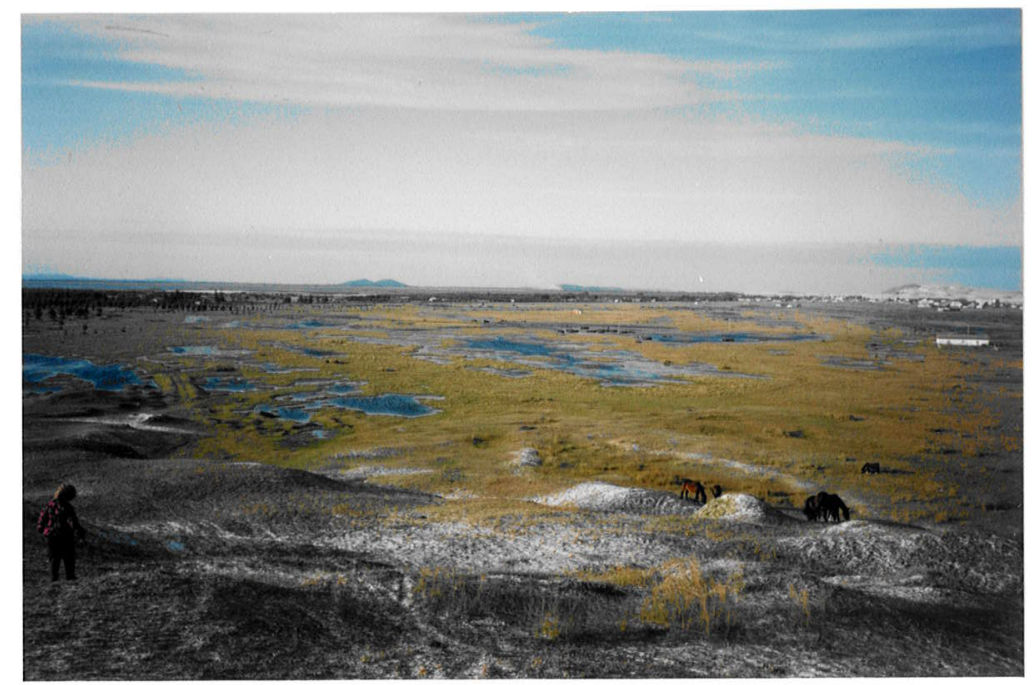

Figura 5.4. "Ponds" digitiformes na frente de leques de sobrelavagem entre a laguna Garopaba do Sul (esquerda) e a Praia Grande do Sul. Em primeiro plano, aparecem restos de um sambaqui (S30A).

O limiar necessário para a reativação da subfácies de leques de sobrelavagem é o rompimento ou o recobrimento do berma e das dunas de orla praial por ondas de alta energia. Esta condição é facilitada pelas características do sistema eólico que recobre o sistema barra-barreira, ou sejam, ausência quase total de dunas frontais e orientação subperpendicular à costa de dunas lineares. Os corredores interdunares alongados, conectados diretamente à praia, tornam-se assim condutos para as águas enchentes de tempestade. Observações de campo e aerofotografia indicam que, mesmo durante preamares de sizígia normais, sucessivos canais transversais à praia formam-se ao longo da extensão externa de cada zona interdunar. Este efeito, em magnitude ampliada, levaria à formação, no interior da barreira, de tantos leques quantos corredores interdunares fossem inundados. A preservação 
preferencial de leques em um trecho restrito da barreira é explicável pela parcial atrofia do sistema eólico mantiforme a sotavento (sudoeste) do canal Camacho, dada a interrupção de aporte eólico exercida por este. Em demais regiōes da barreira, onde o desenvolvimento do sistema eólico mantiforme é completo, a massa de areia dunar em movimento atua como fator de bloqueio ou assoreamento dos canais de ruptura de barreira, reduzindo a formação e/ou preservação de leques de sobrelavagem.

Liquefação de areias pode gerar rupturas na frente da barreira sem que o nivel atingido pela água do mar sobrepuje a altura dos depósitos de póspraia (Lankford 1977). Este fenômeno depende do encharcamento das areias e pode ser favorecido por elevações do lençol freático, associado ao nível da laguna. A superação do limiar envolve portanto variáveis da hidrografia continental, além da energia de ondas e marés, e o fenômeno da sobrelavagem pode ser considerado um evento extremo de comportamento não linear, que leva à dissipação de energia e produção de singularidades espaciais, representadas pelos leques.

\subsubsection{Desembocadura lagunar}

Os limites entre o sistema barra-barreira e o sistema lagunar ao longo da desembocadura da laguna ("inlet") são graduais. Mesmo que se convencione traçar as fronteiras coincidindo com suas margens, a demarcação será arbitrária porque a desembocadura experimenta não somente alternância de fases de abertura e fechamento como mudanças de posição, em escala de tempo compatível com a observação direta. A desembocadura configura-se assim como zona de litígio entre processos de correntes de circulação lagunar e processos de deriva litorânea induzida por ondas do sistema barra-barreira, além de ser influenciada pelo sistema eólico sobreposto. Uma evidência disto é que as principais estruturas sedimentares encontradas nas margens atuais do canal Camacho sào lentes de fluxo granular eólico (figuras 5.90 a 5.92). Para efeito de apresentação somente, a fácies desembocadura lagunar foi incluida no sistema lagunar, deixando-se sua discussão para o item 5.3.2.2.5.

\subsubsection{Praia de mar aberto}

As subfácies praiais (pós-praia e antepraia) foram incluídas como as componentes mais externas da fácies planicie de mar aberto do sistema barra-barreira. Se este estudo fosse estendido aos sedimentos submersos, a fronteira entre face litorânea ("shoreface") e costa afora ("offshore") seria o limite mais natural desta fácies, caracterizada pelo domínio da ação de ondas normais.

De sul para norte, os principais setores praiais abrangidos pelo sistema barra-barreira são : Praia Grande do Sul, Cigana, Praia Grande do Norte, Santa Marta Pequeno, Teresa e Gravatá. Estas praias, exceto zonas mais protegidas, são predominantemente dissipativas na classificação de Wright et al.(1979) a julgar por características como altura das ondas, maior que 1,0 m em média, declive suave e zona de translação de ondas ("surfing") bem desenvolvida. Nas vizinhanças de pontões cristalinos, elas podem adquirir o formato log-espiral (definido conforme Yasso 1965) e ficar sujeitas a padrões complexos de interferência de ondas: parte das frentes de onda atuantes refrata-se a sotamar do obstáculo e retorna em rumo contrário ao de incidência. É o que se verifica nos dois extremos da praia do Cardoso 
(figura 5.6) e no extremo sul da praia de Santa Marta Pequeno, onde o subdesenvolvimento da zona de translação, com aumento de refletividade são características particulares. Outra feição de ocorrência local associada preferencialmente às mesmas áreas sào as dunas frontais(ver item 5.4.2.5.2), as quais são encontradas também em Teresa e Gravatá, dois setores praiais estreitos e curtos do tipo bolso ("pocket beach"), situados em reentrâncias da costa rochosa nos morros Passagem e Entrada da Barra.

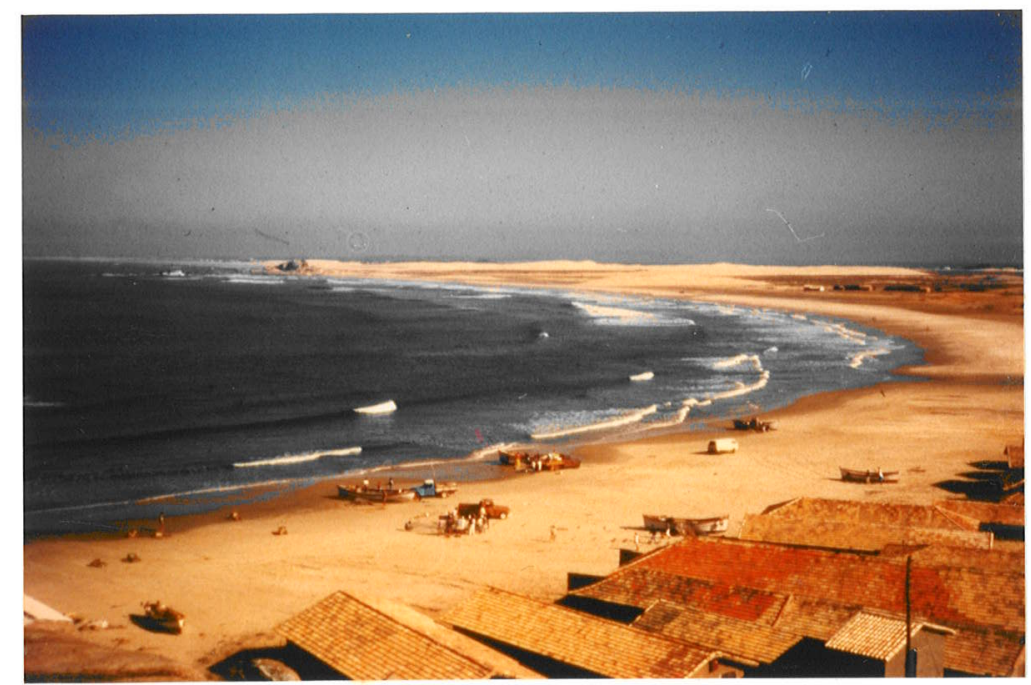

Figura 5.5. Praia do Cardoso vista a partir de sua ponta norte. Inclui-se entre as praias de morfodinâmica menos dissipativa na área de Jaguaruna-Imbituba (comparar com figura 5.17).

A distância média entre a eventual linha de arrebentaçào externa e a interna, estimada com base no exame de aerofotografias, é de cerca de $120 \mathrm{~m}$ nos setores médios mais dissipativos, sendo pouco maior que a distância entre a linha de arrebentação externa e a de espraiamento. Nos trechos log-espirais, a distância entre as linhas de arrebentação e espraiamento cai para até menos de $20 \mathrm{~m}$.

A deriva litorânea longitudinal resultante, indicada por critérios geomorfológicos dentre os descritos por Jacobsen \& Schwartz (1981), é para norte (ENE a NE). Duas evidências são mais significativas: (1) terminações de forma planimétrica côncava, com raio de curvatura mínimo, tipo log-espiral (Yasso 1965), ocorrem melhor desenvolvidas no extremo sul das praias do Cardoso e Santa Marta Pequeno, o que indica contrafluxo por refração para sul e portanto frentes de onda predominantes incidindo rumo norte; (2) sedimentos trazidos à costa através da vazante do canal Camacho acumulam-se preferencialmente a norte da desembocadura lagunar, como evidenciado pela posição de deltas de maré vazante (item 5.3.2.2.5).

\subsubsection{PADRÃO SEDIMENTOLÓGICO}

O sistema barra-barreira foi amostrado em três unidades faciológicas : antepraia, pós-praia (atuais) e planície indiferenciada (holocênica 
antiga), obtendo-se resultados analíticos de granulometria e de mineralogia da fração pesada.

\subsubsection{Granulometria}

Os resultados granulométricos são apresentados em duas tabelas ( $A 1$ e A2); eles foram submetidos a tratamento gráfico (figuras A20 a A27) e estatístico (tabela A3).

O sistema em geral é caracterizado por areias limpas com elevado teor de fraçào areia fina ( 95\%) e diâmetro médio em torno de 2,5 phi $(0,18$ $\mathrm{mm}$ ). Na classificaçào nominal de Folk \& Ward (1957), têm-se areias finas, bem selecionadas e mesocúrticas, com assimetria variando entre ligeiramente positiva e ligeiramente negativa.

A fácies planicie indiferenciada (holocênica antiga) apresenta distribuição granulométrica bruta mais semelhante à antepraia do que à pós-praia atual (tabela A1). Ela possui também tendência para percentil $1 \%$ (P01) mais fino, desvio padrão analítico maior, assimetrias mais negativas e curtoses pouco mais altas que os sedimentos praiais

Quando se comparam entre si as subfácies pós-praia e antepraia, observam-se as seguintes tendências : teor de areia média maior: na antepraia e teor de areia muito fina maior na pós-praia; P01, P50 e diâmetros médios mais grossos na antepraia; assimetrias e curtoses pouco maiores na antepraia. exceções para todas estas regras encontram-se na praia do Cardoso, onde as relações ora se invertem ora são de igualdade.

$\mathrm{Na}$ comparação entre as médias de vários setores praiais, a tendência mais geral é a de diminuição da granulometria (P50 e diâmetros médios) de sul para norte, com exceção da praia da Cigana, cujos sedimentos são os mais grossos devido a um teor relativamente elevado de areia média. As assimetrias aumentam rumo norte até a praia do Cardoso (no caso da assimetria gráfica) ou da Cigana (no caso da assimetria analitica) e passam a cair a partir daí. Demais parâmetros apresentam variação espacial entre setores praiais mais irregular.

Em relação a variação longitudinal de granulometria dentro de cada setor praial, algumas tendências detectadas por recursos gráficos e reforçadas por correlações lineares estatísticas significativas $\left(R^{2}>40 \%\right.$ elou $\left.p>95 \%\right)$ merecem destaque. Em primeiro lugar, existe uma tendência geral para queda do teor de areia média elou aumento do teor de areia fina elou muito fina de sul para norte, com exceção da Praia Grande do Norte (tabela A3). Este comportamento é sugestivo do processo de seleção granulométrica por retenção progressiva de "grossos" a barlamar, classicamente admitido como indicador de rumo de deriva litorânea (Evans 1939; Russell 1939). Em segundo lugar, verificam-se algumas tendências localizadas de variação sul-norte nos parâmetros granulométricos : na subfácies pós-praia da Praia Grande do Sul (figura A21), os desvios padrões caem, P01 afina, as assimetrias aumentam e as curtoses decrescem e tornam-se menos variäveis; na antepraia da Praia Grande do Sul (figuras A22 e A23), o comportamento é semelhante, mas os desvios padrões aumentam, principalmente na primeira metade da praia; na antepraia da Praia Grande do Norte, os desvios padrões e a curtose analítica caem (figura A24). A queda da curtose pode ser relacionada à diminuição de teores nas classes de areia grossa e média de sul para norte, sendo o parâmetro analítico mais sensível a tais 
variações que o parâmetro gráfico. O decréscimo de granulometria, associado a um aumento, ainda que não bem definido, do grau de seleção, pode indicar o processo de seleção progressiva clássico e sugerir rumo de deriva longitudinal para norte. Estas interpretações estão longe de serem conclusivas ou gerais. Nenhum dos dois padrões diagnósticos inequívocos de rumo de transporte de McLaren \& Bowles 1985 ("mais grosso, melhor selecionado e mais positivo" e "mais fino, melhor selecionado e mais negativo") são encontrados, mesmo sob rigores estatísticos menores, em qualquer setor praial: além disto, a Praia Grande do Norte exibe padrões de variação que não coincidem sequer com o padrão clássico. Apesar disto, a deriva litorânea para norte é admitida como mais provável, mesmo porque existe decréscimo de granulometria neste rumo ao longo da praia do sistema barra-barreira como um todo. A exceção, representada pelas areias mais grossas do setor Cigana, pode ser explicada por sua posição a sotamar da desembocadura lagunar do Camacho, a qual traria para a costa, durante marés vazantes associadas a escoamentos continentais elevados, uma certa quantidade de detritos grossos de origem fluvial. O aumento de assimetria no trecho de praia supostamente mais influenciado pelo aporte fluvial está de acordo com o observado em situações similares de outras regiões costeiras (Self 1977; Komar 1977; Giannini 1987,1989). Sob este aspecto, o parâmetro analítico é mais uma vez de sensibilidade superior ao parâmetro gráfico.

A inversão do padrão granulométrico transversal (pós-praia versus antepraia) na praia do Cardoso pode ser explicada por sua maior refletividade morfodinâmica, favorecida principalmente por sua condição de praia semiprotegida, log-espiral. O contraste de parâmetros caudais da distribuição granulométrica entre praia e antepraia atinge neste setor praial sua amplitude máxima, como ocorre em praias mais refletivas de modo geral, por efeito de seleção transversal mais atuante (Bryant 1982). Esta seleção transversal, controlada pela ação da gravidade ao longo do declive acentuado, tende a segregar areias mais grossas na antepraia de areias mais finas na pós-praia. Entretanto, a energia de onda não é suficiente para carrear de volta à antepraia os grãos de areia média porventura levados à pós-praia durante marés muito elevadas. Contribui para este efeito a alta freqüência de ondas incidentes, característica de praias mais refletivas (Wright et al. 1979). Como resultado, a subfácies pós-praia torna-se enriquecida tanto em areia média como em areia muito fina, adquirindo caráter mais leptocúrtico, mais negativo e pior selecionado.

As variaçães lineares estatisticamente mais consistentes na fácies planície indiferenciada (figura A20) são o declínio da assimetria gráfica e o aumento de curtose gráfica e desvios padrões rumo norte. Estas tendências são acompanhadas pelo engrossamento do diâmetro médio ( $p=80 \%$ ) no mesmo rumo. Como estas variações se restringem ao longo da metade norte da barra-barreira, é possivel supor um aporte crescente de grossos à costa a norte da lagoa Santa Marta, seja por influência fluvial seja por hidrodinâmica mais competente do sistema paleolagunar na região de Carniça - Campo Verde.

\subsubsection{Mineralogia}

Os teores em massa de minerais pesados na fração areia muito fina (tabela A4) variam desde 0,4 até $31,3 \%$, nas subfácies praiais atuais, e entre 0,7 e $2,5 \%$, na fácies planície indiferenciada (holocênica antiga). O teor máximo de magnéticos é de $1,2 \%$. Na fração não magnética, a freqüência de contagem de 
minerais transparentes não micáceos oscila entre 24 e 83 \% (tabela A5). Dentre estes, turmalina, estaurolita, pistachita e hornblenda são os únicos minerais correntes em todas as amostras; o primeiro aparece como mineral escasso a predominante, enquanto os outros três variam de raros a abundantes. O mineral com maior freqüência como componente predominante (> $50 \%$ ) é o zircão. Dos demais minerais, rutilo, leucoxênio/anatásio, cianita, sillimanita, granada e hiperstênio variam entre raros e comuns $(\leq 20 \%)$, enquanto zoisita, titanita, augita, pigeonita, tremolita e andalusita são raros ou escassos $(\leq 5 \%)$.

No confronto de mineralogias médias entre subfácies praiais e fácies planicie indife, enciada, observa-se que as freqüências percentuais de zircão e turmalina e os índices de maturidade mineralógica ZTR, r1, r2 e r3 são maiores na fácies indiferenciada (figuras 5.6 e 5.7). Esta tendência verifica-se também quando as médias são tomadas por setor praial, exceto em relação às praias da Cigana e do Cardoso (tabela A5). Regra inversa, mantidas as mesmas exceções, verifica-se em relação às porcentagens de pistachita e hornblenda. Esta maior maturidade da subfácies indiferenciada pode ser atribuida ao efeito mais prolongado da dissolução intraestratai Jevido a idade maior de deposição de seus sedimentos. Os teores elevados de minerais ultraestáveis, e especialmente de zircão, nas praias da Cigana e do Cardoso devem-se à posiçào geográfica destas praias imediatamente a norte do canal Camacho, o qual atua como conduto à costa de sedimentos oriundos da porção sudoeste do delta intralagunar do rio Tubarão. Estes sedimentos são ricos em zircão, a supor pelo predominio absoluto do mineral nos regolitos de granitos intrusivos cambrianos e de sedimentos continentais terciários, principais rochas-fontes potenciais nessa região do delta (amostras R22A, R34A, R50A: tabela 4.3). O fato de a influência do canal ser mais percebida a norte que a sul de sua desembocadura é sugestivo de deriva litorânea resultante para norte (ENE).

Em comparação com a antepraia, a subfácies pós-praia apresenta teores médios de minerais pesados em massa maiores ou aproximadamente iguais (tabela A4) e freqüências de contagem de minerais transparentes menores (figuras 5.8 e 5.9), com exceção, em ambos os casos, para a praia do Cardoso. Além disto, a subfácies pós-praia tende a apresentar freqüências de contagem de zircão mais altas, frequiências de hornblenda mais baixas (figuras 5.10 e 5.11) e valores mais elevados para as quatro razões mineralógicas estudadas ( $r 1 \ldots r 4$ ). Todas estas diferenças podem estar associadas ao contraste de comportamento hidráulico entre minerais de densidades muito distintas; minerais de peso específico mais elevado, como pesados em relação a leves, opacos em relação a transparentes e zircão em relação a hornblenda, tenderiam a se concentrar na pós-praia, impedidos de retornar na ressaca ("backwash") das ondas devido a seu peso maia elevado e ao declive baixo da costa dissipativa. O fato de a tendência de seleção densimétrica transversal inverter-se em setores mais reflexivos (i.e. Cardoso) está relacionado com o mesmo efeito seletivo que concentra areia fina na antepraia destes setores; reforça assim a hipótese de controle hidráulico. Como esta inversão não se estende ao caso zircão versus hornblenda, é possivel porém que um segundo controle, ligado a estabilidade diferencial dos minerais, exerça influência na seleção mineralógica transversal (por exemplo, através da eliminação mais rápida de hornblenda no ambiente mais oxidante da subfácies pós-praia). 
HISTOGRAMA DE MINERAIS PESADOS

SISTEMA BARRA-BARRERA

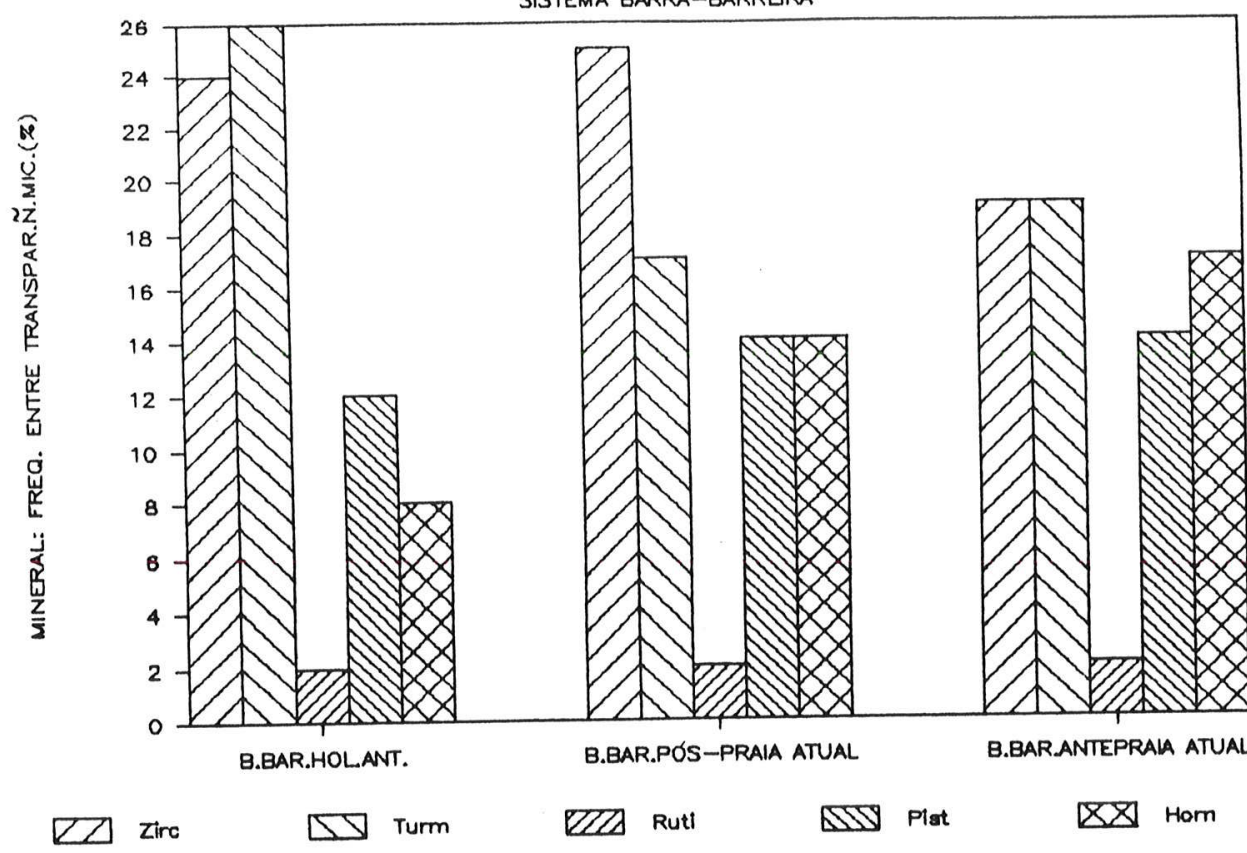

HISTOGRAMA DE RAZÕES MINERALÓGICAS

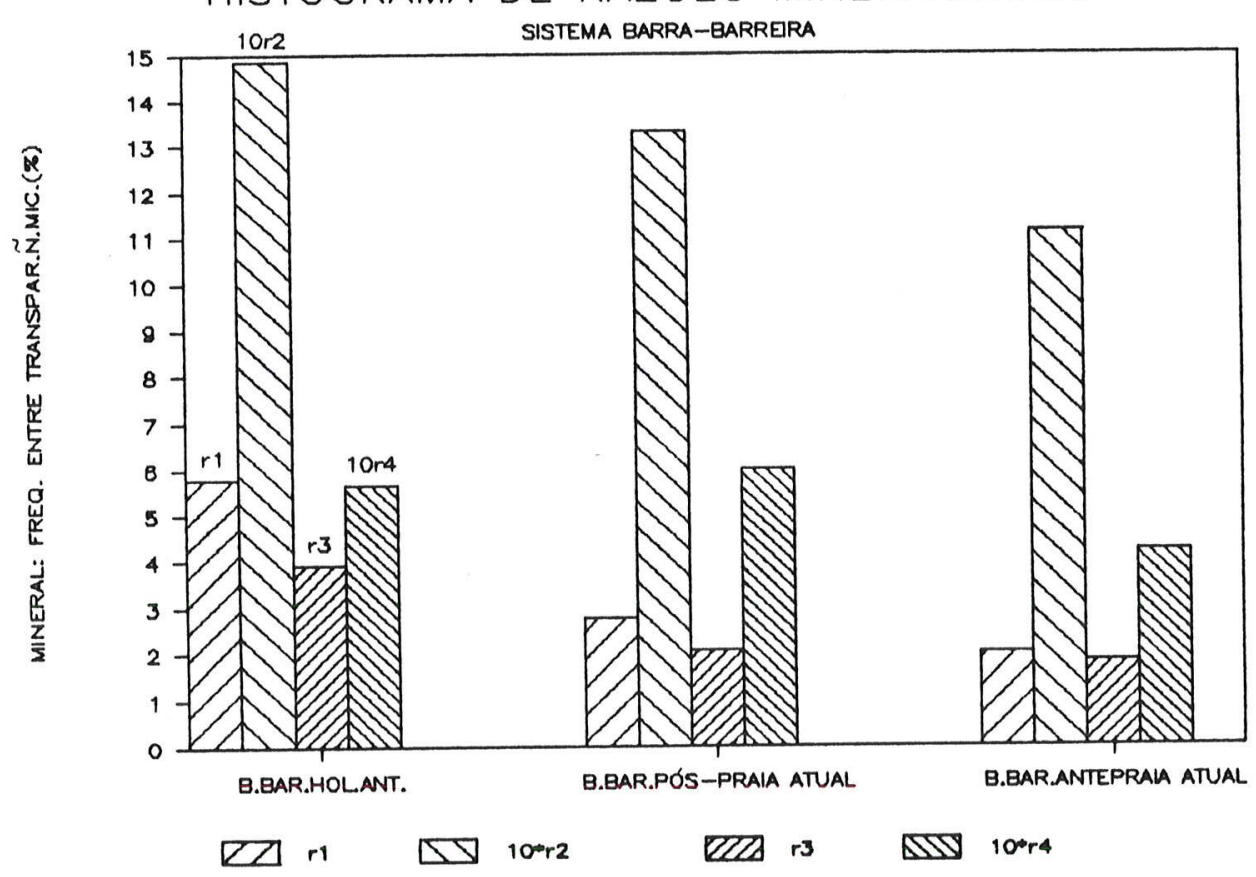

Figuras 5.6 e 5.7. Comparaçăo entre sedimentos de diferentes idades no sistema barra-barreira. 5.6 (superior). Histograma de frequéncias percentuais médias de minerais pesados.

5.7 (inferior). Histograma de razőes mineralogicas médias. 
No exame da variação das mineralogias médias entre os diferentes setores praiais, observa-se que as praias da Cigana e do Cardoso apresentam os maiores teores em massa de minerais pesados e de magnéticos (tabela A4), as maiores freqüências de zircão (figuras 5.10 e 5.11) e de minerais opacos (figuras 5.8 e 5.9) e os maiores indices ZTR (figuras 5.12 e 5.13). A porcentagem de minerais pesados transparentes cai continuamente rumo norte até estas duas praias e tende, a partir dai, a aumentar. O indice ZTR tem comportamento mais ou menos inverso, apresentando estreita correlação com a quantidade de opacos. Hornblenda tem sua concentração máxima na Praia Grande do Sul, cai bruscamente na praia da Cigana e daí passa a aumentar rumo norte até a praia da Teresa. Este padrão de variação mineralógica aparenta ser mais controlado por aportes locais através da desembocadura lagunar e de córregos que recolhem a drenagem de morros rochosos costeiros, que pela estabilidade diferencial dos minerais. A principal fonte de suprimento é o canal Camacho, que eleva os teores de zircão e de opacos nas praias vizinhas, principalmente a norte. A partir destas praias, estes teores tendem a cair em efeito da maior dificuldade destes minerais, por seu elevado equivalente hidráulico, de serem transportados para além dos pontões rochosos.

A variação longitudinal de mineralogia dentro de cada um dos setores praiais estudados é controlada principalmente pela estabilidade diferencial das espécimes ou grupos mineralógicos. Padrões sul-norte de variação freqüencial intrapraia caracterizados por decréscimo de componentes instáveis, como hornblenda, transparentes e o índice INS, e pelo aumento de componentes relativamente estáveis, como zircão, turmalina, opacos e o índice ZTR são encontrados em todas as subfácies praiais cuja correlação linear foi investigada (figuras A25 a A27), à exceção da póspraia do setor Praia Grande do Norte (figura A26). Tais padrões têm sido interpretados em praias extensas como indicadores diretos de rumo resultante de deriva litorânea longitudinal (Giannini 1987). Uma hipoótese para explicar o padrão comparativamente anômalo da Praia Grande do Norte é que o cabo de Santa Marta Grande seja muito mais eficiente no bloqueio e na difração das frentes de onda predominantes vindas de sul que o cabo de Santa Marta Pequeno em relação às frentes de onda vindas de norte. Cabe lembrar que o mesmo setor praial é anômalo também quanto a seus padrões de variação granulométrica (item anterior). Outros tipos de variação diagnósticos de rumo de deriva longitudinal revelam-se aqui menos inequívocos. É o caso de aumentos na freqüência de estaurolita e de alteritos (Giannini 1987) e no teor em massa de minerais pesados magnéticos e total.

A variação de mineralogia nos setores praiais de pequena extensão (Cigana, Cardoso e Teresa) é de interpretação difícil devido à proximidade entre os pontões e/ou canais limitrofes; o padrão resultante é ambíguo, com tendências opostas entre pós-praia e antepraia. A exceção é o índice ZTR da praia do Cardoso, cujo declínio rumo norte em ambas as subfácies parece indicar uma célula de deriva local resultante para sul. Esta interpretação é compativel com o modelo de praias log-espirais em meio a costas de deriva longitudinal predominante rumo norte.

Na subfácies planície indiferenciada, de idade holocênica mais antiga, as tendências mais significativas de variação linear sul-norte são a queda da freqüência de hornblenda e do índice INS e o aumento da freqüência de alteritos (tabela A6). Estes padrões podem resultar de paleocorrentes de deriva litorânea de mesmo rumo que as atuais. 

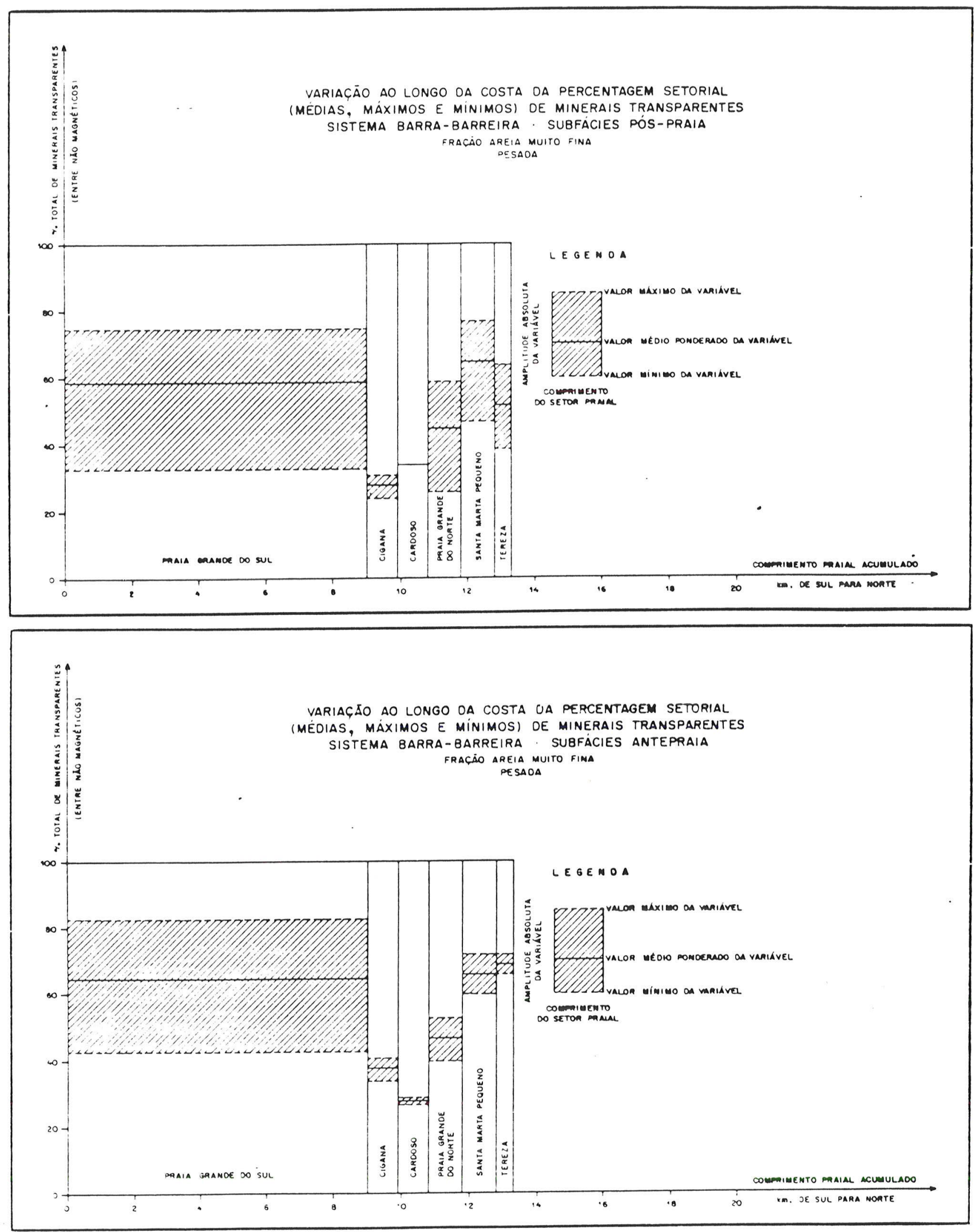

Figuras 5.8 e 5.9. Variação ao longo da costa da porcentagem setorial (médias, máximos e mínimos) de contagem de minerais pesados transparentes - Sistema barra-barreira.

5.8 (superior). Subfácies pós-praia

5.9 (inferior). Subfácies antepraia 

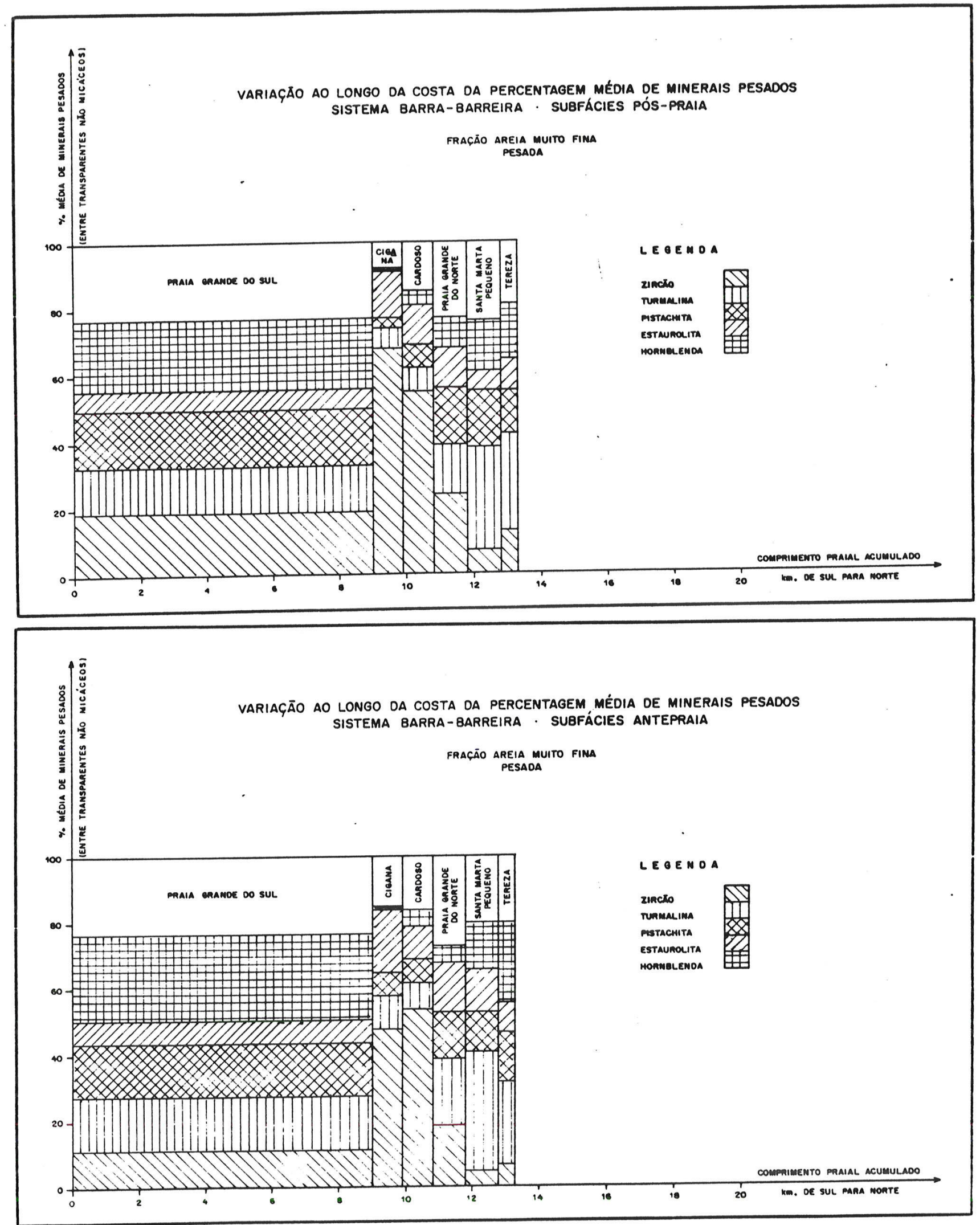

Figuras 5.10 e 5.11. Variaçăo ao longo da costa de porcentagens médias setoriais de contagem de espécimes de minerais pesados - Sistema barra-barreira.

5.10 (superior). Subfácies pós-praia

5.11 (inferior). Subfácies antepraia 

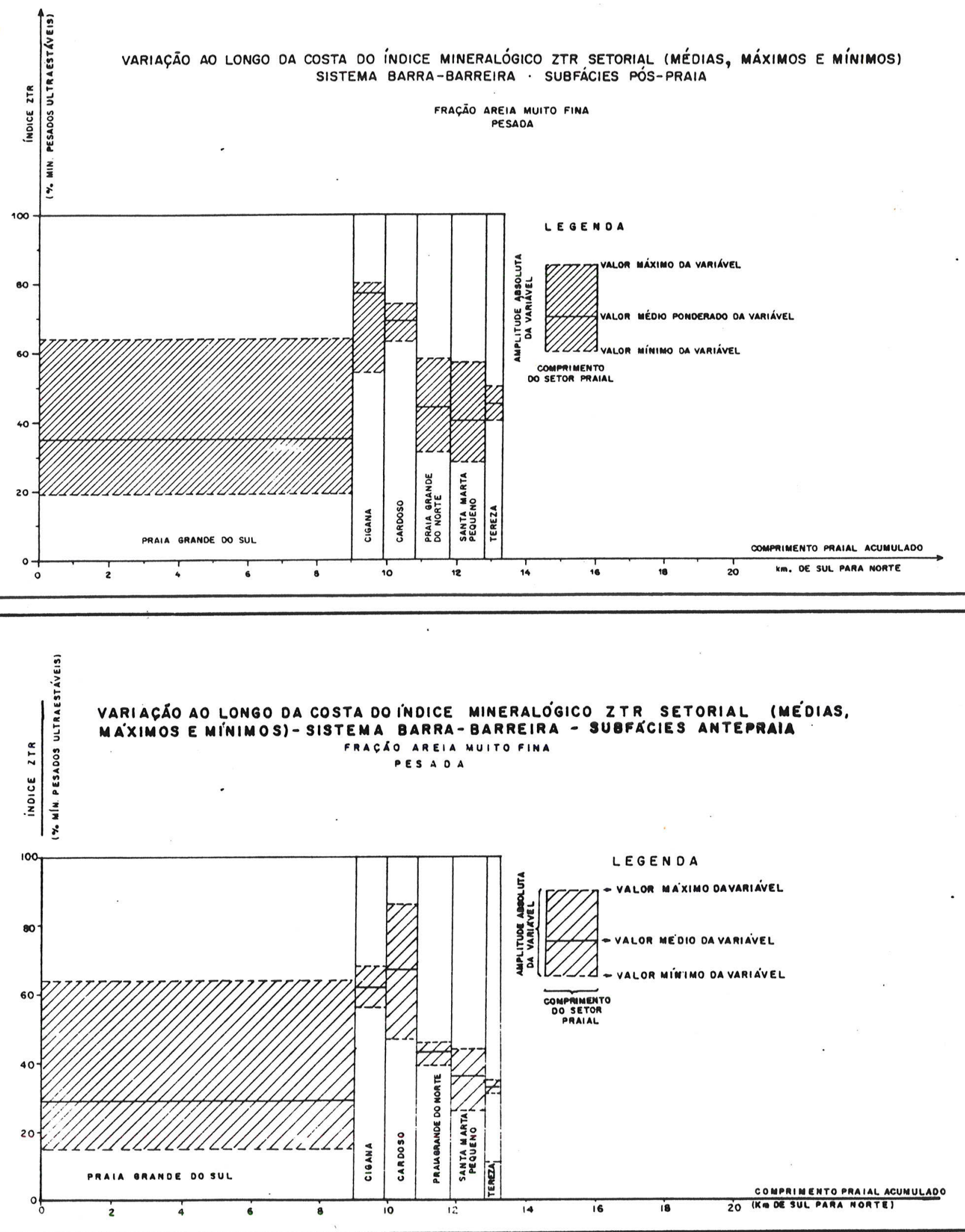

Figuras 5.12 e 5.13. Variaçăo ao longo da costa do índice mineralógico ZTR setorial (médias, máximos e mínimos) - Sistema barra-barreira.

5.12 (superior). Subfácies pós-praia

5.13 (inferior). Subfácies antepraia 


\subsection{SISTEMA PLANICIE COSTEIRA}

\subsubsection{IDADE RÉLATIVA}

Suguio et al. (1986) e Martin et al.(1988b) subdividiram os sedimentos aqui atribuídos ao sistema planície costeira em holocênicos e pleistocênicos, estes últimos relacionados à regressão subseqüente ao máximo transgressivo mundial de 120 mil anos A.P... Os critérios altimétricos (figura 5.14) e aerofotogeológicos de distinção entre terrenos holocênicos e pleistocênicos estabelecidos por Martin et al. (1981) e revistos por Angulo (1992) não podem ser irrestritamente aplicados na área em estudo, devido ao extenso recobrimento do sistema planície costeira por depósitos eólicos de diferentes tipos e gerações, os quais elevam as altitudes originais e obliteram feições diagnósticas como padrões de alinhamentos de cordões e sulcos de paleodrenagem. Neste trabalho, foram buscados critérios adicionais, em princípio de validade local, para distinção de idade dos sedimentos marinhos. Estes critérios incluem a distinção aerofotogeológica e de campo entre diferentes gerações de depósitos eólicos sobrepostos (ver item 5.4.1) e a análise de relações cronológicas entre estas gerações e o evento de transgressão marinha holocênica. Idades relativas das gerações eólicas foram verificadas por datações radiocarbono em sambaquis de posição estratigráfica definida em relação aos depósitos eólicos (item 3.4). O resultado do uso destes critérios foi a confirmação da existência de sedimentos marinhos pleistocênicos e holocênicos, porém com distribuição em mapa levemente distinta da admitida por Suguio et al.(1986) e Martin et al.(1988b). A principal mudança em relação aos mapas daqueles autores é a ampliação da faixa de sedimentos pleistocênicos entre as pontas do Perrixil e Rasa. Esta hipótese é corroborada por análises de minerais pesados que indicam contraste acentuado de maturidade química entre assembléias de amostras holocênicas e pleistocênicas.

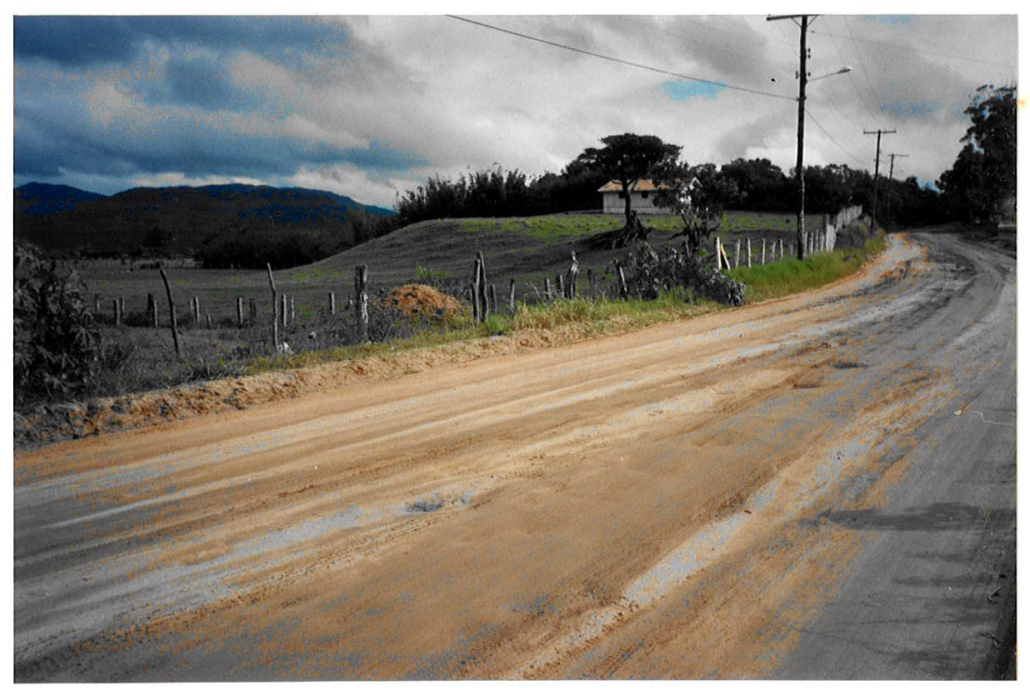

Figura 5.14. Degrau entre o sistema planície costeira pleistocénico e o lagunar a oeste da vila de Mirim. Tipo de feição utilizado por Suguio et al. (1986) para distinguir entre Pleistoceno e Holoceno na área em estudo. 
O guia principal para a identificação de depósitos marinhos pleistocênicos na área entre Jaguaruna e Imbituba é a presença de dunas da geração 2. Estas dunas apresentam características marcantes em aerofotografias e no campo (item 5.4.1.2); elas exibem configurações de truncamento erosivo nas margens oeste da lagoa Garopaba do Sul e norte da lagoa Santo António e na região de Vila Nova (figuras A11 e A15), o que indica terem-se formado antes do máximo transgressivo holocênico. Supõe-se por isto ocorrerem sempre sobre sedimentos da regressão marinha anterior (pleistocênica superior). Porém, em alguns locais, o sistema planicie costeira pleistocênico encontra-se encoberto por dunas atuais (figura 5.15), o que dificulta o seu reconhecimento.

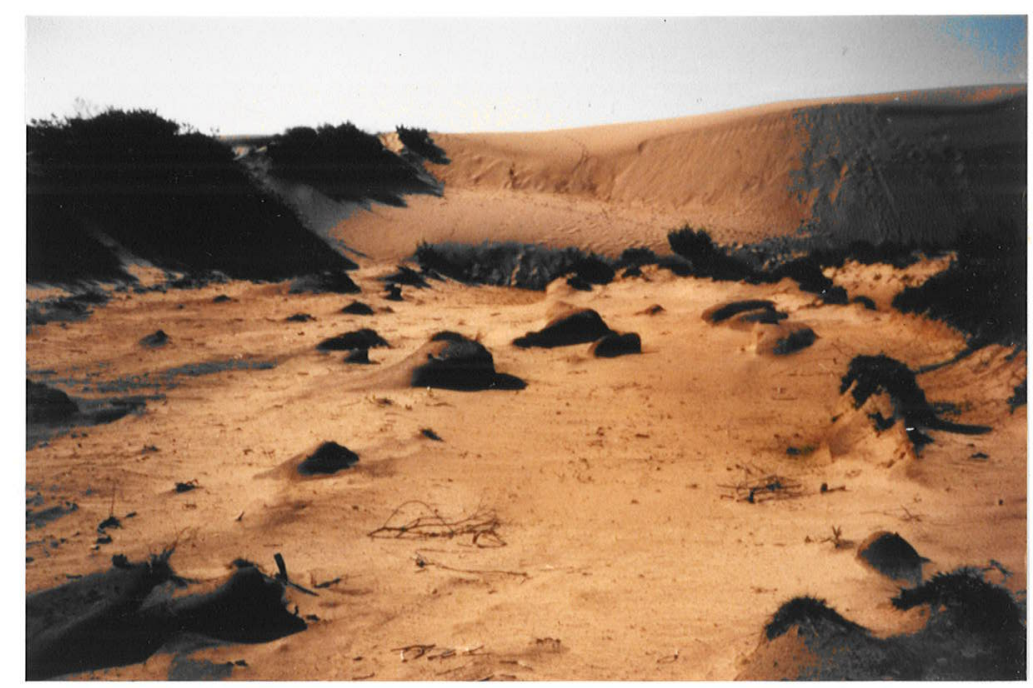

Figura 5.15. "Piçarras", atribuidas ao sistema planície costeira pleistocênico, aflorando sob lençol parabólico ativo. Exposiçăo feita por trator, nas proximidades de ltapirubá.

\subsubsection{PADRÃO FISIOGRÁFICO}

O modelo de hierarquia e distribuição de fácies para o sistema planicie costeira é apresentado na tabela 5.2. Detalhes sobre o padrão em mapa de arranjo de fácies encontram-se nas figuras A11 a A15. As principais unidades faciológicas reconhecidas neste sistema são descritas a seguir.

Tabela 5.2

Distribuicão de facies en superfície no sistead planicie costeira

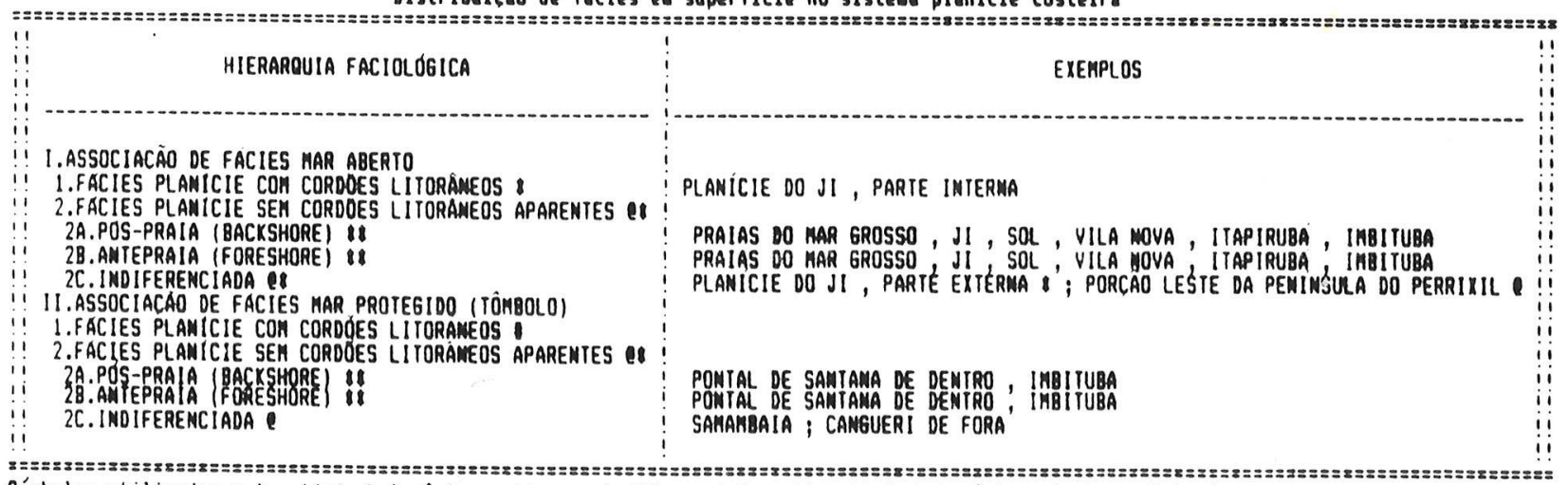

Síbolos utilizados : 1 - idade holocênica antiga ou indiferenciada; 81 - idade holocénica atual d subatual

- idade pleistocénica, provavelaente inferió; - facies de ocorrencia ná comprovada 


\subsubsection{Planície com cordões litorâneos}

Detalhes sobre o processo formador de cordões litorâneos mantêm-se pouco conhecidos. A hipótese de Bird (1973 apud Bird \& Paskoff 1979) segundo o qual elas resultam do rearranjo na praia de sedimentos provindos de maiores profundidades via "princípio de Bruun", após elevações de curto prazo no nivel marinho, implica possiveis relações genéticas entre os cordões e as barras litorâneas ("longshore bars"). Estas possuem sua formação e morfologia controlados pelo regime morfodinâmico costeiro, de tal modo que a geração de barras lineares ou crescêntricas contínuas depende do grau de dissipatividade da praia (Short 1979; Wright et al. 1979; Bowman \& Goldsmith 1985). Apesar disto, a progradação da costa na forma de cordões sucessivos pode ocorrer também em costas de NRM ascendente (Bird \& Paskoff 1979; Moslow 1990), aparentemente relacionada a configuração local de correntes de deriva litorânea longitudinal (Rampino \& Sanders 1983) elou a aporte fluvial intenso, sem relações diretas com o "Princípio de Bruun"

Diante destas incertezas a respeito de sua origem, os cordões litorâneos são interpretados aqui apenas como evidências de progradação da costa e de circulação ou energia de águas costeiras. Deve-se destacar, além disto, que a reconstituição aerofotogeológica de sua morfologia original bem como seu próprio reconhecimento podem ser prejudicados em muito por problemas de preservação (Angulo 1992). Por todas estas razões, a subdivisão faciológica ora adotada entre planicies com e sem cordões litorâneos é de caráter apenas descritivo e tentativo.

Um feixe de mais de $1 \mathrm{~km}$ de largura de cordões litorâneos contínuos e paralelos é reconhecido por Martin et al.(1988b) na parte interna da planície costeira holocênica adjacente à praia do Ji. Uma reconstituição aerofotogeológica mais detalhada deste feixe pode ser encontrada nas figuras A11 e A12. Os cordões apresentam padrão curvilíneo em sua parte sul, devido ao efeito de tômbolo ou pontão exercido pelo morro Mar Grosso, tornando-se mais retilíneos a norte onde atingem a orientação geral NNE. Não existe, porém, perfeito paralelismo entre os cordões mais internos e os mais externos, o que sugere uma deflexão gradual das paleolinhas de costa para leste, até atingir-se uma orientação próxima à atual a cerca de 1,2 km da praia do Ji. Esta mudança de orientação pode ser explicada pelo efeito de tômbolo que a ponta do Ji deve ter começado a desempenhar a partir de certo estágio da progradação. O extremo norte da paleopraia Ji-Sol era, antes disto, a ponta de Itapirubá, e a ponta do Ji apresentava-se ilhada. Os cordões litorâneos mais internos e antigos, os quais encontram-se ancorados na planície costeira pleistocênica atrás do morro Mar Grosso, orientam-se, para norte, rumo a região dos lagos do Estreito, hoje encoberta pelo sistema eólico. Esta geometria permite supor que o limite externo da faixa testemunha pleistocênica esteja situada nesta região, a leste do que é proposto por Martin et al.(1988b), hipótese apoiada pela distribuição observada de depósitos da geração eólica 2. A continuidade do feixe de cordões a norte da coordenada da ponta do Ji pode existir, encoberta pelos depósitos eólicos recentes. Uma hipótese provável é que os cordões litorâneos a norte possuam orientação coincidente ou próxima a das dunas parabólicas das gerações 3 e 4 , o que impede seu reconhecimento seguro. É importante ressaltar também que, dentre os alinhamentos de cordões visiveis, os mais externos, situados cerca de $2 \mathrm{~km}$ a sudoeste da ponta do $\mathrm{Ji}$, orientam-se em direção coincidente com o prolongamento da linha de costa atual na parte central da praia da Sol. Esta disposição de cordões externos permite supor que o 
estágio mais recente de progradação do setor Sol foi quase restrito ao paleotômbolo do Ji, em sua extremidade sul.

\subsubsection{Tômbolos e pontões}

A associação de fácies de mar protegido é representada por tômbolos a retaguarda de ilhas-testemunho de rocha cristalina, as quais, sob regime progradacional continuado, transformam-se de início em pontões costeiros e depois em morros-testemunhos no meio do sistema planície costeira. No sistema pleistocênico, registra-se a ocorrência desta associação de fácies nos bairros de Samambaia, a sudoeste da foz do rio Aratingaúba, e Cangueri de Fora, na margem oeste da laguna Mirim. Nas pontas costeiras do extremo norte da área, como Imbituba, Cravo e Careca do Velho, sedimentos desta associação de fácies podem, por suposição, ocorrer sob os depósitos eólicos das gerações 1 e 2 . Um exemplo desta ocorrência é encontrado entre a ponta do Cravo e a do Catalão, próximo a extremidade sul da praia de Muita Água, onde aflora um ortoconglomerado monomítico de matacões, com matriz constituida por areias bem selecionadas, depositado possivelmente em intervalo de tempo entre as gerações eólicas 1 e 2 (ver item 5.4.1.1). Este depósito parece corresponder ao que Bigarella \& Freire (1960) denominam "tômbolo erosivo", feição resultante do retrabalhamento marinho de depósitos coluviais entre dois pontões rochosos, de onde o mar retiraria seletivamente os materiais mais finos, preenchendo-se os intersticios entre matacões com areias tipicamente costeiras. Depósito deste tipo, descrito por Bigarella \& Becker (1975a,e) em Itajubá (SC), localidade situada $160 \mathrm{~km}$ a norte de Imbituba, apresenta altitude de 9 $\mathrm{m}$ e foi atribuido pelo autor à última transgressão pleistocênica (Sangamon ou RissWürm). O conglomerado de Muita Água pode ser a ele correlacionado, pois a altitude medida, confirmando estimativa anterior de Martin et al.(1988b), é de $8 \mathrm{~m}$.

Os tômbolos pleistocênicos de Samambaia e Cangueri de Fora são constituidos de sedimentos mais grossos e feldspáticos, quando comparados com areias marinhas típicas da região, porém mais selecionados e arredondados que sedimentos coluvionares comuns. Isto sugere terem resultado também do retrabalhamento marinho local de materiais de solo ou colúvio.

O sistema planície costeira holocênico apresenta dois exemplos de tômbolos atuais no extremo norte da praia de Vila Nova, um incipiente defronte à ilha de Santana de Dentro, e outro bem desenvolvido no pontal de Santana de Fora. Paleotômbolos holocênicos encobertos pelo sistema eólico devem ocorrer a oeste do morro Mar Grosso, onde existiram três sambaquis (Bocchi \& Liberatore 1968c; Castro \& Castro 1969b) e a oeste das pontas do Ji e de Itapirubá. Nesta última localidade, são encontrados depósitos de cascalho do tipo tômbolo erosivo, provavelmente formados durante o máximo transgressivo holocênico e retrabalhados ainda hoje em sua porção inferior. Depósitos similares são encontrados em reentrâncias do embasamento (figura 5.16) na ponta do Catalão, mesma área de ocorrência dos ortoconglomerados pleistocênicos, e na extremidade norte da praia de Muita Água. A característica proeminente de todos estes cascalhos é a imbricação dos matacões com mergulho para o mar, indicando arranjo dominado por ondas de saca ("swash"). Este tipo de arranjo é o mais comum em cascalhos praiais (Fritz \& Moore 1988). 


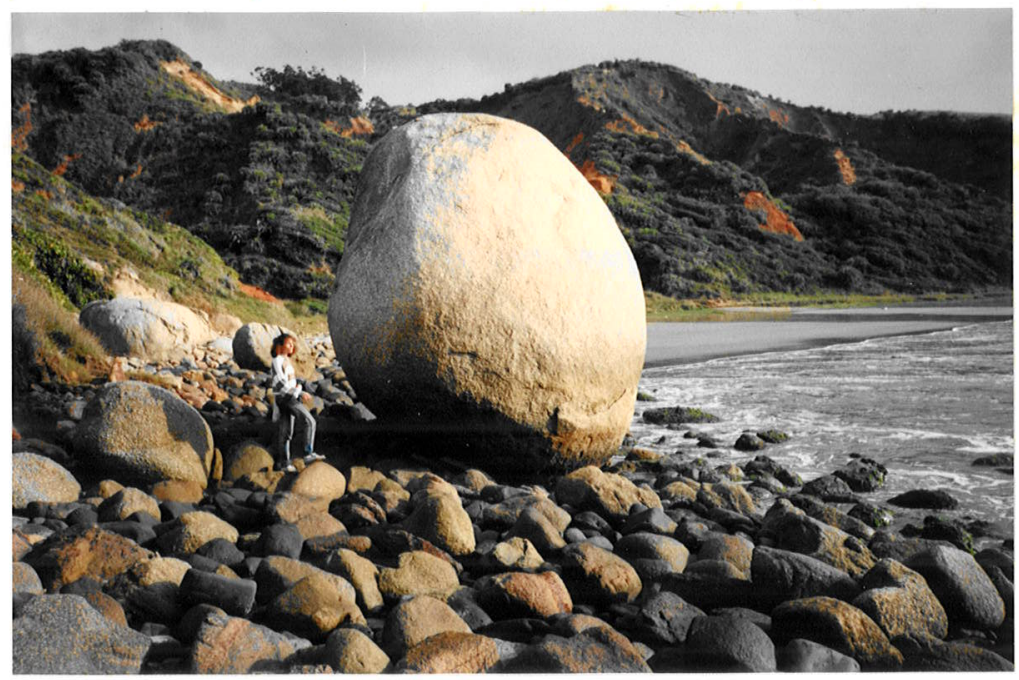

Figura 5.16. Praia de cascalho junto a ponta do Catalăo, extremidade sul da praia de Muita Água. Notar imbricaçăo com mergulho para o mar.

\subsubsection{Praias de mar aberto}

De sul para norte, os principais setores praiais abrangidos pelo sistema planície costeira holocênico atual são Mar Grosso, Ji, Sol, Itapirubá, Vila Nova, Imbituba e Muita Água. Numa avaliação grosseira, estas praias podem ser consideradas dissipativas. As principais evidências são a altura máxima média das ondas, superior a $1,0 \mathrm{~m}$, a morfologia planar e pouco ingreme da face de praia, com berma indefinido, o bom desenvolvimento de barras alongadas submersas e a distância relativamente grande entre as linhas médias de arrebentação e de espraiamento assim como entre a virtual linha de arrebentação externa e a linha de arrebentação principal, ambas girando em torno de $120 \mathrm{~m}$ nas condições prevalecentes (figura 5.17).

A praia de Imbituba, com ondas menores, planimetria logespiral, morfologia pouco mais íngreme na face de praia e pequeno distanciamento entre arrebentação e espraiamento (cerca de $50 \mathrm{~m}$ ), é exceção dentre as praias extensas. A praia do Mar Grosso apresenta características morfológicas intermediárias entre a de Imbituba e as demais. A praia de Muita Água, única praia de bolso investigada em detalhe, caracteriza-se por ondas baixas (menores que $0,5 \mathrm{~m}$ ) alinhadas segundo várias frentes de translação simultâneas (figura 5.18). 

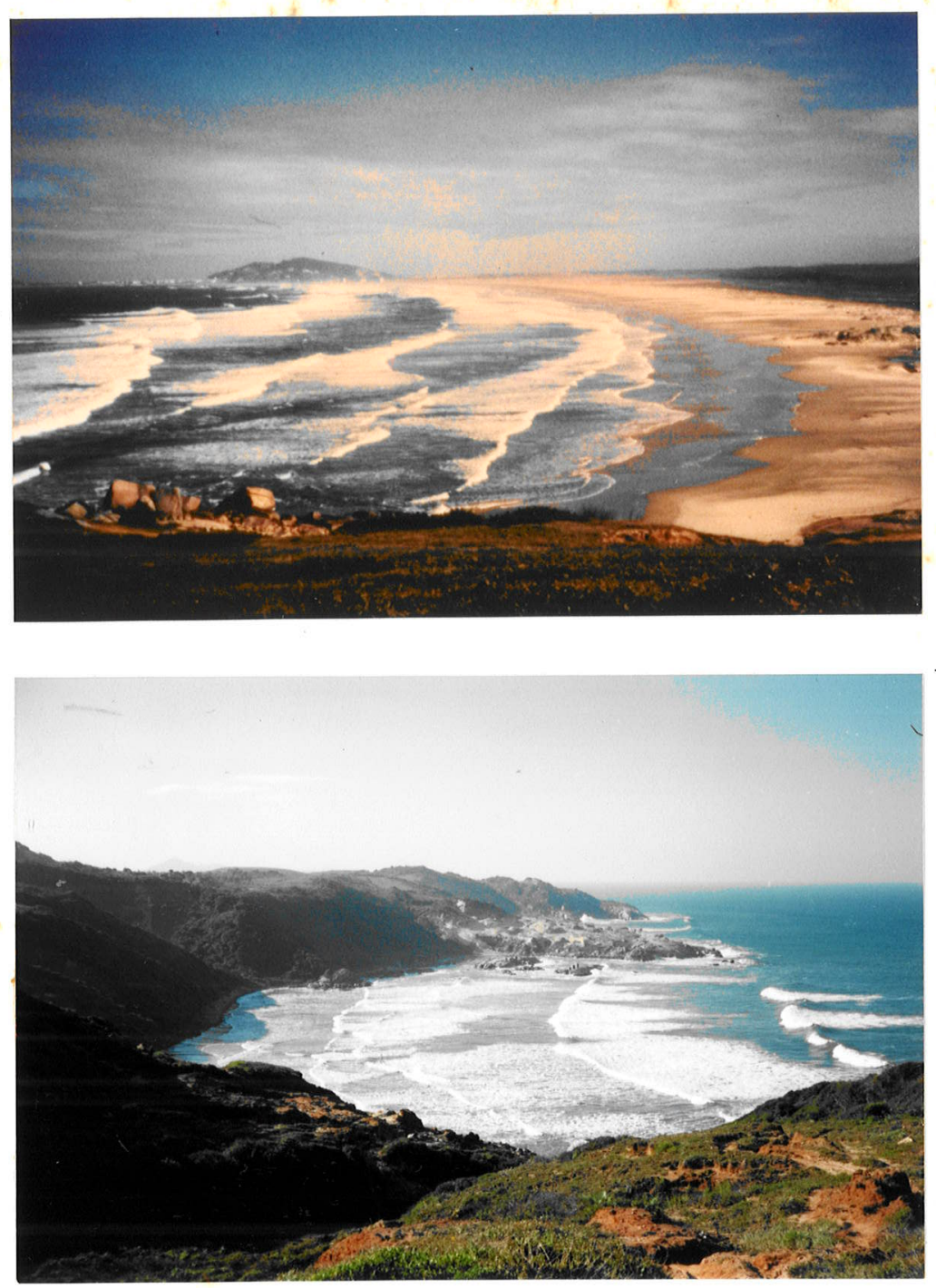

Figuras 5.17 e 5.18. Praias no sistema planície costeira.

5.17 (superior). Praia do Sol vista a partir de sua extremidade norte (ponta de Itapirubá). Inclui-se entre a maioria das praias da área de Jaguaruna-Imbituba que possui morfodinámica mais dissipativa. (Comparar com figura 5.5).

5.18 (inferior). Praia de Muita Água, com paleodunas em erosåo marinha em sua extremidade norte (ponta da Careca do Velho).

Apesar da menor energia de ondas devida ao caráter protegido, a morfodinâmica da praia de Muita Água é predominantemente dissipativa. Contribui para isto o fato de a praia situar-se numa reentrância erosiva de escarpas arenosas formadas por dunas de topo de encosta de gerações 1 e 2 (figuras A19, 5.18 e 5.46); o solapamento pelas ondas das escarpas situadas nos pontões ou no interior da praia durante as marés altas e de tempestade, fornece à face litorânea grandes volumes de sedimentos; além disso, a encosta ingreme diante da praia também favorece o aporte dos mesmos sedimentos através de numerosas ravinas de 
drenagem associadas a nascentes de água no substrato proterozóico encoberto; estas são de atuação quase permanente, de onde se origina sua toponímia. Concentrações de minerais escuros nos sulcos de drenagem pluvial de paleodunas das gerações $1 \mathrm{e}$ 2 indicam tanto aqui como em várias outras localidades onde estas gerações ocorrem, seu grande conteúdo de minerais pesados. Na praia de Muita Água, especialmente após marés altas associadas a chuvas, a concentração natural de minerais pesados (figura 5.19) atinge indices extremos, chegando a constituir lâminas de pelo menos 1,0 $\mathrm{cm}$ de espessura, a teores em massa de pesados maiores que $70 \%$, cobrindo toda a zona emersa da praia. Concentrações de pesados na pós-praia e em dunas frontais podem ser percebidas também, em proporções menores, nas praias de Vila Nova e Imbituba, justamente onde se tem maior aproximação entre as paleodunas das gerações 1 e 2 e a linha de costa (prancha A2).

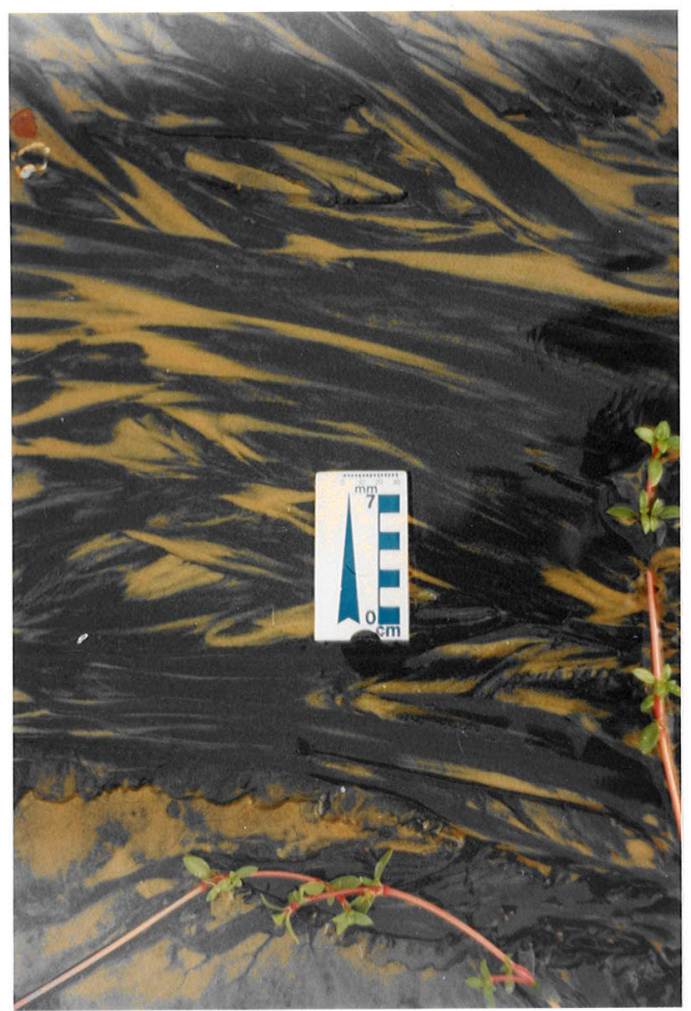

Figura 5.19. Concentração de minerais pesados escuros em sulcos de escorrimento ("rill marks") na praia de Muita Água.

Utilizados os critérios geomorfológicos de Jacobsen \& Schwartz (1981) para dedução de rumo de deriva litorânea longitudinal resultante, diversas feições notadas em aerofotografias evidenciam deriva predominante para norte ao longo das praias extensas do sistema planície costeira atual. Entre elas, merecem destaque: (1) o crescimento preferencial de esporões arenosos emersos ou submersos em zona de sombra a norte de obstáculos costeiros pontuais como ilhas ou pontöes rochosos, conforme Evans (1942 apud Jacobsen \& Schwartz 1981); esta feição é observada, por exemplo, sob a forma de barra longitudinal submersa na ilha de Santana de Fora, praia de Vila Nova, evidenciada pelo aparecimento localizado de uma linha de arrebentação externa ; (2) a presença de terminações praiais planocôncavas de raio de curvatura mínimo, tipo log-espiral (Yasso 1965) sempre no 
extremo sul dos setores costeiros estudados, como melhor exemplificado por Ji, Itapirubá e Imbituba; (3) o desvio de correntes flúvio-lagunares para norte, como indicado por sistema de barras sedimentares submersas a norte do canal da Passagem da Barra, evidenciado por linhas de arrebentação distantes da costa (figura 4.10); (4) o acúmulo preferencial de sedimentos na face sul de obstáculos costeiros transversais à costa, como nos Molhes do Sul em Entrada da Barra (nos molhes de Imbituba, a situação é aparentemente inversa); (5) o aumento rumo norte da largura da praia, perceptível no setor Mar Grosso.

A distribuição diferencial de dunas frontais e dunas transversais desvegetadas ao longo da orla praial pode ser também relacionada a dissipatividade e portanto ao aporte sedimentar por deriva litorânea. Dunas frontais ocorrem preferencialmente nos trechos mais reflexivos como no Mar Grosso, no extremo sul das praias do Ji e Itapirubá e ao longo da parte não escarpada da praia de Imbituba. Nas demais regiões da praias extensas ocorrem dunas transversais. A concentração preferencial de dunas frontais na parte sul das praias e de dunas transversais na parte norte será objeto de análise da descrição interna do sistema eólico (itens 5.4.2.5.2 e 5.4.2.5.3).

\subsubsection{PADRÃO SEDIMENTOLÓGICO}

As unidades faciológicas amostradas foram as subfácies póspraia e antepraia do sistema planície costeira atual, a subfácies indiferenciada de mar aberto do sistema holocênico antigo e subfácies indiferenciadas de mar aberto e de tômbolo do sistema pleistocênico. Para estas unidades foram obtidos resultados de análises granulométrica e mineralógica.

\subsubsection{Granulometria}

Em referência às análises granulométricas são apresentados tabelas de resultados, ( $A 8$ e A9), tabela de regressão estatística ( $A 10)$ e gráficos de variação geográfica (figuras A28 a A39)

De modo geral, o sistema planície costeira pleistocênico de mar aberto é caracterizado por areias finas (teores de 59 a $92 \%$ ), com quantidades subordinadas de areia média e areia muito fina e podendo conter até $12 \%$ de pelíticos de origem em essência pedogênica (tabela A8). Na classificação nominal de Folk \& Ward (1957), têm-se areias finas (média 2,4 phi ou 0,19 mm), com seleção moderada a muito boa, fortemente negativas a quase simétricas, muito leptocúrticas a mesocúrticas (tabela A9). Os sedimentos de tômbolo são mais grossos, pior selecionados e mais positivos, com moda entre areia grossa e areia média.

No sistema planície costeira holocênico antigo, subfácies indiferenciada, ocorrem areias finas (87 a $93 \%)$, pobres em pelíticos (<3\%), com seleção muito boa e distribuição simétrica a mesocúrtica. Características médias similares são encontradas nas subfácies pós-praia e antepraia do sistema holocênico atual.

Em termos de valores médios, o sistema pleistocênico distingue-se do holocênico antigo pela presença de areia grossa e muito grossa, e 
pelos teores mais elevados de areia média $(11 \times 1 \%)$ e de materiais pelíticos $(4 \times 2$ $\%)$. Além disso, na distribuição areia, o diâmetro médio é mais grosso, a seleção é pior e as assimetrias mais negativas (tabela $A 9$ ).

$\mathrm{Na}$ diferenciação entre pós-praia e antepraia, a característica mais distintiva é a tendência da antepraia para teores mais elevados de areia média, exceto nas praias de mar Grosso e Vila Nova, onde estes teores são insignificantes, e na praia de Muita Água, onde a pós-praia é mais influenciada pelos sedimentos relativamente grossos das falésias de paleodunas pleistocênicas. A distribuição granulométrica percentual média dos sedimentos holocênicos antigos é mais semelhante à distribuição média da subfácies pós-praia que à distribuição de antepraia.

No exame da variação de características granulométricas médias por setor praial atual, observam-se tendências para queda do teor de areia média, crescimento do teor de areia muito fina e afinamento de diâmetro médio e de percentil $1 \%$ mais grosso (P01) no sentido sul-norte desde Ji até Vila Nova. As concentrações máximas de areia média e os valores de P01 mais grossos encontramse nas praias de Imbituba e Muita Água. Na praia de Muita Água ocorrem também os maiores teores de areia muito fina e de silte, implicando decréscimo no índice de seleção. Estes materiais finos, ricos em minerais pesados, são provenientes das falésias pleistocênicas que margeiam a praia e não são eliminados para costa afora devido a energia insuficiente e a alta freqüência de incidência das ondas.

Proporções relativamente elevadas de areia muito fina são encontradas ainda na praia do Mar Grosso. Outros padrões de variação interpraial rumo norte são o afinamento do diâmetro médio entre Ji e Vila Nova e o aumento de seleção granulométrica entre Mar Grosso e Vila Nova, além de tendências mais irregulares para queda de assimetrias e de curtoses.

Diversas tendências de variação sul-norte por setor praial foram reconhecidas por recursos gráficos e selecionadas por sua significância estatística $\left(R^{2}>40 \%\right.$ elou $\left.p>95 \%\right)$. Aumento do grau de seleção, acompanhado por afinamento da granulometria ou por redução da assimetria, é registrado na subfácies pós-praia do setor Sol (figura A29) e na antepraia dos setores Itapirubá (figura A30) e Vila Nova (figura A32). Este padrão indica, com alguma incerteza, deriva longitudinal resultante para norte (McLaren \& Bowles 1985). Outros tipos de padrão estatisticamente consistentes são encontrados nos setores Mar Grosso e Imbituba. Na antepraia do setor Mar Grosso, os resultados de correlação linear (tabela A10) indicam engrossamento de granulometria e aumento de assimetria rumo norte (NNW). Entretanto, os diagramas cartesianos (figura A28) permitem observar tratar-se de combinação de duas tendências localizadas, as de afinamento e queda de assimetria suaves na metade sul do setor seguidas de engrossamento e aumento da assimetria acentuados na metade norte. A complexidade do padrão resultante, de difícil interpretação, pode ser atribuída à combinação de efeitos de refração e de aporte lagunar sazonal na extremidade sul do setor praial. A praia de Imbituba é a única na área em estudo a apresentar um dos padrões indices inequívocos de rumo de transporte resultante segundo McLaren \& Bowles (1985), ou seja, a tendência "mais fino, melhor selecionado e mais negativo"; esta tendência, constatada tanto na subfácies pós-praia como na antepraia, ocorre de norte para sul (figuras A33 e A35), portanto em rumo oposto ao rumo de deriva aqui inferido para as praias de Sol, Itapirubá e Vila Nova. Uma série de condições locais de aporte e transporte 
sedimentar pode ser evocada para explicar este padrão "invertido" de deriva litorânea longitudinal efetiva indicado pelo "método de McLaren". Entre estas condições, podemse enumerar: (1) a assimetria longitudinal da praia, sendo a ponta de Imbituba um obstáculo muito mais efetivo às ondas vindas de sul que a ponta do Cravo às ondas procedentes de norte; (2) a orientação geral NNW da linha de costa no setor, que favorece ainda mais a sua proteção em relação às ondas predominantes de sul: (3) a maior erodibilidade da ponta do Cravo, coberta por paleodunas de topo de encosta, em comparação com a ponta de Imbituba, predominantemente granítica, o que aumenta a eficiência relativa da deriva sedimentar no rumo norte-sul; (4) o aporte continental de sedimentos à costa através de pequenos arroios e drenagens pluviais, diferenciado entre as partes sul e norte da praia: os sedimentos eólicos da geração 3 , presentes a sul, são tipicamente mais finos que os sedimentos das gerações 1 e 2 , predominantes a norte; (5) a presença do porto de Imbituba, construído a meados deste século, que constitui um prolongamento em direção NW da ponta homônima e consiste assim em obstáculo adicional à incidência direta de frentes de onda de quadrantes entre sul e leste.

Os molhes na praia de Imbituba, que atendem ao objetivo de evitar o assoreamento do porto, foram construidos possivelmente, já se tendo conhecimento deste rumo de deriva litorânea local para sul. Se é admitida a hipótese, baseada em evidências geomorfológicas, de que a deriva litorânea longitudinal na praia de Ibiraqüera (a norte da ponta da Careca do Velho) retoma o rumo "normal" para norte (NNE), então a região entre as pontas do Cravo e da Careca do Velho define-se como ponto divisor de correntes divergentes o que explica o seu regime erosivo. Por esta razão, esta região é a única ao longo da área estudada em que paleodunas das gerações mais antigas encontram-se em abrasão pelo nível do mar atual. Situação geológica semelhante, sedimentos costeiros mais antigos aflorando preferencialmente em pontos de divergência de células de deriva litorânea, já fora encontrada por Stapor \& May (1983) na costa nordeste da Flórida (EUA).

Em sintese, o padrão geral de variação da granulometria ao largo do sistema planície costeira pode ser atribuido a dois fatores principais: o efeito hidráulico da deriva longitudinal predominante para norte e a proveniência dos sedimentos. Em relação ao segundo aspecto, supõe-se que sedimentos pleistocênicos tenham constituído a fonte imediata para o desenvolvimento da planície costeira holocênica. A redução de granulometria e aumento de seleção ocasionadas pelo retrabalhamento assim implicado é mais evidente nos setores cuja progradação holocênica foi mais intensa, e onde a fonte pleistocênica situa-se portanto mais distante e/ou inativa em relação à costa atual, como nos setores da parte sul do sistema. A tendência longitudinal sul-norte em grande escala para sedimentos praiais modernos cada vez mais finos, melhor selecionados e mais negativos é uma evidência de que a deriva longitudinal predominante determinou a distribuição dos sedimentos quase independente de mudanças locais na natureza do fornecimento sedimentar. As exceções são os setores extremos: a sul, o do Mar Grosso, influenciado pelo aporte flúvio-lagunar do canal Entrada de Barra; a norte, o de Imbituba e o de Muita Água, afetados pela aproximação máxima à costa dos sistemas pleistocênicos marinho e eólico. Hipótese alternativa de que a seleção granodecrescente progressiva de sul para norte seja herdada do sistema planicie costeira pleistocênico não se confirma por resultados estatísticos (tabela $A 10$ ) 


\subsubsection{Mineralogia}

\subsubsection{Minerais pesados}

Os teores em massa de minerais pesados na fração areia muito fina (tabela A11) variam entre 0,3 e $72 \%$, no sistema pleistocênico, e entre 0,1 e $89 \%$, no sistema holocênico atual. A menor variabilidade de teores no sistema holocênico antigo (1 a 2 \%) não deve ser considerada para efeito de interpretação, pois o número de amostras analisadas foi significativamente menor. O teor máximo de magnéticos é de $0,4 \%$ no Pleistoceno e de 1,2 \% no Holoceno. Na fração não magnética, a freqüência de contagem de minerais transparentes não micáceos oscila entre 10 e $45 \%$, no Pleistoceno, e entre 16 e $85 \%$, no Holoceno (tabela A12). Dentre estes, zircão, turmalina, rutilo e cianita são os únicos minerais correntes em todas as amostras pleistocênicas, enquanto apenas turmalina, estaurolita e cianita aparecem em todas as amostras holocênicas. Zircão é o único mineral que chega a ocorrer como predominante (> $50 \%$ ), seja no sistema pleistocênico seja no holocênico, mas hornblenda atinge também a predominância em uma amostra de praia atual, no setor Vila Nova. A predominância de zircão nas subfácies praiais ativas é restrita a proximidades de pontões rochosos cobertos por paleodunas de topo de encosta, como nos extremos das praias de Itapirubá e Imbituba. Dentre os componentes mineralógicos que atingem a abundância (20-50\%), encontram-se turmalina e rutilo, no Pleistoceno, e turmalina, estaurolita e pistachita, no Holoceno. Chegam a comuns (5-20\%), no Pleistoceno, estaurolita, pistachita, sillimanita e cianita, e, no Holoceno, rutilo, leucoxênio/anatásio, apatita, cianita, sillimanita, hiperstênio e alteritos. Demais minerais, com ocorrência de rara a escassa (<5\%) são, no Pleistoceno, leucoxênio/anatásio, apatita, granada, pirocloro, hornblenda, hiperstênio, pigeonita, tremolita, andalusita e alteritos, e, no Holoceno, granada, zoisita, augita, pigeonita, tremolita e andalusita.

$\mathrm{Na}$ comparação entre assembléias médias pleistocênicas e holocênicas antiga e atual, a diferença mais evidente é a maior maturidade mineralógica da primeira, expressa através de valores muito superiores de freqüência individual de zircão (figura 5.20), de indice ZTR (tabela A12), e das razões r1 a r4 (figura 5.21). Além disto, o sistema pleistocênico apresenta teor médio de minerais pesados pelo menos seis vezes maior (tabela A11) e concentração de minerais opacos mais elevada (tabela A12). O contraste de maturidade entre os sistemas pleistocênico e holocênico antigo pode ser atribuído ao maior tempo de atuação de dissolução pósdeposicional nos sedimentos mais antigos. Uma conclusão corolária é que os sedimentos holocênicos não podem ter resultado somente do retrabalhamento do sistema pleistocênico, caso em que neles deveria ser encontrada uma maturidade mineralógica semelhante ou mesmo superior a da assembléia pleistocênica. Este tipo de relação só é observada localmente, como no extremo norte da praia de Imbituba e na praia de Muita Água, onde paleodunas pleistocênicas em erosão são quase a única fonte para os sedimentos praiais. A maturidade mineralógica comparativamente baixa do sistema planície costeira holocênico em maior parte de sua extensão indica o aporte de sedimentos "novos", através de arroios no continente ou de manifestações do "Principio de Bruun" (caso regressivo), na zona submersa. As evidências de renovação do aporte sedimentar diminuem nos arredores das pontas do Ji e Itapirubá 
e em Vila Nova (tabela A12), devido à contribuição sedimentar local de paleodunas pleistocênicas das gerações 1 e 2.
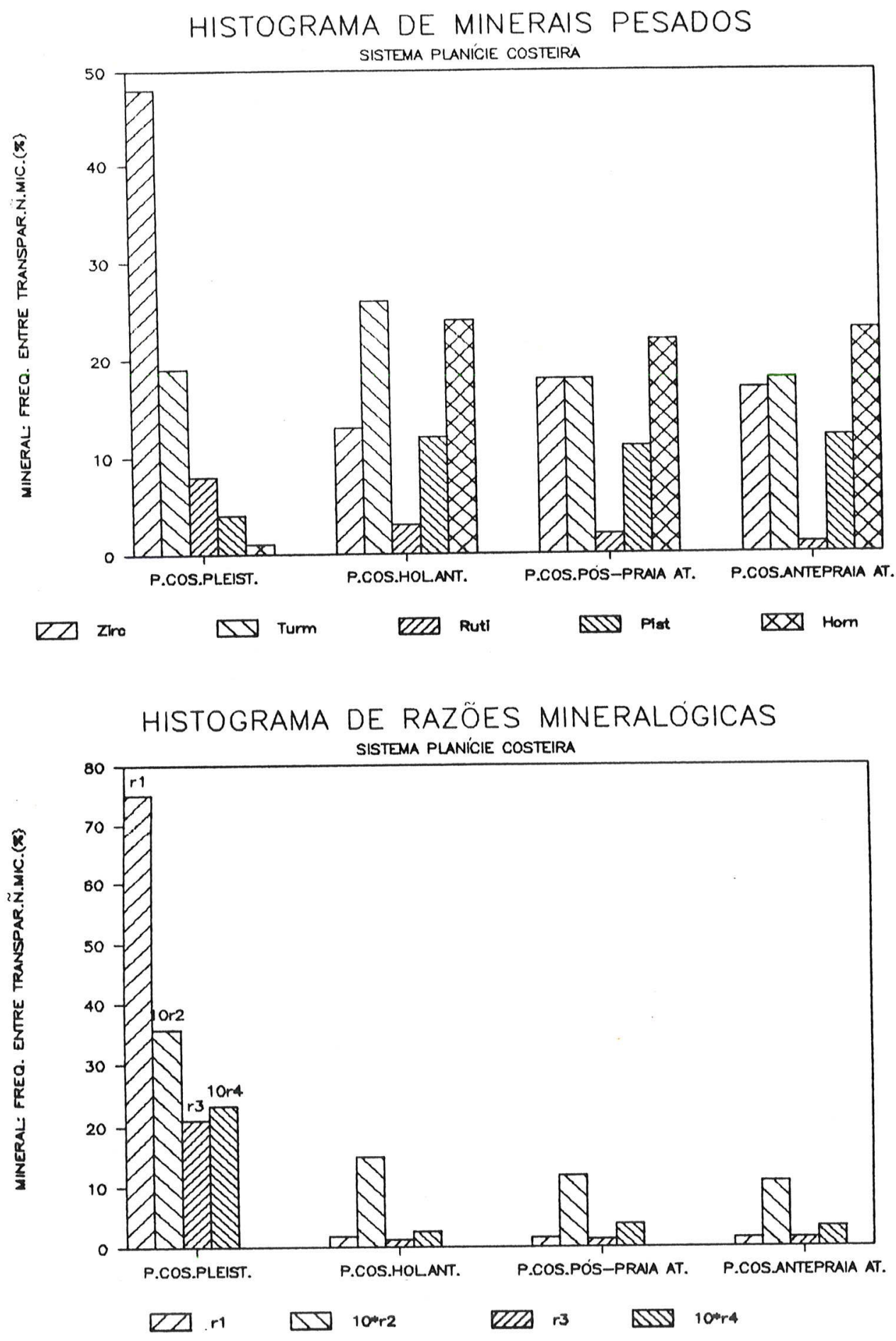

Figuras 5.20 e 5.21. Comparaçăo entre sedimentos de diferentes idades no sistema planície costeira. 5.20 (superior). Histograma de frequéncias percentuais médias de minerais pesados.

5.21 (inferior). Histograma de razóes mineralogicas médias. 
Sedimentos holocênicos antigos e atuais apresentam grande semelhança nos valores de teor em massa da fração densa e de freqüências de contagem de minerais pesados. A diferença aparente entre suas assembléias e maturidades médias, indicadas nas figuras 5.20 e 5.21 não é representativa, pois os resultados referentes ao sistema holocênico antigo são restritos à planície do $\mathrm{Ji}$, enquanto que o sistema atual foi amostrado ao longo de toda sua extensão praial. Quando se comparam as assembléias médias do Holoceno antigo e da praia do $\mathrm{Ji}$ atual, a única discrepância encontrada é um pequeno enriquecimento relativo dos sedimentos antigos em minerais ultraestáveis, com destaque para zircão, o que pode ser atribuido à dissolução intraestratal incipiente. O decréscimo de maturidade nos sedimentos atuais permite sugerir que haja continuidade, até o recente, do fornecimento renovado de sedimentos para a costa.

No confronto entre as assembléias médias das subfácies póspraia e antepraia atuais, as seguintes diferenças destacam-se: a antepraia tende a enriquecer-se em hornblenda e pistachita, enquanto a pós-praia se enriquece em rutilo (figuras 5.22 e 5.23); as razões de maturidade $r 1$ a r4 e ZTR (figuras 5.26 e 5.27), a freqüência de minerais opacos (figuras 5.22 e 5.23) e o teor em massa de minerais pesados total (tabela A11) são ligeiramente superiores na pós-praia. Estas tendências são similares às encontradas no sistema barra-barreira e podem ser atribuídas aos mesmos motivos (item 5.1.3.2.). As diferenças são todavia muito sutis e os casos de exceção mais numerosos, especialmente nas três praias de menor dissipatividade: Mar Grosso, Vila Nova e Imbituba.

O padrão de variação interpraial na mineralogia de pesados é bem definido. De sul para norte, as tendências mais regulares são: aumento do teor em massa de minerais pesados (tabela A11) e elevação da freqüência de zircão (figuras 5.24 e 5.25) a partir da praia do Sol; e queda da freqüência de minerais opacos e índice ZTR até o setor Sol, seguido de elevação até valores máximos na praia de Muita Água (figuras 5.22 e 5.25). Outros componentes variam de modo menos contínuo: estaurolita atinge suas concentrações máximas nos setores praiais Vila Nova e Imbituba, pistachita nas praias do Ji e do Sol e hornblenda ocorre como mineral abundante desde a praia do Mar Grosso até a de Itapirubá. Este padrão não monotônico de variação de mineralogia de pesados pode resultar da combinação de pelo menos dois fatores; o primeiro é a seleção hidráulica progressiva pela deriva litorânea resultante rumo norte, com retenção preferencial de minerais de maior densidade, incluindo opacos, zircão e rutilo; o segundo é a aproximação gradual, rumo norte, entre os sistemas planície costeira e eólico pleistocênicos e a linha de costa atual (prancha A2). A deriva longitudinal seria a responsável principal pelo decréscimo na freqüência de opacos e no índice ZTR até a praia do Sol, enquanto o aporte transversal de sedimentos pleistocênicos maturos cada vez mais próximos à linha de costa explicaria o aumento contínuo de mesmas freqüências a norte da ponta de Itapirubá.

No exame estatístico da variação longitudinal de mineralogia dentro dos setores praiais mais extensos (tabelas A13 a A14), correlaçöes lineares significativas $\left(R^{2}>40 \%\right.$ elou $\left.p>95 \%\right)$ foram encontradas em todas elas. Nas praias do $\mathrm{Ji}$ e de Itapirubá, as tendências observadas (figuras A36, A37 e A39) implicam aumento da maturidade mineralógica rumo norte e deriva longitudinal resultante em mesmo sentido, o que confirma determinações anteriores baseadas em evidências geomorfológicas e texturais. Vale destacar, a respeito do padrão mineralógico 

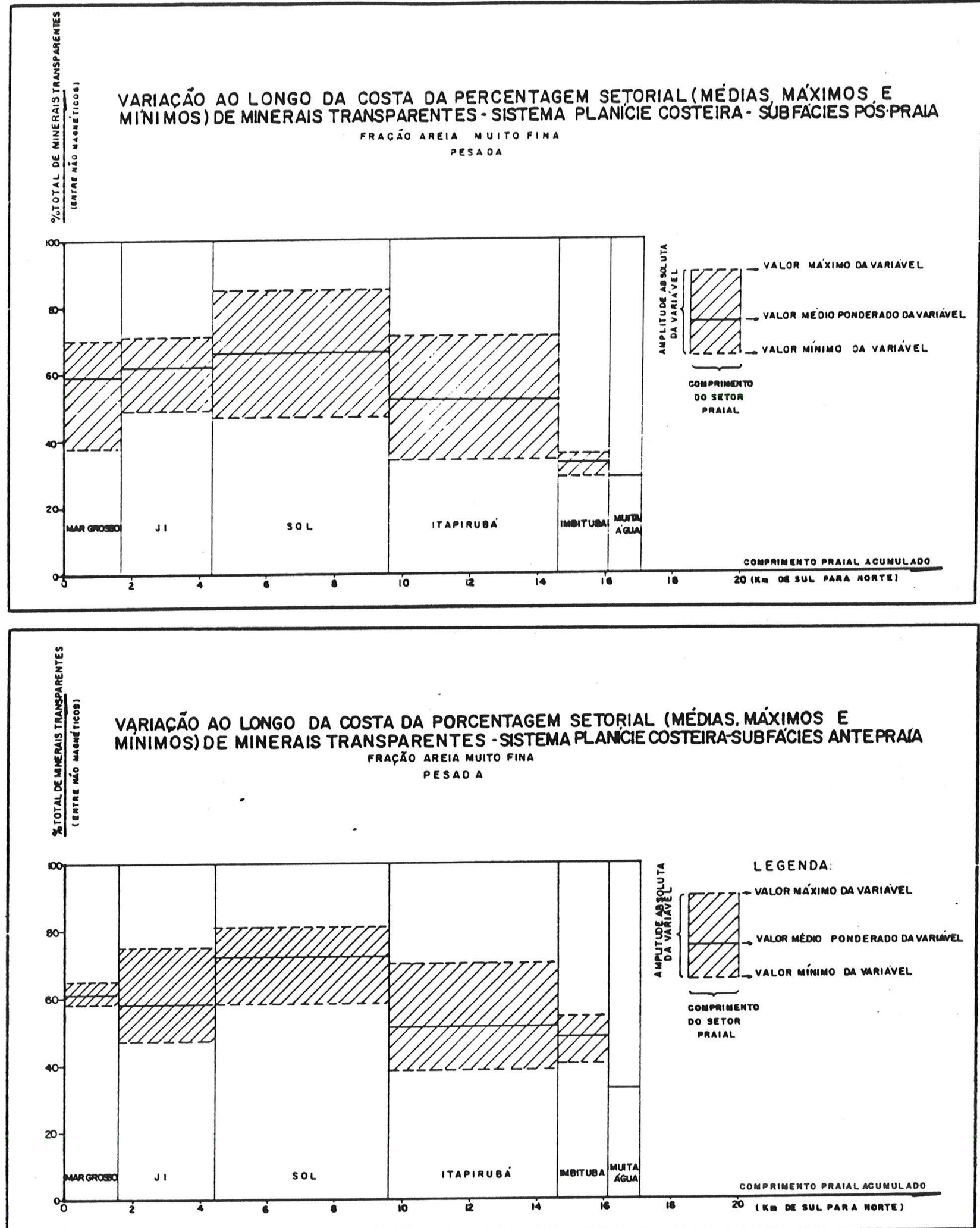

Figuras 5.22 e 5.23. Variaçăo ao longo da costa da porcentagem setorial (médias, máximos e mínimos) de contagem de minerais pesados transparentes - Sistema planície costeira.

5.22 (superior). Subfácies pós-praia

5.23 (inferior). Subfácies antepraia 

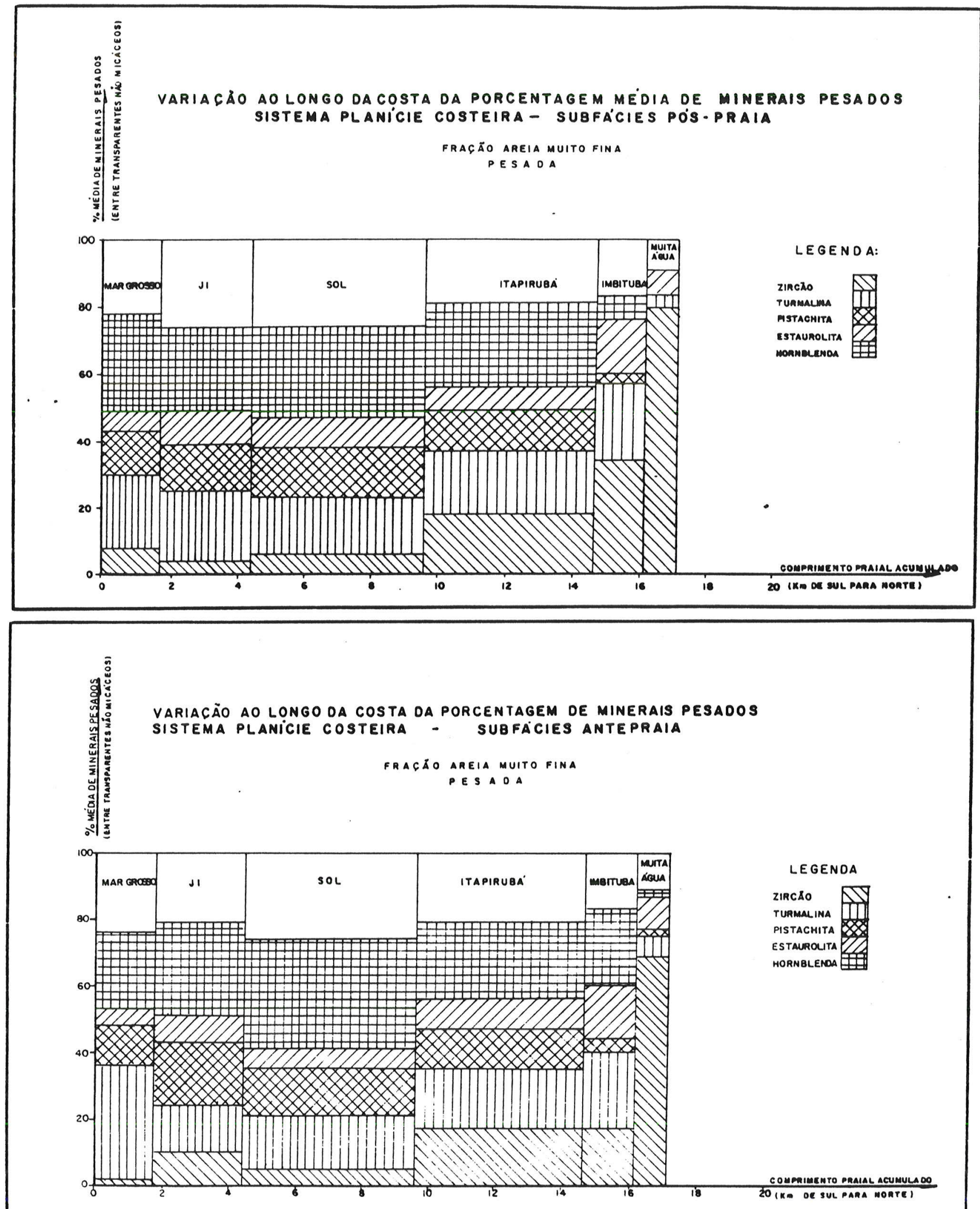

Figuras 5.24 e 5.25. Variaçăo ao longo da costa de porcentagens médias setoriais de contagem de espécimes de minerais pesados - Sistema planície costeira.

5.24 (superior). Subfácies pós-praia

5.25 (inferior). Subfácies antepraia 

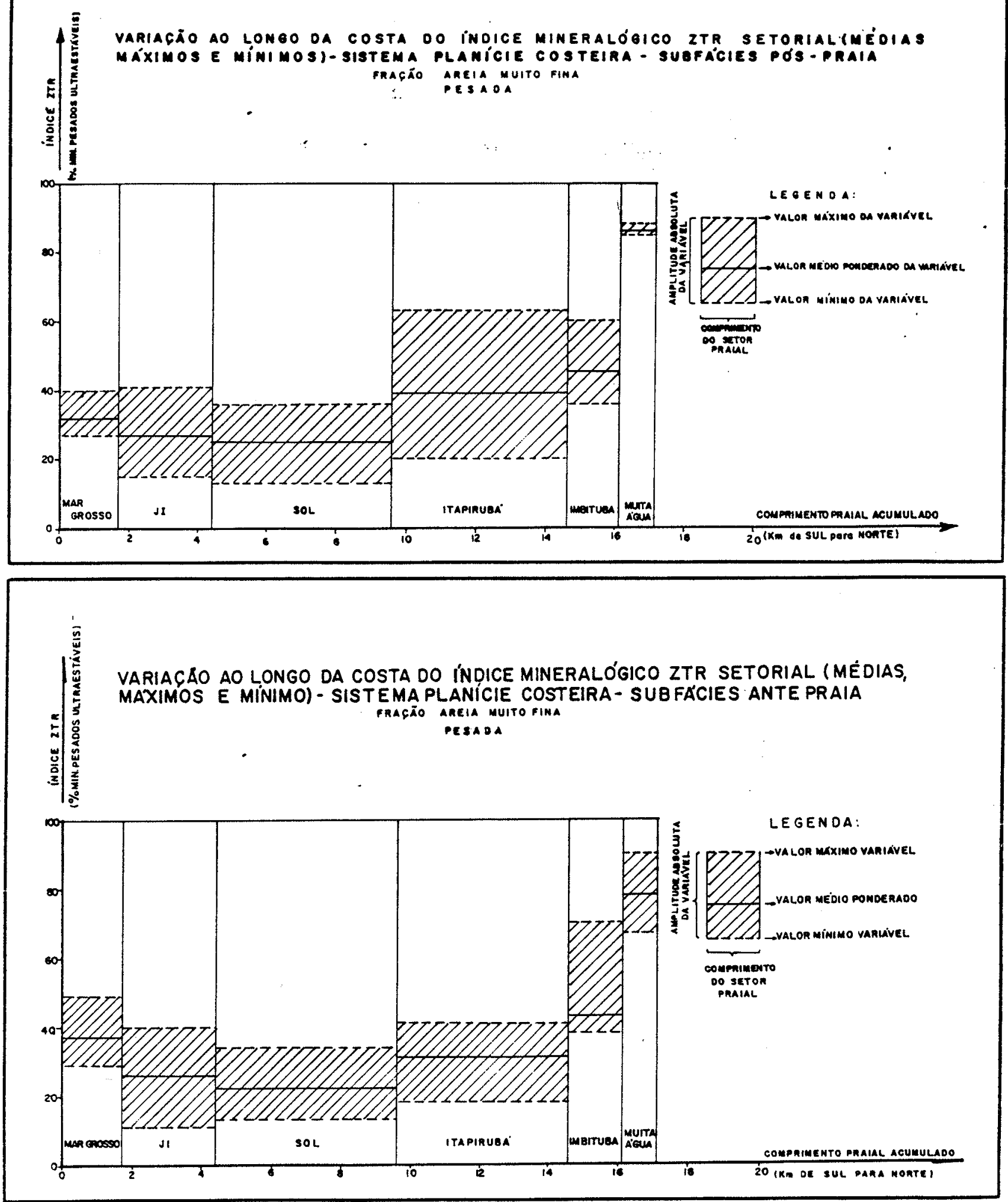

Figuras 5.26 e 5.27. Variaçăo ao longo da costa do índice mineralógico ZTR setorial (médias, máximos e minimos) - Sistema planicie costeira.

5.26 (superior). Subfácies pós-praia

5.27 (inferior). Subfácies antepraia 
longitudinal nestas duas praias, que o teor em massa total da fração pesada apresenta correlação direta com a maturidade, enquanto que com a freqüência de minerais metaestáveis esta correlação pode ser direta ou inversa. A praia do Sol, em contraste, exibe padrões que, em primeira instância, contradizem a hipótese de deriva longitudinal para norte (figura A38). Não existem neste setor, porém, fatores que tenham possibilitado uma inversão local da deriva longitudinal, como a evocada para a praia de Imbituba (item anterior). Parece provável, portanto, que a redução de maturidade mineralógica rumo norte esteja associada a uma questão de proveniência diferencial entre as partes sul e norte deste setor praial. Como já discutido (item 5.2.2.1.), a praia do Sol tem restringido sua progradação recente à região hoje representada pela ponta do $\mathrm{Ji}$, onde deve ter-se desenvolvido um paleotômbolo à retaguarda de testemunhos cristalinos cobertos por dunas de topo de encosta pleistocênicas. O retrabalhamento dos sedimentos maturos destas paleodunas, o qual permanece até hoje, favorece o aumento localizado da maturidade dos sedimentos praiais.

\subsubsection{Minerais leves}

Resultados de estudo de impregnação superficial de grãos leves em areias marinhas dos sistemas barra-barreira e planicie costeira (tabela 5.3) permitem reconhecer duas ordens de grandeza de teor de grãos impregnados.

Tabela 3.3

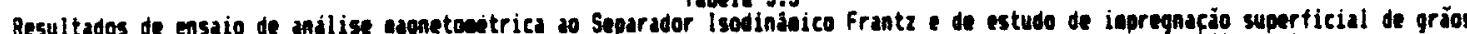

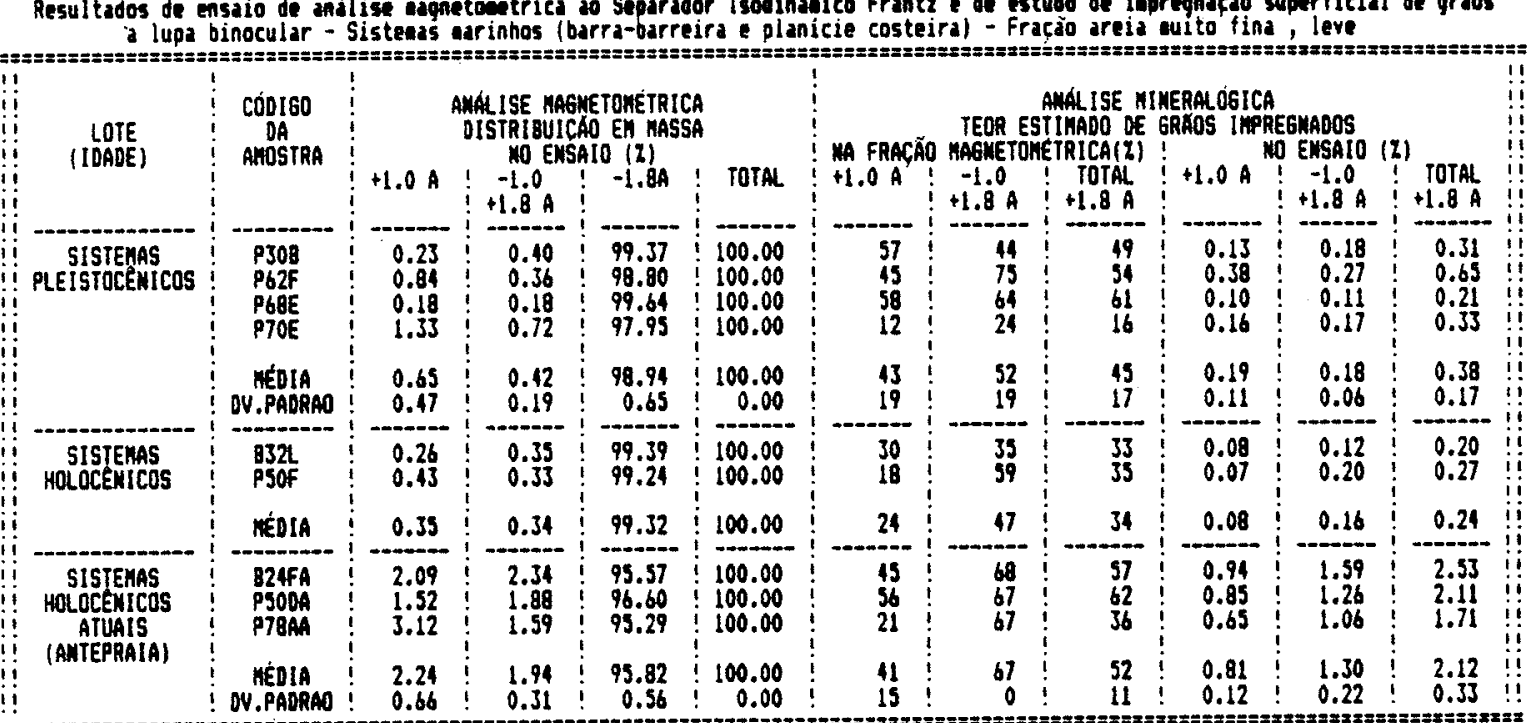

Obs.: notaça adotada para produtos de asgnetoaetria : $+\mathrm{n}=$ atraido en $n \mathrm{~A}$;

- $A=$ a 30 atraido on i.

A ordem de grandeza menor, entre 0,2 e $0,7 \%$ em massa, encontra-se em sedimentos pleistocênicos e holocênicos antigos. A ordem de grandeza maior, entre 1,7 e $2,5 \%$, ocorre em areias de praia atual. As areias mais limpas, no sentido clássico de pureza granulométrica e escassez de material pelítico, são portanto mais impregnadas que as areias mais impuras; este aparente paradoxo significa que o cimento que tinge os sedimentos mais antigos ocorre preferencialmente sob a forma de partículas pelíticas e coloidais livres, preenchendo intersticios entre 
grãos de areia, sem estabelecer com eles ligações fortes (consiste em um material em maior parte lavável, sem necessidade para isso de atrição mecânica). Difere, sob este aspecto, do material cinza escuro ou alaranjado que impregna fraturas e microcrateras de grãos de areia de praia. A questão mais difícil de ser explicada nestes resultados é por quê esta pelicula de impregnação afeta maior número de grãos nos sedimentos marinhos recentes que nos antigos. Pelo menos duas hipóteses podem ser evocadas. A primeira é a de uma maior contribuição, no aporte para a praia atual, de sedimentos "novos", originados do manto de intemperismo de rochas granitóides, e pouco retrabalhados. A segunda hipótese é a de que a água do mar, talvez por seu pH elevado, desfavoreceria a destruição da película existente nos grãos de areia de praia atual, ao contrário das águas vadosas ácidas. Estas duas hipóteses voltarão a ser discutidas quando da estudo da impregnação superficial em outros sistemas deposicionais (itens 5.3.3.3.2 e 5.4.3.3.2.).

\subsection{SISTEMA LAGUNAR}

\subsubsection{IDADE RELATIVA}

A história de formação de estuários e lagunas modernas tem sido situada pela maioria dos autores nos últimos 6 a 8 mil anos (Lankford 1977; Fairbridge 1980, Yáñes Arancibia 1986). Reconhece-se, no entanto, que muitas lagunas sāo formadas através do afogamento, durante a transgressão holocênica, de áreas de topografia baixa preexistentes, entre as quais se pode incluir, em tese, paleolagunas correlatas à transgressão anterior (Riss-Würm ou Sangamon). Este tipo de laguna encontra-se na costa brasileira e inclui-se no que aqui se convencionou denominar baixio-laguna. Tem, como maior exemplo brasileiro, o complexo lagunar Patos-Mirim, RS, cuja individualização é atribuida por Villwock (1984) e Villwock et al.(1986) ao desenvolvimento de "sistema laguna-barreira" ainda no . Pleistoceno superior. Seria deste modo uma laguna de origem primária mais antiga que o que se supõe como regra na literatura.

$\mathrm{Na}$ área em estudo, não se dispõe de evidências seguras que permitam confirmar ou rejeitar a hipótese de origem primária pleistocênica para 0 sistema baixio-laguna. A obtenção destas evidências depende de datações e determinações paleoambientais em sedimentos de subsuperficie ao largo das lagunas Imaruí e Mirim. A presença de paleotômbolos marinhos na margem interna do sistema, cujas altitudes são compativeis com o último máximo transgressivo do Pleistoceno, indica que pelo menos até a época deste máximo, esta margem encontrava-se sob condições de mar aberto. Cabe destacar que à esta época a costa apresentava topografia irregular, aspecto tido como desfavorável à formação de lagunas-barreiras (Lankford 1977).

Lagunas costeiras são continuamente modificadas em sua geometria e portanto em sua faciologia, por diversos agentes de erosão ou colmatação, como migração de dunas ou progradação de deltas internos (Phleger 1951 apud Lankford 1977). Esta dinâmica deixa seu registro na forma de um mosaico de feições remanescentes de distintas fases evolutivas da laguna, muitas vezes 
incompativeis entre si e em desequilibrio com a operação atual do sistema (Tomazelli 1990). Tais são os casos de várzeas turfosas e aluviões recentes desenvolvendo-se sobre cordões praiais ou fundos lagunares antigos. Um modelo de hierarquia de fácies, associando escalas de espaço e tempo (tabelas 5.4 e 5.5), é por esta razão um pré-requisito básico para a compreensão de estrutura, funcionamento e evolução do sistema lagunar. No modelo apresentado, as feições de menor hierarquia são feições atuais e dispõem-se sobre unidades faciológicas de maior hierarquia, cuja origem é cronologicamente mais remota, e assim sucessivamente, até chegar-se às duas associações de fácies maiores. 
Tabela 3.1

Distribuifão de fócies en supertície no sisteas lagunap - Associaço de tácies bain-laguna

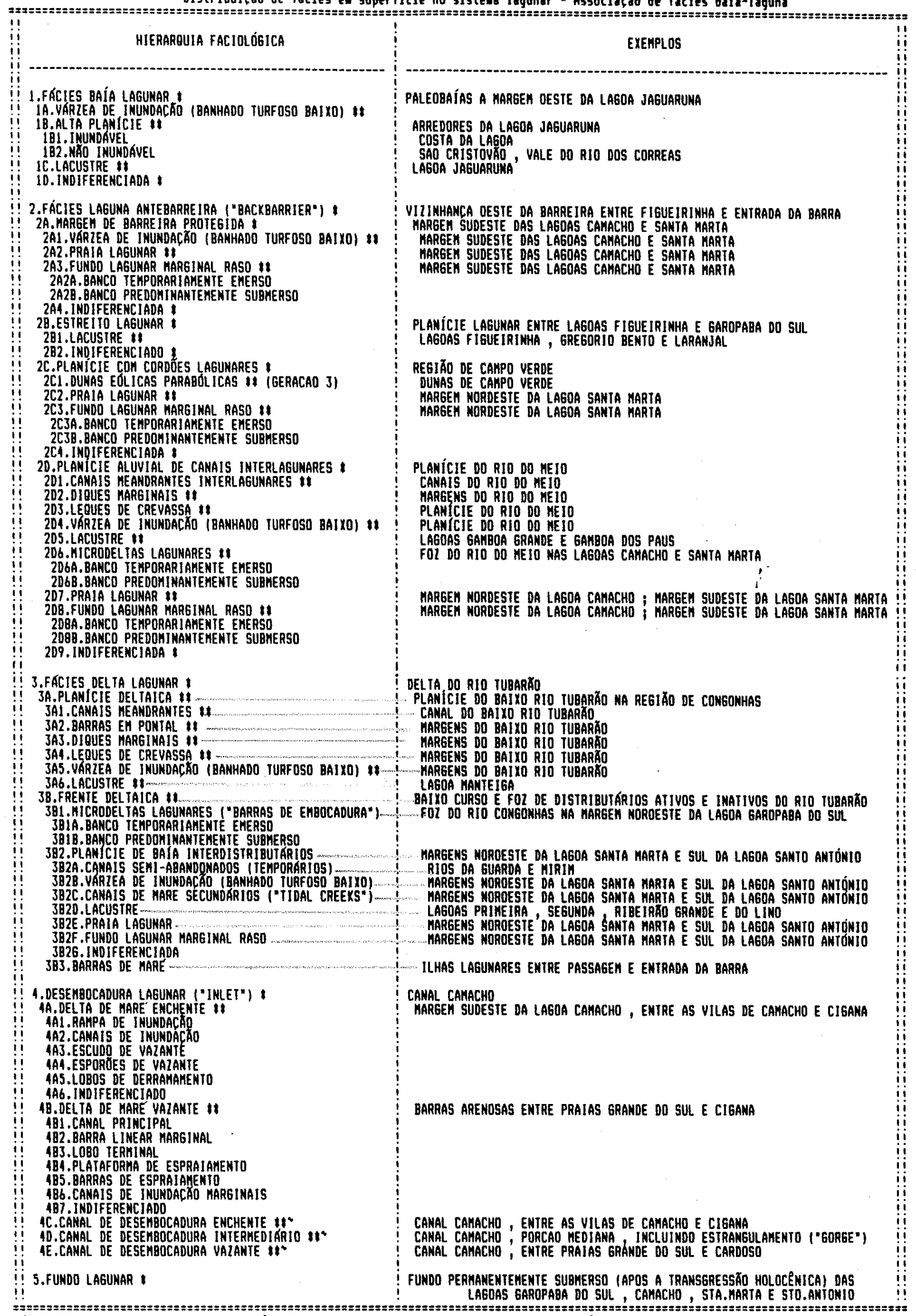

Sínbolos utilizados : :-idade holocênica antiga ou inditerenciada ; 11 - idade holocênica atual a subatual ;

- fácies de transiço coe sistesa barra-barreira 
Tatola 5.3

Distribuiçóo de fícies en supertície no sisteta lagunar - Associaç̃o de tácies baixio-laguna

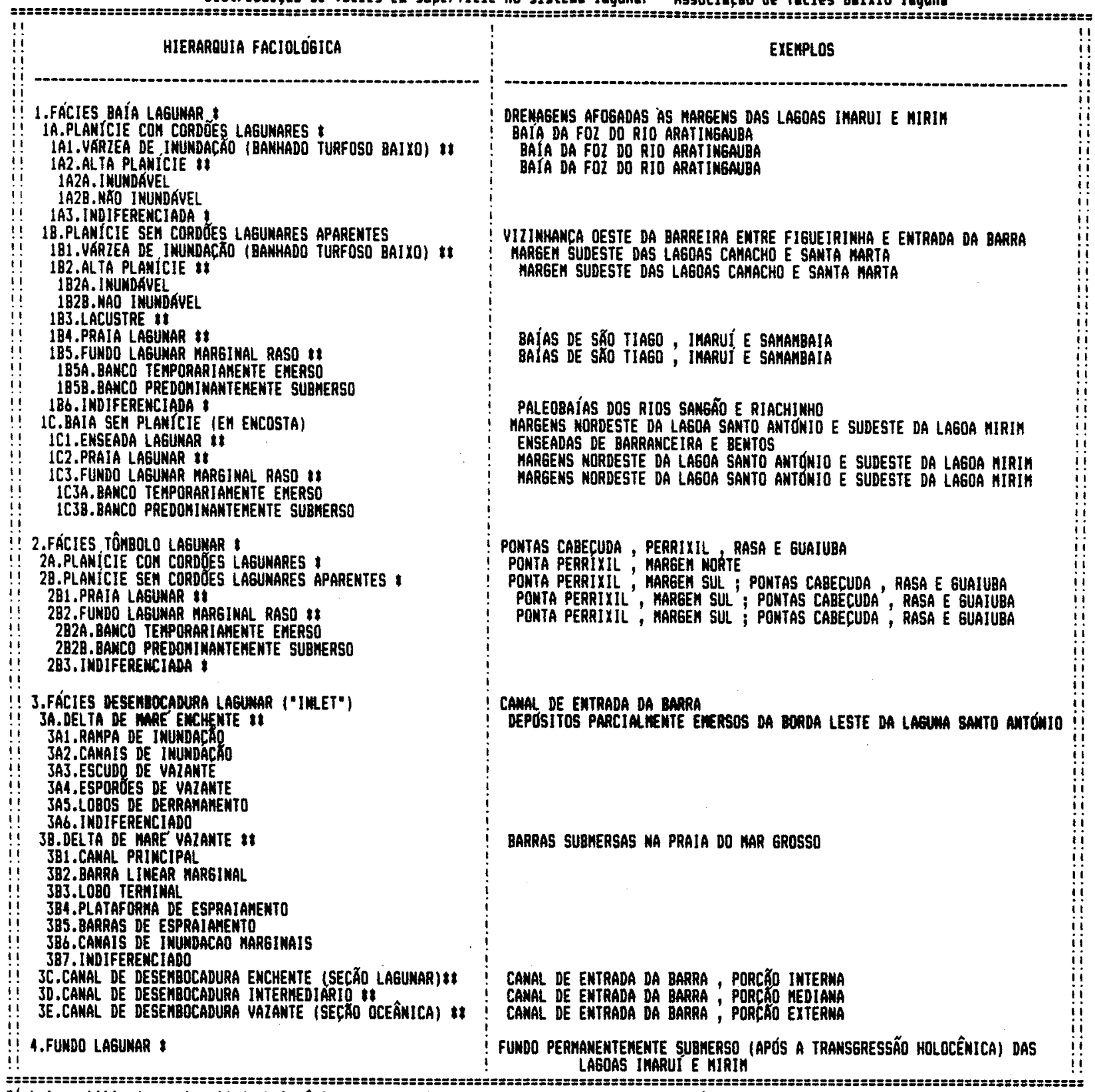

Síabolos utilizados : 1 - idade holocênica antiga ou indiferenciada; 11 - idade holochica atual a subatual

\subsubsection{PADRÃO FISIOGRÁFICO}

\subsubsection{Associações de fácies}

O sistema lagunar entre Jaguaruna e Imbituba é dividido em duas associções de fácies interligadas (item 3.3.4). A associação baía-laguna corresponde ao tipo clássico de laguna costeira isolado por barreiras arenosas geradas no âmbito da transgressão holocênica; é o tipo 3 ("laguna de plataforma interna barrada") na classificação de Lankford (1977), baseada na costa mexicana, ou o tipo 2 ("laguna associada ao máximo transgressivo holocênico") na classificação de Amador (1985), baseada na costa fluminense. Lankford (1977) suspeita da ocorrência preferencial deste tipo de laguna em costas de mais alta energia, enquanto Yáñes- 
Arancibia (1986) associa-o à presença de rios ou paleorrios aportando sedimentos para a formação da barreira. Na associação baía-laguna da área em estudo, validamse ambas as relações. Ela é formada por cinco fácies (tabela 5.4). A primeira, fácies baía lagunar, corresponde a antigas margens e fundos de baías adjacentes da zona serrana cristalina, formadas por ocasião do máximo de NRM holocênico, e caracterizadas por sedimentação em águas rasas de baixa circulação, sob influência de aporte continental por leques de retrabalhamento de colúvio, movimentos de massa e pequenas drenagens. Atualmente, esta fácies é influenciada por sedimentação alúvio-coluvionar e por inundações pluviais temporárias, favorecendo 0 desenvolvimento local de brejos e turfeiras e a manutenção de lagos residuais. A segunda fácies, de delta lagunar, formou-se adjacente à primeira, nas zonas onde processos de sedimentação fluvial foram tão ou mais importantes no assoreamento da baía-laguna que o mecanismo de abaixamento descontínuo do NRM. A terceira fácies, laguna antebarreira, restringe-se a porção da baia-laguna imediatamente vizinha ao sistema barra-barreira. Por sua posição afastada das fontes de sedimentos continentais, é supostamente a última destas três fácies a iniciar seu processo de emersão. É também a mais influenciada pela ação deposicional da maré, do vento, das ondas lagunares e das ondas marinhas de tempestade. Apesar disto, pode apresentar o desenvolvimento recente local de subfácies tipicamente fluviais, similares às de planície deltaica, devido a formação de complexos de canais interligando corpos aquosos remanescentes. Associa-se, à leste, às duas outras fácies desta associação, ambas total ou parcialmente submersas: a desembocadura lagunar e o fundo de lagunas residuais.

A associação de fácies baixio-laguna apresenta correlação com o tipo 1, "laguna de erosão diferencial", de Lankford (1977). Difere da associação baía-laguna, em essência, pela falta de deltas lagunares em escala de fácies e pelo desenvolvimento de tômbolos em torno de morrotes testemunhos de erosão. A influência da sedimentação fluvial na associação baixio-laguna é menor e a da sedimentação eólica é quase nula, o que the confere maior homogeneidade faciológica. O caráter de drenagem afogada favorece maiores profundidade e "comprimento relativo" (razão extensão/largura: Zenkovitch 1967), e propicia assim maior "fetch" e intensidade de ação de ventos na formação de ondas lagunares. A associação destas ondas com as irregularidades topográficas dos testemunhos de erosão enseja a produção de tômbolos alternados com baias erosivas, em torno dos quais a circulação de correntes é intensa, dada a constância da desembocadura lagunar de Entrada da Barra. Essa hidrodinâmica não tem permitido a interligação entre tômbolos de margens opostas, mantendo a continuidade de corpo aquoso que caracteriza a associação baixio-laguna. Na associação baia-laguna, em contraste, a compartimentação do corpo aquoso, devida a seu preenchimento pelo delta lagunar e por pontais externos resultantes da interação entre deltas de maré enchente, leques de sobrelavagem e ondas lagunares fracas, chega a gerar o isolamento completo de lagos e lagunas (Laranjal, Jaguaruna, Manteiga, Santa Marta).

A circulação hídrica intensa na associação baixio-laguna favorece a formação de feições deposicionais peculiares associadas a suas fácies de tômbolo e baía lagunar, tais como encostas erosivas (baías sem planície) e alinhamentos de cordōes. 


\subsubsection{Subfácies principais}

\subsection{Várzeas de inundação e altas planícies}

Várzeas de inundação lagunar ocorrem como subfácies atual nas fácies delta e antebarreira da associação baía-laguna e na fácies baía lagunar da associação baixio-laguna. Incluem-se os terrenos referidos em outros trabalhos sobre a área em estudo como "brejos de lodo" (Pimienta 1958) ou "pântano temperado" (Santos \& Araujo 1987). Incluem também a ocorrência mais meridional de mangue no Brasil (Araujo \& Santos 1987, Herz 1991). Definem-se aqui como áreas de sedimentação gradual organo-pelito-arenosa, influenciada pela presença de vegetação e pelo regime de submersāo rasa ou encharcamento constantes, sem influência significativa de processos de transporte trativo. $O$ afogamento ocorre pela ação direta ou indireta da elevação do nível lagunar, controlado em maior extensão pelas marés, e dá-se a partir de pequenos córregos de drenagem com caráter de canais de maré. Trata-se portanto de sedimentos vegetados compreendidos pela zona intermarés média, do tipo de pântanos salinos baixos ("low salt marshes": Frey \& Basan 1978). Ocorrem em camadas de espessura decimétrica, gradando na base para sedimentos arenosos mais puros. Estes sedimentos arenosos pertencem a alguma das subfácies vizinhas mais comuns à várzea de inundação, tais como areias de leques de crevassa ou de calhas entre barras em pontal, nas fácies antebarreira e delta, ou areias de praia lagunar ou de depósitos coluvionares (alta planície) na fácies baía lagunar.

A subfácies de alta planicie corresponde a antigos fundos lagunares com influência atual de sedimentação aluvionar. Inundações periódicas afetando suas porções mais baixas e levando à manutenção de banhados turfosos são de origem predominantemente continental. Em baias lagunares, ela ocorre em contatos transicionais ao exterior com a subfácies várzea de inundação. Forma-se nesse caso entre esta última subfácies e os depósitos continentais de colúvios e leques de aluviões existentes ao sopé da encosta serrana na borda interior do sistema lagunar. Alterna assim a influência de processos de enxurradas e fluxos de massa continentais, de caráter predominante episódico, com mecanismos de inundação e crescimento centripeto de vegetação típicos de alta intermarés em borda lagunar. A zona inferior desta subfácies, na vizinhança imediata da várzea de inundação lagunar, é caracterizada pela presença de lâminas de caráter turfoso, intercaladas com sedimentos areno-granulosos imaturos. Em direção ao interior, as lâminas turfosas deixam de ocorrer inicialmente em superfície e depois nas intercalações superficiais, indicando o recuo recente dos limites de máxima inundação lagunar. A várzea de inundação lagunar e a zona inundável da alta planície de baía lagunar são membros extremos ideais de uma série de tipos de banhados turfosos atuais, entre os formados por inundaçōes de maré e os gerados por enchentes continentais. Na prática, é difícil separar estes dois agentes, tornando-se muitas vezes arbitrários os limites entre as duas subfácies.

\subsubsection{Lagos residuais}

Lagos residuais de antigos fundos lagunares ocorrem a diferentes niveis de hierarquia faciológica nas fácies baía lagunar, delta lagunar e antebarreira (tabelas 3.1 e 5.4). Estes lagos diferem entre si quanto ao regime 
hidrográfico atual. O lago Laranjal, na associação baía-laguna, próximo a Jaguaruna, caracteriza-se pela influência remota da maré e pelo aporte continental restrito a pequenos córregos. O lago Jaguaruna, na fácies baía lagunar da associação baíalaguna, apresenta aporte fluvial na forma de múltiplos córregos de drenagem provenientes do embasamento cristalino, sem influência significativa da maré. Os lagos de delta lagunar, como Manteiga e Lino, e de antebarreira, como Gamboa Grande e Gamboa dos Paus, refletem influências tanto das inundações fluviais em distributários do rio Tubarão quanto das enchentes de maré. Os lagos Figueirinha e Gregório Bento, na fácies antebarreira, caracterizam-se pela ausência de efeitos de maré normais e pelo escoamento superficial muito reduzido, com possivel tendência à restrição.

Diferentes mecanismos de sedimentação observam-se nas subfácies lacustres modernas na dependência do regime hidrográfico. Tomazelli (1990) menciona cinco mecanismos de colmatação de corpos aquosos em sistemas lagunares costeiros no Sul do Brasil. O mais abrangente e de ação comum é o rebaixamento descontínuo do nivel de base, controlado pela variação de NRM. Os quatro mecanismos específicos são, segundo o autor : o crescimento simétrico e centripeto de vegetação em corpos aquosos estagnados, a deposição de leques de crevassa em lagos situados entre lobos deltaicos, a progressão assimétrica de dunas eólicas, e a interferência antrópica. Dois ou mais destes mecanismos podem alternarse ou ocorrer simultaneamente em diferentes porções de mesmo corpo lacustre. Nos lagos Figueirinha e Gregório Bento, por exemplo, as margens norte e leste são caracterizadas pelo avanço de dunas barcanóides enquanto a margem oeste é influenciada pela colmatação por brejos lagunares.

\subsubsection{Praias lagunares}

O termo praia lagunar é aqui entendido no sentido de zona intermarés onde se tem o espraiamento de ondas induzidas na superficie lagunar pelo vento. Incluem-se nesta definição tanto praias arenosas e pouco vegetadas quanto praias de brejos areno-lamosos vegetados. Largura, granulometria e grau de cobertura vegetal das praias lagunares variam na dependência do aporte sedimentar por correntes, ondas, ventos e movimentos de massa, e de sua posição em relação a trajetória e energia de ondas lagunares e correntes. As ondas lagunares de maior energia e efetividade na dinâmica das praias são as geradas por ventos de raios de atuação ("fetch") máximo na superfície das lagunas, paralelos a extensão maior destas (em geral, SW-NE). Tais ondas podem transportar sedimentos trazidos por correntes fluviais e de maré, redistribuindo-os segundo efeito resultante de deriva longitudinal similar ao de mar aberto. Intensa deriva longitudinal instantânea pôde ser observada nas margens de orientação paralela ao alongamento da laguna (e aos ventos locais mais atuantes), na região entre Cabeçuda e Bentos, margem sudeste da lagoa Imaruí. O rumo sazonal de deriva nas épocas de observação sofreu inversões sucessivas com periodicidade de poucos dias e a altura máxima das ondas não passou de $20 \mathrm{~cm}$. 0 efeito de quebra e espraiamento de ondas restringe-se a uma faixa estreita da margem lagunar, mais rasa que $0,5 \mathrm{~m}$, apesar de formas de leito indicativas de interação de ondas de oscilação com o fundo serem encontradas a profundidades de pelo menos até $1,0 \mathrm{~m}$. 
Emery \& Stevenson (1957) fazem referência a ocorrência ocasional em mares protegidos de "tidal bores" (macaréus), ondas grandes formadas por bloqueio temporário da maré enchente devido a descarga fluvial intensa. Ondas desta natureza parecem atuar episodicamente no sistema lagunar da área em estudo: segundo relatos de moradores, ondas comparáveis às de mar aberto formaram-se na laguna Santo António durante a enchente do rio Tubarão em 1974.

\subsection{Fundo lagunar raso marginal}

A subfácies fundo lagunar raso marginal corresponde a bancos arenosos a areno-pelíticos depositados ao longo de margens paralelas a frentes de onda de maior raio de ação ("fetch") e retrabalhados por correntes secundárias de circulação lagunar marginal (item 3.2.2.4), sem influência direta significativa de suprimento fluvial e de ondas ou aporte de mar aberto. Foram excluídos desta subfácies os microdeltas lagunares e deltas de maré enchente, embora todas estas feições guardem entre si equivalência batimétrica: suas profundidades máximas são pouco maiores que o limite de maré mínima. É possível distinguir-se assim entre fundos rasos temporariamente emersos (durante ciclos de maré), com desenvolvimento de "marismas" em sua zona superior, e fundos rasos predominantemente submersos (Angulo \& Müller 1990; Angulo 1992). Estes fundos lagunares incluem-se entre as zonas sedimentares do litoral sul brasileiro classicamente designadas como "baixios" (Bigarella et al.1957 apud Angulo 1992).

Característica marcante dos fundos rasos marginais na área estudada é sua modelagem superficial por formas de leito de diferentes dimensões, as quais são facilmente reconhecidas em aerofotografias. Consistem em megaondulações de crista reta a pouco sinuosa ("ondas de areia"), perpendiculares ou oblíquas à orientação da margem lagunar, com comprimento de onda variável entre 20 e $150 \mathrm{~m}$. Estas formas dissipam-se nas proximidades da praia lagunar, onde dão lugar a formas menores e mais efêmeras, orientadas em ângulo agudo com a margem e associadas a dinâmica de quebra e espraiamento de ondas lagunares. Fecha-se assim um círculo de interdependência entre ondas lagunares e correntes secundárias na dinâmica costeira lagunar: correntes suprem as ondas com sedimentos, enquanto estas redistribuem os mesmos sedimentos segundo direções que controlam a orientação da linha de praia e portanto a orientação das próprias correntes e seus respectivos bancos marginais. Como resultado disto, a grande maioria das baias e tômbolos lagunares exibe a mesma direção aproximada NW, transversal ao eixo maior do sistema. Analogamente, a quase totalidade dos bancos de areia marginais bem desenvolvidos ocorrem com orientação NW, com cristas de ondas de areia direcionadas segundo NE. Podem ser citados, como exemplos, os fundos rasos marginais da laguna Garopaba do Sul, em sua face oeste (figura A5) e na região de Aroeira (figura A7), e dos tômbolos de Cabeçuda (figura A11), Perrixil (figura A13) e Ponta Rasa - ,Roça Grande (figura A14). Exceções ocorrem nas regiões de Guaiúba e Porto da Vila (figura A15), onde os bancos de areia marginais se estendem em direções próximas a NNE. Não se aproximou nesses locais da configuração de equilibrio transversal ao alongamento do sistema, porque o "fetch" a SW é reduzido pela presença do tômbolo de Ponta Rasa. As margens lagunares com ausência aparente de bancos de fundo raso são as que, situando-se entre tômbolos ou pontais de direção NW, orientam-se segundo NE, subparalelas à costa de mar aberto. É o que 
se tem na borda sudeste das lagunas Camacho, Santa Marta, Imaruí e Mirim. Nestas margens, o transporte ou a erosão de sedimentos prevalecem sobre sua deposição, pois a direção de maior "fetch" de ondas lagunares coincide com a deriva longitudinal e outras correntes marginais secundárias. Nas baias intertômbolos das lagunas Imarui e Mirim, sedimentos pleistocênicos afloram, por esta razão, em barrancos erosivos marginais, sem desenvolvimento de planicie lagunar adjacente (caracteriza-se assim a subfácies baía em encosta).

De modo geral, o rumo de caminhamento das formas de leito marginais pode ser determinado, ao exame aerofotográfico, através da identificação das faces frontais, cie declive mais abrupto, das megaondulações. Rumos inferidos deste modo encontram-se indicados nos mapas de detalhe listados no parágrafo anterior. Um aspecto a observar-se é que pode haver mais de uma hierarquia de formas de leito, cujos rumos de deslocamento não são coincidentes. Aspecto similar já fora descrito por Angulo (1992) em fundos rasos de baias no litoral paranaense. Na área em estudo, o caso mais evidente ocorre no tômbolo de Perrixil (figura A13), em seu lado sul, teoricamente mais exposto à ação de correntes induzidas por maré enchente $\epsilon$ de ondas lagunares vindas de SW. Nesta margem, além das megaondulações comuns, com comprimentos de onda entre 40 e $100 \mathrm{~m}$, encontram-se também megaondulações "gigantes", com comprimentos de onda de 50 a $150 \mathrm{~m}$. Enquanto as formas de leitos maiores migram rumo $N$, como que de encontro às margens do tômbolo, as ondas de areia menores superpostas deslocam-se para NW, divergindo das margens rumo às partes mais profundas da laguna. As formas de hierarquia menor aparentam assim controle por células de circulação secundária cujo padrão anti-horário (para a esquerda do fluxo) é relacionado com a geometria conhecida de manifestação do efeito de Coriolis no Hemisfério Sul (Emery \& Stevenson 1957, Lankford 1977; Dyer 1979,1986). As formas de leito maiores são relacionadas a um fluxo tangencial à curvatura da margem lagunar, dirigido por forças centrifugas. Podem ser atribuídas, deste modo, a correntes de maré enchente e deriva longitudinal de maior velocidade, nas quais o efeito centrifugo é maior que o de Coriolis (Dyer 1986). Em demais fundos rasos da região, as ondas de areia de menor hierarquia, sempre exibindo o mesmo padrão de desvio para a esquerda, são as mais facilmente reconhecidas. As formas de escala maior mem sempre possuem a geometria de face frontal bem diferenciada, de modo que uma parte delas possa comportar-se antes como barras sedimentares que como formas de leito individualizadas. Teriam, nesse caso, sua geometria geral controlada apenas pela combinação de ondas lagunares de maior "fetch" e correntes de maré, a exemplo dos tômbolos e pontais emersos. Um exemplo é a barra semi-emersa no lado sul do tômbolo de Ponta Rasa, visivel nas aerofotografias de $1977 / 79$ (figura A14). Com cerca de $900 \mathrm{~m}$ de extensão, esta barra dispõe-se obliqua à margem lagunar e associa-se a ondas vindas de SW. Se duradoura, poderá representar um pequeno desvio na direção do tômbolo, em busca de configuração de máximo equilíbrio (Zenkovitch 1967).

\subsection{Desembocadura lagunar}

A fácies de desembocadura lagunar é formada por dois conjuntos de barras de maré, um associado a vazante e outro a enchente, interligados entre si por um canal intermediário. Os dois conjuntos de barras de maré são 
classicamente referidos na literatura como "deltas de maré" ("tidal deltas": Lucke 1934), designação que tem sido mantida nos trabalhos mais recentes sobre sedimentação costeira. Modelos de fácies para deltas de maré modernos,foram propostos por Hayes (1975 apud Boothroyd 1978) e Hayes \& Kana (1976), tendo sido revistos e aplicados por Boothroyd (1978), Reinson (1979), Davis (1983) e Moslow (1990), entre outros.

A fácies de desembocadura lagunar é representada no sistema baía-laguna, pelo canal Camacho, e no sistema baixio-laguna, pelo canal Entrada da Barra. O canal Camacho é típico de rompimento de barra-barreira por ondas, caracterizando-se pela instabilidade quanto a posição e abertura (item 4.2.4.2). Em fotografias aéreas de 1977/79, menos de seis anos depois de sua penúltima abertura, é visível um delta de maré enchente bem formado, onde se pode reconhecer a maioria dos componentes morfodinâmicos do modelo de Hayes \& Kana (comparar figuras 5.28 e A7). Atualmente, com o fechamento natural temporário do canal, este delta encontra-se em fase de colonização por várzeas de inundação, sendo difícil a identificação desses componentes no campo.

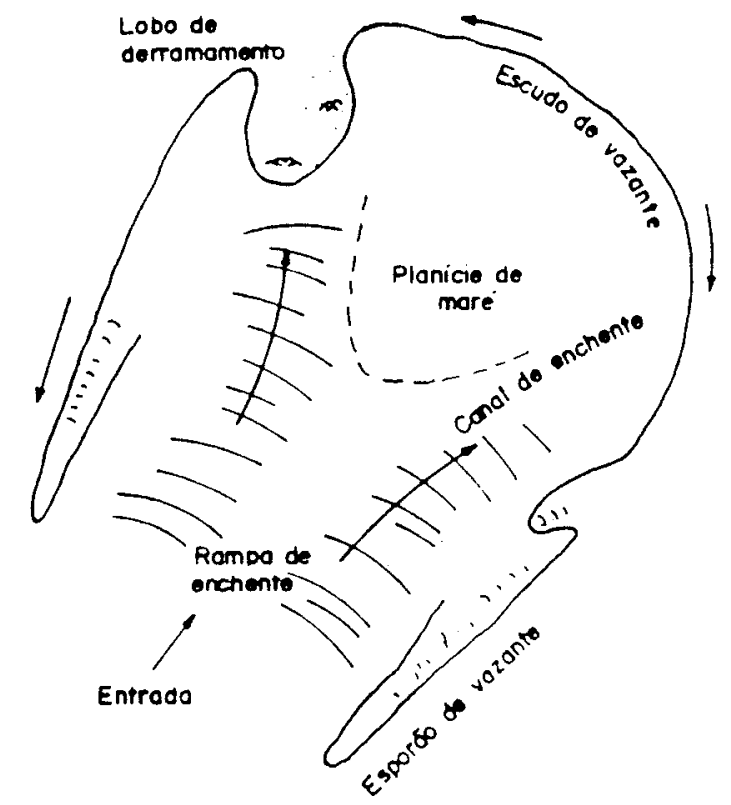

Figura 5.28. Modelo de delta de maré enchente em costa de mesomarés segundo Hayes \& Kana 1976 (apud Angulo 1992).

Um aspecto particular do delta de maré enchente do Camacho (figura A7) é seu caráter duplo: ao interior do escudo de vazante semi-circular, insinuase a presença de um segundo delta com escudo alongado e lobos de derramamento mais proeminentes. Esta configuração pode ser interpretada como resultante de mudanças recentes no alcance de transporte da maré enchente, devidas a oscilações de energia ou alterações de curto prazo no nivel do mar. O delta de maré enchente interno liga-se a depósitos de fundo raso marginal, tanto a nordeste, na laguna Camacho, quanto a oeste, na laguna Garopaba do Sul. Estes últimos associam-se a um conjunto de extensões peninsulares da fácies antebarreira, orientadas segundo NNW, isto é, paralelas ao alongamento dos deltas de maré. Por sua localização, orientação e faciologia, parece provável a relação genética entre esses pontais e o mecanismo formador de deltas de maré enchente. Como elas se situam interiorizadas 
na laguna por cerca de $1 \mathrm{~km}$ em relação aos deltas de maré enchente atuais e uma vez que se enfileiram a sudoeste da posição contemporânea da desembocadura lagunar, conclui-se que tenham sido formadas por paleodesembocaduras lagunares sob constante migração lateral (para nordeste) durante periodo de NRM mais alto que - atual. Há pelo menos três evidências adicionais que reforçam esta hipótese. A primeira é a escassez anômala de depósitos eólicos mantiformes na metade interior da barra-barreira entre os vilarejos de Garopaba do Sul e Camacho, justamente o trecho que compreende as penínsulas. Isto pode ter resultado da existência de paleocanais bloqueando o aporte eólico. A segunda evidência é a ausência de sambaquis no mesmo setor, apesar de incluso na região de maior concentração de sambaquis na área em estudo. Este fato é sugestivo de substrato sujeito a inundações. A terceira evidência é o maior desenvolvimento de leques de sobrelavagem neste setor (item 5.1.2.1). Como os leques tendem a formar-se em "zonas de fraqueza"preexistentes (Davis 1983; Leatherman \& Zaremba 1987), sua ocorrência na área pode estar indicando a reativação parcial de antigos canais de desembocadura lagunar.

Os deltas de maré vazante, por sua posição exposta a mar aberto, resultam da ação combinada de ondas e marés. A diferenciação geométrica e faciológica entre deltas vazantes dominados por ondas e deltas vazantes dominados por marés é enfatizada por Oertel (1975 apud Davis 1983), Davis (1983) e Moslow \& Tye 1984 apud Moslow 1990). Em razão do caráter entre micro e meso-maré da área em estudo (segundo a classificação de Hayes 1975 apud Boothroyd 1978), o delta vazante do Camacho (figura A7) é intermediário entre os dois tipos, com tendência para o domínio por ondas. Ele apresenta, em relação ao modelo clássico de Hayes \& Kana (figura 5.29), concebido para meso-marés típicas, algumas diferenças essenciais;

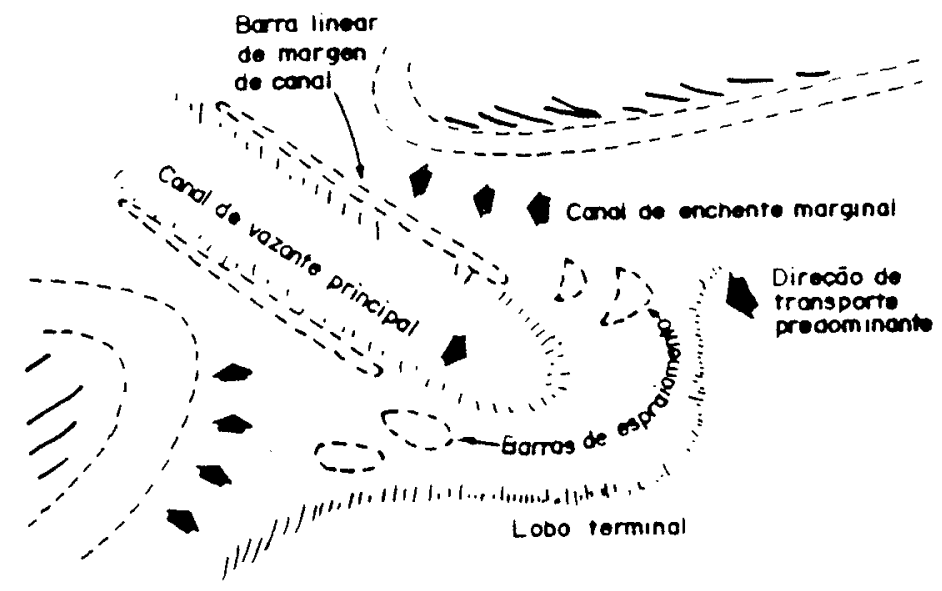

Figura 5.29. Modelo de delta de maré vazante em costa de mesomarés segundo Hayes \& Kana 1976 (apud Angulo 1992).

as barras lineares marginais, por exemplo, encontram-se dissipadas pela ação de ondas, constituindo duas grandes barras de espraiamento de formato em planta triangular, com ápice voltado para o rumo de enchente; os canais de enchente marginal são, deste modo, pouco confinados, o que permite supor que as enchentes na parte externa da desembocadura ocorram predominantemente em lençol, por sobre as barras de espraiamento triangular, em cujo ápice interior elas convergem e finalmente se confinam para formar o delta de maré enchente. O lobo terminal, feição submersa em arco na porção externa do delta de vazante, é seu componente melhor 
desenvolvido. Ele é assimétrico, com prolongamento no rumo ENE, o que indica, segundo critério de Oertel (1975 apud Davis 1983) deriva litorânea longitudinal para mesmo sentido. Reentrâncias erosivas da linha de costa, na base externa das barras triangulares de espraiamento, são feições residuais de canais de sobrelavagem produzidos por marés enchentes associadas a ondas de maior energia. Correspondem deste modo a"canais de sobrelavagem" (Leatherman \& Zaremba 1987). Sua preservação preferencial junto ao delta de maré vazante pode ser atribuída à menor ação local colmatante de dunas eólicas, devido ao umedecimento constante de areia. Supõe-se que estes canais possam desempenhar, durante eventos efêmeros, a função dos canais de enchente marginal do modelo de Hayes \& Kana.

A desembocadura lagunar de Entrada de Barra situa-se entre dois morros do embasamento cristalino proterozóico (figuras 4.5 e A10). Este seu caráter de estreito deve ter impedido mudanças significativas de posição no decorrer de sua evolução holocênica; por esta razão; diversos depósitos de maré, imersos na forma de ilha, ocorrem nas vizinhanças do delta de maré enchente atual; os depósitos situados ao interior do delta, como as ilhas Pedra Branca e Ponta das Pedras (figura 5.30) são possiveis remanescentes de deltas de maré enchente formados por NRM mais altos que 0 atual. A peninsula arenosa do cais da balsa, na margem sul do canal, situa-se ao exterior do delta de maré enchente atual e deve corresponder a um esporão construido pela maré a partir da praia de mar aberto. As ilhas de banhado vizinhas deste esporão a sul são possivelmente decorrentes da zona de remanso e difração por ele criada. Estes depósitos foram referidos na subdivisão faciológica proposta neste trabalho como barras de maré lato sensu (tabela 5.4). Cabe destacar a importante participação do aporte fluvial por distributários do rio Tubarão na formação das barras e deltas de maré enchente de Entrada da Barra. Uma evidência disto é o localização do delta de maré enchente atual, o qual ocorre próximo a foz do principal distributário fluvial ativo. O localização da desembocadura lagunar junto a frente do delta lagunar é uma segunda causa para o intenso desenvolvimento de ilhas e barras de maré. Estas são subfácies transicional entre fácies vizinhas.

A formação de delta de maré vazante típico associado ao canal Entrada da Barra é impossibilitada pela não linearidade da costa, além da presença de molhes (item 4.2.4.3). Apesar disto, parte dos sedimentos trazidos ao mar pela maré vazante é redistribuida a norte pela deriva litorânea, vindo a formar barras de arrebentação distantes da praia (figura 4.10).

\subsubsection{Delta lagunar}

Uma compilação das definições apresentadas para o termo "delta" (Bates \& Jackson 1957, Fisher et al. 1969; Moore \& Asquith 1971 apud Reineck \& Singh 1975; Fairbridge \& Bergeois 1978; Wright 1978; Fisher 1983; Galloway \& Hobday 1983) aponta para alguns pontos de divergência. No âmbito da análise de sistemas deposicionais, Fisher et al.(1969) definem delta como "um sistema deposicional alimentado por rio que resulta em progradação irregular de uma linha de costa". Dominguez (1990) destaca a excessiva generalidade deste tipo de definição. A maioria dos autores tem incluído nele os chamados "deltas dominados por ondas" (Galloway \& Hobday 1983); entretanto, esta inclusão parece incompatível com as definições em que se tentou ser mais preciso, como a de Moore \& Asquith (1971 apud Reineck \& Singh 1975), que fala em sedimentos "depositados primariamente pela 
ação de um rio", ou a de Fairbridge \& Bourgeois (1978), que destaca a deposição em "corpo de água mais profundo e menos turbulento". Dominguez (1990) ressalta que o delta do rio Nilo, o qual inspirou definições clássicas como a de Barrell (1912) e mesmo etmológicas como a de Heródoto, seria na verdade um antigo "delta intralagunar", que só agora começa a alcançar o mar aberto. O termo delta deriva-se portanto de situações em que a ação de ondas é restrita, de modo que seu uso para referir-se a desembocaduras fluviais em costas dominadas por ondas deva ser abandonado (Dominguez 1990). A exceção são os "deltas internos, lagunares ou de cabeceira de baía", do que é exemplo moderno a desembocadura do rio Tubarão (figuras 5.30, A9 e A10).

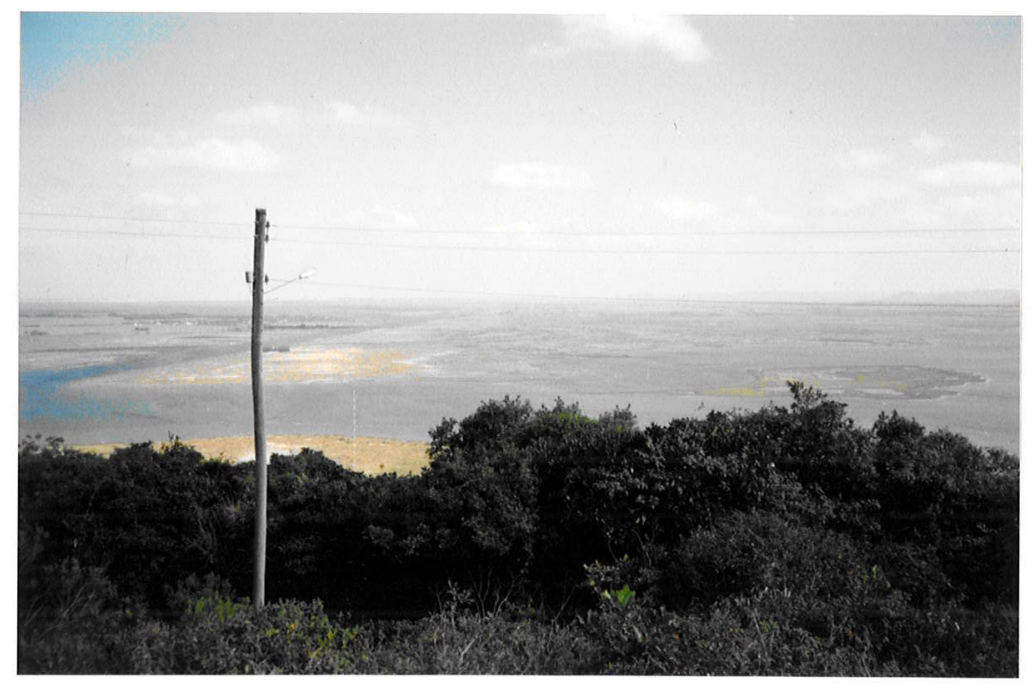

Figura 5.30. Frente nordeste do delta lagunar do rio Tubarăo, vista a partir do morro da Glória.

A formação de deltas internos é uma fase essencial da evolução holocênica de costas de alta energia e elevado aporte fluvial (Lankford 1977; Dominguez 1990; figura 3.14). Tomando como referência a divisão faciológica tripartite dos deltas clássicos, sua frente deltaica é representada por baixos distributários fluviais em zona intermarés, e a planície deltaica corresponde à zona de domínio de processos tipicamente fluviais, sem influência significativa da maré (tabela 5.4). Os distributários fluviais na subfácies planície deltaica funcionam como canais de maré principais, interligados por canais secundários mais estreitos ("tidal creeks"). A característica morfológica comum às duas hierarquias de canais é o meandramento, mas muitos deles encontram-se hoje artificialmente retificados. Diferentes padrões e amplitudes de meandramento combinam-se de modo complexo na margem sul da laguna Santo António, frente de progradação atual do delta lagunar.

Uma das feições sedimentares que preenchem as planícies interdistributárias de frente deltaica são canais abandonados de formas e dimensões variadas. Canais abandonados maiores, como os rios da Guarda e Mirim, representam antigos distributários principais e atestam a constante mudança de posição da zona de avanço preferencial do delta lagunar. Na teoria tradicional de dinâmica deltaica, estas mudanças são vistas como processos autocíclicos; no caso dos deltas de costas afetados por oscilações holocênicas de NRM, como as registradas no Brasil, a retomada da progradação após um afogamento transgressivo é um segundo 
mecanismo, alocíclico, de avulsão e reorientação de distributários (Dominguez 1990). Os canais abandonados dos rios da Guarda e Mirim indicam antigas extensões da frente deltaica e também zonas sujeitas a inundação episódica atual nas margens norte das lagunas Garopaba do Sul e Santa Marta, respectivamente. Nesta última, uma pequena península lagunar ocorre associada ao prolongamento, laguna adentro, de um leque de crevassa na margem erosiva de um meandro do rio Mirim.

Microdeltas lagunares ocorrem dentro da subfácies frente deltaica, associados a desembocadura de pequenos distributários em zonas de baixa energia de circulação lagunar. O maior deles encontra-se na foz do rio Congonhas na margem noroeste da laguna Garopaba do Sul, caracterizado por sedimentos de fundo raso dispostos em morfologia pé-de-pássaro. Feições semelhantes são encontradas na desembocadura de rios em subfácies lacustres, como nos lagos Manteiga e Jaguaruna, e de canais interlagunares (item seguinte).

\subsection{Planície aluvial de canais interlagunares}

A subfácies planície aluvial interlagunar ocorre dentro da fácies antebarreira da associação baía-laguna, na região do rio do Meio, que interliga as margens norte da laguna Camacho e sul da laguna Santa Marta (figura A8). Planicie similar é descrita por Tomazelli (1990) na margem norte da lagoa Tramandaí, na costa do Rio Grande do Sul.

O rio do Meio é um canal moderadamente meandrante, margeado por diques marginais proeminentes e descontínuos e cercado por uma rede complexa de pequenos afluentes meandrantes ativos ou abandonados e de depósitos de leques de crevassa com lagos temporários associados. Os canais menores, hoje parcialmente retificados, atuam como canais de maré ("tidal creeks") e contribuem para o desenvolvimento de várzeas de inundação salobra. Microdeltas desenvolvem-se nas desembocaduras do rio do Meio em cada uma das lagunas por ele interligadas. $\mathrm{Na}$ foz de um canal artificial, construído entre as duas datas das fotografias aéreas estudadas (1952-1977/79), também se formam novos microdeltas de dimensões comparáveis aos gerados pelo rio do Meio. Os microdeltas da laguna Camacho apresentam forma em pé-de-pássaro enquanto seus pares na laguna Santa Marta exibem morfologia lobada. Além disso, os primeiros são maiores. Tais diferenças indicam que o fluxo nos canais interlagunares, apesar de bidirecional, é mais intenso no sentido NE-SW, como se a laguna Camacho exercesse função de "reservatório-ladrão" para a laguna Santa Marta. Isto decorre da atividade permanente da desembocadura lagunar de Entrada da Barra, alimentando a norte a laguna Santa Marta, em contraste ao estado prevalecente de fechamento da desembocadura lagunar do Camacho.

\subsection{Planicies com cordões lagunares}

Feixes de cordões laguriares foram identificados na borda norte do tômbolo do Perrixil, na baía do Pesqueiro e a leste do rio d'Una, todos às margens da lagoa Mirim, associação de fácies baixio-laguna; ocorrem ainda na área de Campo Verde - Carniça, entre a laguna Santa Marta e a desembocadura lagunar de Estrada da Barra, na associação baía-laguna. Sua formação, nos quatro casos, supõese ter resultado de condições favoráveis de progradação e/ou circulação lagunar intensas. 
Os alinhamentos de cordões do Perrixil (figura A13) podem ser reconstituídos, de modo descontínuo, ao longo de toda a extensão longitudinal do tômbolo, onde se supõe tenham crescido numa zona de máximo "fetch" e aporte por frentes de ondas vindas de NE ao longo da laguna Mirim. Ocorrem, ancoradas por paleoilhas de rocha cristalina e terraços marinhos altos. ( $>5 \mathrm{~m}$ ) atribuidos ao Pleistoceno. A margem sul, mais erosiva, não desenvolveu cordões lagunares. Bioclastos carbonáticos de um terraço lagunar situado imediatamente a oeste do alinhamento de cordão mais interno (antigo) foram datados por Martin et al. (1988b), obtendo-se idade de $4240 \pm 200$ anos A.P., a qual seria correspondente a um alto NRM (+ 2,0 m) entre o primeiro e o segundo máximos transgressivos do Holoceno. Esta é possivelmente a idade máxima do feixe de cordões.

Os alinhamentos de cordões lagunares à margem norte da laguna Mirim (figura A12) aparecem tênues e descontinuos em fotografias aéreas. A orientação NW-SE da parte interior do feixe acompanha a direção geral das escarpas pleistocênicas sobre as quais ele se ancora. Em direção à parte externa, os alinhamentos passam a adquirir orientação próxima à de linha de praia lagunar atual. O fator favurável à formação de cordões nesta área foi a progradação localmente intensificada pelo aporte de sedimentos do rio d'Una.

O mais amplo e complexo conjunto de cordões lagunares ocorre na região de Campo Verde (figura A9); ele é aparente em aerofotografias ao longo de uma área de cerca de $15 \mathrm{~km}^{2}$, por onde se estendem alinhamentos nitidos e continuos, apesar de encobertos a leste por depósitos eólicos (ver item 5.3.2.2.9) e de cortados a noroeste pela margem erosiva de um meandro ativo do rio Tubarão. $O$ feixe de alinhamentos apresenta padrão em planta ondulado e truncado (similar ao da seção vertical de uma estrutura "hummocky"), o que faz supor uma progradação interrompida, acompanhada de sucessivas mudanças na configuração da paleolinha de praia lagunar. As relações erosivas do rio Tubarão com os cordões e o fato de mesmo rio encontrar-se aí numa região de baixa planicie e frente deltaicas, de gênese relativamente recente, indicam que os sedimentos deltaicos que cercam o feixe de cordões a norte e a oeste são posteriores a sua formação. Isto significa que, na época de progradação da planície com cordões lagunares, havia, a norte, uma zona lagunar, de circulação franca favorecida por sua proximidade com a desembocadura lagunar de Entrada da Barra. As terras emersas de apoio ou ancoragem dos cordões lagunares deveriam portanto encontrar-se a sul. Observa-se de fato uma faixa de terraços lagunares mais altos ( $>2 \mathrm{~m}$ ), acima da zona intermarés, na região de Carniça, margem nordeste atual da laguna Santa Marta. Conclui-se que a progradação dos cordões lagunares tenha-se dado, a partir desta faixa previamente emersa, no sentido SW-NE, persistindo até o fechamento da zona lagunar a norte, devido a seu preenchimento pelo delta lagunar do rio Tubarão. Fragmentos de concha coletados em terraço lagunar na região de Carniça, atribuidos por Martin et al. (1988b) a paleonivel de 2,5 \pm $0,5 \mathrm{~m}$, foram datados por mesmos autores obtendo-se idades entre 3400 e $3300 \pm 150$ anos A.P., pouco posteriores portanto ao segundo pico transgressivo holocênico admitido por eles para a região. Aceita a hipótese acima sugerida para a progradação da planicie com cordões, esta seria sua máxima idade possível. 


\subsection{Dunas eólicas lagunares}

A planície com cordões lagunares de Campo Verde-Carniça encontra-se parcialmente encoberta por dunas e pequenos lençóis eólicos parabólicos (termo definido no item 5.4.2.5), com fonte e alcance máximo restritos ao próprio sistema lagunar (figura A9). Estes depósitos eólicos, a exemplo dos demais na área em estudo, apresentam rumo de avanço SW. A proveniência principal aparenta encontrar-se nos cordões lagunares, os quais controlam a orientação e geometria dos lençóis parabólicos, caracterizados deste modo por relação largura/comprimento (parâmetros definidos na figura 5.11) anomalamente elevada. No extremo sul da planície com cordões, algumas dunas parabólicas chegam a atingir as margens atuais da laguna Santa Marta.

O aspecto dissipado das dunas lagunares em aerofotografias, e o tipo e grau de recobrimento vegetal observado no campo permitem atribui-las a uma geração eólica inativa subatual, aqui designada geração 3 (ver item 5.4.1.3). Comparações entre fotos de diferentes datas confirmam seu caráter de dunas estabilizadas. Há indícios de pulsos na sedimentação eólica local: Pimienta (1958) descreve corte natural de 1,5 m de espessura na margem erosiva de um meandro do rio Tubarão em Campo Verde, contendo quatro a cinco niveis de material ferruginoso que ele interpretou como registros de "etapas que separaram invasões arenosas sucessivas".

Dois fatores podem ser evocados como responsáveis pela formação de dunas eólicas lagunares exclusiva deste setor. O primeiro é o vasto campo livre de atuação dos ventos prevalecentes de NE ao longo da fácies antebarreira. O segundo é a presença de uma planicie arenosa extensa e seca, com irregularidades topográficas suaves, condições favoráveis ao retrabalhamento pelo vento das areias de cristas de cordões lagunares.

\subsubsection{PADRÃO SEDIMENTOLÓGICO}

\subsubsection{Estruturas sedimentares}

Exposições de espessuras métricas de sedimentos lagunares, permitindo a observação de estruturas sedimentares internas, foram encontradas na localidade de Jaboticabeira, situada entre o lago Jaguaruna e a laguna Garopaba do Sul (figura A6), e no acesso norte à vila de Perrixil (figura A13). A primeira exposição corresponde a um lago artificial de cerca de $200 \mathrm{mil} \mathrm{m}^{2}$ (figuras 5.31 e 5.32) o qual permaneceu aberto durante atividade local de lavra de carbonato bioclástico, encerrada em 1992. A área da escavação situa-se em domínio da fácies baía lagunar da associação baía-laguna à margem noroeste do canal Jaguaruna. A exposição mais completa foi encontrada no barranco noroeste da escavação, dominada por camada conchifera contínua de topo planar e base, parcialmente encoberta, aparentando forma ondulada. A laminação interna, concordante com a base visivel da camada, variou desde plano-paralela até fortemente inclinada, com grandes mudanças de azimute e ângulo de mergulho ao longo do barranco. Esta laminação constitui-se pela alternância de areias granulosas mais e menos bioclásticas (concentração média superior a $50 \%$ 
em volume), com intercalação eventual de lâminas centimétricas de argila arenosa preta, aparentando enriquecimento em matéria orgânica. A camada subjacente é uma argila cinza escuro muito pura e plástica, a qual aflorava sob duas zonas de divergência de mergulho da camada conchifera, configurando assim sua geometria de domos alojados em antiformes. Tornou-se evidente, com isto, a origem deformacional lutocinética da variação de mergulho observada na camada bioclástica. No topo de mesma camada, verificou-se a presença de sinforme preenchido em sua porção basal por areia cinza pouco bioclástica. Este material constituía uma camada centimétrica mais ou menos contínua por todo o barranco, aparentando truncar o topo dos antiformes. Sobre ele, observou-se a presença de camada decimétrica superficial de argila impura, turfosa. Em outros afloramentos menores no interior do lago, a mesma sucessão descrita encontrava-se aparentemente em disposição não deformada (planoparalela).
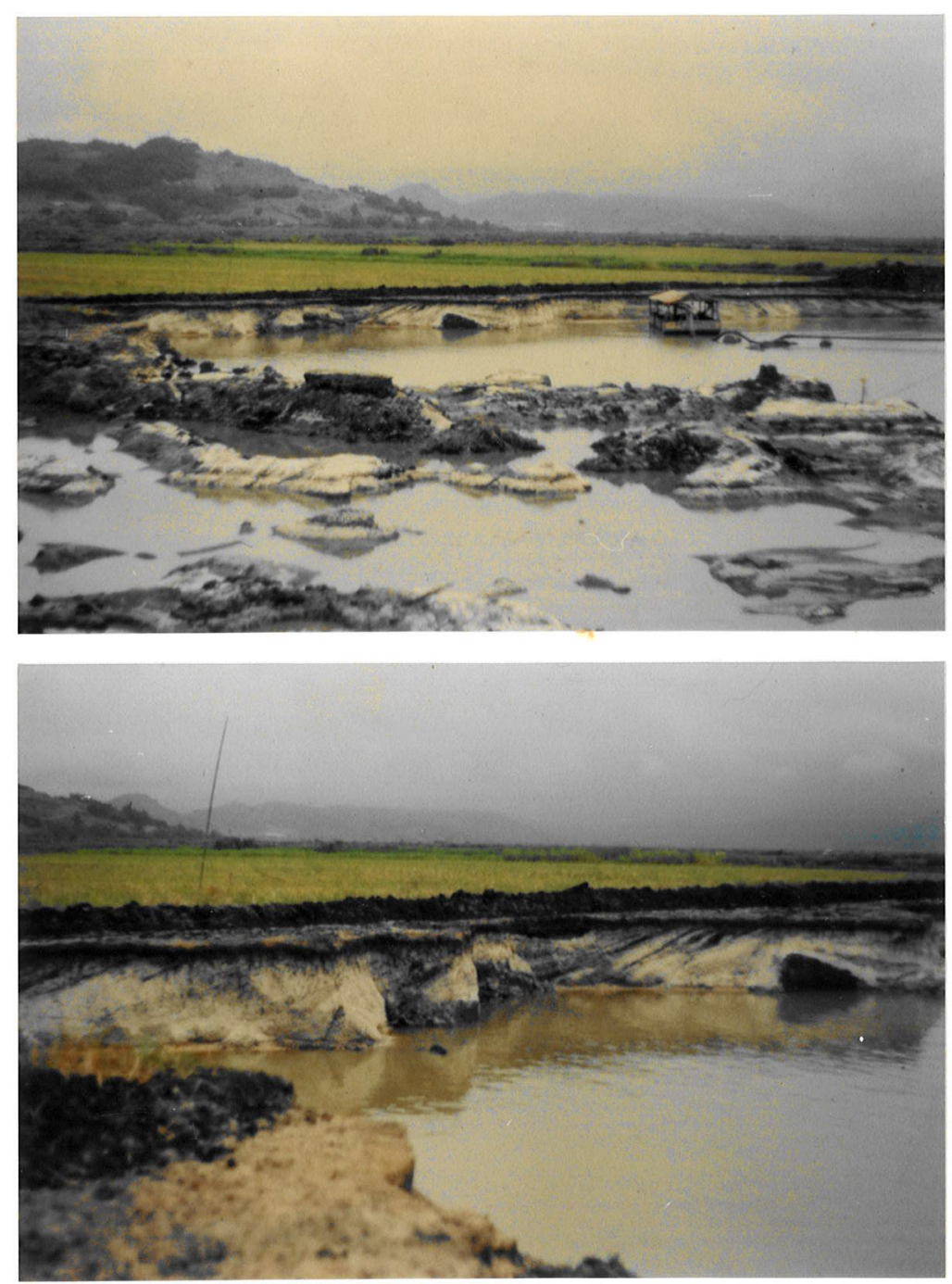

Figuras 5.31 e 5.32. Camada conchífera com deformaçăo induzida por lutocinese, em escavação de lavra de calcário em Jaboticabeira.

5.31 (superior). Aspecto geral da afloramento.

5.32 (inferior). Detalhe destacando antiforme e marcas de raizes. 
A sucessão estratigráfica em Jaboticabeira pode ser interpretada como resultado de variações no nível da paleolaguna. A camada argilosa inferior corresponde a um depósito de suspensão de fundo lagunar profundo, livre da ação de correntes, estagnado e presumivelmente desfavorável à presença de macrobentos. O nível da baía lagunar, à época de sua deposição, estaria alguns metros acima do nivel lagunar atual. O contato superior brusco desta camada com o estrato bioclástico representa uma redução rápida de profundidade. Entre os moluscos encontrados, predominam berbigões (Anomalocardia brasiliana), com presença subordinada de gastrópodos. O habitat dos primeiros são fundos areno-argilosos e lodosos de baías e enseadas, com limite superior de vida no nivel médio de maré baixa (Angulo 1992). Como no local estudado suas carapaças não se encontram em posição de vida (valvas fechadas), apresentando-se com alguma freqüência fragmentadas e arranjadas segundo uma estratificação bastante regular, supõe-se que sua deposição tenha-se dado sob influência de ondas e correntes em fundos rasos lagunares. A geometria original plano-paralela destes depósitos bioclásticos deve ser atribuida a sucessão de leitos planos de regime de fluxo inferior, compativel com a baixa energia da subfácies e com a presença essencial de areia média à seixos (bioclásticos) na granulometria de fundo. Após a deposição desta camada em águas rasas, iniciou-se a fase de deformação por sobrecarga, gerando os domos de lama. Em escala menor, almofadas ("pillows") centimétricas na base da camada bioclástica puderam também ser observadas. Em seguida, o nivel da baía-laguna voltou a baixar; a maior exposição do fundo a ação de ondas lagunares permitiu a erosão e retrabalhamento das irregularidades topográficas provocadas pela lutocinese e a deposição de areias em condições de praia lagunar. Na continuidade do abaixamento de nivel lagunar, a região tornou-se semi-emersa, com formação de turfas em várzeas de inundação. O conjunto de estruturas na exposição de Jaboticabeira registra, deste modo, uma tendência geral para queda de NRM, a despeito de oscilações menores, no transcorrer de sua deposição. Apesar da falta de datações, a seqüência descrita parece compativel com a variação de NRM suposta para a costa catarinense nos últimos 2500 anos (Martin et al.1988b).

A segunda exposição ocorre na lateral norte de uma via de acesso à vila de Perrixil a partir da rodovia BR-101. Inclui-se na subfácies cordões lagunares da fácies tômbolo, na associação de fácies baixio-laguna. Afloram sedimentos arenosos finos a médios irregularmente estratificados, alternando seqüências de lâminas tabulares a lenticulares cinza claro e cinza escuro, estas últimas com maior conteúdo em impurezas pelítico-orgânicas e conchas de moluscos inteiras (figura 5.33). Fragmentos bioclásticos milimétricos também ocorrem. 


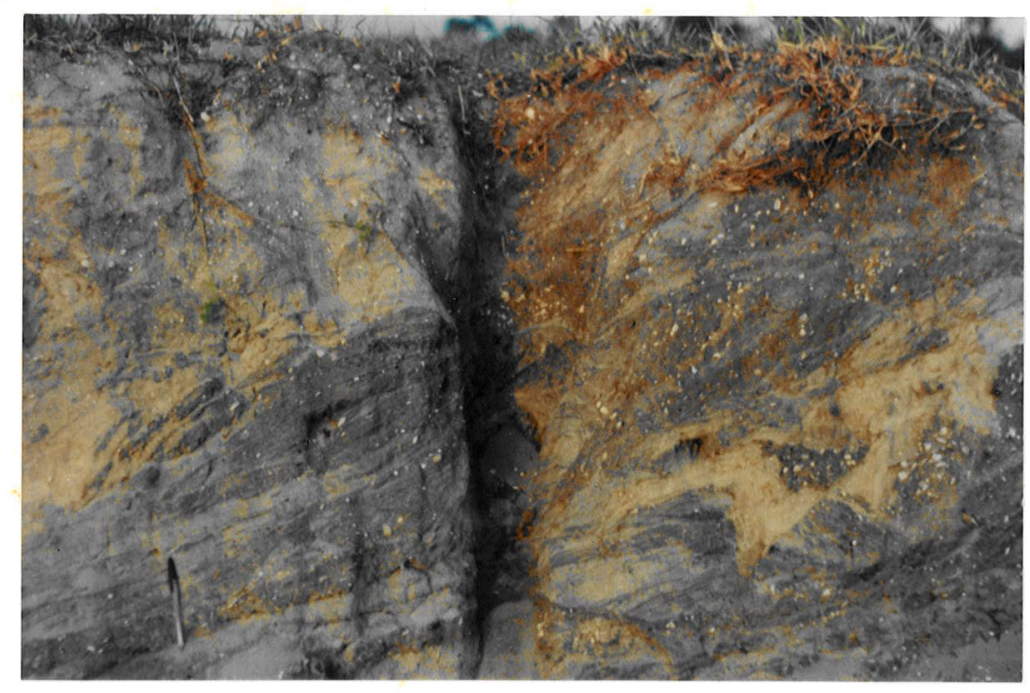

Figura 5.33. Afloramento de areias bioclásticas em Perrixil.

As seqüências de lâminas nesta segunda exposição são predominantemente concordantes e com textura da fração terrígena similar. A atitude geral da estratificação é de mergulho para oeste. Como no fundo raso atual da face norte da península de Perrixil ocorrem ondas de areia ("sand-waves") migrando de ESE para WNW, uma hipótese plausivel para este afloramento é que se trate de estratificações cruzadas tabulares produzidas por migração de ondas de areia em paleofundos rasos. Entre as conchas de moluscos, com predomínio de berbigões, encontram-se raros exemplares em posição de vida assim como em posição hidrodinamicamente instável (convexidade para baixo). Estes fatos não invalidam a hipótese de ondas de areia; a face frontal destas formas de leito, por ser bastante protegida da ação direta de correntes, tem sido observada na literatura como uma zona de preservação de carapaças em posição instável (Suguio 1980); além disso, a ocorrência eventual de avalanchas subaquosas, nas mesmas faces frontais, favorece o revolvimento ao acaso das carapaças e facilita sua preservação quase in situ. $\dot{A}$ observação em detalhe das estratificações cruzadas, ressalta a existência de enclaves decimétricos de material das camadas mais escuras dentro das claras e vice-versa. 0 fato de estes enclaves aparecerem em ambos os tipos de sedimentos desfavorece a interpretação de que possam ser pseudonódulos ("balls") de sobrecarga. Além disso, seu formato irregular e subanguloso é sugestivo de que eles tenham sido depositados em estado pouco plástico, pré-endurecidos, na forma de fragmentos arrancados e retrabalhados da unidade subjacente do topo (erodido) da megaondulação. Esta hipótese é compativel com a idéia de avalanchas de frente de onda de areia influindo na deposição da seqüência. A origem dos enclaves por bioturbação não pode, porém, ser descartada; cavidades pontiagudas, como se fossem "chamas"("flames") invertidas, ocorrem localmente na base das camadas claras, aparentando origem por bioturbação.

Outra estrutura, esta de caráter superficial, que merece destaque no sistema lagunar são barras de espraiamento, observadas em várias praias lagunares arenosas ao longo da margem leste da laguna Imaruí (figura 5.34). Consistem em ondulações de areia longitudinais à praia com crista linear e seção transversal aproximadamente simétrica. Suas dimensões são reduzidas : poucos 
decímetros de largura e 10 a $20 \mathrm{~cm}$ de altura; a extensão, contínua ou interrupta, pode abranger setores praiais inteiros. A permanência destas feições é efêmera. Elas aparecem durante fases de queda acentuada e rápida do nível da laguna em seqüência a picos de maré ou tempestade; preservam-se somente na posição em que o nível lagunar se estabiliza ou reduz sua taxa de declínio. Neste último caso, quando - nível lagunar continua a baixar após a deposição da barra de espraiamento, esta emerge e uma segunda barra submersa começa a se formar. A barra emersa difere da submersa pela crista aguda, por estruturas de escorrimento e microfluxo de areia na sua face frontal e por ligeira assimetria. Estas características desenvolvem-se provavelmente durante o periodo em que o espraiamento deixa de cobrir a altura completa da barra, passando a retrabalhar apenas sua face externa. A base externa das barras e, principalmente a calha formada entre barras paralelas é repositório de minerais pesados e detritos orgânicos. Cortes transversais às barras não revelaram presença de concentrações de minerais pesados ou qualquer outro tipo de diferenciação mineralógica ou textural visível que permitisse a caracterização de estruturas internas.

As barras de espraiamento associam-se com freqüência a microondulações simétricas a quase simétricas de crista sinuosa (figura 5.35), as quais se observam nos fundos rasos lagunares da área em estudo de modó geral. Barras e microondulações correspondem a duas hierarquias de formas de leito lagunares. As primeiras são paralelas à linha de praia, respondem a mudanças no nível da laguna e são formadas por espraiamento de ondas. As últimas são formadas pela interação das ondas com o fundo, respondem a mudanças rápidas de direção de vento e alinham-se sempre paralelas às frentes de ondas que as formam. Ambas podem aflorar juntas, na praia, durante a maré baixa, com direções não coincidentes. As microondulações aparecem ai quase sempre com a crista achatada, o que pode ser atribuído ao seu retrabalhamento por águas empoçadas na praia, movidas pelo vento. Marcas onduladas de onda de crista chata ("reworked flat-topped wave ripples") são descritas na literatura como componente da assembléia de estruturas típica de processos de maré (Fritz \& Moore 1988). O exemplo é ilustrativo de uma observação complementar: a de que sua ocorrência em praias lagunares e marinhas de micromaré, desde que refletivas ou dissipativas represadas (por barras, recifes ou "beach rocks"), é também muito comum. 

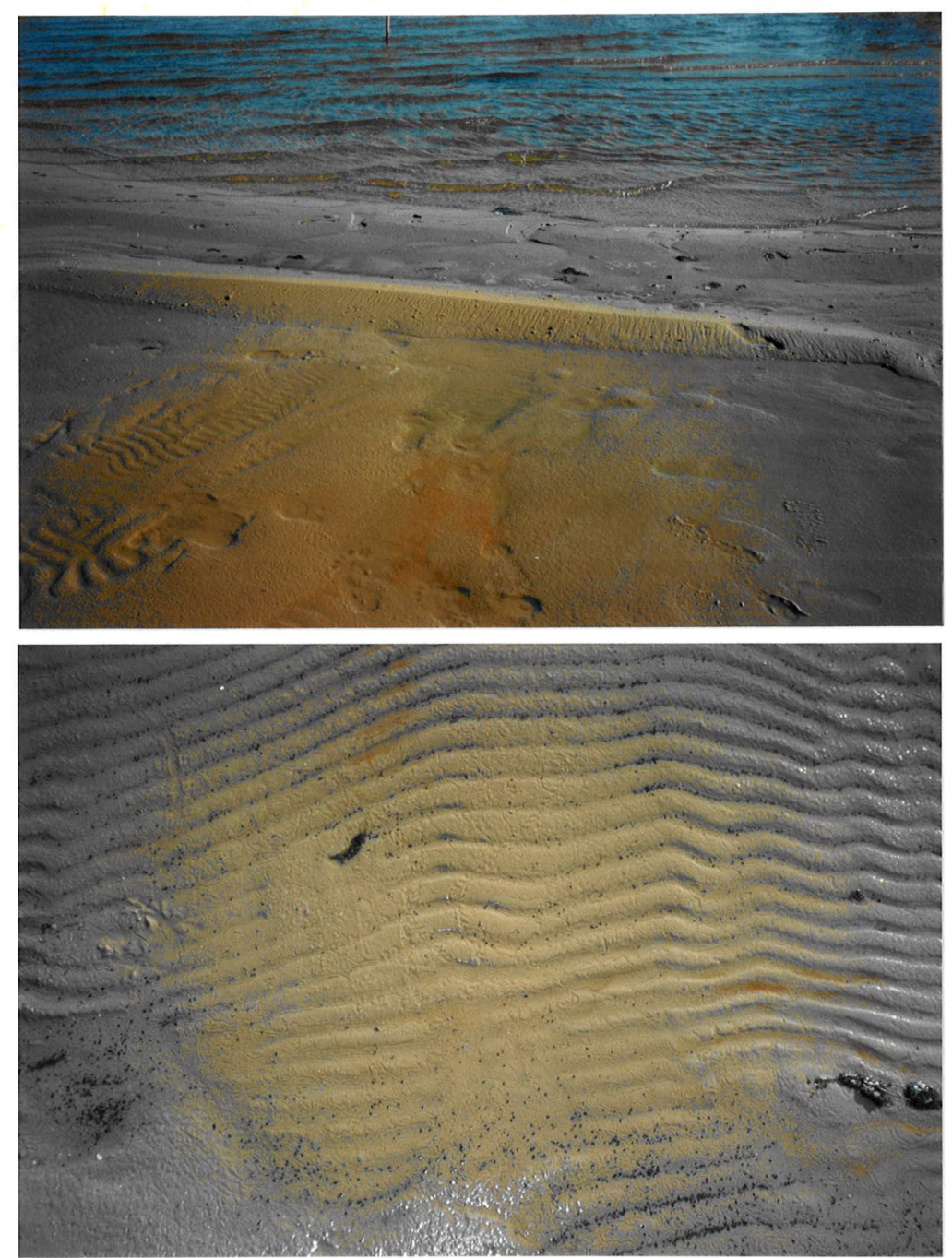

Figuras 5.34 e 5.35. Estruturas superficiais na praia lagunar arenosa de Bentos, margem externa da laguna Imaruí .

5.34 (superior). Barras de espraiamento lagunar.

5.35 (inferior). Microondulaçð̌es de crista sinuosa e topo chato.

\subsubsection{Granulometria}

Os resultados de análise granulométrica em sedimentos do sistema deposicional lagunar, apresentados nas tabelas A15 e A16 foram submetidos a análise de regressão linear com coordenada geográfica (tabela A17).

Cabe ressaltar que os resultados granulométricos apresentados referem-se a amostras sem eliminação da fração carbonática bioclástica. Esta fração ocorre em $27(37 \%)$ das amostras lagunares analisadas, em concentrações que variam de 10 a $100 \%$ em volume estimado de classes granulométricas entre areia média e seixo. Em granulometrias mais finas, a presença de carbonato bioclástico torna-se mais rara (tabela A19). A ocorrência de bioclastos nos sedimentos lagunares dá-se preferencialmente em três tipos de casos, quanto a faciologia: em planícies com alinhamentos de cordões; em tômbolos, com ou sem 
cordões lagunares aparentes; e em barras ou deltas de maré, nas proximidades de canais de acesso a mar aberto. Os bioclastos podem portanto constituir um fator de engrossamento da granulometria nestas fácies. Na maioria dos casos, porém, os bioclastos representam menos que $30 \%$ da classe granulométrica em que ocorrem, sendo de importância secundária na determinação da distribuição granulométrica, em comparação com a fração detrítica.

A associação de fácies baía-laguna inclui areias puras, siltosas ou cascalhosas na classificação de Shepard (1954), com classe modal em areia fina a média, ou, excepcionalmente, em grânulo. $\mathrm{Na}$ classificação nominal de Folk \& Ward (1957) para a distribuição areia, têm-se areias finas ( $87 \%$ dos casos) a médias, com seleção predominantemente muito boa (56 \%) a boa (31\%), assimetria muito negativa a nula $(97 \%)$ e curtose preferencialmente mesocúrtica $(47 \%)$ ou leptocúrtica $(41 \%)$. Presença de seixos detríticos é infreqüente e sempre em quantidade escassa (<1\%).

$\mathrm{Na}$ associação de fácies baixio-laguna, encontram-se areias puras a cascalhosas, com classe modal em areia fina a média, ou, excepcionalmente, em areia muito grossa a grânulo. Parâmetros granulométricos de Folk \& Ward (1957) para a distribuição areia classificam-se nominalmente do seguinte modo: diâmetro médio areia fina a muito grossa, com predomínio de fina a média ( $90 \%$ dos casos); seleção muito boa a muito pobre, com predomínio de boa a moderada ( $80 \%)$; assimetria variável em todo o espectro, predominando negativa (43\%) e muito negativa $(30 \%)$; curtose muito platicúrtica a muito leptocúrtica, com predomínio de mesocúrtica a muito leptocúrtica ( $87 \%)$. Presença de seixos é comum na fácies baíalagunar, onde atinge porcentagem em massa média de $3 \%$ e máxima de $19 \%$. Os seixos de natureza detrítica predominam, com exceção de uma única amostra (L76 A).

Em média, a associação de fácies baía-laguna distingue-se da baixio-laguna por maiores teores de frações silte e areia fina e muito fina e menores teores nas classes granulométricas entre areia média e seixo. Estas diferenças de distribuição granulométrica refletem-se em percentil $1 \%$ (P01), mediana e diâmetros médios mais finos, desvios padrão menores e curtose analítica maior na associação baía-laguna.

$\mathrm{Na}$ comparação entre as fácies integrantes da associação baia-laguna, algumas diferenças entre as características granulométricas médias merecem destaque: pelíticos, areia grossa, areia muito grossa e cascalho enriquecemse nas fácies delta lagunar e antebarreira; areia fina enriquece-se nas fácies antebarreira e desembocadura lagunar (teores em massa de $83 \%$ e $76 \%$ respectivamente); areia média ocorre em teor muito maior na fácies baia lagunar ( 80 $\%$ ) que nas demais (máximo de $21 \%$ ); baía lagunar, como conseqüência, é a fácies de mediana, P01 e diâmetros médios mais grossos, curtose analitica menor e a única com valores de assimetria positivos; piores graus de seleção e curtoses mais elevadas são encontrados nas fácies delta e antebarreira.

$\mathrm{Na}$ associação baixio-laguna, as seguintes diferenças de características granulométricas médias são encontradas entre as fácies baía e tômbolo lagunar: a fácies baía lagunar é mais pobre em areia média e grânulos e mais rica em areia muito fina, areia fina e areia muito grossa; possui, como reflexo, P01 mais fino, mas mediana e diâmetros médios mais grossos; possui também graus de seleção pouco melhores e curtose (analítica) mais alta. 
A fácies antebarreira é caracterizada pela grande homogeneidade de propriedades granulométricas entre subfácies, exceto pela subfácies planicie com cordōes litorâneos (Campo Verde - Carniça), que se destaca das demais pela granulometria mais fina, graus de seleção melhores, assimetria (analítica) mais negativa e curtoses mais elevadas.

$\mathrm{Na}$ fácies delta lagunar, a subfácies barra de maré indiferenciada distingue-se das demais pela granulometria mais grossa, com assimetria menos negativa, pior seleção e curtose mais baixa. A subfácies lacustre apresenta os sedimentos em média mais finos e melhor selecionados do delta.

$\mathrm{Na}$ fácies baía lagunar da associação baixio-laguna, três subfácies foram analisadas; distinguem-se entre si, quanto às caracteristicas granulométricas médias, nos seguintes aspectos: maiores teores em massa da fração cascalho nas subfácies planície com cordões lagunares (teor de $28 \%$ ) e baía em encosta (17\%); maior presença de areia muito grossa na subfácies baía em encosta (21\%); mediana, P01 e diâmetros médios mais grossos na subfácies planicie com cordões e mais finos na planicie sem cordões lagunares aparentes; grau de seleção pior na planície com cordões e melhor na baia em encosta; assimetria (analitica) mais negativa e curtose (analítica) mais elevada na planície sem cordões lagunares, com situação inversa na planicie com cordões lagunares.

A fácies tômbolo lagunar apresenta grande similaridade entre as distribuições granulométricas das subfácies com e sem cordões lagunares, apesar de ligeira tendência para sedimentos mais ricos em areia média, e portanto mais grossos, na última, a qual apresenta em média seleção pior, assimetria analitica menos negativa e curtose analitica menor.

Acredita-se que a maioria dos aspectos acima esboçados de variação de granulometria ao longo do sistema lagunar possa ser atribuída à herança de propriedades e portanto, reduzida a uma questão de proveniència sedimentar. A energia dos processos hidrodinâmicos envolvidos na dispersão dos sedimentos no interior do sistema, mesmo se admitida sua influência na concentração de bioclastos, é pouco significativa quando comparada com a energia de entrada destes sedimentos no sistema através de processos operantes nas fronteiras de sistemas vizinhos, como enchentes fluviais, fluxos de massa em encostas e ondas de tempestade de mar aberto. Como ocorrem pontos múltiplos de entrada preferencial de sedimentos na laguna e como a circulação de correntes no interior dela é compartimentada em inúmeras células, torna-se difícil detectar a influência da hidrodinâmica própria do sistema lagunar através de propriedades granulométricas, pelo menos na escala de amostragem aqui empregada. Uma exceção diz respeito à acumulação de pelíticos terrígenos e orgânicos em várzeas de inundação. Pode-se dizer, deste modo, que a principal causa das diferenciações granulométricas observadas na fração não pelítica dos sedimentos lagunares estudados encontra-se no fato de que maiores aportes de materiais de origem continental implicam granulometria mais grossa, pior selecionada, e mais positiva em relação a maiores aportes de sedimentos marinhos. Tal é o caso da associação baixio-laguna em comparação com a baía-laguna; das fácies antebarreira, delta e baía lagunar em ralação à desembocadura lagunar da associação baía-laguna; da subfácies planicie com cordões lagunares, associada aos sedimentos fluviais do rio Aratingaúba, em relação a demais subfácies de baia lagunar, na associação baixiolaguna; e das subfácies margem de barreira protegida e planície de aluviões interlagunares em relação a planicie com cordões lagunares de Campo Verde, na 
fácies antebarreira: as duas primeiras subfácies algo influenciadas pela fente deltaica do rio Tubarão e a última originada por processos de entrada e circulação de sedimentos marinhos.

As tendências de variação de granulometria no sistema lagunar ao longo da coordenada geográfica sul-norte (tabela A17) não podem ser, pelos motivos expostos, interpretadas através do simples uso das regras de McLaren \& Bowles (1985). Três correlações de regressão linear múltipla, a níveis de confiança maiores ou iguais a $99 \%$ merecem destaque. A primeira delas é o aumento da concentração da areias e diminuição da taxa de pelíticos ao longo da fácies antebarreira. Esta tendência reflete o desaparecimento das subfácies várzeas de inundação, enriquecidas em pelíticos, na porção norte da fácies, ocupada pela planície com cordões lagunares de Campo Verde - Carniça. A segunda tendência, de difícil interpretação, é o afinamento de granulometria, acompanhado por aumento de desviopadrão, assimetria e curtose, ao longo da associação de fácies baía-laguna. A terceira tendência consiste em engrossamento de mediana e diâmetro médio, com aumento de seleção e de assimetria e curtose analíticas, na fácies tômbolo lagunar. Tal variação expressa possivelmente o aumento relativo de aporte fluvial na parte norte da fácies, devido à maior proximidade dos rios Aratingaúba e d'Una e ao maior afastamento em relação à influência marinha do canal Entrada da Barra.

\subsubsection{Mineralogia}

\subsubsection{Minerais pesados}

Os teores em massa de minerais pesados nas frações granulométricas estudadas (tabela $A 18$ ) variam de 0,9 a $14,3 \%$, na associação de fácies baía-laguna, e de 0,7 a 55,2 \% na associação baixio-laguna. Maior amplitude de variação na associação baixio-laguna observa-se também em relação ao teor em massa de minerais magnéticos: 0,01 a $11,1 \%$, contra 0,02 a 0,5 \% na associação baía-laguna. $\mathrm{Na}$ fração pesada desmagnetizada, a freqüência percentual de contagem de grãos carbonáticos bioclásticos oscila entre 0 e $7 \%$ na associação baía-laguna e entre 0 e $20 \%$ na associação baixio-laguna, enquanto a freqüência de grãos micáceos (biotita) varia de 0 a $17 \%$ e de 0 a $9 \%$ respectivamente (tabela A19). Minerais transparentes não micáceos ocorrem no sistema em porcentagens muito variáveis ( 6 a $73 \%$ ). Dentre eles, zircão, turmalina e estaurolita são os únicos minerais encontrados em todas as amostras lagunares estudadas; na associação baia-laguna são de ocorrência generalizada ainda pistachita, cianita e hornblenda. Zircão e turmalina são também os úncos componentes a ocorrerem como predominantes na amostra (> 50 $\%)$, sendo que turmalina apenas na associação baixio-laguna. Dos demais minerais, pistachita, estaurolita e hornblenda atingem a abundância (20-50\%); rutilo, cianita, sillimanita, augita, pigeonita e alteritos chegam a ocorrer como componentes comuns (5-20\%); e leucoxênio/anatásio, apatita, granada, titanita, tremolita e andalusita não passam de escassos ou raros $(\leq 5 \%)$.

No confronto de resultados médios de mineralogia, a associação de fácies baixio-laguna distingue-se da associação baía-laguna pelos maiores teores em massa de minerais magnéticos $(1,2 \times 0,1 \%)$ e não magnéticos (12 $\times 4 \%$ ), e pela maior freqüência de contagem de biotita $(3 \times 1 \%)$. Com referência aos minerais transparentes não micáceos, as principais diferenças entre as duas 
associações de fácies encontram-se nas freqüências médias de turmalina, maior na baixio-laguna, e de pistachita e hornblenda, maiores na baia-laguna (figura 5.36). Como decorrência de sua elevada concentração em turmalina, os sedimentos da associação baixio-laguna apresentam maiores valores para os índices de maturidade mineralógica cujo cálculo utilize este mineral como numerador, ou sejam, ZTR, r1, r2 e r3 (figura 5.37).

Comparações entre as assembléias médias das fácies integrantes da associação baia-laguna permitem reconhecer algumas tendências de concentração diferencial de minerais. Os maiores teores em massa de minerais pesados (tabela $A 18$; ocorrem na fácies desembocadura lagunar ( $8 \%$ ) e os menores na fácies antebarreira (2\%). O teor em massa de minerais magnéticos da desembocadura lagunar é, no entanto o mais baixo $(0,006 \%)$. Minerais opacos (tabela A19) atingem maior freqüência de contagem na fácies delta lagunar ( $81 \%$ ), enquanto bioclastos carbonáticos só se encontram, nas frações estudadas, em sedimentos das fácies delta e desembocadura lagunar. A fácies delta caracteriza-se ainda pela maior freqüência de alteritos (7\%). $O$ índice ZTR atinge seu maior valor na baía lagunar (uma só ár.ostra com $70 \%$ ) e a menor na antebarreira (54\%). O baixo ZTR nesta última associa-se a uma elevada concentração de hornblenda (13\%).

$\mathrm{Na}$ associação baixio-laguna, a comparação de assembléias médias entre as duas fácies amostradas, permite observar ser a fácies baía lagunar mais rica que a fácies tômbolo lagunar em pesados magnéticos ( $3 \times 0,2 \%$ em massa) e não magnéticos $(15 \times 9 \%)$ e nas freqüências de contagem de zircão $(46 \times 30 \%)$ e hornblenda $(6 \times 1 \%)$. A fácies tômbolo lagunar apresenta-se mais rica em turmalina $(44 \times 17 \%)$. Minerais micáceos ocorrem exclusivamente na baia lagunar, e grãos bioclásticos carbonáticos aparecem em ambas as fácies, atingindo máximas concentrações na fácies tômbolo lagunar.

Dentro da fácies baía lagunar da associação baixio-laguna, algumas diferenças marcantes de mineralogia entre subfácies são observadas. A subfácies baía em encosta é mais rica em minerais pesados não magnéticos e magnéticos (teores em massa de 23 e $6 \%$, respectivamente) que as subfácies planicies com cordões lagunares (15 e 0,1\%) e planície sem cordões aparentes ( 7 e $0,1 \%)$. É também a subfácies com maior freqüência de contagem de minerais opacos na fração não magnética ( $86 \%$ ). A subfácies planicie com cordões lagunares é a mais rica em zircão (67\%) e em biotita ( $9 \%$ ).

Análise de regressão linear entre resultados mineralógicos e a coordenada geográfica sul-norte (tabela A20) indica tendências significativas $\left(r^{2}>40\right.$ $\%$ elou $p>95 \%$ ) em três grupos de amostras: na fácies antebarreira, queda dos teores de pesados magnéticos e não magnéticos (figura A40) e aumento na freqüência de rutilo; na fácies baía lagunar da associação baixio-laguna, aumento da quantidade relativa de rutilo e do indice ZTR (figura A41); e na associação baixio-laguna, elevação da freqüência de rutilo e do indice ZTR, com diminuição do índice MET (figura A41). Esta última tendência aparenta ao exame gráfico ser a mais consistente das três, pois manifesta-se de modo regular através de um número elevado de amostras. Pode entretanto, resultar apenas de má distribuição na malha de amostragem, como será discutido adiante. 


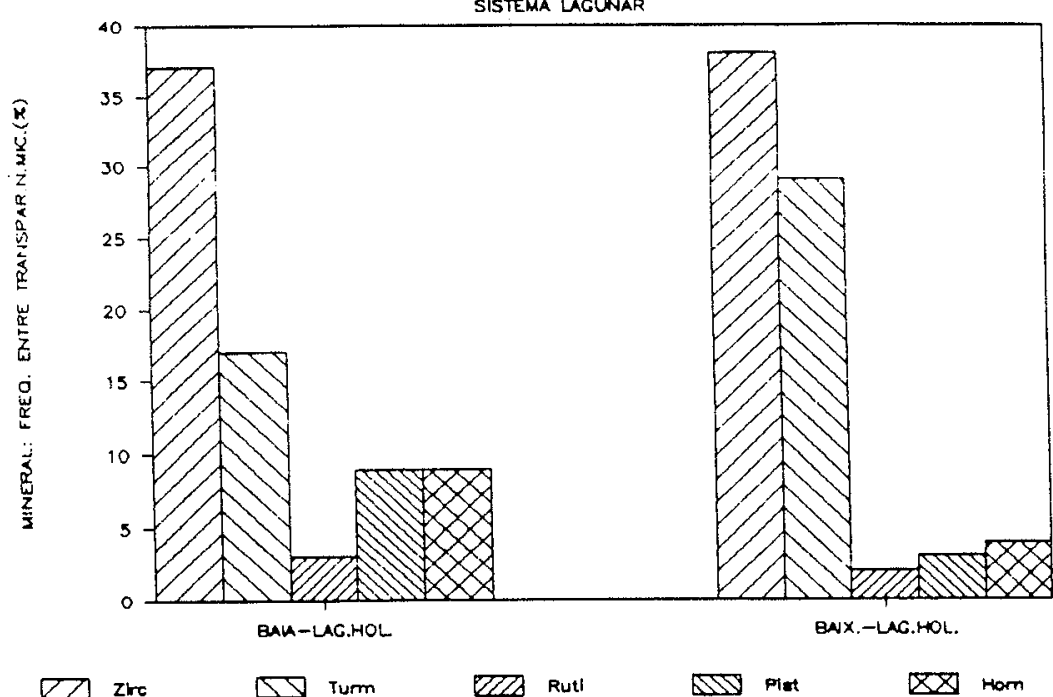

HISTOGRAMA DE RAZÕES MINERALÓGICAS

SISTEMA LAGUNAR

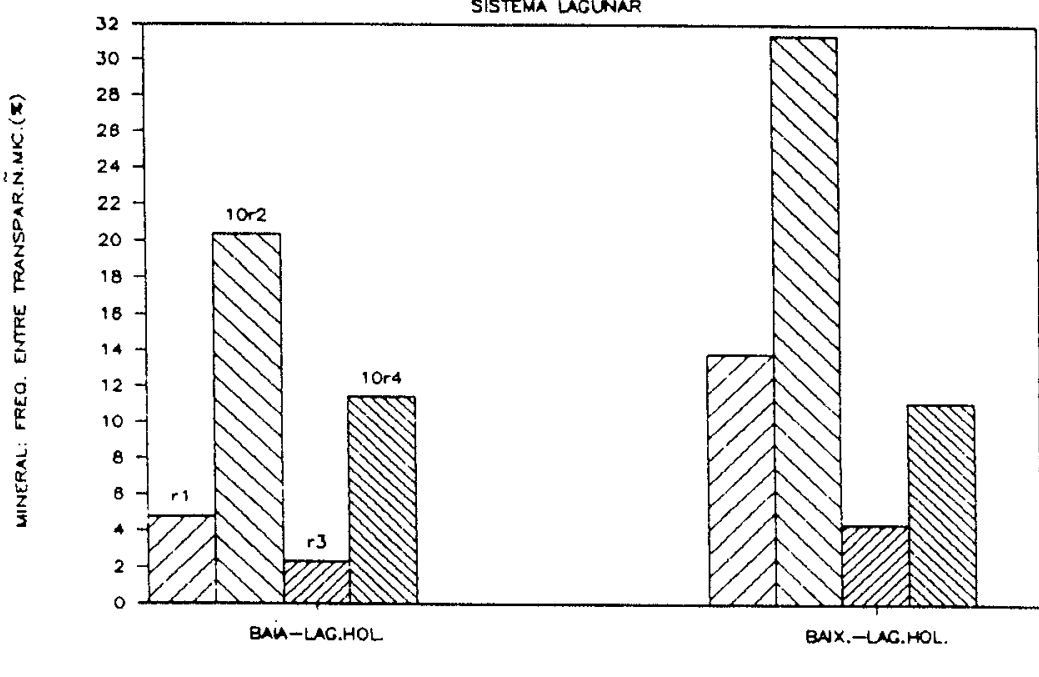

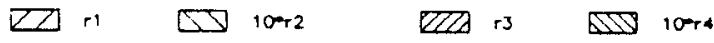

Figura 5.36 e 5.37. Comparaçăo entre associaçōes de fácies no sistema lagunar.

5.36 (superior). Histograma de frequeencias percentuais médias de minerais pesados.

5.37 (inferior). Histograma de razões mineralógicas médias.

A exemplo do padrão granulométrico, a variação de mineralogia ao largo do sistema lagunar é complexa devido aos inúmeros pontos de fornecimento local de sedimentos, principalmente no interior da associação de fácies baixio-laguna. A maior amplitude de variação de parâmetros mineralógicos nesta associação pode ser atribuída a este fato e a sua colocação, "encaixada" entre três áreas fontes muito próximas e de litologias distintas: a oeste, solos, colúvios e aluviões sobre rochas cristalinas tanto intrusivas quanto metamórfico-migmatíticas, fornecendo ampla gama de minerais estáveis e instáveis; a norte, rochas sedimentares da Bacia do Paraná, ricas em minerais ultraestáveis; e a leste, sedimentos da planície costeira pleistocênica e paleodunas das gerações 2 e $2 \mathrm{~A}$, caracterizados por elevados teores de zircão e minerais opacos. $\mathrm{Na}$ associação baía-laguna, os granitos intrusivos cambrianos, fornecedores de zircão, pistachita e hornblenda, são fonte primária comparativamente mais importante, drenada pela bacia hidrográfica do rio Tubarão; esta associação de fácies recebe contribuição de sedimentos pleistocênicos erodidos 
na parte sul do delta lagunar, assim como de sedimentos marinhos holocênicos atuais através dos canais Camacho e Entrada da Barra. A associação baia-laguna encontrase assim muito influenciada por sedimentos fornecidos pela dinâmica da planície costeira quaternária, sob transporte relativamente prolongado, enquanto a associação baixio-laguna é condicionada pela herança quase "in situ" de três tipos de substratos por ela afogados. Este contraste explica as diferenças essenciais de mineralogia encontradas entre as duas associações de fácies, como os maiores ajustes estatísticos com demais sistemas pleistocênicos e holocênicos por parte da associação baialaguna (tabela A19) e as maiores concentrações na associação baixio-laguna de minerais pesados, opacos, micáceos e turmalina.

Dentro da associação baixio-laguna, a fácies baia lagunar, desenvolvida preferencialmente a oeste sob influência predominante de rochas cristalinas é, por conseqüência disso, a mais rica em zircão, hornblenda e biotita, este último mineral já interpretado em trabalhos anteriores como indicador de proximidade da rocha fonte (Giannini 1987). A subfácies baia em encosta, por encontrar-se esculpida em escarpas pleistocênicas, é exceção. A elevação generalizada de índice ZTR de sul para norte na associação decorre possivelmente de um problema de distribuição de amostragem, isto é, coleta preferencial de sedimentos lagunares a norte na margem leste da associação, influenciada por sedimentos pleistocênicos de ZTR alto.

$\mathrm{Na}$ associação baía-laguna, a fácies antebarreira apresenta maior influência dos sedimentos marinhos holocênicos, refletida em teor de pesados e indice ZTR baixos, enquanto a amostra de baía lagunar, por situar-se nas vizinhanças de testemunhos pleistocênicos, exibe o ZTR mais alto. A fácies desembocadura lagunar é a de mineralogia mais semelhante aos sedimentos de praia atual vizinhos, inclusive quanto ao elevado teor em minerais pesados.

\subsection{Minerais leves}

Análise à lupa binocular de impregnação superficial ferruginosa de minerais leves em três amostras do sistema lagunar indicou teores em massa de grãos impregnados entre 0,6 e 2,9\% (tabela 5.6). O teor máximo corresponde a única das amostras estudadas pertencente a associação de fácies baixio-laguna. Este teor equipara-se ao alcançado em amostras de praia marinha atual (tabela 5.3) e de depósitos eólicos ativos (tabela 5.13), enquanto os teores de amostras da associação baia-laguna são de mesma ordem de grandeza dos encontrados em sedimentos marinhos e eólicos mais antigos. Duas hipóteses foram formuladas previamente (item 5.2.3.2.2) para explicar a origem de grãos com pelicula de impregnação: a primeira destaca a influência de sedimentos "novos", recém-saídos do manto de intemperismo de rochas-fontes primárias; esta hipótese é apoiada, no caso do sistema lagunar, pelos maiores teores de grãos impregnados na associação baixio-laguna, dada a posição geográfica desta associação, margeada imediatamente a oeste por encostas de rochas granitóides; a segunda hipótese supõe o efeito diferencial de águas salgadas e águas vadosas ácidas na dissolução pós-deposicional da película; este efeito não aparenta importância no sistema lagunar, apesar de os sedimentos de praia lagunar atual, sob a influência de águas salgadas, apresentarem teores de grãos impregnados de fato mais elevados. 
Tabela 5.6

Resultados de ensaio de análise agnetonétrica ao Separador Isodinâico frantz e de estudo de inpregnacio superficial de gräos a lupa binocular - Sistena lagunar - Fracáo areia euito fina, leve

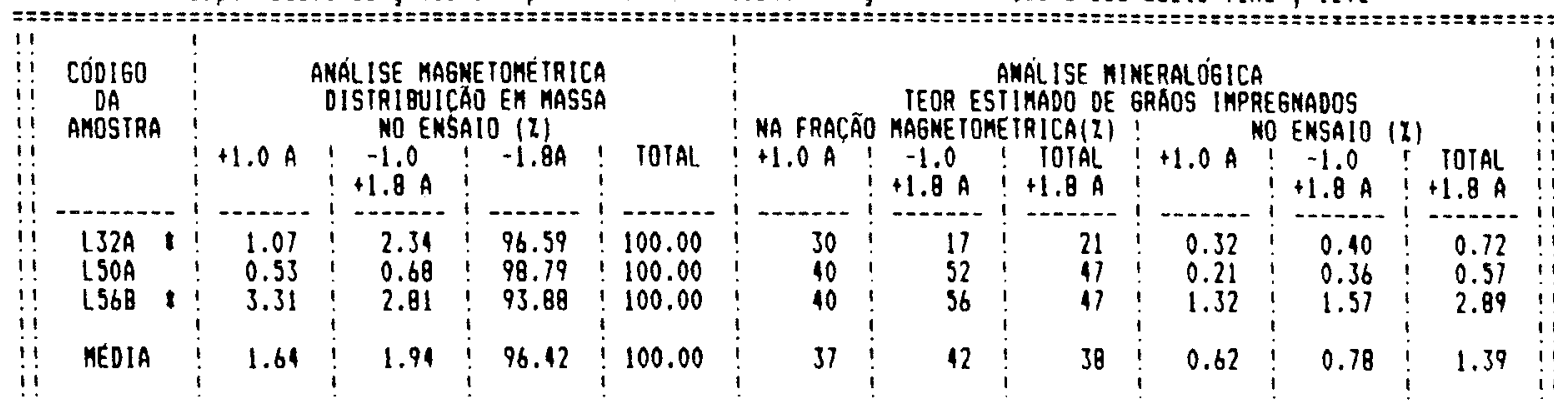

Obs.:1 - I para anostras de sedinentos atuais;

2 - notac\$o adotada para produtos de magnetonetria $:+n=$ atraido en $n A$;

- $n A=$ não atraído en $n A$.

\subsubsection{Matéria orgânica}

O teor de matéria orgânica em onze amostras turfosas do sistema lagunar variou desde 2,8 até $59,0 \%$ (tabela 5.7 ). Teores máximo e mínimo foram encontrados em mesma subfácies. A dependência entre teor e faciologia parece restringir-se à produção de teor médio mais elevado na subfácies frente deltaica. $O$ substrato ou rocha fonte próxima ao sedimento turfoso exerce maior influência aparente sobre o teor. As duas amostras mais ricas em matéria orgânica (L28B e L32G), com ordem de grandeza de teor discrepante em relação às demais, são as únicas situadas em paleobaía lagunar associada a sedimentos pleistocênicos. As amostras restantes, inclusive as de frente deltaica, coletaram-se nas adjacências de encostas de rocha cristalina. Seu teor de matéria orgânica relativamente reduzido indica que aporte detrítico por transporte trativo e gravitacional a partir destas encostas ocorre mesmo durante o desenvolvimento de camadas de turfa, e não somente no seu soterramento final, como previamente discutido (item 5.3.2.2.1).

Tabela 5.7

Resultados de ensaio de dosage de eateria organica total por ataque con agua oxigenada a quente - Sisteea lagunar - Anostras de sedimentos turfosos

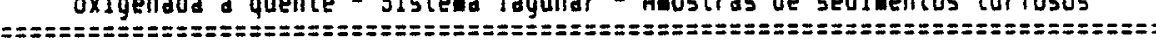

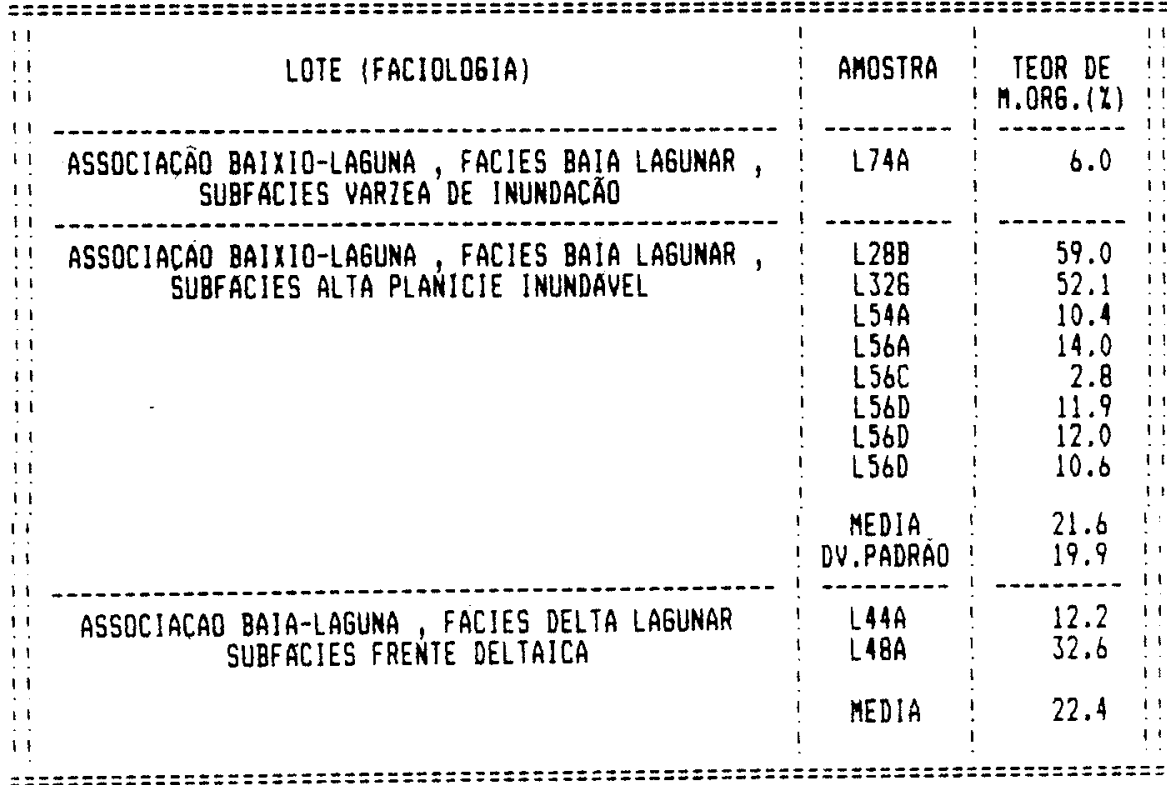




\subsection{SISTEMA EÓLICO}

\subsubsection{IDADE RELATIVA}

Relações de idade entre sedimentos pertencentes ao sistema eólico foram estabelecidas com base em dois tipos de informações. O primeiro tipo rẹfere-se a descrição de quatro diferentes "unidade de empilhamento" em seções verticais naturais, a maioria delas em rampas de areia e dunas de topo de encosta (termos discutidos no item 5.4.2.2). O segundo tipo de informação refere-se a cinco "variedades morfológicas" (e eventualmente morfoecológicas) de depósitos eólicos com diferentes graus de dissecação, mapeadas em superfície através de aerofotogeologia com controle de campo. A correlação entre unidades de empilhamento e variedades morfológicas permite supor a existência e possibilidade de distinção entre pelo menos quatro gerações eólicas na área em estudo. Esta hipótese é em parte apoiada por resultados analíticos de granulometria e, em especial, de mineralogia.

\subsubsection{Unidades de empilhamento}

Às unidades de empilhamento, atribui-se o caráter de unidades estratigráficas descritivas informais, sem qualquer conotação genética a priori.

Elas foram denominadas unidades 1 a 4 , da inferior para a superior. Esta seqüência, na maioria dos afloramentos, ocorre incompleta; a distinção entre as unidades 1, 2 e 4 ora é feita apenas com base em observação de diferenças no grau de pedogênese, indicativas mas não suficientes para a caracterização de hiatos de tempo entre as unidades; ora é também baseada na verificação de superficies erosivas separando unidades, como ocorre, por exemplo, entre as unidades 1 e 2 na Ponta da llhota e sob o lençol parabólico ativo de Vila Nova - Roça Grande (figuras 5.39 e 5.40). Não foram encontradas superfícies erosivas na base da unidade 3. Esta é também a única das quatro unidades distintas a apresentar com freqüência caráter transicional em seu contato basal.

A unidade 1 é formada por areias de aspecto predominantemente maciço, com cimentação intensa evidenciada por elevado grau de consolidação e associada a cores vivas. A cimentação chega a formar arenitos só desagregáveis ao martelo; entretanto, quando sujeitos à ação prolongada de umidade, podem tornar-se friáveis. As cores mais comuns são o vermelho pardacento, 0 vermelho carmim e o vermelho alaranjado, mas ocorrem também o amarelo alaranjado, - cinza claro e o preto acinzentado, este último associado a paleossolos orgânicos desenvolvidos localmente no topo da unidade (figuras 5:39 e 5.40). Estruturas são raramente visiveis. Bandas de infiltração (sensu Pye 1983a) do tipo incluído nas "estruturas de dissipação" de Bigarella (1975a,b) ocorrem descontínuas e quase inteiramente obliteradas pela cimentação generalizada. Laminações primárias tipo risca de agulha (termo definido no item 5.4.3.1) foram encontradas no morro Santa Marta Grande, restritas a áreas com cobertura por areias eólicas inconsolidadas 
(unidade 4), cuja remobilização pelo vento parece fundamental para a abrasão diferencial e conseqüente evidenciamento da estrutura.
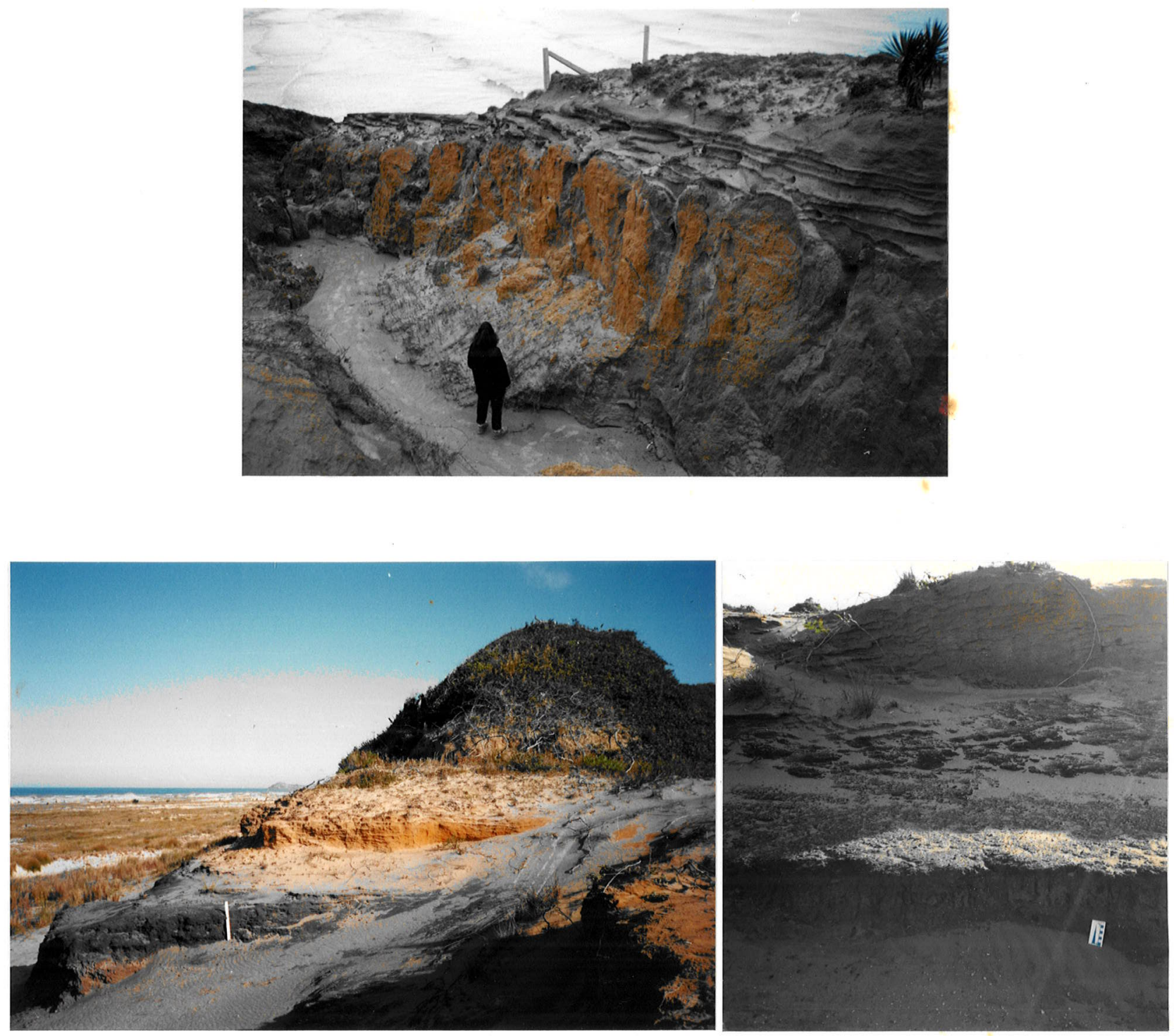

Figuras 5.38 a 5.40. Unidades de empilhamento eblicas.

5.38 (superior). Unidades 1, 2 e 3 em ravina pluvial cortando duna de topo de encosta no flanco sudeste do morro Santa Marta. 3 é considerada pedogenética.

5.39 (inferior esquerda). Unidades 1, 2 e 3 em paleoescarpa de abrasão marinha a sul de Vila Nova. 3 é considerada deposicional. Escala, marcando camada preta no topo da unidade 1, tem $50 \mathrm{~cm}$. 5.40 (inferior direita). Detalhe do afloramento anterior, destacando nivel de marcas de raízes (?) sob a camada preta. 
Em seus afloramentos ao longo do lençol parabólico Vila Nova - Roça Grande, a unidade 1 é marcada no topo pela presença de um provável paleossolo orgânico com bioturbações lato sensu (figuras 5.40 e 5.41). Ela ocorre nesse local sob a forma de camada tabular com topo plano a irregular de arenito amarelo alaranjado a cinza, a qual passa acima, de modo brusco, para camada de areia preta, rica em matéria orgânica. Esta contém numerosos tubos subverticais, em sua maioria com aspecto de marcas de raizes, alcançando em alguns pontos a camada inferior de arenito claro (figura 5.42). A unidade 2 sobrepõe-se à camada preta ou diretamente à camada cinza com bioturbações, tendo sua base marcada em grande extensão pela concentração de grânulos e pequenos seixos de quartzo, associados a areia angulosa.
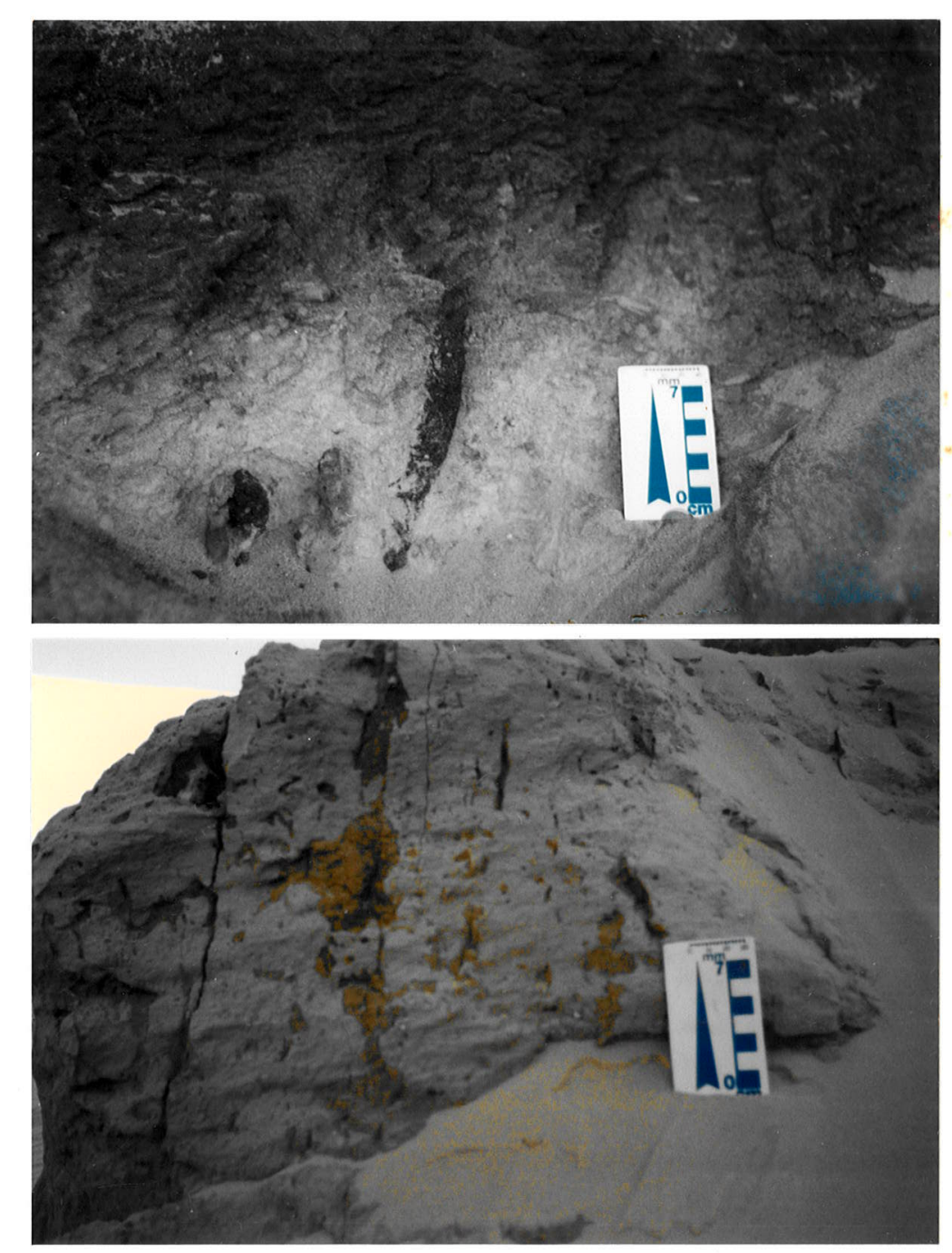

Figuras 5.41 e 5.42. Bioturbações no topo da unidade 1 na regiåo de Vila Nova. 5.41 (superior). Na camada preta (aspecto de raizes).

5.42 (inferior). Abaixo da camada preta.

A seqüência encontrada nestes afloramentos corresponde a que foi descrita por Bigarella \& Becker (1975d), para localidade "3 km a sul da cidade 
de Imbituba" (figura 5.43). Estes autores referem-se à camada preta no topo da unidade 1 como "areia turfosa" e atribuem-na a paleossolo, com variações locais para depósitos de pântano ("swampy deposits"); o nível de rudáceos na base da unidade 2 é descrito por eles como "stone line" e interpretado como colúvio e paleopavimento. Datação carbono 14 de fragmentos de madeira extraídos do nível escuro, realizada por mesmos autores, indica idade superior a 35 mil anos, que seria a idade mínima possivel para a unidade 1. Bigarella \& Becker (1975d) correlacionam o depósito datado ao interglacial Sangamon (Riss-Würm), interpretação que será mantida neste trabalho. Deste modo, a camada preta teria sido gerada da erosão e afogamento da unidade eólica 1 pelo mar (possivelmente fechado) e do desenvolvimento subseqüente de solos orgânicos em zonas constantemente alagadas, com brejos lagunares. Esta idéia é compatível com a altitude do topo da unidade 1 no local, que é poucos metros inferior ao máximo suposto para a última transgressão pleistocênica na costa sul brasileira ( $8 \pm 2 \mathrm{~m}$, segundo Martin et al.1988a,b).

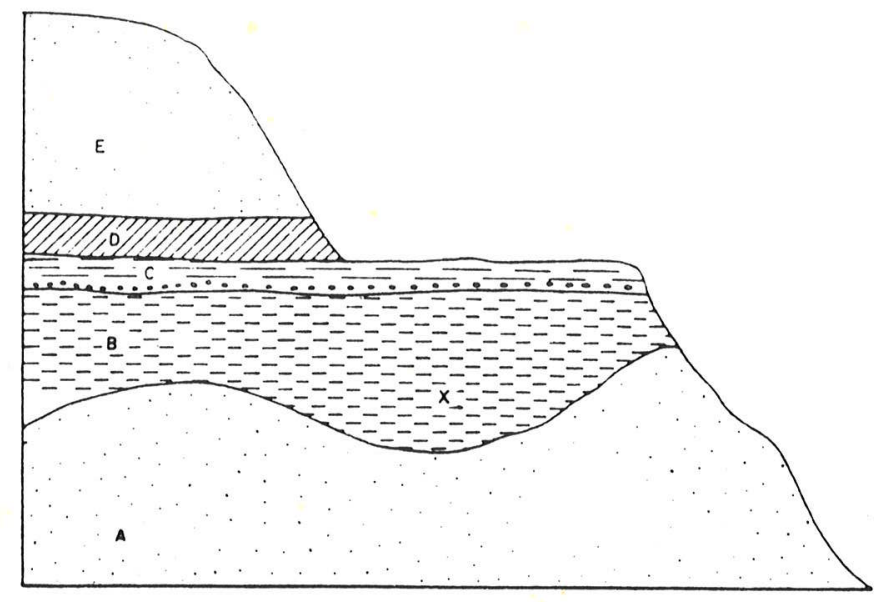

Figura 5.43. Seçăo geológica de "campo de dunas fóssil situado $3 \mathrm{~km}$ a sul de Imbituba" (Vila Nova), segundo Bigarella (1975c). As unidades $A$ e $E$ săo areias maciças, $B$ é em parte um paleossolo e $D$ contem "estruturas de dissipação". Fragmentos vegetais coletados em $B(X)$ foram datados por radiocarbono (idade maior que 35 mil anos).

A seqüência aflorante no lençol parabólico de Vila Nova Roça Grande guarda não somente o registro da ação erosiva da transgressão do Pleistoceno superior como também da última transgressão deglacial. Em vários pontos ao longo do lençol, a deflação ativa sobre areias da geração eólica atual deixa aflorar uma falésia de altura métrica de unidade 2 , repousando sobre ampla plataforma da unidade 1 (figura 5.39). Esta plataforma, com mergulho suave rumo ao mar e altitude entre 4 e $6 \mathrm{~m}$, é sustentada por arenitos cinza ou amarelados muito duros e resistentes eventualmente capeados pelo paleopavimento. Esta feição pode ser considerada remanescente da abrasão marinha diferencial atuante sobre as unidades 1 e 2 durante o máximo transgressivo holocênico. É provável que a pequena escarpa esculpida na unidade 2 demarque o limite máximo dessa transgressão.

Em várias pontas costeiras, como nas da llhota e do Ji, a unidade 1, entalhada sob a forma de encosta mais ou menos ingreme, é cavalgada por sedimentos de gerações mais novas dispostas em rampas de areia (figura 5.44). Ela tende por isto a aflorar preferencialmente nas partes mais altas e interiores dos 
pontões, estando erodida ou encoberta nas porções mais baixas. Uma exceção para esta regra ocorre nos arredores da praia de Muita Água, em Imbituba, onde as unidades 1 e 2 afloram ambas muito próximas à costa, chegando a sofrer erosão marinha atual localizada, por ondas de maior energia (figura 5.18). Essa abrasão marinha pode ser atribuída a conjunção de dois fatores. O primeiro deles é a deriva litorânea longitudinal, que teria nesta localidade um ponto de divergência de rumos (itens 5.2.3.1 e 5.2.3.2.1); por conseqüência, esta seria uma zona de inanição e liberação de sedimentos, ficando sujeita a erosão. O segundo fator é que, talvez por efeito da erosão mais rápida, a linha de costa na região de Muita Água encontra-se não aos pés de paleorrampas eólicas, mas já no interior de paleodunas de topo de encosta; este fator favorece a formação de escarpas arenosas íngremes, de modo que declínios significativos de NRM não impliquem em distâncias significativas de progragradação. A conclusão é que enquanto em outras regiões o máximo NRM holocênico deixou evidências de ter erodido paleodunas das gerações 1 e 2, e de terse sucedido de progradação regressiva da linha de costa, na região de Muita Água a erosão local prosseguiu ocorrendo mesmo a NRM declinante, sem que houvesse progradação significativa. Nas escarpas arenosas entre as pontas do Cravo e do Catalão, um nivel de cascalho de $8 \mathrm{~m}$ de altitude atribuido por Martin et al.(1988b) ao máximo transgressivo de 120 mil anos A.P. (figura 5.45), ocorre ao sopé de um patamar de relevo suavemente inclinado para o mar e que atinge mais de $12 \mathrm{~m}$ de altitude ao interior. O mesmo patamar reaparece em outros locais próximos, como na margem sul da praia de Muita Água (figura 5.46), esculpido sobre areias vermelhas características da unidade 1. No topo das areias que cobrem e colmatam os interstícios do cascalho, observa-se um nível preto, enriquecido em matéria orgânica e com aspecto de paleossolo. Estas areias seriam portanto resultantes do retrabalhamento pelo mar transgressivo do Pleistoceno superior, de dunas de topo de encosta da unidade 1. O paleossolo e a superficie erosiva no seu topo indicariam um hiato entre a deposição das unidades eólicas 1 e 2. Teria-se evidenciado, segundo esta interpretação, que a idade da unidade 1 no local é anterior ao máximo transgressivo de cerca de 120 mil anos A.P.

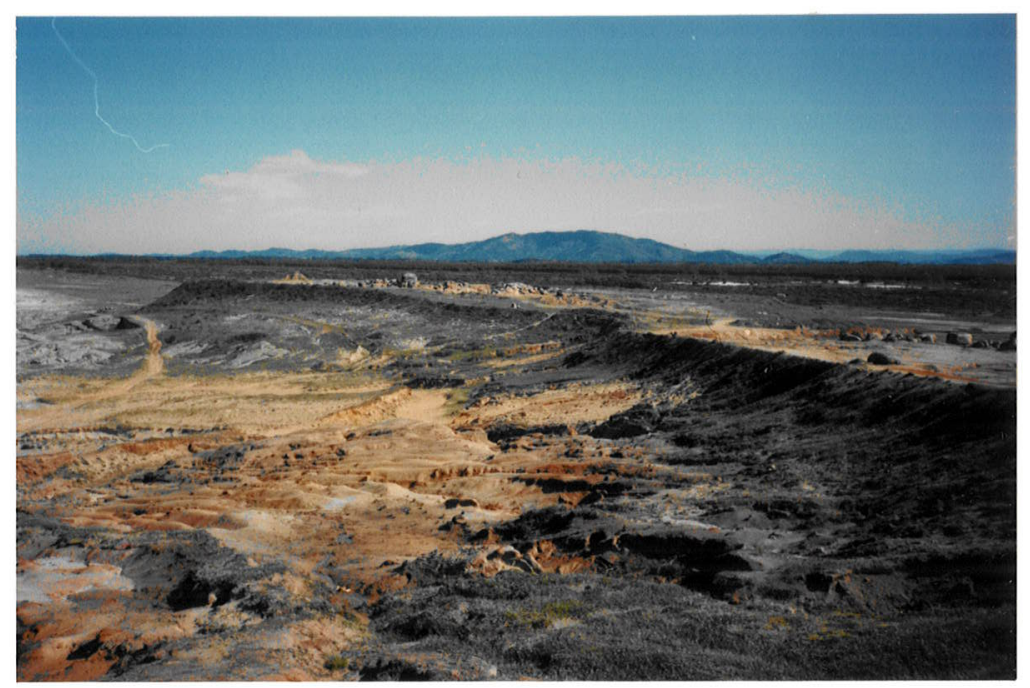

Figura 5.44. Encosta esculpida sobre granitos e sedimentos eólicos da geração 1, cavalgada por rampas de areia da geração 2, na ponta do Ji. Notar ravinas pluviais. 

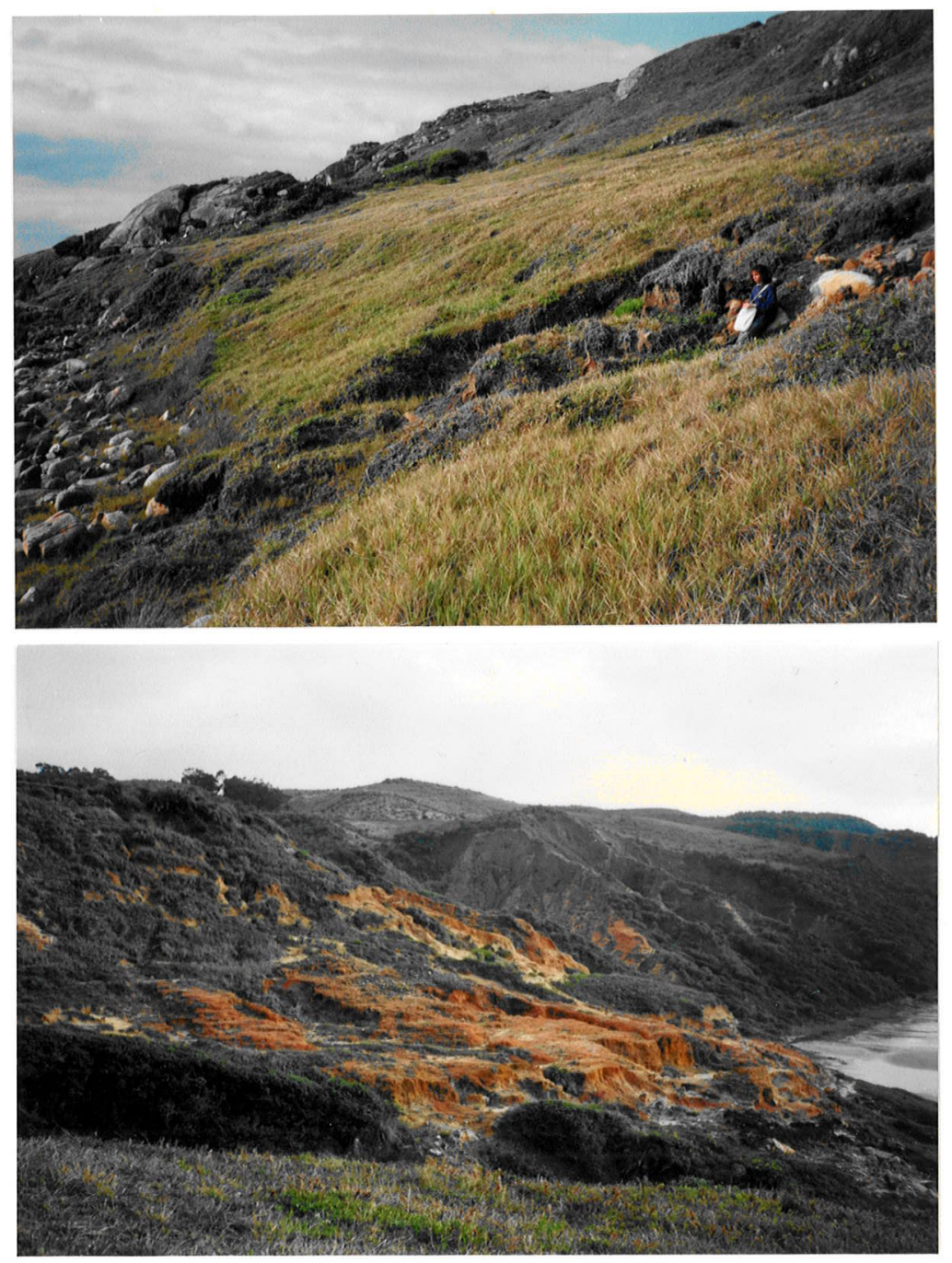

Figuras 5.45 e 5.46. Morfoestratigrafia da unidade 1 em dunas de topo de encosta entre Catalăo e praia de Muita Água.

5.45 (superior). Escarpa de abrasão marinha e conglomerado praial, ao sopé de patamar de relevo. 5.46 (inferior). O mesmo patamar, coberto por areias mais claras atribuídas à unidade 2.

Sob o aspecto textural, a característica de campo mais comum aos sedimentos da unidade 1 é a presença de grânulos e/ou pequenos seixos de quartzo, feldspato ou material lítico, os quais ocorrem dispersos e em quantidades variáveis; eles foram observados tanto em dunas de topo de encosta (llhota, Ji, Itabirubá) como nos depósitos sem obstáculo fixo de Vila Nova.

A unidade 2 é constituída por areias predominantemente pouco consolidadas, exibindo ampla variedade de estruturas sedimentares primárias e pedogenéticas. A cimentação pedogenética diferencial é uma caracteristica marcante; ela não apenas forma manchas e bandas nodulares de contorno irregular como ressalta superfícies de geometria definida relacionadas a estruturas primárias como estratificações cruzadas, bioturbações e fundos de paleocanal. A cor e o grau de endurecimento da areia podem variar bastante, num mesmo local, em função desta cimentação heterogênea. Os aspectos mais comuns são o de uma areia parda escura 
a amarelada, maciçóide, com nódulos decimétricos irregulares e acumulações brechóides intraformacionais, ou de uma areia amarelada ou parda alaranjada com bandas de infiltração pedogenética e estruturas erosivas e deformacionais. Sob o aspecto textural, destaca-se a presença de grânulos e seixos de materiais os mais diversos, incluindo fragmentos retrabalhados da unidade 1 . Ao contrário do que ocorre na unidade 1 , os clastos tendem a formar concentrações sob a forma de preenchimento em paleocanais, paleopavimentos ("stone lines"), camadas lenticulares de espessura até decimétrica e sobre superfícies de $2^{a}$ ordem (figuras 5.101 a 5.103). Elas atestam, assim, a importante interferência de processos pluviais na "dissipação" geomorfológica da paleodunas (Bigarella 1975a). Paleocanais e paleopavimentos ocorrem na parte inferior da unidade 2, inclusive em seu contato basal com a unidade 1, como pode ser observado pelo menos na ponta da llhota (figura 5.47) e no lençol de Vila Nova - Roça Grande. Este fato apóia a hipótese de disconformidade erosiva entre as duas unidades, como já indicado pelo exame de suas relações geomorfológicas e pelo registro de paleossolos no topo da unidade inferior.

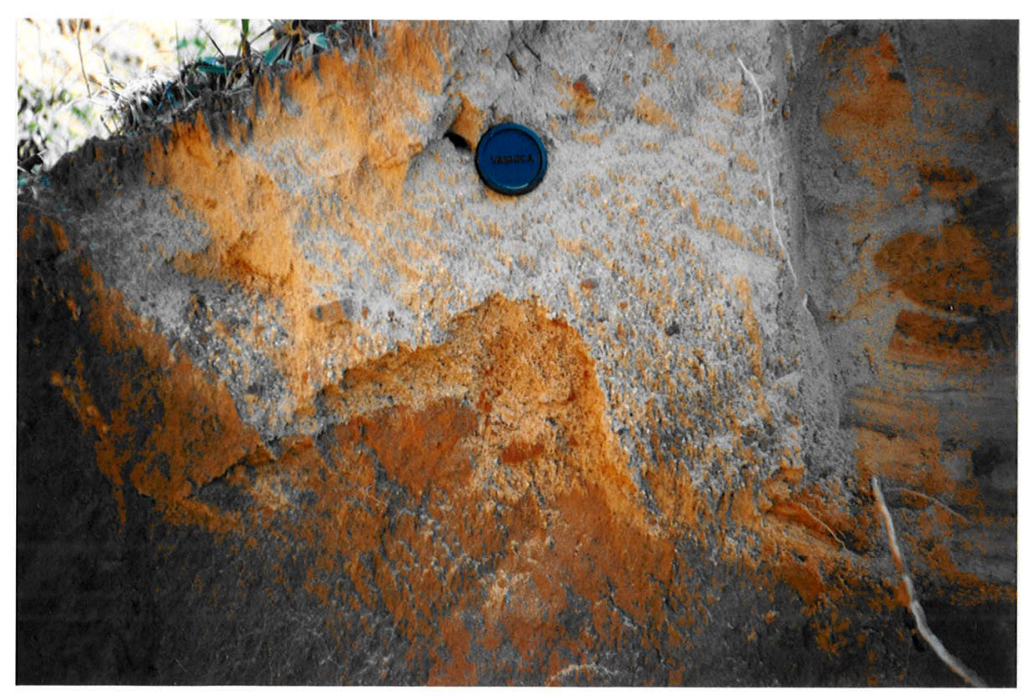

Figura 5.47. Brecha intraformacional no contato basal da unidade $2 \mathrm{com}$ a unidade 1. Dunas de topo de encosta da ponta da llhota.

A unidade 3 ocorre na forma de uma camada de pequena espessura (menor que $60 \mathrm{~cm}$ ) de areias amareladas ou cinza, quase sem consolidação, em contato brusco ou gradual com a unidade subjacente (1 ou 2). Ela apresenta-se colonizada por vegetação de porte pequeno a médio, mas não aparenta concentração significativa de material húmico; pode também ser cavalgada por areias eólicas inconsolidadas atuais, de cor mais clara. Possui aspecto maciço, sempre que repousa sobre a unidade 1, mas apresenta estratificações e laminações em parte dos casos em que recobre areias bandadas da unidade 2. As estruturas, se presentes, mantêm a direção geral observada na unidade subjacente, mas diferem pela ausência de cimentação pedogenética diferencial visível e pela geometria planar mais regular. $\mathrm{Na}$ maioria dos afloramentos, a base da unidade acompanha a topografia da superfície. Pela posição estratigráfica e modo de ocorrência da unidade 3 , admite-se que pode se tratar tanto de uma unidade de sedimentação (figura 5.39) quanto de porção superior de uma unidade sedimentar diferenciada por processos pedogênicos 
de eluviação (figura 5.38); suas características físicas são, em essência, as mesmas encontradas por Angulo (1992) em horizontes pedológicos A e E (antigo A2) de solos arenosos do litoral paranaense.

A unidade 4 é formada de areias de cor branca, amarelo claro ou cinza claro, inconsolidadas e pertencentes a draas ativos que cavalgam sedimentos eólicos preexistentes, como ocorre nas rampas e dunas de topo de escarpa de Santa Marta Grande e Entrada da Barra e no lençol parabólico de Vila Nova - Roça Grande. Em várias dunas de topo de escarpa, depósitos desta unidade formam-se também, em extensão restrita, às custas do retrabalhamento eólico atual de areias das unidades 2 e 3. Este efeito é verificado, por exemplo, nas pontas de Santa Marta Grande, Catalão e Careca do Velho.

Estas areias "retrabalhadas" diferem das areias eólicas fornecidas pela praia por sua cor mais amarelada, herdada das unidades eólicas de origem. $O$ contraste entre dunas atuais brancas e amarelas é notável no extremo norte da praia do Cardoso. Para efeito de amostragem da unidade 4 nessas áreas, apenas as areias brancas foram consideradas.

\subsubsection{Variedades geomorfológicas}

Critérios de campo e aerofotogeologia, em maior parte geomorfológicos, permitiram o reconhecimento de cinco variedades de depósitos eólicos. A origem de seus aspectos diferenciados foi atribuida, por suposição, a suas idades distintas. As cinco variedades, na ordem suposta de idade decrescente, foram denominadas $1,2 \mathrm{~A}, 2,3$ e 4 . Cabe ressalvar que os padrões diagnósticos de cada uma, em fotografias aéreas, descaracterizam-se quando se trata de dunas de topo de encosta e de dunas cavalgantes de modo geral, pois, nesses casos, a morfologia do depósito passa a ser influenciado pela topografia de seu substrato deposicional, o obstáculo fixo. Este fato dificultou a correlação direta entre as variedades geomorfológicas de depósitos eólicos e as unidades de empillhamento descritas no item anterior, uma vez que estas encontram-se melhor caracterizadas, provavelmente por uma questão de exposição, em dunas de topo de encosta.

A variedade 1 ocorre com exclusividade ao longo de uma faixa costeira de cerca de $500 \mathrm{~m}$ de largura que se estende da parte norte da praia de Imbituba à ponta da Careca do Velho, incluindo assim a região da praia de Muita Água (figuras A.19 e 5.46). Nesta faixa, encontram-se afloramentos da unidade 1, com resíduos erosivos de recobrimento pela unidade 2. Caracteriza-se pela dissecação geomorfológica intensa, com desenvolvimento proeminente de ravinas de drenagem em V, profundas e transversais à costa. Em perfis topográficos NW-SE (figuras 5.48, perfis 5 e 6), seu aspecto mais típico é a sucessão de picos desiguais e irregularmente espaçados, alcançando altitudes relativamente elevadas $(60$ a $90 \mathrm{~m})$. Não se encontram formas remanescentes de deposição eólica, sendo virtualmente impossivel a identificação das faces de barla e sotavento, e mesmo de cristas dunares.

A variedade 2 ocorre em três padrōes ligeiramente distintos, os quais foram atribuídos a cada um dos três tipos de associações de fácies propostos. O padrão relacionado a associação dunas e lençóis parabólicos ocorre em várias regiōes: junto à margem oeste da laguna Garopaba do Sul (figura A5); entre a borda nordeste da laguna Santo António e a vila do Estreito (figuras A11 e A12); e no prolongamento sudoeste do lençol ativo de Vila Nova - Roça Grande (figuras A14 e 
5.49). Caracteriza-se pela dissecação fluvial moderada, controlada por vales interdunares entre feições deposicionais alongadas segundo orientação aproximada SW-NE, cuja correspondência com braços de parabólicas é visivel em aerofotografias na maioria dos casos. Este aspecto pode ser observado também em perfis topográficos transversais (figura 5.48, perfis 2, 3 e 4) onde se destacam pares de vertentes simétricas, de altitude entre 15 e $45 \mathrm{~m}$. Encontram-se preservadas ainda formas remanescentes de deflação (item 5.4.2.6.6). As faces de barla e sotavento, mesmo que algo modificadas, podem ser identificadas com freqüência.

A variedade 2 foi mapeada também na associação de fácies depósitos mantiformes, nos arredores de Jaguaruna (figuras A1 a A3 e 5.50) e entre as margens noroeste da lagoa Mirim e oeste da lagoa lbiraqüera (figura A18); nestas áreas, reconhece-se a presença de formas parabólicas aplainadas, cujo padrão em aerofotografias resulta tênue e descontínuo. Nos perfis transversais, há a presença característica de pares de vertentes simétricas, porém com comprimento de onda várias vezes maior que na associação dunas e lençóis (figura 5.48, perfis 1, 5, 6 e 7). 0 terceiro tipo de padrão geomorfológico associado à variedade 2 encontra-se a nordeste do morro Mirim, entre as vilas de Ribanceira do Sul e Ribanceira do Norte (figuras A19 e 5.48, perfil 5). Os alinhamentos intercordões nesta área são menos tênues que na associação depósitos mantiformes, mas apresentam irregularidades; além disso, não se observam fechamentos parabólicos. Acredita-se que este padrão possa estar associado ao fato de se tratar de dunas que cavalgam obstáculos, a julgar pelas elevadas cotas altimétricas indicadas nas cartas topográficas e pela presença de testemunhos cristalinos nos arredores. A associação de fácies não pôde ser determinada, a exemplo do que ocorre em outras dunas de topo, utilizando-se por isso a designação de associação indiferenciada.

Os sedimentos da veriedade 2 são, em superficie, areias pouco consolidadas de coloração cinza claro, branca, amarelada ou rósea. Vários cortes puderam ser observados nas associações dunas e lençóis parabólicos, predominando areias amareladas a pardas contendo estratificaçōes cruzadas. Em alguns dos cortes mais profundos, como os encontrados no bairro de Cabeçuda, em Laguna, a parte mediana do perfil apresenta bandas irregulares de infiltração, com "aspecto de unidade 2". O mesmo ocorre nas dunas da região de Ribanceira do Sul, em Imbituba, atribuídas à associação de fácies indiferenciada. Supõe-se, com isto, haver correlação entre a variedade 2 e a unidade 2. Nas seções verticais, observa-se também, com freqüência, uma camada superior delgada de areia de cor clara, que é o que se vê em superficie. Esta camada correlaciona-se à unidade 3.

A variedade $2 \mathrm{~A}$ ocorre nas vizinhanças, ao interior, da variedade 2 a leste da peninsula do Perrixil, região das vilas de Caputera e Estreito (figura A13) Caracteriza-se por formas elevadas (> $20 \mathrm{~m}$ ), alongadas na mesma direção das dunas da variedade 2 , porém com morfologia em planta mais irregular. Ë formada em superfície por areias claras pouco consolidadas, mas a ausência de cortes não permitiu a avaliação da estruturação e pedogênese interna. Em razão de sua posição mais interior e da morfologia mais dissecada, adotou-se a hipótese de trabalho, a ser melhor verificada, de que se trata de dunas mais antigas que a variedade 2. Contribui para esta interpretação o reconhecimento da ocorrência local, em área vizinha, de domos-testemunhos de areia, em meio a zonas de dominio da variedade 2 , os quais parecem remanescentes de uma geração eólica anterior (figura 5.48; item 5.4.2.5.1). 


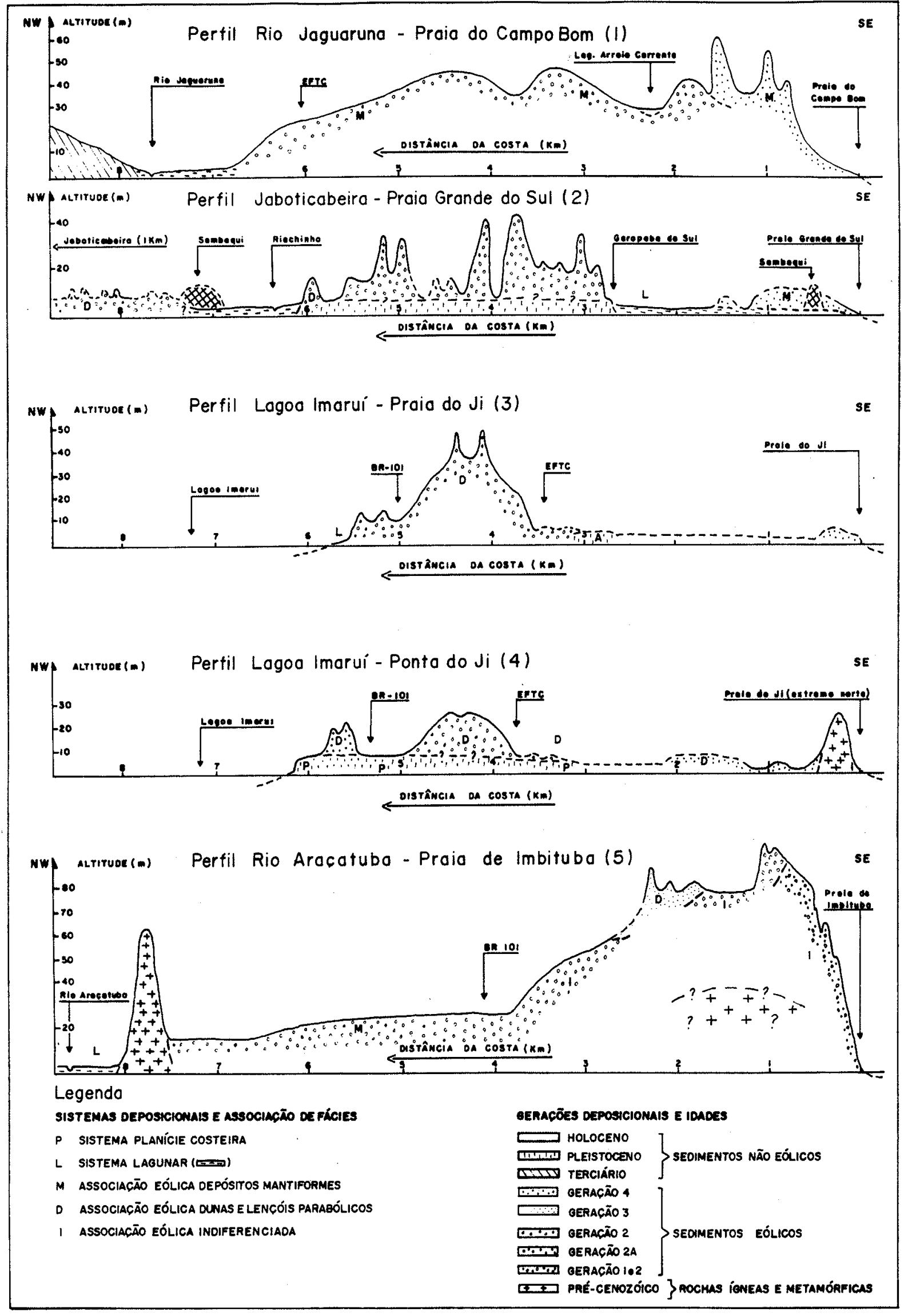

Figura 5.48. Perfis topográfico-geológicos NW-SE (I. Perfis 1 a 5) 


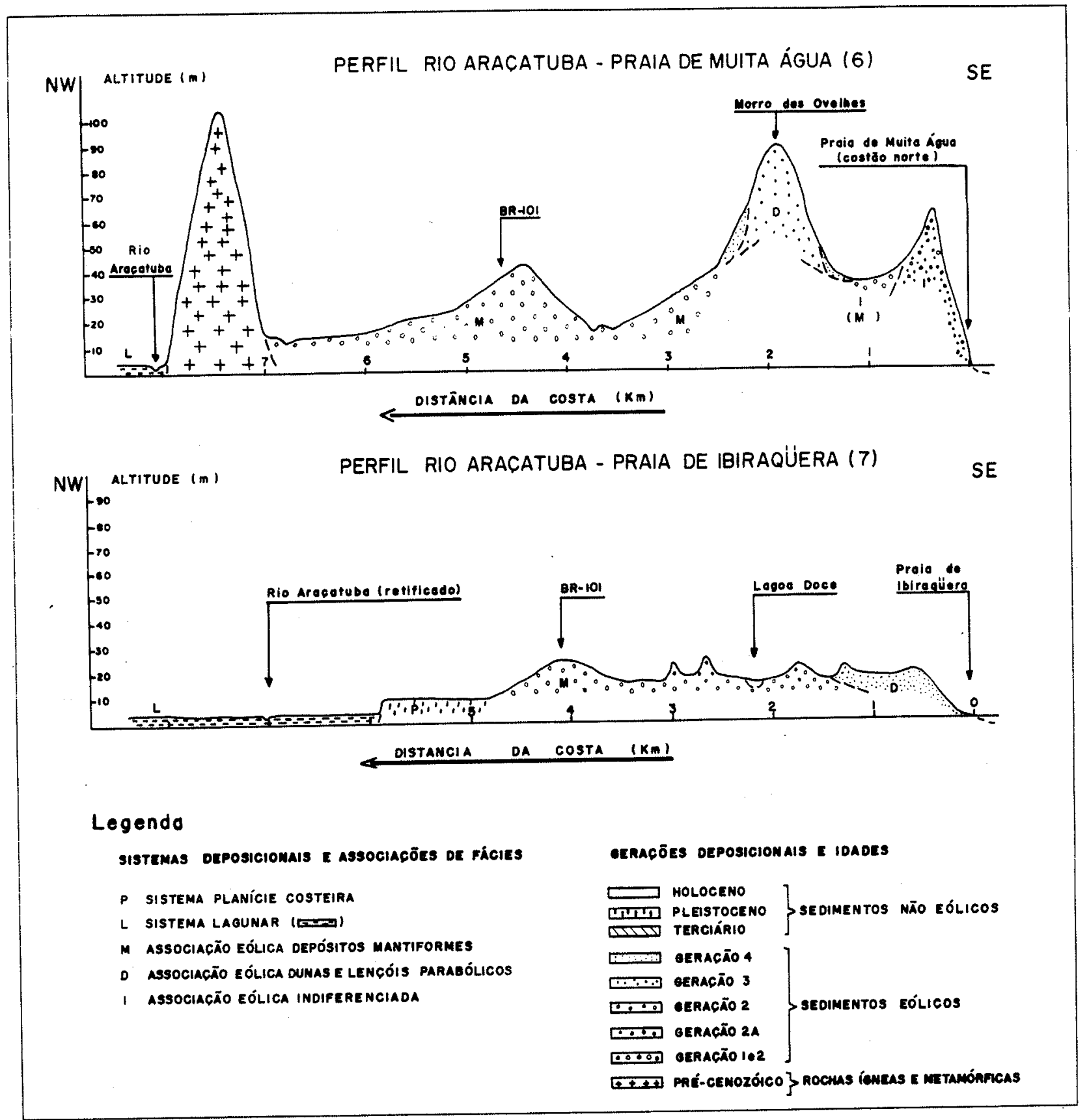

Figura 5.48. Perfis topográfico-geológicos NW-SE (II.Perfis 6 e 7) 


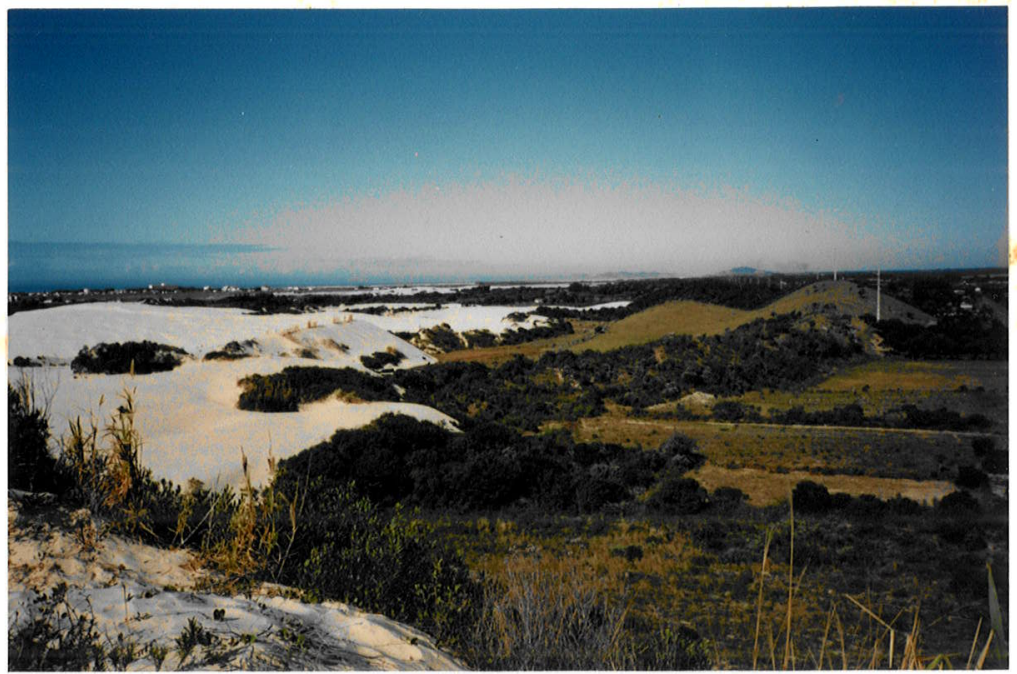

Figura 5.49. Frentes do lençol parabólico ativo de Vila Nova - Roça Grande, cobrindo dunas parabólicas da geração 2.

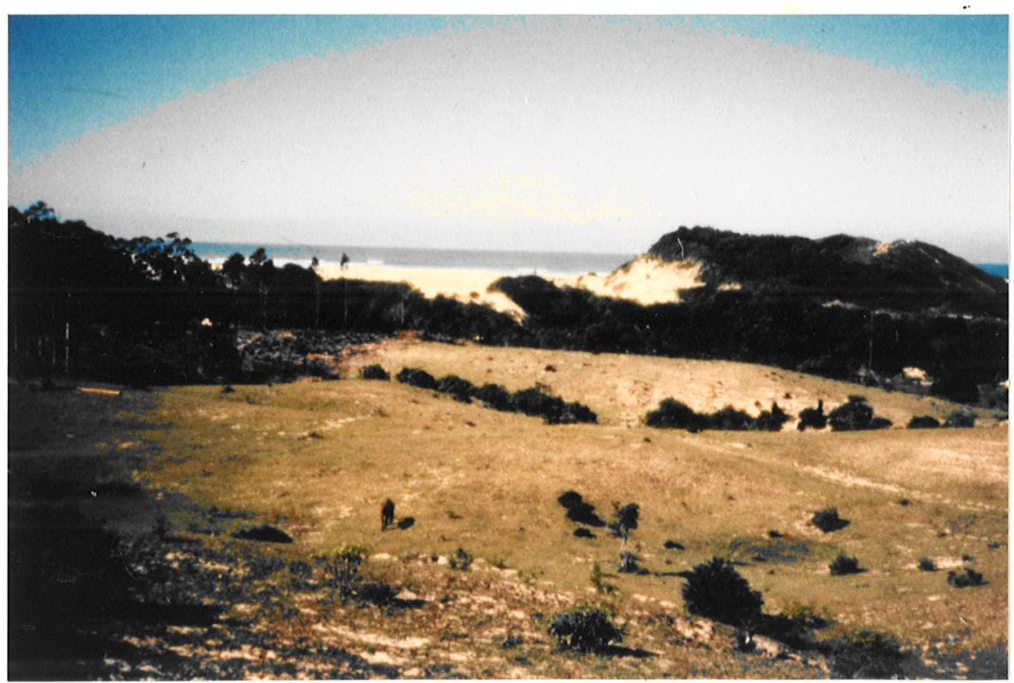

Figura 5.50. Morfologia da associaçăo de fácies depósitos mantiformes de gerações 2 (primeiro plano) e 4, próximo a Arroio Corrente, Jaguaruna. A lateral interna do manto ativo é parcialmente vegetada, o que se explica pela baixa taxa de avanço das areias no sentido transversal à costa.

A variedade 3 apresenta-se na forma de rastros lineares residuais a barlavento de lençóis parabólicos ativos (variedade 4) ou como dunas parabólicas alongadas, muitas vezes imbricadas (item 5.4.2.3). As características comuns a estes dois tipos de depósitos no exame de aerofotografias de diferentes datas são a imobilidade e a textura clara e manchada, de contorno quase sempre mal definido. No campo, verifica-se que as manchas correspondem a núcleos de cobertura vegetal e que a indefinição de limites decorre da altura reduzida $(<3 \mathrm{~m})$ e do caráter deflacionar dos depósitos. Exceção para este último aspecto encontra-se nas formas parabólicas de mais de $10 \mathrm{~m}$ de altura que recobrem depósitos da variedade 2 na região do morro das Ovelhas, em Imbituba (figuras $A 19$ e 5.51). Os depósitos baixos 
possuem muitas vezes o aspecto de dunas frontais estabelecidas (Hesp 1983, 1988) interiores, embora esta não seja a sua origem.

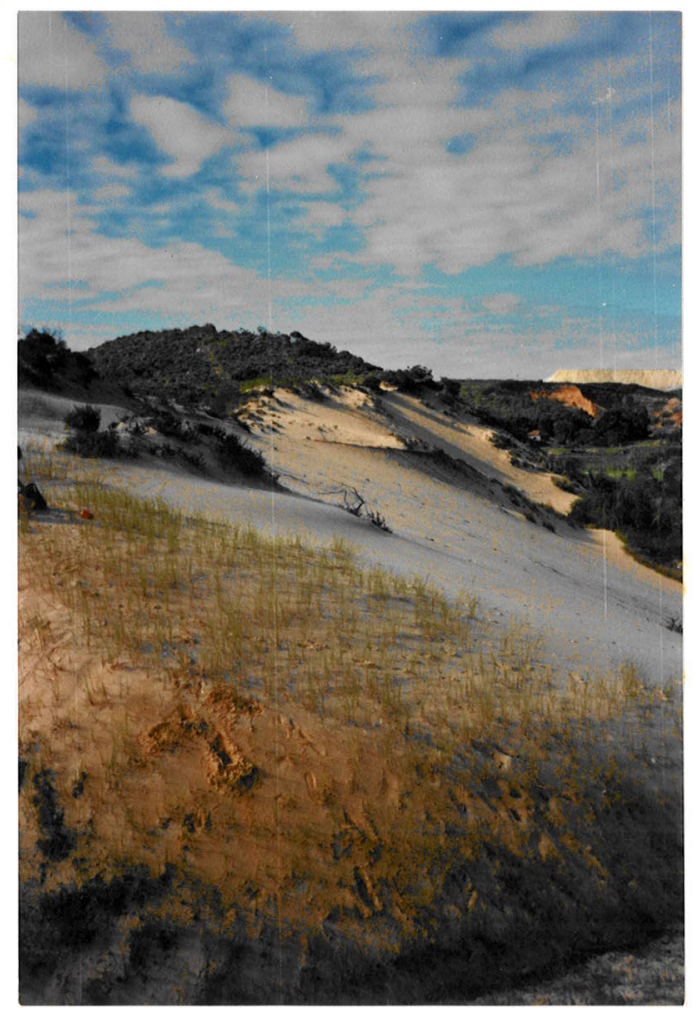

Figura 5.51. Aspecto parcial do lençol parabólico geraçăo 3 de Ribanceira, Imbituba, recobrindo dunas geração 2 (cor alaranjada, ao fundo). Em último plano, à direita, observa-se pilha de rejeito de indústria carbonifera.

Os depósitos da variedade 3 são formados por areias finas inconsolidadas cinza claro, amareladas ou brancas, estas últimas muito semelhantes às que constituem a maioria das dunas ativas. Diferem de dunas ativas vegetadas (parabólicas) da variedade 4 pela ausência de frentes de avanço desvegetadas, pela distribuição indiscriminada da vegetação ao longo do corpo dunar e pela eventual presença de sinais extensivos de pedogênese incipiente (individualização de horizonte A).

A variedade 4 corresponde a dunas ativas, total ou parcialmente vegetadas, constituídas por areias de colorações claras, amareladas ou esbranquiçadas. A vegetação, quando presente, participa na sedimentação eólica em andamento, seja em dunas frontais, seja em parabólicas. Nestas últimas, a cobertura vegetal distribui-se de modo organizado, em contraste ao que ocorre na variedade 3 , concentrando-se em geral na parte inferior dos flancos de sotavento (figura 5.50). Sua mobilidade rumo SW pode ser constatada e estimada através da comparação de aerofotografias de diferentes datas (item 5.4.2.3). A morfologia em perfil transversal (figura 5.48; perfis 1, 2 e 7) assemelha-se a de depósitos da variedade 2, mas, em fotografias aéreas, formas barcanas e barcanóides superpostas podem ser reconhecidas e mapeadas com muito maior facilidade. Lençóis e dunas eólicas do tipo 4 cobrem grandes extensões contínuas dos sistemas holocênicos barra-barreira e 
planície costeira, chegando a cavalgar alguns dos pontões cristalinos recobertos por paleodunas de topo. Sua correlação com a unidade 4 é diretamente observada.

\subsubsection{Gerações eólicas}

Partindo-se da premissa de que as correlações descritivas traçadas entre unidades de empilhamento e variedades de superfície possuam também caráter cronológico relativo, pelo menos quatro gerações de depósitos eólicos podem ser reconhecidas. As gerações 1,2 e 4 resultam da correlação entre as respectivas unidades e variedades. Não há nenhuma evidência de campo que permita a correlação geral entre a variedade 3 e a unidade 3 , pois em muitos afloramentos a unidade 3 aparenta ter caráter apenas pedogênico (figura 5.38), e não deposicional (figura 5.39). Não se têm dúvidas de que a variedade 3 é mais nova que a 2, a qual chega a recobrir, e mais antiga que as dunas ativas da geração 4 . Ela define portanto a geração 3. A estas quatro gerações deve ser acrescentada uma quinta, em caráter duvidoso, a geração $2 \mathrm{~A}$.

Com base na datação obtida por Bigarella (1975c) para a unidade 1, a geração 1 é mais antiga que 35 mil anos. As gerações 2 e $2 \mathrm{~A}$ podem ser consideradas como anteriores ao máximo transgressivo de 5100 anos A.P., pois os seus depósitos encontram-se truncados erosivamente pelas margens do sistema lagunar, o qual atingiu nessa época a sua máxima extensão. Datações em sambaquis não precisam nem contrariam essas hipóteses de idades. A base do sambaqui do cabo de Santa Marta Pequeno (S38A), que repousa diretamente sobre sedimentos eólicos da geração 1 , foi datada em $4530 \pm 70$ anos A.P.. O topo do sambaqui do Estreito (S58A), construido sobre paleodunas da geração $2 \mathrm{~A}$, foi datado em $4080 \pm 70$ A.P.. A geração 4 cavalga e é portanto mais nova que os sambaquis $S 30 B$ e $S 30 D$, ambos com idade mínima de $3780 \pm 70$ anos A.P.

\subsubsection{PADRÃO FISIOGRÁFICO}

O exame do padrão espacial de arranjo de fácies no sistema eólico da área em estudo é antecedido de uma revisão sobre a moorfodinâmica de acumulações eólicas costeiras enquanto critério e subsídio para classificação e nomenclatura de tipos de depósitos.

\subsubsection{A questão da escala}

A obra clássica na abordagem da questão da escala de ondulações eólicas é a de Wilson (1972) que, estudando dunas transversais da Namíbia, concluiu pela existência de três hierarquias de formas de leito eólicas, as microondulações ou ôndulas ("ripples"), as dunas e os draas (dunas gigantes), distintas com base na relação entre granulometria da areia e comprimento de onda (figura 5.52). De acordo com este autor, dunas e microondulações seriam diferenciadas pelo comprimento, com um valor limitrofe em torno de $3 \mathrm{~m}$, mas poderiam apresentar superposições em suas alturas. Jackson (1975) elaborou uma classificação similar, dividindo as ondulações eólicas em micro, meso e macroformas, 
mas avaliou o comprimento máximo das microformas, correlacionáveis às ôndulas de Wilson (1972), em apenas $1 \mathrm{~m}$. Trabalhos posteriores evidenciaram, porém, que uma diferenciação universal entre hierarquias de formas de leito deve-se estabelecer muito mais sobre bases genéticas que quantitativas.
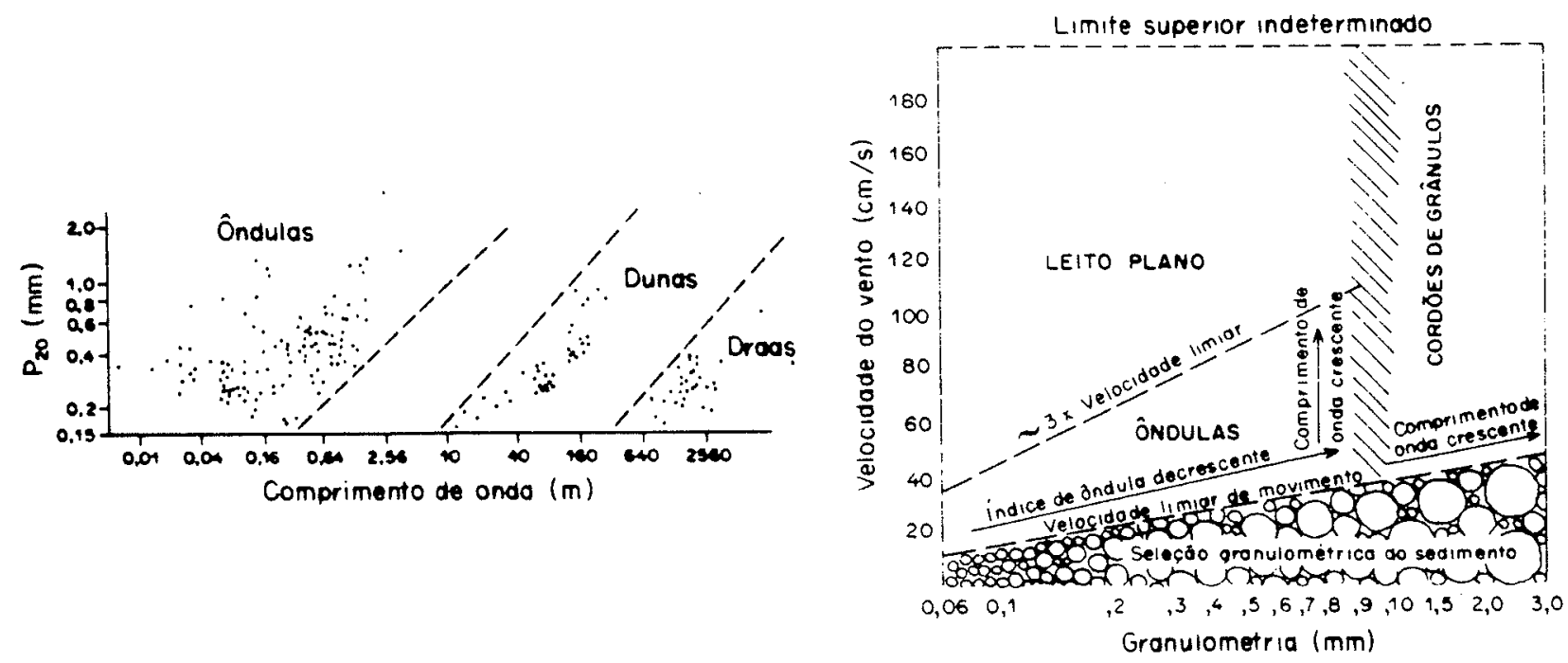

Figuras 5.52 e 5.53. Diagramas sobre dimensăo e morfologia das formas deposicionais produzidas pelo vento.

5.52 (esquerda). Granulometria (percentil 20\% mais grosso) versus comprimento de onda, para formas de leito eolicas transversais, segundo Wilson (1972).

5.53 (direita). Formas de leito eólicas em funçăo de tamanho de grăo, seleção granulométrica e velocidade do vento, conforme Fritz \& Moore (1988).

Brookfield (1977) iniciou a abordagem da questão sob seu lado genético, estendendo os princípios de hierarquia de formas de leito subaquosas de Allen (1968) ao contexto eólico. De acordo com estes princípios, formas de leito eólicas menores podem cavalgar e sobrepor-se somente a formas maiores de mesma hierarquia ou de hierarquia imediatamente superior. Deste modo, draas resultariam, segundo o autor, da fusão de dunas. Com base nisto, McKee (1979) empregou o termo "compostos" para referir-se a depósitos produzidos pela coalescência de dunas de mesmo tipo morfológico e o termo "complexos" para designar os produtos de fusão de dunas de tipos diferentes. Para Kocurek (1981), draa seria assim um termo genérico que engloba ao mesmo tempo sistemas dunares complexos e compostos. Não há, portanto, diferença entre "mares ou campos de dunas" (McKee 1979; Short 1988) coalescidas e draas.

\subsubsection{Cavalgamento de depósitos eólicos}

De acordo com Wilson (1972), formas de leito eólicas crescem enquanto não for atingido o equilibrio entre suas dimensões e as condições de deriva eólica potencial e suprimento sedimentar. Uma vez alcançado o equilibrio, e mantidas as mesmas condições, as formas passam a migrar. A falta de qualquer uma das condições impossibilita a permanência de dunas ativas. Por outro lado, se ambas as condições forem satisfeitas, mas se o suprimento for muito maior que a capacidade de 
deriva do vento, a taxa de deposição será maior que a de migração das dunas e estas passarão primeiro a entulhar as planícies interdunas e depois a se empilhar umas às outras no fenômeno conhecido como cavalgamento ("climbing": Brookfield 1977; McKee 1979, 1982; Short 1988) ou superposição ("overlapping": McKee 1982, 1983; Lancaster 1988; Short 1988). Brookfield (1977) formulou um modelo para este fenômeno, baseado em analogias com os mecanismos de cavalgamento de marcas onduladas (figura 5.54)

A

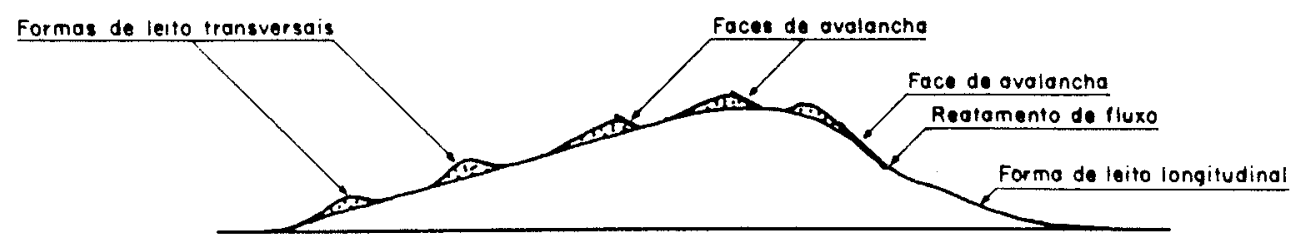

B

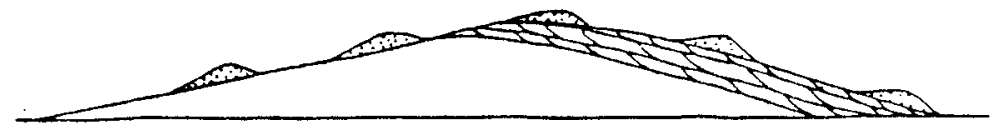

Figura 5.54. Secões esquemáticas em perfil de dunas cavalgantes transversais sobre draas barcanoides com (A) e sem (B) faces de deslizamento. Em A, as dunas transversais modificam-se primeiro para formas parcialmente longitudinais, no flanco de sotavento do draa, e finalmente para formas longitudinais puras na zona interdraas. Em B, o cavalgamento sem modificação das dunas transversais gera pseudoestratificaçס̃es internas, que são superficies de $2^{a}$ ordem. Segundo Wilson (1972 apud Brookfield 1977).

A partir de uma classificação de McKee (1982, 1983), admitese que dois tipos de cavalgamento de depósitos eólicos possam ser diferenciadas. $O$ primeiro ocorre no lado barlavento de obstáculos fixos de qualquer natureza, os quais funcionam como barreira natural ao vento efetivo, criando um excesso localizado de suprimento sedimentar. O segundo tipo de cavalgamento difere do primeiro, em essência, pela ausência de obstáculo fixo. Ele pode ser causado por um desequilíbrio quantitativo entre aporte de areia e competência do vento, como também pela convergência ou interferência de ventos simultâneos de direções diversas (McKee 1982). Incluem-se, entre os casos de cavalgamento eólico, a formação de dunas estreladas ("star dunes") no topo de cordōes longitudinais em áreas de regime eólico multidirecional (McKee 1982), a interligação lateral de barcanas compondo cadeias barcanóides longitudinais (McKee \& Tibbits 1964), o empilhamento sucessivo de barcanas ou barcanóides resultando em draas compostos com morfologia "em telha" ("shingle structure": McKee 1982, 1983), o estabelecimento de cadeias transversais lineares a barcanóides sobre draas mantiformes e lençóis parabólicos (Blarasin \& Sánches 1977; Short 1988) e o encavalamento de cordões transversais barcanóides, com redução da distância interdunas (McKee 1982, 1983). Os três últimos casos são encontrados, na área em estudo, associados ou não a presença de obstáculos fixos (figuras 5.68 e 5.71). Caracteriza-se assim a função de "subfácies de cavalgamento" exercida pelas dunas transversais dentro das fácies formas parabólicas (tabela 5.9) e manto de areia (tabela 5.8), em contraste ao caráter de "subfácies de migração" das frentes parabólicas. Deve-se ressaltar que parte das dunas cavalgantes com obstáculo fixo encontradas na área não se limita a sobrepor depósitos eólicos ativos, em migração, pois recobre o próprio anteparo fixo. Dunas com esta particularidade já 
foram referidas por Bigarella (1975a) no litoral catarinense sob a designação de "dunas de captação" e por Villwock et al.(1986) dentro de sua "barreira I" na costa do Rio Grande do Sul. Depósitos eólicos nos flancos ou no topo de obstáculos fixos têm sido também reconhecidos na Austrália, onde são denominados respectivamente "sand ramps" (Short 1988) e "cliff-top dunes" (Jennings 1967) ou "perched dunes" (Semeniuk et al.1989), termos que podem ser traduzidos como "rampas de areia", "dunas de topo de escarpa" e "dunas empoleiradas". A designação "rampas de areia" é adotada neste trabalho. Ela já fora utilizada por Bigarella (1975a) com referência a feições de dissipação pluvial em dunas eólicas. Observações feitas na área em estudo indicam que as rampas eólicas de modo geral apresentam em maior ou menor grau influência de processos de dissipação, de modo que os sentidos atribuidos ao termo por Bigarella (1975a) e por Short (1988) são em essência correspondentes. À designação "duna de topo de escarpa" é acrescentada neste trabalho a variante "duna de topo de encosta", que se pode considerar como mais abrangente, uma vez que o termo "escarpa" restringe-se a encosta ingreme.

De acordo com Lancaster (1988), a maioria das grandes formas de loito eólicas (draas ou "dunas compostas") é resultado de interação de dunas, formadas durante e após a individualização da megaforma. Dunas coalescentes podem ser consideradas como formadoras primárias do draa, cuja morfologia superficial é em seguida modificada por dunas superimpostas, que estimulam seu crescimento elou migração. Segundo o mesmo autor, existe um tamanho relativo minimo para que uma duna ou draa possa ser superimposta por formas menores, fato sugerido estatisticamente por medidas em dunas de mesmo tipo e região, como no caso do diagrama de Wilson (1972). Por outro lado, o espectro de dimensões de dunas simples e compostas, baseado em amostras de dados menos restritos, é contínuo. Isto indica, de acordo com Lancaster (1988), que a transformação de uma duna em draa ocorra como simples questão de tempo, desde que mantido um saldo positivo no aporte de areia. Uma vez formado através deste processo, o draa pode crescer em maior ou menor velocidade, em função de mecanismos de cavalgamento de formas de leito, em especial os ocorridos no flanco de sotavento (figura 5.54 b). Segundo o autor, quanto maior o ângulo da superfície de cavalgamento, maior é o crescimento vertical do draa.

\subsubsection{Taxas de migração de depósitos eólicos}

Se a deriva eólica potencial é considerada homogênea ao longo da área costeira em análise, variações locais na taxa de migração de formas eólicas de mesma escala refletem diferenças de campo de atuação do vento ("fetch"), topografia, cobertura vegetal, granulometria e de disponibilidade de sedimentos. Na área de Jaguaruna-Imbituba, as taxas de migração estimadas (tabela 5.8) variam desde 3 até $30 \mathrm{~m} / \mathrm{ano}$. 
Tabela 5.8

Ouantificacăo do deslocamento recente de dunas eolicas de geracào 4 co base ee conparacáo de aerototogratias verticais de datas diferentes (1952 x 1977-1979)

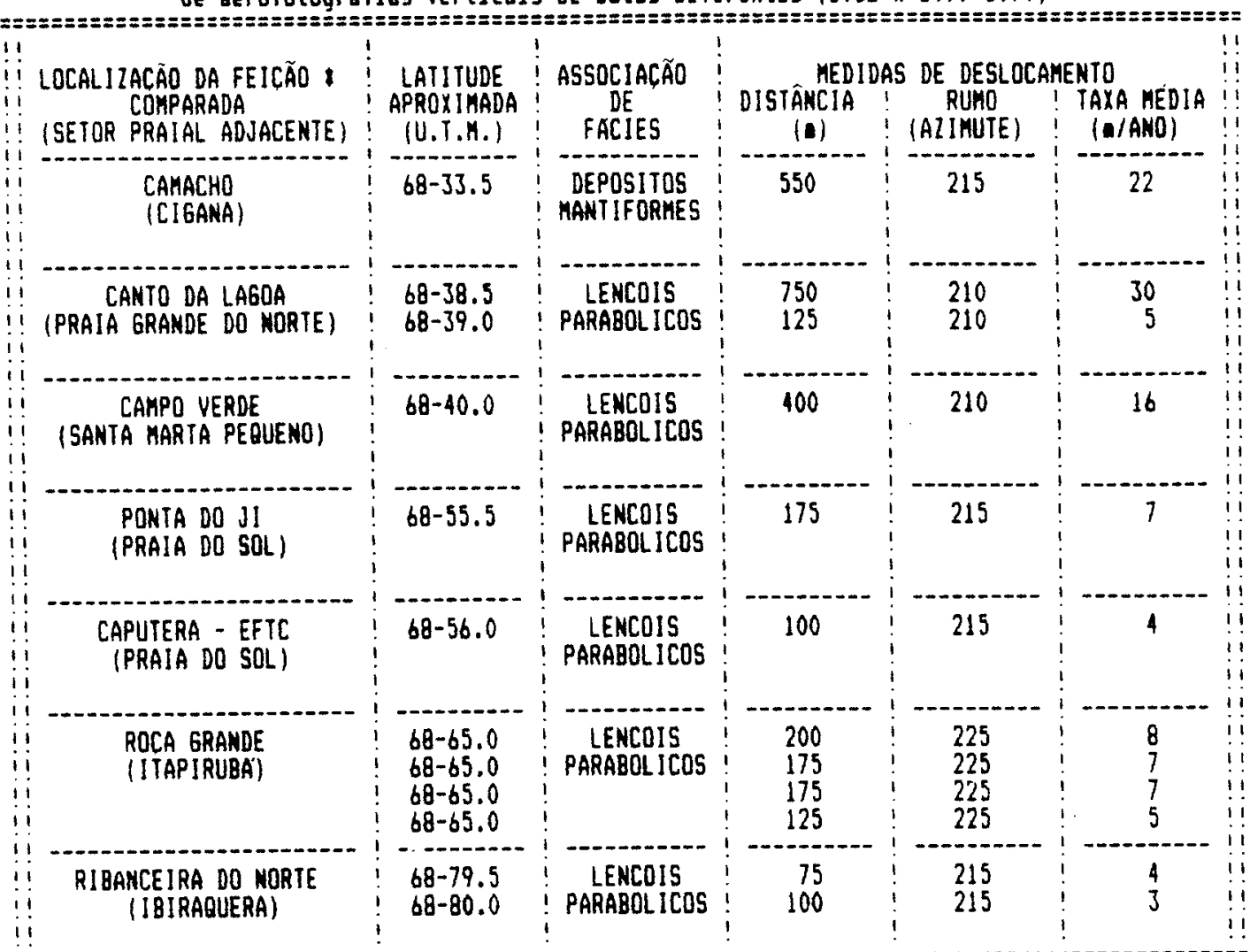

Obs. (1) : todas as teicóes corresponden a trentes de lencois ou dunas parabolicos.

De modo geral, as maiores taxas de migração pelo vento ocorrem em depósitos situados sobre o sistema barra-barreira ( $18 \mathrm{~m} / \mathrm{ano}$ em média), e em especial, na associação de fácies mantiforme. Vários fatores podem contribuir para este fato: 1) diferenças, quanto a evolução sedimentar pós-máximo NRM holocênico, entre os sistemas barra-barreira e planície costeira, o primeiro tendo maior atraso na recuperação do equilíbrio pelo "principio de Bruun", e portanto maior excesso de areia disponivel na praia; vale lembrar que a formação de barreira e a de dunas costeiras transgressivas são ambas respostas a um excesso de areia criado pela grande defasagem entre a transgressão marinha e o mecanismo de erosão praial previsto por Bruun (1962); isto significa que o sistema barra-barreira formou-se numa região, onde, por certos motivos, esta defasagem é maior; um destes motivos é o declive da plataforma interna, que se torna suave a sul da Laguna (figura 3.3); 2) a grande extensão da Praia Grande do Sul, favorecendo a manutenção ininterrupta, no espaço, de costas dissipativas; 3) a aproximação entre linha de costa atual e sedimentos pleistocênicos na região de Imbituba, implicando aumento na granulometria do sedimento fornecido e sugerindo regime de deriva litorânea local pouco favorável à deposição praial; este fator relaciona-se, em particular, às baixas taxas de deslocamento medidas no lençol eólico de Ibiraqüera - Ribanceira do Norte.

\subsubsection{Critérios para nomenclatura de depósitos eólicos}

Existe um grande número de classificações e terminologias para tipos de dunas eólicas (Hack 1941; Cooper 1958, 1967; McKee 1966,1979,1982 Goldsmith 1978; Breed \& Grow 1979; Davies 1980; Hesp 1981,1983,1988; Mainguet 
1983,1984; Short 1988, Semeniuk et al.1989). Uma compilação da nomenclatura citada nestes trabalhos permite listar mais de meia centena de termos, a maioria deles aplicáveis a dunas costeiras. Entre estes, reconhecem-se tanto termos pretensamente genéticos (Goldsmith et al.1977. apud Goldsmith 1978) como termos descritivos (figura 5.55: Semeniuk et al.1989). Porém, na maioria dos casos, critérios genéticos e descritivos são utilizados de modo indiscriminado numa mesma classificação; além disso, confundem-se com freqüência, na caracterização de tipos descritivos, aspectos morfológicos escalares (formato) com aspectos morfológicos vetoriais (orientação relativa ao vento ou a praia e simetria). Quanto aos tipos genéticos, a ênfase é dada, na maioria das vezes, à morfoecologia (relação entre geomorfologia e cobertura vegetal), como exemplificam os trabalhos de Goldsmith (1978), Hesp (1981,1983,1988), Mainguet $(1983,1984)$ e Semeniuk et al.(1989). Goldsmith (1978) considera a vegetação como critério classificatório mesmo após a estabilização da duna. Deste modo, sua categoria de "dunas vegetadas" é apresentada como um sinônimo de dunas fixas. Neste caso, entretanto, a vegetação é antes um critério para avaliação de idade relativa da duna que para sua caracterização morfodinâmica.

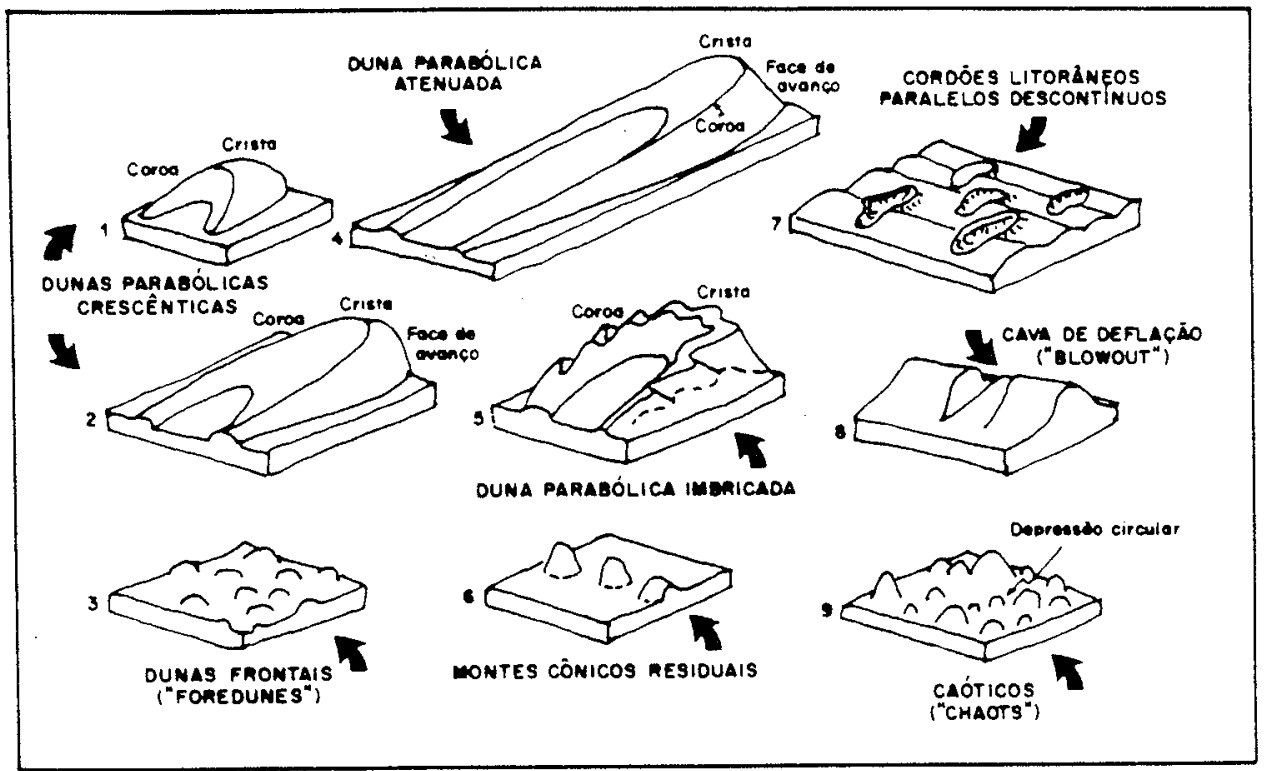

Figura 5.55. Feiçסes geométricas das formas de relevo mais comuns produzidas por deposiçăo ou deflação eólica em zonas costeiras, segundo Semeniuk et al.(1989).

Quatro princípios foram adotados neste trabalho para organizar o uso da terminologia de depósitos eólicos compilada de obras anteriores e adaptá-la à construção de uma hierarquia de fácies: (1) manter a acepção original dos termos' empregados; (2) estabelecer virtuais associações entre termos diferentes utilizados para mesmo tipo de duna; (3) evitar na classificação implicações de escala a priori, de modo que os termos sirvam para designar tanto draas (associações de fácies e fácies) quanto dunas simples (subfácies); (4) discernir os termos referentes a critérios distintos de descrição, através de uma classificação que conjugue, em niveis de hierarquia sucessivos, estes diferentes critérios; as hierarquias de critério adotadas foram a posição relativa no sistema deposicional, a morfologia escalar, a morfologia vetorial e os aspectos morfoecológicos, obtendo-se como resultado a classificação 
resumida nas tabelas 5.9 a 5.11. Comentários adicionais sobre a definição dos termos utilizados são apresentados nos subitens seguintes.

\subsubsection{Associaçōes de fácies}

As duas associações de fácies diferenciadas no sistema deposicional eólico distinguem-se entre si quanto ao desenvolvimento de zona deflacionar proximal (item 3.3.5); têm em comum a presença de lençóis de areia com forma parabólica geral (no caso da associação lençóis parabólicos) ou pelo menos parcial (no caso das frentes da associação depósitos mantiformes). A definição de lençóis de areia eólica que pode ser compilada de McKee $(1979,1982,1983)$ é a de corpos tabulares extensos ligeiramente ondulados em superfície, onde as evidências de deposição eólica são tão nítidas nas cristas quanto nas depressões de relevo. Nesta definição, parecem encaixar-se os "campos de dunas" ("dune fields") de Short (1988), descritos como "áreas extensas de areias eólicas desvegetadas, resultantes ou da coalescência de "blow-outs" parabólicas ou da instabilização maciça de dunas frontais e transporte direto praia - duna frontal - duna interior". Da comparação entre a figura 5.56, reproduzida de Short (1988), e a figura 5.57, extraida de Tomazelli (1990), é possível concluir por uma correspondência entre os campos de dunas formados por coalescência de "blow-outs" parabólicos, referidos pelo primeiro autor, e os "lençóis arenosos parabólicos" mencionados pelo segundo. De modo análogo, há equivalência entre os campos de dunas gerados por "instabilização maciça de dunas frontais" e os "depósitos eólicos mantiformes". A distinção entre os dois tipos de lençóis ou campos de dunas reconhecida por Short (1988) e por Tomazelli (1990) é aplicável à área de Jaguaruna-Imbituba. Nas áreas de aporte eólico mais efetivo, com concentração preferencial sobre o sistema barra-barreira (parte sul da área), a deposição de areia eólica na berma praial ocorre em taxa maior que a velocidade de crescimento normal de vegetação pioneira, o que dificulta o desenvolvimento perene de dunas frontais incipientes. Este estado de desequilíbrio favorece a "instabilização maciça de dunas frontais", mencionada por Short (1988), dando vez ao desenvolvimento de extensos mantos de areia eólica que se iniciam na orla praial e só terminam nas frentes parabólicas interiores, distantes por até dezenas de quilômetros (tabela 5.12). Nas áreas costeiras de aporte eólico menor, as quais repousam preferencialmente sobre o sistema planicie costeira, as dunas frontais não se instabilizam, mas sofrem deflação gradual pelo ventos prevalescentes, formando dunas parabólicas de migração lenta (tabela 5.7), as quais se coalescem em maior ou menor grau na forma de lençóis parabólicos de dimensões variáveis. Apesar disso, os lençóis arenosos são sempre menos extensos que os depósitos mantiformes (tabela 5.12). 
Tabela 5.9

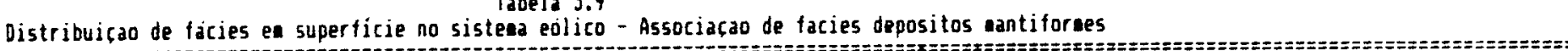

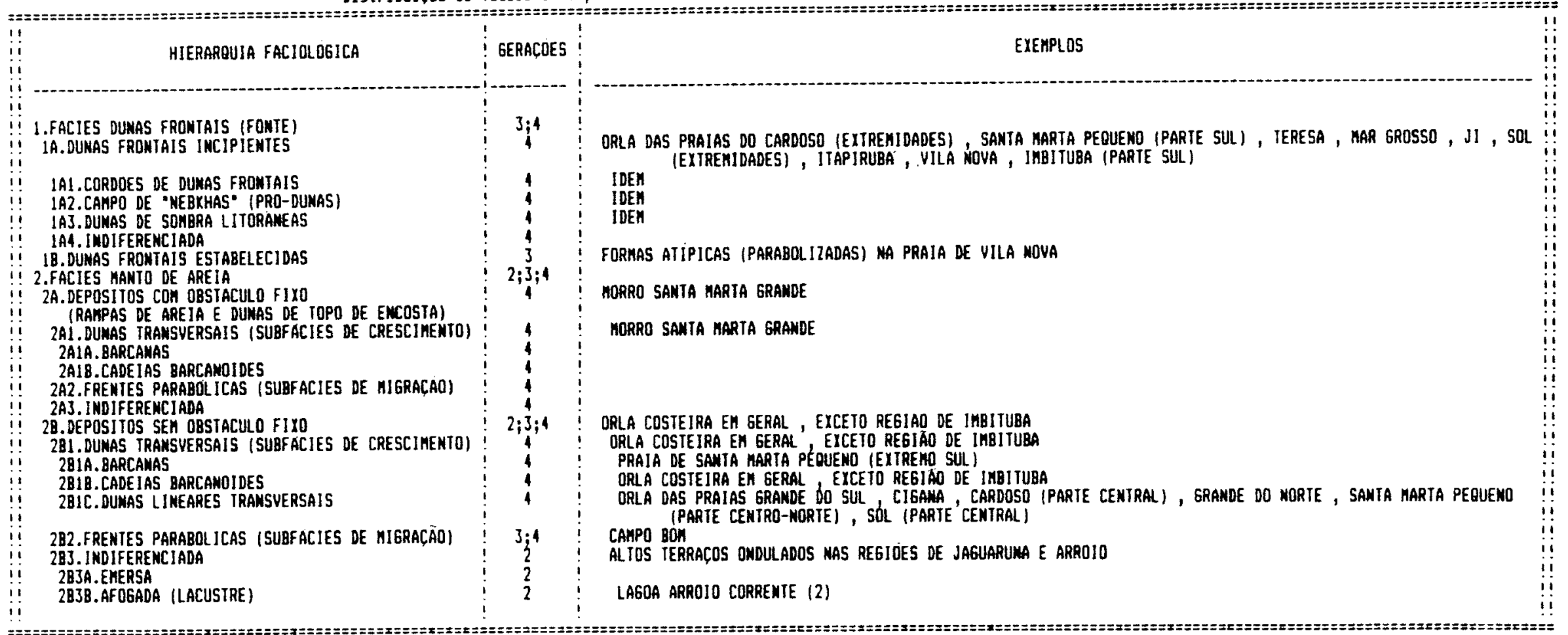


Tabela 5.10
Distribuicad de lacies en superficie no sistea eolico - Associacao de facies dunas e lencois parabolicos

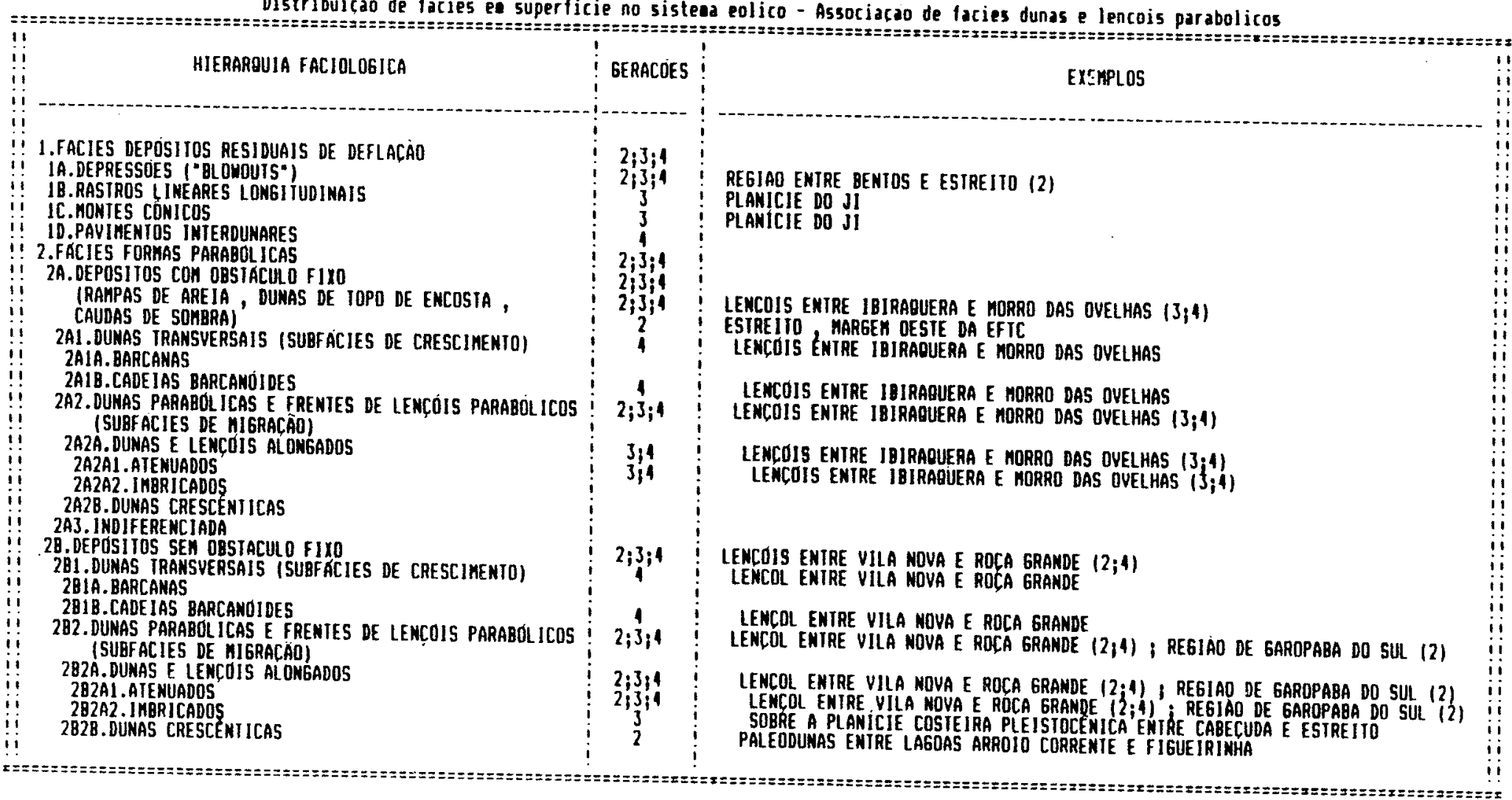

Distribuicao de facies en superticie Tabela 5.11

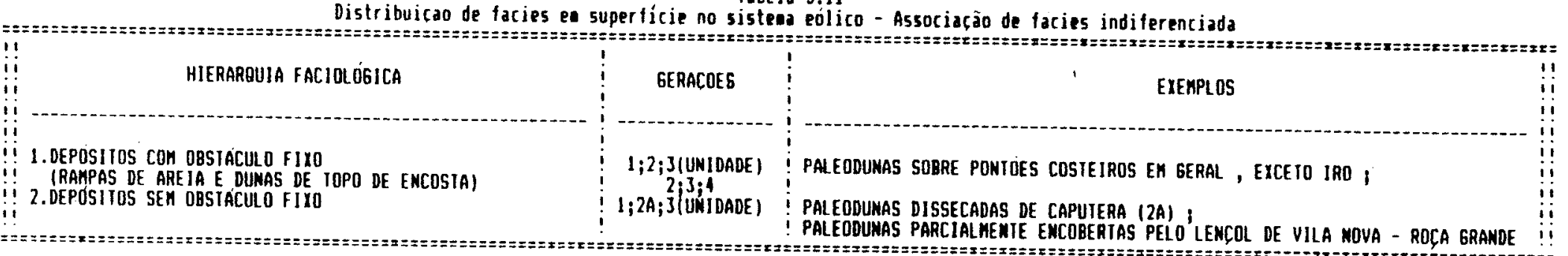



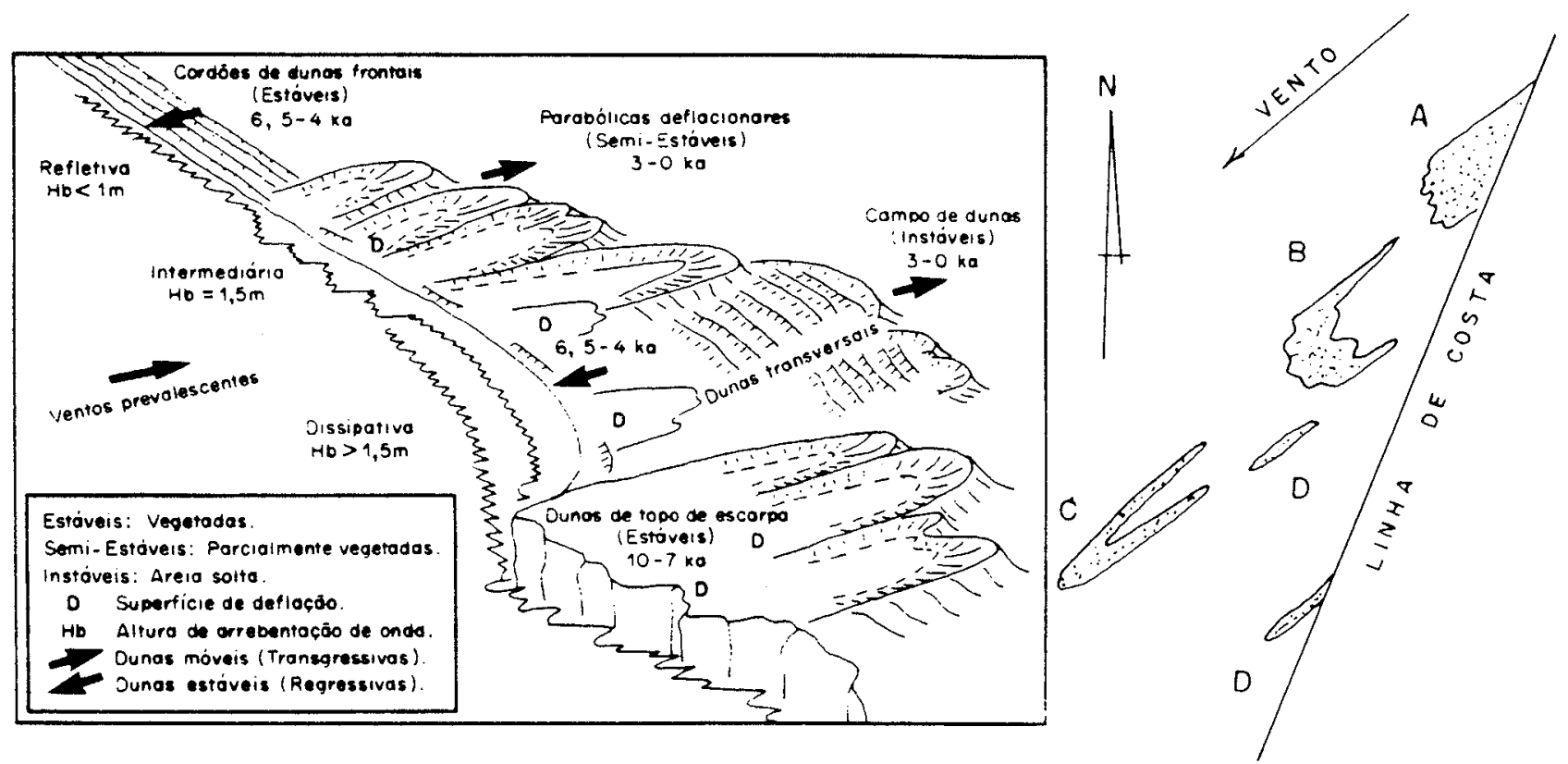

Figuras 5.56 e 5.57. Classificações morfologicas de depósitos eólicos.

5.56. (esquerda) Tipologia e geraçס̃es de dunas eólicas na costa sul da Austrália associadas a diferentes morfodinâmicas praiais, segundo Short (1988).

5.57. (direita) Feiçס̃es eólicas longitudinais na costa gaúcha segundo Tomazelli (1990) : A. Depósitos eólicos mantiformes; B. Lençóis arenosos parabólicos; C. Dunas parabólicas; D. Dunas lineares.

Tabela 5.12

Parànetros norfonetricos de depósitos eolicos da geraçá 4 , detersinados coe base es exase de aerofotografias 1:29.000 (1977-1979)

\begin{tabular}{|c|c|c|c|c|c|c|c|c|c|c|}
\hline \multirow{2}{*}{\multicolumn{2}{|c|}{$\begin{array}{l}\text { LOCALILACÃO DO DEPOSITO } \\
\text { (SETOR PRAIAL ADJACENTE) } \\
\text { GAROPABA DO SUL A LAGOA } \\
\text { BONITA (PRAIA GRANDE } \\
\text { DO SUL) }\end{array}$}} & \multirow{2}{*}{$\begin{array}{c}\text { ASSOCIACÃO DE FÁCIES } \\
\text { PRINCIPAL } \\
\text { DEPOSIITOS } \\
\text { MANTIFORMES }\end{array}$} & $\begin{array}{l}\text { PARAAETROS DE } \\
\text { COMPRIMENTOO } \\
\text { (A) } \\
\text { MAXX. }=21500\end{array}$ & \multicolumn{2}{|c|}{$\begin{array}{c}\text { ASSOCIACÃO } \\
\text { LARGUAAA } \\
\text { (1) }\end{array}$} & FÁCIES & \multicolumn{2}{|c|}{$\begin{array}{l}\text { PARÂMETROS } \\
\text { ESPACAMENTO } \\
\text { (1) }\end{array}$} & \multicolumn{2}{|c|}{$\begin{array}{c}\text { DE FÁCIES \& } \\
\text { CURVATURA } \\
\text { (a) }\end{array}$} \\
\hline & & & & $\begin{array}{l}\text { MÁI } \\
\text { MED } \\
\text { HII }\end{array}$ & $\begin{array}{r}1675 \\
1500 \\
175\end{array}$ & CADEIAS BARCANOIDES & & & & \\
\hline & & i & & & & & & & & \\
\hline & & 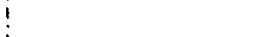 & & & & & & & & \\
\hline & & ! & & & & & & & & \\
\hline & $\begin{array}{l}\text { POHIA DA } \\
\text { DO CANAC } \\
\text { PEQUENO/E }\end{array}$ & $\begin{array}{c}\text { DEF } \\
\text { MAM }\end{array}$ & $12200 !$ & $\begin{array}{l}\text { MAX. }= \\
\text { MED.= } \\
\text { MIM. }=\end{array}$ & $\begin{array}{r}1490 \\
900 \\
200\end{array}$ & CAD & & & & 75 \\
\hline & $\begin{array}{l}\text { RDE } \\
\text { PEQUENO) }\end{array}$ & $\varliminf^{\vdots}$ LENC & MÁX. $=$ & $\begin{array}{l}\text { MAI } \\
\text { MEI } \\
\text { HII }\end{array}$ & $\begin{array}{r}125 \\
100 \\
25\end{array}$ & & & 75 & & 90 \\
\hline & VILA NOVA & LENCOIS $P$ & MÁr $=1500$ & & $\begin{array}{r}1050 \\
450 \\
100\end{array}$ & & & & & $\begin{array}{r}100 \\
75\end{array}$ \\
\hline & $\begin{array}{l}\text { LAGOA } 18 \\
\text { A ARROIO }\end{array}$ & Lencóls P & MÁx $=2900 !$ & $\begin{array}{l}\text { MAL }= \\
\text { MED }= \\
\text { MIN.= }\end{array}$ & $\begin{array}{r}1200 \\
450 \\
150\end{array}$ & CANDIDES & $\begin{array}{l}\text { MAX. }= \\
\text { MEO. } \\
\text { MIN. }=\end{array}$ & $\begin{array}{r}100 \\
75 \\
10\end{array}$ & $\begin{array}{l}M G X== \\
M E D= \\
M I X=\end{array}$ & $\begin{array}{r}125 \\
80 \\
40\end{array}$ \\
\hline
\end{tabular}

Obs.(1) : parâatros morfometricos previanente definidos neste trabaliho (figura 1.10 )

Enquanto associações de fácies, lençóis parabólicos e depósitos mantiformes são tipos de depósitos relacionados no espaço. A diferença básica admitida entre as duas associações encontra-se na zona proximal, onde se tem a presença típica de planície deflacionar, na primeira associação, ou de dunas frontais, na segunda. As dunas frontais, quando instáveis, de ocorrência restrita e/ou temporária, constituem a fonte imediata de areia para a associação depósitos 
mantiformes; quando estáveis, formando cordões contínuos e perenes devido a baixa efetividade da deriva eólica, são a fácies única de depósitos mantiformes abortados, isto é, não desenvolvidos completamente por falta de areia. A associação lençóis parabólicos situa-se sempre à frente da associação depósitos mantiformes, seja esta abortada ou não, dela se separando por uma área de deflação, que é sua fácies mais proximal. Lençóis parabólicos ativos formados a partir da deflação de depósitos mantiformes abortados (dunas frontais estáveis) podem ser vistos, por exemplo, na parte sul da praia de Itapirubá (figura A14) enquanto lençóis parabólicos à frente de depósitos mantiformes desenvolvidos são encontrados na praia do Sol (figura A13) ou a noroeste de Canto da Lagoa (figura $A 9$ ).

A distinção entre as duas associações de fácies eólicas adquire dificuldades adicionais quando no estudo de paleodunas (gerações 1, $2 \mathrm{~A}$ e 2 ). Em algumas áreas, em particular onde aflora a geração 1 e em dunas de topo de encosta, não foram encontrados critérios aerofotogeológicos ou de campo que permitissem esta distinção. Para estes casos, admitiu-se uma terceira categoria, indiferenciada, de associação de fácies. Para demais casos, puderam ser usados critérios distintivos estabelecidos com base na observação, nas gerações 3 e 4 , de duas características geomorfológicas exclusivas de lençóis parabólicos: presença de rastros lineares longitudinais e de cavas semi-circulares de deflação e fortes gradientes de relevo entre feições paralelas longitudinais. Em aerofotografias, a observação destas características não é dificultada pelo desenvolvimento da cobertura vegetal em paleodunas pouco dissecadas, como se deduz da comparação entre dunas menos e mais vegetadas das gerações 4 e 3 , respectivamente; a presença da vegetação pode, pelo contrário, torná-las mais evidentes na medida em que diminui a reflexão da luz pela superfície clara das areias. A dissecação fluvial moderada, do mesmo modo, ressalta os vales estreitos entre braços de parabólicas e rastros de deflação. Com base nisto, foi possivel reconhecer a presença de paleolençóis parabólicos atribuídos à geração 2 ao longo de maior parte da cobertura eólica existente sobre o sistema planície costeira, como na região de Garopaba do Sul e no setor que se estende de Cabeçuda a Estreito. A associação de fácies depósitos mantiformes foi atribuida em caráter tentativo às regiões da cidade de Jaguaruna (figuras A1 e A3) e das vilas de Nova Brasilia e Arroio (figura A18 e A19), a oeste de Imbituba. Nestas áreas, ambas de cota topográfica relativamente elevada (12 a $34 \mathrm{~m}$ ), encontram-se ondulações amplas e suaves, com 0,5 a $2 \mathrm{~m}$ de amplitude e 20 a $60 \mathrm{~m}$ de comprimento de onda, orientadas preferencialmente segundo SW-NE. Em aerofotografias, observam-se formas parabólicas e transversais tênues e descontínuas, em padrão muito distinto do de lençóis parabólicos. Uma hipótese alternativa para explicar as características geomorfológicas deste terreno seria de dunas parabólicas da geração 2 ou mais antigas, muito dissipadas. O fenômeno da dissipação, porém, não é suficientemente relatado na literatura, a não ser em dunas de captação (Bigarella 1975a); referência de Bigarella $(1970 / 71,1972)$ à ocorrência de dissipação em dunas costeiras sem obstáculo no Paraná foram questionadas por Angulo (1992). 


\subsubsection{Fácies e subfácies principais}

\subsection{Depósitos com obstáculo fixo}

Rampas de areia e dunas de topo de encosta ativas são encontradas na ponta do Costão do llhote, no flanco oeste da ponta da lihota e na parte norte dos morros Santa Marta Grande e Entrada da Barra (figura 5.58). Rampas de ocorrência mais restrita e descontínua, associadas a retrabalhamento local de areias de paleodunas de topo, ocorrem também nas pontas do Ji e Careca do Velho. Paleodunas de topo de encosta (figura 5.59 e 5.60) encontram-se em todas as pontas costeiras da região entre Jaguaruna e Imbituba, à exceção do Costão do llhote e da ponta do Iró. Nào há referência sobre o caráter eólico destes depósitos na literatura prévia sobre a área, e a ocorrência da ponta do Ji foi interpretada originalmente por Guerra (1953) como um terraço marinho de 12 a $13 \mathrm{~m}$ de altitude. Na região de Imbituba e Ibiraqüera, as paleodunas de topo estendem-se continente adentro a julgar pela cota topográfica elevada de depósitos eólicos interiores ( $>30 \mathrm{~m}$ ), e pela presença em meio a estes depósitos de testemunhos de rocha granitóide como o existente no morro das Ovelhas (figuras A18 e A19). Este tipo de rocha constitui o substrato primário de todas as dunas de topo de encosta citadas. Não foram incluidas dentre as dunas de topo de encosta, neste trabalho, as areias eólicas que possuem como substrato primário depósitos eólicos costeiros quaternários mais antigos, como ocorre na parte interior do lençol parabólico ativo de Vila Nova - Roça Grande (figura 5.39).

A localização privilegiada da dunas de topo de encosta, a altitudes protegidas da ação erosiva ou colmatante associada a regressões e transgressões marinhas, torna-as registros potenciais dos principais eventos geradores de dunas costeiras na região. Além disso, o sulcamento rápido das vertentes de areia fracamente consolidada por ravinas de drenagem pluvial propicia a formação de canhões profundos, com exposições de 0,5 a $10 \mathrm{~m}$ de espessura de sedimentos (figura 5.59), as quais favorecem o estudo da estratigrafia dos depósitos. No fundo destas ravinas de drenagem, ocorrem concentraçōes arenosas de minerais pesados e grânulos e seixos de feldspato e fragmentos líticos, angulosos, ou de areias semi-consolidadas da geração 1, arredondados. Paleocanais decimétricos a métricos, preenchidos por mesma gama de materiais, encontram-se com freqüência expostos nas paredes de ravinas nas pontas da llhota e do Ji, o que evidencia que o fenômeno de sulcamento nestas dunas de topo de encosta deu-se, em outras épocas, em posições não muito distantes das atuais. O tipo de preenchimento destas ravinas atuais e antigas sugere tratar-se de zonas preferenciais de sedimentação episódica por enxurradas confinadas. Quando escavados em areias atribuidas a geração 1, os paleocanais apresentam formas irregulares, localmente angulosas e em degrau, e exibem, especificamente na ponta da Ilhota, preenchimento eventual por conglomerados intraformacionais (figura 5.47). Tais características fazem supor a escavação em areia previamente consolidada. Quando cortam areias atribuidas a geração 2, os paleocanais possuem formas côncavas arredondadas ou são amalgamados, e o conglomerado basal do preenchimento não possui aparentemente fragmentos líticos sedimentares que não sejam os da geração 1. Neste caso, portanto, não se tem evidência de consolidação prévia das areias escavadas pela enxurrada (figuras 5.101 e 5.102). 

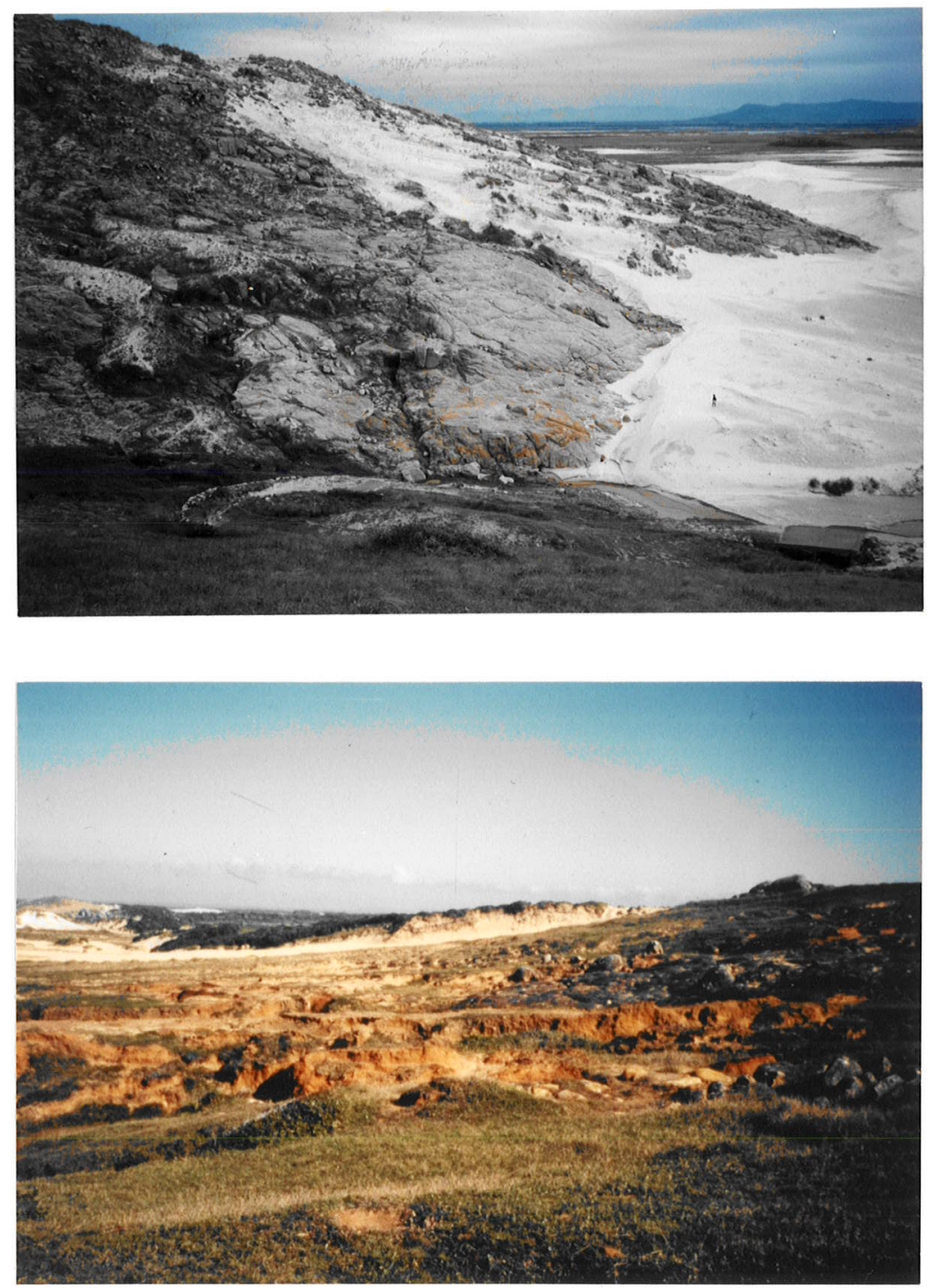

Figuras 5.58 e 5.59. Aspecto geral de dunas com obstáculo fixo.

5.58 (superior). Geraçăo 4 no flanco norte do morro Santa Marta Grande.

5.59 (inferior). Geraçס̃es 3 e 4 (areias claras) sobre 1 e 2 na Ponta da llhota. 


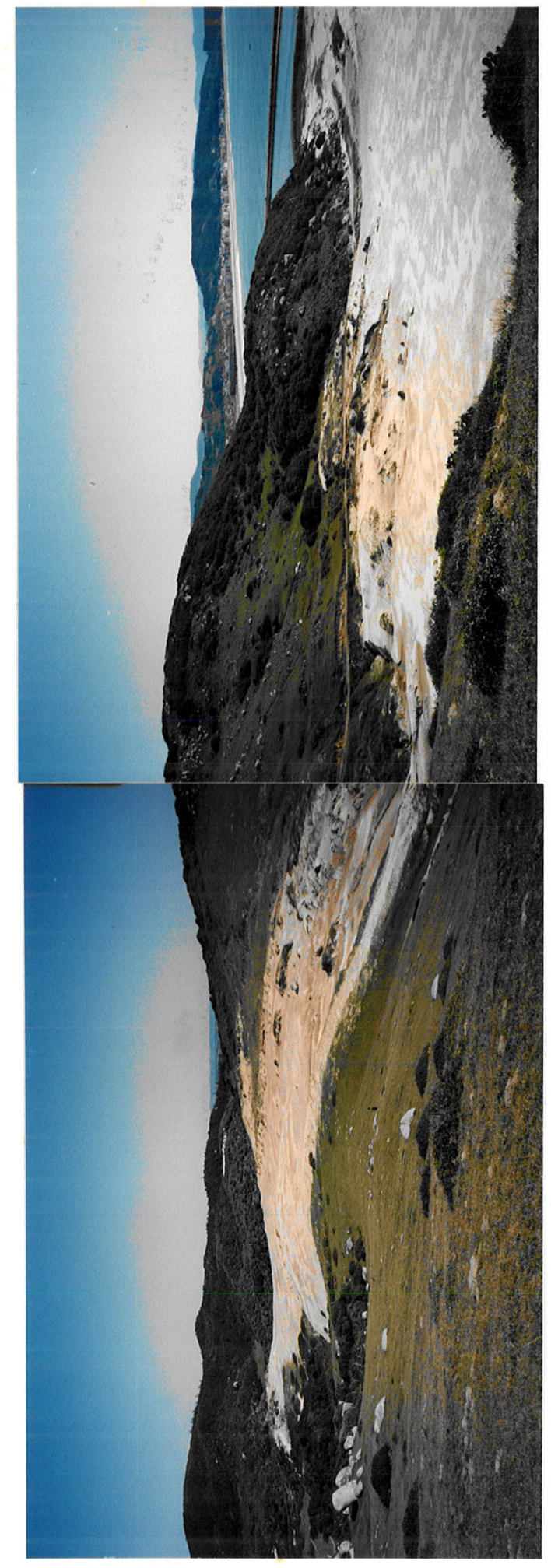

Figura 5.60. Lençol parabólico ativo cavalgando depósitos de topo de encosta da geração 2 no morro de Entrada da Barra. 
Ravinas cortando inteiramente sedimentos inconsolidados de geração eólica recente (4) podem ser vistas nos flancos oeste (interior) e norte (Praia Grande do Norte) da rampa de areia de Santa Marta Grande e também na rampa de Entrada da Barra (Molhes do Sul). Em Santa Marta Grande, as ravinas atingem o substrato constituído no local de rochas granitóides cortadas por diques de diabásio, e alongam-se preferencialmente através destes últimos. Em Entrada da Barra, elas expõem o substrato de areias com cimento orgânico preto, pertencentes a unidade de posição morfoestratigráfica duvidosa (1 ou 2 ?). Essas ravinas são temporárias, e atravessam sucessivos ciclos com duração de horas a dias, que alternam fases de colmatação pelo vento ou por desmoronamentos de material inconsolidado e fases de reabertura. Leques de avalancha de areia assoreando ravinas puderam ser observados em Santa Marta Grande. No mesmo local, as paredes de ravinas de drenagem exibem laminações cruzadas eólicas, em areia fina, alternadas com superfícies e lâminas discordantes ricas em areia grossa e grânulos, atribuídas a avalanchas de material misto eólico-coluvionar; os dois tipos de laminações apresentam-se com deformações suaves e com crenulações milimétricas em padrão estilolítico (figura 5.61). Estas deformações e crenulações são muito semelhantes às encontradas em crostas de impregnação de paleodunas da região e às ilustradas por Bigarella (1975a) em outras partes do litoral catarinense. Isto permite supor que a origem primária destas últimas estruturas seja pelo menos em parte, penecontemporânea à deposição e independente da impregnação que as ressalta. Uma causa provável para a deformação, no caso das dunas inconsolidadas de Santa Marta Grande, é a perda de sustentação do empacotamento de grãos de areia nas proximidades da zona erodida pelo canal de drenagem.

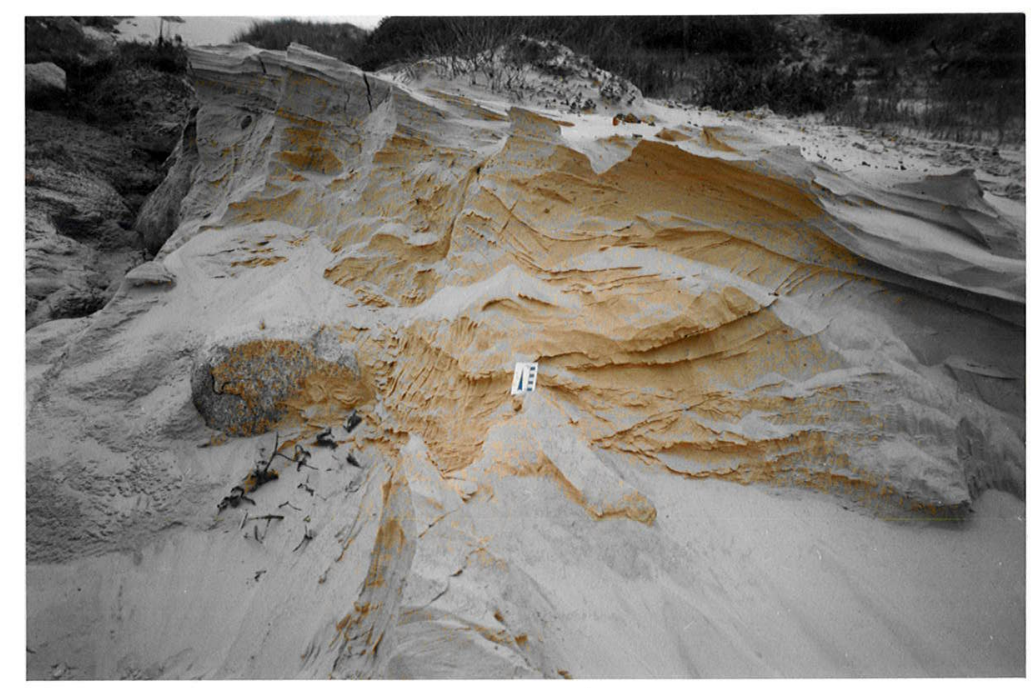

Figura 5.61. Lâminas deformadas em padrão estilolítico, em rampa eólica geração 4 no lado noroeste do morro Santa Marta Grande. Escala: $7 \mathrm{~cm}$.

Paleopavimentos ("stones lines"), ricos em grânulos e pequenos seixos, encontram-se não somente em meio à unidade 4 na rampa de areia de Santa Marta Grande, como também entre as unidades 1(?) e 4 na rampa de Entrada da Barra. Pavimentos superficiais recém-formados puderam ser também observados. Em Santa Marta Grande, eles compreendem, além do cascalho oriundo 
da desintegração da rocha granitóide, conchas e instrumentos líticos escorregados dos diversos sambaquis existentes no topo do morro. Este material forma acumulações em forma de leque no terço inferior da rampa de areia. Nas porções intermediárias e superior da rampa de barlavento, a ocorrência de deslizamentos sedimentares, associados a formação desses pavimentos, faz-se registrada nas paredes de ravinas de drenagem pela presença de superfícies discordantes com rumo de mergulho NE, separando seqüências decimétricas de laminações cruzadas frontais eólicas com mergulho para SW (figuras 5.85 e 5.86). Estas superfícies de truncamento ("bounding surfaces") não são geradas exclusivamente por movimentos subaquosos, pois feições de reversão temporária das faces de avalancha eólica são observados na área com freqüência. Se confirmada sua extensão lateral, estes truncamentos representariam a preservação em barlavento de superfícies de $2^{\mathrm{a}}$ ordem, na nomenclatura de Brookfield (1977; ver item 5.4.3.1.1).

Além de dunas de topo de encosta e rampas de areia, outro tipo de depósito eólico associado a obstáculo fixo com possível presença na área em estudo são megadunas de sombra, de forma parabólica, desenvolvidas no lado sotavento de irregularidades topográficas pontuais. Feições similares são referidas na literatura por Bagnold (1954) e Wilson (1989) sob a denominação de caudas de areia ("sand tails"). A existência de pelo menos quatro paleodunas deste tipo, nas proximidades da vila de Caputera, margem sudeste da laguna Mirim entre a rodovia BR-101 e a linha ferroviária (figura A13), foi conjecturada com base em interpretação aerofotogeológica. No campo, os virtuais obstáculos são também feições topográficas muito proeminentes; no entanto, ao contrário do que se pôde supor de início, não há qualquer evidência de constituição litológica distinta da das dunas parabólicas de geração 2 neles ancoradas. Deste modo, o caráter de caudas de sombra destas dunas não foi confirmado. Não se descarta, porém, a hipótese de que estas dunas parabólicas tenham sido geradas na zona de sombra aerodinâmica de depósitos eólicos previamente estabilizados. Esta hipótese é alimentada pela suspeita de existência de uma geração eólica anterior, denominada $2 \mathrm{~A}$, justamente nesta mesma região (item 5.4.1.2). Efeito de sombra eólica similar, exercido por montes cônicos ou dômicos residuais de deflação pertencentes a geração 3, pode ser observado sobre dunas parabólicas atuais (geração 4) em diferentes partes da associação de fácies lençóis parabólicos (figuras A13 e 5.81).

\subsection{Cordões de dunas fontais}

Hesp (1988) define dunas frontais ("foredunes") como "dunas paralelas à costa formadas por deposição eólica dentro da vegetação". Uma compilação da terminologia já utilizada para referir-se a esta classe de feições permite listar, entre outros, os seguintes nomes: dunas-banco, dunas-barreira, dunas de fonte protegida, embrionárias, de retenção, de precipitação, praiais, impedidas, dunascordão e antedunas. São também comumente denominadas "dunas vegetadas" (Tinley 1985; Tomazelli 1990) ou "parcialmente vegetadas" (Goldsmith 1978). A maioria destes termos foi usada para descrever feições locais específicas e eles não obrigatoriamente possuem perfeita equivalência entre si; além disso, vários deles revelam-se inadequados por serem usados em outros tipos genéticos de dunas como é o caso dos termos "duna de precipitação" ("precipitation ridge dunes" de Bigarella 1972) e "dunas vegetadas". Parece vantajoso, portanto, o emprego de um termo que 
seja definido de modo rigoroso mas abrangente, como é o caso das "dunas frontais" de Hesp (1988).

O critério para individualização das dunas frontais como uma das duas fácies da associação depósitos mantiformes (tabela 5.9) é o de sua posição espacial definida dentro da associação faciológica. Sob o critério morfológico vetorial, as dunas frontais são caracterizadas pelo paralelismo à costa, não possuindo portanto uma orientação definida em relação aos ventos prevalecentes. Deve-se ressaltar que esta orientação, incluida na definição de Hesp (1988), refere-se à escala de cordão de dunas frontais (equivalente a escala de "draa"). Em escala menor, de dunas individuais, a morfologia das dunas frontais pode variar, de onde o reconhecimento na literatura de subtipos como "nebkhas"ou "pró-dunas" (Bigarella 1970/71, 1972; McKee 1979) e dunas de sombra ou "shadow-dunes" (Bagnold 1941, 1954; McBride \& Hayes 1962), este último de ocorrência não exclusiva de cordões de dunas frontais. Uma classificação morfoecológica em escala de cordão é proposta por Hesp $(1983,1988)$. Nesta classificação, distingue-se entre dunas frontais incipientes, formadas pelo trapeamento inicial da areia em meio a espécies estoloniformes de vegetação pioneira, e dunas frontais estabelecidas, geradas pela colonização de dunas incipientes por espécies de vegetais em esteira, tufo ou arbusto.

$\mathrm{Na}$ área costeira estudada, predominam, dentre as dunas frontais, as incipientes. A ausência de dunas estabelecidas típicas deve-se à grande intensidade do aporte sedimentar eólico. Mesmo nos setores de orla costeira onde o aporte não é suficientemente elevado para impedir a manutenção perene de dunas frontais incipientes, como nas praias de Mar Grosso e Vila Nova, as dunas frontais interiores, estabelecidas, apresentam-se reativadas e parabolizadas pela deflação. De mesmo modo, pró-dunas são raras ou efêmeras, sendo mais comum a ocorrência de dunas de sombra fortemente assimétricas, formando conjuntos nas áreas interdunares litorâneas e interiores.

Dunas frontais incipientes distribuem-se na área em estudo segundo padrões geográficos relacionados com a variação de morfodinâmica praial. No sistema barra-barreira, sua ocorrência só é contínua ao longo das praias de Teresa e Gravatá, ambas praias de bolso. Na Praia Grande do Sul, dunas frontais restringemse aos arredores de grandes complexos de canais de sobrelavagem e lagos ("ponds"), formados temporariamente nas planícies entre dunas lineares mais espaçadas. Com o umedecimento generalizado da areia nestas áreas, o aporte eólico diminui, permitindo - crescimento de vegetação pioneira e a formação efêmera de dunas incipientes (figura 5.62). Na praia do Cardoso, de pequena extensão e portanto mais protegida da ação de ondas por seus pontões limitrofes, dunas frontais são mais freqüentes, em particular em suas extremidades. Na Praia Grande do Norte, elas voltam a estar ausentes, substituidas por dunas transversais lineares; esta praia é caracterizada pela abundância de areia eólica e intenso desenvolvimento de dunas transversais, devido ao efeito de anteparo fixo exercido, em sua extremidade sul, pelo morro de Santa Marta Grande (figura 5.1). Na praia de Santa Marta Pequeno, dunas frontais ocorrem restritas à porção sul. 


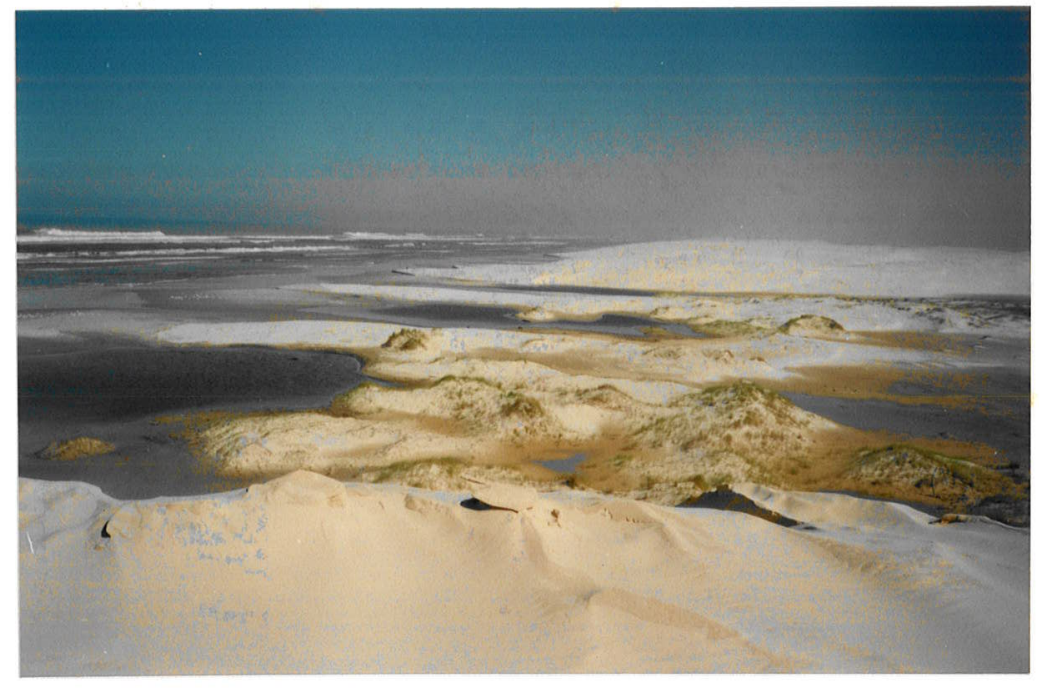

Figura 5.62. Ocorrencia local de dunas frontais incipientes associada a calhas interdunares inundadas. Campo de dunas lineares transversais na Praia Grande do Sul, após chuvas relacionadas ao "El Niño" de maio-junho de 1992.

Nas praias do sistema planície costeira, dunas frontais são mais freqüentes. Elas ocorrem, de modo mais ou menos contínuo, ao longo das praias de Mar Grosso, Ji, Itapirubá, e Vila Nova, e ainda na porção não escarpada (sul) da praia de Imbituba. Nas extremidades norte das praias de Ji e Itapirubá, há escassez de dunas frontais, em detrimento da formação de dunas lineares transversais baixas (< 3 $\mathrm{m})$. Na praia do Sol, as dunas frontais aparecem restritas às porções extremas do setor, desenvolvendo-se preferencialmente na borda sul.

A ausência ou escassez de dunas frontais nas praias mais expostas e de maior energia de onda é uma conseqüência dos princípios que relacionam morfodinâmicas costeiras mais dissipativas a maior potencial de aporte eólico (item 2.2.4.3). Quanto maior este aporte maior a instabilização das dunas frontais, as quais dão lugar a dunas lineares transversais. Ocorre assim um dipolo entre estes dois tipos de dunas costeiras, controlado pelo aporte de areia pelo vento. Além da energia e dissipatividade da praia, o aporte eólico efetivo depende da disponibilidade inicial de sedimento em granulometria adequada, a qual é controlada pelo fornecimento continental e da plataforma submersa ("onshore") e pela redispersão por deriva litorânea longitudinal. O desenvolvimento preferencial sistemático de dunas frontais nos extremos sul e de dunas transversais nos extremos norte das praias estudadas é uma conseqüência do efeito da deriva longitudinal, transportando areia rumo norte. O aumento relativo de dunas frontais nas praias de Itapirubá e Vila Nova, apesar de serem praias tão expostas e dissipativas quanto praias do sistema barra-barreira ricas em dunas transversais, pode ser atribuido também a uma questão de aporte primário, pois estas praias são mais próximas e portanto mais sujeitas a influência de areias pleistocênicas, as quais, além de mais grossas, são mais consolidadas e menos erodiveis.

Um exemplo típico de variação longitudinal na morfologia de dunas de orla costeira, sob efeito da disponibilidade de areia controlada por deriva litorânea, foi observado na praia do Ji. Ao longo desta praia, sucedem-se, de sul para norte, as seguintes formas eólicas: (1) dunas frontais altas $(2,5$ a $4 \mathrm{~m})$, dômicas, pouco 
erodidas (figura 5.63); (2) dunas frontais de altura média (1,5 a 2,5 m), dômicas, sobre degrau erosivo ondulado, com menos de $0,5 \mathrm{~m}$ de altura, de areias eólicas desvegetadas a pouco vegetadas (figura 5.64); (3) dunas frontais baixas $(0,5$ a 1,5 m), erodidas, descontínuas e em certos locais ilhadas pela água (figura 5.65), associadas a embriões de dunas lineares transversais (altura inferior a $1 \mathrm{~m}$ ); estes aparentam resultar do rearranjo, por água mais ventos, de areias erodidas das dunas frontais, como indicado pela presença de montículos vegetados esparsos; (4) dunas lineares transversais inteiramente desvegetadas, com 0,5 a $2 \mathrm{~m}$ de altura, parcialmente separadas entre si e erodidas pelo mar na forma de falésias de abrasão (figura 5.66). A posição e dimensõ $̇$ destas formas ao longo da praia variam com a época do ano, na dependência de condições climáticas. Fica evidente, através de sua associação no tempo e no espaço, que dunas transversais lineares formam-se às custas da destruição de dunas frontais incipientes e que estas dependem da colonização das primeiras por vegetação.

A mudança perceptivel de distribuição e dimensões das dunas frontais em escala de poucos anos faz supor que sua duração possa ser breve e que seus depósitus sejam, pelo menos em parte, muito recentes. Uma evidência deste último aspecto é o registro de camadas de aterro usado no calçamento de vias urbanas a beira-mar, separando co-seqüenncias de estratificações cruzadas (figura 5.67). Incorporação de objetos de uso humano moderno em dunas frontais incipientes já houvera sido observada no litoral paranaense por Angulo (1992). 

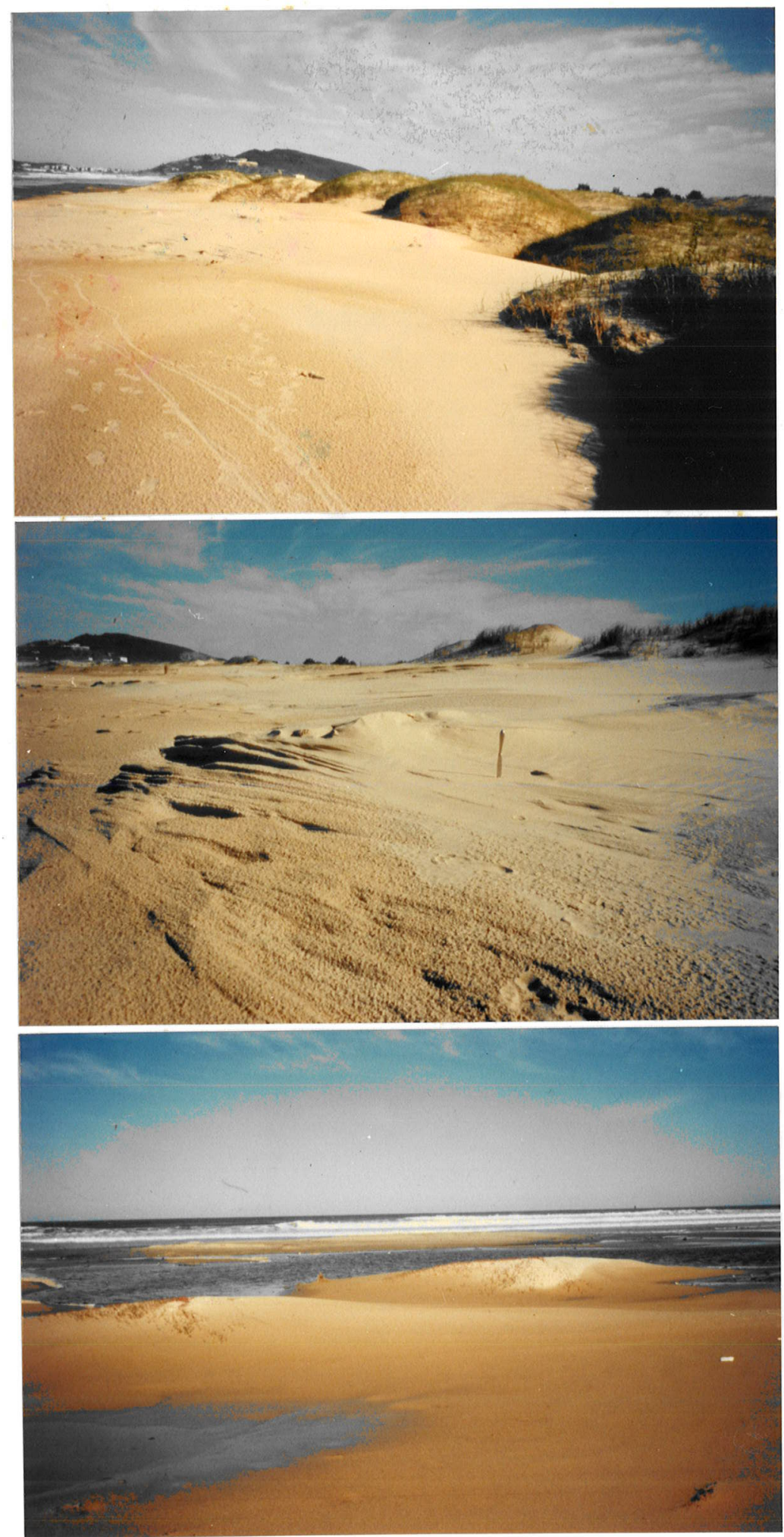

Figuras 5.63 a 5.65. Variaçăo na morfologia de dunas frontais e lineares transversais na praia do Ji, de sul para norte.

5.63 (superior). Dunas frontais dómicas bem desenvolvidas.

5.64 (meio). Restos de erosão de dunas lineares (primeiro plano) associados a dunas frontais baixas. 5.65 (inferior). Destruição quase total de dunas frontais, associada a maior desenvolvimento de dunas lineares (ver figura 5.66). 


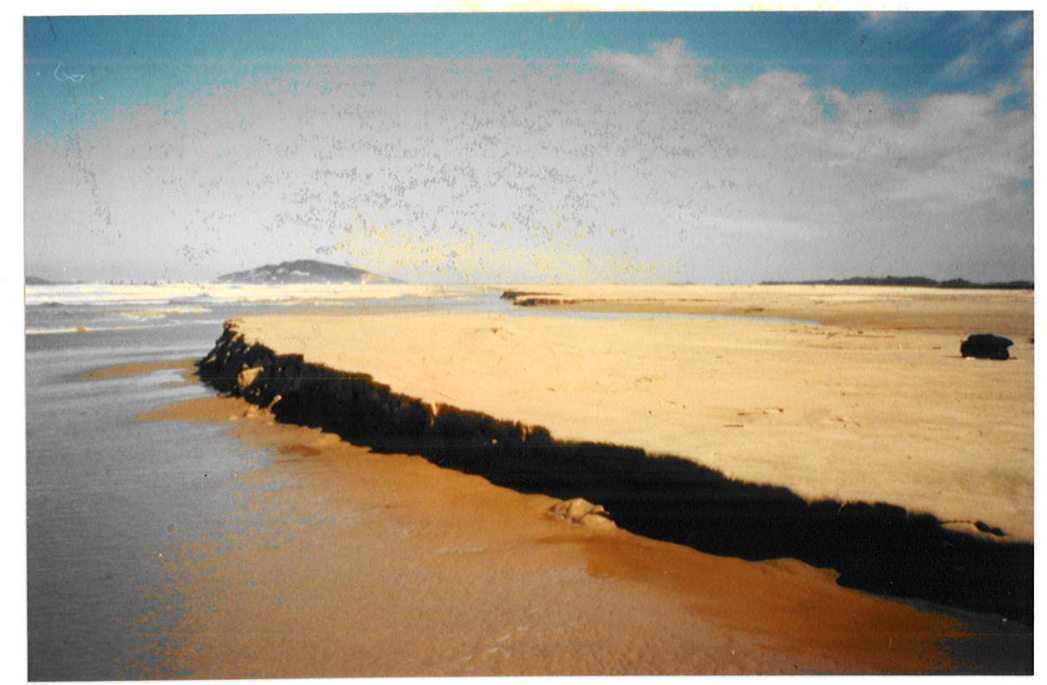

Figura 5.66. Dunas lineares transversais com falésias de abrasão marinha de altura métrica. Porção norte da praia do Ji.

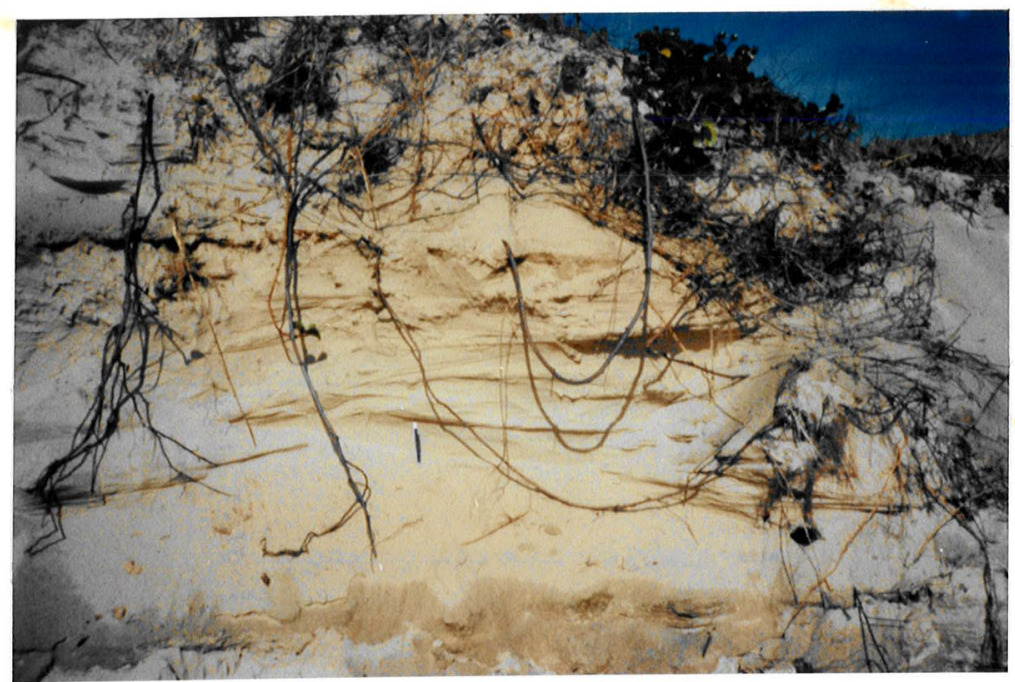

Figura 5.67. Seção transversal à praia em uma duna frontal na parte sul da praia do Sol. A superfície de separaçăo maior é um pavimento artificial.

\subsubsection{Dunas lineares transversais}

O termo linear é aplicado neste trabalho a dunas e cordões alongadios de crista sub-retilínea, independente de sua orientação e da presença de sinuosidades elou descontinuidades de ordem menor. O emprego do termo como indicativo de orientação paralela ao vento principal, conforme difundido na escola norte-americana (McKee 1982), é considerado inadequado, pois confunde atributos escalar e vetorial de morfologia dunar. Sob este aspecto, dá-se preferência à nomenclatura corrente na literatura australiana, onde se subdividem as dunas lineares em longitudinais e transversais (perpendiculares ou oblíquas). 
Dunas lineares transversais incluem, entre os principais tipos genéticos descritos na literatura, as dunas transversais clássicas (Hack 1941; Cooper 1958,1967; Spearing 1974; Goldsmith 1978; McKee 1982; Short 1988; Ward 1988), tipicamente perpendiculares e desvegetadas, as "transversais de precipitação" (Cooper 1958,1967; Goldsmith 1978; Short 1988), retidas por vegetação na margem distal de campo de dunas, e as "transversais desvegetadas associadas a dunas vegetadas", atribuidas por Goldsmith (1978) a reativação parcial de dunas fixas. Apenas a variedade oblíqua do tipo transversal clássico é importante na área em estudo, onde ocorre na orla de praias dissipativas com suficiente aporte sedimentar. Dunas de precipitação típicas são ausentes na região, devido ao subparalelismo entre ventos mais efetivos e linha de costa e, por extensão, entre estes ventos e as margens de áreas interiores florestadas. Lençóis parabólicos com frentes lineares avançando sobre zona urbana, semelhantes a dunas transversais de precipitação podem ser vistas atualmente na cidade de Laguna, a sudoeste do morro Mar Grosso. Outro tipo de fenômeno de precipitação ocorre na borda interior de mantos de areia e grandes lençóis parabólicos, devido a uma componente secundária de migração da duna, transversal a seu alongamento (figuras A1, 5.50 e 5.68).

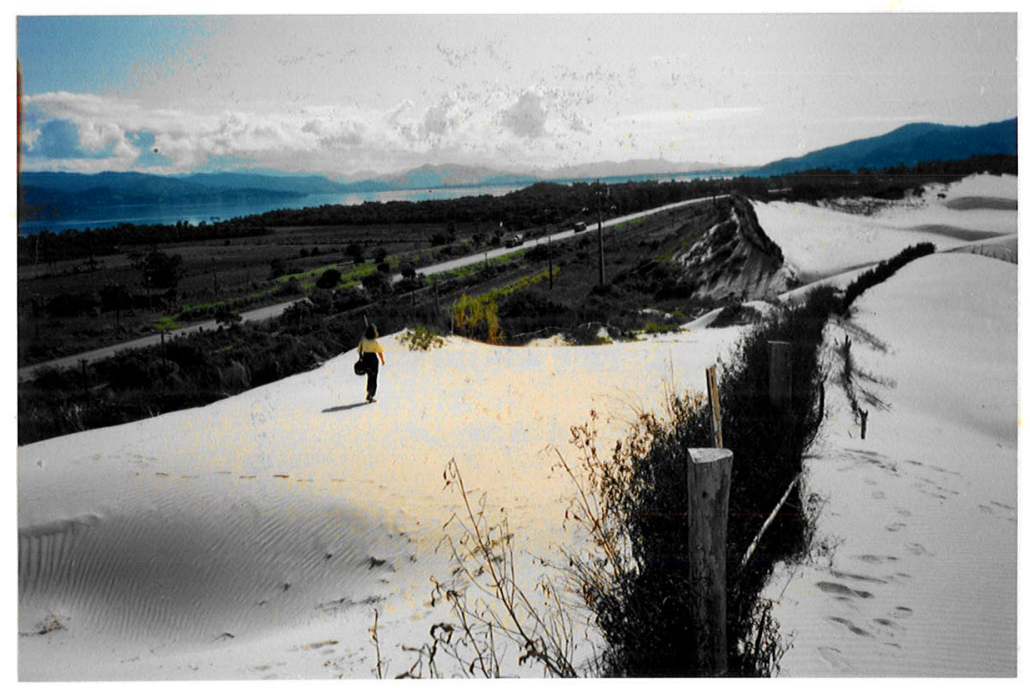

Figura 5.68. Cercas de contençåo de areia na margem interna do lençol parabólico ativo de Vila Nova Roça Grande. As cercas controlam uma componente para oeste de migraçào do lençol.

As dunas transversais de orla praial (figuras 5.69 e 5.70) constituem a primeira (mais proximal) das fácies geradas por instabilização maciça de dunas frontais dentro da associação faciológica depósitos mantiformes. Como nas dunas transversais de modo geral, sua morfologia pode ser atribuída ao excesso de areia em relação à capacidade de remoção pelo vento, no caso relacionado a sua grande proximidade.com a área fonte. Com o afastamento gradual da fonte, a tendência prevista é de modificação gradual de morfologia: barcanóides-barcanasparabólicas (Fisher 1983; Mckee 1983). Tal tendência é válida na área costeira estudada. Entretanto, enquanto a transição barcanóides - frentes parabólicas ocorre em essência ao longo do eixo NE-SW de mantos de areia, a passagem de lineares transversais para barcanóides verifica-se no eixo transversal à linha de costa. Isto significa que existe continuidade entre as cristas de dunas lineares e as cristas de 
cadeias barcanóides, numa gradação contínua de formas no sentido praia-interior. Esta gradação, evidente, por exemplo, na Praia Grande do Sul (figuras A1 a A4), acontece também no aspecto vetorial, passando a orientação geral de NNW, oblíqua aos ventos prevalecentes, nas dunas lineares, para NW, perpendicular, nas cadeias barcanóides mais interiores. Existe, além disso, aumento de largura, espaço interdunar e altura das dunas no sentido lineares-barcanóides (tabela 5.12).
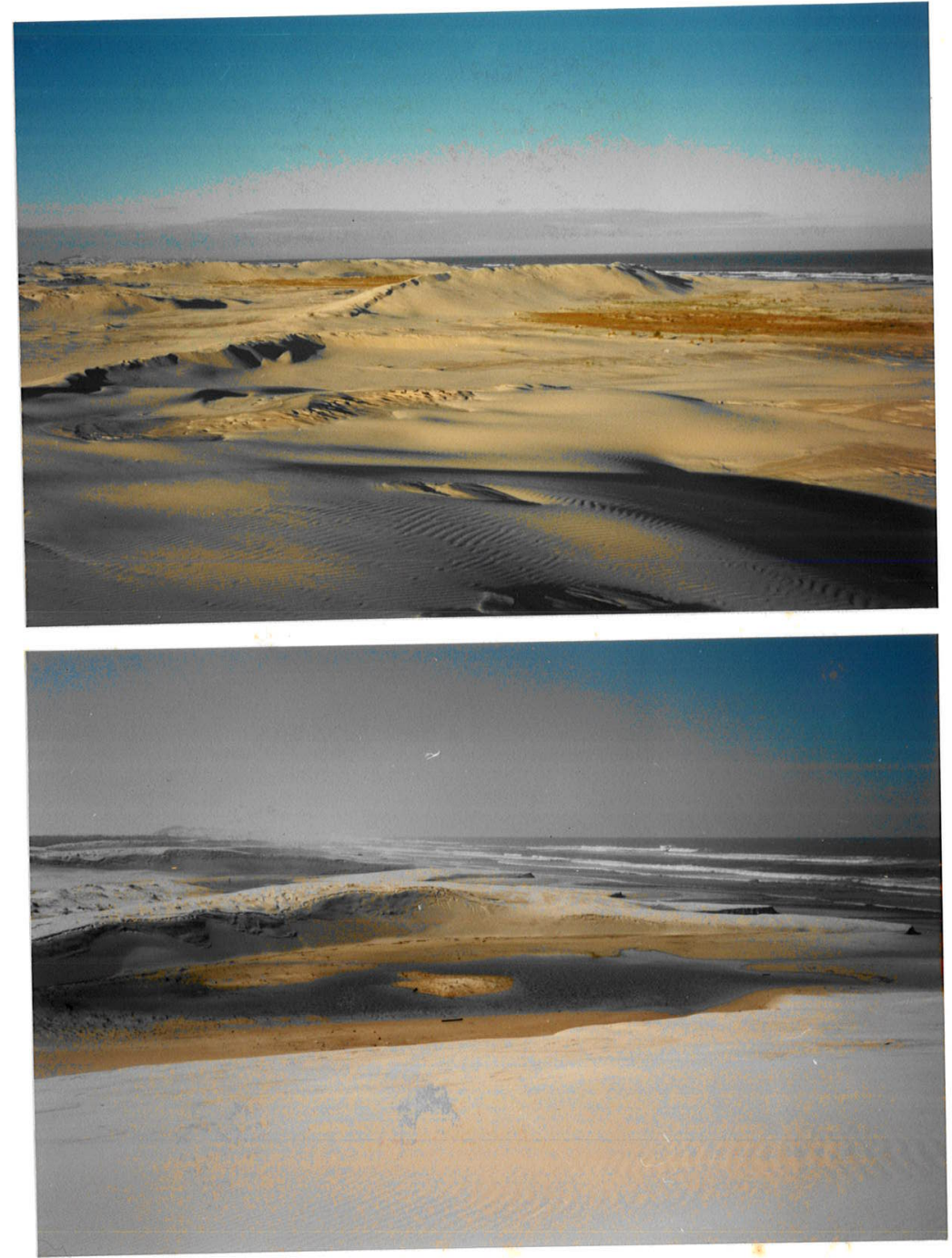

Figuras 5.69 e 5.70. Aspecto geral de dunas lineares transversais na Praia Grande do Sul 5.69 (superior). Em condiçठ̋es meteorológicas normais.

5.70 (inferior). Em condições "El Niño", com formaçăo de corredores inundados.

As dunas lineares não podem ser simplesmente consideradas como extensões de cadeias barcanóides, pois ocorrem mesmo onde estas estão ausentes. Suas diferenças morfológicas em relação às cadeias barcanóides podem ser atribuídas à influência de dois fatores típicos da orla praial. O primeiro refere-se a ação de ventos do mar ("onshore winds"), conduzindo areia das dunas lineares para as dunas barcanóides e influindo na remodelagem das primeiras. O segundo fator são as ondas de marés elevadas, as quais formam cúspides pronunciadas, com entrada 
intermitente de água através dos corredores interdunares; este fenômeno pode reduzir o aporte de areia seca de praia para as dunas lineares e, quando em área extensa, favorecer a formação local e temporária de dunas frontais incipientes (figura 5.62).

Marés de tempestade de média intensidade, as quais ocorrem em especial durante o inverno, são suficientes para que a zona de propagação ("surfing") das ondas atinja a base das dunas lineares transversais, gerando barrancos de solapamento erosivo de até $2 \mathrm{~m}$ de altura (figuras 5.62, 5.55 e 5.70). Nestes barrancos, é possivel observar a sucessão de seqüências de laminações cruzadas de alto ângulo, mergulhando para SW (figura 5.71), o que confirma o rumo de mergulho de faces de avalarcha superficiais constantemente observado no campo e em aerofotografias. Durante mesmas tempestades, as eventuais dunas frontais podem ser parcial ou inteiramente destruidas.

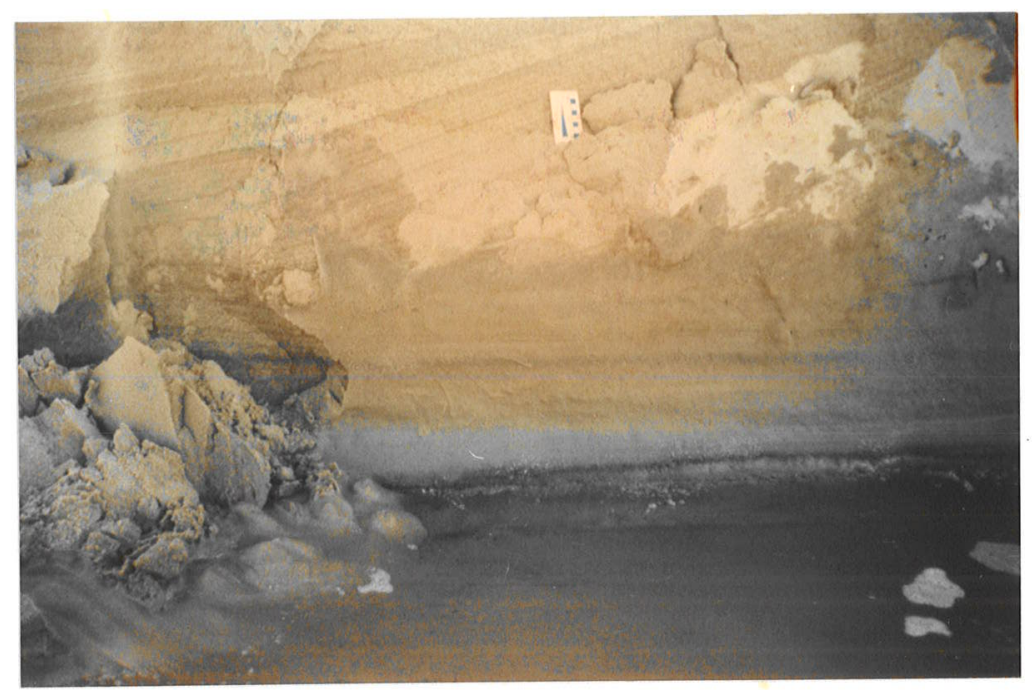

Figura 5.71. Seçăo paralela à direçăo da costa produzida por abrasăo marinha em uma duna linear transversal. Na base, observa-se laminaçào praial de baixo ángulo, ressaltada por concentraçס̄es de minerais pesados. Parte norte da praia do Ji.

\subsection{Dunas barcanas e cadeias barcanóides}

As barcanas são dunas crescênticas transversais e simétricas em relação à direção do vento efetivo. Aparentam-se às dunas lineares transversais clássicas quanto a posição no sistema, orientação e morfoecologia (desvegetadas). Uma das formas mais comuns de associação transicional entre as duas formas são as cadeias barcanóides, cordões sinuosos transversais aparentando resultar da coalescência lateral de barcanas (figura 5.72). Na área em estudo, formas barcanas puras são muito raras, mas cadeias barcanóides constituem a mais importante subfácies de cavalgamento em lençóis parabólicos e depósitos mantiformes.

De acordo com Fisher (1983), dunas barcanas têm sua ocorrência favorecida pela presença de áreas planas livres, com aporte moderado de areia. Estas condições parecem ter sido alcançadas localmente na parte sul da praia de Santa Marta Pequeno, onde a menor disponibilidade de areia devido a deriva litorânea rumo norte e a desvegetação artificial promovida nos arredores de um núcleo de habitações permitiram a formação de um pequeno campo de barcanas. Condições 
semelhantes ocorrem também na planicie de deflação de dunas e lençóis parabólicos, onde se encontram às vezes formas barcanas aplainadas (item 5.4.2.6.6). Dunas similares a barcanas, porém assimétricas, podem ser observadas ainda na continuação ao interior de dunas transversais lineares nas áreas em que a associação depósitos mantiformes não apresenta largura suficiente para o desenvolvimento de barcanóides. É o caso da Praia Grande do Sul, no trecho que se avizinha a lagos digitiformes associados a sobrelavagem (figura 5.73).

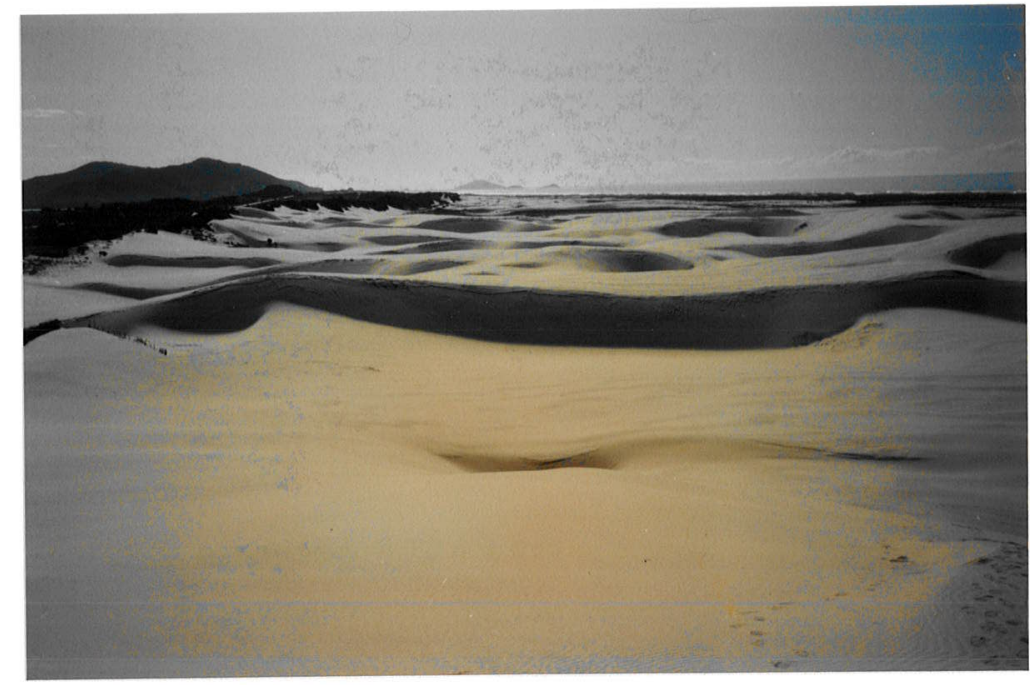

Figura 5.72. Cadeias barcanóides superpostas ao lençol parabólico ativo de Vila Nova - Roça Grande, vistas de sudoeste (barlavento).

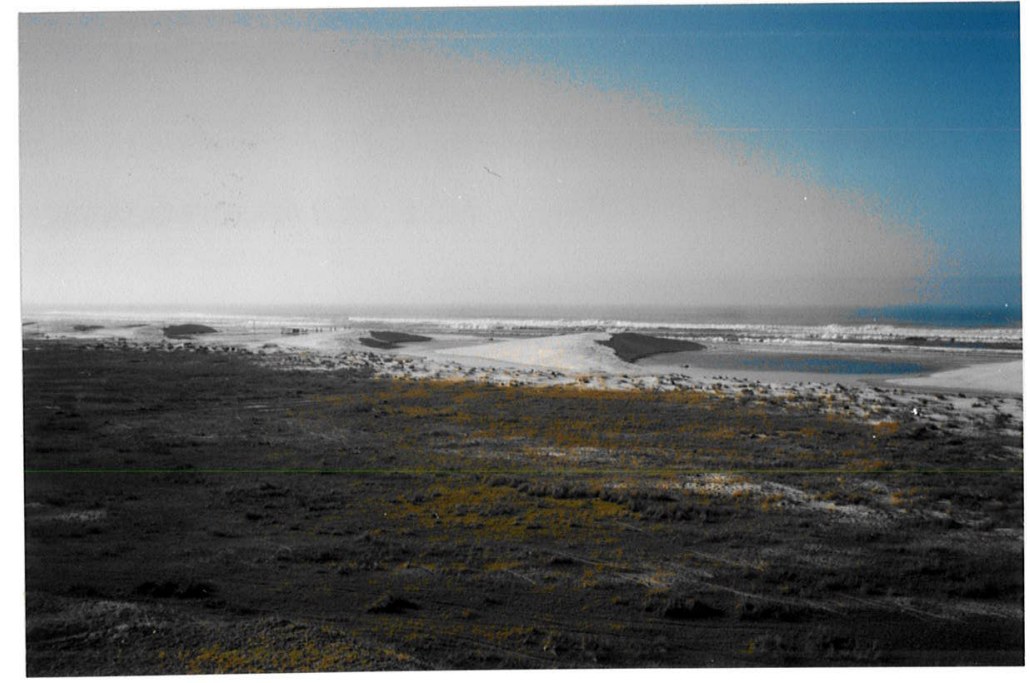

Figura 5.73. Dunas lineares transversais similares a barcanas, na Praia Grande do Sul, próximo a vila de Garopaba do Sul. Notar aumento das dimensões no rumo do vento gerador (para SW).

Cadeias barcanóides possuem suas dimensões diretamente proporcionais às dimensões do "draa" (lençol ou manto de areia) sobre o qual ocorrem; deste modo, as cadeias mais altas, longas, largas e interespaçadas tendem a ocorrer na associação depósitos mantiformes (tabela 5.12). Dentre os lençóis 
parabólicos, as maiores dimensões médias de cadeias barcanóides são encontradas no lençol de Vila Nova - Roça Grande (figura 5.72), que é também o de maior extensão. São comuns feições de reversão temporária de cadeias barcanóides, geradas por ventos mais fortes de $S$ e SW, intercalados com chuvas. Durante o inverno, diversos tipos de características de dunas reversas podem tornar-se proeminentes, tais como: erosão das faces de avalancha normais (mergulho SW), com exposição de sequências espessas de estratificações cruzadas tabulares, tangenciais na base ou festonadas-acanaladas de grande porte (figura 5.74); formação de faces de avalancha secundárias (mergulho NE), compondo degraus métricos no declive suave de barlavento dos dráas (figura 5.75); e erosão da zona de crista principal (a SW), sob a forma de brechas de torrões de areia úmida, e formação de uma nova linha de crista, deslocada para NE (figuras 5.76 e 5.77). Todas estas feições de reversão são muito mais características de cadeias barcanóides que de dunas lineares transversais e parabólicas.
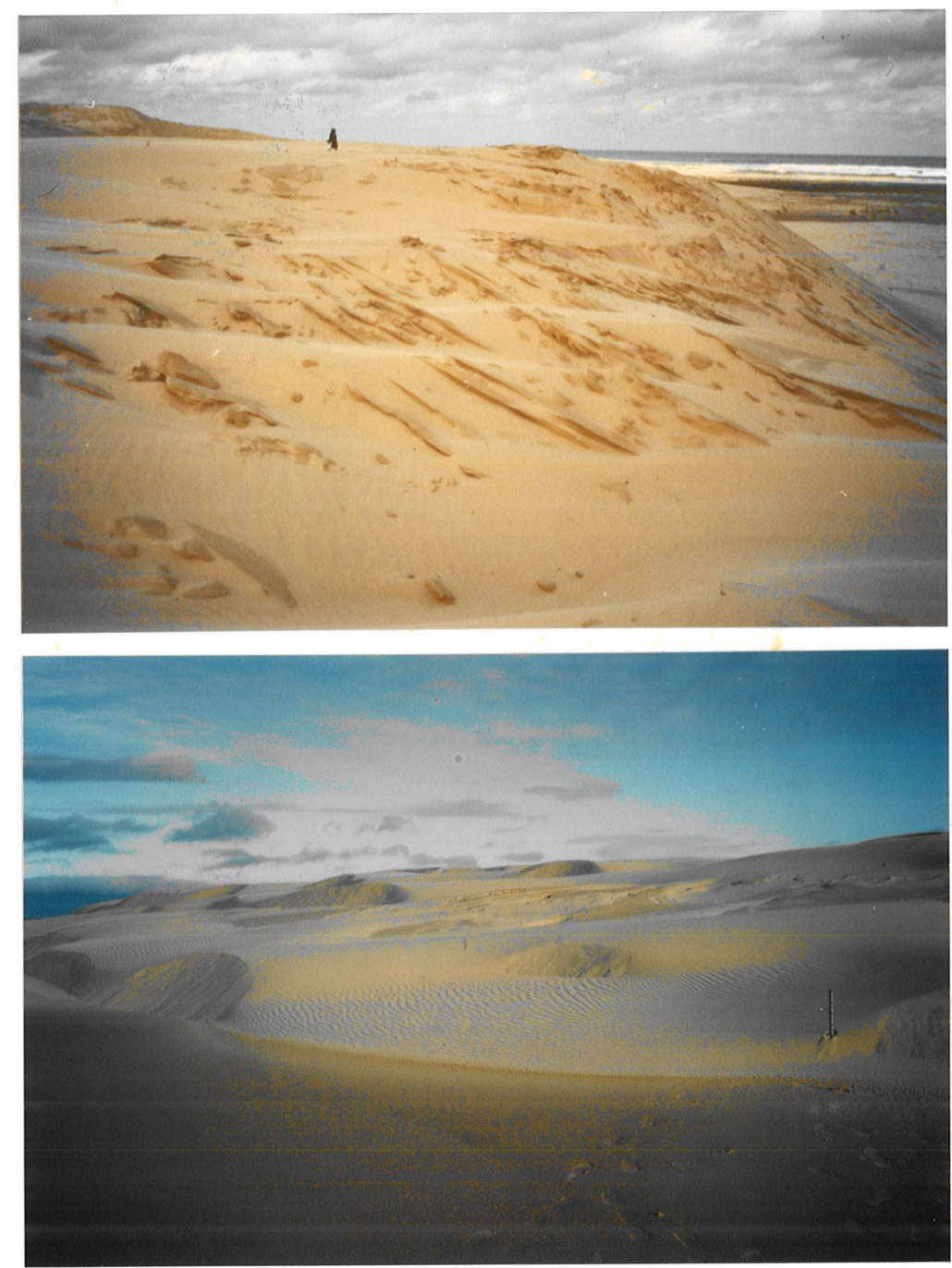

Figuras 5.74 e 5.75. Feiçס̃es de reversão eólica. Manto de areia na parte norte da Praia Grande do Sul. 5.74 (superior). Exposição erosiva de estratificações cruzadas frontais em cadeias barcanóides. 5.75 (inferior). Pequenas faces de avalancha no lado barlavento (nordeste) de lençol parabólico. Escala, à direita $(50 \mathrm{~cm})$. 

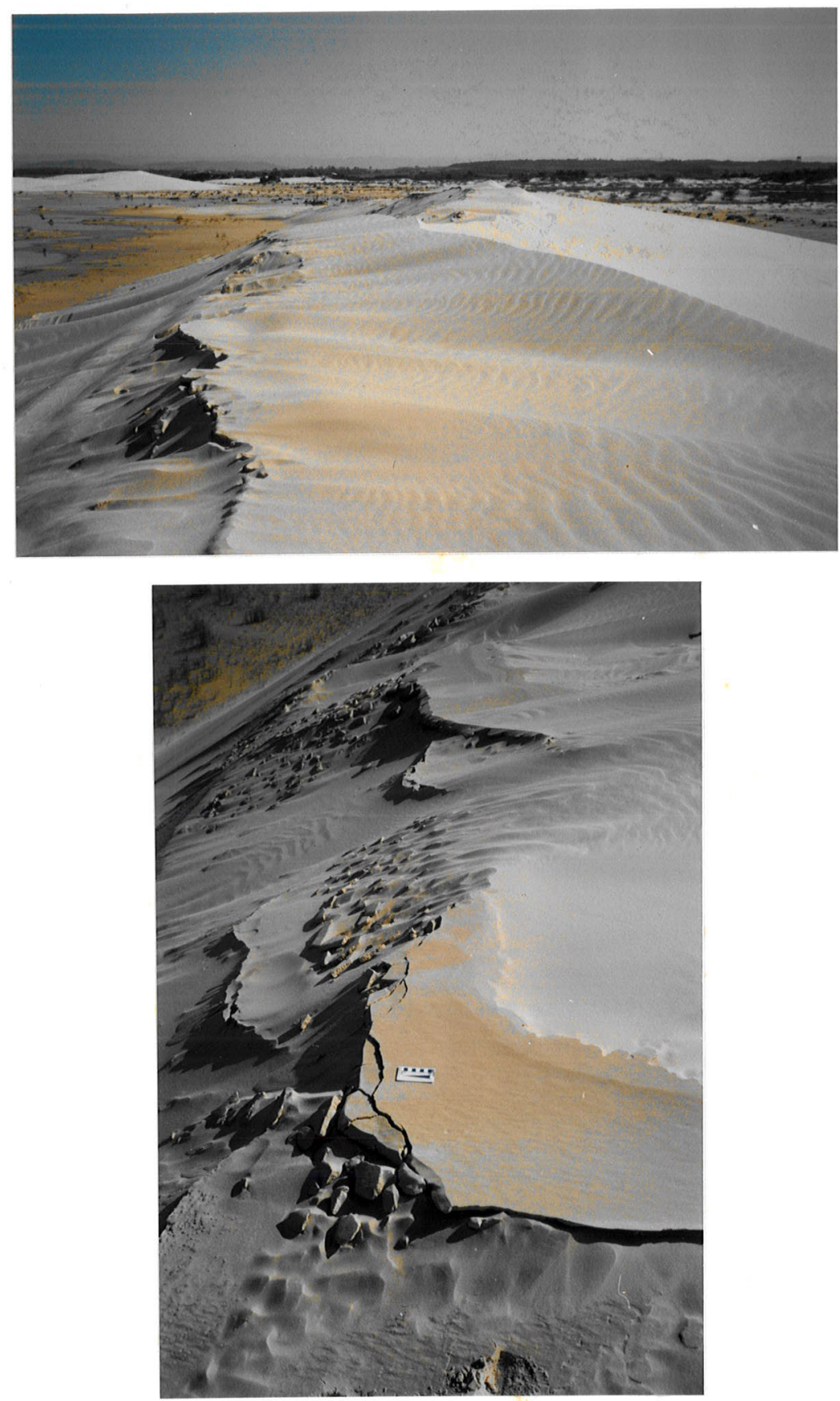

Figuras 5.76 e 5.77. Feições de reversão eólica em cadeias barcanóides. Região de Garopaba do Sul. 5.76 (superior). Segunda linha de crista, formada a nordeste (direita) da crista "normal". 5.77 (inferior). Formação de brechas de areia úmida na crista "normal". Escala: $7 \mathrm{~cm}$.

\subsection{Frentes e dunas parabólicas}

O termo "duna parabólica" foi introduzido por Steenstrüp (1894 apud Howell 1960) para descrever dunas com formato em planta análogo ao de uma parábola alongada, cuja concavidade era voltada contra o vento. Com o tempo, o seu uso generalizou-se para outras formas parabólicas em $U, V$ ou meia-lua, com o mesmo tipo de orientação. Smith (1941) propôs que todas estas formas recebessem a denominação genérica de dunas ipsiloidais ("upsiloidal"), reservando-se à categoria de 
dunas parabólicas exclusivamente as dunas em conformidade com a descrição original. Esta proposta não tem grande difusão, mesmo porque as formas ipsiloidais não deixam de ser descritivamente parabólicas. Em outra classificação genéticodescritiva para dunas parabólicas, Goldsmith (1978) distingue entre as formas que ocorrem em conjunto, sob o efeito contendor da vegetação e as que ocorrem isoladas, por ruptura deflacionar de cristas de dunas lineares parcialmente vegetadas. Pode-se estabelecer correlação entre as classificações de Smith (1941) e de Goldsmith (1978), pois a maioria das dunas em conjunto do segundo autor correspondente a dunas parabólicas stricto sensu do primeiro, enquanto que as dunas isoladas são quase sempre apenas formas ipsiloidais. Uma terceira classificação, também correlacionável às anteriores, é a que se encontra em Short (1988), distinguindo respectivamente dunas parabólicas e parabólicas de deflação ("blowouts parabolics"). O mesmo autor utiliza ainda o termo "longwalled parabolics" para designar os cordões longitudinais resultantes da estabilização de dunas parabólicas deslocadas por distâncias superiores a $100 \mathrm{~m}$. Em outra classificação, esta de caráter mais descritivo, Semeniuk et al.(1989) definem três formas de dunas parabólicas (figura 5.55): crescêntrica, curta ou alongada; atenuada, com elevada relação extensão/largura; e crenulada ("fretted"), na qual "os braços da duna desenvolveram dunas parabólicas e "blowouts" menores subsidiários". Os dois primeiros tipos correspondem em grande parte, mais uma vez, às formas distintas por Smith (1941). O terceiro tipo, que já houvera sido descrito por Tinley (1985 apud Semeniuk et al. 1989) sob a denominação de "dunas parabólicas compostas imbricadas", representa uma morfologia associada a condição de menor suprimento em relação a dunas atenuadas.

As três variedades morfológicas diferenciadas por Semeniuk et al. (1989) podem ser identificadas na área em estudo, através do exame de aerofotografias. A morfologia atenuada é a mais comum, ocorrendo em depósitos das gerações 2, 3 e 4. A crescêntica foi reconhecida apenas localmente, nas bordas interiores de lençóis e mantos de areia atuais ou antigos, influenciadas por ventos secundários transversais à costa (figura A1), e como depósitos baixos e dissipados na zona de deflação de lençóis parabólicos. Estes últimos, por sua posição particular dentro da associação de fácies, foram descritos como elementos de uma fácies distinta. A forma crenulada ocorre em depósitos baixos $(<2 \mathrm{~m})$ da geração 3 , os quais se estendem contínuos ao longo de quilômetros, por sobre a planície costeira adjacente à praia do Ji (figuras A11 a A13). Deve-se acrescentar, na descrição da morfologia destes três tipos de depósitos, que seus braços podem exibir alturas e larguras muito variáveis, chegando mesmo a estar completamente unidos através de um lençol de areia com mergulho suave para barlavento (figuras 5.78 e 5.79). Deste aspecto, resulta a diferenciação entre dunas e lençóis parabólicos (figura 5.57). No que se refere ao entulhamento do espaço interdunar parabólico, existe completa gradação entre dunas e lençóis, de modo que na prática a diferenciação entre tipos intermediários é arbitrária. Um critério adicional para definir um depósito parabólico como lençol é seu caráter composto, com formas parabólicas subsidiárias presentes no nariz da parábola maior. Estas formas são aqui denominadas frentes (de lençóis) parabólicas. Elas estão presentes na zona de avanço de ambas as associações de fácies (figuras 5.78 e 5.79), mas tendem a apresentar morfologias mais lineares, regulares e alongadas na associação lençóis parabólicos (comparar, por exemplo, as figuras A1 com A14 e 5.78 com 5.79). Permanecem dúvidas, no caso de depósitos parabólicos estabilizados (geração 2), se se trata de antigas frentes de lençóis 
parabólicos ou de dunas parabólicas stricto sensu (figura 5.50). São, de qualquer modo, feições longitudinais tão ou mais proeminentes em relevo e comprimento, que as frentes e dunas atuais; comparam-se aos "longwalled parabolics", indicando migração linear extensa e devem portanto ser atribuidas a associação de fácies dunas e lençóis parabólicos.

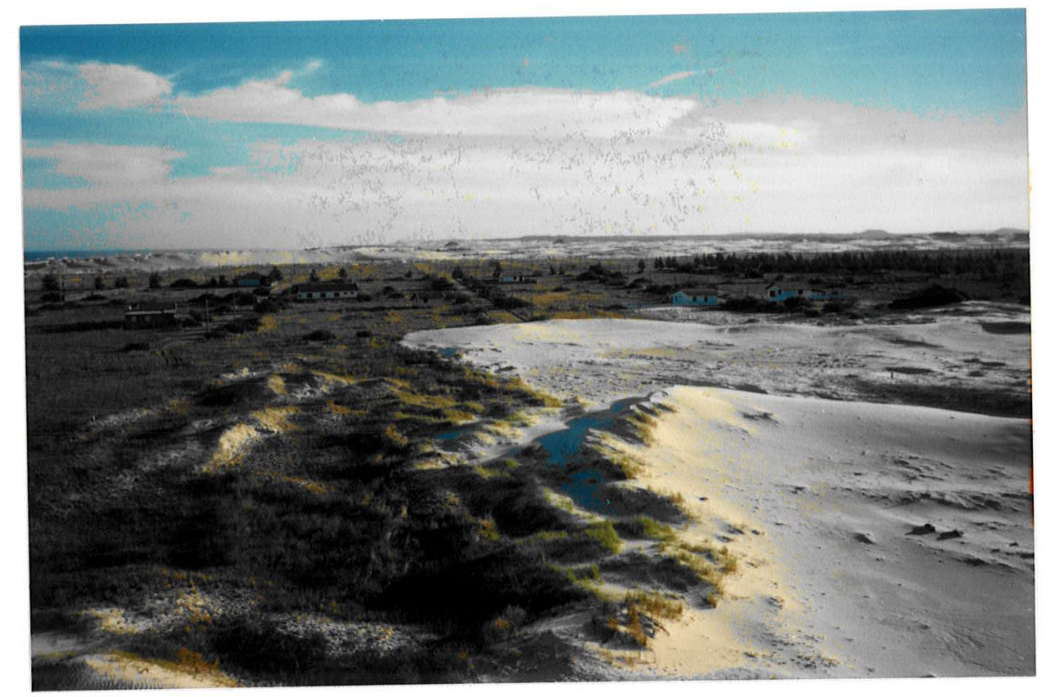

Figura 5.78. Frentes parabólicas da associação mantiforme na região de Dunas do Sul, a sudoeste da lagoa Laranjal.

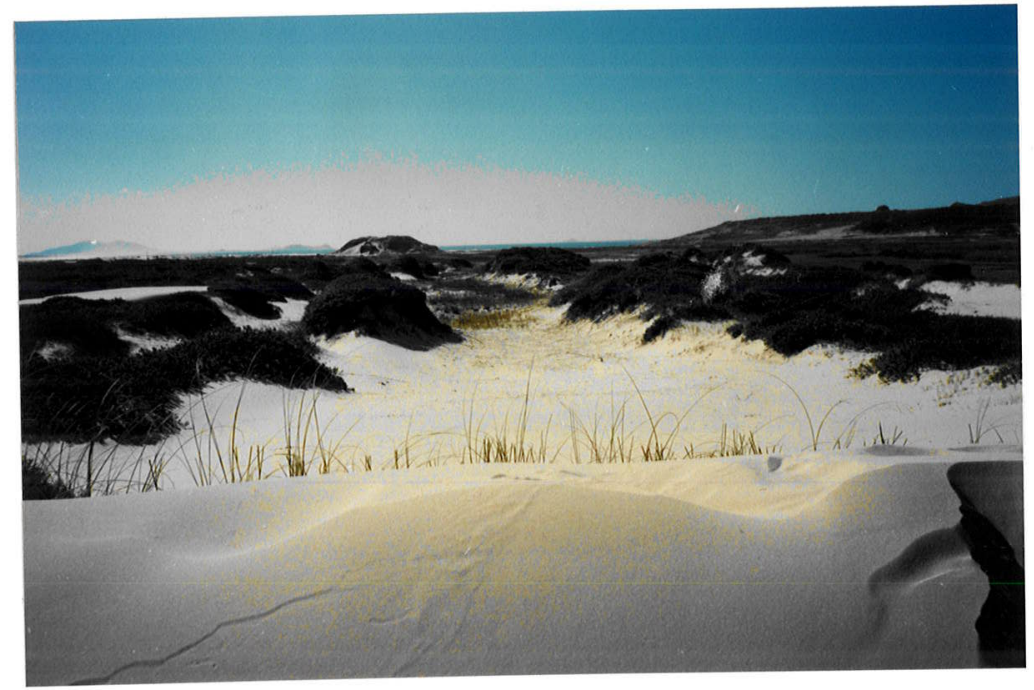

Figura 5.79. Pequeno lençol parabólico a sudoeste da ponta do Ji (direita, ao fundo), visto a partir da face de avanço. Notar montículos vegetados nas laterais, alinhados divergentemente em direçào à face frontal, e corredor deflacionar interno, semi-desvegetado.

A vegetação, em forma de arbustos e tufos, recobre preferencialmente as laterais externas, de sotavento, de dunas e frentes parabólicas ativas. A face de avanço (Semeniuk et al.1989) constitui uma superfície tipicamente desvegetada (figuras 5.79). Nas dunas e frentes espessas e íngremes, ela exibe perfil convexo (figura 5.80), em contraste ao perfil côncavo da face de avalancha de dunas 
barcanas e barcanóides (figuras 5.87 e 5.88). Na zona interdunar e na porção interna dos braços podem ser encontrados montes de areia vegetadas, dômicos ou alongados, resquícios estabilizados de antigas posições do depósito parabólico. Estes gradam, em direção às partes mais baixas e próximas do depósito parabólico, para rastros e montes residuais de deflação (item 5.4.2.6.6). Em alguns locais, montes residuais vegetados relativamente altos $(>3 \mathrm{~m}$ ) agem como obstáculo ao avanço de novas frentes e dunas parabólicas ativas (figura 5.81), gerando o efeito de sombra eólica. Nem sempre há sinais de pedogênese nos depósitos residuais, atribuidos à geração 3 , e a maneira mais prática de distingui-los, em meio a parábolas da geração 4 é através de sua posição discordante e da distribuição e função de sua cobertura vegetal.

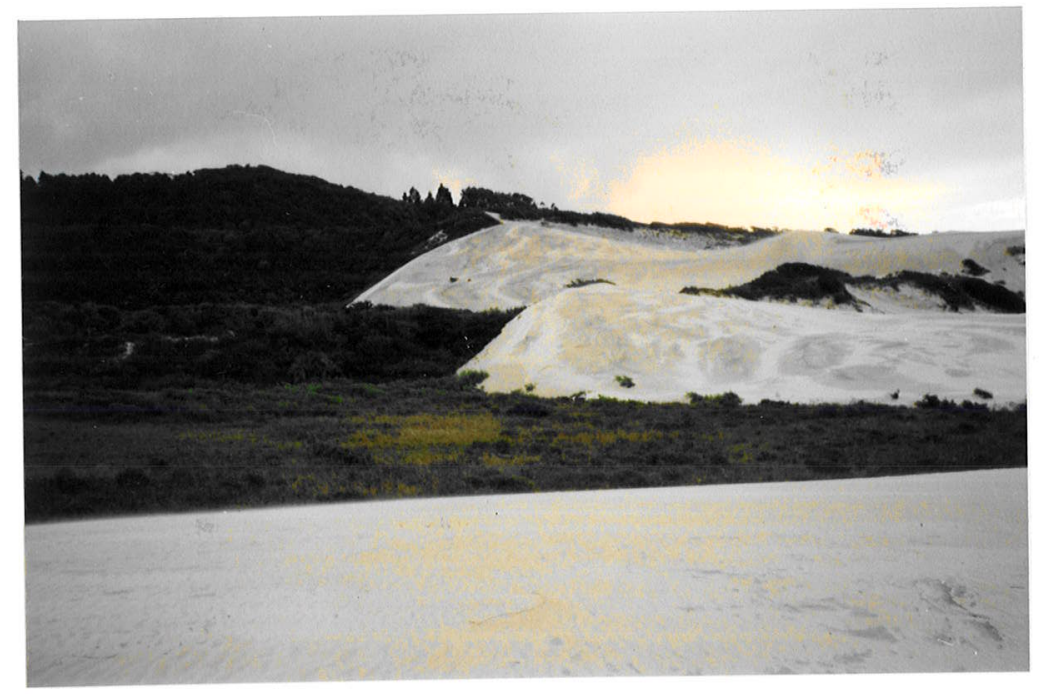

Figura 5.80. Vista lateral das frentes do lençol parabólico ativo de Ibiraqüera-Arroio, cavalgando lençóis parabólicos da geraçăo 3 (elevaçðes vegetadas), e depósitos eólicos indiferenciados da geração 2 (terreno vegetado plano).

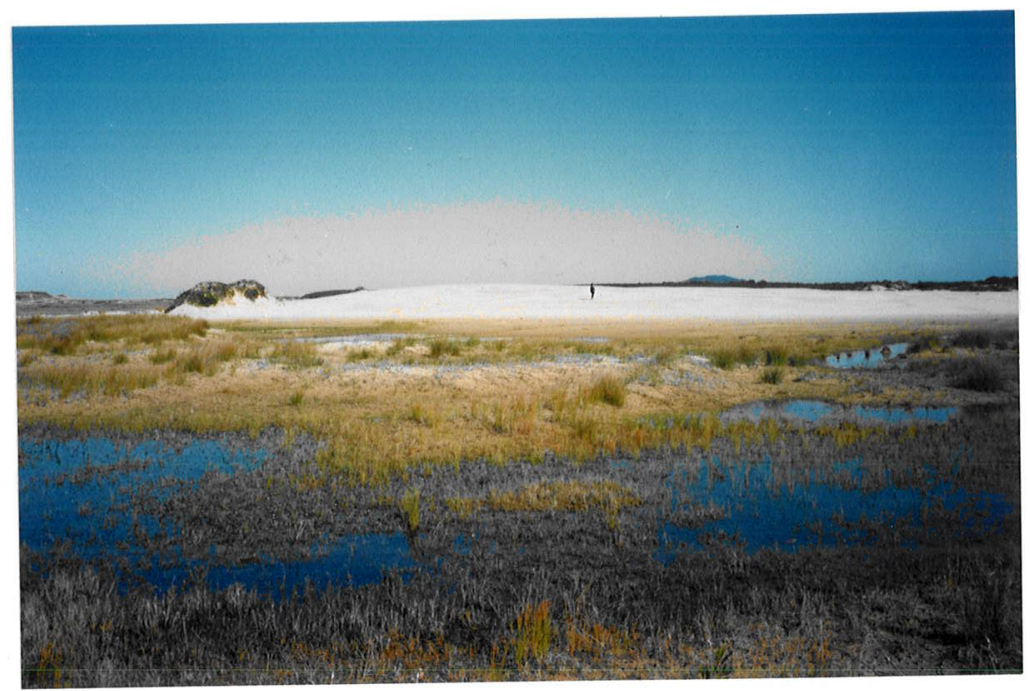

Figura 5.81. Montes residuais de deflaçăo de lençóis parabólicos da geração 3, exercendo efeito de sombra sobre lençóis da geração 4. Próximo à praia do Sol. 


\subsection{Depósitos residuais de deflação versus interdunas}

Extensas superfícies planares a ligeiramente côncavas, moldadas pela ação predominantemente erosiva do vento, ocorrem a barlavento das dunas e lençóis parabólicos. Estas superficies preservam depósitos reliquiares da passagem rumo SW das dunas ou lençóis e são sujeitas ao soterramento temporário por novas frentes de avanço. São, portanto, superfície interdunares, tanto no espaço como no tempo. Uma definição para interdunas, compilada de McKee $(1979,1982$, 1983) é a de zonas aplainadas, onde opera uma miscelânea de processos não eólicos, deposicionais, com prucessos eólicos, erosivos. Este conceito clássico de interdunas é mais abrangente que o que se atribui neste trabalho para a fácies de deflação, pois ele inclui também as interdunas suspensas ou entulhadas de draas (lençóis e mantos de areia),isto é, interdunas onde a ação deposicional eólica é muito evidente. Por uma questão de hierarquia interna do sistema eólico, tais interdunas dentro de fácies lençóis parabólicos e mantos de areia são aqui consideradas apenas como subfácies, no mesmo nível de crista, barla e sotavento dunar

Caracteristica geomorfológica comum a todos os tipos de interdunas é seu relevo aplainado, atribuído por Kocurek \& Neilson (1986) a um ou mais dentre cinco fatores: granulometria grossa, cimentação superficial, nível de água elevado, enchentes periódicas e cobertura vegetal. Os três últimos fatores são importantes nas interdunas da área estudada. Langford (1989) destacou como de essencial relevância os processos de oscilação do nível freático. Seis tipos principais de depósitos foram identificados por McKee (1982) em interdunas desérticas, um dos quais são as deflacionares residuais; os outros cinco são areias vegetadas, areias com cruzadas truncadas erosivamente, depósitos lacustres, areias maciças com ou sem microondulações e "sebkhas" ou "playas". Os três primeiros acham-se presentes nas interdunas costeiras em estudo. Os lagos, em sua maioria "ponds" temporários, podem resultar da invasão de águas pluviais e marinhas e/ou da elevação do lençol freático. Uma lista de estruturas superficiais mais comuns nas interdunas costeiras da região de Tramandaí (RS) é apresentada por Tomazelli (1990). A presença de mesmas estruturas estende-se à área abordada neste trabalho. A elas, acrescentam-se ainda microcones de sombra (figura 5.82), feição mencionada por Collinson \& Thompson (1982), e que pode ocorrer também na pós-praia.

Quatro subfácies puderam ser reconhecidas dentro da fácies depósitos residuais de deflação (tabela 5.10). A primeira é a do pavimento plano, constituido por areias do sistema marinho, sobreposto localmente por uma camada fina de areias eólicas. Inundações pluviais e colonização por vegetação rasteira, formando brejos vegetados, ocorrem de modo sazonal. Em contraste às interdunas desvegetadas no interior de lençóis de areia, estratificações cruzadas eólicas estão ausente nesta subfácies. Em seu lugar ocorrem laminações irregulares aparentemente plano-paralelas, mal definidas, com níveis enriquecidos em matéria orgânica. Laminações similares, atribuídas a deposição de areia eólica em suspensão por atrito com vegetação ou aderência em superfície úmida, são descritas no topo de dunas vegetadas (Goldsmith 1978) e em lençóis eólicos de clima temperado (Schwan 1988). A segunda subfácies são rastros lineares longitudinais de deflação, deixados como resquícios do deslocamento dos braços de dunas e lençóis parabólicas. Ocorrem como montes vegetados de altura irregular e relativamente baixa $(<2 \mathrm{~m}$ ), paralelamente alinhados, atribuidos às gerações 2 e 3-4. Feições comparáveis são 
ilustradas por Tomazelli (1990) na costa gaucha ( $D$, na figura 5.57). A terceira subfácies é representada por domos e cones de deflação ("conical hill residuals", de Semeniuk et al.1989), montículos vegetados de altura métrica a submétrica, com ocorrência pontual e irregular reconhecidos nas gerações 3-4. A quarta subfácies é o das depressões ou cavas de deflação ("blowouts"), as quais ocorrem conjugadas com ondulações de forma barcana instabilizada (parabolizada). As cavas podem ser reconhecidas em aerofotografias, nas gerações eólicas 2 e 3-4, sob a forma de manchas escuras transversais com formato crescêntico a semi-circular, tendo a convexidade voltada para barlavento. Suas dimensões variam entre 10 e $50 \mathrm{~m}$ de largura por 50 a $200 \mathrm{~m}$ de comprimento. No campo, as cavas apresentam-se como zonas vegetadas e/ou temporariamente alagadas, alternadas com ondulações, compondo juntos longos corredores margeados por rastros lineares longitudinais ou braços de parabólicas.

Seções expostas em domos e rastros residuais revelam a presença de estratificações cruzadas tabulares com mergulho forte para SW

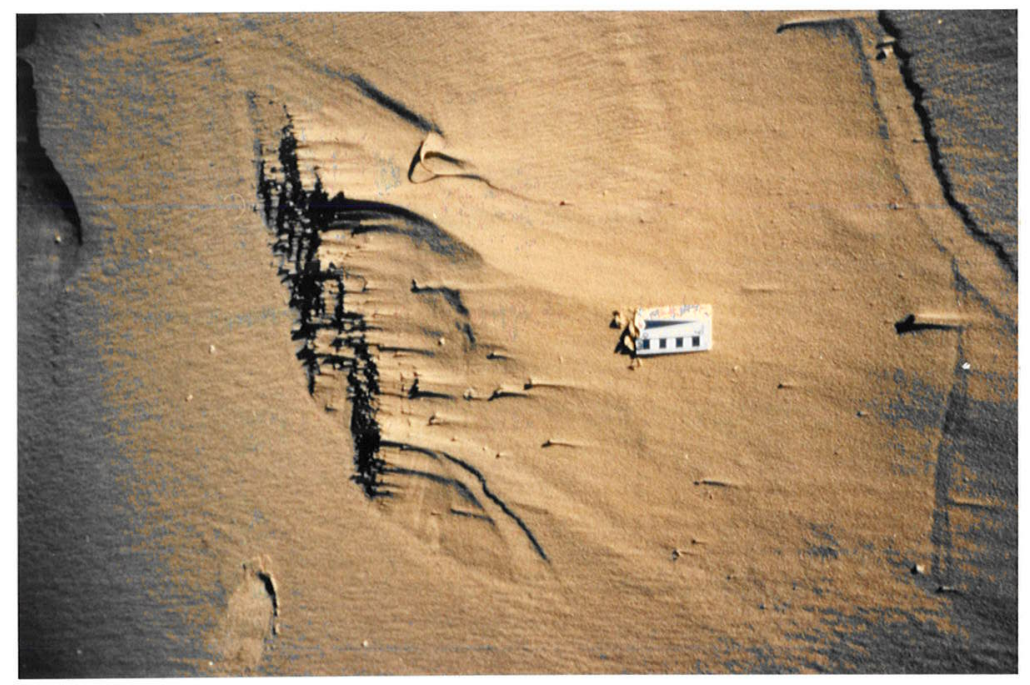

Figura 5.82. Microcones de sombra : estrutura superficial erosiva de planicies interdunares. A seta, na escala, indica o rumo do vento gerador.

\subsection{Depósitos lacustres}

Interdunas suspensas afogadas ocorrem como subfácies atual do sistema eólico geração 2 nas lagoas Bonita, Arroio Corrente (figura A1) e Doce do Arroio. As duas últimas podem ser remanescentes de afogamento pelo mar transgressivo de 5100 anos A.P. (caráter de "overbank") e mantêm, ainda hoje, pequena influência de marés. No mapa geológico (prancha A2), elas foram associadas, por simplificação, ao sistema lagunar. A rigor, são subfácies lacustres do sistema eólico. Uma característica específica das lagoas Arroio Corrente e Doce do Arroio é a sedimentação bioclástica, representada por vasas de carapaças silicosas descritas como "terras de diatomáceas" ou "diatomitos" (Castro \& Castro 1969a; Sousa 1973; Willig et al.1974). De acordo com a descrição de Castro \& Castro (1960a), o "minério" do lago Doce do Arroio ocorre em subsuperfície a espessura máxima de 5,0 $\mathrm{m}$ e média de $2,5 \mathrm{~m}$. Quando seca ao sol, a vasa exibe coloração cinza claro, 
sugestiva de seu baixo conteúdo em impurezas orgânicas; análise química apresentada por mesmos autores indica teor de $93 \%$ de sílica, dos quais aproximadamente $70 \%$ em biodetritos. Amostras de superficie coletadas durante a realização de trabalhos de campo, nas lagoas Boniła, Gregório Bento e Arroio Corrente, não revelaram indícios de presença de diatomáceas.

\subsubsection{PADRÃO SEDIMENTOLÓGICO}

\subsubsection{Estruturas sedimentares}

Comentários breves sobre estruturas sedimentares contidas nas subfácies eólicas reconhecidas já foram apresentados nos itens precedentes. Nesta seção, procura-se aprofundar a discussão acerca de três assuntos sobre estruturas eólicas específicas, em relação às quais se considerou que a área costeira em estudo poderia ilustrar novos aspectos: a análise de hierarquias de superfícies eólicas, de grande valia na compreensão da dinâmica de cavalgamento sedimentar; a estruturação de dunas frontais incipientes, no caso formadas ao longo de uma direção subparalela aos ventos mais efetivos; e as estruturas em dunas de topo de encosta e rampas de areia, com ênfase ao que Bigarella $(1975 a, b)$ denominou "estruturas de dissipação", de origem controversa.

\subsection{Hierarquias de superfícies eólicas}

A origem das superfícies de truncamento ("bounding surfaces") eólicas de porte maior tem-se mostrado assunto polêmico. Estruturas deste tipo, descritas originalmente por Stokes $(1961,1968)$, Phoenix (1963), McKee (1966) e Thompson (1969), consistem de superficies planares ou convexas para cima, eventualmente demarcadas por uma linha de rudáceos ou por cimentação ferruginosa. Segundo Stokes (1968), o espaçamento entre estas superfícies, que ele denominou "planos de truncamento paralelo múltiplo" ("multiple parallel truncation bedding planes"), varia muito de um caso para outro, desde dezenas até menos de $1 \mathrm{~m}$, mas tende a ser constante numa mesma formação. A explicação deste autor para a gênese de tais estruturas pode ser considerada clássica: os planos seriam gerados pela intercepção da superfície deposicional pelo lençol freático através do efeito combinado de elevação do nível de água e de aumento da relação erosão/deposição. O umedecimento da areia superficial impediria o prosseguimento de processos erosivos, favorecendo o soterramento por novas seqüências eólicas.

Para Brookfield (1977), o modelo de Stokes (1968) não explica a forma planar da maioria das superficies de separação extensas, a não ser que o lençol freático intercepte planicies interdunares formando "sebkhas". O autor sugere um mecanismo alternativo de formação para tais superfícies, as quais ele denomina superficies de $1^{\text {a }}$ ordem (figuras 5.54 e 5.83); este mecanismo seria o cavalgamento do costado de barlavento de draas preexistentes por draas superimpostos. Nesta hipótese, a preservação permanente de superficies de truncamento sucessivas requer elevação do nível de base, posterior ou concomitante à sua gênese, dependendo de controles geológicos regionais de longo prazo e não de 
variáveis mais imediatas como aporte de areia ou nível freático. Esta última premissa de Brookfield (1977) só é válida, todavia, para draas superpostos, em grande ergs. Em ergs pequenos e nos campos de dunas de costas úmidas, variáveis imediatas adquirem relevância, mesmo porque o cavalgamento de draas pode não chegar a acontecer antes que o draa preexistente já se encontre estabilizado por vegetação e pedogênese. Com isto, pode ocorrer nesses casos o desenvolvimento de superfícies com paleossolos (Bigarella 1975a; Glassford \& Semeniuk 1990), que podem ser definidas como superficies de super-separação ("super bounding surfaces"), na nomenclatura de Kocurek (1988), e que abrangem em parte as "super-superfícies" ("super-surfaces") de Talbot (1985).

$A$

$B$
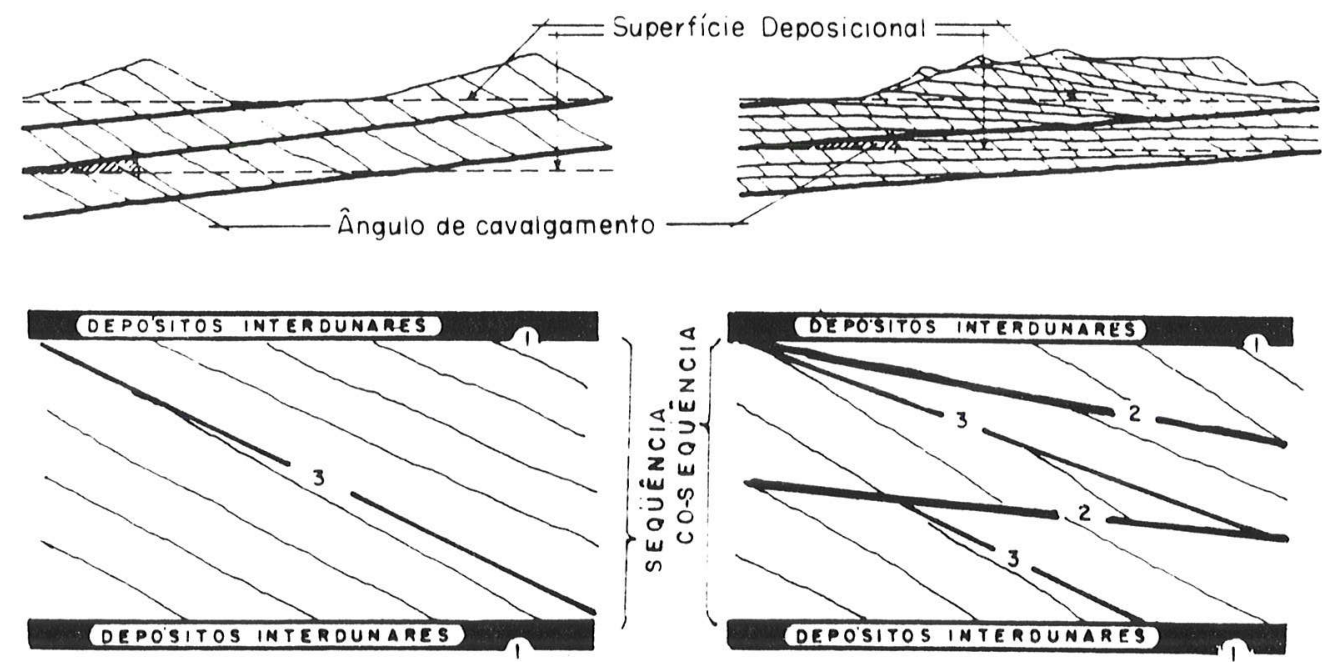

Figura 5.83. Modelo para formaçăo de superficies de $1^{a}$ ordem através da migração de dunas simples (A) e draas (B), segundo Kocurek (1988). Superfícies de $1^{a}, 2^{a}$ e $3^{a}$ ordem indicadas por 1,2 e 3 , respectivamente.

$\mathrm{Na}$ área costeira em estudo, as superfícies de hierarquia maior correspondem às separações entre unidades 1, 2 e 3 ou 4 definidas em dunas de topo de encosta. Características como brechas basais, bioturbações e concentração de matéria orgânica coloidal permitem atribuir a estas superficies o caráter de antigos solos, pavimentos ou fundos de ravina, indicativos de super-separação. Sua morfologia varia localmente entre planar escalonada e muito irregular, com mergulho, em geral, acompanhando a topografia do embasamento cristalino parcialmente encoberto. Não há evidências de superfícies puramente erosivas, em grande escala, compativeis com a definição de superfícies de $1^{\text {a }}$ ordem de Brookfield (1977) e Kocurek $(1981,1988)$.

Em escala imediatamente menor, reconhece-se a existência de superfícies de $2^{a}$ ordem (Brookfield 1977; Kocurek 1988), caracterizadas pelo mergulho suave para sotavento e pela posição entre seqüências submétricas de cruzadas tabulares (figura 5.83). Quanto à origem, Brookfield (1977) descarta a relação com planos de deflação em frente dunar, proposta em princípio por Bagnold (1954) e McKee (1966), pois há notável regularidade de espaçamento e de mergulho. Seu processo formador seria o cavalgamento de formas de leito superpostas no flanco de sotavento de uma megaduna sem face de avalancha (Brookfield 1977; Rubin \& 
Hunter 1982; Lancaster 1988), como se vê na figura 5.54 B. São atribuídos a esta classe de superfícies, na área estudada, planos com extensão de pelo menos algumas dezenas de metros existentes em rampas de areia. Dentro da unidade 2, estes planos aparecem ressaltados por cimentação limonítica nodular, separando seqüências de cruzadas menores ligeiramente discordantes, estas com cimentação menos intensa. Estas superfícies apresentam-se expostas em seções verticais de paredes de drenagem, encontrando-se as melhores exposições no flanco sul da ponta do Ji (figura 5.84).

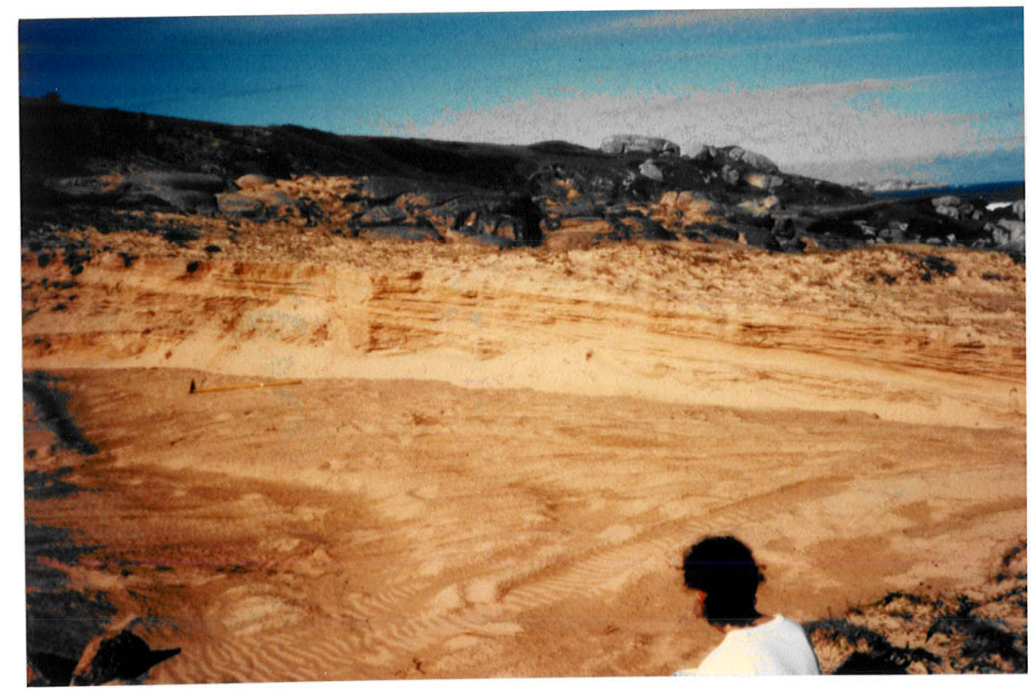

Figura 5.84. Estratificações cruzadas de grande extensão e baixo mergulho no flanco sudeste de rampa de areia élica geraçăo 2, na ponta do Ji. Definem-se três camadas principais, separadas por superficies de $2^{a}$ ordem, e contendo sequências de lâminas iniciadas por superfícies de terceira.

Todas as exposições encontradas nesta como nas demais rampas de areia da geração 2 ocorrem ao lado sudoeste (sotavento) das dunas de topo de encosta; não se encontraram, deste modo, evidências de preservação destas superfícies, enquanto estruturas internas, em rampas de barlavento. Esta possibilidade não é prevista no modelo de Brookfield (1977), porque este supõe o avanço constante do draa por meio de cavalgamento dunar, com a decorrente erosão das seqüências de cruzadas de barlavento ("backset"). Como se trata, no caso das rampas de areia, de draas com anteparo fixo, é possivel que os "backsets" possam se acumular por encavalamento de dunas transversais e barcanóides, sem erosão total. Em exposições verticais de rampas eólicas da geração 4, planos de truncamento de $2^{\mathrm{a}}$ ordem encontram-se tanto a sota quanto a barlavento, como por exemplo nos morros Santa Marta Grande (figura 5.85) e Entrada da Barra. As superfícies de barlavento mergulham no rumo do declive da rampa (NE) separando seqüências de laminações cruzadas frontais com mergulho para SW. Supõe-se a participação de processos gravitacionais na formação destes planos os quais podem englobar pavimentos de detritos grosseiros. Em dunas simples, como é o caso em áreas costeiras de alguns tipos de dunas frontais, Kocurek $(1981,1988)$ demonstrou que as superficies de $2^{a}$ ordem são virtualmente ausentes (figura 5.83).

Superficies de $3^{a}$ ordem (Brookfield 1977) são, como as anteriores, planares ou curvas, porém em escala de delimitação de seqüências de 
laminações cruzadas. Estas superfícies truncam as laminações cruzadas abaixo e são concordantemente transgredidas pelas laminações acima. Constituem-se assim em verdadeiras superfícies de reativação. Brookfield (1977) baseia-se na interpretação clássica que associa tais superfícies a flutuações rápidas de velocidade e direção do vento (McKee 1966; Stokes 1968) para considerá-las representativas de períodos de deflação atuantes sobre as formas de leito menores. Esta deflação ocorreria de dois rnodos possiveis: por modificações regionais no regime de vento ou por mudança a mais longo prazo na configuração dunar. Nas dunas em estudo, superfícies de $3^{a}$ ordem observam-se de maneira local e difusa em paleorrampas da geração 2 (figura 5.84); sua acentuação por nódulos limoníticos é irregular e fraca; além disso, nas seções de ravinas de drenagem, por ser a maioria destas subperpendicular ao vento efetivo, aparecem quase sempre concordantes com as laminações internas da seqüência de lâminas subjacente, podendo com elas confundir-se. Nas rampas de geração 4 a barlavento do morro Santa Marta Grande, elas puderam, porém, ser observadas de modo claro (figura 5.85). São nítidas também em dunas frontais (figura 5.67) e em barcanóides (figura 5.86).

No interior das seqüências delimitadas por truncamentos de $3^{a}$ ordem, definem-se superfícies de laminação associadas a feições descritas sob designações diversas mas de gênese primária equivalente tais cömo os "tipos (básicos) de estratificação eólica" de Hunter (1977) e de Kocurek \& Dott Jr. (1981), as "estruturas físicas de mesoescala" de White \& Curran (1988) e a "laminação risca de agulha" ("pin stripe lamination") de Fryberger \& Schenk (1988). A maioria destas "superfícies de menor ordem" é constituida de laminações cruzadas, pois laminações eólicas de leito plano são formas instáveis de alta energia (Hunter 1977; Fritz \& Moore 1988). As laminações cruzadas, por sua vez, são divididas por todos os autores citados neste parágrafo em três tipos principais, distintos quanto a um critério de processo formador: ôndulas cavalgantes ("climbing ripples"), queda de grãos ("grain fall") e fluxo de areia ou de grãos ("sand flow"). A laminação do tipo cavalgante ocorre à semelhança do processo descrito por Jopling (1965) para ôndulas subaquosas, através do cavalgamento de marcas onduladas sob relação tração/suspensão mais baixa que a necessária para migração frontal simples das ondulações. As diferenças possiveis são o maior aplainamento das ôndulas eólicas (figura 5.87), devido ao efeito da energia de impacto dos grãos, e a tendência para a produção de cavalgamento subcrítico, isto é, sem preservação das faces de barlavento (ângulo de cavalgamento menor que ângulo da face de barlavento), em parte pela mesma razão. Outra característica típica das ôndulas cavalgantes eólicas é o caráter indistinto das laminações frontais ("ripple-foreset crosslaminae" de Hunter 1977), de modo que em geral só se preservam os planos de cavalgamento com mergulho para barlavento, também conhecidos como "pseudo-acamamento" ("pseudobedding" : McKee 1939), "pseudo-estratificação" ("pseudo-stratification": Hunter 1974) ou "estratificação de cavalgamento transladante" ("climbing translatent stratification": Hunter 1977). Devido à tendência para concentração de grãos maiores na crista de cada microondulação, o alinhamento de cristas ao longo da pseudo-estratificação pode ser marcado por uma granulometria mais grossa (Fryberger \& Schenk 1988). 


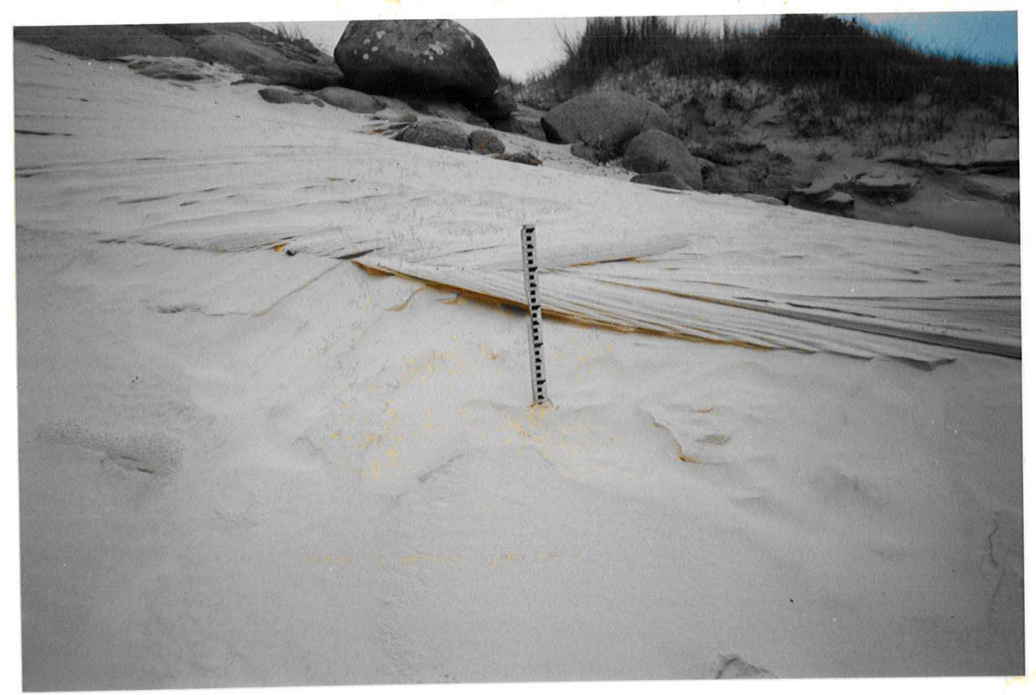

Figura 5.85. Superfície de $2^{a}$ ordem em rampa eólica de barlavento, no flanco norte do morro Santa Marta Grande. A superficie mergulha para NE e separa seqüencia de lâminas inferior com mergulho rumo $S$ de seqüéncia superior com mergulho rumo $S W$. Escala : $50 \mathrm{~cm}$.

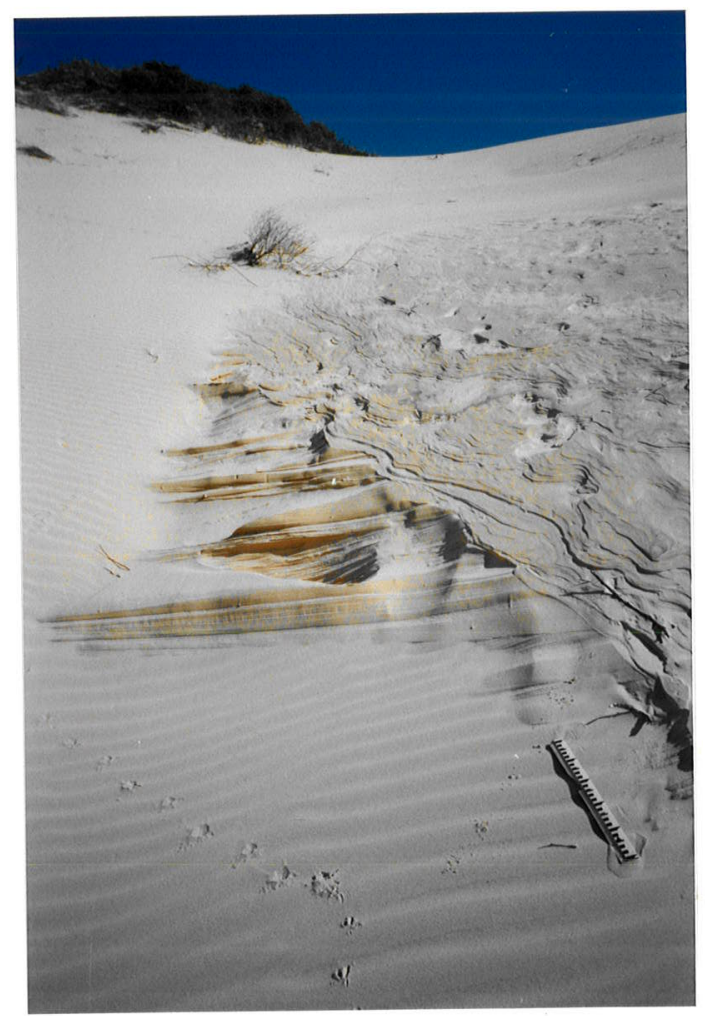

Figura 5.86. Sucessão de seqüencias de lâminas iniciadas por superficies de $3^{a}$ ordem no flanco sotavento de cadeia barcanóide. 


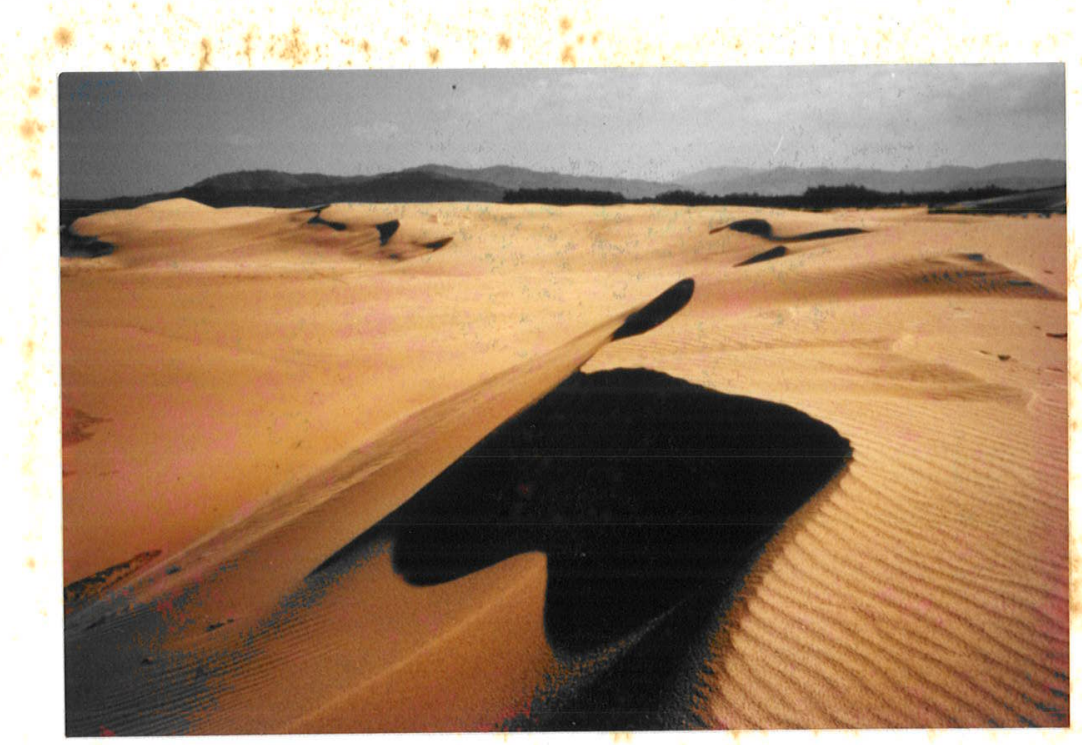

Figura 5.87. Marcas onduladas aplainadas na superficie de duna barcanóide. As marcas do flanco de barlavento são produzidas pelo vento principal e as da frente por vento secundário. Notar perfil cóncavo para cima em sotavento.

As laminações eólicas de queda de grãos também possuem analogia com estruturas de origem subaquosa (Jopling 1964, 1966 apud Kocurek \& Dott 1981; Allen 1965). Formam-se em essência através do mecanismo de rajadas ou flutuações erráticas na velocidade do vento, classicamente descrito por Otto (1935). A cada valor de velocidade, corresponde uma granulometria depositada na frente da ôndula ou duna por saltação-suspensão (queda "vertical" de grãos). O processo cria laminações com espessura de poucos grãos, exibindo seleção granulométrica interna apurada, e pode formar, ao acaso, tanto gradações inversas quanto normais, mesmo porque os limites entre intra-seqüências são em maior parte arbitrários (Hunter 1977; Fryberger \& Schenk 1988).

Queda de grãos e fluxo de areia são dois processos geneticamente associados e seus produtos com freqüência ocorrem alternados em afloramentos (Hunter 1977). Os grãos mais pesados que a capacidade de transporte e deposição do vento durante o mecanismo de queda dos grãos aglomeram-se na crista da ôndula ou da duna, por processos trativos, em uma acumulação compacta e portanto de ângulo ingreme. Periodicamente, através de uma energia de ativação fornecida à crista, esta acumulação desestabiliza-se e flui por avalancha, através da superfície de sotavento, até atingir um empacotamento aberto e estável em relação à energia dissipada. Este processo gravitacional de expansão da areia, denominado dilação, dá-se por meio de choques sucessivos entre grãos adjacentes, mecanismo físico conhecido como pressão dispersiva (Collinson \& Thompson 1982). Dependendo da intensidade do fluxo e da heterogeneidade granulométrica, a pressão dispersiva pode materializar-se em gradação inversa. A porção do flanco de sotavento afetada pela avalancha gravitacional de areia tende ao aplainamento erosivo na parte superior e à acumulação em leque ou língua na parte inferior (figura 5.88 a 5.90). A zona intermediária superior da frente de dunas constantemente afetada e moldada pelo processo tende a adquirir, por conseqüência, um perfil que grada de planar abrupto para suave e ligeiramente côncavo para cima em direção à base dunar. Esta zona e especialmente sua parte planar são comumente denominadas rampa ou face de 


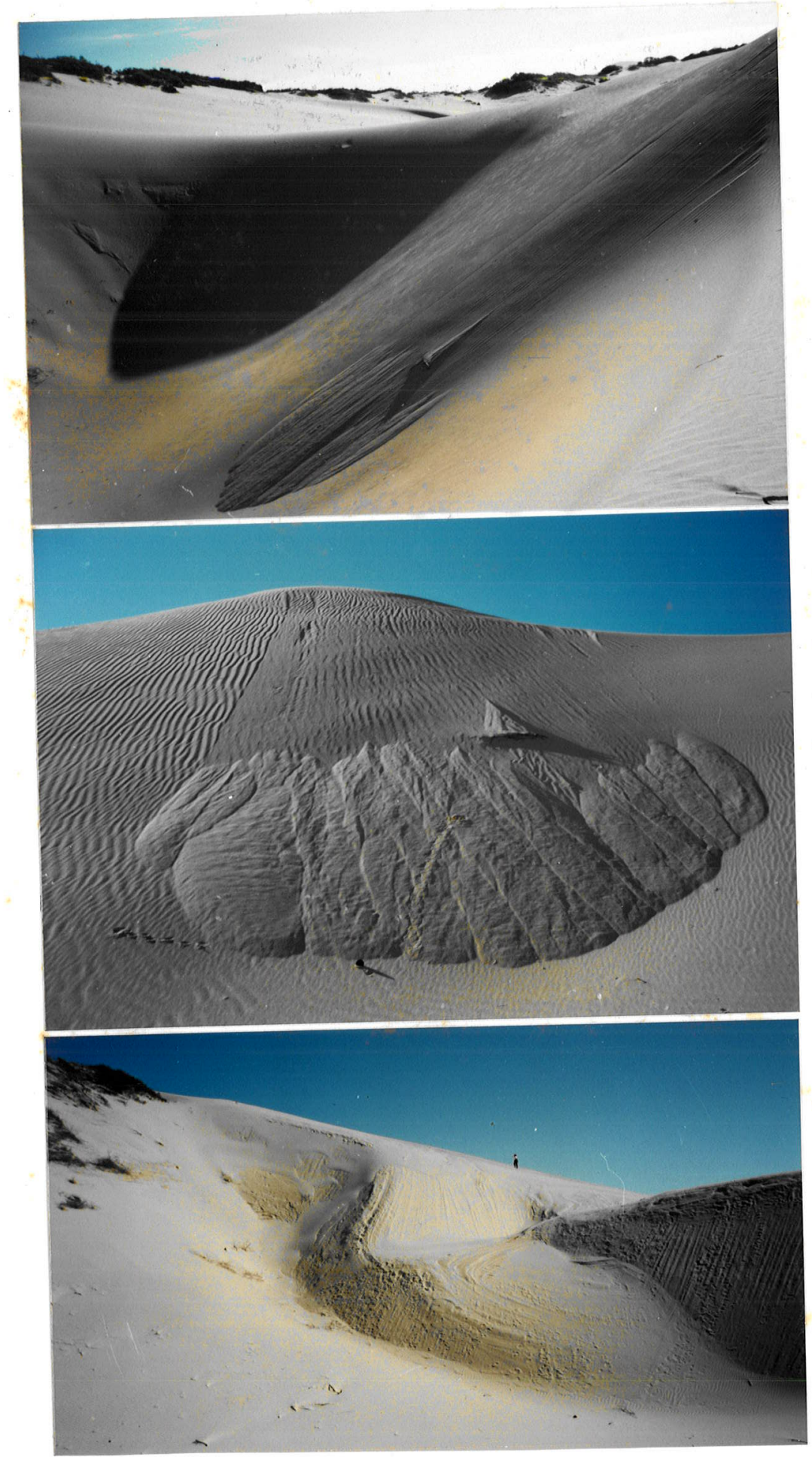

Figura 5.88 a 5.90. Morfologia de depósitos de avalancha em cadeias barcanóides. Porção distal do lençol parabólico de Vila Nova - Roça Grande.

5.88 (superior). Leque composto por coalescência de pequenas línguas de fluxo de areia, em visła lateral.

5.89 (meio). Mesmo leque em vista frontal.

5.90 (inferior). Morfologia "em tobogan", produzida por junçăo de avalanchas em cadeias transversais entre si. Este fenómeno é característico da margem interna de lençóis e mantos de areia, devido ao desvio e à desaceleração da migração dunar por efeito da presença de vegetação. Notar encurvamento das estrias de fluxo granular. 
deslizamento ("slipface"). O processo de fluxo de areia tem sido amplamente documentado tanto em dunas subaquosas (McKee 1957; Jopling 1965; Allen 1965) como em dunas eólicas (Bagnold 1941; McKee et al.1971; Hunter 1977; Kocurek \& Dott 1981; McKee 1982; Fryberger \& Schenk 1988; White \& Curran 1988). Taira \& Scholle (1979) e Sallenger (1979) comparam os produtos gerados pelo mesmo processo nos dois ambientes. Propostas de classificação para depósitos de avalancha gravitacional eólica, baseadas no critério de umidade e coesão da areia, são apresentadas por diferentes autores (McKee et al.1971; McKee \& Bigarella 1972; Hunter 1977; McKee 1982).

Os três processos geradores de laminações cruzadas são capazes de produzir fina alternância entre lâminas bem selecionadas de grãos finos e de grãos grossos, uma característica que já era destacada por Glennie (1970). Fryberger \& Schenk (1988) sustentam que a laminação fina, com bimodalidade granulométrica acentuada por cimentação eodiagenética vadosa diferencial, é a feição de maior eficiência na diagnose da origem eólica da laminação cruzada em depósitos antigos e modernos. Os autores denominam esta feição de "laminação risca de agulha" ("pin stripe lamination").

Nas dunas costeiras de Jaguaruna-Imbituba, a estrutura descrita por Fryberger \& Shenk (1988) pode ser observada, macroscopicamente, nos depósitos das gerações 4 e 3, em geral. Apesar da ausência virtual de cimentação, estes depósitos possuem laminações finas ressaltadas graças a abrasão diferencial exercida por ventos recentes sobre as superficies expostas de areia inconsolidada (figura 5.64, por exemplo). Exceções são encontradas dentre as estruturas lenticulares de fluxo de areia truncadas por superficies interdunares atuais (figuras 5.91 a 5.93). Laminações risca de agulha ocorrem com freqüência também em depósitos pouco cimentados da geração 2, inclusive nas lentes de fluxo granular (figuras 5.94 e 5.95). Entretanto, a cimentação pedogênica intensa, encontrada na geração 1 e em alguns casos da geração 2, torna quase sempre impossivel a identificação de campo da mesma estrutura; exceções são os afloramentos que se encontram em condições de intensa e prolongada exposição aos agentes intempéricos e principalmente ao vento, como os depósitos tentativamente atribuidos à geração 1 no alto de dunas de topo no morro Santa Marta Grande (figuras 5.96 e 5.97); nesses casos, a ação abrasiva do vento carreando areias em suspensão escava preferencialmente as lâminas menos cimentadas da estrutura risca de agulha, tornando-a proeminente. 

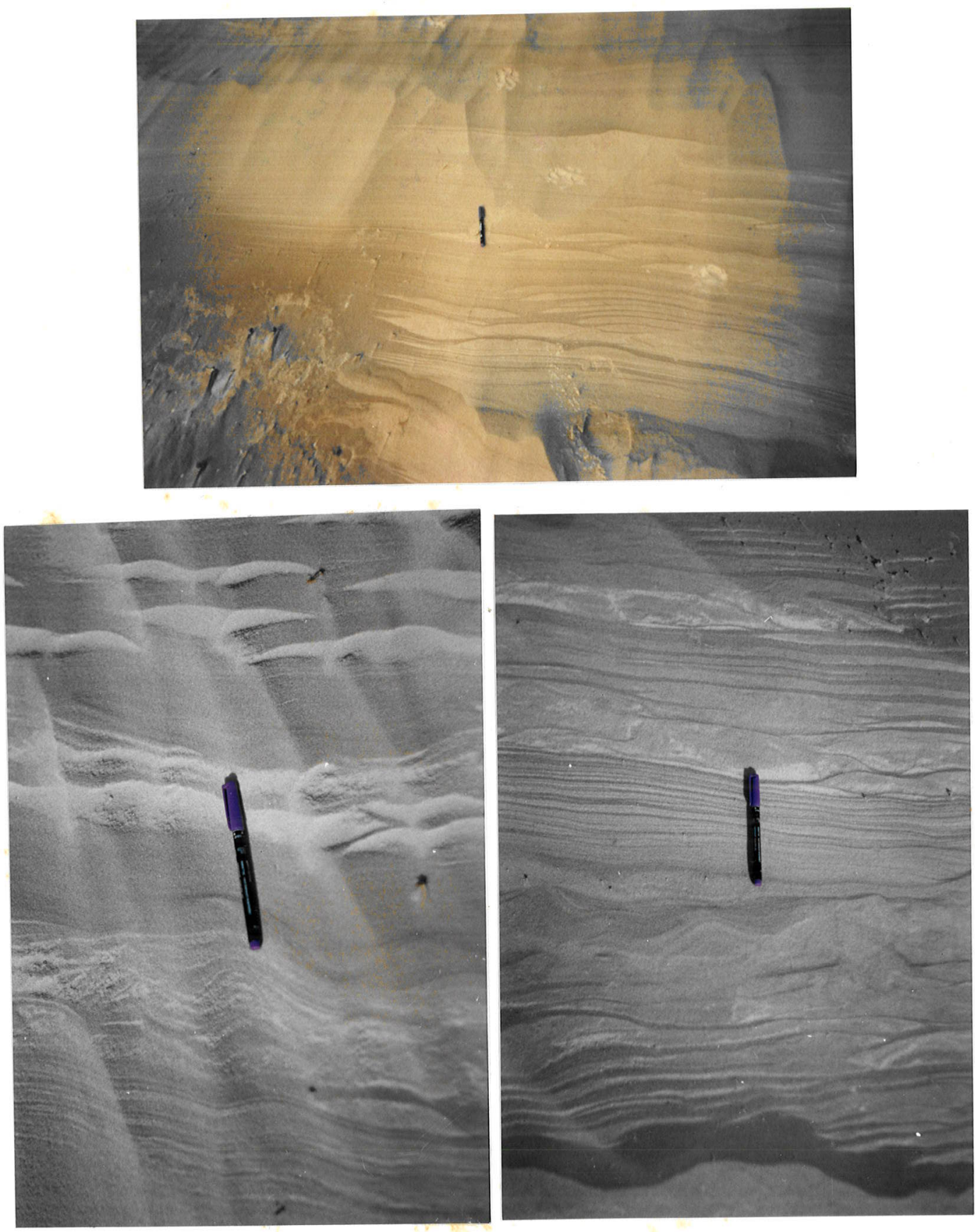

Figuras 5.91 a 5.93. Estruturas em frentes de dunas parabolicas truncadas na horizontal por pavimentos interdunares.

5.91 (superior). Aspecto geral de lentes de fluxo granular coalescidas ou individuais em meio a laminação fina e regular característica de queda de grăos.

5.92 (inferior esquerda). Detalhe de mesmo tipo de estrutura. Na parte inferior da foto ocorre provável laminação de óndulas cavalgantes sob nivel perturbado por liquefação. A cor mais clara das lentes de fluxo de areia decorre de empacotamento mais aberto dos grãos.

5.93 (inferior direita). Lâminas lenticulares de fluxo granular alternadas com laminação fina regular de queda de grãos. Notar presença de dobras convolutas afetando as láminas finas. 

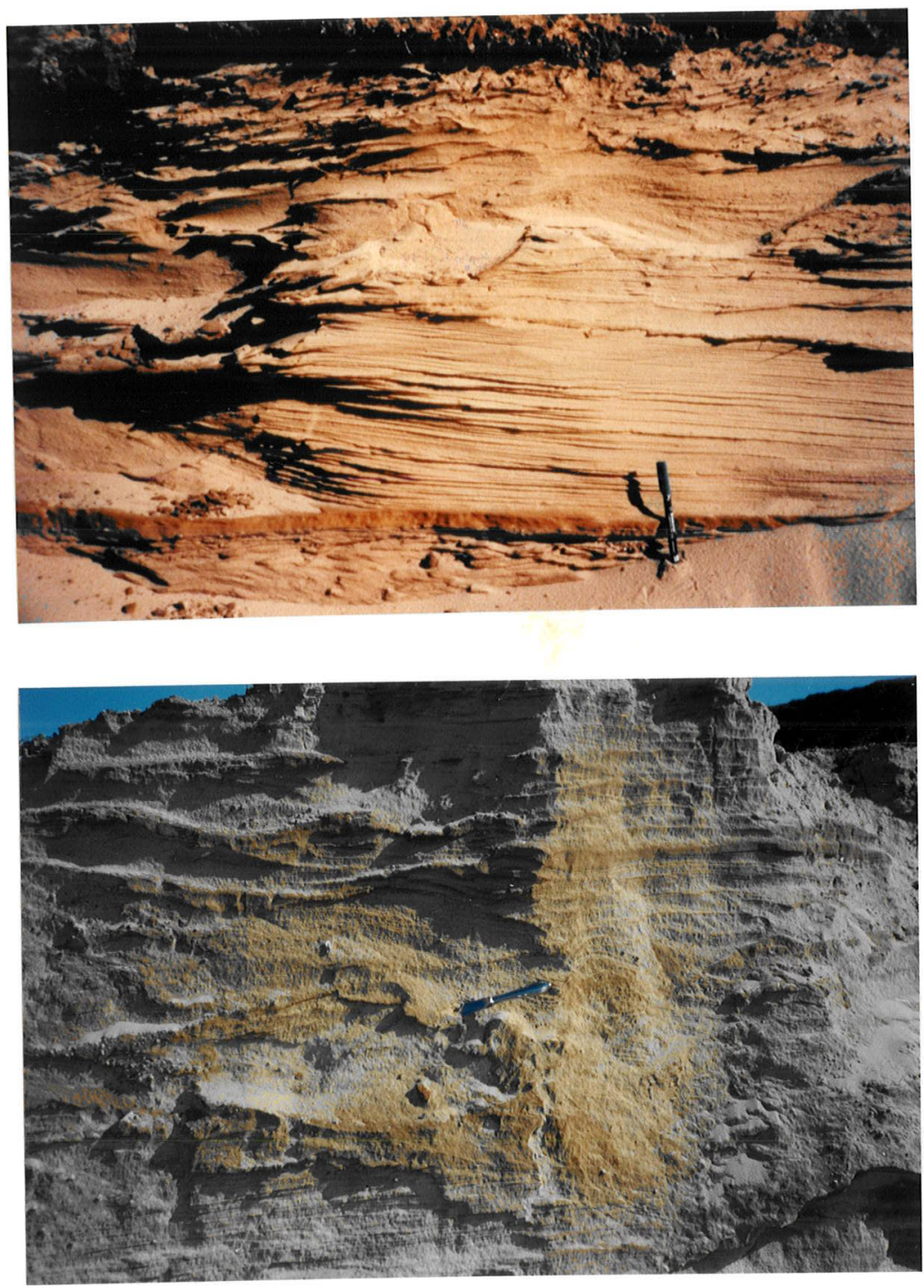

Figuras 5.94 e 5.95. Laminação risca de agulha em depósitos eólicos geração 2. Rampas de areia na ponta do Ji.

5.94 (superior). Em provável estratificação cavalgante subcrítica, com desenvolvimento incipiente de crostas planares. Notar superficie de $2^{a}$ ordem na base da foto.

5.95 (inferior). Em corte semi-frontal a láminas lenticulares de fluxo de grăos, alternadas com láminas finas de queda de grãos. 

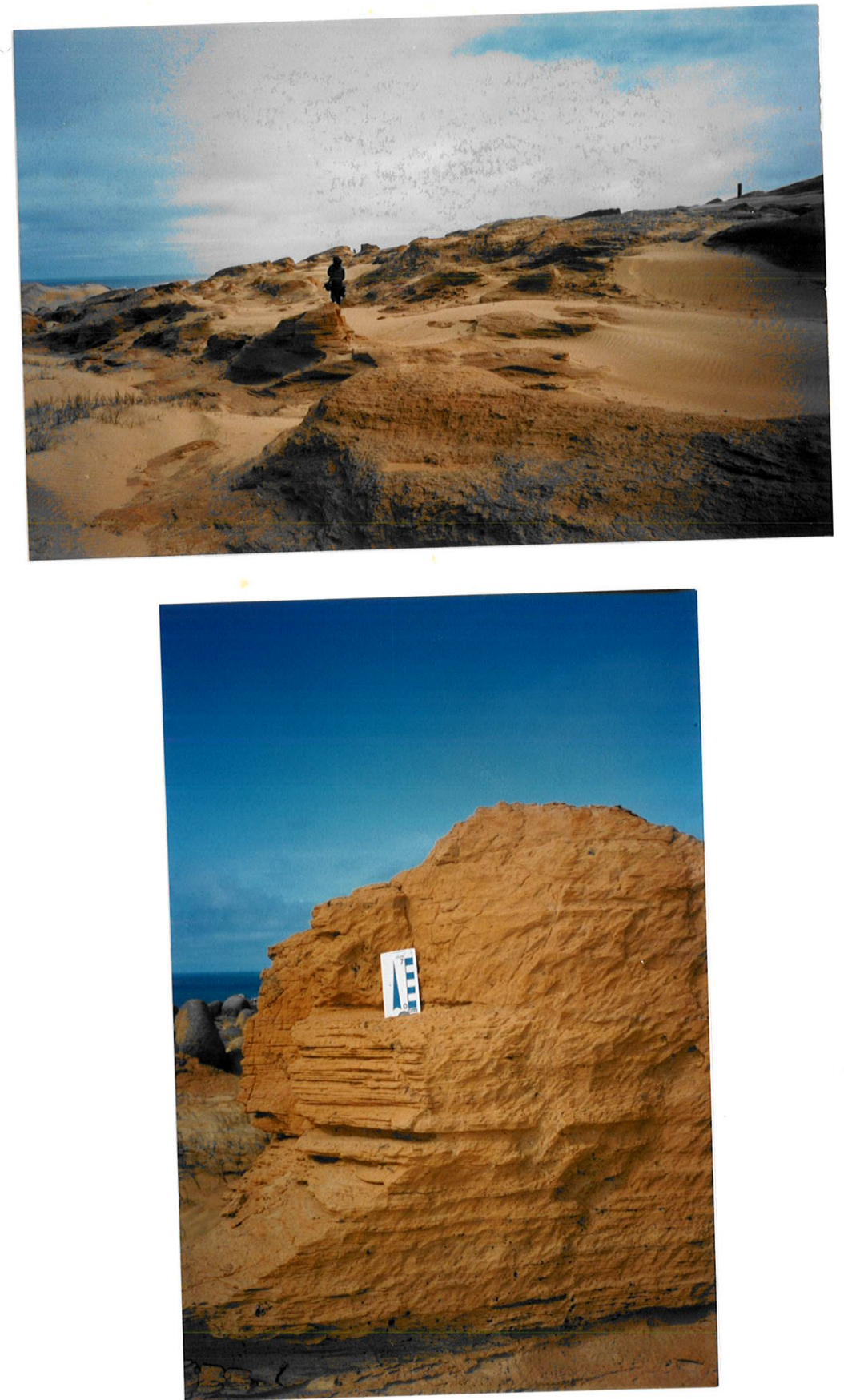

Figuras 5.96 e 5.97. Laminaçăo risca de agulha em depósitos eólicos geração 1. Dunas de topo de encosta no morro Santa Marta Grande.

5.96 (superior). Aspecto geral, notando-se recobrimento por areias inconsolidadas da unidade 4 5.97 (inferior). Aspecto de detalhe.

O processo formador de lâminas eólicas nem sempre pode ser
inferido, a menos que se preservem microondulações, sugestivas de origem por cavalgamento transladante, ou que ocorram exposiçōes de formas lenticulares, típicas de seções transversais a depósitos de fluxo de areia. Ambos os casos, o primeiro raro e o segundo muito comum, foram observados em superfícies interdunares atuais 
truncando estratificações dunares da geração 4 (figuras 5.91 a 5.93). Uma das razões desta aparente raridade de estruturas produzidas por marcas onduladas, além da dificuldade de reconhecimento, pode ser a não formação ou preservação. Em dunas lineares e cadeias barcanóides da área, observou-se que microondulações causadas pelo vento prevalecente só se mantêm na face de barlavento, enquanto que, a sotavento, microondulações geradas por ventos secundários podem existir temporariamente (figura 5.87); as marcas onduladas de barlavento são sucessivamente erodidas pelo próprio vento durante o avanço da duna e tendem a não se preservar no registro geológico; as de sotavento só serão preservadas se não houver destruição por avalanchas de areia seca ou úmida, típicas da dinâmica da frente dunar. Estas observações são compativeis com conclusões obtidas por Hunter (1977) e por Kocurek \& Dott (1981) sobre a distribuição espacial dos tipos de laminação ao largo da superfície de dunas barcanas ativas (figura 5.98). Segundo estas conclusões, as laminações cruzadas de fluxo de grãos desenvolvem-se preferencialmente nas faces de avalancha, enquanto que as de queda de grãos se formam nas zonas de separação de fluxo na orla do flanco de sotavento. As microondulações aparecem no flanco de barlavento, na lateral externa dos braços de barcanas e na parte basal do lado de sotavento; sua possibilidade de preservação restringe-se a estas duas últimas zonas. Na área em estudo, a lateral externa dos braços é uma zona muito exposta e sujeita à erosão por ventos reversos de S e SW e chuvas associadas; a parte basal do sotavento também pode ser erodida por efeito periódico de inundações marinhas e pluviais dos corredores interdunares. Pode-se observar que o encharcamento da base dunar, ocasionando sua liquefação, é uma das modalidades de erosão. Dobras convolutas, interpretadas como produtos de liquefação, são a mais comum estrutura associada a laminações risca de agulha de padrão planar (figura 5.99) e podem ser atribuídas à saturacão por água na base da frente dunar.
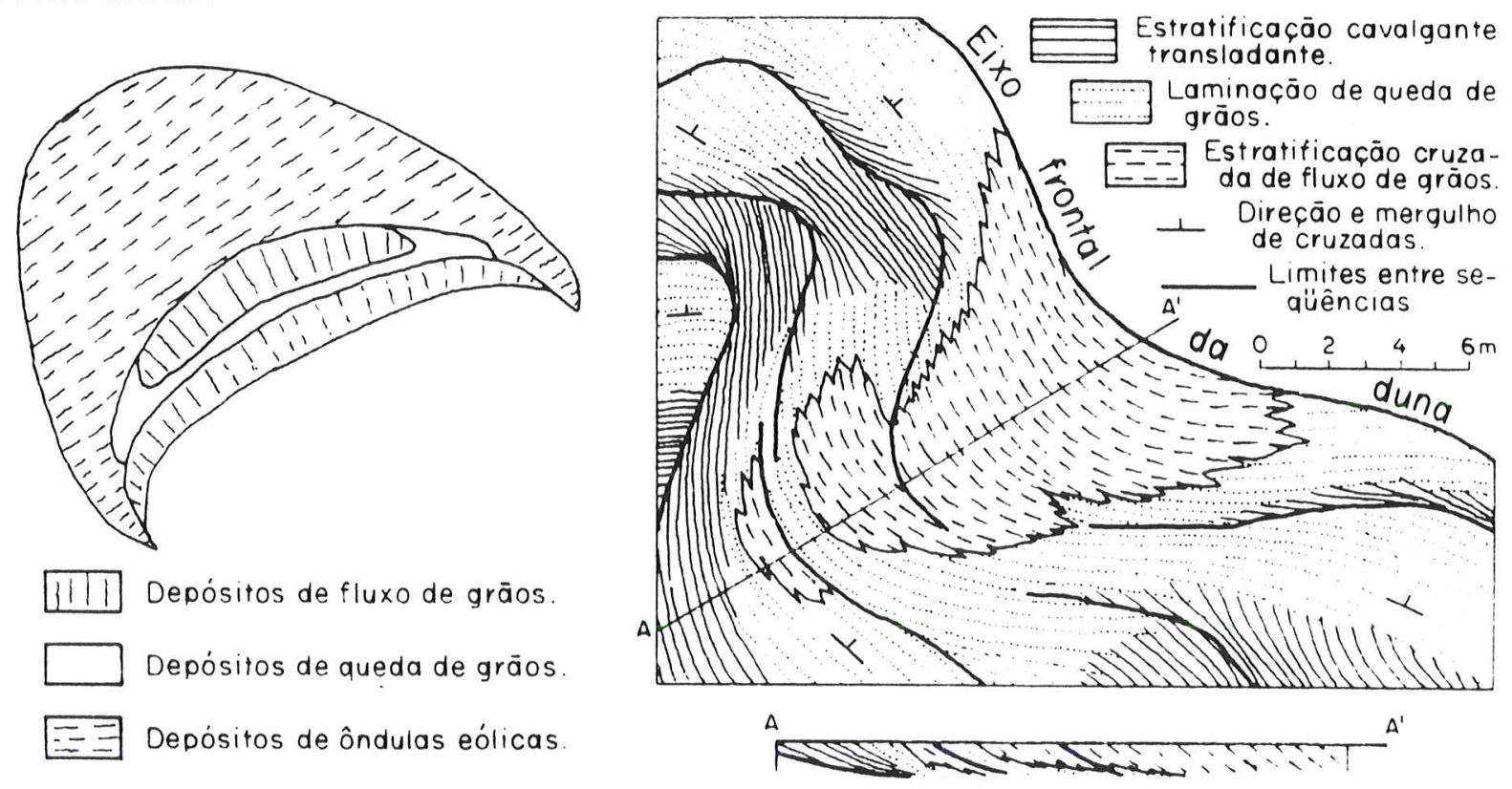

Figura 5.98. Distribuição em mapas e perfil (eixo $A A^{\prime}$, à direita) dos principais tipos de estratificação laminar em dunas eólicas barcanas (esquerda) e transversais ou barcanóides (direita). Segundo Hunter (1977) e Kocurek \& Dott (1981). 


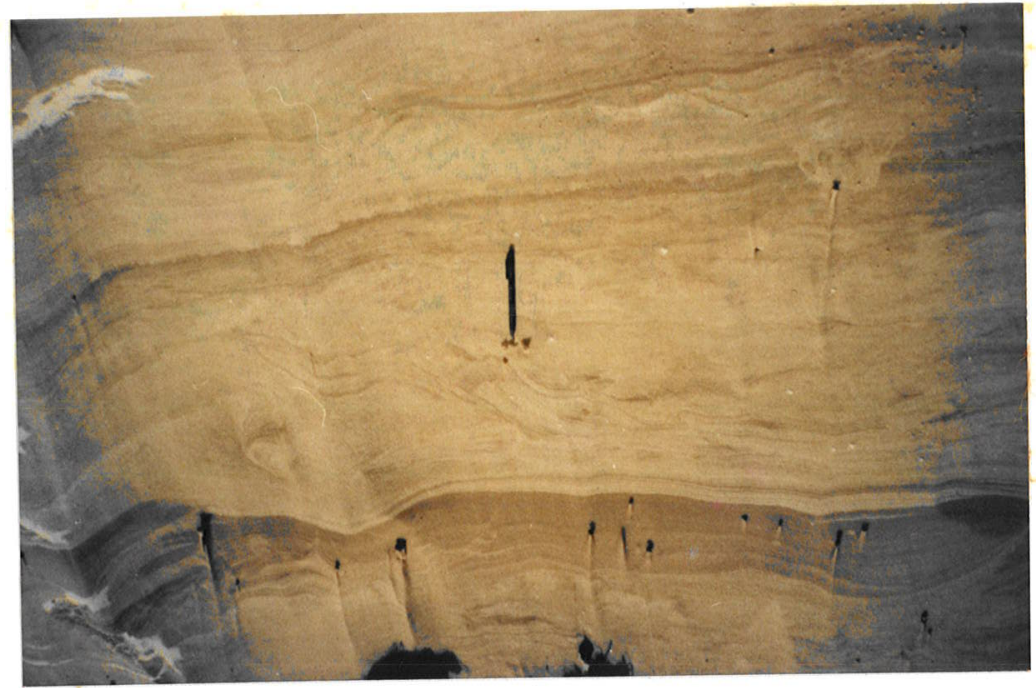

Figura 5.99. Laminações eólicas com convoluções geradas por liquefação. Pavimento interdunar em barcanóides próximo ao canal Camacho.

\subsection{Estratificações em dunas frontais}

Estruturas internas de dunas frontais foram estudadas, entre outros autores, por Bigarella et al.(1969), Goldsmith $(1973,1978)$ e Hesp $(1983,1988)$. As principais características destas estruturas, com base nos autores citados, são 0 predomínio de estratificações cruzadas de baixo ângulo $\left(<20^{\circ}\right)$, a preservação de estratificações de barlavento e de topo da duna ("backset"e "topset" segundo Hesp 1983) e a ausência de feições de avalancha. Hesp (1988) reconheceu cinco estágios de evolução morfológica de dunas frontais estabelecidas do Sudeste da Austrália, desde cordões contínuos e bem vegetados (estágios 1 e 2) até montes residuais com pouca vegetação (estágios 4 e 5). Essa seqüência evolutiva é acompanhada de aumento de complexidade na estruturação interna da duna. Nas dunas simples dos estágios iniciais, ocorrem laminações monótonas interrompidas apenas por superfícies como de reativação ou $3^{a}$ ordem. Nas dunas de estágios mais tardios, tornam-se freqüentes estratificações com geometria similar a superfícies de $2^{a}$ ordem e de superseparação, geradas respectivamente por cavas de deflação ("blowouts") e por abrasão marinha ou formação de solos. Dunas frontais incipientes na área em estudo apresentam predominio de estruturação interna compativel com a dos estágios 2 e 3 de Hesp (1988)

Pequeno número de atitudes, tomadas em estratificações cruzadas expostas em cortes de abrasão marinha em dunas frontais na parte sul da praia de Itapirubá, apresentou ampla dispersão de azimute de mergulho (figura 5.100), variando entre NE e SW. O vetor médio, ainda que de pouca consistência estatistica resultou para NW, mesmo quadrante onde foram verificados os valores mais elevados de ângulo de mergulho (290). A inclinação média foi de apenas 140 . Pelo critério modificado de Fernandes 1992 (item 2.5.6), estes resultados são considerados estatisticamente confiáveis. Eles podem ser atribuidos à combinação da influência de ventos em três direções: os prevalecentes de NE, predominantes de SW e os ventos do mar, de SE; estes últimos, por atingirem a duna perpendicularmente a sua extensão, seriam os principais responsáveis pela expansão da duna ao interior e pela 
produção de camadas de ângulo mais íngreme. A relativa ausência de estratificações cruzadas de barlavento, com mergulho para SE, pode ser atribuida à erosão pelo mar da porção externa das dunas analisadas. Em outros setores praiais, como no sul da praia do $\mathrm{Ji}$, as estratificações de barlavento encontram-se preservadas e, em maior parte, aparentam continuidade com as estruturas de topo e sotavento dunar (figura 5.67).
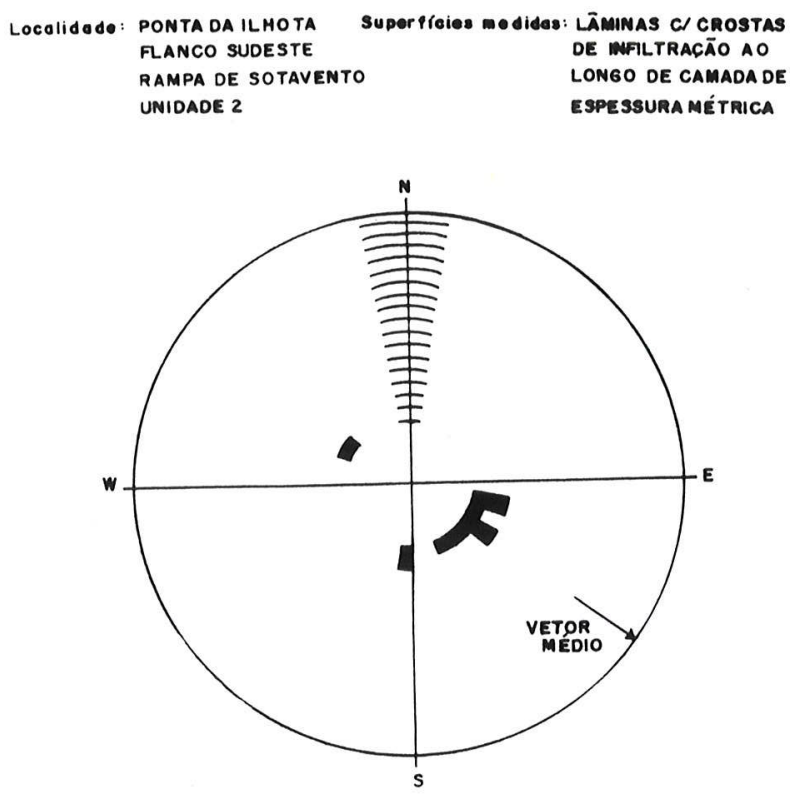

Número de medidas: 14
Direçđo média da inclinac đo: N 126 Fotor de consistencio: 0,44 Inclinocào móximo: 200
Inclinacdo mádia: 7

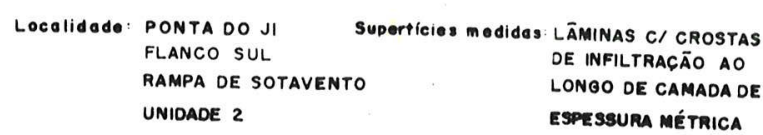
RAMPA DE SOTAVENTO LONOO DE CAMADA DE
UNIDADE LONGO DE GAMADA D

Superpicies modidas: LĀMINAS CI CROSTAS

Direço módia da inclineço: N 237 Fotor de consistêncio: 0,57

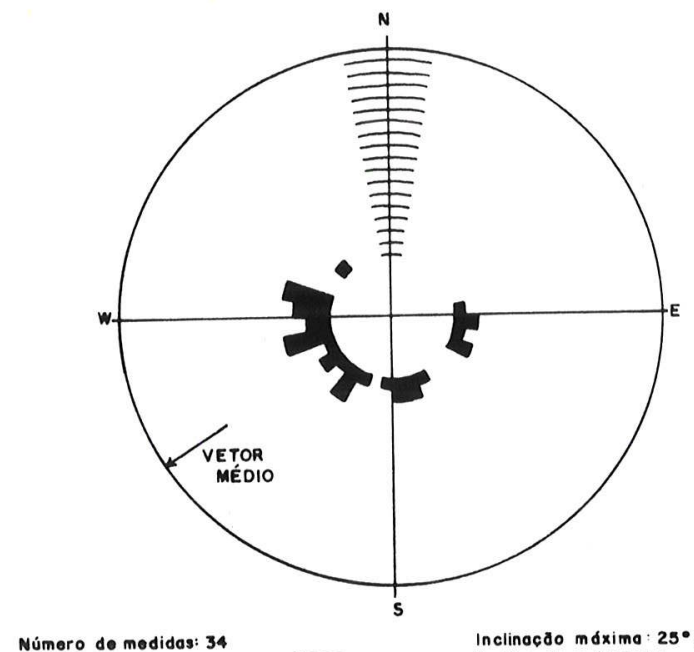

Número de medidas: 39

Inclinacdo móximo : $25^{\circ}(\mathrm{SW})$

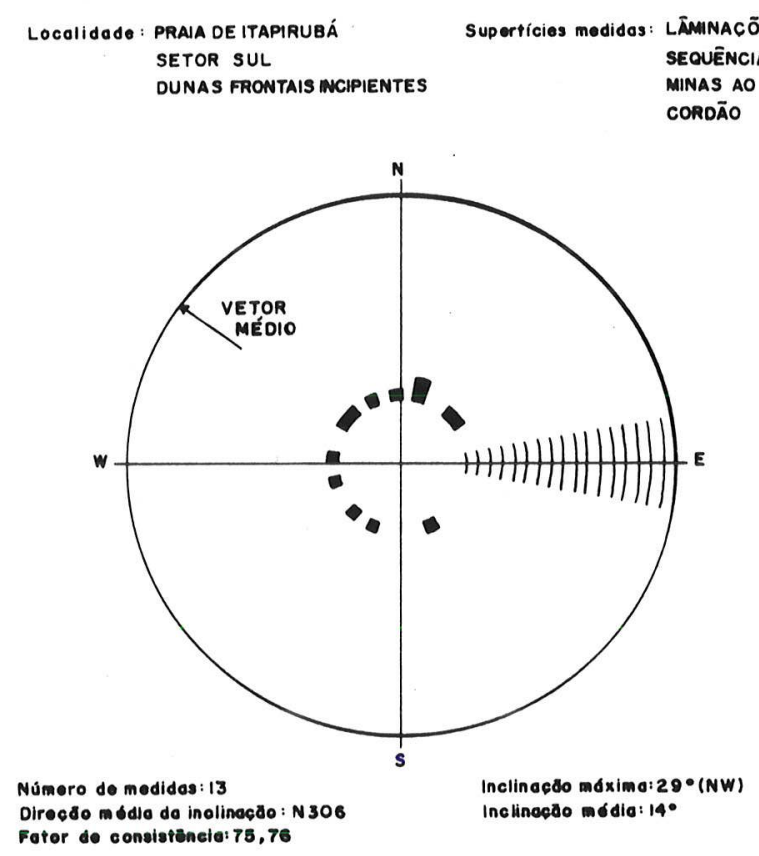

Figura 5.100. Diagramas circulares para azimutes de mergulho em estratificaçбes cruzadas de depósitos eólicos. 


\subsection{Estruturas em rampas de areia e dunas de topo de encosta}

\subsection{Introdução}

Estruturas sedimentares variadas em rampas de areia e "dunas de captação" (de topo de encosta) na llha de Santa Catarina foram descritas por Bigarella $(1975 a, b)$ sob a designação de "estruturas de dissipação". Esta denominação refere-se à sua atribuição, por mesmo autor, a efeitos de degradação físico-morfológica (i.é.,"dissipação") de dunas eólicas através de "deslizamentos complexos", devidos principalmente a chuvas pesadas de caráter episódico e recorrente. De acordo com Bigarella (1975a), a presença destas estruturas atestaria, deste modo, a ocorrência de um paleoclima mais árido que o atual, capaz de alternar fases de crescimento dunar com fases de erosão e dissipação pluvial.

Maior parte das estruturas referidas por Bigarella (1975a,b) encontra-se também nas rampas e dunas de topo de encosta da área costeira entre Jaguaruna e Imbituba (figuras 5.101 a 5.107). Entre elas, incluem-se "areias brechadas" (intraformacionais), "lâminas truncadas" ou "fadeouts" (reinterpretadas por Fryberger \& Schenk 1988 como truncamentos entre lentes de fluxo de areia), "dobras recumbentes", "falhas intraformacionais", deformações de sobrecarga, canais de corte e preenchimento e "estruturas maciças" em materiais mal selecionados. Além destas, a forma mais freqüente e típica de "estrutura de dissipação" na costa catarinense consiste em um bandamento tabular ou lenticular contorcido, alternando niveis mais escuros e mais endurecidos, enriquecidos em colóides ferruginosos e eventualmente em detritos grossos, com niveis de material arenoso mais claro e inconsolidado (figuras 5.105 a 5.107).

Yaalon \& Fränzle (1975) propuseram a subdivisão das "estruturas de dissipação" de Bigarella (1975a,b) em dois tipos: "estruturas de translocação e impregnação", formadas por "translocação vertical ou oblíqua de substâncias coloidais em uma fase líquida" e "estruturas deformacionais", no sentido de deformação dunar, um substitutivo para o termo "de dissipação", considerado por eles como ambíguo. Esta proposição não é satisfatória porque o termo "deformacionais" também possui outras conotações no estudo de estruturas sedimentares (Selley 1976 apud Suguio 1980) e porque as duas classes de estruturas propostas não são mutuamente exclusivas : observa-se que o efeito de impregnação afeta e/ou ressalta tanto estruturas produzidas por dissipação dunar quanto estruturas primárias com outras origens. Por esta razão, o termo "impregnação" é adotado neste trabalho sempre em sentido abrangente. Quanto à denominação original "estruturas de dissipação", deve-se ressaltar que seu uso tem sido desvirtuado para denotar exclusivamente as estruturas onduladas de impregnação pedogênica, numa inversão da proposta de Yaalon \& Fränzle (1975), como fazem por exemplo Ahlbrandt \& Fryberger (1980). Este uso corrente aumenta a confusão em torno do termo e torna conveniente o seu abandono. Pye (1983a) referiu-se aos bandamentos ondulados como "estruturas de infiltração", num sentido similar ao das "estruturas de impregnação e infiltração" de Yaalon \& Fränzle (1975); neste trabalho, prefere-se a designação bandas de infiltração (ou de impregnação), que é mais precisa. O termo "infiltração" foi proposto por Pye (1983a) com base na premissa de que a morfologia destas estruturas seja mais comumente relacionada ao limite de penetração de frentes úmidas causadas por chuvas pesadas que a superfícies primárias de acamamento 
ou deformação. Segundo mesmo autor, concentrações de silte e argila, sejam primárias ou secundárias, seriam determinantes na distribuição da umidade e da cimentação preferencial por óxidos e outros compostos dissolvidos na água intersticial. A simples variação de granulometria da areia também pode desempenhar esta função, uma vez que influi na tensão superficial da água contida nos interstícios.

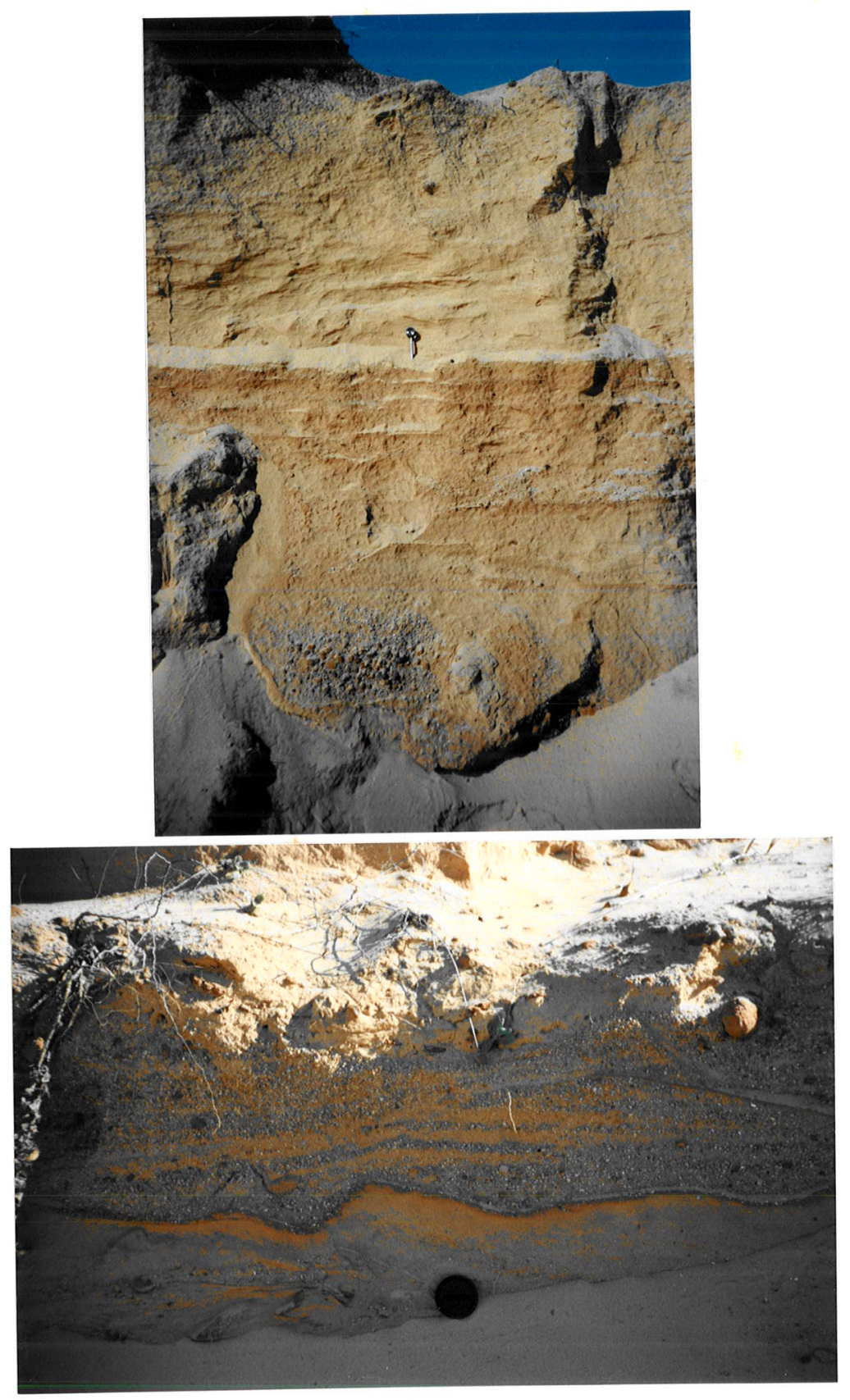

Figuras 5.101 e 5.102. Dois tipos de paraconglomerados intraformacionais em dunas com obstáculo fixo, geração 2, na ponta da llhota. 5.101 (superior). Brecha "amalgamada" (sentido de Mutti \& Ricci-Lucchi 1972), com gradação inversanormal; formada por fluxo granular subaquoso.

5.102 (inferior). Brecha sobre superfície erosiva nitida, ressaltada por crosta de infiltração, contendo estratificação plano-paralela incipiente; formada por tração em regime de fluxo superior. 


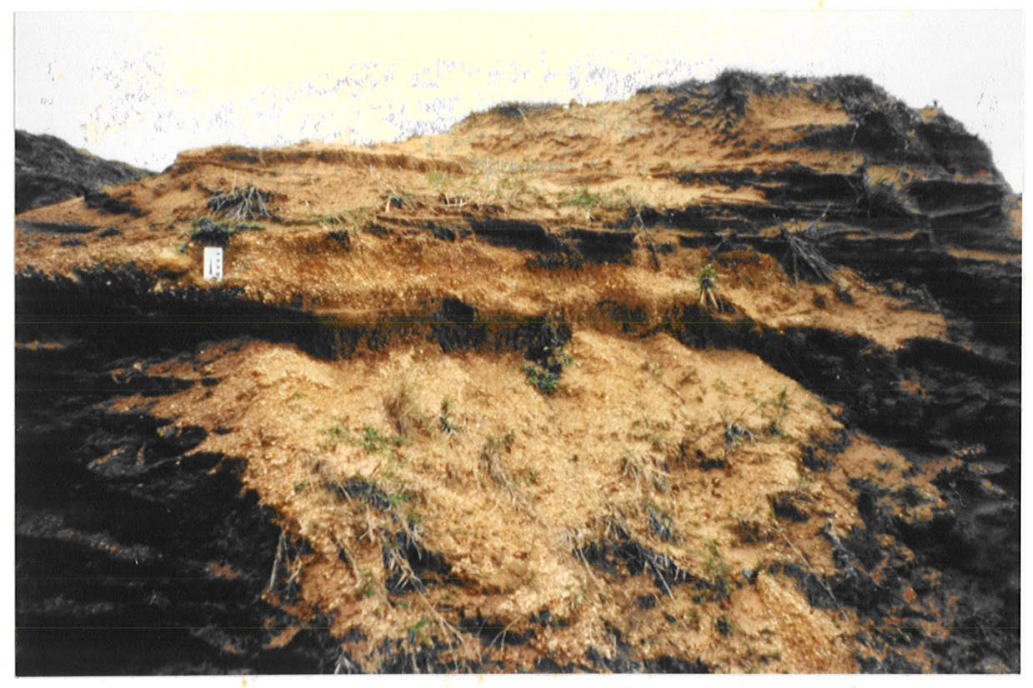

Figura 5.103. Camada lenticular de brecha rica em feldspato e fragmentos líticos, em meio a areias com crostas de infiltraçăo. Rampa eólica geraçăo 2, face nordeste da ponta de Santa Marta Grande. Escala : $7 \mathrm{~cm}$.

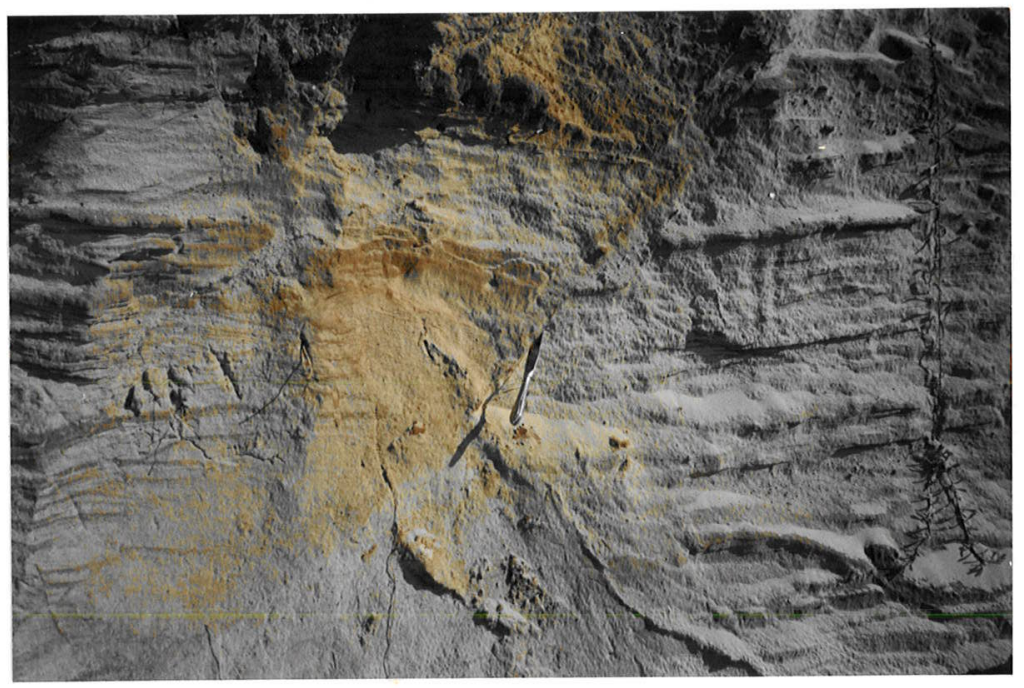

Figura 5.104. Plano de deslizamento rúptil em depósito eólico com lentes de fluxo de areia. Rampa de areia de sotavento, geraçăo 2, na ponta do Ji. 

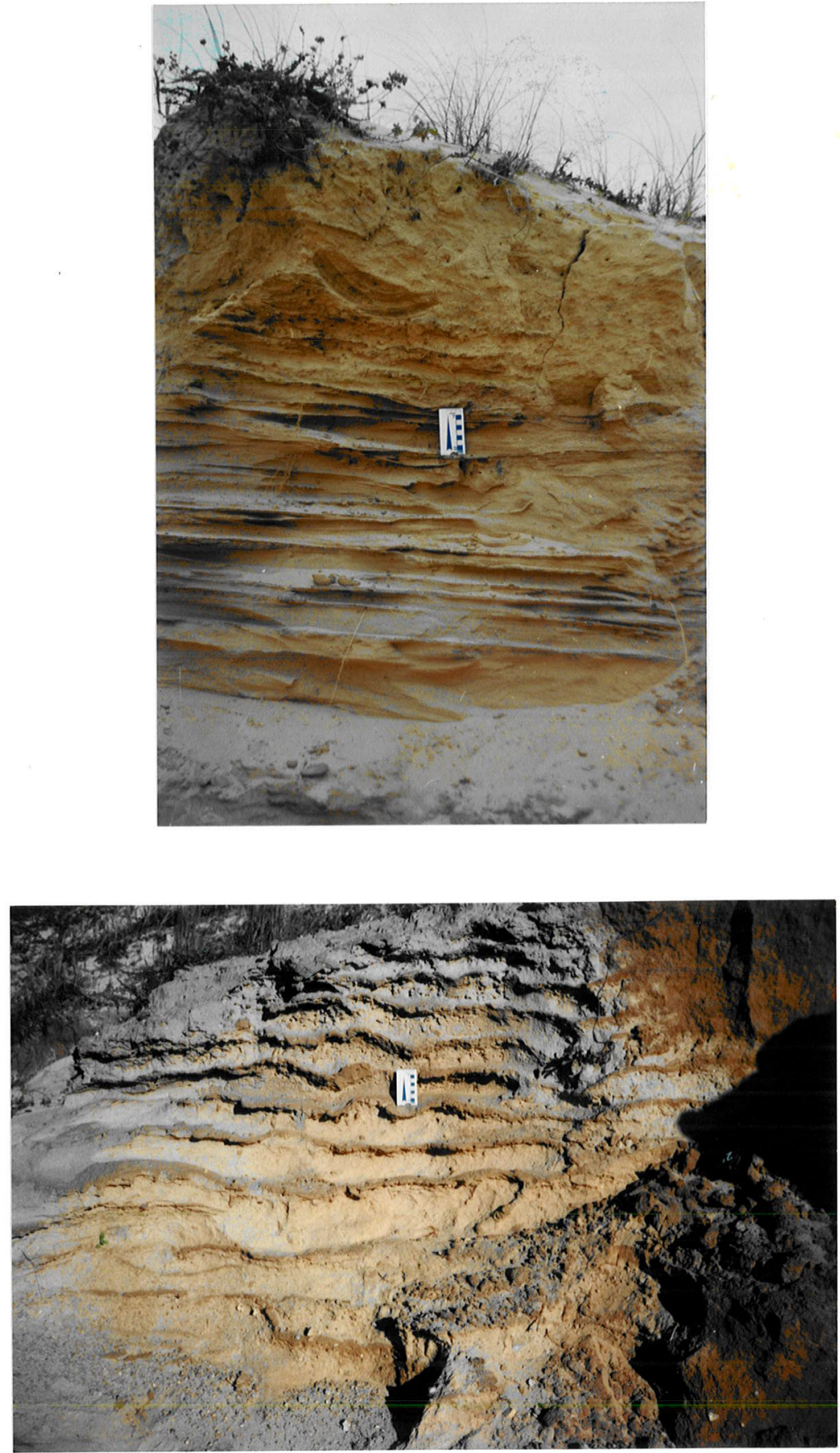

Figuras 5.105 e 5.106. Bandas de infiltraçăo em dunas de topo de encosta, geração 2 . 5.105 (superior). Bandas planares na ponta do Ji.

5.106 (inferior). Bandas contorcidas na ponta do Cravo. 


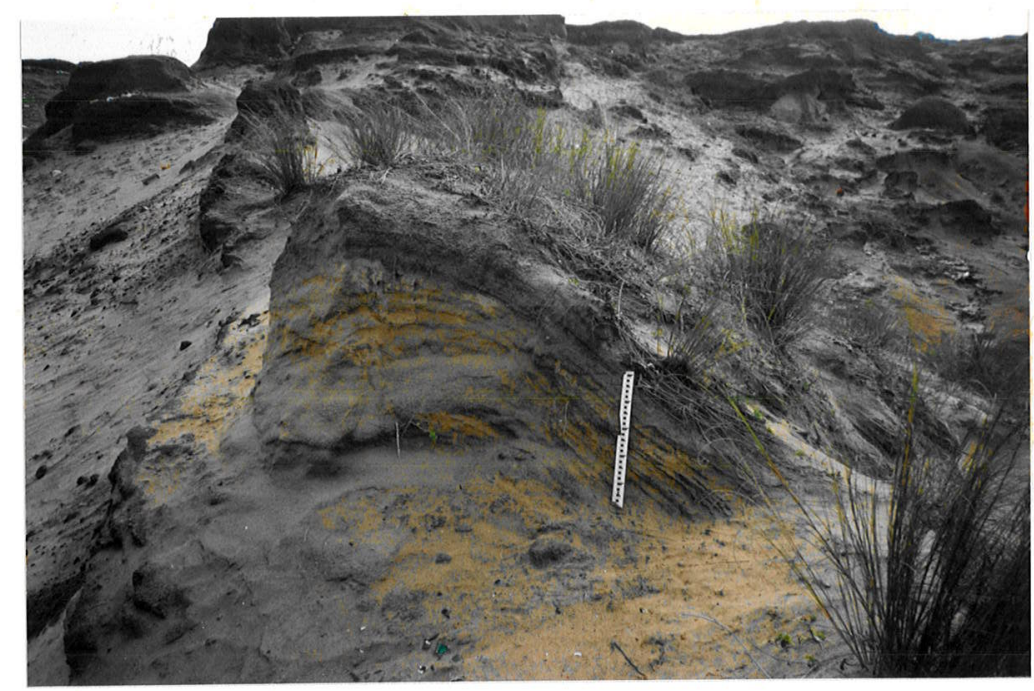

Figura 5.107. Bandas de infiltraçăo contorcidas acompanhando a superficie topográfica e com mergulho maior que o ángijlo de repouso de areia. Dunas de topo de encosta na ponta de Itapirubá. Escala: 50 $\mathrm{cm}$.

\subsection{Discussão genética}

Os niveis mais escuros das estruturas bandadas de infiltração teriam sido formadas, segundo Bigarella (1975a), no decorrer de episódios de dissipação, ainda que vários de seus aspectos, como a contorção, a presença de microfalhas e de tubos e mesmo algum enriquecimento adicional em colóides pudessem ter sido adquiridos em fase penecontemporânea (ou posterior?) à deposição. A influência da pedogênese, no entanto, é considerada pelo autor de importância subordinada; segundo ele, a quantidade de minerais pesados (potencialmente geradores de produtos de alteração coloidais) existente nas areias eólicas não seria suficiente para explicar o elevado teor de fração coloidal mineral impregnando os sedimentos; os colóides impregnantes seriam originados, portanto, da deposição primária ou de remobilização de argilas de colúvios e fluxos de lama, concentrando-se em superfícies de dissipação. Na área em estudo, essas sucessões de niveis escuros e claros alternam areias com contrastes de grau de consolidação tênues ou proeminentes; neste último caso, as bandas escuras formam crostas nodulares mais resistentes à erosão, com enriquecimento aparente em hidróxidos de ferro elou manganês e matéria orgânica. Estes bandamentos, assim como a maioria das estruturas mencionadas, ocorrem melhor desenvolvidos nos sedimentos da unidade 2. Nas paleodunas da unidade 1, o bandamento, quando presente, é obliterado pela cimentação ferruginosa homogênea. Na unidade 4, observou-se apenas um caso de formação local de crostas incipientes, no morro Santa Marta Grande. Distribuição estratigráfica análoga de estruturas foi encontrada por Bigarella (1975a) em duna de topo de encosta no morro da Joaquina, na llha de Santa Catarina (figura 6.1). Bandas de impregnação formando crostas nodulares foram também observadas fora de dunas de topo de encosta, em depósitos de geração 2 sobre a porção interior do sistema planície costeira, entre a cidade de Laguna e o ponta de Cabeçuda. Em superficie, as areias desta localidade destacam-se das vizinhas, pela sua cor amarela, semelhante à encontrada com freqüência na parte superior da 
unidade 2 em dunas de topo de encosta. Há aparente continuidade geomorfológica entre esses cordões dunares parabólicos de areia amarela e os de areia cinza claro.

Existem dois aspectos a discutir-se na interpretação dada por Bigarella (1975a) a suas "estruturas de dissipação": a origem por descaracterização morfológica pluvial, com introdução essencialmente singenética de material coloidal, e a implicação de paleoclima mais árido. Com relação ao primeiro aspecto, a participação das chuvas na remodelagem de dunas de topo de encosta e rampas de areia é observada na área em estudo hoje em dia; ela ocorre de dois modos: através de enxurradas em lençol, que espalham os sedimentos das porções superiores da duna em direção à base das rampas de areia, na forma de leques coaiescidos de pequena espessura; e através de enxurradas confinadas em ravinas erosivas, no interior das quais se têm concentrações de minerais pesados e detritos grossos. Produtos do primeiro mecanismo, observados em dunas recentes (4), são lentes delgadas (<20 cm) e extensas, com base indistinta e de geometria regular, constituidas de areias mais grossas ou cascalhosas que as areias eólicas subjacentes. Depósitos com estas características são encontrados no interior da unidade 2 (figura 5.103). Produtos do segundo mecanismo são canais preenchidos profundos $(>20 \mathrm{~cm})$, com base irregular marcada por sedimentos grossos e pesados. Depósitos correspondentes são observados no interior da unidade 2 e na superfície de separação entre as unidades 1 e 2 (figuras 5.101 a 5.103). Deve-se distinguir entre a forma abrupta dos canais no contato entre as unidades 1 e 2 , e a forma arredondada comum aos paleocanais do interior da unidade 2; esta diferença pode ser atribuida a contrastes no grau de consolidação prévia do sedimento escavado pelo canal (item 5.4.1.1).

Com base na distribuição de estruturas relacionadas à dissipação, conclui-se que os mesmos tipos de processos pluviais que influem na morfodinâmica dunar atual influíram também durante a deposição da unidade 2 . Estruturas como brechas e falhas intraformacionais ou deformações de sobrecarga e liquefação ocorrem nas proximidades ou no interior de lentes e canais e estão ligadas a estes mecanismos de dissipação pluvial, como admitido por Bigarella (1975a,b). Outras, e em particular os bandamentos de impregnação, não possuem mesmas relações, pelo menos tão evidentes. Cabe, portanto, analisar sua origem.

Para discutir-se a origem das bandas de impregnação, convém dividi-las em dois grupos: no primeiro, incluem-se as bandas coincidentes com superfícies primárias de descontinuidade física, como fundos de paleocanais (figuras 5.101 e 5.102), planos de truncamento de $2^{a}$ e $3^{a}$ ordem (figura 5.103 e 5.105) e niveis de bioturbações; o segundo grupo é o das bandas lenticulares contorcidas (figuras 5.106 e 5.107), sem relações geométricas evidentes com superfícies primárias. Na interpretação de Bigarella (1975a), ambos resultam em essência da acumulação ou infiltração de colóides trazidos em suspensão nas águas pluviais e originados do manto intempérico de rocha cristalina. Esta hipótese é possivel no primeiro grupo, ainda que o mecanismo não deva ser considerado como obrigatório ou essencial; a evidência foi encontrada no flanco interior (oeste) do morro Santa Marta Grande, onde a lavagem de colóides ferruginosos oriundos do regolito de rocha granitóide e de paleodunas de geração 1 , situados na parte superior do afloramento de rampa de areia, forma crostas submilimétricas impregnando superficies encobertas ou expostas de dunas recém-formadas. Bigarella (1975a) associa a maioria dos bandamentos contorcidos do segundo grupo a sucessões de lentes de fluxo de areia, intercaladas 
com filmes de material coloidal. Entretanto, a geometria típica do fluxo de areia não se encontra preservada em nenhum afloramento. Além disso, verifica-se, em vários locais, que a morfologia geral destas bandas acompanha a superfície topográfica, sem apresentar relação aparente com estrutura primária (figura 5.107). Outra evidência da gênese secundária das bandas onduladas escuras é sua ocorrência mesmo em dunas sem obstáculo fixo, onde inexistem fontes próximas para o fornecimento primário de material coloidal. Origem pedogênica tem sido atribuída a estruturas similares em sedimentos depositados em outras condições, como as "bandas onduladas" descritas por Suguio \& Coimbra (1976) na "Formação Bauru" da Bacia do Paraná. Com base neste conjunto de evidências, supõe-se que a concentração pedogenética de colóides possua caráter essencial na formação dos bandamentos de impregnação da unidade 2 , e que a relação entre as superficies com concentração preferencial e superfícies primárias de dissipação não tenha caráter obrigatório, como já defendido por Yaalon \& Fränzle (1975). Se as variáveis que controlam a geometria das bandas não são conhecidas senão de modo aproximado, esta é uma regra válida para estruturas nodulares de modo geral (Collinson \& Thompson 1982).

O segundo aspecto a se discutir na interpretação de Bigarella (1975a,b) é o das "estruturas de dissipação" enquanto indicadoras de paleoclima. A maioria das estruturas cuja origem primária é evidente (primeiro grupo) encontra-se em formação nas condições atuais, sob influências dos mecanismos de dissipação. Até mesmo o caráter ondulado das bandas contorcidas do segundo grupo parece estar associado à deformação de lâminas nas vizinhanças de canais erosivos, como observado em sedimentos atuais (item 5.4.2.5.1). As estruturas de corte, desbarrancamento e redeposição em leques na base de canhões erosivos de drenagem pluvial têm sido descritos em formação também em outras regiões, sejam semi-áridas, como em paleodunas pedogeneizadas da Nigéria (Talbot \& Williams 1978), sejam úmidas, como em paleodunas da costa leste da Austrália (Pye 1983a). Conclui-se que a formação de tais estruturas erosivas é dependente da existência de encostas abruptas, condição comum em paleodunas de topo de escarpa, e não da manifestação de clima seco. Resta examinar se sua preservação também independe do clima. De acordo com Pye (1983a), a preservação destas estruturas no registro geológico requer o seu soterramento subseqüente por dunas eólicas. Como o cavalgamento de paleorrampas dissecadas por dunas atuais é observado em várias pontões costeiros da região, o soterramento parece não depender também de clima semi-árido. A influência do clima na facilidade de formação e preservação de "estruturas de dissipação", e portanto em sua quantidade no registro geológico, nem por isto pode ser descartada. Dois possiveis reflexos desta influência é a abundância de estruturas produzidas por enxurrada na unidade 2, em contraste a sua escassez nas unidades 1 e 4 , e a ocorrência preferencial de pavimentos de ferricrete naquela mesma unidade. Têm-se assim indicios de maior sazonalidade na precipitação durante a deposição da unidade 2. Na unidade 1, a mistura homogênea de materiais eólicos e coluvionares, característica já destacada por Bigarella (1975a), é sugestiva da ocorrência de fluxos gravitacionais e pode ser interpretada como evidência de chuvas bem distribuídas no tempo. 
Medidas de atitude em crostas de bandamento de impregnação planares foram realizadas na unidade 2 aflorante em ravinas de drenagem, nas rampas de sotavento de dunas de topo de encosta nas pontas da llhota e do Ji. Os planos medidos ocorrem dentro de diferentes seqüências de lâminas, separados entre si por superfícies amplas de $2^{a}$ ordem (figura 5.84). Estendem-se assim por toda a camada delimitada entre superfícies de $2^{a}$ ordem; em vista disto, mesmo um pequeno número de medidas ( $>7$ ), como o realizado na ponta da llhota, pode ser considerado confiável para efeito de tratamento estatístico, se for usado o critério modificado de Fernandes 1992 (item 2.5.6). Cabe ressalvar, no entanto, que, por indisponibilidade de exposições, as medidas tomadas na ponta da llhota limitaramse à parte sudeste da rampa de sotavento.

As rosáceas obtidas (figura 5.100) indicam mergulhos preferenciais para SE, na ponta da llhota, e grande variação ao largo do hemisfério sul, com concentração em WSW, na ponta do Ji. Os ângulos de inclinação média são baixos $\left(7^{\circ}\right)$, e valores máximos, em torno de $20^{\circ}$, concentram-se nos azimutes modais. Interpreta-se que as superficies medidas correspondem a porção inferior de rampas de avalancha em draas com "sliface" (caso A na figura 5.54). Esse modelo explica o baixo ângulo de mergulho das laminações. A dispersão dos azimutes na ponta do Ji é atribuida ao controle exercido pelo obstáculo fixo (morro cristalino) na geometria do fluxo aéreo e das avalanchas. A rampa de sotavento teria a forma de um leque alongado (parabólico) influenciado pelo efeito de sombra, com estratificações dispersando-se, por cerca de $180^{\circ}$, em torno do azimute dos ventos prevalescentes (WSW). O padrão de dispersão assim obtido não é muito diferente do padrão característico da frente de um grande lençol parabólico (Bigarella 1975a). Na ponta da Ilhota, a concentração de planos com mergulho para SE deve-se à posição do afloramento estudado, restrita à parte sudeste da rampa. Acredita-se que uma amostragem melhor distribuída de medições ao longo da secção transversal à rampa eólica nesta localidade forneceria padrão de atitudes análogo ao encontrado na ponta do Ji.

\subsubsection{Granulometria}

\subsection{Associação de fácies depósitos mantiformes}

Com referência às análise granulométricas da associação depósitos mantiformes são apresentados resultados brutos (tabela A22), percentis e parâmetros de distribuição (tabela A23), resultados de regressão estatística (tabela A24) e gráficos de variação geográfica (figuras A42 a A44).

De modo geral, esta associação de fácies é caracterizada por areias finas, com quantidades subordinadas de areia muito fina e areia média. Na classificação nominal de Folk \& Ward (1957), têm-se areias finas com seleção muito boa, assimetria negativa a, predominantemente, positiva e curtoses plati e leptocúrticas.

Na comparação de valores médios entre gerações eólicas, a geração 2 destaca-se por seu elevado teor em areia média (12\%), apresentando também percentil $1 \%$ (P01), mediana (P50) e diâmetro médio mais grossos e pior 
seleção. Os sedimentos da geração 4 são os mais ricos em areia fina (93 \%), os melhor selecionados e os mais platicúrticos. Os sedimentos da geração 3 possuem P50, P01 e diâmetro médio mais finos e assimetria maior, o que se relaciona a seu teor relativamente elevado em areia muito fina (13\%). Estes resultados para geração 3 não podem ser considerados como significativos para comparação, uma vez que se baseiam em apenas três amostras, todas de subfácies frente parabólica, tipicamente constituida por areias muito finas.

As duas fácies da associação depósitos mantiformes na geração 4 diferem de modo significativo entre si quanto aos valores médios de diẩmetro médio e mediana. A diferença origina-se nas proporções de areia fina e muito fina. A fácies dunas frontais é mais pobre que a fácies manto de areia em areia fina $(91 \times 95 \%)$ e mais rica em areia muito fina $(8,5 \times 4,2 \%)$. Apresenta, além disso, maior variabilidade (desvio-padrão por classe textural). A granulometria mais grossa da fácies dunas frontais não é esperada se se considera seu caráter mais proximal. Duas explicações distintas podem ser sugeridas. A primeira é a de que a vegetação e os sais existentes nas dunas frontais teriam capacidade de reter preferencialmente as partículas mais finas, como é possivel supor com base no efeito que estas variáveis exercem na coesão e mobilidade dos grãos (Chepill \& Woodruff 1963 apud Friberger 1979; Nickling 1983; Sarre 1988; Smith 1988). A segunda explicação é a de que as areias de praias que contêm dunas frontais seriam, na área estudada, mais finas, hipótese pouco compativel com os resultados encontrados nas subfácies praiais de sistemas marinhos.

A comparação de granulometrias médias entre as três subfácies amostradas dentro da fácies manto de areia (geração 4) revela que a subfácies cadeias barcanóides concentra os maiores teores de areia grossa, areia média e areia fina (96,4\%), apresentando P01, P50 e diâmetro médio mais grossos. A subfácies frentes parabólicas é a de granulometria mais fina, em decorrência de seu teor relativamente elevado $(7,0 \%)$ de areia muito fina. É também a que apresenta maior concentração de silte. As dunas lineares possuem em geral caracteristicas intermediárias, exceto pelas assimetrias, que são as mais elevadas da fácies. O contraste grosso versus fino entre barcanóides e frentes parabólicas é compativel com o modelo de afinamento de granulometria rumo às subfácies distais. A exemplo do que se observou no parágrafo anterior em relação às dunas frontais, a subfácies mais próxima à praia, no caso dunas lineares transversais, é mais fina que uma subfácies vizinha ao interior, a de cadeias barcanóides. O efeito da salinidade retendo preferencialmente os grãos menores é mais uma vez uma explicação aceitável. De mesmo efeito decorreriam suas tendências para assimetrias mais positivas e curtoses menores

$\mathrm{Na}$ comparação de resultados médios de granulometria entre barlavento, crista e sotavento, encontram-se alguns aspectos comuns às três subfácies do manto de areia. A regra mais geral é o afinamento de diâmetro médio e P50 de barla para sotavento. O percentil P01 também afina no mesmo sentido nas subfácies barcanóides e frentes parabólicas. Grosso modo, estas tendências correspondem a aumento de areia muito fina e/ou a decréscimo de areias finas, média e grossa. O barlavento caracteriza-se pela pior seleção e a crista dunar por curtoses mais elevadas. As assimetrias caem de barla para sotavento nas subfácies dunas lineares transversais e frentes parabólicas, mas apresentam comportamento inverso nas cadeias barcanóides. A verificação geral da regra "mais fino, melhor selecionado e 
mais negativo" de McLaren \& Bowles (1985), de barla para sotavento, naquelas duas primeiras subfácies, é evidência do transporte resultante uniredicional no sentido do vento prevalecente; uma hipótese para explicar o padrão menos inequívoco de variação granulométrica intradunar na subfácies cadeias barcanóides é o caráter reverso (sensu McKee 1982) destas dunas. A reversão não se manifesta tão claramente na morfologia de dunas lineares e frentes parabólicas quanto nas uarcanóides, como já mencionado (item 5.4.2.5.4). Os resultados granulométricos encontrados aparentam refletir esta diferença. Uma razão possível é a menor mobilidade das areias em dunas lineares e frentes parabólicas. Nas dunas lineares, a impregnação por sais inais umidade de aerossol marinho tornaria a movimentação da areia por ventos temporários mais lenta. Nas frentes parabólicas, a cobertura vegetal nas laterais e na planície frontal às dunas diminuiria a carga de impacto dos ventos de SW, reduzindo sua capacidade de erosão.

Análise de regressão linear entre atributos granulométricos e a coordenada geográfica sul-norte em várias fácies e subfácies da associação depósitos mantiformes (tabela A.24) indica correlações mais significativas $\left(R^{2}>40\right.$ elou $p>95$ $\%$ ) para os parâmetros caudais assimetria e curtose. Tendências sul-norte de decréscimo de assimetria e/ou aumento de curtose foram detectadas nas fácies ou subfácies dunas frontais (barlavento, crista e sotavento), dunas lineares transversais (crista) e cadeias barcanóides (barlavento), como se vê nas figuras A42 e A43. Nas dunas frontais, as variações de assimetria e curtose são acompanhadas por tendências, a níveis de significado estatístico menor, para afinamento de diâmetro médio e aumento do grau de seleção. Verifica-se com isto um dos padrões de variação geográfica de granulometria de McLaren \& Bowles (1985), o "mais fino, melhor selecionado e mais negativo"; esta evidência de transporte rumo norte permite a interpretação de que a variação granulométrica ao longo das dunas frontais reflita a variação nas areias de praia adjacentes, como seria esperado. Desse modo, o padrão granulométrico sul-norte encontrado é uma decorrência da deriva litorânea longitudinal predominantemente dirigida para norte, como inferido no estudo de sistemas marinhos. $O$ resultado confirma também a idéia de que o efeito residual de transporte paralelo a praia pelo vento é pouco expressivo no caso de dunas frontais, pelo menos em escala interpraial.

\subsubsection{Associação de fácies dunas e lençóis parabólicos}

Com relação às análises granulométricas da associação dunas e lençóis parabólicos, apresentam-se resultados brutos (tabela A29), percentis e parâmetros da distribuição de freqüências (tabela $A 30$ ), resultados de regressão estatística (tabela A31) e gráficos de variação geográfica (figuras A51 a A53).

A associação é caracterizada por sedimentos com classe modal dominante em areia fina ( 56 a $99 \%$ em massa), contendo teores muito variáveis de areia média (até $41 \%$ ), areia muito fina (ate $29 \%$ ) e pelíticos (até $9 \%$ ). Na classificação nominal de Folk \& Ward (1957), têm-se areias finas com seleção muito boa a moderadamente boa em distribuição lepto a platicúrtica. A assimetria é muito variável, mas o valor médio por agrupamento faciológico indica o predomínio de distribuições quase simétricas.

Da geração eólica mais antiga (2) para a mais nova (4), observam-se tendências médias para decréscimo nos teores de areia grossa, areia 
média e pelíticos e para aumento nos teores de areia fina e areia muito fina; percentis P50 e P01 e diâmetros médios afinam com a redução da idade, o desvio-padrão decresce e assimetrias e curtose analítica aumentam. Os sedimentos da unidade 3 destacam-se dos demais pelos teores médios mais elevados de areia grossa $(1,2 \%)$ e areia média $(10 \%)$ e pela escassez relativa de areia fina $(79 \%)$ e areia muito fina $(3,9$ $\%)$. Apresentam a assimetria média mais negativa. Os resultados comparativos entre as três gerações estudadas podem ser atribuídos ao efeito de afinamento seletivo progressivo através das sucessivas fases de atividade eólica. Os sedimentos grossos contidos nas dunas mais antigas foram preferencialmente retidos na drenagem que dissecou estas dunas, liberando-se em direção à costa e portanto à área-fonte de dunas mais novas apenas os sedimentos mais finos. Neste modelo, a granulometria relativamente grossa da unidade 3 amostrada indica sua relação genética com sedimentos de gerações eólicas mais velhas e reforça a hipótese anteriormente aventada (item 5.4.1.1) de que se trata de horizonte pedológico das unidades 1 e 2.

Os sedimentos da subfácies formas parabólicas com obstáculo

fixo são, em termos de resultados granulométricos médios, mais grossos, pior selecionados e mais leptocúrticos que os da subfácies formas parabólicas sem obstáculo fixo. Estas diferenças, observadas tanto na geração 3 quanto na 4 , decorrem do enriquecimento relativo das rampas de areia e dunas de topo de encosta em sedimentos da fração areia média, o que pode ser atribuido ao aporte de material de origem coluvionar através de enxurradas e fluxos de massa. $O$ valor médio relativamente grosso de P01 nos depósitos com obstáculo fixo relaciona-se assim com sua grande proximidade em relação à rocha-fonte, nesses processos.

Da comparação entre resultados médios de crista, barla e sotavento dentro de diferentes subfácies, a única tendência comum a todas elas é a de granulometria mais grossa no barlavento. O desvio padrão, quando variável, também é maior no barlavento.

Tendências de variação sul-norte a confiabilidades estatísticas elevadas ( $R^{2}>40 \%$ elou $p>95 \%$ ) foram encontradas ao longo de depósitos das três gerações amostradas. As tendências mais comuns são para engrossamento da granulometria (figuras A51 e A52), decréscimo nas assimetrias (figuras A51 e A53) e aumento nas curtoses (figura A53). Estas tendências podem ser atribuídas a aumento de aporte de sedimentos preexistentes (pleistocênicos), mais grossos e negativos, na parte norte da área estudada.

\subsection{Associação de fácies eólica indiferenciada}

Com referência às análises granulométricas da associação eólica indiferenciada são apresentados resultados brutos (tabela A36) e percentis e parâmetros de distribuição freqüencial (tabela A37).

De modo geral, os sedimentos incluidos neste grupo são areias finas com quantidades subordinadas de areia muito fina e areia média, e presença freqüente de fração pelítica e areia grossa. $\mathrm{Na}$ comparação de características médias entre as gerações 1, 2A e 2 e a unidade 3 , a unidade 3 e a geração 1 destacam-se pelos maiores teores de areia grossa e muito grossa, pela presença mais comum de grânulos, por diâmetro médio e P50 mais grossos, pelos maiores valores de desvio padrão e curtose e pelas menores assimetrias analíticas. A geração 1 destaca-se ainda por seu teor elevado em pelíticos (14\%), enquanto a 
unidade 3 distingue-se pelo P01 mais grosso na distribuição areia. A geração $2 \mathrm{~A}$ é a mais rica em areia fina. Possui, além de os valores mais finos de P01 e P50, os maiores de assimetria e os menores de curtose, desvio-padrão e teor em pelíticos. A geração 2 ocupa em geral classificações granulométricas intermediárias entre as demais. É a mais rica em areia média.

As características granulométricas da unidade 3 , bastante distintas das da geração 3, permite admitir que não há correlação entre ambas, hipótese a ser melhor verificada através de minerais pesados. Na comparação entre as unidades $3 / 1$ ( 3 sobre 1) e $3 / 2$ ( 3 sobre 2 ), observa-se que a primeira é mais rica que a segunda nas fraçōes areia grossa e muito grossa, reproduzindo sob este aspecto a relação que existe entre as gerações 1 e 2 . Este fato é mais uma evidência a favor da hipótese de que a unidade 3 amostrada, é antes um solo sobre sedimentos de unidades antigas que uma unidade deposicional independente.

A granulometria fina e bem selecionada da geração $2 A$, admitida em hipótese de trabalho como mais antiga que a geração 2 (item 5.4.1), contraria a regra geral de afinamento e aumento de seleção com a queda da idade, verificada em outras associações de fácies eólicas e marinhas. Seus sedimentos são em média bastante mais finos também que os da geração 2 nas demais associações eólicas, mesmo quando se consideram exclusivamente as fácies sem obstáculo fixo. Quanto à distribuição granulométrica bruta, a geração $2 \mathrm{~A}$ é mais próxima das gerações 3 e 4 que das gerações eólicas mais antigas. A variação intradunar de características granulométricas médias nesta geração é compativel com a regra geral: afinamento de diâmetro médio e P50 de barla para sotavento. Esta tendência associa-se a decréscimo de areia fina e aumento de areia muito fina.

O confronto, quanto a valores médios de granulometria, entre crostas $e$ intercrostas de bandamento de impregnação na unidade 2 permite reconhecer, como principais diferenças, os maiores teores, nas crostas, de cascalho, areia muito grossa, areia média e pelíticos. Estas diferenças implicam em diâmetro médio, P50 e P01 mais grossos nas crostas. Quando as amostras de crosta e intercrosta de cada ponto de amostragem são comparadas independentemente entre si, observa-se que na maioria $(80 \%)$ dos casos não existem diferenças significativas de distribuição granulométrica entre elas. Este fato confirma que a associção das crostas a superfícies primárias de dissipação e de deposição de material coluvionar, embora possivel, não pode ser admitida como regra geral. Cabe ressaltar que das cinco amostras de bandamento coletadas, a única com bandas planares, e que foram interpretadas no campo como superfícies primárias, é também a única com contraste acentuado de granulometria entre crosta e intercrosta na fração areia. Esta amostra (E54C(2)) foi coletada na paleorrampa da areia da ponta do Ji, na mesma exposição de bandamento em que se fizeram medidas de atitudes (item 5.4.3.1.3). A concentração de detritos grossos ao longo de uma parte de seus planos de impregnação é sugestiva da ação de enxurradas em lençol, aplainando e depositando material misto coluvionar-eólico sobre as formas de leito da paleorrampa. A concentração de grossos, por este processo, é maior nas superfícies mais marcantes e extensas, interpretadas como sendo de $2^{a}$ ordem. 


\subsubsection{Mineralogia}

\subsection{Minerais pesados}

\subsection{Associação de fácies depósitos mantiformes}

Os teores em massa de minerais pesados na fração areia muito fina (tabela A.25) variam de 0,6 a $26 \%$, nos depósitos de geração 2 , e de 0,4 a $20 \%$, nos de geração 4; os teores máximos de minerais pesados magnéticos são de $1,8 \%$ e $0,6 \%$, respectivamente. Na fração não magnética, a freqüência de contagem de minerais transparentes não micáceos oscila entre 26 e $45 \%$, na geração 2, e entre 26 a $80 \%$, na geração 4 (tabela A26). Dentre estes, zircão, turmalina, rutilo, estaurolita, pistachita, cianita e sillimanita são minerais correntes em todas as amostras estudadas da geração 2, enquanto apenas zircão, turmalina, estaurolita e hornblenda ocorrem em todas as amostras da geração 4. Zircão é o único mineral, em ambas as gerações, que chega à categoria quantitativa de predominante $(>50 \%)$. Na geração 2, turmalina e estaurolita variam entre comuns e abundantes (5-50\%). Dos demais minerais só chegam a ocorrer como comuns (5-20\%), nessa mesma geração, rutilo, pistachita e cianita; outros minerais, encontrando-se como raros e/ou escassos (< $5 \%$ ), são: leucoxênio/anatásio, granada, hornblenda, hiperstênio, andalusita e alteritos. $\mathrm{Na}$ geração 4, atingem a abundância em algumas amostras turmalina, estaurolita, pistachita e hornblenda. Chegam a ser comuns leucoxênio/anatásio, rutilo, cianita, sillimanita, hiperstênio e alteritos. Granada, augita, pigeonita e tremolita variam entre raros e escassos, e zoisita, apatita, titanita, enstatita e andalusita ocorrem exclusivamente como minerais raros. A maior diversidade mineralógica da geração 4 é um dentre vários indícios de sua maturidade química relativamente baixa, o que pode ser atribuido a menor efeito de dissolução intraestratal.

Outras diferenças entre as duas gerações eólicas analisadas apresentam-se evidentes através da comparação entre seus respectivos valores médios. A geração 2 apresenta teores médios de minerais pesados mais elevados, seja na fração magnética $(0,3 \times 0,1 \%)$, seja na não magnética $(9,5 \times 3,6 \%)$. É também mais rica, quanto a freqüências de contagem (tabela A26; figura 5.108) em opacos, zircão $(45 \times 23 \%)$ e rutilo $(6 \times 3 \%)$, além de apresentar valores mais elevados para todos os indices de maturidade mineralógica estudados (figura 5.109). A geração 4 é mais rica em minerais metaestáveis e instáveis como pistachita $(13 \times 5 \%)$ e hornblenda $(17 \times 4 \%)$ e nos produtos da alteração destes minerais(alteritos: $3 \times 2 \%$ ). É mais rica também em turmalina $(19 \times 13 \%)$, o que pode ser explicado por duas hipóteses; instabilidade diferencial de turmalina, em relação a zircão e rutilo, à dissolução intraestratal, ou fornecimento recente preferencial de mesmo mineral.

A comparação entre fácies dunas frontais e manto de areia, na geração 4, revela ser a primeira pouco mais rica em minerais pesados magnéticos e em opacos $(51 \times 46 \%)$. As freqüências de contagem de minerais transparentes não micáceos também indicam forte semelhança entre as fácies. 

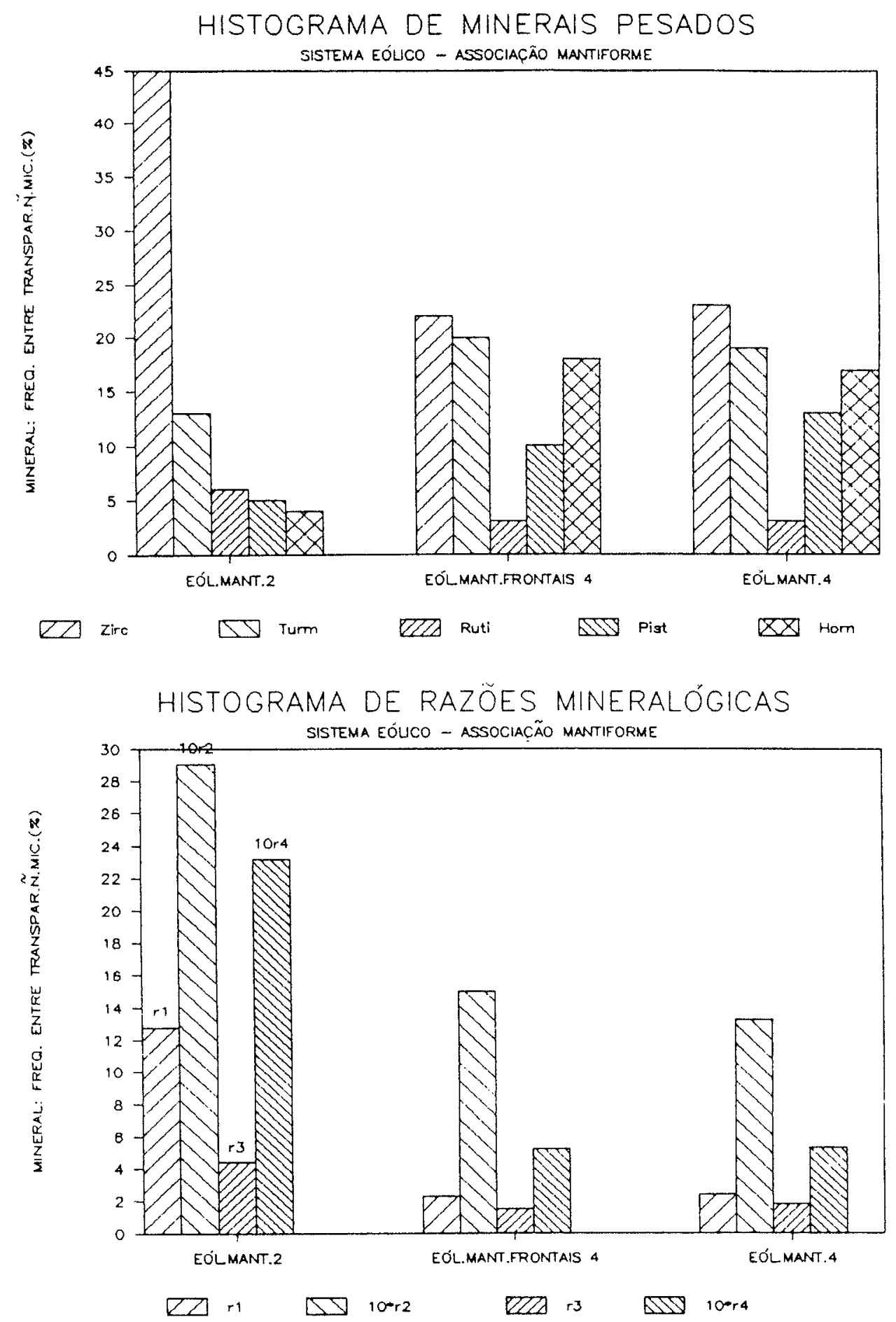

Figura 5.108 e 5.109. Comparaçăo entre sedimentos de diferentes geraçర̃es eólicas, na associação de fácies depósitos mantiformes.

5.108 (superior). Histograma de frequeencias percentuais médias de minerais pesados.

5.109 (inferior). Histograma de razões mineralógicas médias.

Quando se confrontam as mineralogias médias das três subfácies amostradas dentro da fácies manto de areia, variações tornam-se mais evidentes. Teores em massa de minerais pesados magnéticos e não magnéticos atingern seu máximo nas dunas lineares transversais. Freqüências de contagem de 
opacos, zircão e estaurolita são maiores nas frentes parabólicas e menores nas cadeias barcanóides. Turmalina apresenta comportamento inverso e hornblenda encontra-se mais concentrada na subfácies dunas lineares transversais. Considerando-se que dunas lineares e barcanóides apresentam subfácies proximais do manto de areia eólica, e que as frentes parabólicas são sua subfácies distal, a variação descrita de mineralogia pode estar relacionada a uma eliminação gradual pelo transporte eólico dos minerais menos estáveis.

As variações intradunares de mineralogia média são em geral pequenas e de significado duvidoso. As variações mais significativas sào encontradas na subfácies dunas lineares transversais, onde a face de barlavento distingue-se de crista e sotavento pela maior concentração em componentes de densidade relativamente elevada como minerais pesados (teor em massa), opacos e zircão (freqüências de contagem). No campo, pode-se observar a concentração temporária de minerais pesados na face de barlavento de dunas lineares e barcanóides (figura 5.110).

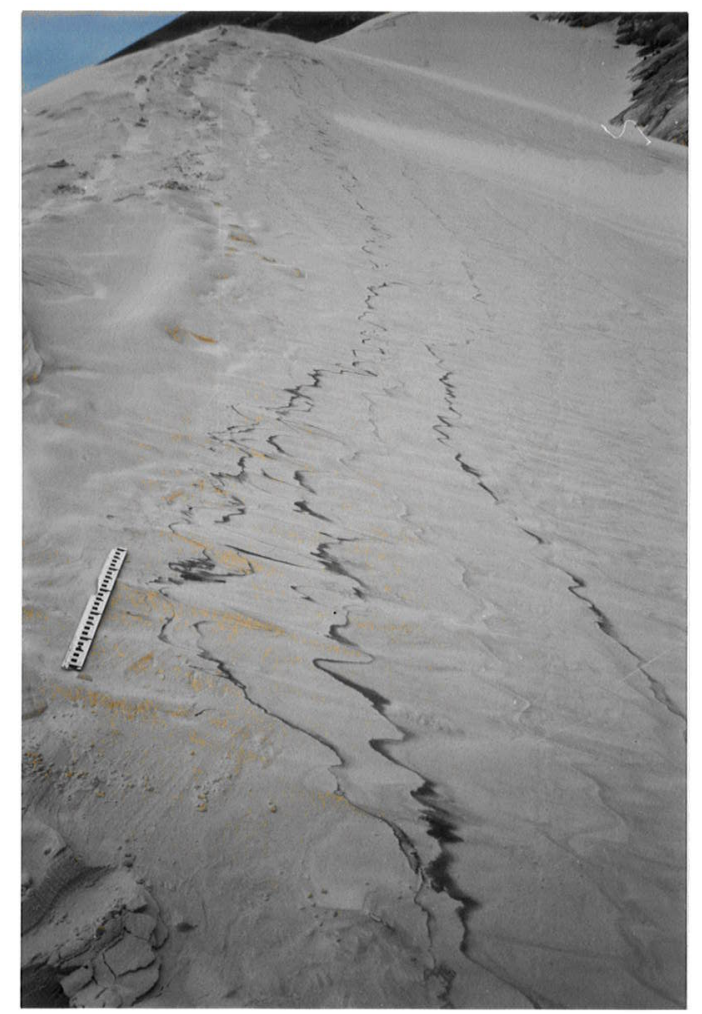

Figura 5.110. Concentraçס̃es superficiais de minerais pesados na face de barlavento temporária (reversa) de cadeia barcanóide.

Tendências de variação sul-norte de mineralogia a niveis de correlação estatística linear mais significativos ( $R^{2}>40 \%$; $>95 \%$ ) verificam-se nas subfácies do manto de areia na geração 4 (figuras A47 a A49). As tendências são de difícil interpretação devido a distribuição das amostras por longa área, supondo-se que reflitam mais a complexa variação de mineralogia nas áreas fontes praiais ao longo dos sistemas barra-barreira e planicie costeira que o efeito de transporte por ventos prevalescentes rumo SW. Uma evidência disso são as tendências quase comuns para aumento de concentração de minerais instáveis rumo norte, ambas relacionadas à 
deriva litorânea e ao acréscimo da contribuição de áreas fontes pleistocênicas e paleozóicas neste rumo

\subsection{Associação de fácies dunas e lençóis parabólicos}

Os teores em massa de minerais pesados na fração areia muito fina (tabela A32) variam de 0,6 a $11 \%$, nas gerações 2 e 4 , e atingem $25 \%$, na geração 3 representada na região de Imbituba. O teor máximo de minerais pesados magnéticos também se encontra na geração 3 e é de apenas 0,33\%. Na fração magnética, a freqüência de contagem de minerais transparentes não micáceos oscila entre 24 e $74 \%$, registrando-se os valores mais baixos em sedimentos da geração 2 e os mais altos na geração 4 (tabela A33). Dentre estes minerais, os que ocorrem em todas as amostras estudadas são zircão, turmalina, rutilo, estaurolita, pistachita, cianita e sillimanita. Zircão é o único mineral a ocorrer como predominante (> $50 \%)$, nas gerações 2 e 3 . Chegam a ser abundantes (20-50\%) turmalina, em todas as gerações, pistachita e hornblenda, nas gerações 3 e 4 , e estaurolita, apenas na geração 3. Atingem no máximo a categoria de minerais comuns $(5-20 \%)$ rutilo, cianita e sillimanita, em todas as gerações, leucoxênio-anatásio e estaurolita, nas gerações 2 e 4, e pistachita, na geração 2. Restritos às categorias de minerais escassos e raros (s $5 \%$ ), encontram-se alteritos, em todas as gerações, granada, nas gerações 2 e 3 , hiperstênio e augita, nas gerações 3 e 4, hornblenda e andaluzita na geração 2, titanita, na geração 3 , e pigeonita, na geração 4 .

$\mathrm{Na}$ comparação entre assembléias mineralógicas médias das três gerações estudadas, observam-se tendências para decréscimo nas quantidades de minerais opacos, zircão, rutilo e índice ZTR da geração mais antiga para a mais nova. Tendências inversas ocorrem com pistachita, hornblenda e indice INS (tabela A33; figura 5.111). Todas as razões de maturidade mineralógica diminuem com a redução da idade da geração, exceto $r 2$, que na geração 4 é pouco maior que na geração 3 (figura 5.112). Essas tendências permitem supor que 0 efeito de retrabalhamento sucessivo de sedimentos preexistentes, cuja existência foi admitida com base em resultados granulométricos, não prevalece, no âmbito da mineralogia, sobre o efeito da dissolução pós-deposicional. Vale lembrar, em apoio a esta hipótese, que pesquisas recentes de Morton \& Smale (1990) sugerem que a eliminação de minerais pesados instáveis por transporte mecânico é um processo modificador de mineralogia de importância muito subordinada em comparação com mecanismos de dissolução química, ao contrário do que se supunha em trabalhos clássicos

Na comparação entre fácies da geração 3, observa-se ser a fácies formas parabólicas em média mais rica em minerais pesados, zircão e estaurolita que a fácies depósitos residuais de deflação. Apresenta também índice ZTR e razões de maturidade mineralógica mais elevados. Estas diferenças podem ser atribuídas a duas causas possiveis: a primeira é um suposto enriquecimento das fácies mais distais em minerais resistentes ao transporte; a segunda, mais provável ou importante, é o fato de a fácies formas parabólicas estar preferencialmente representada na região de imbituba, cujos sedimentos-fonte são previamente enriquecidos em minerais ultraestáveis e opacos. 


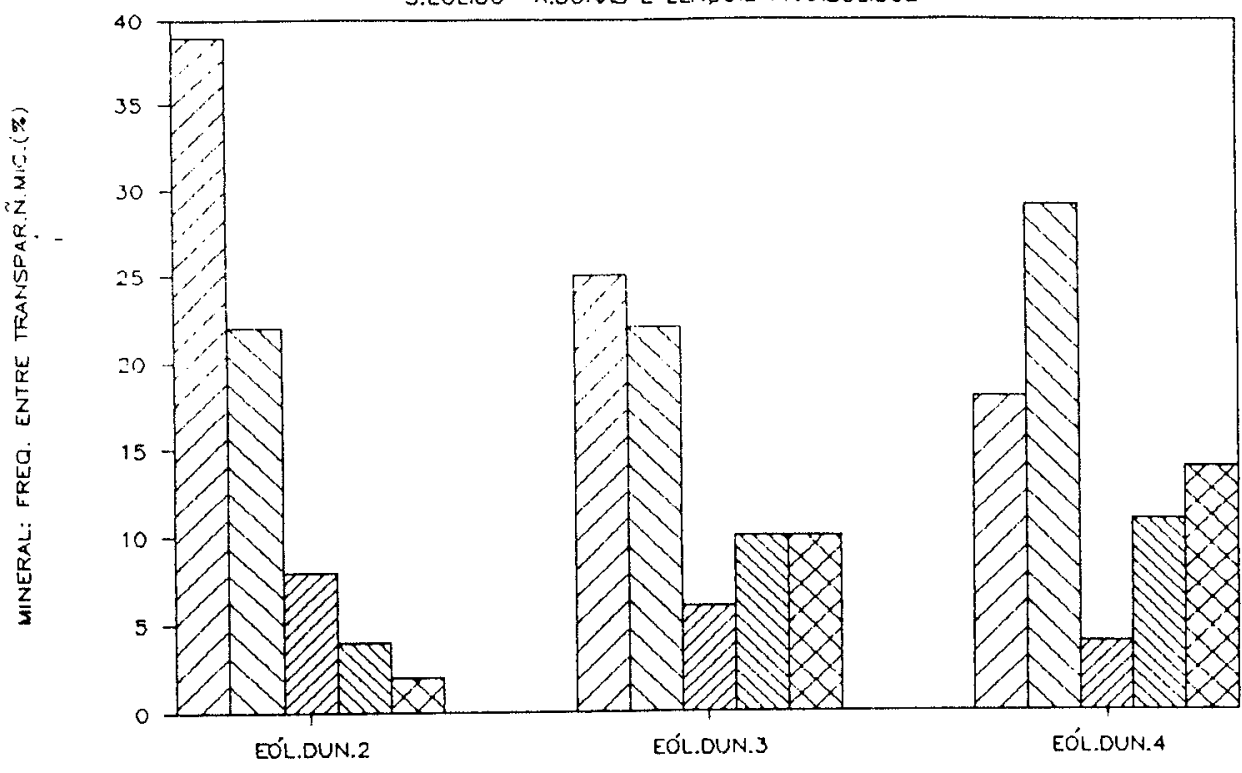

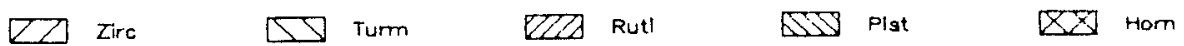

HISTOGRAMA DE RAZÕES MINERALÓGICAS

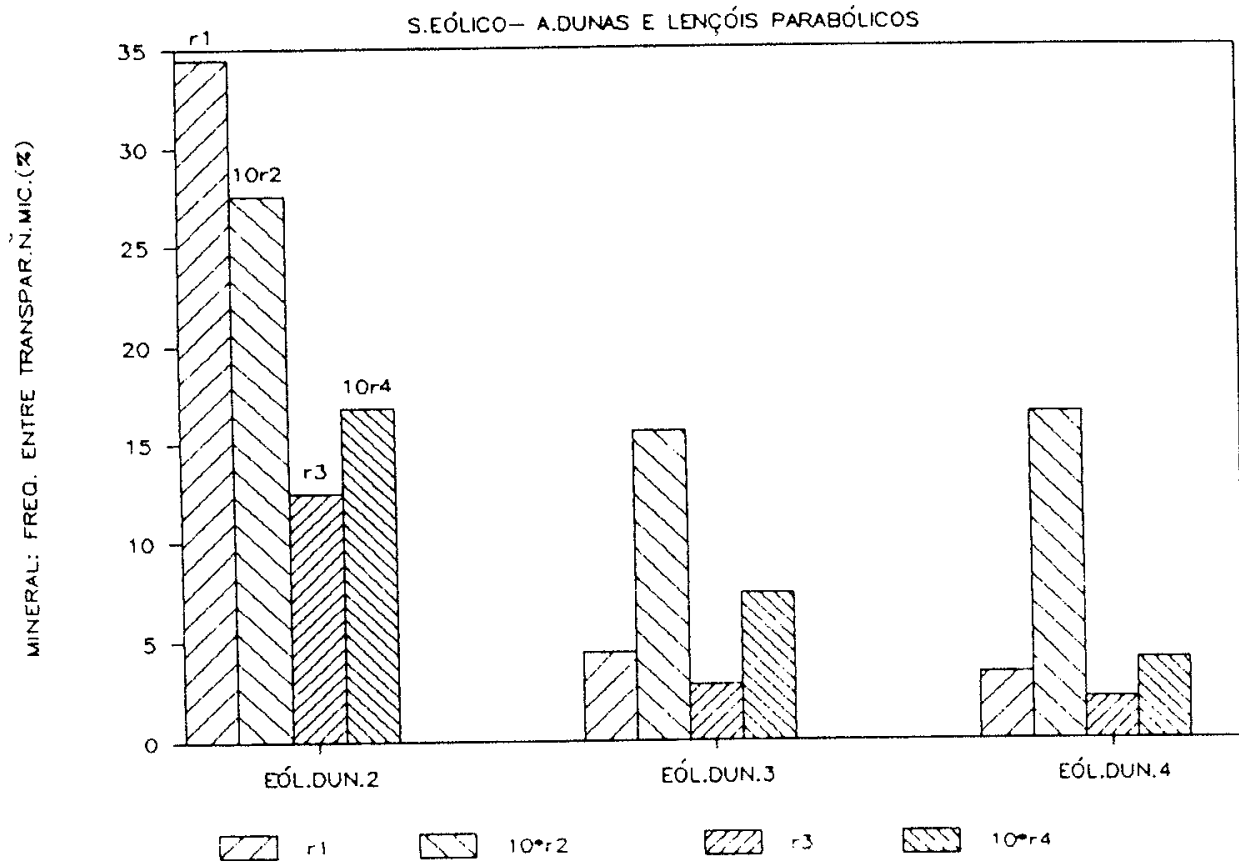

Figura 5.111 e 5.112. Comparação entre sedimentos de diferentes geraçס̃es eólicas na associaçăo de fácies dunas e lençóis parabolicos.

5.111 (superior). Histograma de freqüencias percentuais médias de minerais pesados.

5.112 (inferior). Histograma de razóes mineralógicas médias.

Dentro da fácies formas parabólicas da geração 3 , a comparação entre as subfácies com e sem obstáculo fixo indica ser a primeira mais rica em minerais pesados, zircão e estaurolita e mais pobre em cianita, pistachita e hornblenda. 
As únicas correlações estatísticas lineares com coordenadas geográficas sul-norte a niveis de confiança elevados ( $p>95 \%$ ) ocorrem ao longo dos depósitos pertencentes à geração 2 (figura A54). Freqüências de contagem de zircão e indice ZTR tendem a aumentar rumo norte, enquanto os valores de freqüencia de pistachita e índices MET e INS apresentam comportamento inverso. Estas tendências imitam as que são observadas ao longo das praias do sistema planície costeira, devendo portanto refletir a influência da proveniência sedimentar imediata.

\subsection{Associação de fácies eólica indiferenciada}

Os teores em massa de minerais pesados na fração areia muito fina (tabela $A 38$ ) variam de 2,3 a $39 \%$ na geração 1 , de 4,0 a $44 \%$ na geração $2 A$, de 5,6 a $23 \%$ na geração 2 e de 3,7 a $27 \%$ na unidade 3 . Na fração não magnética, a freqüência de contagem total de minerais transparentes não micáceos oscila entre 14 e $37 \%$, com maiores amplitudes na geração 1 (tabela A39). Zircão, turmalina, rutilo, estaurolita e cianita são minerais presentes em todas as amostras estudadas. Ȧiém destes, pistachita, sillimanita, hornblenda e alteritos ocorrem em todas as amostras da geração $2 \mathrm{~A}$, pistachita e cianita em todas as amostras da geração 2, e sillimanita em todas as da unidade 3 . Zircão é o único mineral a atingir a categoria quantitativa de predominante (>50\%), exceto na geração $2 \mathrm{~A}$. Atingem a abundância (20-50 \%) turmalina, na geração $2 \mathrm{~A}$ e na unidade 3 , e turmalina, estaurolita, pistachita e hornblenda, na unidade 2. Ocorrem ainda, na geração 1 , turmalina, leucoxênio/anatásio, pistachita, zoisita, sillimanita, granada, titanita, hornblenda, hipestênio e alteritos; na geração $2 \mathrm{~A}$, leucoxênio/anatásio, granada e hipestênio; na geração 2, apatita, sillimanita, granada, espinélio, hiperstênio, pigeonita e alteritos; na unidade 3, leucoxênio/anatásio, pistachita, granada, titanita, hornblenda, hiperstênio e alteritos.

As gerações 1 e $2 A$, além da diversidade mineralógica relativamente reduzida, têm em comum os teores médios em massa de minerais pesados magnéticos mais baixos e de não magnéticos mais altos (tabela A38). A geração 1 e a unidade 3 são as mais ricas em zircão, enquanto que a geração $2 A$ é a mais rica em turmalina (figura 5.113). Pistachita e hornblenda têm seus teores aumentados nas gerações supostamente mais novas. As razões de maturidade r1 a r4 tendem a decrescer no mesmo sentido (figura 5.114). Deve-se destacar que a unidade $3 / 2$ (3 sobre 2) é similar mineralogicamente à unidade 2, mas não apresenta afinidades com a geração 3 (figuras 5.115 e 5.116). Este padrão de variação da mineralogia média através das diversas gerações ou unidades da associação indiferenciada é reafirmativo do caráter de solo da unidade 3 amostrada. Além disso, dá indicação, ao contrário dos resultados granulométricos, de aproximação genética da unidade $2 \mathrm{~A}$ com as unidades mais antigas, 1 e 2 . Sendo a mineralogia de pesados mais apropriada para o traçado de correlações que a granulometria, considera-se fortalecida a hipótese inicial de idade da geração $2 \mathrm{~A}$ intermediária entre as gerações 1 e 2 .

Os resultados médios de mineralogia de crostas e intercrostas de bandamentos de impregnação são próximos entre si, apesar de um teor em massa de minerais pesados pouco maior nas bandas intercrostas $(14,4 \times 10,3 \%)$. A comparação entre crostas e intercrostas de cada amostra, uma a uma, não revela diferenças consistentes, além do teor total. As maiores amplitudes são encontradas nas freqüências de contagem de turmalina, a qual não apresenta, no entanto, 
tendência definida para enriquecimento em qualquer um dos dois tipos de bandas amostradas. Estes resultados não fornecem evidência segura de deposição primária diferencial, tampouco de efeito de dissolução pós-deposicional preferencial nas bandas intercrostas.

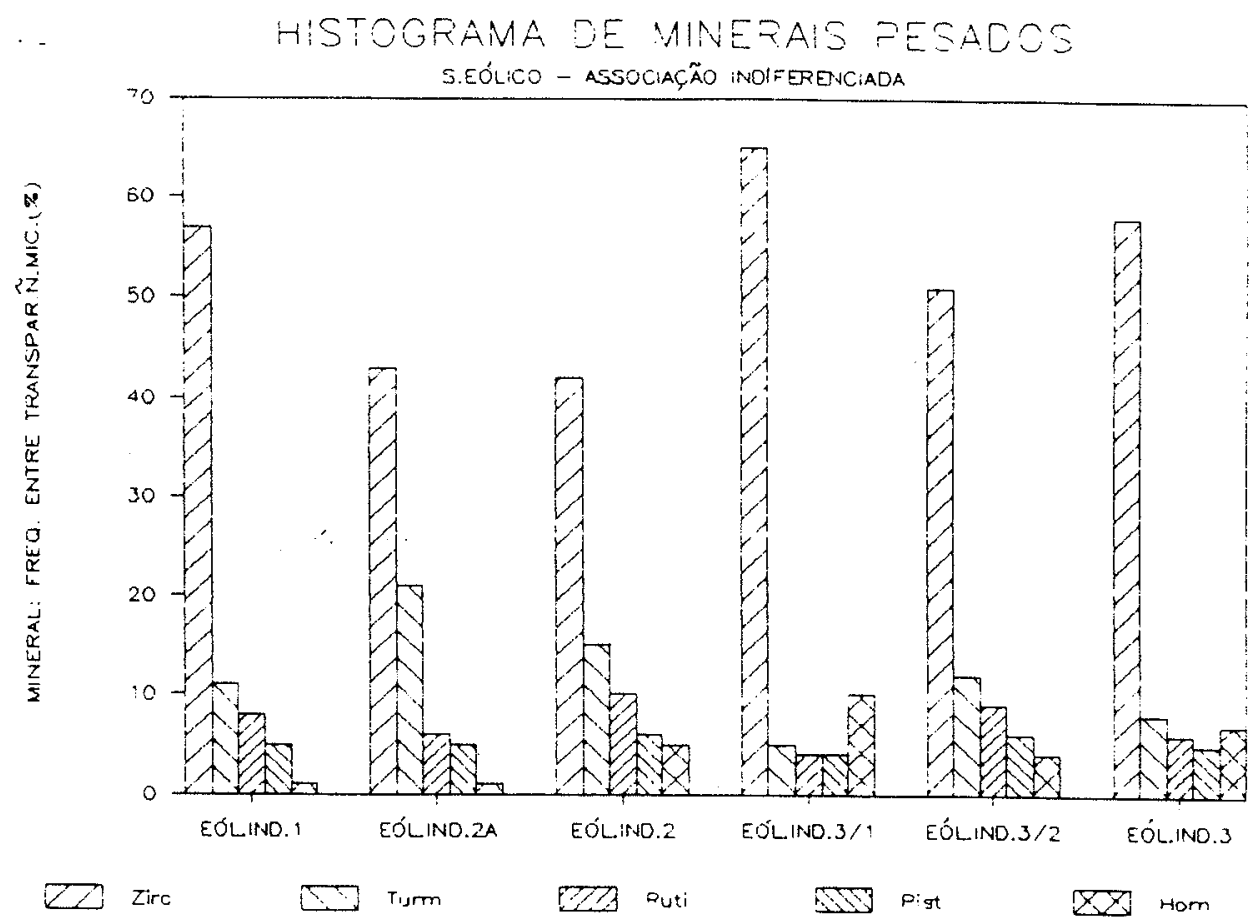

HISTOGRAMA DE RAZÕES MINERALÓGICAS S.EÓlICO - ASSOCIAÇÃO INDIFERENCIADA

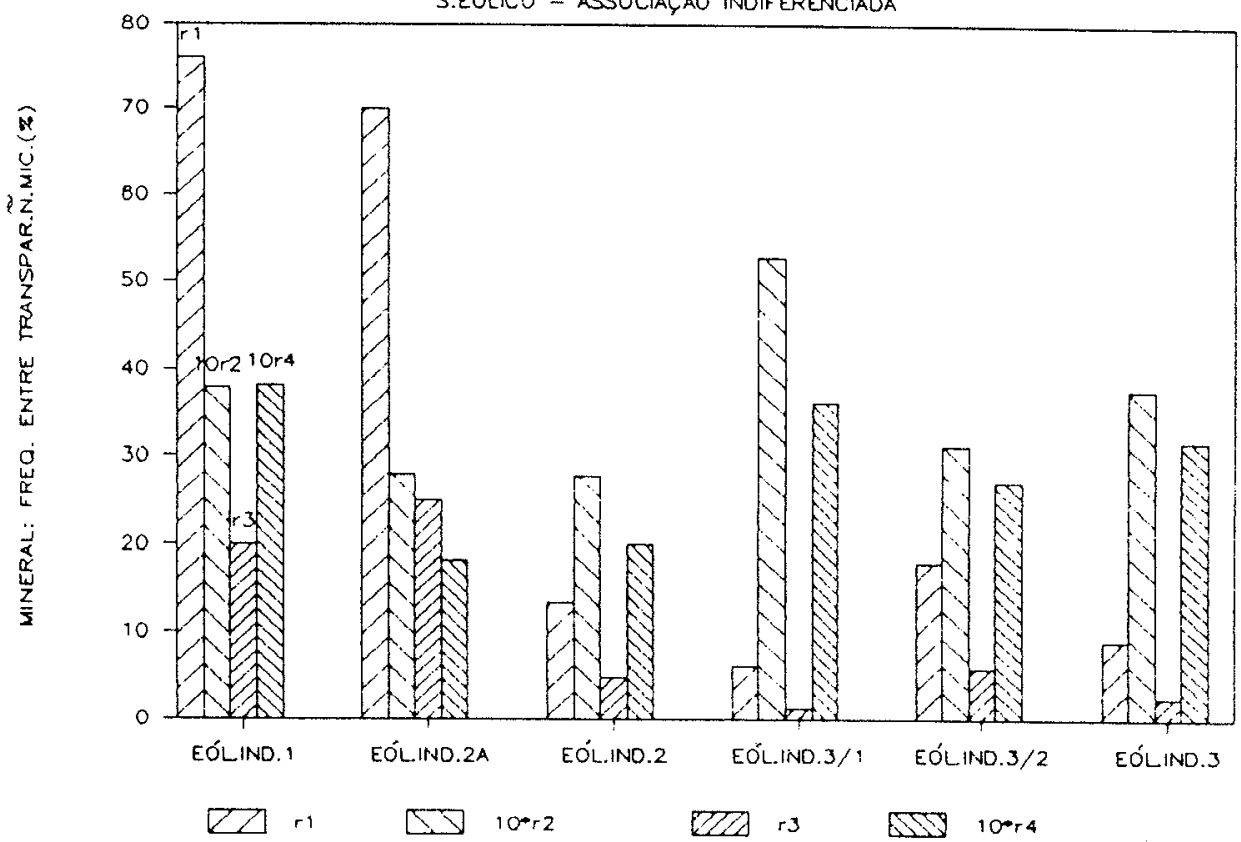

Figura 5.113 e 5.114. Comparação entre sedimentos de diferentes gerações eólicas na associaçào de fácies indiferenciada.

5.113 (superior). Histograma de freqüências percentuais médias de minerais pesados.

5.114 (inferior). Histograma de razões mineralogicas médias. 
HISTOGRAMA DE MINERAIS PESADOS

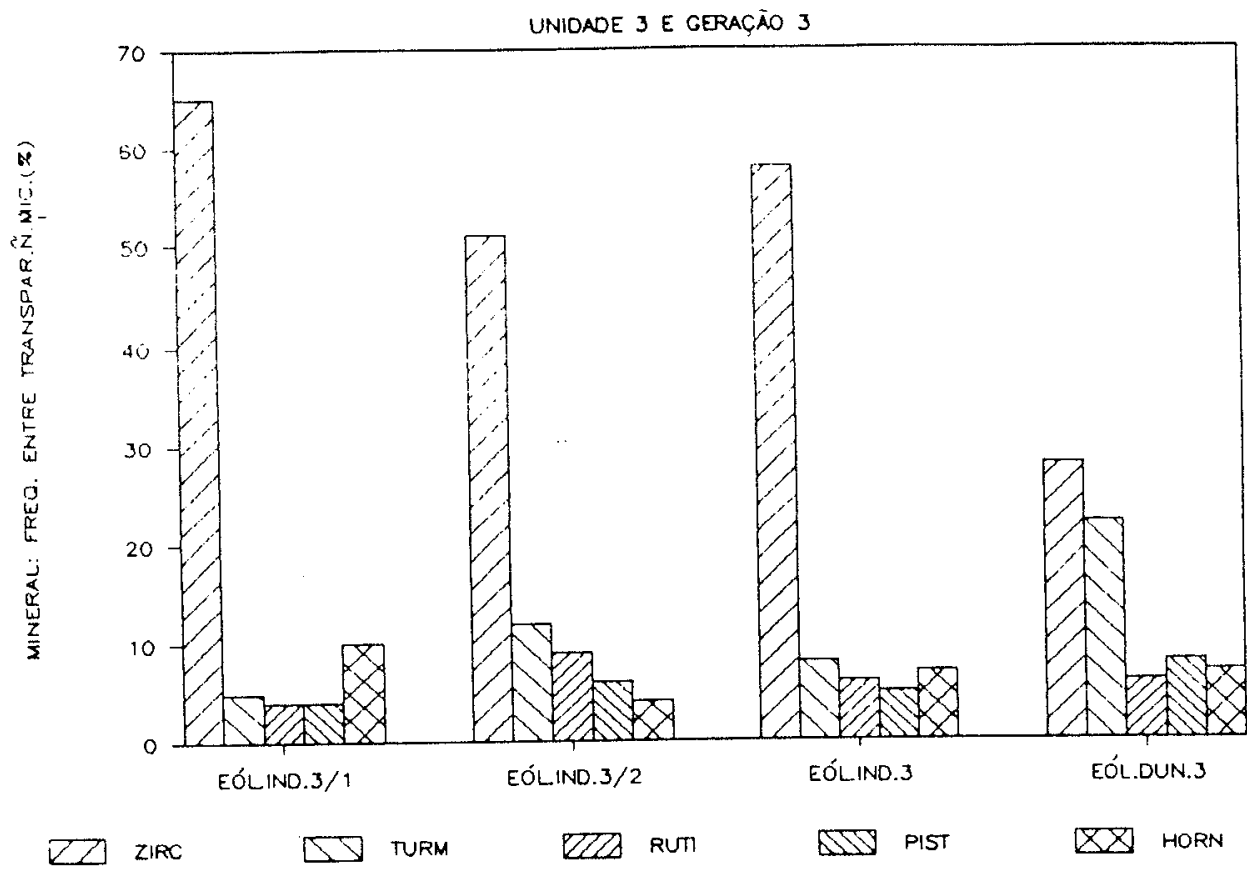

HISTOGRAMA DE RAZÕES MINERALÓGICAS GERACÁO 3 E UNIDADE 3

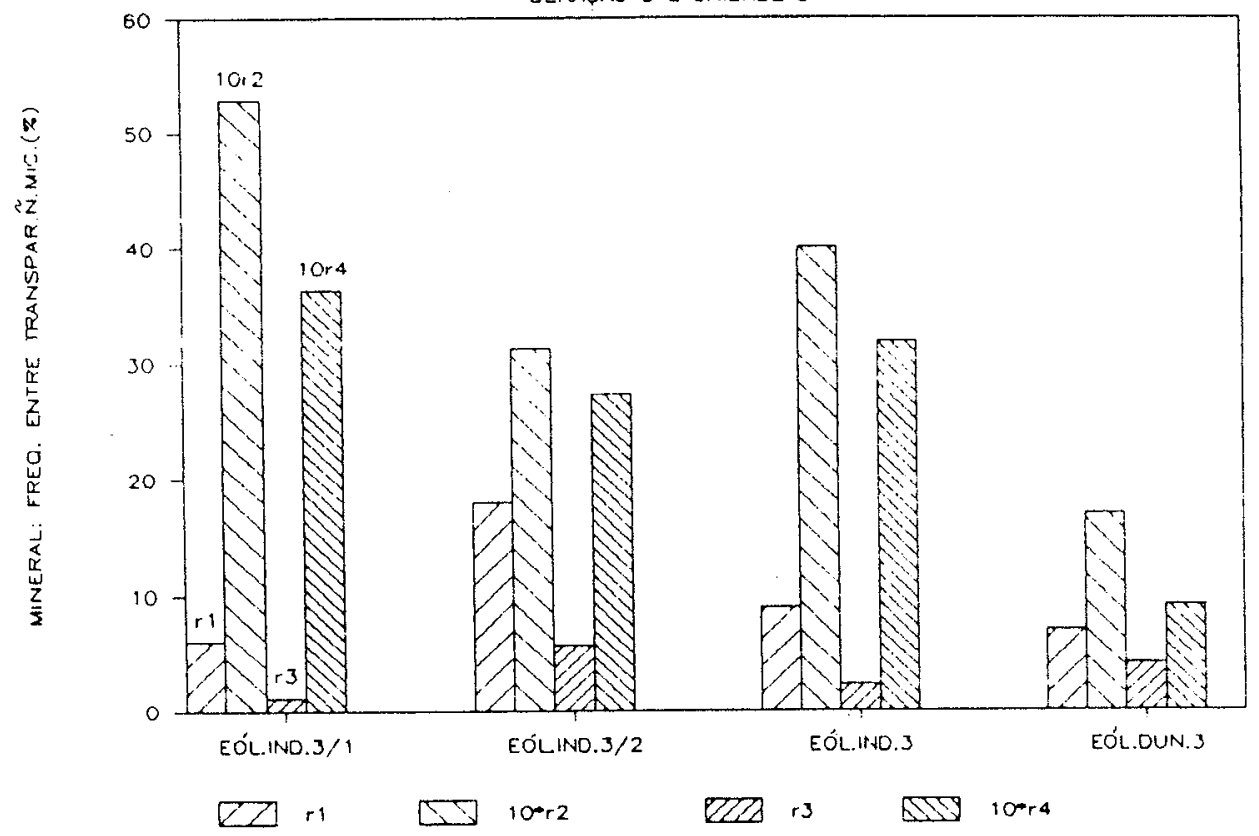

Figura 5.115 e 5.116. Comparação entre unidades faciológicas eólicas pertencentes a geração 3 ou unidade 3.

5.115 (superior). Histograma de frequéncias percentuais médias de minerais pesados.

5.116 (inferior). Histograma de razóes mineralógicas médias.

Estudos de análise estatística de regressão linear em relação à coordenada geográfica sul-norte indicam correlações elevadas $\left(R^{2}>40 \%\right.$ e/ou $p>95$ $\%)$ em sedimentos com bandas de impregnação em rampas de areia e dunas de topo 
de encosta (figura A56). A tendência geral é para aumento rumo norte da freqüência de minerais ultraestáveis. Interpreta-se este padrão de variação como reflexo do aumento da importância de sedimentos pleistocênicos marinhos e eólicos da geração 1 , enquanto fonte para a sedimentação eólica da geração 2 .

\subsection{Impregnação em minerais leves e a cor nos sedimentos eólicos}

A cor é um critério auxiliar de campo na identificação da geração eólica (figura 5.117). Determinação de teor em massa de grãos de quartzo com impregnação superficial foi feita em 19 amostras de fração leve de sedimentos eólicos, representativas das principais gerações ou unidades (tabela 5.13). Os resultados podem ser divididos em duas ordens de grandeza distintas, a exemplo do que se obteve nos sistemas marinhos e lagunares. Os teores mais baixos, oscilando entre 0,1 e 1,4\%, ocorrem em sedimentos de paleodunas, enquanto os mais elevados, variando desde 1,7 até 2,6 \%, encontram-se em areias de dunas ativas. Diferenças menores, entre médias com desvio-padrão amostral relativamente grande e portanto de significado geológico duvidoso, foram encontradas entre as várias gerações de paleodunas. Os teores de grãos impregnados em crostas e intercrostas de bandamento de infiltração são próximos entre si. A exceção ocorre na amostra coletada na paleorrampa da ponta do Ji (E54C(2)), cujo bandamento possui origem primária, pelo menos em parte; neste caso, o teor em massa de grãos impregnados nas crostas corresponde ao dobro do teor nas intercrostas $(1,0 \times 0,5 \%)$.

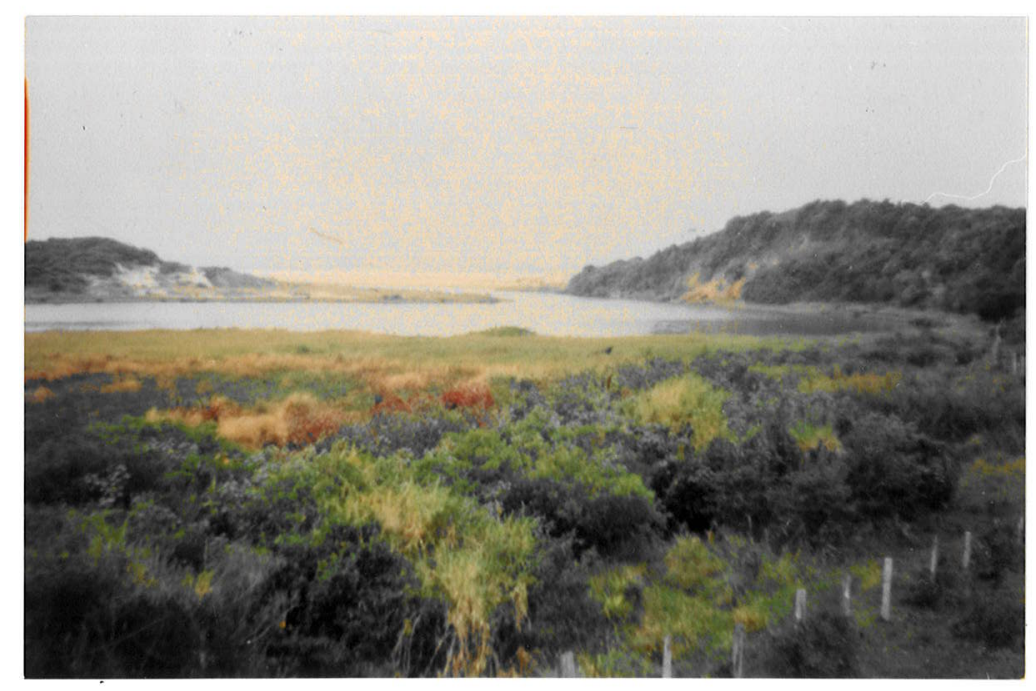

Figura 5.117. Contraste de cor entre duas gerações eólicas em margens opostas do arroio Paes Leme, Imbituba. A sul (direita), dunas avermelhadas da geraçăo 2; a norte, dunas esbranquiçadas da geraçăo 3. 
Tabela 5.13

Resultados de ensaio de analise agnetoetrica a Separador Isodinàcico frantz e de estudo de iepregnaçäo superticial de gräos

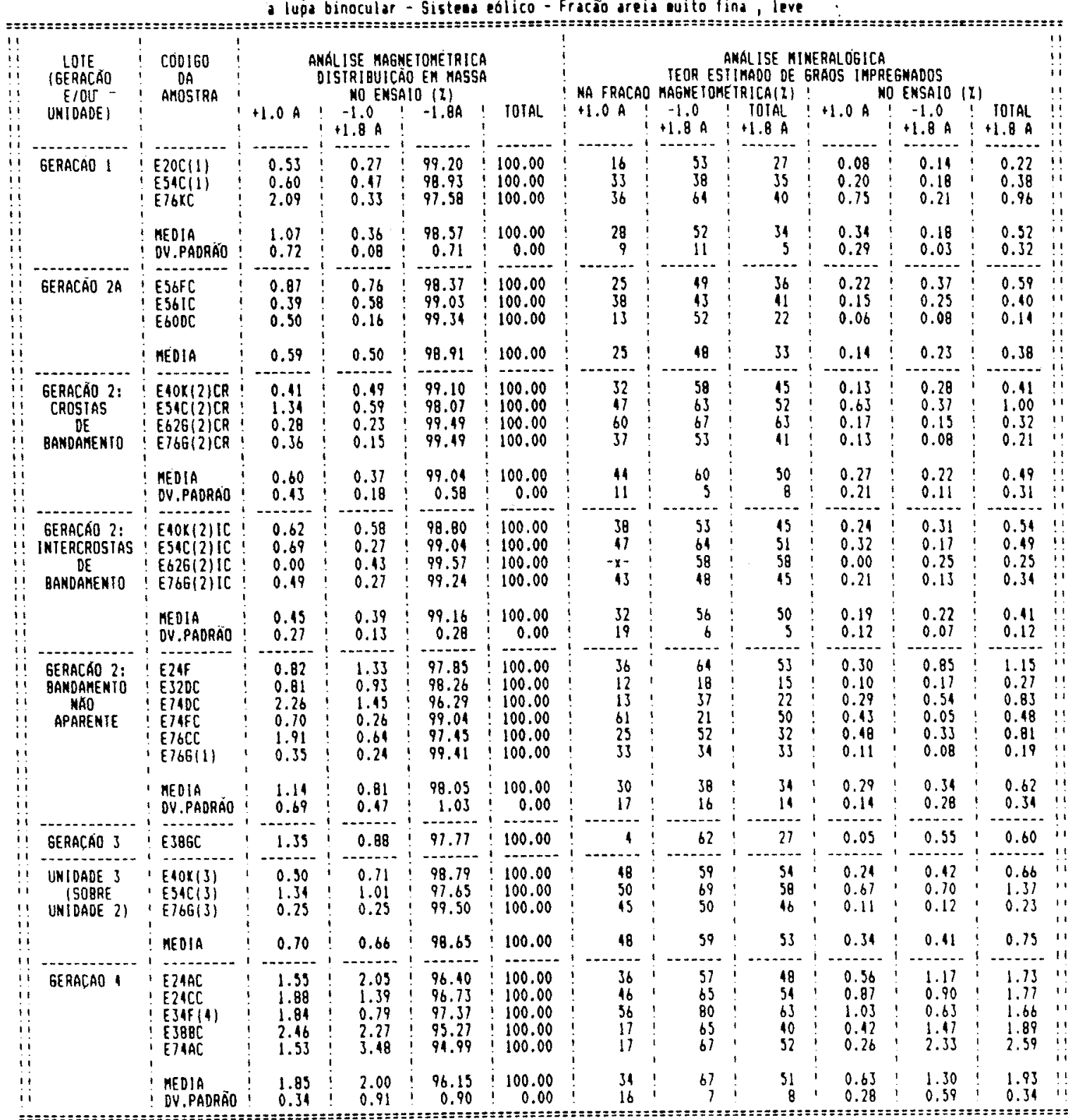

Obs.: notacio adotada para produtos de eagnetocetria: $+n$ A $=$ atraido em $n$ A i

$\mathrm{Na}$ interpretação de resultados de estudo de impregnação superficial em outros sistemas deposicionais (itens 5.2.3.2.2. e 5.3.3.3.2), duas hipótese foram cogitadas para explicar a origem e distribuição de grãos impregnados. A primeira hipótese, de que estes grãos seriam fornecidos preferencialmente por sedimentos "novos", recém-saídos do manto intempérico de granitóides, é compativel com o aumento de teor nas crostas da paleorrampa do $\mathrm{Ji}$, nas quais a maior presença de fragmentos líticos e feldspato indica contribuição de rocha cristalina próxima. A segunda hipótese, de que as águas vadosas ácidas teriam participação na eliminação química da película impregnante, também não pode ser refutada com base nos resultados obtidos no sistema eólico: o menor teor de grãos impregnados em dunas de 
geração 4 pode ser atribuido a presença de uma película salina, com efeito protetor, nos grãos de areia destas dunas (Smith 1988).

Os resultados de estudos de impregnação superficial em sedimentos tanto marinhos como eólicos indicam que as areias mais puras, do ponto de vista textural, e que são também as de colorações mais claras, possuem as maiores concentrações de grãos com impregnação ferruginosa. Este fato permite supor que os óxidos e hidróxidos de ferro que pigmentam os sedimentos antigos em tons de amarelo, vermelho e pardo (Pye 1983a) ocorram neste caso na forma de partículas livres, tendo ligação fraca ou ausente com a superficie dos grãos. Embora faltem dados de espessura $\epsilon$ teor de ferro nas películas impregnantes de diferentes amostras, que respaldem melhor esta suposição, há evidências de campo e laboratório que the dão reforço. No campo, verifica-se com freqüência a dispersão de pigmento avermelhado de dunas de geração 1 por águas pluviais, formando sulcos de escorrimento no fundo de ravinas de drenagem. Em laboratório, observa-se, durante a elutriação de areias de paleodunas, a rápida eliminação do material pigmentante por água corrente. No caso de amostras de manto intempérico de rochas cristalinas, esta eliminação, cm contraste, é sempre lenta e parcial.

A partir de estudos prévios de diversos autores, pode-se afirmar que a cimentação e a pigmentaçāo em paleodunas quaternárias ocorrem de pelo menos três modos diferentes: 1) pela infiltração de argilas oriundas do manto intempérico do embasamento, transportadas por águas pluviais (Folk 1969,1976; Bigarella 1975a; Walker 1979); 2) pela alteração diagenética autóctone de minerais metaestáveis contendo ferro, como magnetita, hornblenda e augita (Williams \& Yaalon 1977 apud Pye 1983a; Walker 1979; Pye 1983a); 3) pela herança, da área-fonte, de grãos previamente impregnados (Bessler 1976 apud McKee 1982; Wasson 1983). Nas paleodunas da área em estudo, é provável a ocorrência dos três tipos de processos. 0 terceiro é responsável em parte pela impregnação superficial profunda dos grãos de areia. Esta impregnação não é suficiente, entretanto, para explicar a grande quantidade de material ferruginoso pelitico e coloidal em muitas paleodunas, em especial na geração 1. Parte deste material ocorre como preenchimento intersticial livre, devendo ter-se originado pelos dois primeiros processos. O processo 1 tem influência evidente em superficies de avalancha pluvial de rampas de areia atuais, devendo ter ocorrido também durante a construção de paleodunas. O processo 2 é função do tempo (Wasson 1983) e sua ocorrência é evidenciada pelo aumento de cor e cimentação nas unidades mais profundas e antigas. Dentro da unidade 2, este aumento ocorre de modo gradual, como já fora observado por Bigarella (1975a) em depósitos correlacionados da llha de Santa Catarina. Por esta razão, as bandas de impregnação gradam em profundidade para areias escuras com pigmentação mais homogênea. Entre as unidades 2 e 1, o aumento de cimentação é brusco e às vezes marcado por superficie erosiva. Não parece possivel que só o processo 1 tenha sido suficiente para produzir as mudanças de cor tanto bruscas quanto graduais como sustenta Bigarella (1975a). Além disso, o argumento, por ele utilizado para refutar a influência do processo 2 , de que o conteúdo de minerais pesados das paleodunas é irrisório para justificar toda sua pigmentação, não é válido, pelo menos para a área em estudo: teores médios de minerais pesados de 8 a $12 \%$, com máximo de $39 \%$, são encontrados na fração areia muito fina das gerações 1 e 2 (tabelas A25, A32 e A38); deve-se lembrar que se trata de teores residuais, pois há evidências de dissolução intraestratal intensa 


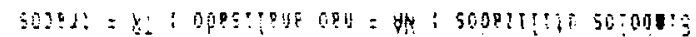

\begin{tabular}{|c|c|c|c|c|c|c|c|c|c|c|c|c|c|c|}
\hline SiA & ; & $\vdots$ & $i$ & $\vdots$ & & i & $\vdots$ & & i & & & & ' & 1: \\
\hline $\begin{array}{l}\because 50 \\
\because 50\end{array}$ & $\begin{array}{ll}1 & i^{\circ} \\
1 & i 81\end{array}$ & $\begin{array}{l}2 \cdot 2 \\
\vdots 2\end{array}$ & $\vdots<2$ & $\vdots 5$ & $6 \%$ & i 0.001 & $i$ & 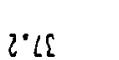 & 1 & 8.29 & $\vdots$ & $\begin{array}{c}\text { Oyyayd AS36 } \\
\text { OIIJW }\end{array}$ & & $\stackrel{i}{i i}$ \\
\hline $11 \quad \ldots$ & $i$ & $i$ & i & $i$ & & $i$ & $i$ & & 1 & & $i$ & & 1 & ii \\
\hline$\because 20$ & $12 \hbar$ & $i\{1$ & ～ & $i$ & H & $i 0.001$ & i & HN & 1 & H & $i$ & $(5) 99(3)$ & & ii \\
\hline$\because 00$ & 10.62 & 110 & ； & $i \theta$ & $\forall N$ & 0.001 & i & HN & 1 & $H$ & $i$ & (c) J653 & & ii \\
\hline$\because \because$ & 1691 & $i t^{\circ} l$ & $i 0.6$ & $i b$ & fi & 10.001 & i & lis & $i$ & $6^{\circ} \mathrm{st}$ & 1 & [s/gos\} & $i$ & ii \\
\hline$\therefore 0$ & $10^{\circ} L$ & 110 & i & $i$ & WN & 10.001 & $\vdots$ & 故 & $i$ & 㖶 & $i$ & $94(c)$ not & & "1 \\
\hline$\therefore 60$ & is.2i & $i 6.9$ & $i 1$ & $i$ & fis & $i 0.001$ & i & $\{02$ & $i$ & $l \circ b l$ & $i$ & (E) $\operatorname{dir}\{]$ & & \\
\hline$\because 0.0$ & i 6.21 & i 10 & i & $i 5$ & Hil & $i 0.001$ & $i$ & HN & i & 为 & $i$ & $(\varepsilon) 302\}$ & $\varepsilon$ & ii \\
\hline 50 & $\therefore 5 \%$ & $i 8.5$ & $!$ & ! & & 0.001 & $\vdots$ & & $\vdots$ & & $i$ & $\forall I 034$ & & ii 25 \\
\hline$i$ & 1 & 1 & i & i & & i & i & & $i$ & & 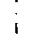 & & $\vdots$ & ii \\
\hline$\therefore \varepsilon 0$ & $i q$ & i 9.6 & $i 9.8$ & 10 & 0.1 & 0.001 & $i$ & $9 \circ 68$ & $i$ & 601 & $\vdots$ & (2) 9913 & i 31N3y4dy OHN & $i i$ \\
\hline$\therefore 0.0$ & $i 16$ & $i[0$ & $i \quad H$ & i & 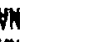 & 10.001 & i & H & $i$ & in & $i$ & (2) 9293 & ¿ OlN3инanus & $i i$ \\
\hline & 11991 & $i 6$. & ；俩 & $i v$ & $m$ & 10.001 & $i$ & $m$ & $i$ & $m$ & $i$ & (2) 9053 & $i$ & ii \\
\hline 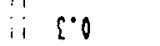 & 106 & 162 & i & $\vdots$ & & ! & $\frac{1}{i}$ & & $i$ & & $i$ & ayzayd As & & !! \\
\hline$\therefore 50$ & $i[91$ & $i \quad 0$ & $i<1$ & i 9 & $\varphi \cdot[$ & 0.001 & $i$ & S.it & $\vdots$ & $P \cdot B S$ & $i$ & UIOJH & & $\stackrel{!}{\prime \prime}$ \\
\hline $1 i$ & $i$ & $i$ & i & $i$ & & $i$ & $i$ & & $i$ & & $i$ & & $i$ & ii \\
\hline$\because 00$ & 16.91 & $i l^{\prime} 0$ & i & $i \quad$ & H & i 0.001 & $i$ & H & i & th & $i$ & {$[1 / 2) 99[3$} & & ii \\
\hline$\therefore 10$ & $i 2 \Omega$ & $i 6.2$ & i 8.1 & i 1 & 1 & $i 0.001$ & $i$ & 1.29 & $i$ & $\sigma^{\circ} L \varepsilon$ & $i$ & 653 & 748931MI & ii \\
\hline$\therefore 20$ & ||$s \mid$ & $i 0.1$ & i & $i \quad b$ & H & $i 0.001$ & $i$ & $\omega$ & i & $M$ & $i$ & III(2)106] & 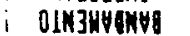 & 11 \\
\hline $118 \%$ & 1001 & $i l \cdot l$ & $i 9^{\circ} 1$ & i i & l'9 & $i 0.001$ & $i$ & 8.02 & i & $206 c$ & $i$ & [I(z) J6\{\} & $i$ & 11 \\
\hline 110 & 0.11 & 5 & $\vdots$ & $\vdots$ & & $i$ & $i$ & & $i$ & & $i$ & 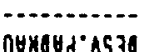 & & $i$ \\
\hline$\therefore i 0$ & $i 0.82$ & $\{.1$ & $i \quad l$ & $i<$ & LI & 0.001 & $\vdots$ & bis & $\vdots$ & 9.96 & $\vdots$ & 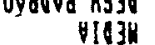 & $\vdots$ & $! !$ \\
\hline$i i$ & $i$ & $i$ & i & $i$ & & $\mathrm{i}$ & $\mathrm{i}$ & & $i$ & & $i$ & & $i$ & ii \\
\hline$\because 00$ & $\therefore$ PO & $i 10$ & ；明 & $i b$ & m & $i 0.001$ & $i$ & H & $i$ & W & $i$ & $31(2) 99 / 3$ & & ii \\
\hline ii 0.0 & 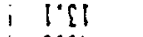 & $\div 10$ & i & $i r$ & 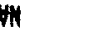 & $i 0.0$ & $i$ & 到 & $i$ & & $i$ & 293 & OLMJUYNAY & $\therefore$ \\
\hline$\therefore 10$ & $i 9.51$ & i 51 & 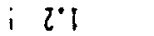 & $i s$ & 20 & $i 0.00$ & $i$ & 0.08 & $i$ & 0.02 & $i$ & JI(Z)J6s] & 30 & 11 \\
\hline$i i 20$ & i $8.0 \Omega$ & $i 9^{\circ} 0$ & i & & Hh & $i 0.001$ & $i$ & $m$ & i & 政 & $i$ & JI(2) 106 3 & SHISO8J4JIMI & 11 \\
\hline ii 80 & $i 202$ & $i l^{\circ}$ & $i{ }^{\prime} 1$ & $i 0$ & 0.5 & $i 0.0$ & $i$ & 8.92 & $i$ & $2 \Omega l$ & i & $11[3$ & $\vdots$ & ii \\
\hline ii $l 0$ & $i 12$ & $i 8^{\circ} 1$ & 11 & $i$ & $1 \cdot 2$ & $i$ & $\mathrm{i}$ & $l \cdot l$ & $i$ & $l n$ & $i$ & OHZGYd'AS36 & & 11 \\
\hline 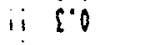 & $i \quad i$ & 6.5 & $i \quad 17$ & $\vdots$ & $9 \cdot 2$ & $i 0.001$ & $i$ & 8.18 & $i$ & I.sq & i & VIO3H & i & ii \\
\hline $1 i s 0$ & $i \quad .$. & $i \quad 1.0$ & $i$ & i & & $i$ & $i$ & & $i$ & & $i$ & & $\vdots$ & ii \\
\hline 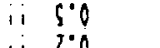 & i 1'l & i 6.9 & 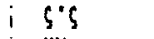 & $i$ & $t$ & $i 0.001$ & $i$ & $l \circ b l$ & $\mathrm{i}$ & 202 & $i$ & $y(z$ & & ii \\
\hline ii 20 & 19.5 & $i 0^{\circ}\{$ & ｉ & i & 粠 & $i 0.0$ & $i$ & W & $i$ & M & $i$ & 293 & ¿ ONG3ngane! & ii \\
\hline$\therefore 10$ & i 0.6 & i 0.9 & i $5 \%$ & $i s$ & $\varsigma^{\circ} 2$ & $i 0.001$ & $i$ & [.85 & $i$ & L'I & $i$ & $83(2) 3453$ & 30 & $\pi$ \\
\hline ii 110 & i $\{?$ & 1\{\} & i 6.6 & i & 100 & $i 00$ & $i$ & 126 & $i$ & $9 . \mathrm{l}$ & i & & Syisoys & ii \\
\hline$\because i 10$ & 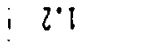 & 168 & $i \cdot i$ & $i 0$ & 0.9 & $i 00$ & $i$ & $9 \cdot 82$ & $\vdots$ & bill & $\vdots$ & {$[\hat{]}]$} & 7 & $\because !$ \\
\hline$i i\{0$ & 1 & $i s$. & $\div 1.8$ & $i 2$ & 21 & ! & 1 & 8.61 & $i$ & 8.61 & $i$ & $048098^{\circ}$ AS30 & & ii \\
\hline ii 9.0 & $i \quad 1$ & i s'b & $i 1 \cdot 21$ & $i 6$ & 61 & $i 0.001$ & $\vdots$ & 0.28 & $i$ & 0.41 & $i$ & Hid 34 & ; & ii \\
\hline ii & i & $\mathrm{i}$ & i & i & & $\mathrm{i}$ & $i$ & & $i$ & & $i$ & & $i$ & ii \\
\hline ii 90 & i $5^{\circ} L$ & i $5^{\circ} \mathrm{L}$ & $i 5^{\circ} \mathrm{l}$ & $i$ & 81 & $i 0.001$ & $i$ & 0.001 & $i$ & $a 1$ & 1 & [1)Jts] & $i$ & ii \\
\hline ii $\{0$ & 191 & $i \quad 66 !$ & $i 0.81$ & $i i$ & $\dot{l}$ & 10.001 & $i$ & 1016 & $i$ & 9.8 & i & $0+3$ & i & ii \\
\hline$\because i \quad l 0$ & i 91 & $i 9.51$ & i & $i$ & WH & i 0.001 & $i$ & H & i & H & i & $0 d 01(1)$ 10t] & & ii \\
\hline i) 10 & $i 0^{\circ} \xi$ & $i \ddot{l} l$ & i l's & i 1 & 12 & $i 0.0$ & i & 8.06 & $i$ & $i 62$ & i & $3548(1) \times 0+3$ & i & II \\
\hline ii 10 & $i \quad 8 . \tilde{L}$ & 116 & $i<\zeta$ & $i$ & l' & $i 00$ & $i$ & 9.09 & $i$ & 165 & $i$ & 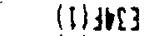 & $i$ & ii \\
\hline ii 101 & $6^{\circ} \mathrm{E}$ & $i 8^{\circ} 22$ & $i 9 . \zeta 2$ & $:$ & $2 \cdot 2$ & $i 0.0$ & i & 1.26 & $i$ & $6^{\circ} \mathrm{L}$ & i & 1113023 & 1 & ii \\
\hline (口) & & $!$ & $!$ & $!$ & & $!$ & $t$ & & 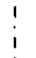 & & 1 & & $\vdots$ & 11 \\
\hline (z). 1504y & i (z) & $7 \$ 101$ & i $\quad 771987$ & i & 31115 & $i \quad 10101$ & & 471984 & $i$ & 31115 & i & & $i$ & ii \\
\hline !' & IN 30 yo3! & & $\begin{array}{l}\text { (3) HoISONY } \\
\text { HSSH }\end{array}$ & & & 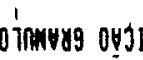 & & $\begin{array}{l}10179 \\
81516\end{array}$ & & & ! & 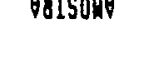 & 30tmm & $1 !$ \\
\hline & & i & & & & & & & & & i & & i & ii \\
\hline
\end{tabular}

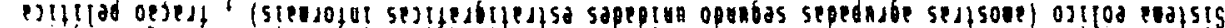

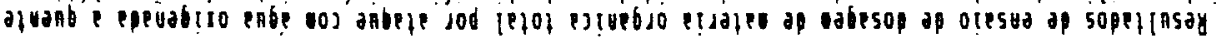
W's elatel

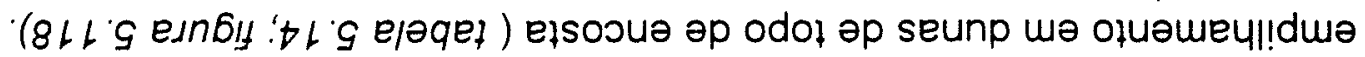

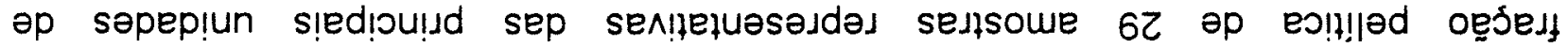

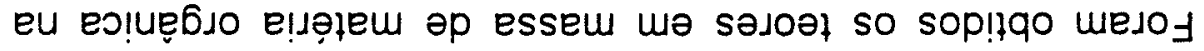


HISTOGRAMA - TEORES DE MATÉRIA ORGÂNICA

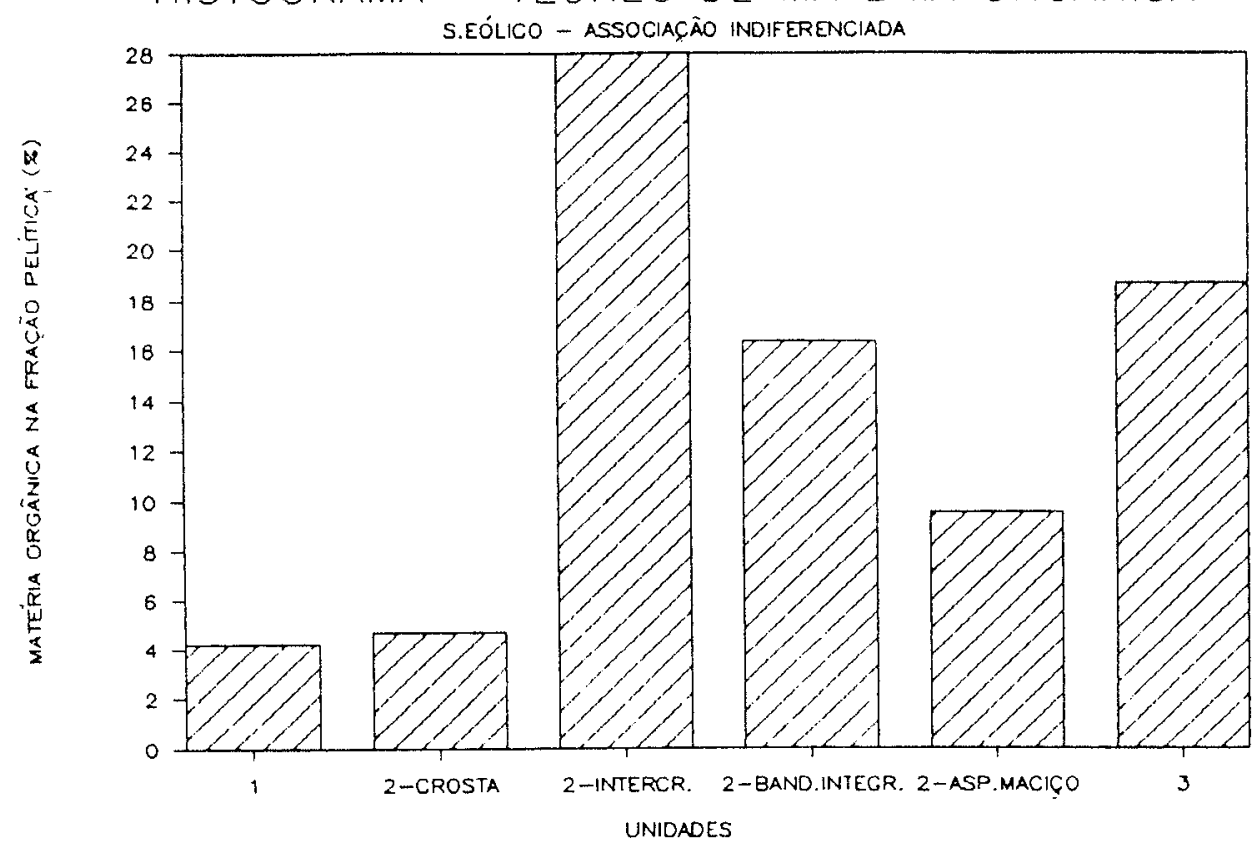

Figura 5.118. Histograma de comparação entre unidades ou geraçס̃es na associação de fácies indiferenciada, quanto a teor de matéria orgánica na fração pelitica.

Os resultados podem ser agrupados em três tipos de sedimentos quanto ao grau aparente de pigmentação e litificação: teores mais baixos ( 4,4 a $4,7 \%$ ) nos sedimentos muito pigmentados da unidade 1 e de crostas de bandamento de infiltração na unidade 2 ; teores intermediários $(9,5$ a 16,3 \%) nos sedimentos com pigmentação moderada da unidade 2 (integral); e teores mais elevados $(18,7$ a $28,0 \%)$ nos sedimentos inconsolidados e pouco pigmentados da unidade 3 e de bandas intercrostas na unidade 2. Esta distinção mantém-se válida quando se comparam amostras de unidades diferentes pertencentes a um mesmo ponto de amostragem.

A relação inversa entre teor de matéria orgânica na fração pelítica e grau de pigmentação de sedimentos eólicos permite sugerir que os processos de cimentação e pigmentação formadores da matriz pelítica sejam em essência inorgânicos. Dos dois processos capazes de gerar matriz evocados no item anterior, quais sejam a infiltração de pelitos detríticos (1) e a alteração diagenética autóctone (2), apenas o primeiro pode introduzir matéria orgânica no sedimento. Isto é sugerido pelo aumento relativo de teor de matéria orgânica na amostra da unidade 2 da ponta do $\mathrm{Ji}_{1}$ (E54C) única em que a influência de fluxos de lama na formação do depósito é evidente. Nos sedimentos pobres em fração pelitica da unidade 3 e das intercrostas da unidade 2, a matéria orgânica não pode ter-se originado pelo processo (1), mas somente por mecanismos pedogênicos de migração e concentração de húmus. 


\section{CAPÍTULO 6. DISCUSSÃO FINAL}

\subsection{SÍNTESE DA EVOLUÇÃO PALEOGEOGRÁFICA}

A evolução paleogeográfica quaternária da área costeira entre Jaguaruna e Imbituba obedece em linhas gerais à sucessão de eventos descritos por Suguio \& Martin 1987 (figura 3.7). Não foram encontradas evidências seguras em superfície de depósitos formados durante episódios transgressivo-regressivos anteriores ao do Pleistoceno superior. Neste último, o NRM na área deve ter atingido em torno de $8 \mathrm{~m}$ (Martin et al. 1988a), o suficiente para alcançar a margem externa da serra do Taboleiro. Apesar disto, a preservação, ao sopé da serra, de terraços regressivos correlatos a este evento é apenas local, incluindo paleotômbolos nas localidades de Samambaia e Cangueri de Fora. Testemunhos destes terraços são completamente ausentes no setor de orla serrana hoje ocupado por sedimentos do delta lagunar do rio Tubarão. Este fato pode ser explicado por duas hipóteses diferentes. A primeira é a de que os paleorrios Tubarão e Capivari teriam sido afogados pelo máximo transgressivo do Pleistoceno superior, formando-se uma baia estuarina que impediu a deposição de terraços costeiros, neste setor, durante a regressão subseqüente. Estes teriam sido depositados apenas na parte externa, marinha franca, da baia (a leste de Jaboticabeira), possivelmente sob a forma de um sistema barra-barreira. A segunda hipótese é a de que os terraços marinhos regressivos foram depositados junto à serra, apesar da presença dos rios, e posteriormente erodidos em sua totalidade por dissecação fluvial iniciada na fase de baixo NRM do final do Pleistoceno, e por abrasão marinha no Holoceno.

Durante o minimo NRM correspondente ao periodo glacial Würm (Wisconsin), a orla serrana e depósitos marinhos nela ancorados foram intensamente dissecados. O paleorrio Tubarão atingia a costa na atual plataforma externa na área em que hoje são encontrados depósitos de areias com bioclastos (Martins \& Martins 1985). Estes representam possivelmente uma feição remanescente da existência nessa época de um complexo flúvio-lagunar ou estuarino associado à foz do paleorrio. Com a rápida elevação de NRM iniciada entre 15 e 20 mil anos A.P., esta paleocosta, afogada, teria adquirido o caráter de "plataforma abandonada", o que explica a manutenção dos mesmos depósitos, sem remobilização significativa. No máximo transgressivo de 5100 anos A.P., o mar já teria erodido maior parte dos terraços pleistocênicos, afogado a desembocadura dos rios Tubarão, Capivari, Aratingaúba e d'Una, formando o sistema lagunar holocênico, e iniciado a deposição do sistema barra-barreira no limite externo do sistema lagunar defronte ao rio Tubarão. $\mathrm{Na}$ fase de tendência regressiva geral que se segue, maior parte da baía-laguna formada no máximo NRM anterior é colmatada pela emersão de fundos rasos devida ao declínio de NRM e, principalmente, pelo avanço do delta do rio Tubarão. Os sistemas planicie costeira e barra-barreira holocênicos progradam até a posição de linha de costa atual. No sistema planície costeira, a progradação é maior no trecho vizinho às praias do Mar Grosso e Ji, devido à formação, desde o início da fase regressiva, de um grande tômbolo ancorado no flanco oeste dos morros da cidade de Laguna (Glória e Mar Grosso). A presença de uma zona de sombra de difração de ondas neste ponto foi importante também para a máxima preservação de terraços 
pleistocênicos na região entre Cabeçuda e Perrixil. Na parte norte da área estudada, entre as pontas do Cravo e Careca do Velho, a orientação e fisiografia da costa gerou uma zona de divergência de células de deriva litorânea; por esta razão, este setor praial tem experimentado constante erosão e retrabalhamento das escarpas ingremes formadas por paleodunas, sem evidência de progradação holocênica significativa.

Com o fechamento gradual da baia-laguna pelo delta do rio

Tubarão, no decorrer dos últimos 5 mil anos, muitas mudanças supõe-se terem ocorrido nessa associação de fácies, como restrição das lagunas remanescentes, desvios e abandonos de distributários e instabilização e deslocamento de desembocaduras lagunares. Estas mudanças resultaram da sucessão no tempo de mecanismos graduais de retroalimentação autociclicos e eventos episódicos, incluindo oscilações rápidas submilenares de NRM e manifestações do fenômeno "El Niño". O registro deposicional de superfície permite reconstituir algumas das mudanças mais prováveis, embora sem poder situá-las com precisão na escala de tempo. Sabe-se, por exemplo, da análise da dinâmica atual, que durante periodos de alta descarga fluvial combinada com nivel do mar elevado por marés, distributários semi-inativos do delta lagunar podem reestabelecer comunicação efêmera com as lagunas; nas mesmas épocas, a vazão em canais interlagunares é intensificada, o volume de água dos corpos lagunares amplia-se e as desembocaduras lagunares assoreadas tendem a romper-se. Por analogia com esta situação, é possivel esboçar a dinâmica da interação baia-laguna versus barra-barreira durante épocas de maior descarga fluvial elou NRM mais alto, ocorridas no passado holocênico. Supōe-se, deste modo, que nestas épocas o delta tivesse distributários ativos em outras frentes, além da atual na laguna Santo António; a frente deltaica do rio da Madre, na margem noroeste da laguna de Garopaba do Sul - Camacho, acelerava a atividade da desembocadura lagunar do Camacho, então situada no centro hidráulico da laguna, isto é, defronte ao atual pontal lagunar (Aroeira). Com o declínio de NRM e a desativação gradual do rio da Madre, o fluxo de entrada na laguna Garopaba do Sul - Camacho torna-se cada vez mais restrito à vazão intermitente do rio do Meio, na margem nordeste; a desembocadura lagunar do Camacho passa a migrar rumo NE, em busca da zona de maior pressão hidráulica, deixando atrás de si pontais lagunares retrabalhados de deltas de maré enchente, os quais contribuem ainda mais para a compartimentação interna da laguna e desequilíbrio da pressão hidráulica. A migração ocorre através de sucessivos eventos de rompimento após fases de fechamento, as quais se tornam mais freqüentes e prolongadas à medida que o NRM declina, até atingir-se a fase atual de relativa estabilidade.

A evolução paleogeográfica da área costeira entre Jaguaruna e Imbituba é completada pelo desenvolvimento de dunas eólicas, assunto que é tratado em separado no item seguinte.

\subsection{EVENTOS DE DEPOSIÇÃO EOLICA NO QUATERNÁRIO SUPERIOR : UMA TENTATIVA DE CORRELAÇÃO ENTRE CONTINENTES}

A correlação de gerações eólicas aqui identificadas com eventos de formação de dunas costeiras no Quaternário de outras regiões do mundo é dificultada pelo fato de pelo menos uma parte destas gerações e eventos ser 
controlada por condiçōes de aporte, clima e variações de NRM de curta duração geológica (poucos milênios); devido a relação de hierarquia que tempo e espaço mantêm entre si em geologia, curta duração implica quase sempre extensão geográfica restrita e, portanto, impossibilidade de correlações que sejam mais que locais. Apesar disto, com o avanço de pesquisas envolvendo a datação de gerações eólicas em outros paises, em especial Austrália e Japão, torna-se evidente a existência de correlações gerais ou aproximadas entre estas gerações em diferentes continentes. Levando-se em consideração o princípio de Short(1988), que descreve a interação entre formação de dunas e flutuações de NRM, o primeiro requisito bésico que torna possivel n traçado de correlações entre regiōes tão distantes é a semelhança entre elas quanto ao padrão de variação de NRM, inclusive no Holoceno. É significativo portanto que o padrão holocênico transgressivo-regressivo deduzido para a costa brasileira, desprezadas oscilações menores de duração secular (figura 3.4), tenha sido encontrado também em outras costas como as de Nova Zelândia (Gibb 1983 apud Isla 1989), Japão (Ota \& Machida 1987; Ota et al.1990; Suguio 1993) e Austrália (Chappel 1983; Belperio et al.1984; Semeniuk \& Semeniuk 1991). O segundo requilisito essencial para o traçado dessas correlações é que a seqüência de eventos em cada região comparada possua extensão significativa pelo menos em escala semi-regional. O litoral centro-sul de Santa Catarina, a exemplo de várias regiōes costeiras de Austrália e Japão, atende a esta condição; é o que sugere a grande semelhança entre o empilhamento de unidades eólicas reconhecidas na área de Jaguaruna-Imbituba e a sucessão descrita por Bigarella (1975a) em Florianópolis (figura 6.1).

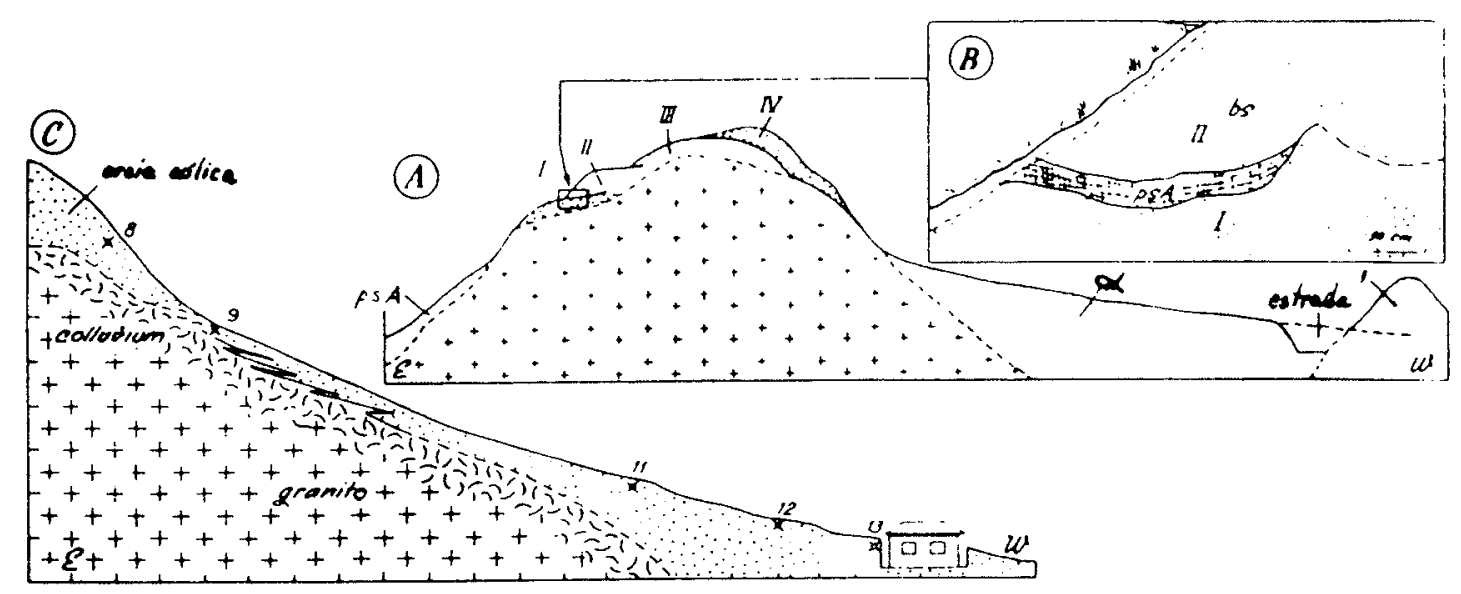

Figura 6.1. Relações morfoestratigráficas em "dunas de captação" do morro da Joaquina, Florianópolis, segundo Bigarella (1975a). Em A, vêem-se quatro unidades: I é uma "seqüéncia avermelhada", com paleopavimento basal; II é "sequéncia marrom", contendo humatos; III é "sequencia amarelada" com "estruturas de dissipaçăo"; e IV é duna atual, com estruturas primárias. Alfa é unidade indiferenciada e psA, um paleossolo entre I e II, visto em detalhe no quadro B. Em C, representa-se a "rampa de areia" desenvolvida no episódio de tempestade de 22/07/1973. As unidades I a IV podem ser correlacionadas com unidades reconhecidas em Jaguaruna-Imbituba do seguinte modo: $I=1 ; I I+I I=2 ; I V=4$.

Três a quatro eventos principais de formação de dunas eólicas costeiras têm sido identificados no Quaternário superior de Oceania e Japão. O primeiro situa-se no final do Pleistoceno. Wasson (1983), na costa de Simpson, região 
semi-árida da Austrália, atribui a este evento areias com avermelhamento pedogênico no topo, de idade "significativamente anterior" a 23 mil anos. Pye (1983b), com base em datações e no uso de modelos morfo-estratigráficos de acumulação eólica, associa a maioria das dunas pleistocênicas de Queensland, Nordeste da Austrália, ao último evento interglacial. Endo (1986) situa a formação de dunas eólicas pleistocênicas no Japão no -intervalo entre 70 e 11 mil anos A.P. Entretanto, estas dunas são intercaladas com inúmeros níveis de cinzas vulcânicas ("tephras"), as quais podem ter criado suprimentos locais e temporários de sedimentos eólicos (Endo 1986).

$O$ segundo evento formador de dunas manifesta-se em esjpecial na primeira metade do Holoceno, encerrando-se logo após o seu máximo NRM. No Japão, este evento corresponde à primeira fase de formação das denominadas "Dunas Antigas" ("Older Dunes"), ocorrida entre 7500 e 6000 anos A.P. (Endo 1986). A descrição das dunas depositadas nesta fase corresponde a de rampas eólicas ou dunas de topo de encosta. No Sudeste da Austrália, o segundo evento manifesta-se entre 8000 e 5500 anos A.P., depositando dunas que logo em seguida são parcialmente erodidas pelo máximo transgressivo (Ohmori et al. 1987). No Sul da Austrália, Short (1988) situa o evento correspondente entre 10000 e 6500 anos A.P. e também o associa à formação de dunas de topo de escarpa. Em Queensland, Pye (1983b) identifica uma geração de dunas no Holoceno médio (5700 a 4400 A.P.), possivelmente correlata. Em várias outras regiōes da Nova Zelândia e da Austrália, dunas fósseis distantes da costa atual já haviam sido anteriormente atribuidas à elevação pós-glacial de NRM (Brothers 1954 e Bird 1964 apud Goldsmith 1978; Jennings 1957; Davis 1980).

O terceiro evento ocorre entre o máximo transgressivo holocênico e o inicio da formação de dunas atuais. No Japão, ele pode ser associado à segunda fase deposicional das "Dunas Antigas", entre 6 e 3 mil anos A.P., quando um aumento de aridez acelera a deposição eólica (Endo 1986). No Sudeste da Austrália, uma fase igualmente seca com formação de dunas mais altas e largas é relatada por Onmori et al.(1987) para o periodo entre 5500 e 2700 A.P. No Sul da Austrália, Cook (1986 apud Short 1988) descreve evento formador de dunas correlacionável, entre 3500 e 2000 A.P.. Em Queensland, Pye (1983b) refere-se à idade de mesma geração como mais nova que 4 mil anos.

O quarto evento formador de dunas costeiras na Oceania e no Japão segue até hoje; apesar disso, muitas das dunas desta geração já se encontram estabilizadas por processos artificiais ou naturais. $O$ início da geração varia de 2700 A.P., no Sudeste da Austrália (Ohmori et al.1987) a apenas 1000 A.P., no Sul do mesmo país (Cook 1986 apud Short 1988). Observa-se grande discrepância entre subfases de estabilização e ativação de dunas eólicas nas diferentes regiōes.

O primeiro e segundo eventos estão relacionados a elevações de NRM no âmbito de deglaciações. Possuem, deste modo, um condicionamento de caráter global; se a sincronia entre suas manifestações nas diferentes regiões analisadas não é absoluta, é porque os máximos NRM de cada região não foram alcançados exatamente ao mesmo tempo; e se seus depósitos não se desenvolveram igualmente em toda parte, isto se deve apenas a melhor ou pior satisfação de condições locais imediatas de deposição eólica, como regime eólico e de ondas, granulometria, morfodinâmica praial e deriva litorânea. Há fortes indicíos, porém, de que existe sincronia em relação a episódios transgressivos correlatos. A formação de dunas eólicas durante transgressões pós-glaciais é resposta do sistema costeiro a 
mudanças bruscas em seu estado de equilibrio. Representa portanto uma evolução espontânea deste sistema em busca de novo eqilibrio metaestável de maior ordem e dissipação de energia. O modo de manifestação desta mudança, envolvendo ou não o desenvolvimento de dunas eólicas, depende da combinação entre variáveis imediatas e locais.

O terceiro e quarto eventos ocorrem durante a fase de semiestabilização de NRM que sucede o máximo transgressivo holocênico. Esta fase tem o predomínio de um só estado de equilibrio dinâmico, a menos de defasagens na aquisição deste equilíbrio devidas ao efeito atrasado da transgressão brusca que o antecedeu. Um exemplo disto é dado por Short (1988), em relação ao Sul da Austrália, onde a formação de dunas frontais perdura após a transgressão, até que o excesso de areia criado por esta se esgote em 4 mil A.P.(figura 6.2). A partir desse momento, a retomada da atividade deposicional eólica passa a depender da criação de novos excessos de areia por efeito de variáveis imediatas sob NRM estável. Pequenas variáveis imediatas, tais como o aumento de aridez postulado por Endo (1986) e Ohmori et al.(1987), provocam reaçōes de retroalimentação. Sua sucessão determina o caráter pulsátil da deposição eólica nos últimos milênios. Como estas flutuações não são necessariamente globais, não há uma sincronia consistente entre estes pulsos deposicionais menores em diferentes regiões.
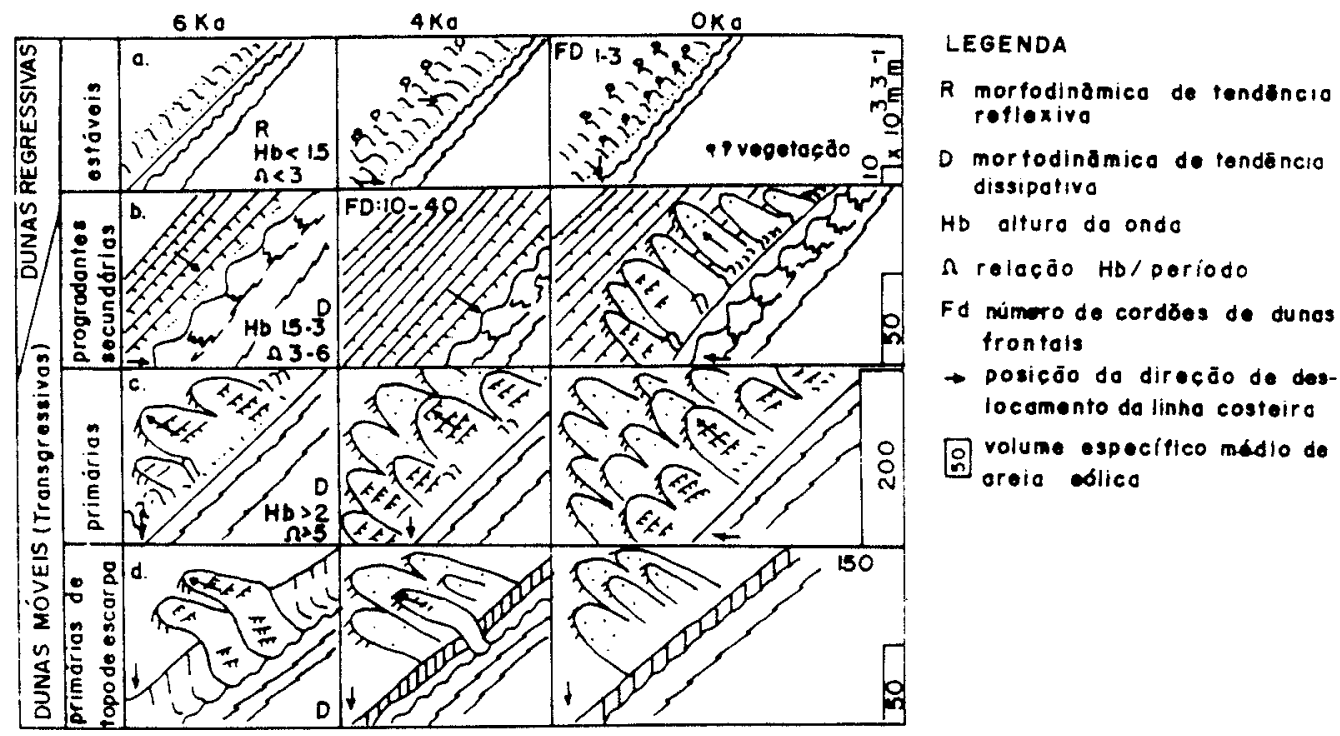

Figura 6.2. Modos e tempos de formaçăo de dunas em barreiras regressivas (a,b) e transgressivas (b,c,d). Modelo baseado no caso do Sul da Austrália, simplificado de Short (1988).

Uma classificação genética de dunas eólicas, que ressalta a distinção entre a deposição causada por evolução espontânea do sistema costeiro, modificado pela transgressão marinha (holocênica, no caso), e a deposição devida a retroalimentação, foi concebida por Short (1988). Embora não tenha sido proposta nestes termos, a classificação de Short (1988) expressa-se melhor sob enfoque sistêmico pelo qual aqui se apresenta. Ela reaproveita os termos "dunas primárias" e "dunas secundárias", empregados originalmente por Davies (1980) para distinguir entre as dunas diretamente derivadas de areias praiais e as formadas de dunas preexistentes, respectivamente. Na redefinição de Short (1988), as dunas primárias 
são ligadas à resposta de evolução espontânea à transgressão, e as secundárias, as geradas por retroalimentação, após a exaustão do excesso de areia acumulada pela transgressão (figura 6.2). Nas costas em que este excesso é maior, o caráter primário, defasado, pode perdurar até hoje.

A classificação de Short (1988) fornece critérios adicionais importantes para o estabelecimento de correlaçōes entre as gerações eólicas de Santa Catarina e as de Japão e Austrália. Seguindo-se esta classificação, a associação de fácies mantiforme aqui reconhecida é formada por depósitos primários, enquanto a associação dunas e lençóis parabólicos constitui-se de depósitos secundários, gerados por deflação de dunas primárias frontais ou transgressivas. A presença da associação mantiforme significa que em parte da costa estudada, em essencial no sistema barra-barreira, há ainda excesso de areia ligado a transgressão marinha pósglacial. Short (1988) supõe em seu modelo para a costa sulaustraliana (figura 6.2), que dunas de topo de escarpa só possam ter-se formado enquanto dunas primárias, sofrendo estabilização após a exaustão do excesso de areia. Adotada esta premissa, a presença de pelo menos três unidades estratigráficas $(1,2$ e 3 ou 4) em dunas de topo de encosta da região de Jaguaruna-Imbituba indicaria o registro de influência de mesmo número de transgressões marinhas importantes. Isto se o aporte eólico ligado a uma transgressão não for interrompido, e dividido em duas fases, devido ao ilhamento do obstáculo fixo pelo mar transgressivo, na fase de NRM máximo. O modelo de Short (1988) assume uma situação de escarpa paralela e ventos transversais à costa; nesta situação, apenas o retrabalhamento pelo vento do material erodido da escarpa durante a transgressão possibilita o seu cavalgamento. O caso da costa em estudo é, no entanto, oposto ao modelo: escarpas (ou encostas) ocorrem em diferentes disposições e o vento prevalecente é subparalelo à costa. Neste caso, o vento pode soprar areias oriundas de outras fontes (a nordeste), e fornecidas por outros desequilibrios que não o provocado por transgressão. Existem assim três causas possiveis para interrupções no recobrimento eólico do obstáculo fixo e formação de unidades de empilhamento em dunas de topo de encosta da região: 1) intervalo entre duas transgressões marinhas; 2) pausa temporária no aporte eólico desencadeado por uma mesma transgressão, devido ao afogamento da área fonte; e 3) oscilações nas variáveis imediatas, após a exaustão do aporte ligado a uma transgressão. Com isto, a regra que associa o número de unidades estratigráficas ao número de transgressões só é válida para as dunas de topo de encosta em que as unidades forem primárias e em que não houver ocorrido submersão total das áreas fontes. Em relação ao Holoceno, o único depósito com obstáculo que satisfaz estas condições é o do flanco oeste do morro Santa Marta Grande; ele é cavalgado por dunas primárias atuais (geração 4) e encontra-se na parte interna do sistema barrabarreira, de modo que mesmo durante o máximo NRM holocênico, sua área fonte praial deve ter permanecido emersa. Este depósito é também o único em que o contato entre a unidade 4 e a unidade 2 é gradual (figura 6.3). Em outras porções do mesmo morro, cercadas pelo mar hoje elou durante o máximo NRM holocênico, estas unidades, quanto presentes, exibem contatos nitidos (figuras 5.38 e 5.97). 0 afloramento do flanco oeste do morro Santa Marta Grande pode assim ser considerado chave na interpretação das gerações eólicas, uma vez que a transição entre as gerações 2 e 4 permite associá-las à reação de evolução espontânea a um mesmo evento transgressivo. As dunas eólicas da área em estudo estariam deste modo 
associadas a não mais que duas transgressões marinhas, sendo que a geração 2 desencadeada na última transgressão holocênica.

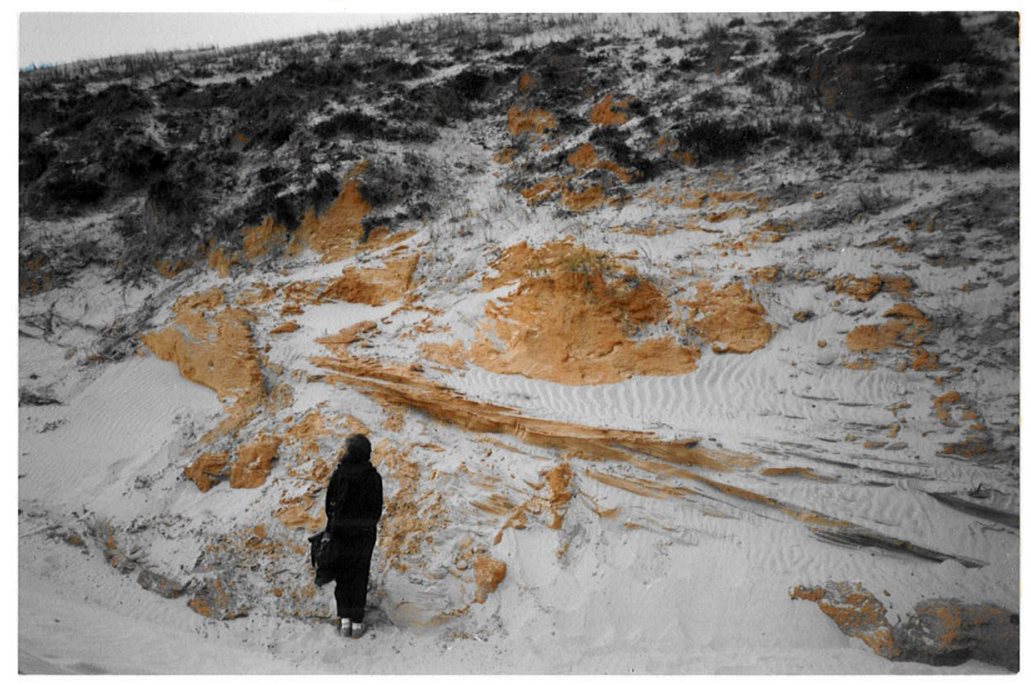

Figura 6.3. Escarpas irregulares de arenito pardacento com aspecto maciço, geração 1, colmatadas e "abraçadas" por areias estratificadas de gerações mais novas (2 a 4). Flanco oeste do morro Santa Marta Grande. Rumos de mergulho entre W e SW.

A geração 1 é atribuída tentativamente ao primeiro evento descrito para Japão e Austrália. Suas dunas teriam sido formadas durante a transgressão marinha do Pleitoceno superior ou, em menor parte, logo após o pico transgressivo, em analogia ao que ocorre em relação à transgressão holocênica. A maioria delas teria sido afogada e erodida pelo máximo NRM de $8 \mathrm{~m}$. Dunas de topo de escarpa acima desta altitude puderam ser preservadas, motivo pelo qual esta geração aflora quase exclusivamente sobre pontões rochosos. Exceção encontra-se nos afloramentos parcialmente encobertos pelo lençol parabólico ativo de Vila Nova Roça Grande (figuras 5.39 a 5.42), onde areias desta geração ocorrem a altitudes de menos de $5 \mathrm{~m}$. Neste local, a unidade 1 apresenta-se em maior parte capeada por uma camada de paleossolo negro rico em matéria orgânica (descrito no item 5.4.4.1) e que pode ser atribuido a brejos lagunares formados durante a transgressão marinha do Pleistoceno superior. Camada de areia preta possivelmente correlata ocorrem na porção baixa $(<8 \mathrm{~m})$ da rampa eólica de Entrada da Barra, passando na base para areias pardas, que também podem corresponder a restos de erosão e afogamento de paleodunas da geração 1.

A geração 2 lato sensu (2 e 2A) apresenta-se truncada erosivamente pelas margens do sistema lagunar formado durante o máximo NRM holocênico e inclui importante reativação de dunas de topo de encosta e rampas eólicas. Apresenta assim duas características essenciais de dunas do segundo evento do Japão e Austrália, com o qual possui provável correlação. Com base nisto, o limite superior de idade da geração 2 estaria situado em torno da época de máximo NRM, em 5100 A.P.. Esta última hipótese é admitida aqui com reservas: se existe passagem gradual entre as unidades 2 e 4 nas dunas de topo de encosta de Santa Marta Grande, é possivel que a geração 2 sobre a planície litorânea também tenha continuado a se desenvolver mesmo após o máximo transgressivo. Esta possibilidade 
é improvável em relação aos depósitos eólicos formados sobre o sistema planicie costeira, onde a parte interior do sistema holocênico não possui dunas, indicando que houve um hiato na atividade eólica durante o início da regressão que sucedeu ao máximo de 5100 A.P.; mas é admissivel no caso de depósitos eólicos sobre o sistema barra-barreira, mesmo porque a faciologia eólica indica que o aporte sedimentar nessa região tem sido mais intenso (maior desenvolvimento da associação de fácies mantiformes). Ainda assim, existe um argumento favorável ao limite de idade da geração 2 em 5100 anos: com a regressão subseqüente a esta data e a redução da influência de ventos e tempestades devido ao afastamento do mar, as dunas primárias préexistentes tendem a se estabilizar por vegetação, e a formação de novas dunas limita-se a cordões frontais progradantes sucessivamente abandonados (Goldsmith 1978; Pye 1983b; Short 1988) ou a outro tipo de dunas de orla praial. A ausência de resquícios destes depósitos em superficie indica que eles ou foram erodidos pelo próprio vento resultando na formação da geração 4 ou encontram-se soterradas por esta geração. Nos pontōes cristalinos, a escassez de vegetação e o caráter de anteparo explicariam a deposição ininterrupta em locais favorecidos como o flanco oeste do morro Santa Marta Grande.

O quarto evento é representado na área em estudo pelas gerações 3 e 4 . A pedogênese e cobertura vegetal incipientes em depósitos da geração 3 permitem sugerir que sua idade final não seja superior a poucos séculos. Dentro desta geração, dois tipos genéticos (faciológicos) devem ser distintos. 0 primeiro corresponde a residuos de deflação abandonados, os quais não representam um pulso independente de atividade eólica, mas apenas o resultado normal de deslocamento de dunas secundárias da geração 4. Uma estimativa baseada na velocidade de migração das frentes parabólicas ativas associadas a estes depósitos residuais indica idades variáveis entre cerca de 100 e 300 anos. O segundo tipo genético é o dos lençóis parabólicos, incluindo as grandes formas atenuadas, que cavalgam o morro das Ovelhas e a zona urbana de Imbituba, e as pequenas formas imbricadas da planicie pleistocênica adjacentes às praias de Ji e Sol. Acredita-se que estes lençóis relacionem-se a um pulso de atividade eólica gerado por oscilações em variáveis imediatas. Nas áreas de grande aporte eólico, sobre o sistema barrabarreira, este pulso tem continuidade com o pulso seguinte ligado à geração 4; nestas áreas, os lençóis parabólicos da geração 4 remobilizam e/ou recobrem os da geração 3 , os quais, por esta razão, não se distinguem em superficie. Os depósitos da geração 4 que ali se vêem são uma extensão, ininterrupta no tempo, da geração 3. Nas áreas de pequeno aporte, que se estendem sobre todo o sistema planicie costeira, existe um hiato deposicional entre os dois pulsos de atividade eólica. É significativo que os mais espessos lençóis da geração 3 ocorram no extremo norte da área, onde se registra a menor taxa de migração da dunas ativas (tabela 5.7), associada a aporte sedimentar reduzido. Na região de Imbituba, os lençóis parabólicos do quarto evento pertencem apenas à geração 3 , o que indica que o pulso que desencadeou a geração 4 , provavelmente mais fraco, não foi suficiente, nesse local, senão para formar dunas frontais. 


\section{REFERÊNCIAS BIBLIOGRÁFICAS}

ABREU,S.F. 1928. Sambaquis de Imbituba e Laguna, Santa Catarina. Rev. Soc. Geog., Separata.

ABREU,S.F. 1944a. O problema dos sambaquis. I: Sambaquis de Imbituba e Laguna Santa Catarina. Bol. Geográfico, 2(20):1136-1143.

ABREU,S.F. 1944b. O problema dos sambaquis. II: Sambaquis de Imbituba e Laguna, Santa Catarina. Bol. Geográfico, 2(21):1298-1311.

AHLBRANDT,T.S. \& FRYBERGER,S.G. 1980. Eolian deposits in the Nebraska Sand Hills. U.S., Geol.Surv., Profess. Papers, 1120A:1-23.

ALBUQUERQUE,L.F.F. \& HORBACH,R. 1972. Nota Explicativa sobre a Revisão do Mapeamento da Porção Gondvânica da Quadrícula de Tubarão/Laguna e Rio do Sul, SC. Porto Alegre, DNPM-1 Distrito. Relat. Interno (inéd.).

ALLEN,J.R.L. 1965. Sedimentation to the lee small underwater sand waves: an experimental study. J.Geol.,73(1):95-116.

ALMEIDA,F.F.M. 1953. Contribuição à geomorfologia da região oriental de Santa Catarina. In: ASSEMBLÉIA GERAL ORDINÁRIA DA ASSOCIAÇÃO DOS GEÓGRAFOS DO BRASIL, 4, Goiânia, 1948. Anais Assoc. Geóg. Brasil, São Paulo, AGB, v.3, tomo 1, p.10-37

ALMEIDA,F.F.M. 1991. O alinhamento magmático de Cabo Frio. In:SIMPÓsIO DE GEOLOGIA DO SUDESTE, 2, São Paulo.Atas...São Paulo, SBG/SP-RJ. p.423437.

AMADOR,E.S. 1985. Lagunas fluminenses : classificação com base na origem, idade e processos da evolução. An. Acad. Brasil. Ciênc., 57(4):526-527.

ANDERTON,R. 1985. Clastic facies models and facies analysis. In:BRENCHLEY,P.J. \& WILLIAMS,B.P.J. eds. Recent Development and Applied Aspects. Oxford, The Geol.Soc.- Blackwell Scientific Publ. p.31-47.

ANGULO,R.J. 1992. Geologia da Planície Costeira do Estado do Paraná. São Paulo, Inst.Geoc. Univ.S.Paulo. Tese de Doutoramento (inéd.). 334p.

ANGULO,R.J. \& MÜLLER,A.C.P. 1990. Preliminary characterization of some tidal flat ecosystems on the State of Paraná Coast, Brasil. In : SIMPÓSIO SOBRE ECOSSISTEMAS DA COSTA SUL E SUDESTE BRASILEIRA, 2, Águas de Lindóia. Síntesedos Conhecimentos... São Paulo, Publ.Aciesp (39)Il. p.158-168.

ARANTES,J.T. 1992. El Niño. Quando o tempo enlouquece. Os Caminhos da Terra, 1(5):67-70.

ARAÚJO,D.S.D. \& SANTOS,M.G.F.V. 1987. Caracterização estrutural dos manguezais de Laguna, Santa Catarina. In: SIMPÓSIO SOBRE ECOSSISTEMAS DA COSTA SUL E SUDESTE BRASILEIRA, Cananéia. Síntese dos Conhecimentos, v.2... São Paulo, Public. Aciesp (54)II. p.152.

ASMUS,H.E. 1978. Hipóteses sobre a origem dos sistemas de zonas de fraturas oceânicas/alinhamentos continentais que ocorrem nas regiões sudeste e sul do Brasil. In :PETROBRAS. Aspectos Estruturais da Margem Continental Leste e Sudeste do Brasil. Rio de Janeiro, p.39-73. (Série Projeto Remac, 4).

ASMUS,H.E. 1981. Relacionamento genético de feiçōes geológicas da margem continental sudeste brasileira e da área continental emersa adjacente. In: SIMPÓSIO REGIONAL DE GEOLOGIA, 3, Curitiba. Atas... São Paulo, SBG. v.1, p.262-273.

ASSEEZ,L.O. 1972. Triangular presentation of textural data in interpretation of depositional environments. Sediment.Petrol.,42(3):729-731.

BAGNOLD,R.A. 1954. The Physics of Blown Sand and Desert Dunes. London, Methuen, 265p. 
BARREL,J. 1912. Criteria for the recognition of ancient delta deposits. Bull.Geol.Soc.Am., 23(3):377-446.

BASEI,M.A.S. 1985. O Cinturão Dom Feliciano em Santa Catarina. São Paulo, Inst.Geoc. Univ.S.Paulo. Tese de Doutoramento (inéd.).

BATES,R.L. \& JACKSON, J.A.eds. 1957. Dictionary of Geological Terms. New York, Am. Geol.Inst., Anchor Press, 1984. 571p.

BELPERIO,A.P.; HAILS,J.R.; GOSTIN,V.A.; POLACH,H.A. 1984. The stratigraphy of coastal carbonate banks and Holocene sea levels of northern Spencer Gulf, South Australia. In:HAILS,J.R. \& GOSTIN,V.A.eds. The Spencer Gulf Region.Marine Geol.,61(2/4):297-313.

BERTALANFFY,L.V. 1937. La concepción organísmica. In: Perspectivas en la Teoría General de Sistemas. Madrid, Alianza Universidad Ed., 1ed.cast.,1979. p.89-93.

BERTALANFFY,L.V. 1950. Sistemas abiertos en física y biologia. In : Perspectivas en la Teoria General de Sistemas. Madrid, Alianza Universidad Ed., 1 ed.cast., 1979. p.115-124.

BERTALANFFY,L.V. 1960. Nuevos patrones en el pensamiento biológico y médico. In: Perspectivas en la Teoria General de Sistemas. Madrid, Alianza Universidad Ed., 1 ed.cast., 1979. p.37-48.

BERTALANFFY,L.V. 1965. Modelos teóricos en biología.In: Perspectivas en la Teoría General de Sistemas. Madrid, Alianza Universidad Ed., 1 ed.cast., 1979. p.94-103.

BERTALANFFY,L.V. 1968. Teoria Geral de Sistemas. Petrópolis, Ed. Vozes Ltda. 2 ed.portug., 1975. 351p

BERTALANFFY,L.V. 1972. Historia y desarollo de la teoria general de sistemas. In: Perspectivas en la Teoría General de Sistemas. Madrid, Alianza Universidad Ed. 1 ed.cast., 1979. p.137-156.

BIGARELLA, J.J. 1972. Eolian environments:their characteristics, recognition, and importance. In : RIGBY,J.K. \& HAMBLIN,W.K. eds .Recognition of Ancient Sedimentary Environments. Soc. Econ. Paleontologists Mineralogists. Spec.Publ., 16:12-62.

BIGARELLA, J.J. 1975a. Lagoa dune field (State of Santa Catarina, Brazil), a model of eolian and pluvial activity In: INTERNATIONAL SYMPOSIUM ON THE QUATERNARY, Curitiba. Special Contributions... Bol.Paranaense Geoc.,(33):133 $-167$.

BIGARELLA,J.J. 1975b. Structures developed by the dissipation of sand dunes. In: INTERNATIONAL SYMPOSIUM ON THE QUATERNARY. Curitiba . Abstracts... Bol.Paranaense Geoc.,(33):44-45.

BIGARELLA,J.J. \& BECKER,R.D. 1975a. Brazilian marine reworked gravel deposits. In: INTERNATIONAL SYMPOSIUM ON THE QUATERNARY, Curitiba. Topics for discussion, XIV...Bol. Paranaense Geoc.,(33):251-265.

BIGARELLA,J.J. \& BECKER,R.D. 1975b. Catastrophic events in the Tubarão area. In INTERNATIONAL SYMPOSIUM ON THE QUATERNARY, Curitiba Topics for discussion, VI... Bol.Paranaense Geoc.,(33):200-206.

BIGARELLA,J.J. \& BECKER,R.D. 1975c. Correlative deposits. In : INTERNATIONAL SYMPOSIUM ON THE QUATERNARY, Curitiba.Topics for Discussion, X.. Bol.Paranaense Geoc., (33):225-230.

BIGARELLA,J.J. \& BECKER,R.D. 1975d. Sea level changes. In:INTERNATIONAL. SYMPOSIUM ON THE QUATERNARY, Curitiba.Topics for Discussion, XIII. Bol.Paranaense Geoc., (33):245-251.

BIGARELLA,J.J. \& BECKER,R.D. 1975e. State of Santa Catarina.In: INTERNATIONAL SYMPOSIUM ON THE QUATERNARY, Curitiba. Itinerary... Bol.Paranaense Geoc.,(33):311-329. 
BIGARELLA,J.J. \& FREIRE,S.S. 1960. Nota sobre a ocorrência de cascalheiros marinhos no litoral do Paraná. Bol.Univ.Paraná, Geologia,(3):1-22.

BIGARELLA,J.J. \& SALAMUNI,R. 1961. Ocorrência de sedimentos continentais na região litorânea de Santa Catarina e sua significação paleoclimática. Bol.Paranaense Geol.,(4/5):179-187.

BIGARELLA,J.J.; BECKER,R.D.; DUARTE,G.M. 1969. Coastal dune structures from Paraná, Brazil. Marine Geol.,7:5-55.

BIGARELLA,J.J. ; DUARTE,G.M. ; BECKER,R.D. 1970/1971. Structural characteristics of the dune, foredune, interdune, beach, beach-dune ridge and sand ridge deposits. Bol.Paranaense Geoc.,(28/29):9-72, 32 fig.

BIGARELLA,J.J. ; MARQUES,P.L.,FILHO ; AB'SABER,A.N. 1961. Ocorrência de sedimentos remanescentes nas fraldas da serra do lquererim (Garuva, $S C$ ). Bol.Paranaense Geog. ,(4/5):82-93.

BIGARELLA,J.J.; MOUSINHO,M.R.; SILVA,J.X. 1956. Pediplanos, pedimentos e seus depósitos correlativos no Brasil. Bol. Paranaense Geog.,(16/17):117-151.

BIRD,E.C.F. \& PASKOFF,R. 1979. Relationships between vertical change of land-sea level and the advance and retreat of coastlines. In: INTERN.SYMP. ON COASTAL EVOL.IN THE QUATERNARY, São Paulo, 1978 Proceedings... São Paulo, IGUSP-FAPESP. p.29-40.

BLARASIN,M.T. \& SANCHEZ,M.L. 1987. Secuencia evolutiva de dunas cuaternarias en el sector de Laguna Oscura, Dpto. Rio Cuarto. Provincia de Cordoba Republica Argentina. In : CONGRESSO GEOLOGICO ARGENTINO, 10, San Miguel de Tucuman. Atas... SGA, v.3. p.297-300.

BOCCHI,P.R. \& LIBERATORE,G. 1968a. Análise químicas de sambaquis e concheiros naturais em Santa Catarina. In: CONGRESSO BRASILEIRO DE GEOLOGIA, 22, Belo Horizonte. Resumo das Comunicações... Belo Horizonte, SBG. p.43.

BOCCHI,P.R. \& LIBERATORE,G. 1968b. Relatório Complementar da Vistoria Efetuada junto aos Sambaquis e Concheiros Naturais (Terraços) no Leste do Estado de Santa Catarina entre as Cidades de Jaguaruna e Imbituba, Levando-se em Consideração as Análises Químicas para P2O5, CaO e MgO das Amostras Coletadas durante a Vistoria. Porto Alegre, DNPM-1 Distrito. Relat. Interno (inéd.).

BOCCHI,P.R. \& LIBERATORE,G. 1968c. Relatório Preliminar da Vistoria Efetuada junto aos Sambaquis e Concheiros Naturais (Terraços) no Leste do Estado de Santa Catarina entre as Cidades de Jaguaruna e Imbituba. Porto Alegre, DNPM1 Distrito. Relat. Interno (inéd.). $46 p$.

BOCCHI,P.R. \& LIBERATORE,G. 1968d. Relatório preliminar da vistoria efetuada junto aos sambaquis e concheiros naturais (terraços) no Leste do Estado de Santa Catarina entre as cidades de Jaguaruna e Imbituba. In : CONGRESSO BRASILEIRO DE GEOLOGIA , Belo Horizonte, Resumo das Comunicações... Belo Horizonte, SBG, p.44-45.

BOOTHROYD,J.C. 1978. Mesotidal inlets and estuaries. In :DAVIES,R.A.,Jr. ed. Coastal Sedimentary Environments. Amsterdam, Springer Verlag. p. 287-360.

BOWMAN,D. \& GOLDSMITH,V. 1983. Bar morphology of dissipative beaches: an empirical model. Marine Geol, 51(1/2):15-33.

BOYD,D.R. \& DYER,B.F. 1964. Frio barrier system of South Texas. Trans. Gulf Coast Assoc.Docs. 14:309-322.

BREED,C.S. \& GROW,T. 1979. Morphology and distribution of dunes in sand seas observed by remote sensing. In : McKEE,E.D.ed. A Study of Global Sand Seas. U.S. Geol. Surv., Profess.Papers, 1052:253-302.

BRITO NEVES,B.B.; SILVA,A.B.; ALBUQUERQUE,J.P.T.; BARROS, C.A.F. 1979. Geologia e províncias hidrogeológicas de Santa Catarina. Mineração e Metalurgia,(416):22-34. 
BROOKFIELD,M.E. 1977. The origin of bounding surfaces in ancient aeolian sandstones. Sedimentology, 24(3):303-332.

BRUUN,P. 1962. Sea level rise as a cause of shore erosion.Am. Soc. Civil Engin. Proc., J. Waterways Harbors Div., 88:117-130.

BRUUN,P. 1978. Stability of Tidal Inlets. Theory and Engineering. Amsterdam, Elsevier. 510p. (Developments in Geotechnical Engineering, 23).

BRUUN,P. 1987. Sea level rise effects on shoreline position. J.Waterway Port Coastal Ocean Engin.,113(5): 550-553.

BRYANT,E. 1982. Behaviour of grain size characteristics on refletive and dissipative foreshores, Broken Bay, Australia. J.Sediment.Petrol., 52(2):431-450.

CAMPBELL,C.V. 1967. Lamina, laminaset, bed and bedset. Sedimentology, 8:7-26.

CARTER, R.W.G. 1988. Coastal Environments . London, Academic Press. 617p.

CARVER,R.E. 1971. Heavy mineral separation. In: CARVER,R.E.ed. Procedures in Sedimentary Petrology. New York, Wiley - Interscience. p. 427-452.

CASTRO,V.H.S. \& CASTRO,E.C. 1969a. Geologia da Quadrícula de Laguna, SC. Porto Alegre, DMPM-10 Distrito. Relat. Interno (inéd.), 38p.

CASTRO,V.H.S. \& CASTRO,E.C. 1969b. Geologia da Quadricula de Laguna. In CONGRESSO BRASILEIRO DE GEOLOGIA, 23, Salvador. Bol.Especial (1), Resumo das Conferências e das Comunicações... Salvador, SBG, p.23.

CHAPPELL,J. 1967. Recognizing fossil strand lines from grain size analysis. J.Sediment.Petrol., 37(1):157-165.

CHAPPELL,J. 1983. Evidence for smoothly falling sea level relative to North Queensland, Australia, during the last 6,000 years. Nature, 302:406-408.

CHORLEY,R.J. \& KENNEDY,B.A. 1971. Physical Geography: A Systems Approach. London, Prentice-Hall.

COIMBRA,A.M. \& GIANNINI,P.C.F. 1989. Estruturas e Fácies Sedimentares na Bacia do Paraná, Regiões de Vila Velha -Ponta Grossa-Castro Tibaji (PR) e de Piraju Fartura -Taguaí (SP). Curitiba, Univ. Federal Paraná. Roteiro de Aula de Campo (inéd.),

COLLINSON, J.D. \& THOMPSON,D.B. 1982. Sedimentary Structures.London, George Allen \& Unwin. 187p.

COOPER,W.S. 1958. Coastal sand dunes of Oregon and Washington. Geol.Soc.Am., Mem., 72:169p.

COOPER,W.S. 1967. Coastal dunes of California. Geol.Soc.Am., Mem., 104:131p.

COUTINHO,J.M.V. \& COIMBRA,A.M. 1974. Os pesados do Barreiras na costa oriental brasileira : estudo de áreas-fonte. In: CONGRESSO BRASILEIRO DE GEOLOGIA, 28, Porto Alegre. Anais... Porto Alegre, SBG. v. 5, p.27-41.

DAVIES.J.L. 1964. A morphogenic approach to world shorelines. Z.Geomorphol., $8(1): 27-42$

DAVIES,J.L. 1980. Geographical Variation in Coastal Development. London, Longmans, 2 ed. $212 p$.

DAVIS,J.H. \& EHRLICH,R. 1970. Relationhips between measures of sediment sizefrequency distributions and the nature of sediments. Bull.Geol.Soc.Am., 81(11):3537-3548.

DAVIS,R.A.,Jr. 1983. Depositional Systems. A Genetic Approach to Sedimentary Geology. New Jersey, Prentice-Hall. 669p.

DEAN,R.G. 1987. Additional sediment input to the nearshore region. Shore \& Beach, 55(3/4):76-81.

DELATTRE,P. 1981. Teoria dos Sistemas e Epistemologia. Lisboa, A Regra do Jogo. 107p. (Cadernos de Filosofia,2).

DELLA FAVERA,J.C. 1984. Eventos de sedimentação episódica nas bacias brasileiras. Uma contribuição para atestar o caráter pontuado do registro sedimentar. In: 
CONGRESSO BRASILEIRO DE GEOLOGIA, 33, Rio de Janeiro. Anais... Rio de Janeiro, SBG. v.1, p.489-501.

DELLA FAVERA,J.C. 1990. Tempestitos na Bacia do Parnaiba. Porto Alegre, Univ.Federal Rio Grande do Sul. Tese de Doutoramento (inéd.). 2v., 280p.

DHN (Diretoria de Hidrografia e Navegação). 1989. Porto de Imbituba. In: DHN. Tábua de Marés. Rio de Janeiro, Minist.Marinha. p.173-176.

DIAS NETO,C.M. 1986. Contribuição à Análise Sismotectônica da Região Sudeste do Brasil. São Paulo, Inst. Geoc. Univ.S.Paulo. Dissertação de Mestrado (inéd.). 121p.

DIETZ,V. 1973. Experiments on the influence of transport on shape and roundness of heavy minerals. Contrib. Sedimentol.,1:69-102.

DOEGLAS,D.J. 1960. Grain-size indices, classification and environment. Sedimentology, 10(1):83-100.

DOMINGUEZ,J.M.L. 1990. Deltas dominados por ondas : críticas às idéias atuais com referência particular ao modelo de Coleman \& Wright. Rev.Bras.Geoc.,20(14):352-361.

DOOGE,J.C.I. 1968. The hydrologic cycle as a closed system. Bull.Assoc. Scientif. Hidrol.,13(1):58-68.

DOTT,R.H., Jr. 1964. Wacke, graywacke and matrix - what approach to immature sandstone classification? J. Sediment. Petrol.,34(3):625-632.

DOTT,R.H.,Jr. 1983. Episodic sedimentation; How normal is average? Does it matter? J.Sediment.Petrol., 53(1):5-23.

DUANE,D.B. 1964. Significance of skewness in recent sediments, Western Pamlico Sound, North Carolina. J. Sediment.Petrol., 34(4):864-874.

DUBOIS,R.N. 1975. Support and refinement of the Bruun Rule on beach erosion. J.Geol., 83(5):651-657.

DUBOIS,R.N. 1976. Nearshore evidence in support of the Bruun Rule on shore erosion. J.Geol., 84(4):485-491.

DUBOIS,R.N. 1977. Predicting beach erosion as a function of rising water level. J.Geol.,85(4):470-476.

DUBOIS,R.N. 1982. Relation among wave conditions, sediments, texture, and rising sea level : an opinion. Shore \& Beach, 50(2):30-32.

DUBOIS,R.N. 1992. A re-evaluation of Bruun's Rule and supporting evidence J. Coastal Research, 8(3):618-628.

DYER,K.R. 1979. Estuaries and estuarine sedimentation. In: DYER,K.R.ed. Estuarine Hidrography and Sedimentation. Cambridge, Cambridge University Press. p.1-18.

DYER,K.R. 1986. Coastal and Estuarine Sediment Dynamics. London, WileyInterscience. 342p.

EL ELLA,R.A. \& COLLEMAN,J.M. 1985. Discrimination between depositional environments using grain-size analyses. Sedimentology, 32(5):743-748.

EMERY,K.O. \& STEVENSON,R.E. 1957. Physical and chemical characteristics. In: EMERY,K.O.ed. Estuaries and Lagoons. New York, Geol.Soc.Am., Mem.,67(1):673-693.

EMMERLING,M. \& TANNER,W.F. 1974. Splitting error in replicating sand size analyses. Geol.Soc.Am.,Abstr., 6:352.

ENDO,K. 1986. Coastal sand dunes in Japan. Proc. Inst. Natural Sci.,(21):37-54.

EVANS,O.F. 1939. Sorting and transportation of material in swash and backwash. J. Sediment. Petrol., 9(1):28-31.

FAIRBRIDGE,R.W. \& BOURGEOIS,J.W.eds. 1978. The Encyclopedia of Sedimentology. Stroudsburg - Pennsylvania, Dowden, Hutchinson \& Ross. 901p.

FERNANDES, L.A. 1992. A Cobertura Cretácea Suprabasáltica no Paraná e Pontal do Paranapanema (SP) : os Grupos Bauru e Caiuá. São Paulo, 
Inst.Geoc.Univ.S.Paulo. Dissertação de Mestrado (inéd.). 129p., 6 anexos, 2 mapas.

FERREIRA,L.A.D. 1969. Relatório da Geologia da Quadrícula Rio Fortuna, SC, Escala Aproximada 1:50.000. Porto Alegre, DNPM 1 Distrito. Relat. Interno (inéd.). 19p.

FICHTER,L.S. 1988. Process-response modeling and the scientific process. J.Geol. Education, 36:72-78.

FINK,B.H. 1989. Effects of dune overwash during the January 18,1988 storm at the Tijuana Estuary, San Diego, California. Shore \& Beach, 57(4):41-43.

FINKEL,H.J. 1959. The barchans of Southern Peru. J.Geol.,67(6):614-647

FISHER,R.A. \& YATES,F. 1938. Tablas Estadísticas. Madrid, Aguilar, 1954. 131p.

FISHER,W.L. 1983. Facies Analysis in Reservoir Geology. Ouro Preto, Univ. Federal Ouro Preto. Apostila de Curso (inéd.) 66p.

FISHER,W.L. \& MCGOWEN,J.H. 1967. Depositional systems in Wilcox Group (Eocene) of Texas and their relation to occurrence of oil and gas. Bull.Am.Assoc. Petrol. Geologists, 53(1):30-54, 1969.

FISHER,W.L.; BROWN,L.F.,Jr.; SCOTT,A.J.; McGOWEN,J.H. 1969. Delta systems in the exploration of oil and gas. Bureau Econ. Geol., Univ. Texas. 212p.

FOLK,R.L. 1951. Stages of textural maturity in sedimentary rocks J.Sediment.Petrol.,21(3):127-130.

FOLK,R.L. 1969. Grain shape and diagenesis in the Simpson Desert, Northern Territory, Australia. Geol.Soc.Am., Progr.Ann.Meeting, (68/69).

FOLK,R.L. 1976. Reddening of desert sands: Simpson Desert, Northern Territory, Australia. J.Sediment.Petrol.,46(3):604-615.

FOLK,R.L. \& WARD,W.C. 1957. Brazos River bar, a study in the significance of grainsize parameters. J.Sediment. Petrol., 27(1):2-26.

FRAGOSO-CESAR,A.R.S. 1980. O Cráton do Rio de la Plata e o Cinturão Dom Feliciano no Escudo Uruguaio-Sul-Riograndense. In: CONGRESSO BRASILEIRO DE GEOLOGIA, 31, Balneário Camboriú. Anais... Florianópolis, SBG. V.5, p.2879-2892.

FRAGOSO-CESAR,A.R.S. 1991. Tectônica de Placas no Ciclo Brasiliano: As Orogenias dos Cinturões Dom Feliciano e Ribeira no Rio Grande do Sul. São Paulo, Inst. Geoc. Univ.S.Paulo. Tese de Doutoramento (inéd.). 367p

FREY,R.W. \& BASAN,P.B. 1978. Coastal salt marshes. In: DAVIES,R.A., Jr. ed. Coastal Sedimentary Environments. Amsterdam, Springer Verlag. p.101-166

FRITZ,W.J. \& MOORE,J.N. 1988. Basics of Physical Stratigraphy and Sedimentology New York, John Wiley \& Sons. 371p.

FRYBERGER,S.G. 1979. Dune forms and wind regime. In: McKEE,E.D. ed. A Study of Global Sand Seas. U.S., Geol. Survey, Profess. Papers, 1052:83-134.

FRYBERGER,S.G. \& SCHENK,C. 1988. Pin stripe lamination: a distinctive feature of modern and ancient eolian sediments. Sediment. Geol.,55(1/2):1-15.

GALEHOUSE,J.S. 1971a. Point-counting. In: CARVER,R.E. ed. Procedures in Sedimentary Petrology. New York, Wiley- Interscience. p.385-407.

GALEHOUSE, J.S. 1971b. Sedimentation analysis. In: CARVER,R.E. ed. Procedures in Sedimentary Petrology. New York, Wiley-Interscience. p.69-94.

GALLOWAY,W.E. 1979. I.Introduction: the concept of natural systems. In: GALLOWAY,W.E.; KREITLER,C.W.; MCGOWEN,J.H. eds. Depositional and Ground Water Flow Sistems in the Exploration for Uranium. Austin, Bureau of Econ. Geol. The Univ. of Texas, p.1-2.

GALLOWAY,W.E. \& HOBDAY,D.K. 1983. Terrigenous Clastic Depositional Systems New York, Springer-Verlag, $423 \mathrm{p}$.

GARCIA,M. 1986. O meio ambiente. In: GAPLAN-SC. Atlas de Santa Catarina. Rio de Janeiro, Aerofoto Cruzeiro.p.39-40. 
GIANNINI,P.C.F. 1987. Sedimentação Quaternária na Planicie Costeira de PeruíbeItanhaém (SP). São Paulo, Inst.Geoc. Univ.S.Paulo. Dissert.de Mestrado (inéd.). 2v., 234p., 3 mapas.

GIANNINI,P.C.F. 1989. Evolução quaternária da planície costeira de Peruibe-Itanhaém (SP) segundo resultados granulométricos: um confronto de métodos de tratamento estatístico. Bol.Paranaense Geoc.,(38):1-50.

GIANNINI,P.C.F. 1991. Sedimentologia de Sistemas Deposicionais Superficiais no Quaternário Costeiro entre Jaguaruna e Imbituba, SC. São Paulo, Inst. Geoc. Univ.S.Paulo. Exame de Qualificação (inéd.). $141 \mathrm{p}$.

GIBBS,R.J. 1972. The accuracy of particle-size analyses utilizing settling tubes. J.Sediment.Petrol., 42(1):141-145.

GLASSFORD,D.K. \& SEMENIUK,V. 1990. Stratificacion and desconformities in yellow sands of the Bassendean and Spearwood Dunes, Swan Coastal Plain, SouthWestern Australia. J.Royal Soc. Western Australia, 72(3):75-92.

GLENNIE,K.W. 1970. Sedimentary Enviroments. Amsterdam, Elsevier. 222p. (Developments in Sedimentology,14).

GOLDSMITH,V.1973. Internal geometry and origin of vegetated coastal sand dunes. J.Sediment. Petrol.,43(49):1128-1142.

GOLDSMITH,V. 1978. Coastal dunes. In: DAVIES Jr.,R.A. ed. Coastal sedimentary enviroments. Amsterdam, Springer Verlag. p.171-235.

GRANT-GROSS,M. 1971. Carbon determination. In: CARVER,R.E. ed. Procedures in Sedimentary Petrology. New York, Wiley-Intersciense. p.573-596.

GREENSMITH,J.T. \& TUCKER,E.V. 1986. Compaction and consolidation. In: VAN DE PLASSCHE,O. ed. Sea-level Research: a Manual for the Collection and Evaluation of Data. Norwich, Geo Books. p.591-604.

GREENWOOD,B. 1978. Spacial variability of texture over a beach dune complex, North Devon, England. Sediment. Geol.,21(1):27-44.

GREGORY,K.J. 1985. A Natureza da Geografia Fisica. Rio de Janeiro, Bertrand Brasil, 1992.367p.

GUERRA,A.T. 1950a. Apreciações sobre o valor dos sambaquis como indicadores de variação dos oceanos. Bol. Geog., 8(90):850-853.

GUERRA,A.T. 1950b. Contribuição ao estudo da geomorfologia e do Quaternário do litoral de Laguna (Santa Catarina). Rev.Bras. Geog., 12(4):535-564.

GUERRA,A. T. 1953. Notas sobre alguns sambaquis e terraços do litoral de Laguna (Santa Catarina). In: ASSEMBLÉIA GERAL ORDINÁRIA DA ASSOCIAÇÃO DOS GEÓGRAFOS DO BRASIL, 6, Nova Friburgo, 1951. Anais Assoc. Geóg.Brasil, São Paulo, AGB, 1953, v.5, tomo 1, p.11-24.

HACK,J.T. 1941. Dunes of the Western Navajos County. Geol. Rev., 31:240-263.

HASUI,V.; CARNEIRO,C.D.R.; COIMBRA,A.M. 1975. The Ribeira folded belt. Rev.Bras. Geog., 5(4):257-266.

HAYES,M.O. \& KANA,T.W. eds 1976. Terrigenous Clastic Deposicional Enviroments. Columbia Coastal Research Div., Univ. South Carolina, 302p. (Tech. Rept., 11).

HAYES,M.O. \& SCOTT,A.J. 1964. Enviromental complexes, South Texas coast. Trans. Gulf Coast Assoc. Geol. Soc., 14:237-240.

HARBAUGH,J.W. \& MERRIAN,D.F. 1968. Computer Aplication in Stratigraphic Analisis. New York, Wiley-Intersciense. 257p.

HERZ,R. 1991. Manguezais do Brasil. São Paulo, Inst. Oceanogr. Univ.S.Paulo 240p

HESP,P.A. 1981. The formation of shadow dunes. J.Sediment.Petrol., 51(1):101-112.

HESP,P.A. 1983. Morphodynamics of incipient foredunes in New South Wales, Austrália. In: BROOKFIELD,M.E. \& AHLBRANDT,T.S.eds. Eolian Sediments and Processes. Amsterdam, Elsevier. p.325-342 (Developments in Sedimentology, 38). 
HESP,P.A. 1988. Morphofology, dynamics and internal stratification of some established foredunes in Southeast Austrália. Sediment.Geol., 55(1/2):17-41.

HESS,H.H. 1956. Notes on operation of Frantz Isodynamic Magnetic Separator. Princeton, Separator S.G. Frantz Co. 8p.

HOWELL, J.W. 1960. Glossary of Geology and Related Sciences.Washington, Am. Geol.Inst. 325p.

HORBACH,R. \& MARIMON,R.G. 1980. Esboço da evolução tectônica e seu significado na gênese dos depósitos de fluorita do sudeste catarinense. In: CONGRESSO BRASILEIRO DE GEOLOGIA, Balneário Camboriú, Anais... Florianópolis, SBG. . V.3, p.1540-1551.

HORN, N.O. 1988. Geologia das Folhas de Torres, Três Cachoeiras, Arroio Teixeira e Maquiné, Nordeste do Rio Grande do Sul. Porto Alegre, Curso de Pós-Graduação em Geociências, Univ .Federal Rio Grande do Sul. Dissertação de Mestrado (inéd.).241p.

HSU,K.J. 1983. Actualistic catastrophism. Sedimentology, 30(1):3-9.

HUBERT, J.F. 1962. A zircon-tourmaline-rutile maturity index and the interdependence of the composicion of heavy mineral assemblages with the gross composition and texture of sandstones. J.Sediment.Petrol.,32(3):440- 450.

HUGGET,R.J. 1985. Earth Surface Systems. New York, Springer-Verlag. 270p

HUNTER,R.E. 1974. Types of eolian strata and pseudostrata (abstr.). Ann. Meeting Abstr. Am. Ass. Petrol. Geol. \& Soc. Econ. Paleontologists Mineralogists, 1:47-48.

HUNTER,R.E. 1976. Comparison of eolian and subaqueous sandflow cross-strata (abstr.) . Bull.Am .Assoc. Petrol. Geologists, 60(4):683-684.

HUNTER,R.E. 1977. Basic types of stratification in small dunes. Sedimentology, 24(3):361-387

HUNTER,R.E. \& RICHMOND,B.M. 1988. Daily cicles in coastal dunes. Sediment. Geol., 55(1/2):43-68.

HURT,W.R. 1974. The interrelationships between the natural environment and four sambaquis, Coast of Santa Catarina, Brazil. Indiana, Indiana Univ. Museum, 23p. (Ocasional Papers and Monographs, 1).

INMAN,D.L. \& DOLAN,R. 1989. The Outer Banks of North Carolina: budget of sediment and inlet dynamics along a migrating barrier system. J.Coastal Research, 5(2):193-237.

ISLA,F.I. 1989. Holocene sea-level fluctuation in the Southern Hemisphere. Quatern.Sci.Rev.,8(4):359-368.

ISPHORDING,W.C. 1972. Analysis of variance applied to measures of central tendency and dispersion in sediment. J. Sediment. Petrol.,42(1):107-121.

ISSLER,R.S. 1982. Evento geodinâmico brasiliano - fechamento de oceano e colisão continental dos crátons rio de la Plata e Dom Feliciano: granitos a duas micas e ofiolitos. In : CONGRESSO BRASILEIRO DE GEOLOGIA, 32, Salvador. Anais... Salvador, SBG,.v.1,p.24-38.

ISSLER,R.S. 1983. Evolução crustal da Faixa Arco-Fossa Tijucas e Faixa Magmática Pedras Grandes : Cráton Dom Feliciano. In: SIMPÓSIO SUL-BRASILEIRO DE GEOLOGIA, I, Porto Alegre. Anais... Porto Alegre, SBG. v.1,p.19-36.

JACKSON II,R.G. 1975. Hierarchical attributes and a unifying model of bedforms, composed of cohesionless material and produced by shearing flow. Bull.Geol.Soc.Am.,86(11):1523-1533.

JACOBSEN,E.E. \& SCHWARTZ,M.L. 1981. The use of geomorphic indicators to determine the direction of net shore-drift. Shore \& Beach, 49(3):38-49.

JENNINGS, J.N. 1957. On the orientation of parabolic or U-dunes. Geol.J., 123(4): 474480 .

JENNINGS,J.N. 1967. Cliff-top dunes. Austr. Geogr. Stud., 5:40-49. 
JOPLING,A.V. 1965. Laboratory of sorting processes in cross-bedded deposits. In: MIDDLETON, G.V .ed. Primary Sedimentary Structures and their Hydrodinamic Interpretacion: A Symposion.Soc.Econ.Paleontologists Mineralogists, Spec.Public.12:53-65.

JORDAN,D.W.; TOBIN,R.G.; LUNDEGARD,P.; SAMUELS,N.; SCHAUF,F.; THAELER, J.; VANBEUREN,V.; POTTER,P.E. 1981. Comparations of methods of size analysis for sands of theAmazon-Solimões Rivers, Brazil and Peru. Sedimentology, 28(1):123-128.

KOCUREK,G. 1981. Significance of interdune deposits and bounding surfaces in eolian dune sands. Sedimentology, 28(6):753-780.

KOCUREK, G. 1988. First-order and super bounding surfaces in eolian sequences. Bounding surfaces revisited. Sediment.Petrol, 56(1/4):193-206.

KOCUREK,G. \& DOTT,R.H.Jr. 1981. Distinction and uses of stratification types in the interpretation of eoliansand. J. Sediment.Petrol., 51(2):579-595.

KOCUREK,G. \& NEILSON,J. 1986. Conditions favourable for the formation of warm climate aeolian sand sheets. Sedimentology, 33(6):795-816.

KOLDIJK,W.S. 1968. On enviroment-sensitive grain-size parameters. Sedimentology, 10(1):57-69.

KOMAR,P. 1977. Selective longshore transport rates in different grain size fractions within a beach. J. Sediment. Petrol., 47(4):1444-1453.

KOWSMANN,R.O. \& COSTA,M.P.A. 1979. Sedimentação Quaternária da Margem Continental Brasileira e das Áreas Oceânicas Adjacentes. Rio de Janeiro, Petrobrás/Cenpes/Dintep. 55p, 3 mapas (Série Projeto Remac,8).

KOWSMANN,R.O.; COSTA,M.P.A.; VICALVI,M.A.; COUTINHO,M.G.N. GAMBOA,L.A.P. 1977. Modelo da sedimentação holocênica na plataforma continental sul brasileira. In: Petrobrás. Evolução Sedimentar Holocênica da Plataforma Continental e do Talude do Sul do Brasil. Rio de Janeiro Petrobrás/Cenpes/Dintep.p7-26. (Série Projeto Remac,2).

KRUMBEIN.W.C. 1938. Size frequency distribution of sediments and the normal phi curve. J. Sediment. Petrol, ,8(1):84-90.

KRUMBEIN,W.C. \& SLOSS, L.L. 1963. Stratigraphy and Sedimentation. San Francisco, Freeman, 2 ed. 660p

KRYNINE,P.D. 1946. The tourmaline group in sediments. J. Geol., 54(1):64-87

KUX,H.J.H. \& VALERIANO,D.M. 1982. Resultados preliminaresda interpretação automática de dados do MSS-Landsat, aplicada a estudos de área de rejeito de carvão, naregião de Criciúma, Estado de Santa Catarina, Brasil. In: SIMPÓsıO BRASILEIRO DE SENSORIAMENTO REMOTO, 2, Brasilia. Anais ... São José dos Campos, INPE. v.3.p.705-712.

LABORATÓRIO DE SEDIMENTOLOGIA-IGUSP (Inst.Geoc.Univ.S.Paulo) 1991 Manual do Programa de Granulometria LABSE2.COM. São Paulo, IGUSP. Apostila (inéd.). 11p.

LANCASTER,N. 1988. The develoment of large aeolian bedforms. Sediment. Geol., 55(1/2):68-69.

LANDIM,P.M.B. 1983. Análise Estatística de Dados Geológicos. Rio Claro, UNESP. Apostila de Curso (inéd.).104p.

LANGFORD,R.P. 1989. Fluvial-aeolian interactions. Part I, modern systems. Sedimentology, 36(6):1023-1036.

LANKFORD, R.L. 1977. Coastal lagoons of Mexico. Their origin and classification. In: WILEY, M. ed. Estuarine Processes. New York, Academic Press Inc. v.1,p.182215.

LAUFFER,M.A. 1975. Entropy-Driven Processes in Biology. New York, Springer-Verlag. 
LEATHERMAN,S.P. 1983. Barrier dynamics and landward migration with Holocene sea-level rise. Nature, 301:415-417

LEATHERMAN,S.P. 1987. Time frames for barrier island migration. Shore \& Beach, $55(3 / 4): 82-86$.

LEATHERMAN,S.P. \& ZAREMBA,R.E. 1987. Overwash and aeolian processes on a U.S. Northeast coast barrier. Sediment.Geol.,52(3/4):183-206.

!EINZ,V. 1949. Contribuição à geologia dos derrames basálticos do sul do Brasil. Bol. Faculd.Filos. Ciênc. Letras Univ. S.Paulo, Bol. Geologia, 91(5):61p.

LIMA,R.L. \& ANGULO,R.J. 1990. Descoberta de microfora em um nivel linhítico da Formação Alexandra, Terciário do Estado do Paraná, Brasil. Anais Acad. Bras. Ciên.,62(4): 357-371.

LISTER G.S.; ETHERRIDGE,M.A.; SYMONDS,P.A. 1986. Deatchment faulting and the evolution of passive continental margins. Geology, 14(3):246-250.

LIVINGSTONE,I. 1989. Temporal trends in grain-size measures on a linear sand dune. Sedimentology, 36(6):1017-1022

MACEDO,A.C.M. \& FERREIRA,C.S. 1976. Sobre perfis estratigráficos no Quaternário de Tubarão, SantaCatarina. Anais Acad.Bras. Ciênc., 48(3):603-604.

MACEDO,J.M. 1987. Evolução estrutural da bacia de Santos e áreas continentais adjacentes. In: SIMPÓSIO SUL-BRASILEIRO DE GEOLOGIA, 3, Curitiba. Atas... Curitiba, SBG, v. 2, p.875-895.

MACEDO,J.M.; BACOCCOLI,G.; GAMBOA,L.A.P. 1991. O tectonismo mesocenozóico da região Sudeste. In: SIMP.GEOL.SUDESTE, 2, São Paulo. Atas... São Paulo, SBG/SP-RJ, p.429-433.

MAINGUET,M. 1983. Dunes vives, dunes fixées, dunes vêtues: une classification silon le bilan d'alimentation, le regime éolien et la dinamique des édifices sableux. Z. Geomorphol., suppl.- bd.45:265-285.

MAINGUET,M. 1984. A classification of dunes based on aeoliandynamics and the sand budget. In: EL-BAZ, F. ed. Desert and Arid Lands. Nyhoff, The Hague. p.31-58

MARTIN,L. \& SUGUIO,K. 1976. O Quaternário marinho do Estado de São Paulo. In: CONGRESSO BRASILEIRO DE GEOLOGIA, Ouro Preto. Anais... Ouro Preto, SBG, v.1, p.281-294

MARTIN,L. \& SUGUIO,K. 1986. Excursion route along the coastal plains of the states of Paraná and Santa Catarina. In: INTERNATIONAL SYMPOSIUM ON SEA LEVEL CHANGES AND QUATERNARY SHORELINES, São Paulo. Special Publication (1)... São Paulo, IGUSP-FAPESP. 124p

MARTIN,L;; BITTENCOURT,A.C.S.P.; VILAS-BOAS,G.S.1981. Diferenciation sur photographies aériennes des terracessableuses pléistocènes et holocènes du littoral del'etat de Bahia (Brésil). Photo Intérprétation, 3(4/5).

MARTIN,L.; FLEXOR,J.M.; SUGUIO,K. 1991. Possible changes in the Holocene wind pattern recorded on southastern Brazilian coast. In: GLOBAL CHANGES IN SOUTH AMERICA DURING THE QUATERNARY, São Paulo. Procedings... Bol. IG-USP, PUbI.ESP. (8):117-132.

MARTIN,L.; SUGUIO,K.; FLEXOR,J.N. 1986. Relative sea-level reconstruction during the last 7,000 years along the States of Paraná and Santa Catarina coastal plains: additional information derived from shell-middens: In: INTERNATIONAL SYMPOSIUM ON SEA LEVEL CHANGES AND QUATERNARY SHORELINES, São Paulo. Quaternary South Am. Antarct. Peninsula, 4(11):219-236.

MARTIN.L.; SUGUIO,K.; FLEXOR,J.M. 1988a. Hauts niveaux marins pleistocenes du litoral bresilien. Palaeogeog., Palaeoclimat., Palaecol., 68(3):231-239

MARTIN,L.; SUGUIO,K; FLEXOR,J.M.; AZEVEDO,A.E.G. 1988b. Mapa Geológico do Quaternário Costeiro dos Estados do Paraná e Santa Catarina. Brasilia. DNPM, 40p., 2 mapas (Série Geologia 28, Seção Geologia Básica 18). 
MARTINS,L.R.S. 1962. Significado da assimetria e curtose na análise estastistica. Not. Geomorf., 5(9/10):31-38.

MARTINS,L.R.S. 1965. Significance of skewness and kurtosis in environmental interpretation. J. Sediment. Petrol., 35(3):768-770.

MARTINS,L.R.S. \& MARTINS.I.R. 1974. Propriedades texturais dos sedimentos litorâneos de Santa Catarina. III - Trecho Laguna - Araranguá. Pesquisas, 3:17-34.

MARTINS,L.R.S. \& MARTINS,I.R. 1985. Contribuição a sedimentologia da plataforma externa e talude superior de Santa Catarina. Pesquisas, 17:91-111.

MARTINS L.R.S.; PODOLSKY,V.M.; EICHER,B.B. 1970. Sedimentos praiais de Santa Catarina (II - Trecho: Laguna - Imbituba). Notas e Estudos, Escola de Geologia, 2(1):27-44.

MARTINS,R. 1964. Uso do separador magnético no estudo de minerais pesados. Bol.Paranaense Geog., (10-15):311-323.

McBRIDE,E.F. \& HAYES,M.O. 1962. Dune cross-bedding on Mustang Island, Texas. Bull.Am.Assoc. Petrol. Geologists, 64(4):546-551.

McCAVE,I.N. 1978. Grain size trends and transport along beaches: example from eastern England. Marine Geol., 28(1/2):M43-M51.

MCKEE,E.D. 1939. Some types of bedding in the Colorado river delta. J.Geol.,47(1):6481.

MCKEE,E.D. 1957. Primary structures in some recent sediments .Bull.Am.Assoc. Petrol.Geologists, 41(8):1704-1747.

MCKEE,E.D. 1966. Structures of dunes at white Sands National Monument, New Mexico. Sedimentology, 7(1):1-60.

MCKEE,E.D. 1979. A study of global sand seas. U.S.Geol.Survey, Profess.Papers, 1052:423p.

MCKEE,E.D. 1982. Sedimentary structures in dunes of the Namib Desert, South West Africa. Geol. Soc. Am., Spec.Papers, 118:64p.

McKEE,E.D. 1983. Eolian sand bodies of the word. In: BROOKFIELD,M.E. \& AHLBRANDT, T.S.eds. Eolian Sediments and Processes. Amsterdam, Elsevier.p. 1-25 (Develoments in Sedimentology,38).

McKEE,E.D. \& BIGARELLA,J.J. 1972. Deformational structures in Brazilian coastal dunes. J. Sediment. Petrol. 42(3):670-681.

McKEE,E.D. \& TIBBITS,C.G.Jr. 1964. Primary structures of a seif dune and association deposits in Lybia. J. Sediment. Petrol., 34(1):5-17.

MCKEE,E.D. \& WEIR,G.W. 1953. Terminology for stratification and cross stratification in sedimentary rocks. Bull. Geol. Soc. Am.,63(4):381-390.

McKEE,E.D.; DOUGLAS,J.R.; RITTENHOUSE,S. 1971. Deformation of lee-side laminae in eolian dunes. Bull. Geol. Soc. Am. 82(2):359-378.

MCLAREN,P. 1981. An interpretation of trends in grain size measures. J.Sediment. Petrol.,51(2):611-624.

MCLAREN,P. 1982. Hydraulic control of grain-size distributions in a macrotidal estuary - discussion. Sedimentology, 29(3):437-439.

MCLAREN,P. \& BOWLES,D. 1985. The effects of sediment transport on grain-size distributions. J. Sediment. Petrol.,55(4):457-470.

MCLAREN,P. \& BOWLES,D. 1991. A critique of the "McLaren method" for defining sediment transport patho - Reply. J.Sediment Petrol.,61(1):147

MELLO,M.S. 1990. A Formação Pariquera-Açu e Depósitos Relacionados: Sedimentação, Tectônica e Geomorfogênese. São Paulo, Inst.Geoc. Univ. S.Paulo. Dissert. de Mestrado (inéd.). 211p.

MILLER,R.L. 1956. Trend surfaces: their application on analysis and description of enviroments of sedimentation: 1. the relation of sediment-size parameters to current wave system and physiography. J. Geol., 64(5):425-446. 
MILLIKEN,K.L. 1988. Loss of provenance information through subsurface diagenesis in Plio-Pleitocene sandstones, northern Gulf of Mexico. J. Sediment.Petrol.,58(6): 992-1002.

MILLIKEN,K.L. \& MACK,L.E. 1990. Subsurface dissolution of heavy minerals, Frio Formation sandstones of the ancestral Rio Grande Province, South Texas. Sediment. Geol.,68(3):187-199.

MÔNACO,O.A.; TRAMONTINA,H.G.; WILLIG,C.D.; VALENTINI,N.; ZIR,J.A.,FILHO; CONTE,C.N. 1974a. Folha Porto Alegre (SH-22). In: DNPM. Carta Geológica do Brasil ao Milionésimo. Folhas Geológicas. Mapa.

MÓNACO,O.A.; ZIR,J.A.,FILHO; TRAMONTINA,H.C.; KNIJNIK,P.R. 1974b. Folha Curitiba (SG-22) In: DNPM. Carta Geológica do Brasil ao Milionésimo. Folhas Geológicas. Mapa.

MONTEIRO,C.A.F. 1958. Atlas Geográfico de Santa Catarina. Florianópolis, IBGE Dpto Estadual de Geografia e Cartografia (Série 2, publ.2).

MORAD,S. \& ALDAHAN,A.A. 1986. Alteration of detrital Fe-Ti oxides in sedimentary rocks. Bull. Geol.Soc.Am.,97(5):567-578.

MORGENTAL,A. \& KIRCHNER,C.A. 1983. Síntese do mapa previsional do distrit de fluorita de Santa Catarina. In: SIMPÖSIO SUL-BRASILEIRO DE GEOLOGIA, 1 , Porto Alegre Atas...Porto Alegre, SBG/RS-SC.p.294-306.

MORTON,A.C. 1984. Stability of ditrital heavy minerals in Tertiary sandstones from the North Sea basin. Clays Clay Miner., 19:287-308.

MORTON,A.C. 1987. Influences of provenance and diagenesis of detrital garnet suites in the Paleocene Forties Sandstones, central North Sea. J.Sediment.Petrol., 57(6): 1027-1032.

MORTON,A.C. \& SMALE,D. 1990. The effects of transport and weatherina on heavy minerals from the Cascade River, New Zealand. Sediment. Geol.,68(1/2):117-123.

MOSLOW,T.F. 1990. Coastal and Shelf Sedimentation Models. In: CONGRESSO BRASILEIRO DE GEOLOGIA, 36, Natal. Short Course. Natal, SBG. 124p.

MUTTI,E. \& RICCI-LUCCHI,F. 1972. Le torbiditi dell'Appennino Setentrionale introduzione all'analisi de facies. Mem. Soc.ltal.,11:161-199.

NICKLING,W.C. 1983. The stabilizing role of bouding agents on the entrainment of sediments by the wind. Sedimentology, 31(1):11-17.

OHMORI,H.; ENDO,K.; UESUGI,Y.; HORIKOSHI,M. 1987. Stratigrafy and geomorphologic history of Holocene dunefield near Millicent along the southeastern coast of South Austrália, 96(1):1-22.

ORLANDI,V. \& SILVA,L.C. 1979. Mapa de fácies metamórficas do Estado de Santa Catarina escala 1:1.000.000. Acta Geolog. Leopoldinense, (6):125-132.

ORSELLI,L. 1986. Climatologia. In: Gaplan - SC. Atlas de Santa Catarina. Rio de Janeiro, Aerofoto Cruzeiro. p.38-39.

ORTEGA Y GASSET,J. 1930. La Rebelión de las Masas. Madrid, Revista de Occidente, 2. ed., 1951. p. 113-312 (Obras Completas, 4).

OTA,Y. \& MACHIDA,H. 1987. In: TOOLEY,M.J. \& SHENNAN,l.ed. Sea level changes. London, Basil Blackwell. p.182-224. (The Institute of British Geographers Special Publication Series, 20).

OTA,Y.; UMITSU,M.; MATSUSHIMA,Y. 1990. Recent Japanese research on relative sea-level changes in the Holocene and related problems (Review of studies between 1980 and 1988). The Quaternary Research, 29(1):31-48.

OTTO,G.H. 1935. The sedimentation unit and its use in field sampling. J.Geol.,46(4):569-582.

PAIVA,G. 1933. Geologia do municipio de Lages, Santa Catarina. Bol.Ser.Min., (69):114. 
PARFENOFF,A.; POMEROL,C.; TOURENQ,J. 1970. Le Minéraux en Grains. Paris, Masson et Cie Éd, 580p.

PEREIRA,M.J. \& MACEDO,J.M. 1990. A bacia de Santos: perspectivas de uma nova província petrolifera na plataforma continental sudeste brasileira Bol. Geoc. Petrobrás, 4(1):3-11.

PETTIJOHN,F.J.1941. Persistence of heavy minerals and geologic age. J.Geol., 49(2):612-625.

PETTIJOHN,F.J. 1957. Sedimentary Rocks. New York, Harper International, 3ed., 1975. $628 \mathrm{p}$

PETTIJOHN,F.J.; POTTER,P.E.; SEIVER,R. 1972. Sand and Sandstone. New York, Springer-Verlag, 2.ed., 1987.553p.

PETRI;S. \& SUGUIO,K. 1973. Stratigrafy of the Iguape-Cananeia lagoonal region sedimentary deposits, São Paulo State, Brasil. Part II. Heavy mineral studies, micro - organisms inventories and stratigraphical interpretations. Bol.IG.Inst. Geog. USP, 4:71-85.

PHOENIX,D.A. 1963. Geology of the Lees Ferry area, Coconino County, Arizona. U.S. Geol.Survey,Bull., 1137:1-86.

PICADA,R.S. 1971. Ensaio sobre a tectônica do escudo sul-riograndense. Caracterização dos sistemas de falhas. In: CONGRESSO BRASILEIRO DE GEOLOGIA,25, São Paulo. Anais... São Paulo, SBG. v.1,p.167-191.

PICKRILL,R.A. 1985. Beach changes on low energy lake shorelines, Lakes Manapouri and Te Anau, New Zealand. J. Coastal Research, 1(2):353-363.

PILKEY,O.H. 1989. The engineering of sand. J.Geol.Education, 37:308-311.

PILKEY,O.H. 1991. Coastal erosion. Episodes, 14(1):46-51

PIMIENTA,J. 1958. A Faixa Costeira Meridional de Santa Catarina. Rio de Janeiro, DNPM/DGM. 104p. (Bol. 176).

PONÇANO,W.L. 1986. Sobre a interpretação ambiental de parâmetros estatísticos granulométricos : exemplos de sedimentos quaternários da costa brasileira. Rev. Bras. Geoc., 16(2):157-170.

POPPER,K.R. 1934. A lógica da investigação científica. In: CIVITA,V.ed.Popper. São Paulo, Abril Cultural,1980.p. 3-124 (Série Os Pensadores).

PRIGOGINE,I. 1980. From Being to Becoming: Time and Complexity in the Phisical Sciences. New York, Freeman.272p.

PUTZER,H. 1953. Diatrofismo "germmanótipo" e sua relação com o vulcanismo basáltico na parte meridional de Santa Catarina. Bol. Soc.Bras. Geol., 2(2):37-74.

PUTZER, 1935. Geologia da Folha de Tubarão. Rio de Janeiro, DNPM/DFPM. 94p (Boletim 96).

PYE,K. 1983a. Early post-deposicional modification of eolian dune sands. In BROOKFIELD, M.E. \& AHLBRANDT, T. S. eds. Eolian Sediments and Processes Amsterdam, Elsevier. p. 197-221. (Developments in Sedimentology. 38).

PYE,K. 1983b. Formation and history of Queensland coastal dunes. Z. Geomorphol., suppl-bd. 45:175-204

RADAMBRASIL-IBGE. 1986a. Geologia. In: GAPLAN - SC. Atlas de Santa Catarina Rio de Janeiro, Aerofoto Cruzeiro. p.29-31, mapa B1.

RADAMBRASIL-IBGE. 1986b. Geomorfologia. In : GAPLAN - SC. Atlas de Santa Catarina. Rio de Janeiro, Aerofoto Cruzeiro.p.31, mapa B2.

RADAMBRASIL-IBGE. 1986c. Hidrografia. In: GAPLAN-SC. Atlas de Santa Catarina. Rio de Janeiro, Aerofoto Cruzeiro. p.32-33, mapas B3-B5.

RAMPINO,N.R. \& SANDERS,J.E. 1983. Barrier island evolution in response to sea level rise : reply. J. Sediment. Petrol., 53(3):1031-1033.

REINECK,H.E. \& SINGH,I.B. 1975. Depositional Sedimentary Enviroments. New York, Springer-Verlag, 2ed., 1980. 549p. 
REINSON,G.E. 1979. Barrier island systems. In: WALKER, R.G. ed. Facies Models. Ottawa, Geosc. Canada, 1979,p. 57-74. (Reprint Series,1).

RUBIN,D.M. \& HUNTER,R. 1982. Bedform climbing in theory and nature. Sedimentology, 29(1):121-138.

RUSSEL,R.D. 1937. Mineral composition of Mississippi river sands. Bull.Geol.Soc.Am., 48(9):1307-1348.

RUSSEL,R.D. 1939. Effects of transportation on sedimentary particles. In: TRASK, P.D. ed. Recent Marine Sediments. A Symposium. London, Thomas Murly \& Co. p.3247.

SALLENGER,A.H.,Jr. 1979. Inverse grading and hydraulic equivalence in grain-flow deposits. J.Sediment.Petrol., 42(2):553-562.

SANTOS,J.P. 1978. Estudos hidrogeológicos da planície costeira de Imbituba-Santa Catarina. In: CONGRESSO BRASILEIRO DE GEOLOGIA, 30, Recife. Bol.(1), Resumo das Comunicações... Recife, SBG.p.364.

SANTOS,M.C.F. \& ARAÚJO,D.S.D. 1987. Primeiras considerações sobre os pântanos herbáceos salinos do complexo estuarino-lagunar de Laguna, Santa Catarina. In : SIMPÓSIO SOBRE ECOSSISTEMAS DA COSTA SUL E SUDESTE BRASILEIRA

Cananéia. Sintese dos Conhecimentos,v.2...São Paulo, Public. ACIESP 954) II.p. 150.

SARRE,R.D. 1988. Evaluation of aeolian sand transport equations using intertidal zone measurements, Sauton Sands, England. Sedimentology, 35(4):671-821.

SCHUMM,S.A. \& LICHTY,R.W. 1965. Time, space and causality in geomorphology. Am.J.Sci., 263(2):110-119.

SCHWAM,J. 1988. The structure and genesis of Weichselian to Early Holocene aeolian sand sheets in western Europe. Sediment. Geol., 55(3/4):197-232.

SCHWARTZ,M.L. 1965. Laboratory study of sea-level rise as a cause of shore erosion. J.Geol., 73(3):528-534.

SCHWARTZ,M.L. 1967. The Bruun theory of sea-level rise as a cause of shore erosion. J. Geol., 75(1):76-92.

SELF,R.P. 1977. Longshore variation in beach sands Nautla area, Veracruz, Mexico. J. Sediment. Petrol., 47(47):1437-1443.

SEMENIUK, V. \& SEMENIUK,C.A. 1991. Radiocarbon ages of some coastal landforms in the Peel-Harvey estuary, south-western Austrália. J. Royal Soc. Western Australia, 73(3):61-71.

SEMENIUK,V.; CRESWELL,I.D.; WURM,P.A.S. 1989. The Quindalup Dunes: the regional system, phisical framework and vegetation habitats. J.Royal Soc. Western Austrália, $71(2 / 3): 23-47$.

SENGUPTA,S. \& VEENSTRA,H.J. 1968. On Sieving and settling tecniques for sand analysis. Sedimentology, 11:83-98.

SHIDELER,G.L. 1973. Textural trend analysis of coastal barrier sediments along the Middle Atlantic Bight, North Carolina. Sediments. Geol., 9(3):195-220.

SHORT,A.D. 1979. Three - dimensional beach stage model. J.Geol., 87(5):553-571.

SHORT,A.D. 1988. Holocene coastal dune formation in Southern Austrália: a case study. Sediment. Geol., 55(1/2):121-142.

SHORT,A.D. \& HESP,P.A. 1982. Wave, beach and dune interactions in South - eastern Austrália. Marine Geol., 48(4):259-284.

SHUISKY,Y.D. \& SCHWARTZ,M.L. 1983. Basic principles of sediment budget study in the coastal zone. Shore \& Beach, 51(1):34-41.

SHULZ,A.,Jr. ; ALBUQUERQUE,L.F.F.; RODRIGUES,C.S. 1970. Geologia da Quadrícula de Florianópolis, SC. Porto Alegre, DNPM/CPRM - 1 Distrito. Relat. Interno (inéd.).75p. 
SILVA,L.C. 1987. Geologia do Pré-Cambriano /Eopaleozóico de Santa Catarina. In: SILVA,I.C. \& BORTOLUZZI, C. A. eds. Texto Explicativo para o Mapa Geológico do Estado de Santa Catarina. Florianópolis, DNPM-CRM. p.11-90. (Série Textos Básicos de Geologia e Recursos Minerais de Santa Catarina,1).

SILVA,M.A.S. 1982. Avaliação dos depósitos wolframíticos no complexo metamórfico Brusque, SC: 1 - área de catinga. Est.Tecnolog., Acta Geolog. Leopoldinense, 16:33-94.

SILVEIRA,J.D. 1964. Morfologia do litoral. In : AZEVEDO,A ed.Brasil: A Terra e o Homem, v.l: As Bases Físicas. São Paulo, Cia. Ed. Nacional.p.253-305.

SMITH,A.W. 1988. The behaviour of natural sand dunes. Shore \& Beach, 56(4):24-29

SMITH,H.T.U. 1941. Jpsiloidal dunes. J. Geomorph.,4(3):251.

SMITHSON,F. 1941. The alteration of detrital minerals in the Mesozoic rocks of Yorkshire. Geol.Mag., 78(1):97-112.

SOARES,P.C. 1992. Tectônica Sinsedimentar Cíclica na Bacia do Paraná - Controles. Curitiba, Dpto. Geologia Univ.Fed. Paraná Tese Prof.Titular (inéd.).131p.

SOCCI,A. \& TANNER,W.F. 1980. Little know but important papers on grain-size analysis. Sedimentology, 27(1): 231-232.

SPEARING.D.R. 1974. Summary Sheets of Sedimentary Deposits. Geol.Soc. Am., 7 fol.

STAPOR,F.W. \& MAY,J.P. 1983. The cellular nature of littoral drift along the northeast Florida coast. Marine Geol.,51 (3) : 217-237.

STOKES,W.L. 1961. Fluvial and aeolian sandstone bodies in Colorado Plateau. In: PETERSON, J. A. \& OSMOND,J.C. eds. Geometry of Sandstone Bodies. Tulsa, Am. Assoc. Petroleum Geologists.p.151-178.

STOKES,W.L. 1968. Multiple parallel - truncation bedding planes a feature of wind deposited sandstone formations. J.Sediment.Petrol., 38(2):510-515.

STRAHLER,A.N. 1977. Geografia física. Barcelona, Omega. 767p.

STRAHLER,A.N. 1980. Systems theory in physical geography. Phys. Geog., 1(1):1-27.

SUGUIO,K. 1980. Rochas Sedimentares São Paulo, Edgard Blucher - Edusp. 500p.

SUGUIO,K. 1993. Holocene relative sea-level changes along the Central Brazilian and Japanese coasts: possible significance of their similarities and differences. An.Acad.Brasil. Ciênc., 65(4): no prelo.

SUGUIO,K. \& COIMBRA,A.M. 1976. Estudo sedimentológico das "bandas onduladas" de solos da Formação Bauru na área balisada pelas cidades de Osvaldo Cruz, Rancharia e Tupã, Estado de São Paulo. Bol.IG-USP, 7:113-129.

SUGUIO,K. \& MARTIN,L. 1978. Formações quaternárias marinhas do litoral paulista e sul fluminense. In : INTERNATIONAL SYMPOSIUM ON COASTAL EVOLUTION IN THE QUATERNARY, São Paulo. Special Publication (1).São Paulo, IGCB/IGUSP/SBG, 55p.

SUGUIO,K. \& MARTIN.L. 1987. Classificação de costas e evolução geológica das planicies litorâneas quaternárias do sudeste e sul do Brasil. In : SIMPÖSIO SOBRE ECOSSISTEMAS DA COSTA E SUDESTE BRASILEIRA, Cananéia. Sintese dos Conhecimentos, $V$ 1...São Paulo, Public. ACIESP (54) I.p. 1-28

SUGUIO,K.; COIMBRA,A.M.;GUARDADO,L.R. 1974. Correlação sedimentológica de arenitos da Bacia do Paraná. Bol. IG-USP, 5:85-116.

SUGUIO,K.; MARTIN, L.; DOMINGUEZ,J.M.L. 1982. Evolução da planicie costeira do rio Doce(ES) durante o Quaternário: influência das flutuações do nível do mar. In : SIMPÓSIO DO QUATERNÁRIO DO BRASIL,4, Rio de Janeiro. Atas... Rio de Janeiro.p.93-116.

SUGUIO,K.; MARTIN,L.; FLEXOR,J.M.; AZEVEDO,A.E.G. 1986. The quaternary sedimentary deposits in the states of Paraná and Santa Catarina coastal plains. In: INTERNATIONAL SYMPOSIUM ON SEA LEVEL CHANGES AND 
QUATERNARY SHORELINES, São Paulo. Quaternary South Am. Antarctic. Peninsula, 4:3-25.

SWAN,D.; CLAQUE, J.J. ; LUTERNAUER,J.L. 1978. Grain - size statistics I: evaluation of the Folk and Ward graphic measures. J. Sediment.Petrol.,48(3):863-878.

SWAN,D.; CLAQUE,J.J.; LUTERNAUER,J.L.; 1979. Grain - size statistics.II: evaluation of grouped moment measures. J. Sediment. Petrol.,69(2):487-501.

TAIRA,A. \& SCHOLLE,P.A. 1978a. Discrimination of depositional environments using settling tube data. J.Sediment. Petrol.,49(3):787-800.

TAIRA,A. \& SCHOLLE,P.A. 1979b. Origin of bimodal sands in some modern enviroments. J.Sediment.Petrol., 49(3):777-786.

TALBOT,M.R. 1985. Major bounding surfaces in aeolian sandstone - a climatic model. Sedimentology, $32(2)$ : 257-265.

TALBOT,M.R. \& WILLIAMS,M.A.J. 1978. Erosion of fixes dunes in the Sahel, Central Niger. Earth Surf. Processes, 3:107-114.

TEIXEIRA,C.A.S. 1969. Relatório Preliminar da Geologia das Quadrículas de Braço do Norte e Morro da Fumaça, 1:50.000. Porto Alegre, DNPM- 1 Distrito. Relat. Interno (inéd.).

TERJUNG,W.B. 1976. Climatology for geographers. Ann.Assoc.Am.Geog., 66: 199222.

THOM,R. 1972. Structural Stability and Morphogenesis. Massachussets, W.A. Benjamin, Reading.

THOMPSON,D.B. 1969. Dome-shaped aeolian dunes in the Frodshammember of the so - called "Kreuper" sandstone formation (Scithian-Anisian: Triassic) at Frodsham, Cheshire(England). Sediment. Geol., 3:263-289.

TOMAZELLI,L.J. 1990. Contribuição ao Estudo dos Sistemas Deposicionais Holocênicos do Nordeste da Provincia Costeira do Rio Grande do Sul com Ênfase no Sistema Eólico. Porto Alegre, Univ.Federal Rio Grande do Sul. Tese de Doutorado (inéd.).270p.

TOMAZELLI,L.J. \& VILLWOCK,J.A. 1989. Processos erosivos atuais na costa do Rio Grande do Sul, Brasil: evidências de uma provável tendência contemporânea de elevação do nivel relativo do mar. In : CONGRESSO DA ASSOCIAÇĀO

BRASILEIRA DE ESTUDOS DO QUATERNÁRIO, 2, Rio de Janeiro. Anais... Rio de Janeiro, ABEQUA. No prelo.

TOMMASI,L.R. 1987. Santa Catarina. In : Poluição marinha : Brasil. Public. Especial Inst. Oceanogr. Univ. S. Paulo, (5):20-21.

TONNELAT, J.1978. Thermodynamique et Biologie. Paris, Maloine.2v.,p.

TRAININI,D.R.; DIAS,A.A.; KREBES,A.S.J.; SOUZA,E.C.; CAPELETTI,I.; TONIOLO,J.A.; SILVA,M.A.S. 1978. Projeto Vidal Ramos-Biguaçu. Relatório Final. Porto Alegre, DNPM /CPRM, 5v., mapas. Relat. Interno (inéd.).

TUCKER,R.E. \& WACHER,H.L. 1980. Effectiveness of discriminating beach dune and river sands by moments and the cumulative weight percentagens. J.Sediment.Petrol.,50(1):165-173.

VILLWOCK,J.A. 1984. Geology of the coastal province of Rio Grande do Sul, Southern Brazil. A Synthesis. Pesquisas, 16:5-49.

VILLWOCK,J.A. 1987. Processos costeiros e a formação das praias arenosas e campos de dunas ao longo da costa sul e sudeste brasileira. In: SIMPÓSIO SOBRE ECOSSISTEMAS DA COSTA SUL E SUDESTE BRASILEIRA, Cananéia. Síntese dos conhecimentos, v. $1 \ldots$ São Paulo, Public. ACIESP (54) i. p.380-398.

VILLWOCK,J.A. \& TOMAZELLI,L.J. 1989. Sea-level changes and Holocene evolution in the Rio Grande do Sul Coastal Plain, Brazil. In : INTERNATIONAL SYMPOSIUM ON GLOBAL CHANGES IN SOUTH AMERICA DURING THE 
QUATERNARY, São Paulo. Special Publication INQUA. p.192-196.

(1)... São Paulo, ABEQUA-

VILLWOCK,J.A. ; DEHNHARDT,E.A.; LOSS,E.L.; HOFMEISTER,T. 1980. Turfas da província costeira do Rio Grande do Sul: Geologia do depósito de Águas Claras. In : CON GRESSO BRASILEIRO DE GEOLOGIA, 31, Balneário Camboriú. Anais... Florianópolis, SBG. v.1,p.500-512.

VILLWOCK, J.A.; TOMAZELLI,L.J.; LOSS,E.L.; DEHNHARDT,E.A.; HORN,N.O.FILHO; BACHI,F.A.; DEHNHARDT,B.A. 1986. Geology of the Rio Grande do Sul Coastal Province. In: INTERNATIONAL SYMPOSIUM ON SEA LEVEL CHANGES AND QUATERNARY SHORELINES, São Paulo. Quaternary South Am. Antartic.Peninsula, 4:79-97.

WALKER,R.G. 1976. Facies and facies models. General introduction. In: WALKER,R.G. ed. Facies Models. Toronto, Geosc. Canada, 1979,p.1-7. (Reprint Series, 1).

WALKER,R.G. \& MIDDLETON,G.V. 1977. Eolian sands. In : WALKER,R.G. ed. Facies Models. Toronto, Geosc. Canada, 1979,p.33-41. (Reprint Series,1).

WALKER,T.R. 1979. Red color in dune sand. In: McKEE,E.D. ed. A Study of Global Sand Seas. U. S., Geol. Survey, Profess. Papers, 1052:62-81.

WARD,J.D. 1988. Eolian, fluvial and pan (playa) facies of the Tertiary Tsondab Sandstone formation in the central Namib Desert, Namibia. Sediment. Geol.,55(1/2):143-162.

WASSON,R.J. 1983. Dune sediment types sand colour, sediment provenance and hydrology in the Strzelecki - Simpson dunefield, Austrália. In : BROOKFIELD, $M$. E. \& AHLBRANDT, T. S. eds. Eolian Sediments and Process. Elsevier.p.165-195 (Develpments in Sedimentology,38).

WEBB,C.K.; STOW,D.A.; BARON,K.S. 1989. Morphologic response of an inlet-barrier beach system to a major storm. Shore \& Beach, 57(4):37-40.

WEISHAR,L.L. \& WOOD,W.L. 1983. An evaluation of offshore and beach changes on a tideless coast. J. Sediment. Petrol., 53(3):847-858.

WELLER, J.M. 1958. Stratigrafic facies differentation and nomenclature. Bull.Am.Assoc. Petrol. Geologists, 42(3):609-639.

WERNICK,E. \& PENALVA,F. 1978. Contribuição ao conhecimento das rochas granitóides do sul do Brasil. Rev.Bras. Geoc., 8(2):113-133.

WHITE,B. \& CURRAN,A.1988. Mesoscale physical sedimentary structures and trace fossils in Holocene carbonate eolianites from San Salvador Island. Bahamas. Sediment. Geol.,55(1/2):163-184.

WIENER,C. 1876. Estudos sobre os sambaquis do sul do Brazil. Arch. Museu Nacional, 1:3-20.

WILLIAMS,A.T. 1986. Lotus 1-2-3 Release 2. Rio de Janeiro, Livros Técnicos e Cientificos, 2ed., 1988. 316p.

WILLIG,C.D.; VALENTINI,N.; CONTE,C.N.; ZIR,J.A.,FILHO; MÔNACO,O.A. 1974. Texto Explicativo: Folha Porta Alegre (SH-22) - Folha Lagoa Mirim (SI-22). In: Carta Geológica do Brasil ao Milionésimo. Brasilia, DNPM. 99p.

WILSON.I.G. 1972. Aeolian bedforms, their developments and origins. Sedimentology, 19(2):173-210.

WILSON,P. 1989. Nature, origin and age of Holocene aeolian sand on Muckish Mountain, Co. Donegal, Ireland. Boreas, 18(2):159-168.

WINKELMOLEN,A.M. 1982. Critical remarks on grain parameters, with special emphases on shape. Sedimentology, 29(2):255-265.

WRIGHT,L.D. 1978. River deltas. In : DAVIS,R.A., Jr ed. Coastal Sedimentary Environments. Amsterdam, Springer-Verlag.p.5-68. 
WRIGHT,L.D.; CHAPPEL,J.; THOM,B.; BRADSHAW,M.; COWELL,P. 1979. Morphodynamics of reflective and dissipative beach and inshore systems : South Austrália. Marine Geol,,32(1):105-140.

WU,F.T. 1981. Minerais Pesados de Seqüências Arenosas Paleozóica e Mesozóica no Centro-Leste do Estado de São Paulo. São Paulo, Inst. Geoc. Univ. S. Paulo. Dissert. de Mestrado (inéd.).78p.

WU,F.T. 1989. Proveniência de Rochas Arenosas do Subgrupo Itararé no Sul do Estado de São Paulo. São Paulo, Inst.Geoc.Univ.S.Paulo. Tese de Doutoramento (inéd.).165p.

YAALON,D.H. \& FRANZLE,O. 1975. Working group on rock weathering, soils and sedimentary structures. In : INTERNATIONAL SYMPOSIUM ON THE QUATERNARY, Curitiba. Final Report...Bol.Paranaense Geoc.,(33):355-356.

YASSO,E.W. 1965. Plan geometry of headland-bay beaches. J.Geol.,73(5):702-714

ZEMBRUSCKI S.G. 1979. Brasil. Margem Continental. Mapa Fisiográfico (Ärea Sul). Rio de Janeiro, Petrobras/Cenpes/Dintep. (Série Projeto Remac).

ZENKOVITCH,V.P. 1967. Processes of Coastal Development. Edinburgh-London, Oliver \& Boyd. 738p. 